\title{
Paleontological Overview \\ of Oil Shale and Tar Sands Areas in Colorado, Utah, and Wyoming
}

Prepared by:

Paul C. Murphey, Ph.D. and David Daitch, M.S.

Argonne National Laboratory

Prepared for:

The U.S. Department of the Interior, Bureau of Land Management

December 2007

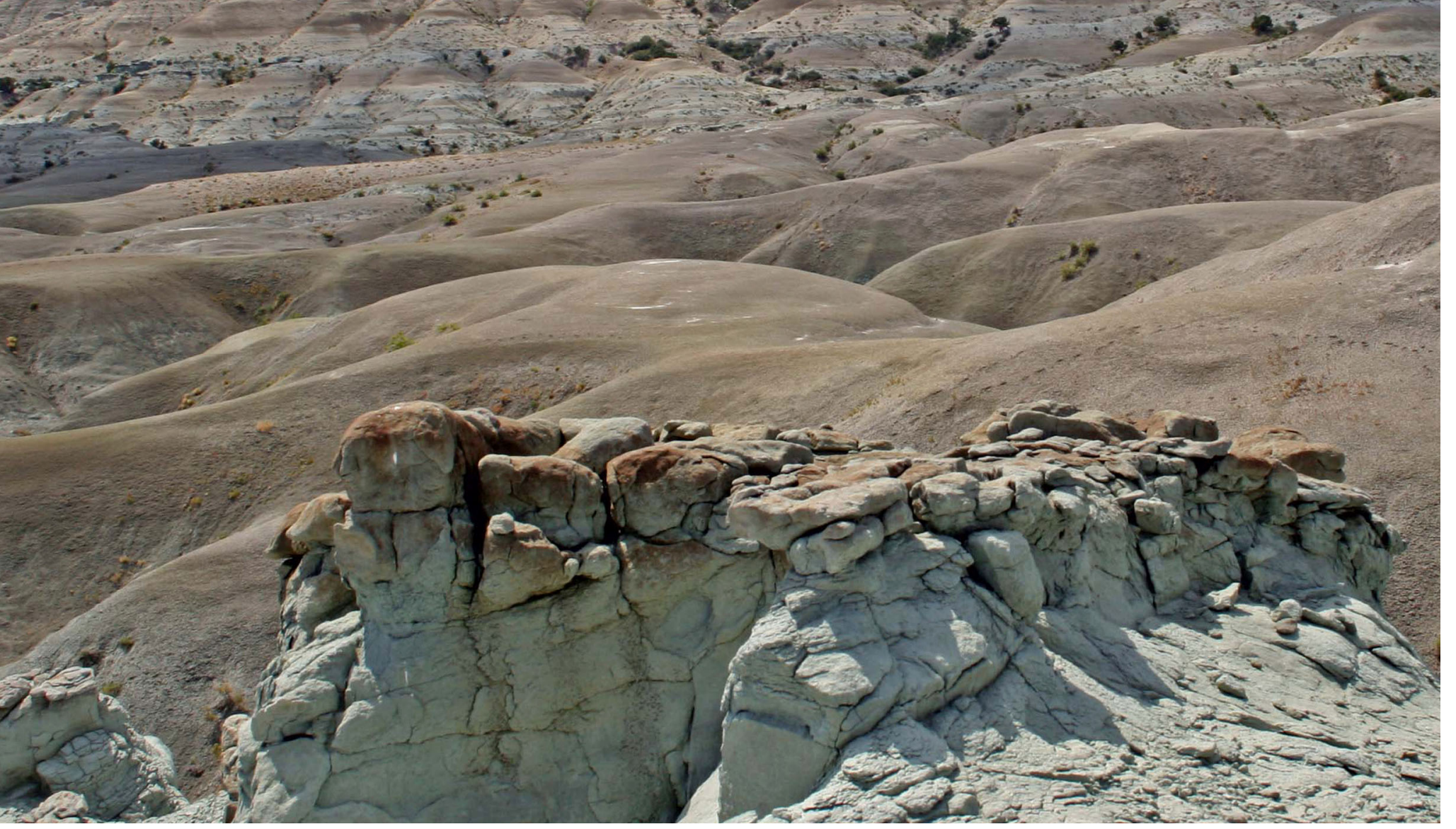


On the cover:

Exposures of the upper Bridger Formation at Old Hat Mountain in Uinta County, Wyoming. 


\section{PALEONTOLOGICAL OVERVIEW OF OIL SHALE AND TAR SANDS AREAS IN COLORADO, UTAH, AND WYOMING}

\section{Prepared by:}

Paul C. Murphey, Ph.D.* and David Daitch, M.S.*

Argonne National Laboratory

Prepared for:

The U.S. Department of the Interior, Bureau of Land Management

December 2007

\footnotetext{
* Murphey is currently associated with the Department of Paleontology, San Diego Natural History Museum and Daitch with the Department of Ecology and Evolutionary Biology, University of Colorado, Boulder.
} 



\section{CONTENTS}

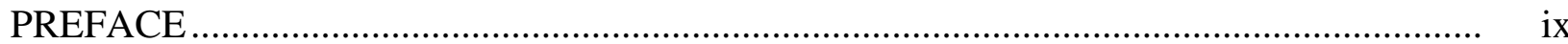

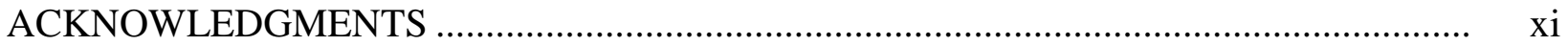

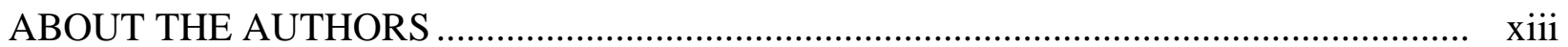

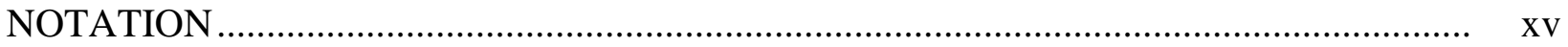

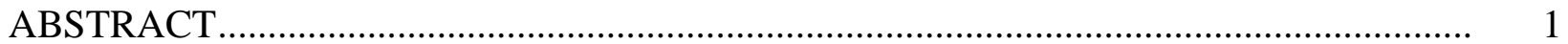

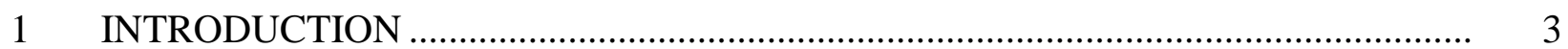

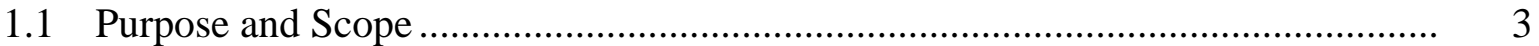

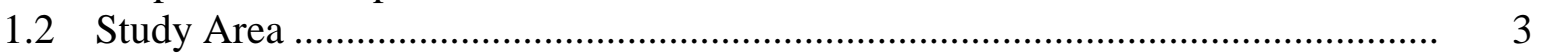

1.3 Definition and Significance of Paleontological Resources..................................... 8

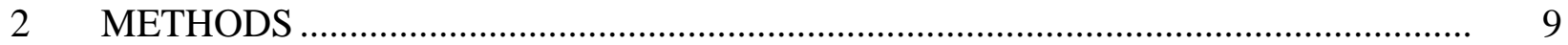

$3 \quad$ RESOURCE ASSESSMENT GUIDELINES …….................................................... 13

3.1 BLM Conditions 1-3 .......................................................................... 13

3.2 Potential Fossil Yield Classification ................................................................... 14

4 GREATER GREEN RIVER BASIN, WYOMING AND COLORADO ............................. 19

4.1 Geologic Setting and Depositional History ………............................................. 19

4.2 Paleoenvironmental Summary .............................................................................. 21

4.3 Previous Paleontological Work and Related Investigations ................................... 23

4.4 Geologic Units and Paleontological Resources ……………………………........ 28

4.4.1 Wasatch Formation ......................................................................... 28

4.4.2 Green River Formation ................................................................... $\quad 30$

4.4.3 Bridger Formation............................................................................. 34

4.4.4 Washakie Formation ......................................................................... 38

4.4.5 Bishop Conglomerate........................................................................... 40

4.4.6 Browns Park Formation ......................................................................... 41

4.4.7 Pleistocene- and Holocene-Age Surficial Deposits ................................. 42

4.5 Paleontological Resource Assessment Summary …………………………….... 42

$5 \quad$ PICEANCE CREEK BASIN, COLORADO ………................................................ 45

5.1 Geologic Setting and Depositional History ……………………………......... 45

5.2 Paleoenvironmental Summary ………………………………………….... $\quad 50$

5.3 Previous Paleontological Work and Related Investigations ................................. 52 


\section{CONTENTS (Cont.)}

5.4 Geologic Units and Paleontological Resources ………....................................... 54

5.4.1 DeBeque Formation ............................................................................... 57

5.4.2 Green River Formation ..................................................................... 58

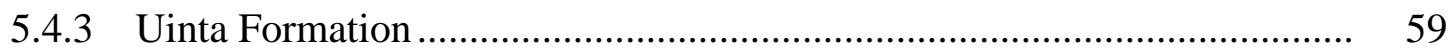

5.4.4 Pleistocene- and Holocene-Age Surficial Deposits ................................. 60

5.5 Paleontological Resource Assessment Summary …………………………....... 61

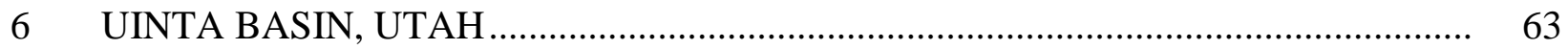

6.1 Geologic Setting and Depositional History ………………………………..... 63

6.2 Paleoenvironmental Summary .......................................................................... 69

6.3 Previous Paleontological Work and Related Investigations .................................. 71

6.4 Geologic Units and Paleontological Resources …………………........................ 72

6.4.1 Mesaverde Group ........................................................................... $\quad 72$

6.4.2 Wasatch Formation .............................................................................. $\quad 75$

6.4.3 Green River Formation ..................................................................... 77

6.4.4 Uinta Formation ................................................................................ $\quad 79$

6.4.5 Duchesne River Formation ........................................................................ 81

6.4.6 Pleistocene- and Holocene-Age Surficial Deposits ................................... 83

6.5 Paleontological Resource Assessment Summary ……………………………...... 84

7 EAST-CENTRAL AND SOUTHEASTERN UTAH SPECIAL

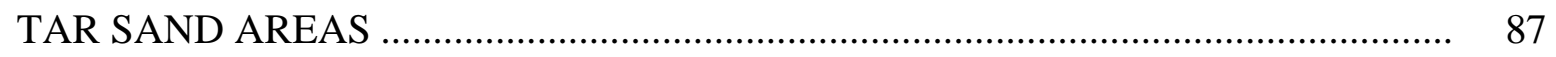

7.1 Geologic Setting and Depositional History …………………………………..... 87

7.2 Paleoenvironmental Summary ........................................................................... 89

7.3 Previous Paleontological Work and Related Investigations ................................... $\quad 92$

7.4 Geologic Units and Paleontological Resources …………..................................... 94

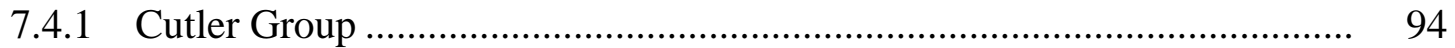

7.4.2 Kaibab Limestone ……………………………….............................. 99

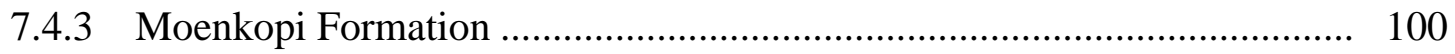

7.4.4 Chinle Formation ................................................................................ 102

7.4.5 Pleistocene- and Holocene-Age Surficial Deposits .................................. 104

7.5 Paleontological Resource Assessment Summary …………………………….... 105

8 CONCLUSIONS AND RECOMMENDATIONS …................................................. 107

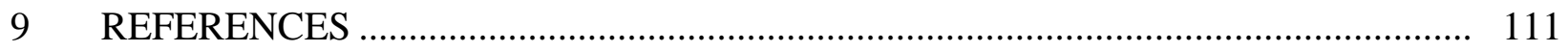

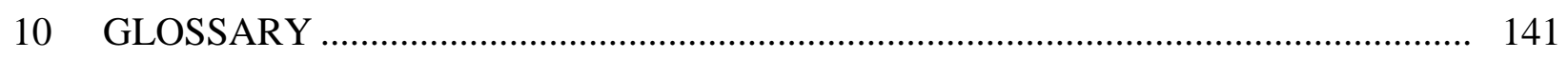




\section{CONTENTS (Cont.)}

APPENDIX A: Bibliography of Relevant Literature and Technical Reports for the Oil Shale and Tar Sands PEIS Study Area

APPENDIX B: Bibliography of Geologic Maps Covering the Oil Shale and Tar Sands PEIS Study Area

APPENDIX C: Taxonomic Lists of Fossils from Potentially Affected Geologic Units within the Oil Shale and Tar Sands PEIS Study Area....

APPENDIX D: BLM Sensitivity Maps of Paleontological Formations within the Oil Shale and Tar Sands PEIS Study Area

\section{TABLES}

1 Summary of STSAs Included in This Study and Their Locations, Ages, and Geologic Provenances....

2 Summary of North American Cenozoic Land Mammal Ages

3 Summary of Programmatic-Level Paleontological Sensitivities of Geologic Units within the Greater Green River Basin in Southwestern Wyoming and Northwestern Colorado

4 Summary of Programmatic-Level Paleontological Sensitivities of Geologic Units within the Piceance Creek Basin in Northwestern Colorado

5 Summary of Programmatic-Level Paleontological Sensitivities of Geologic Units within the Uinta Basin in Northeastern Utah

6 Summary of Programmatic-Level Paleontological Sensitivities of Geologic Units within the STSAs Located in East-Central and Southeastern Utah

\section{FIGURES}

1 Map of the Oil Shale Basins in Colorado, Utah, and Wyoming Evaluated in This Report and the Most Geologically Prospective Oil Shale Resources Evaluated in the Oil Shale and Tar Sands PEIS 


\section{FIGURES (Cont.)}

2 Map Showing the Locations of Basins and Uplifts Created during the Laramide Orogeny in Northeastern Utah, Northwestern Colorado, and Southwestern Wyoming

3 Map of Designated STSAs in Utah Evaluated in This Report

4 Index Map of the Greater Green River Basin Showing Depositional Subbasins and Major Structural Features.

5 Generalized Stratigraphic Correlation of Eocene Rocks across the Central Part of the Greater Green River Basin

6 Generalized Stratigraphic Correlation Chart of Rock Units in Fossil Basin.

7 General Stratigraphic Features of the Bridger Formation

8 Generalized Stratigraphic Correlation Diagram for Late Cretaceous and Early Tertiary Rocks in the Northern Piceance Creek and Northeastern Uinta Basins

9 Generalized Stratigraphic Correlation Diagram for Late Cretaceous and Early Tertiary Rocks in the Southern Piceance Creek and Southeastern Uinta Basins

10 Generalized Correlation Chart for the Northern Piceance Creek and East-Central Uinta Basins

11 Lithologic Cross Section through the Central Part of the Uinta Basin from Southwest to North.

12 Stratigraphic Nomenclature and Correlation Chart of Triassic Strata in Southern Utah, Northeastern Arizona, and Northwestern New Mexico

13 Stratigraphic Column for the San Rafael Swell Area, East-Central Utah

14 Cross Section Showing Stratigraphic Relationships and Nomenclature for the Cutler Group in the Paradox Basin

15 Stratigraphic Correlation Chart of Terrestrial Fossil-Bearing Units of the Moenkopi Formation 


\section{FIGURES (Cont.)}

\section{The figures listed below are oversized maps and can be found in the pockets at the back of this report.}

D-1 Paleontological Sensitivity of Formations That May Be Impacted by Oil Shale Development in Colorado Using the BLM Classification System

D-2 Paleontological Sensitivity of Formations That May Be Impacted by Oil Shale Development in Colorado Using the USFS Potential Fossil Yield Classification System

D-3 Paleontological Sensitivity of Formations That May Be Impacted by Oil Shale or Tar Sands Development in Utah Using the BLM Classification System

D-4 Paleontological Sensitivity of Formations That May Be Impacted by Oil Shale or Tar Sands Development in Utah Using the USFS Potential Fossil Yield Classification System

D-5 Paleontological Sensitivity of Formations That May Be Impacted by Oil Shale Development in Wyoming Using the BLM Classification System

D-6 Paleontological Sensitivity of Formations That May Be Impacted by Oil Shale Development in Wyoming Using the USFS Potential Fossil Yield Classification System 


\section{PREFACE}

In August 2005, the U.S. Congress enacted the Energy Policy Act of 2005, Public Law 109-58. In Section 369 of this Act, also known as the "Oil Shale, Tar Sands, and Other Strategic Unconventional Fuels Act of 2005," Congress declared that oil shale and tar sands (and other unconventional fuels) are strategically important domestic energy resources that should be developed to reduce the nation's growing dependence on oil from politically and economically unstable foreign sources. In addition, Congress declared that both research- and commercial-scale development of oil shale and tar sands should (1) be conducted in an environmentally sound manner using management practices that will minimize potential impacts, (2) occur with an emphasis on sustainability, and (3) benefit the United States while taking into account concerns of the affected states and communities. To support this declaration of policy, Congress directed the Secretary of the Interior to undertake a series of steps, several of which are directly related to the development of a commercial leasing program for oil shale and tar sands. One of these steps was the completion of a programmatic environmental impact statement (PEIS) to analyze the impacts of a commercial leasing program for oil shale and tar sands resources on public lands, with an emphasis on the most geologically prospective lands in Colorado, Utah, and Wyoming. For oil shale, the scope of the PEIS analysis includes public lands within the Green River, Washakie, Uinta, and Piceance Creek Basins. For tar sands, the scope includes Special Tar Sand Areas (STSAs) located in Utah.

This paleontological resources overview report was prepared in support of the Oil Shale and Tar Sands Resource Management Plan Amendments to Address Land Use Allocations in Colorado, Utah, and Wyoming and PEIS, and it is intended to be used by Bureau of Land Management (BLM) regional paleontologists and field office staff to support future projectspecific analyses. Additional information about the PEIS can be found at http://ostseis.anl.gov. 


\section{ACKNOWLEDGMENTS}

This report was prepared at the request of the U.S. Department of the Interior, Bureau of Land Management (BLM), and the U.S. Department of Energy's Argonne National Laboratory. Its purpose is to provide an overview of paleontological resources in portions of three western states in support of the Oil Shale and Tar Sands Resource Management Plan Amendments to Address Land Use Allocations in Colorado, Utah, and Wyoming and Programmatic

Environmental Impact Statement. In this report, we have attempted to synthesize and summarize the monumental efforts of a large number of scientists who have focused their research on paleontological and geological problems in portions of Wyoming, Colorado, and Utah. These efforts have been ongoing for more than 135 years. During the course of our analysis, we were humbled by the vast amount of research that has been conducted in this geographic area. Working within a limited timeframe, we sought to capture the most important research in our report, but we know that, despite our best efforts, it is not comprehensive.

We extend our deepest thanks to the many professional and avocational paleontologists and geologists who have contributed to the wealth of knowledge that now exists about the ancient environments, biotas, and geologic history of Colorado, Utah, and Wyoming. Their efforts have included countless hours in the field and laboratory and have resulted in an understanding of this region that is unprecedented worldwide. Future scientific methods and improved technologies will facilitate the advancement of our knowledge about the history of this region, while continuing to provide educational opportunities for future generations.

We also thank our colleagues at the BLM and museums throughout the Rocky Mountain West for providing information helpful to our analysis. Special thanks go out to the BLM's regional paleontologists, Harley Armstrong, Dale Hanson, Scott Foss, and Pat Hester, as well as the many BLM field office staff members who work tirelessly to manage and preserve nonrenewable paleontological resources on the nation's public lands. 


\section{ABOUT THE AUTHORS}

Paul C. Murphey earned master's and Ph.D. degrees in Geological Sciences with emphases in vertebrate paleontology in 1995 and 2001, respectively. These graduate degrees were both conferred at the University of Colorado at Boulder. His doctoral research focused on the stratigraphy, depositional environments, distribution of fossils, and taphonomy of the Bridger Formation (middle Eocene) of southwestern Wyoming. This work included geologic mapping of more than $1,000 \mathrm{~km}^{2}$ of the southern Green River Basin. Dr. Murphey's prior professional appointments include Collections Manager of Paleontology and Osteology in the Geological Section of the University of Colorado Museum of Natural History, Instructor in the Master's of Museum and Field Studies at the University of Colorado, Lecturer in the Department of Geological Sciences at the University of Colorado, Graduate Faculty Member at the University of Colorado, Principal Investigator of Paleontology at SWCA Environmental Consultants, and Associate Curator of Paleontology and Associate Director of Paleoservices in the Department of Paleontology, San Diego Natural History Museum. Since 1995, Dr. Murphey has worked as a Principal Investigator on hundreds of paleontological resource management-related projects throughout the western United States. He has also worked collaboratively with the Bureau of Land Management (BLM) on projects, including geologic mapping and a predictive model for paleontological resources on BLM lands in southwestern Wyoming. Dr. Murphey currently holds a Research Associate appointment at the Biodiversity Research Center of the Californias, Department of Paleontology, San Diego Natural History Museum. His current field-based research focuses on vertebrate paleoecology, taphonomy, and mammalian biostratigraphy with an emphasis on the Bridgerian-Uintan transition in Wyoming, Utah, and Colorado. As a consultant and a researcher active on federally administered lands, Dr. Murphey has a broad interest in paleontological resource management and related land use issues. He is also an avid pianist and recording engineer, a sailing and scuba diving enthusiast, and he makes a darn fine margarita.

David Daitch earned a master's degree in Geological Sciences with an emphasis in paleontology from the University of Colorado in 2001. His master's thesis focused on tempo and mode of evolution in the Eocene carnivore Didymictis. He is currently a Ph.D. candidate in the Department of Ecology and Evolutionary Biology at the University of Colorado at Boulder. His doctoral research is centered on the evolutionary implications of population-level divergence in tooth shape. This research approach correlates shape divergence with molecular divergence, geographic distance, and environmental parameters in order to test evolutionary hypotheses. Mr. Daitch has taught paleobiology, general biology, evolution, vertebrate zoology, mammalogy, and the biology department's writing laboratory, and was awarded a departmental teaching award and fellowship in 2006. Mr. Daitch has worked with Dr. Murphey on numerous fieldbased paleontological projects in Colorado, Utah, and Wyoming, and cooks the world's most delicious duck confit (sometimes simultaneously). 


\section{NOTATION}

The following is a list of the abbreviations, acronyms, and units of measure used in this document. (Some acronyms and abbreviations used only in tables may be defined only in those tables.)

\section{GENERAL ACRONYMS AND ABBREVIATIONS}

\begin{tabular}{|c|c|}
\hline AMNH & American Museum of Natural History \\
\hline APE & Area of Potential Effect \\
\hline BLM & Bureau of Land Management \\
\hline EIS & environmental impact statement \\
\hline GIS & geographic information system \\
\hline NALMA & North American Land Mammal Ages \\
\hline PEIS & programmatic environmental impact statement \\
\hline PFYC & Potential Fossil Yield Classification \\
\hline STSA & Special Tar Sand Area \\
\hline UCMP & University of California Museum of Paleontology \\
\hline US & U.S. Forest Service \\
\hline USGS & U.S. Geological Survey \\
\hline
\end{tabular}

\section{UNITS OF MEASURE}

$\begin{array}{ll}\text { ac } & \text { acre(s) } \\ { }^{\circ} \mathrm{F} & \text { degree(s) Fahrenheit } \\ \mathrm{ft} & \text { foot (feet) } \\ \text { in. } & \text { inch(es) } \\ \mathrm{Ma} & \text { megannum(s) } \\ \mathrm{mi} & \text { mile(s) } \\ \mathrm{mi}^{2} & \text { square mile(s) }\end{array}$




\title{
PALEONTOLOGICAL OVERVIEW OF OIL SHALE AND TAR SANDS AREAS IN COLORADO, UTAH, AND WYOMING
}

\author{
by
}

\author{
Paul C. Murphey, Ph.D. \\ Department of Paleontology, San Diego Natural History Museum
}

David Daitch, M.S.

Department of Ecology and Evolutionary Biology, University of Colorado at Boulder

\begin{abstract}
In this report, the paleontological content and sensitivities of potentially affected geologic units within the study area for the Oil Shale and Tar Sands Resource Management Plan Amendments to Address Land Use Allocations in Colorado, Utah, and Wyoming and Programmatic Environmental Impact Statement (PEIS) are reviewed, evaluated, and summarized. On the basis of the results of the analysis, programmatic-level recommendations are made.

As defined in the scope of the PEIS, commercially viable oil shale deposits are contained within Eocene-age rocks of the Green River Formation, which are widely distributed in the greater Green River Basin in southwestern Wyoming and northwestern Colorado, the Piceance Creek Basin in northwestern Colorado, and the Uinta Basin in northeastern Utah. ${ }^{1}$ Eleven Special Tar Sand Areas (as designated by the Secretary of the Interior) are located within the Uinta Basin in northeastern Utah in Cretaceous-age rocks of the Mesaverde Group, and Eocene-age rocks of the Wasatch Formation, Douglas Creek and Parachute Creek members of the Green River Formation, and the Uinta Formation. In portions of east-central and southeastern Utah, tar sands deposits are contained within rocks of the Permian-age White Rim Sandstone of the Cutler Group and Kaibab Limestone, and in Triassic-age rocks of the Hoskinnini, Black Dragon, and Torrey members of the Moenkopi Formation and the Shinarump Member of the Chinle Formation. Numerous other sedimentary rock units overlie or occur in close stratigraphic proximity to the units containing oil shale and tar sands, and these could potentially be impacted during commercial extraction of hydrocarbon resources.
\end{abstract}

1 While the Oil Shale and Tar Sands PEIS scope of analysis for oil shale focuses on the most geologically prospective oil shale resources, this report evaluates the larger area encompassed within sedimentary basins that contain rocks of the Green River Formation. 
The study area is known to contain some of the most fossiliferous sedimentary rock units in North America. Because of their fossil content, these units have been the focus of continuous scientific inquiry for approximately the last 135 years. The rich fossil record ranges in age from the Upper Pennsylvanian Period to the Upper Pleistocene Epoch and represents a temporally discontinuous span of approximately 300 million years. Collectively, these units (formations and members thereof) have produced an estimate of millions of scientifically significant fossil specimens from thousands of fossil localities. Paleontologic and associated geologic fieldwork in the study area has produced an unprecedented amount of scientific data, which continue to be used to study a wide variety of aspects of Paleozoic, Mesozoic, and Cenozoic biotas, including their evolution, biostratigraphy, paleobiogeography, paleoenvironments, taphonomy, and paleoecology. Fossils include highly diverse assemblages of vertebrates (fishes, amphibians, reptiles, birds, and mammals), invertebrates (mollusks, arthropods, and insects), and plants, including the holotypes of many presently recognized taxa. These fossils are housed in museums throughout the United States and have been the subject of thousands of published scientific studies. Much of our knowledge of late Paleozoic through middle Tertiary climates, environments, and biotas of North America comes from studies of fossils and geology of the study area for the Oil Shale and Tar Sands PEIS and surrounding regions. Future fossil collections and the resulting research and educational opportunities will include the application of new technologies and will undoubtedly both refine and supplement our present knowledge of the history of life.

The study area for the Oil Shale and Tar Sands PEIS contains 33 mapped bedrock geologic formations and surficial deposits, many of which have been subdivided into members or other subunits, and a variety of surficial deposits. Using the U.S. Department of the Interior, Bureau of Land Management's (BLM's) paleontological resource classification system (BLM 1998), the study area includes 11 Condition 1 areas, 15 Condition 2 areas, and 7 Condition 3 areas. Using the Potential Fossil Yield Classification (USFS 1996), which the BLM was considering as adopting as policy during the writing of this document, the study area includes 0 Class 1 units, 13 Class 2 units, 10 Class 3 units, and 11 Class 4/5 units. Depending upon the sensitivities of affected geologic units, commercial development of oil shale and tar sands has the potential to adversely impact scientifically significant nonrenewable paleontological resources. Adverse impacts can be reduced to below the level of significance through project-specific analyses and, as appropriate, paleontological mitigation. 


\section{INTRODUCTION}

\subsection{PURPOSE AND SCOPE}

This study is a paleontological overview of the areas within Colorado, Utah, and Wyoming where oil shale and tar sands resources are present. It was prepared in support of the Oil Shale and Tar Sands Resource Management Plan Amendments to Address Land Use Allocations in Colorado, Utah, and Wyoming and Programmatic Environmental Impact Statement (PEIS). This PEIS evaluates the potential impacts of alternatives identifying U.S. Department of the Interior, Bureau of Land Management (BLM)-administered lands as available for application for commercial leasing of oil shale resources within the three states and of tar sands resources within Utah. The scope of the analysis of the PEIS also includes an assessment of the potential effects of future commercial leasing. Oil shale resources exist within the Green River Formation in the greater Green River Basin (including Fossil Basin) in southwestern Wyoming and northwestern Colorado, the Piceance Creek Basin in northwestern Colorado, and the Uinta Basin in northeastern Utah. While the PEIS's scope of analysis focuses on the most geologically prospective oil shale resources underlain by federal mineral rights administered by the BLM, this overview report evaluates the larger area encompassed within sedimentary basins that contain rocks of the Green River Formation (Figures 1 and 2). The 11 designated Special Tar Sand Areas (STSAs) evaluated in the PEIS are located in portions of the Uinta Basin and east-central and southeastern Utah (Figure 3 and Table 1). ${ }^{2}$

\subsection{STUDY AREA}

Oil shale deposits are contained within sedimentary deposits of the lacustrine Green River Formation of Eocene age. Deposits of tar sand are contained within the Cutler Group, Kaibab Limestone, Moenkopi Formation, Chinle Formation, Mesaverde Group, Wasatch Formation, Green River Formation, and Uinta Formation (Table 1). In total, the study area includes 17 mapped potentially fossiliferous geologic formations, many of which have been subdivided into members or other subunits, as well as a variety of younger surficial deposits that could be impacted during commercial extraction of hydrocarbon resources from oil shale and tar sands.

2 The 11 STSA deposits that are evaluated in the PEIS are those deposits classified in the 11 sets of geologic reports (minutes) prepared by the U.S. Geological Survey (USGS) in 1980 and 1981, and formalized by Congress in the Combined Hydrocarbon Leasing Act of 1981 (Public Law [P.L.] 97-78). The boundaries of the designated STSAs were determined by the Secretary of the Interior's orders of November 20, 1980

(45 FR 76800-76801) and January 21, 1981 (46 FR 6077-6078). 


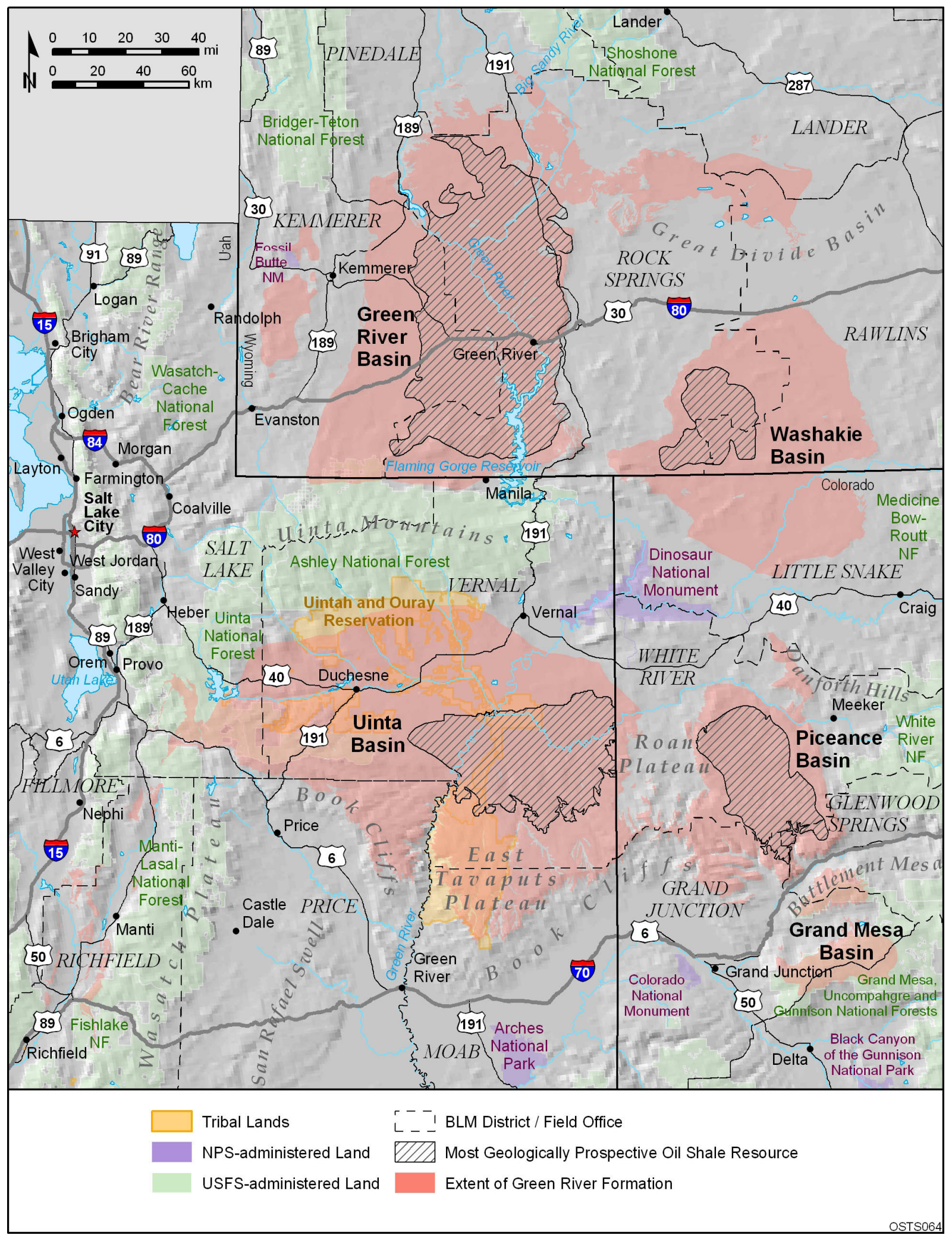

FIGURE 1 Map of the Oil Shale Basins in Colorado, Utah, and Wyoming Evaluated in This Report and the Most Geologically Prospective Oil Shale Resources Evaluated in the Oil Shale and Tar Sands PEIS 


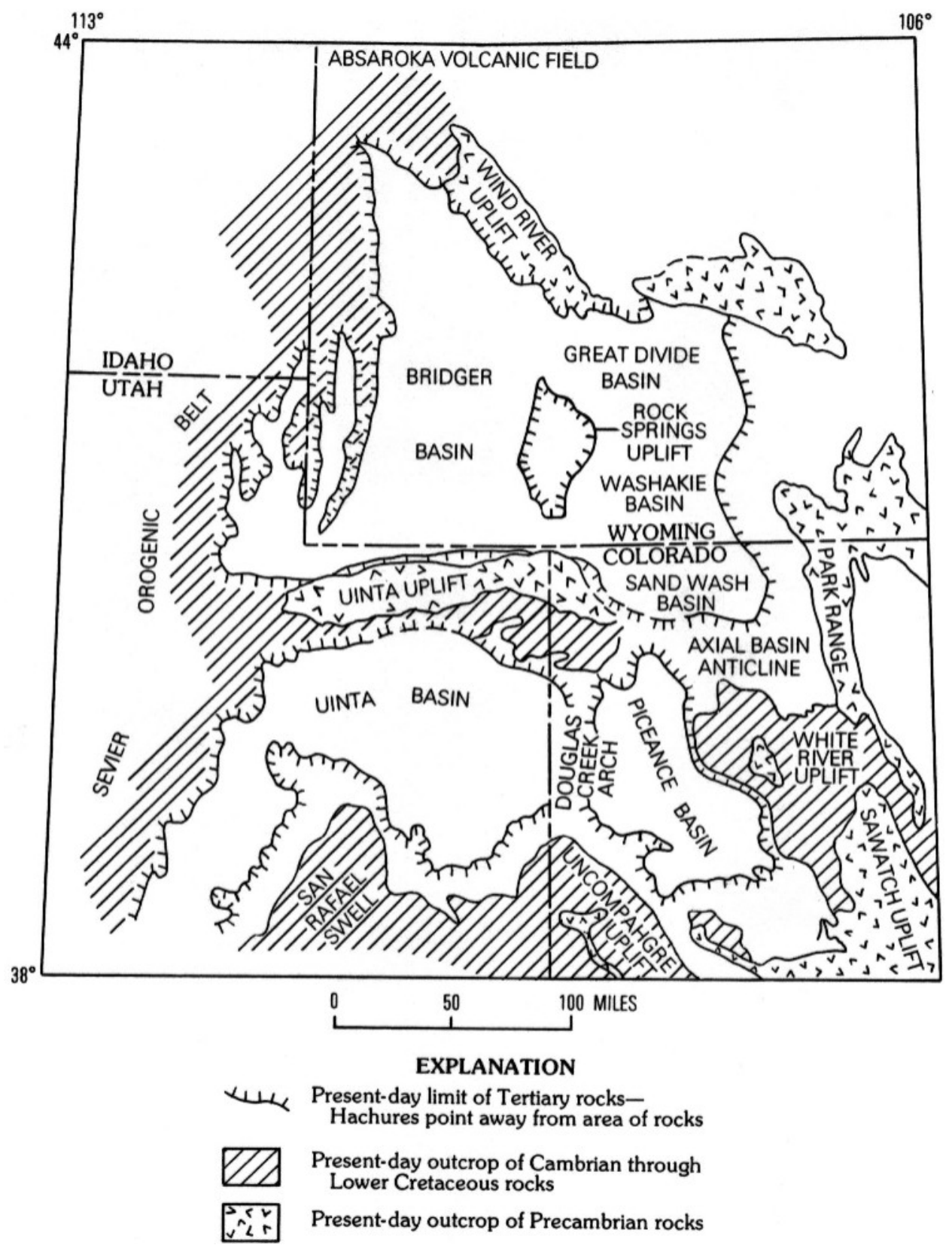

FIGURE 2 Map Showing the Locations of Basins and Uplifts Created during the Laramide Orogeny in Northeastern Utah, Northwestern Colorado, and Southwestern Wyoming (Source: Johnson 1989) (The Greater Green River Basin includes what is shown on the map as the Bridger Basin, Great Divide Basin, Washakie Basin, and Sand Wash Basin. Fossil Basin, unlabeled on the map, is the narrow north-to-south-trending basin located in southwestern Wyoming just to the west of the Bridger Basin.) 


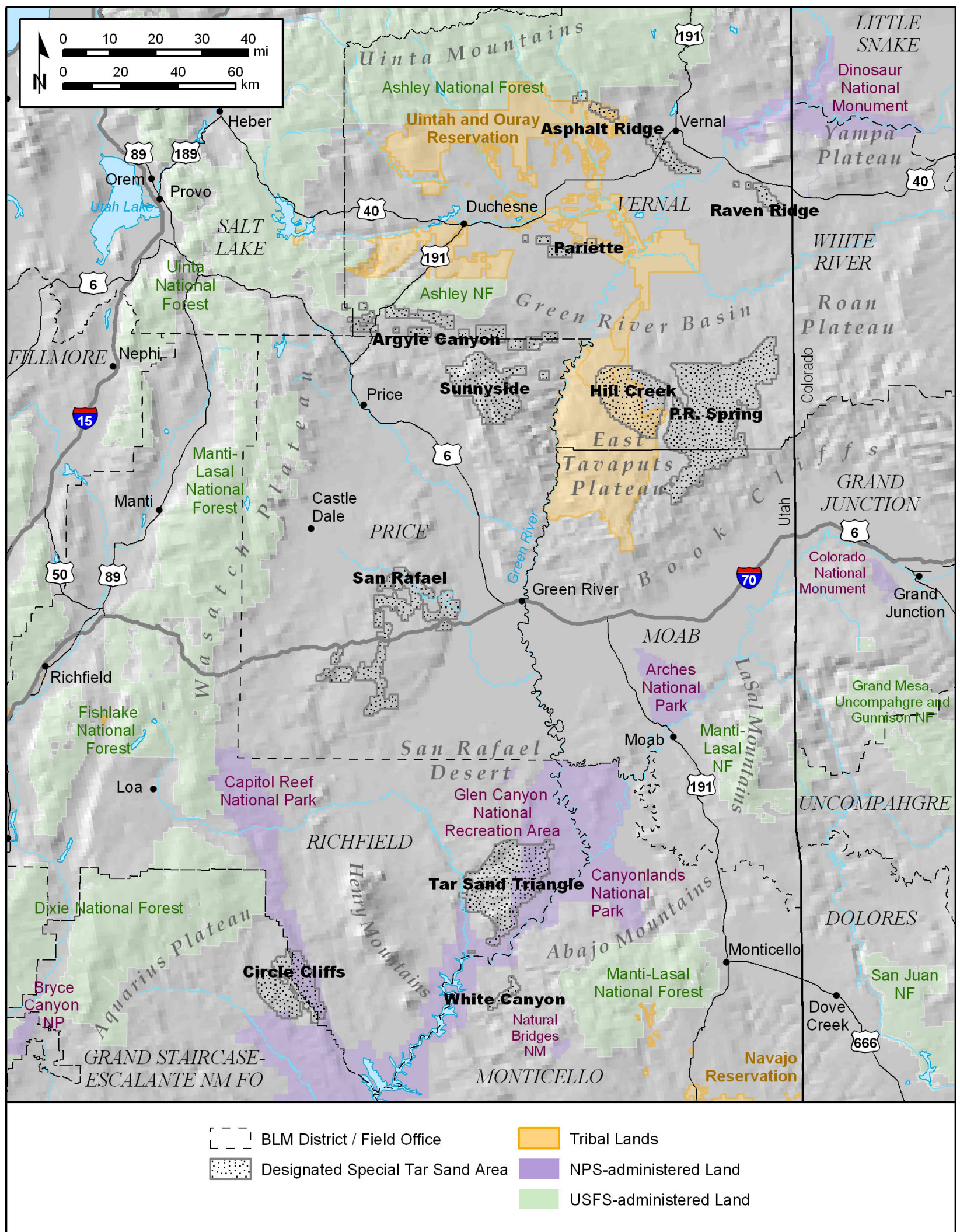

\section{FIGURE 3 Map of Designated STSAs in Utah Evaluated in This Report}


TABLE 1 Summary of STSAs Included in This Study and Their Locations, Ages, and Geologic Provenances

\begin{tabular}{|c|c|c|c|}
\hline Name & Productive Units & Ages of Units & Location \\
\hline $\begin{array}{l}\text { Argyle Canyon- } \\
\text { Willow Creek }\end{array}$ & $\begin{array}{l}\text { Parachute Creek Member, Green River } \\
\text { Formation, Uinta Formation (formerly } \\
\text { Evacuation Creek Member of Green } \\
\text { River Formation) }\end{array}$ & Eocene & $\begin{array}{l}\text { Duchesne County, Uinta } \\
\text { Basin, east-central Utah }\end{array}$ \\
\hline $\begin{array}{l}\text { Asphalt Ridge- } \\
\text { Whiterocks and } \\
\text { Vicinity }\end{array}$ & $\begin{array}{l}\text { Mesaverde Group; Duchesne River } \\
\text { Formation }\end{array}$ & $\begin{array}{l}\text { Cretaceous, } \\
\text { Eocene }\end{array}$ & $\begin{array}{l}\text { Uintah County, Uinta Basin, } \\
\text { northeastern Utah }\end{array}$ \\
\hline $\begin{array}{l}\text { Circle Cliffs } \\
\text { East and West } \\
\text { Flanks }\end{array}$ & $\begin{array}{l}\text { Kaibab Limestone; Torrey Member, } \\
\text { Moenkopi Formation; Shinarump } \\
\text { Member, Chinle Formation }\end{array}$ & Permian, Triassic & $\begin{array}{l}\text { Garfield County, south- } \\
\text { central Utah }\end{array}$ \\
\hline Hill Creek & $\begin{array}{l}\text { Douglas Creek and Parachute Creek } \\
\text { members of Green River Formation }\end{array}$ & Eocene & $\begin{array}{l}\text { Uintah County, Uinta Basin, } \\
\text { northeastern Utah }\end{array}$ \\
\hline Pariette & Uinta Formation & Eocene & $\begin{array}{l}\text { Duchesne and Uintah } \\
\text { counties, Uinta Basin, } \\
\text { northeastern Utah }\end{array}$ \\
\hline P.R. Spring & $\begin{array}{l}\text { Douglas Creek Member, Green River } \\
\text { Formation }\end{array}$ & Eocene & $\begin{array}{l}\text { Uintah and Grand counties, } \\
\text { Uinta Basin, northeastern } \\
\text { Utah }\end{array}$ \\
\hline $\begin{array}{l}\text { Raven Ridge- } \\
\text { Rim Rock and } \\
\text { Vicinity }\end{array}$ & $\begin{array}{l}\text { Parachute Creek Member, Green River } \\
\text { Formation }\end{array}$ & Eocene & $\begin{array}{l}\text { Uintah County, Uinta Basin, } \\
\text { northeastern Utah }\end{array}$ \\
\hline San Rafael Swell & $\begin{array}{l}\text { Black Dragon and Torrey members, } \\
\text { Moenkopi Formation }\end{array}$ & Triassic & $\begin{array}{l}\text { Emery County, east-central } \\
\text { Utah }\end{array}$ \\
\hline $\begin{array}{l}\text { Sunnyside and } \\
\text { Vicinity }\end{array}$ & Wasatch Formation & Eocene & $\begin{array}{l}\text { Carbon County, Uinta } \\
\text { Basin, east-central Utah }\end{array}$ \\
\hline $\begin{array}{l}\text { Tar Sand } \\
\text { Triangle }\end{array}$ & White Rim Sandstone, Cutler Group & Permian & $\begin{array}{l}\text { Garfield and Wayne } \\
\text { counties, southeast central } \\
\text { Utah }\end{array}$ \\
\hline White Canyon & $\begin{array}{l}\text { Hoskinnini Member, Moenkopi } \\
\text { Formation }\end{array}$ & Triassic & $\begin{array}{l}\text { San Juan County, southeast } \\
\text { Utah }\end{array}$ \\
\hline
\end{tabular}

Source: USGS (1980a-k). 


\subsection{DEFINITION AND SIGNIFICANCE OF PALEONTOLOGICAL RESOURCES}

Paleontology is a multidisciplinary science that combines elements of geology, biology, chemistry, and physics in an effort to understand the history of life on earth. Paleontological resources, or fossils, are the remains, imprints, or traces of once-living organisms preserved in rocks and sediments. These include mineralized, partially mineralized, or unmineralized bones and teeth, soft tissues, shells, wood, leaf impressions, footprints, burrows, and microscopic remains. The fossil record is the only evidence that life on earth has existed for more than 3.6 billion years. Fossils are considered nonrenewable resources because the organisms they represent no longer exist. Thus, once destroyed, a fossil can never be replaced. Fossils are important scientific and educational resources because they are used to:

- Study the phylogenetic relationships among extinct organisms, as well as their relationships to modern groups;

- Elucidate the taphonomic, behavioral, temporal, and diagenetic pathways responsible for fossil preservation, including the biases inherent in the fossil record;

- Reconstruct ancient environments, climate change, and paleoecological relationships;

- Provide a measure of relative geologic dating, which forms the basis for biochronology and biostratigraphy, and which is an independent and corroborating line of evidence for isotopic dating;

- Study the geographic distribution of organisms and tectonic movements of land masses and ocean basins through time;

- Study patterns and processes of evolution, extinction, and speciation; and

- Identify past and potential future human-caused impacts on global environments and climates. 


\section{METHODS}

The purpose of this paleontological overview study is to analyze and evaluate the paleontological sensitivities of geologic units within the Area of Potential Effect (APE) for the Oil Shale and Tar Sands PEIS by researching the units' known fossil content, paleontologic significance, stratigraphic relations, and geographic distribution. The scope of the study includes a review of relevant scientific literature, published geologic maps, and unpublished technical reports (some of which the BLM furnished for inclusion in the analysis). Institutional and agency fossil locality record searches were not conducted because of schedule and budgetary constraints. However, the focus on published literature is appropriate for the programmatic level of detail used for this study. The findings of this study are intended to be used to prepare the paleontological resources section of the PEIS. They are also intended to be used by BLM regional paleontologists, and by the staff of affected BLM field offices in Colorado, Utah, and Wyoming to support future project-specific analyses.

The literature search was conducted both at libraries and online. The primary libraries used were the Earth Sciences Library at the University of Colorado at Boulder and the library of the Biodiversity Research Center of the Californias, San Diego Natural History Museum. Online resources included primarily GeoRef and the Chinook library catalogue at the University of Colorado. Electronic copies of some papers were obtained from online services, including EBSCO (www.ebsco.com), BioOne (www.bioone.com), Blackwell (www.blackwellsynergy.com), and GeoScienceWorld (rmg.geoscienceworld.org). The bibliographies (Appendices A and B) are not considered to be comprehensive because of schedule and budgetary constraints; however, it is believed that the most relevant paleontological publications and significant related geologic papers are listed. Bibliographic data were compiled with EndNote 9.0 software and are organized in approximate ascending stratigraphic order within each geographic region covered in this report. References that include more than one formation in their titles are listed in each applicable bibliographic subsection.

For each of the geographic regions covered in this analysis (greater Green River Basin, Piceance Creek Basin, Uinta Basin, and east-central and southern Utah), this report includes a depositional and paleoenvironmental summary, history of paleontological and related geological investigations, and a general discussion of the paleontology and geology of each potentially affected geologic unit. Note that these discussions are focused specifically on the rock units, time intervals, and fossils that could potentially be affected by commercial development of oil shale and tar sands resources, and not on older (i.e., stratigraphically lower) rock units that would not be affected.

Organizationally, this document is designed so that users may select the applicable geographic area for their field office (e.g., Uinta Basin, Utah, or Green River Basin, Wyoming) and obtain the needed information without having to read the entire document. This approach necessitated some degree of repetition of text sections (usually with slight modifications) and references in the bibliography (e.g., for instances in which the same formation occurs in two different oil shale areas or STSAs). 
Both published and unpublished literature in combination with the current BLM classification system (BLM 1998) and the U.S. Forest Service (USFS) Potential Fossil Yield Classification (PFYC) System (USFS 1996), which the BLM was considering as adopting as policy during the writing of this document, were used to compile a list of potentially affected geologic units within each geographic region in the study area. This list includes the age of each unit, typical fossil content, and a resource assessment that uses both classification systems (see Tables 3, 4, 5, and 6, presented in Sections 4.5, 5.5, 6.5, and 7.5, respectively). In this study, Class 4/5 was added to the existing PFYC as a substitute for Classes 4 and 5 . This was done because, by definition, Class 4 units have lowered risks of human- or natural-caused adverse impacts on paleontological resources. At this level of analysis, and lacking sufficient data, it was not possible in most cases to determine whether Class 4 or Class 5 was most appropriate. The combined Class $4 / 5$ was used to address this issue. The resource classification designations presented in this report were made in consultation with BLM regional paleontologists Harley Armstrong, Dale Hanson, and Scott Foss.

As stated in Chapter 1, the APE for this study includes the greater Green River Basin, Piceance Creek Basin, Uinta Basin, and smaller designated areas of east-central and southern Utah that contain tar sands outside of the Uinta Basin. For the analysis, it was essential to include more geologic units than those that actually contain the oil shale and tar sands resources. This is because most of the sedimentary rock units that stratigraphically and/or topographically overlie or intertongue with the oil shale and tar sands reservoir rocks have the potential to contain scientifically significant fossils, and these units could also potentially be impacted by activities related to commercial hydrocarbon extraction.

North American Land Mammal Ages (NALMAs), which are referred to throughout the report, are summarized in Table 2.

In association with the data acquisition phase of this study, a list of geologic maps at various scales that cover the study area was compiled with USGS indexes, library catalogues, and online resources. This list is included in the report as a separate bibliography of geologic maps (Appendix B).

Appendix $\mathrm{C}$ is a compilation of taxonomic lists of known fossils grouped by formation (from generally oldest to youngest) within the PEIS study area. Common names of vertebrate, invertebrate, and plant fossils are included wherever possible and as appropriate. Generic names of fossil taxa were taken from published references as cited on each taxonomic list unless otherwise indicated. For vertebrates, partial higher taxonomy is also provided. For fishes, amphibians, reptiles, and birds, the higher taxonomy of Carroll (1988) was used. For mammals, the higher taxonomy of McKenna and Bell (1997) was used. For invertebrates, plants, and ichnofossils, the higher taxonomy was either omitted or was retained as listed in the source publication.

Six paleontological sensitivity maps of the study area were prepared using resource sensitivity designations supplied by BLM regional paleontologists at a scale of 1:500,000 (Appendix D). These maps show the distribution of geologic units that could potentially be impacted by oil shale and tar sands development. Because this report employed two 
classification systems, the BLM classification system (Conditions 1-3) (BLM 1998) and the PFYC system (Classes 1-5) (USFS 1996), two sets of maps for each affected state, one for each classification system, are provided. A scale of 1:500,000 was chosen because smaller scale geologic mapping was not available for parts of the study area. The sensitivity designations shown on these maps under both classification systems were assigned by BLM regional paleontologists and do not correlate completely with the designations presented in the body of this report. These designations are color coded according to the BLM's scheme. In consultation with the BLM, it was decided that the purpose of these maps is to provide general guidance only, and that using the same scale for all the maps was desirable as it provides consistency. It is anticipated that smaller scale maps, as available, will be employed for project-specific analyses within the study area. It is important to note that at the 1:500,000 scale, the paleontological sensitivity maps do not reflect the level of geologic detail (of formations and members) presented in the body of this report. This lack of detail in the large-scale geologic maps results in the combination of geologic units to which differing paleontological sensitivities are assigned in this report. In constructing the paleontological sensitivity maps, this was dealt with by applying the highest resource sensitivity designation to each combined unit. For example, if members of the Green River Formation are not distinguished on the 1:500,000 scale geologic map, a PFYC Class 5 designation is applied to the entire Green River Formation because at least one of its members is designated as Class 5. It is recommended that users of this report refer to Tables 3, 4, 5 , and 6 for comprehensive lists of potentially affected geologic units and their paleontological sensitivity designations. 
TABLE 2 Summary of North American Cenozoic Land Mammal Ages $^{a}$

\begin{tabular}{|c|c|c|}
\hline \multicolumn{2}{|c|}{ Epoch } & NALMA \\
\hline Pleistocene (1.77) & $\begin{array}{l}\text { Late }(0.25-0.01) \\
\text { Middle }(0.78-0.25) \\
\text { Early }(1.77-0.78)\end{array}$ & $\begin{array}{l}\text { Rancholabrean }(0.25-0.01) \\
\text { Irvingtonian }(1.77-0.25)\end{array}$ \\
\hline Pliocene (5.32) & $\begin{array}{l}\text { Late }(3.58-1.77) \\
\text { Early }(5.32-3.58)\end{array}$ & Blancan (4.7-1.77) \\
\hline Miocene (23.8) & $\begin{array}{l}\text { Late (11.2-5.32) } \\
\text { Middle (16.4-11.2) } \\
\text { Early }(23.8-16.4)\end{array}$ & $\begin{array}{l}\text { Hemphillian }(9.0-4.7) \\
\text { Clarendonian }(11.5-9.0) \\
\text { Barstovian }(15.9-11.5) \\
\text { Hemingfordian (19.0-15.9) } \\
\text { Arikareean }(30.0-19.0)\end{array}$ \\
\hline Oligocene (33.7) & $\begin{array}{l}\text { Late }(28.5-23.8) \\
\text { Early }(33.7-28.5)\end{array}$ & $\begin{array}{l}\text { Arikareean }(30.0-19.0) \\
\text { Whitneyan }(32.0-30.0) \\
\text { Orellan }(33.7-32.0)\end{array}$ \\
\hline Eocene (54.8) & $\begin{array}{l}\text { Late }(37.0-33.7) \\
\text { Middle }(49.0-37.0)\end{array}$ & $\begin{array}{l}\text { Chadronian (37.0-33.7) } \\
\text { Duchesnean (40.5-37.0) } \\
\text { Uintan }(46.0-40.5) \\
\text { Bridgerian }(50.3-46.0) \\
\text { Wasatchian }(55.5-50.3)\end{array}$ \\
\hline Paleocene (65.0) & $\begin{array}{l}\text { Late }(60.9-54.8) \\
\text { Early }(65.0-60.9)\end{array}$ & $\begin{array}{l}\text { Clarkforkian }(56.0-55.5) \\
\text { Tiffanian }(60.9-56.0) \\
\text { Torrejonian }(64.0-60.9) \\
\text { Puercan }(65.0-64.0)\end{array}$ \\
\hline
\end{tabular}

a The vertical axis of the table is not drawn to scale. Beginning and end dates for each age are shown in parentheses in Ma (millions of years before present). In most cases, NALMAs do not correspond precisely with epoch boundaries. Numeric ages taken from Woodburne and Swisher (1995). 


\section{RESOURCE ASSESSMENT GUIDELINES}

Geographic areas and geologic units within the study area for the Oil Shale and Tar Sands PEIS were classified by using two paleontological resource management classification systems. The BLM's General Procedural Guidance for Paleontological Resource Management (BLM 1998) uses the classification system presented in Section 3.1. This manual is currently being revised by the BLM's regional paleontologists, and the PFYC, a system developed by the USFS (1996), is being considered as a replacement for the existing paleontological resource management classification system (BLM Conditions 1-3). The PFYC is presented in Section 3.2. Both of these paleontological resource management classification systems are included in this analysis because the transition from the BLM conditions to the PFYC was not complete at the time of this writing. ${ }^{3}$

\subsection{BLM CONDITIONS 1-3}

Paleontological resource classification is a ranking of areas according to their potential to contain vertebrate fossils or noteworthy occurrences of invertebrate or plant fossils. These rankings are used in land use planning, as well as to identify areas that may warrant special management and/or special designation such as Areas of Critical Environmental Concern. The BLM (1998) classifies public lands on the basis of the potential for paleontological "areas" to contain noteworthy occurrences of fossils by using the following criteria:

- Condition 1: Areas that are known to contain vertebrate fossils or noteworthy occurrences of invertebrate or plant fossils. Consideration of paleontological resources will be necessary if the field office review of available information indicates that such fossils are present in the area.

- Condition 2: Areas with exposures of geological units or settings that have high potential to contain vertebrate fossils or noteworthy occurrences of invertebrate or plant fossils. The presence of geologic units from which such fossils have been recovered elsewhere may require further assessment of these same units where they are exposed in the area of consideration.

- Condition 3: Areas that are very unlikely to produce vertebrate fossils or noteworthy occurrences of invertebrate or plant fossils on the basis of their surficial geology, igneous or metamorphic rocks, extremely young alluvium, colluvium, or eolian deposits or the presence of deep soils. However, if possible it should be noted at what depth bedrock may be expected in order to

3 On October 15, 2007, the BLM issued Instruction Memorandum No. 2008-009 (BLM 2007) regarding the PFYC system for paleontological resources on public lands. The PFYC system will replace the current condition classification as part of a larger effort to update Handbook H-8270-1. The PFYC system is discussed in Section 3.2. 
determine if fossiliferous deposits may be uncovered during surfacedisturbing activities.

Either Condition 1 or Condition 2 may trigger the initiation of a formal analysis of existing data prior to the authorization of land use actions involving surface disturbance or transfer of title. Condition 3 suggests that further paleontological consideration is generally unnecessary.

\subsection{POTENTIAL FOSSIL YIELD CLASSIFICATION}

Occurrences of paleontological resources are closely related to the geologic units that contain them. The potential for finding important paleontological resources can, therefore, be broadly predicted by the presence of the pertinent geologic units at or near the surface. Therefore, geologic mapping can be used as a proxy for assessing the potential for the occurrence of important paleontological resources. The PFYC system was originally developed by the USFS Paleontology Center of Excellence and the Region 2 Paleo Initiative (1996). It has recently been adopted with modifications by the BLM, but remains very similar to the system described below. Differences between the systems are footnoted in the text, but overall, these differences are unlikely to affect the designations in Chapters 4 through 7 of this report. The PFYC system should be utilized for land use planning efforts and for the preliminary assessment of potential impacts and mitigation needs for specific projects.

Under the PFYC system, geologic units are classified on the basis of the relative abundance of vertebrate fossils or uncommon invertebrate or plant fossils and their sensitivity to adverse impacts, with a higher class number indicating a higher potential. This classification should be applied at the geologic formation or member level. It is not intended to be an assessment of whether important fossils are known to occur occasionally in these units (i.e., a few important fossils or localities widely scattered throughout a formation does not necessarily indicate a higher class), nor is it intended to be applied to specific sites or areas. The classification system is intended to provide baseline guidance for assessing and mitigating impacts to paleontological resources. In many situations, the classification should be an intermediate step in the analysis, and should be used to assess additional mitigation needs. For the purpose of this overview study, Class 4/5 was added to the PFYC and replaces Classes 4 and 5 (see Chapter 2 for explanation).

- Class $1: 4$ Geologic units that are not likely to contain recognizable fossil remains. This includes units that are igneous or metamorphic in origin (but excludes tuffs), as well as units that are Precambrian in age or older. Management concern for paleontological resources in Class 1 units is negligible or not applicable. No assessment or mitigation is needed except in very rare circumstances. The occurrence of significant fossils in Class 1 units is nonexistent or extremely rare.

4 In the PFYC system adopted by the BLM (2007), Class 1 is designated as having "Very Low" paleontological potential and sensitivity to adverse impacts. 
- Class $2:^{5}$ Sedimentary geologic units that are not likely to contain vertebrate fossils or scientifically significant nonvertebrate fossils. ${ }^{6}$ This includes units in which vertebrate or significant nonvertebrate fossils are unknown or very rare, units that are younger than 10,000 years before present, units that are eolian in origin, and units that exhibit significant diagenetic alteration. The potential for impacting vertebrate fossils or uncommon invertebrate or plant fossils is low. Management concern for paleontological resources is low, and management actions are not likely to be needed. Localities containing important resources may exist but would be rare and would not influence the classification.

- Class 3:7 Fossiliferous sedimentary geologic units where fossil content varies in significance, abundance, and predictable occurrence, or sedimentary units of unknown fossil potential. These units are often marine in origin with sporadic known occurrences of vertebrate fossils. Vertebrate fossils and uncommon nonvertebrate fossils are known to occur inconsistently, and predictability is known to be low. Class 3 includes units that are poorly studied and/or poorly documented, so that the potential yield cannot be assigned without ground reconnaissance. Management concern for paleontological resources in these units is moderate or cannot be determined from existing data. Surface-disturbing activities may require field assessment to determine a further course of action.

The Class 3 category includes a broad range of potential impacts. Geologic units of unknown potential, as well as units of moderate or infrequent fossil occurrence are included. Assessment and mitigation efforts also include a broad range of options. Surface-disturbing activities will require sufficient assessment to determine whether significant fossil resources occur in the area of a proposed action and whether the action could affect the paleontological resources. Authorizations for any surface-disturbing activities should include the following statement, or one similar in nature:

5 In the PFYC system adopted by the BLM (2007), Class 2 is designated as having "Low" paleontological potential and sensitivity to adverse impacts.

6 Nonvertebrates refers to fossil invertebrates and plants.

7 The PFYC system adopted by the BLM (2007) further divides Class 3 into Class 3a-Moderate Potential and Class 3b-Unknown Potential, with the following abbreviated descriptions:

Class $3 \mathrm{a}$ - Moderate Potential. Units are known to contain vertebrate fossils or scientifically significant nonvertebrate fossils, but these occurrences are widely scattered. The potential for a project to be sited on or impact a signficiant fossil locality is low, but is somewhat higher for common fossils.

Class $3 b$ - Unknown Potential. Units exhibit geologic features and preservational conditions that suggest significant fossils could be present, but little information about the paleontological resources of the unit or the area is known. The units in this class may eventually be placed in another class when sufficient survey and research is performed. 
"The operator shall immediately bring any paleontological resources discovered as a result of operations under this authorization to the attention of the BLM authorized officer. The operator shall suspend all activities in the vicinity of such discovery until notified to proceed by the authorized officer, and shall protect the site from damage or looting. The authorized officer will evaluate, or will have evaluated, such discoveries as soon as possible but not later than five working days after being notified. Appropriate measures to mitigate adverse effects to significant paleontological resources will be determined by the authorized officer after consulting with the operator. The operator is responsible for the cost of any investigation necessary for the evaluation and for any mitigation measures. There is no need to suspend operations if the operator can avoid further impacts to a discovered site, however, the discovery shall be brought to the attention of the authorized officer as soon as possible and protected from damage or looting."

- Class 4: ${ }^{8}$ Class 4 units are Class 5 geologic units (see below) that have lowered risks of human-caused adverse impacts and/or lowered risk of natural degradation. They include bedrock units with extensive soil or vegetative cover, bedrock exposures that are limited or not expected to be impacted, units with areas of exposed outcrop that are smaller than two contiguous acres, units in which outcrops form cliffs of sufficient height and slope so that impacts are minimized by topographic effects, and units where other characteristics are present that lower the vulnerability of both known and unidentified fossil localities.

The potential for impacting significant fossils is moderate to high, and is dependent on the proposed action. The bedrock unit is Class 5, but a protective layer of soil, thin alluvial material, or other mitigating circumstances may lessen or prevent potential impacts to the bedrock resulting from the activity. Mitigation efforts must include assessment of the disturbance, such as removal or penetration of protective surface alluvium or soils, potential for future accelerated erosion, or increased ease of access resulting in greater looting potential. If impacts to significant fossils are anticipated, on-the-ground surveys before authorization of the surfacedisturbing action will usually be necessary. On-site monitoring may also be

8 In the PFYC system adopted by the BLM (2007), Class 4 is designated as having "High" paleontological potential and sensitivity to adverse impacts. It is also further divided into Classes $4 \mathrm{a}$ and $4 \mathrm{~b}$. The description given for the above system is similar to Class $4 \mathrm{~b}$. Class $4 \mathrm{a}$ includes units that are exposed with little or no soil or vegetative cover and extensive outcrop areas with exposed bedrock areas often larger than 2 acres. Paleontological resources may be susceptible to adverse impacts from surface-disturbing actions and illegal collection activities. 
necessary during construction activities. Management prescriptions for resource preservation and conservation through controlled access or special management designation should be considered. Class 4 and Class 5 units are often combined as Class 5 for general application, such as planning efforts or preliminary assessments, as Class 4 is determined from local mitigating conditions and the impacts of the planned action.

- Class 5:9 Highly fossiliferous geologic units that regularly and predictably produce vertebrate fossils or uncommon invertebrate or plant fossils and that are at risk of human-caused adverse impacts or natural degradation. These include units in which vertebrate fossils or uncommon invertebrate or plant fossils are known and documented to occur consistently, predictably, or abundantly. Class 5 pertains to highly sensitive units that are well exposed with little or no soil or vegetative cover, units in which outcrop areas are extensive, and exposed bedrock areas that are larger than two contiguous acres.

Management concern for paleontological resources in Class 5 units/areas is high, because the potential for impacting significant fossils is high. Vertebrate fossils or uncommon nonvertebrate fossils are known from the impacted area or can reasonably be expected to occur in the impacted area. Assessment by a qualified paleontologist is required in advance of surface-disturbing activities or land-tenure adjustments, and mitigation will often be necessary before and/or during surface-disturbing actions. Field surveys before authorization of any surface-disturbing activities will usually be necessary. On-site monitoring may also be necessary during construction activities. Designation of areas of special interest and concern may be appropriate.

9 In the PFYC system adopted by the BLM (2007), Class 5 is designated as having "Very High" paleontological potential and sensitivity to adverse impacts. It is also further divided into Class $5 \mathrm{a}$ and Class $5 \mathrm{~b}$. The definition of Class $5 \mathrm{a}$ is similar to the definition for Class $4 \mathrm{a}$ in footnote 8 , but notes that the unit is frequently the focus of illegal collecting activities. 


\section{GREATER GREEN RIVER BASIN, WYOMING AND COLORADO}

Deposits of oil shale are contained within sedimentary rocks of the Green River Formation. The Green River Formation was deposited in an ancient lake system that existed from the late Paleocene to the middle Eocene Epoch in what is now Colorado, Utah, and Wyoming. The smallest and oldest of these lakes, Fossil Lake, was deposited in Fossil Basin, which is located in the Wyoming overthrust belt just to the west of the Green River Basin in southwestern Wyoming. Lake Gosiute was deposited in the greater Green River Basin, which includes the Green River and Washakie basins in southwestern Wyoming, and the Sand Wash Basin in northwestern Colorado. Lake Uinta was deposited in the Uinta Basin in northeastern Utah and the Piceance Creek Basin in northwestern Colorado.

\subsection{GEOLOGIC SETTING AND DEPOSITIONAL HISTORY}

The greater Green River Basin occupies approximately 20,000 $\mathrm{mi}^{2}$ of southwestern Wyoming and northwestern Colorado (Roehler 1992a). Structurally, it is a large asymmetrical syncline with gently dipping flanks $\left(3^{\circ}\right.$ to $\left.5^{\circ}\right)$ and an approximately north-south axis (Koenig 1960; Roehler 1992a). The greater Green River Basin is divided into four smaller basins by three intrabasin arches. The largest of these arches, the north-south trending Rock Springs uplift, divides the basin into roughly equal halves, with the Green River Basin to the west, and the Great Divide, Sand Wash, and Washakie basins to the east (Figure 4). Although it was apparently never structurally connected to the adjacent Green River Basin, Fossil Basin is included in this section of the report because of its similar age, paleontology, and geology.

The greater Green River Basin (including Fossil Basin), Uinta Basin, and Piceance Creek Basin began forming during the Laramide orogeny, a period of tectonism in western North America that was initiated during the late Cretaceous and continued episodically for approximately 30 million years until the late Eocene. In addition to the uplifting of surrounding mountain ranges, Laramide tectonism resulted in rapid subsidence in basin depositional centers, and lacustrine and fluvial deposition in these intermontane basins was mostly continuous. Lacustrine deposition was characterized by a complex history of expansions and contractions in response to basin subsidence, climatic conditions, and volcanic activity (Murphey 2001; Murphey and Evanoff 2007; Roehler 1992b). The last major Laramide-associated event in the greater Green River Basin was the final late Eocene rise of the Rock Springs uplift (Roehler 1992a).

The greater Green River Basin was filled with Paleocene and Eocene fluvial and lacustrine sediments, and, during the Eocene, sedimentation appears to have been continuous in most of the basin. The oldest Tertiary rock units in the greater Green River Basin, the Paleocene Fort Union Formation and the early Eocene Wasatch Formation, are exposed mostly along its eastern and western flanks. The Green River Formation is the most well known of the formations present within the greater Green River Basin because of its economic potential and locally wellpreserved fossils. Occupying the center of the basin in the shape of a large, irregular lens 


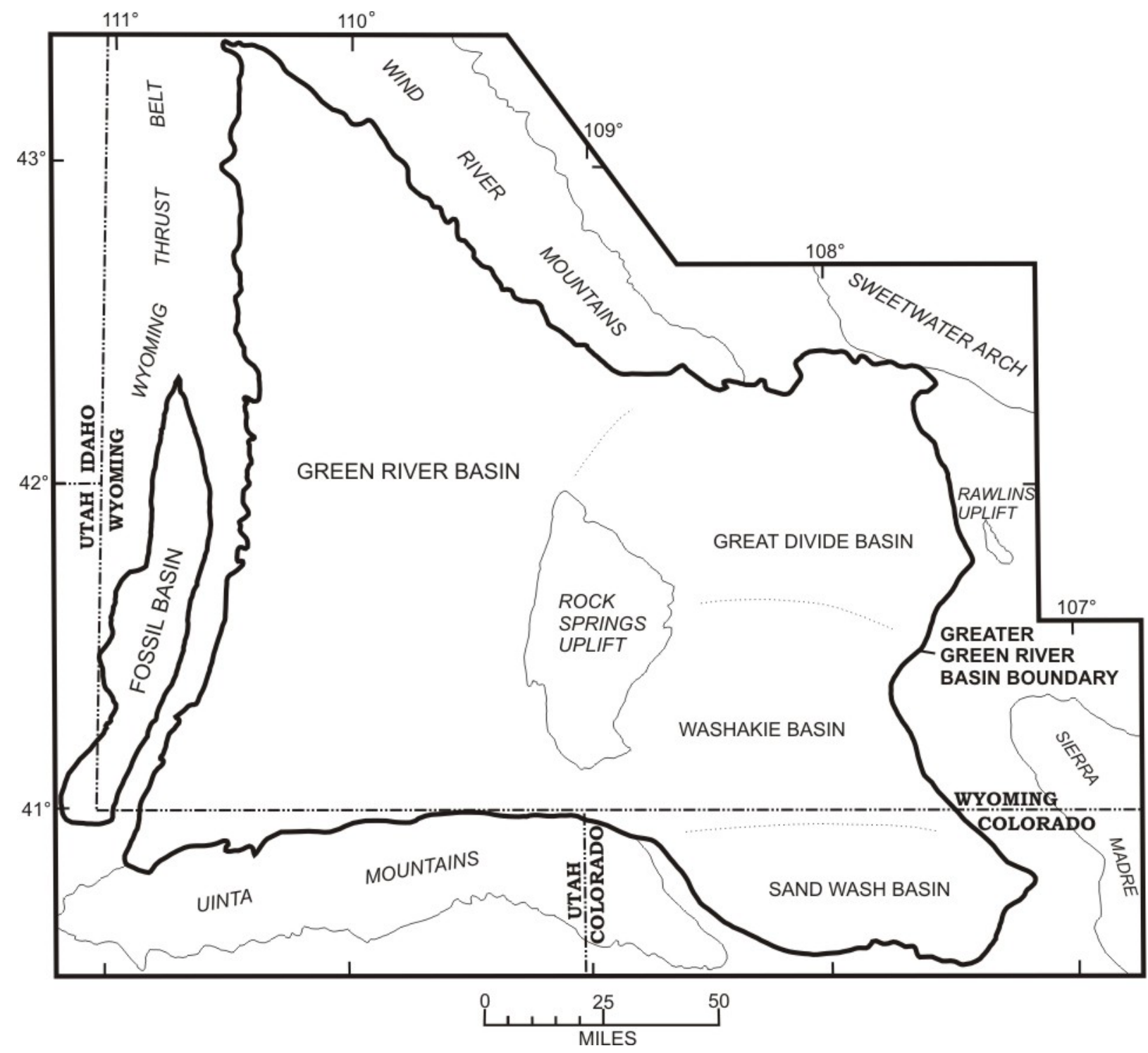

FIGURE 4 Index Map of the Greater Green River Basin Showing Depositional Subbasins and Major Structural Features (modified from Roehler 1992a)

(Bradley 1964a; Roehler 1992a, 1993), it is the result of at least five million years of lacustrine deposition, lasting from about 53.5 to 48.5 megannum (Ma) (Smith 2001). Lithologically, the Green River Formation in the greater Green River Basin is a complex sequence of limestone, shale, and sandstone beds with a maximum thickness of approximately 2,750 ft (Roehler 1993). It was deposited lateral to and above the predominantly fluvial Wasatch Formation, and lateral to and below the fluvial and lacustrine Bridger and Washakie formations. The Laney Member is the uppermost member of the Green River Formation in Wyoming and represents the final phase of development of Lake Gosiute. The Bridger, Green River, and Washakie formations are locally and unconformably overlain by the Oligocene Bishop Conglomerate and the middle-to-lateMiocene Browns Park Formation. Since the Eocene, the greater Green River Basin has been modified by erosion, regional uplift, and normal faulting, but the basic structure of the basin 
remains the same as it was during deposition of the Wasatch, Green River, Washakie, and Bridger formations.

Like the Greater Green River Basin, Fossil Basin was filled with lacustrine and fluvial sediments. Fossil Lake was by far the smallest and shortest-lived of the Eocene intermontane lakes, persisting for several million years and, at its maximum extent, covering an area of several hundred square miles (Grande 1984). In the Fossil Basin, the Green River Formation consists of the Fossil Butte and Angelo members, which are stratigraphically separated by the mudstone tongue of the Wasatch Formation (Buchheim 1994). Most of the fossil fishes for which the Green River Formation in Fossil Basin is world renowned are preserved in the middle unit of the Fossil Butte Member in finely laminated kerogenous carbonate beds.

The Washakie Basin is a high, structural, and topographic intermontane basin filled with mostly Eocene lacustrine sediments of the Green River Formation and predominantly fluvial sediments of the Wasatch and Washakie formations that occupies approximately $4,000 \mathrm{mi}^{2}$ of southern Wyoming from near the Colorado border to approximately 40 mi north (Turnbull 1978). It is bounded by the Rock Springs uplift to the west, the Wamsutter arch to the northeast, and the Cherokee Ridge to the south (Roehler 1992a; Turnbull 1978). The Cherokee Ridge is a younger structural arch that separates the Washakie Basin from the Sand Wash Basin, and this ridge is partly capped by the Browns Park Formation. The Sand Wash Basin is a southern subbasin of the Washakie Basin that is approximately $600 \mathrm{mi}^{2}$ in size. It is located entirely within Moffat County, Colorado. With mammalian fossils representative of the early part of the Uintan NALMA, the Washakie Formation in the Washakie and Sand Wash basins includes the youngest Eocene-age rocks in the greater Green River Basin.

\subsection{PALEOENVIRONMENTAL SUMMARY}

Numerous studies based on paleontological and geological evidence have concluded that the Eocene-age rock units in the greater Green River and Fossil basins were deposited in warm temperate, subtropical, and tropical climatic conditions (Roehler 1993). Perhaps the most reliable information concerning paleoclimates comes from analysis of plant mega- and micro-fossils. According to Leopold and MacGinitie (1972), early Eocene floras (based on palynology of samples collected from the Niland Tongue of the Wasatch Formation and the Luman and Tipton tongues of the Green River Formation) suggest a humid subtropical to warm temperate climate with summer rainfall and only mild frost and with a mean annual temperature of $55^{\circ} \mathrm{F}$. Nichols (1987) concluded that the climate of the basin floor during deposition of the Niland Tongue was subtropical, without freezing temperatures.

The earliest middle Eocene climates pertaining to the Cathedral Bluffs Tongue of the Wasatch Formation and the Wilkins Peak Member of the Green River Formation were interpreted as generally hot and dry (Leopold and MacGinitie 1972). Climatic conditions in the early-middle Eocene during deposition of the lower part of the Laney Member of the Green River Formation were characterized as warm and humid with tropical affinities. Floras of the upper part of the Laney Member indicate a change to cooler, subhumid conditions (Leopold and MacGinitie 1972). Both pollen and leaf data from the Washakie Formation indicate a dry but 
temperate climate (Leopold and MacGinitie 1972). Roehler (1993) reported that in a written communication MacGinitie reinterpreted temperature and precipitation ranges on the basis of palynology of samples collected from the Washakie Basin by Roehler (1992a). His reinterpretation estimated mean annual temperatures of $65^{\circ} \mathrm{F}$ during the early Eocene, $63^{\circ} \mathrm{F}$ during the earliest middle Eocene, and $62^{\circ} \mathrm{F}$ during the middle Eocene. Average annual precipitation was estimated at more than 40 in. during the early Eocene, 25 to 35 in. during the earliest middle Eocene, and 15 to 20 in. in the middle Eocene. Sedimentological evidence of a more arid climate during the middle Eocene (transitional Uintan NALMA) includes massive beds of gypsum capping the Turtle Bluff Member of the Bridger Formation (Murphey 2001; Murphey and Evanoff 2007). The shift from dominantly tropical forest environments to moreopen, savanna-like conditions in the Eocene intermontane basins during late Bridgerian (early-middle Eocene) and Uintan (middle Eocene) times has also been studied by using ecological diversity analysis applied to mammalian faunas (Townsend 2004; Murphey and Townsend 2005).

During the Paleocene and earliest Eocene, deposition in the greater Green River and Fossils basins was predominantly fluvial, with terrigenous and volcaniclastic sediments accumulating in river drainages and on adjacent floodplains. The onset of lacustrine deposition associated with the Green River lake system may have commenced as early as the late Paleocene (Grande and Buchheim 1994). Lake sediments accumulated on broad floodplains of low topographic relief, and the lake waters expanded and contracted numerous times over the next approximately five million years in response to climatic changes, tectonic influences, and episodic volcanic activity. Most volcaniclastic sediments were apparently transported from distant sources such as the Absaroka Volcanic Field in what is now northwestern Wyoming. These sediments were washed into the basin in rivers and streams and deposited fluvially. Some volcaniclastic sediments were transported into the basin via eolian processes and deposited as ash fall in lakes and on floodplains. A large influx of fluvially transported volcaniclastic sediment is believed to have led to the final middle Eocene filling of Lake Gosiute (Mauger 1977; Murphey 2001, Murphey and Evanoff 2007; Surdam and Stanley 1979). Mauger (1977) and Surdam and Stanley (1979) estimated that Lake Gosiute was extinguished about $44 \mathrm{Ma}$.

As indicated by fossil distribution and diversity, the Green River lakes and their forested margins provided highly favorable habitats and preservational environments for both aquatic and terrestrial organisms. Lake margin habitats, riparian corridors, and floodplains were typically covered with luxuriant vegetation, including a variety of trees and bushes such as palm, cinnamon, oak, maple, lilac, and hazel, as well as cattails and rushes. Insects of many varieties lived in the lakes and forests and are locally well preserved in lake sediments. A variety of terrestrial and aquatic mollusks (clams and snails) are also known to have inhabited the Green River lakes (Hanley 1974). Crayfish, prawn, and ostracods inhabited the warm lake waters, as did a diversity of fish species, including relatives of the herring, perch, paddlefish, bowfin, gar, catfish, and stingray (Grande 1984; Grande and Buchheim 1994; McGrew and Casilliano 1975). Frogs, crocodiles, and turtles were common residents of shallower proximal shoreline waters. A diversity of reptile species, including tortoise, lizards, and snakes, inhabited the forests surrounding Eocene lakes and ponds. Flamingos, hawks, rails, stone curlews, and other bird species frequented the forests, wetlands, and lakes (Murphey et al. 2001). The forests teemed 
with the primitive ancestors of many modern mammalian groups, including rodents, insectivores, bats, primates, perissodactyls (horse, rhinoceros, and tapir), and carnivores, as well as more bizarre archaic forms such as creodonts, brontotheres, and massive six-horned uintatheres (Gazin 1976; Grande and Buchheim 1994; Gunnell and Bartels 1994; McGrew and Casilliano 1975; Murphey et al. 2001).

The fossil vertebrate, insect, mollusk, and plant assemblages of the greater Green River Basin provide an unprecedented opportunity to study Eocene paleocommunities and paleoenvironments. Indeed, studies of these fossils and the rocks in which they are preserved are the source of much of our knowledge of the Eocene Epoch of North America. The vertebrate faunas are of particular scientific importance because, among other things, they represent an exceptional record of early Tertiary mammalian evolution and diversification spanning the Wasatchian, Bridgerian, and earliest Uintan NALMAs.

\subsection{PREVIOUS PALEONTOLOGICAL WORK AND RELATED INVESTIGATIONS}

John Colter, who traveled to the headwaters of the Green River in 1807 , was probably the first white man to visit the Green River Basin (Chadey 1973). Hundreds of subsequent trappers and explorers traversed the basin during the first half of the nineteenth century, and a number of records of these early explorations make reference to fossils and coal (Roehler 1992a). The earliest scientific observations on the geology of the Green River Basin were made by Army Lt. John C. Fremont. After entering the basin through South Pass at the southern end of the Wind River Mountain, Fremont (1845) described varicolored rocks (now known as Eocene-age Wasatch Formation) along the Big Sandy and New Fork rivers. He also collected fossil shells from near Cumberland Gap (Veatch 1907). The earliest vertebrate fossils reported from the Green River Basin were fishes discovered in what is now known as the Green River Formation. In 1856, Dr. John Evans collected a specimen of a fossil fish from an unknown Green River Formation locality west of Green River City. He sent this specimen to paleontologist Joseph Leidy in Philadelphia for study, and Leidy named it Clupea humilis (later renamed Knightia humilis) (West 1990). Hayden (1871) described the discovery of a locality he referred to as the "petrified fish cut" along the main line of the Union Pacific Railroad about 2 mi west of Green River. Employees of the railroad had initially discovered the locality and later turned many specimens over to Hayden. Paleontologist E.D. Cope described the fish fossils from the petrified fish cut in Hayden's (1871) expedition report. Peale (1879) was the first to mention fish fossils from the Green River Formation in Fossil Basin (McGrew and Casilliano 1975).

The initial discovery of mammalian fossils in the Green River Basin was probably made by a long-time local resident. Trapper Jack Robinson (also called Robertson) found what he described as a "petrified grizzly bear" sometime in the late 1860 s in what is now called the Bridger Formation but had initially been named the "Bridger Group" by Ferdinand V. Hayden in 1869. This story was related to Joseph Leidy by Judge William Carter of Fort Bridger as an explanation for the name "Grizzly Buttes," an area 10 to 15 mi southeast of Fort Bridger where fossils were particularly common. (The name Grizzly Buttes has since disappeared from the local geographic vocabulary.) 
Several government geological and topographical surveys with specific but overlapping territories were operating in the southern Green River Basin between 1867 and 1879. Hayden and his party collected along the Henrys Fork valley and further north in the vicinity of Church Buttes in 1870 as part of the 1867 to 1878 U.S. Geological and Geographical Survey of the Territories (Hayden 1873). Fossils collected by Hayden's group were sent to Joseph Leidy in Philadelphia for study and were described in his 1873 monograph on fossil vertebrates. Later paleontological studies for the Hayden Survey were carried out by E.D. Cope. Under the direction of John Wesley Powell, the U.S. Geological and Geographical Survey of the Territories, Second Division (1875-1876), worked along the Henrys Fork River in 1869, and in a corridor 10 to $20 \mathrm{mi}$ wide on either side of the Green River in 1871 (Powell 1876). The U.S. Geological Survey of the Fortieth Parallel (1867-1872), directed by Clarence King, worked in the Green River Basin in 1871 and 1872. The fossils collected by the King Survey were sent to O.C. Marsh for description. Most of the fossils collected during these surveys were discovered in the Bridger Formation.

Many of the early scientific expeditions to the Green River Basin were based out of Fort Bridger, an Army post since the 1857 Mormon War that was originally set up as a trading post in 1843 by trapper and guide Jim Bridger and his partner Louis Vasquez. Judge Carter and Dr. J. Van A. Carter, later residents of Fort Bridger, maintained an active correspondence with Joseph Leidy in Philadelphia during the late 1860s and early 1870s. This correspondence included mailing fossils to Leidy, which were described in subsequent publications (Leidy 1869, 1871, 1872a,b, 1873). Leidy, who is often regarded as the father of North American vertebrate paleontology (Lanham 1973), named the first Bridger Formation fossil to be formally described, the omomyid primate Omomys carteri, after Dr. Carter (Leidy 1869). Omomys carteri was also the first-described fossil primate from North America.

Early reports of fossils from the Green River Basin did not go unnoticed by rival paleontologists O.C. Marsh and E.D. Cope. The incidents that set the stage for the long and bitter conflict between these two men began in the Green River Basin while they were prospecting in the Bridger Formation in 1872. Sometimes referred to as the "bone wars," the dispute between Marsh and Cope lasted for more than 30 years and included efforts by each man to destroy the scientific reputation and integrity of the other. This conflict soured Leidy's interest in paleontology and led to his eventual abandonment of the discipline.

Professor Marsh was the first professional paleontologist to collect fossils from the Bridger Formation; he brought crews with him from Yale College for four consecutive summers from 1870 to 1873 . Leidy's only excursion to the West took place in 1872, when he visited the Bridger badlands guided by the Carter brothers of Fort Bridger. Cope's only visit to the Bridger badlands occurred in 1872, while Cope was attached to the Hayden survey as the paleontologist. This visit infuriated Marsh, who, at the time, considered the Green River Basin and Bridger Formation his exclusive fossil-collecting territory. By the late 1870s, Cope and Marsh had left the Green River Basin for good, although both men independently and at different times retained the services of paid fossil collector Sam Smith (West 1990).

Other early fossil collectors who visited the Green River Basin in 1877 and 1878 included H.F. Osborn, W.B. Scott, and F. Speir for Princeton University. Scott returned to the 
area with Speir in 1886. Jacob Wortman and J.W. Gidley collected for the American Museum of Natural History (AMNH) in 1893. The early fossil-collecting expeditions to the Green River Basin resulted in large collections of fossils primarily from the Bridger Formation at the Philadelphia Academy of Natural Sciences (Leidy), Yale University (Marsh), the AMNH (which purchased Cope's collection just before the turn of the century), and Princeton University (Osborn, Scott, and Speir). Unfortunately, these early collectors paid little attention to the stratigraphic provenance of the fossils they collected. Their collections do, nevertheless, contain the holotypes of most presently recognized Bridgerian mammal taxa.

In 1902, Henry Fairfield Osborn, who was then the USGS paleontologist, initiated the first program of stratigraphic fossil collection to take place in the Green River Basin and one of the first in North America. Osborn charged Walter Granger and William Diller Matthew of the AMNH with the task of carrying out the study. Matthew was also directed to find a uintathere to display at the AMNH. The AMNH party, led by Granger, worked in the Bridger basin from 1903 to 1906 (Matthew 1909). The second halves of the 1903 and 1905 field seasons were devoted to mapping and describing the stratigraphy of the Bridger Formation, while the remainder of the time was spent searching the badlands for fossils. The efforts of the AMNH parties over these four years resulted in an excellent fossil collection that was, for its time, very well documented stratigraphically.

These AMNH expeditions also resulted in the first paper to be published on the geology of the Bridger Formation, which was authored by William J. Sinclair (1906), who had joined the AMNH field party for the summer of 1905. In Matthew's classic 1909 monograph, The Carnivora and Insectivora of the Bridger Basin, Middle Eocene, the geology of the Bridger Formation was described briefly, and a system of stratigraphic subdivisions for the formation was introduced. These subdivisions, Bridger A-E, were based on areally extensive limestones, which he called "white layers."

Following the early fossil-collecting expeditions of the nineteenth century and initial scientific field studies conducted by AMNH crews in the early twentieth century, the Bridger Formation in the Green River Basin has remained the focus of almost continuous paleontologic inquiry because of its abundant and diverse vertebrate fossils, although Matthew's (1909) original stratigraphy was only recently refined. West (1990) wrote an excellent historical summary of vertebrate paleontological work in the Green River Basin from 1840 to 1910. A thorough review of the history of paleontologic and stratigraphic investigations on the Bridger Formation in the Green River Basin was compiled by Murphey (2001) and Murphey and Evanoff (2007). As excerpted from these and other publications, important paleontological and related geological investigations that have taken place in the Green River Basin during the twentieth and early twenty-first centuries are summarized below.

H.F. Osborn (1929) devoted considerable discussion to the Bridger Formation and its fossils in his monograph, The Titanotheres of Ancient Wyoming, Dakota, and Nebraska. H.E. Wood (1934) divided the Bridger Formation into two members. The Blacks Fork Member corresponds to Matthew's Bridger A and B, and the Twin Buttes Member corresponds to Matthew's Bridger C and D, with the Sage Creek White Layer marking their boundary (Figure 5). Contrary to rules of stratigraphic nomenclature, these members were defined on 
perceived faunal differences rather than lithologic differences. The informal usage of the terms "Blacksforkian" and "Twinbuttean" as land mammal subages derives from the names of the two Bridger members. Under the direction of J.W. Gidley, followed by C.L. Gazin, the Smithsonian Institution began an active collecting program in the Bridger Formation beginning in 1930. Gazin was active in the Green River Basin from 1941 to 1968. This period of activity resulted in a relatively large and well-documented collection that was the subject of numerous publications by Gazin focused primarily on the systematic paleontology of Bridgerian mammal fossils (e.g., 1934, 1946, 1949, 1957, 1958, 1965, 1968, and 1976).

P.O. McGrew and R. Sullivan worked on the stratigraphy and paleontology of the Bridger A in the late 1960s and published the results of their work in 1970. R.M West began an active collecting program for the Milwaukee Public Museum in 1970 and worked in the basin until the late 1970s. West's work, which also resulted in a large number of paleontological publications, included the use of screen-washing techniques to collect microvertebrates, a portion of the fauna that had not been previously well sampled. Like Wood (1934) and Koenig (1960), West (1976) noted difficulties with the correlation of Matthew's white layers across the basin and suggested that a bipartite division of the Bridger into upper (Twin Buttes) and lower (Blacks Fork) members was most appropriate. West and Hutchison (1981) named Matthew's Bridger E the Cedar Mountain Member, adding a third member to the Bridger Formation. Paleontological and geological studies of Tabernacle Butte, an isolated remnant of the Bridger Formation of late Bridgerian age with an important fossil fauna, were published by McGrew (1959), McKenna et al. (1962), and West and Atkins (1970).

Evanoff et al. (1998), Murphey et al. (1999), Murphey (2001), and Murphey and Evanoff (2007) significantly refined Matthew's (1909) Bridger Formation stratigraphic scheme. Their work included the addition of newly described marker units; the establishment of new stratigraphic subdivisions and correlation of marker units across the southern part of the basin where the most complete stratigraphic sequence is exposed; descriptions of detailed stratigraphic sections measured through the Bridger B, C, D, and E; renaming of the Cedar Mountain Member to the Turtle Bluff Member in order to conform with the rules of stratigraphic nomenclature; stratigraphic positioning of more than 500 fossil localities; isotopic dating of four ash-fall tuffs; and geologic mapping of more than $600 \mathrm{mi}^{2}$ of the southern Green River Basin at a scale of 1:24,000 (see Section 4.4.3). Brand et al. (2000) have completed detailed studies of fossil turtle taphonomy in the Bridger Formation and is in the process of publishing a series of geologic maps, at the 1:24,000 scale, of a large area of the central Green River Basin where rocks of the Blacks Fork Member of the Bridger Formation are well exposed. Buchheim et al. (2000) have studied lacustrine-to-fluvial floodplain deposition in the Bridger Formation (Unit B).

U.S. Geological Survey geologists have made significant contributions to geologic investigations in the greater Green River Basin. Over his long career, W.H. Bradley (1926a,b, 1945, 1959, 1964a,b, 1969) mapped, described, and correlated strata and studied various other aspects of the Green River Formation and associated Eocene-age rock units in Wyoming, Colorado, and Utah. H.W. Roehler, with his impressive 50-year career, published a series of detailed papers on his stratigraphic work in the Green River Formation and other Eocene-age rock units in the greater Green River Basin, including the Wasatch, Bridger, and Washakie formations $(1973,1985,1992 a, b, c, 1993)$. Other important contributions to the stratigraphy and 
sedimentology of the Green River Formation in Wyoming, Colorado, and Utah were published by Surdam and Stanley (1980a,b).

Because of its locally exquisite fossil preservation, most of the paleontological work in the Green River Formation of the greater Green River Basin has focused on Fossil Basin, although Green River Formation fossil localities are known across southwestern Wyoming. Efforts to establish the lithostratigraphic and chronostratigraphic framework of the Fossil Basin included the work of Veatch (1907), Schultz (1914), Rubey at al. (1968a,b), and Oriel and Tracey (1970). More recent geologic and paleontologic work has focused on the stratigraphy, paleoenvironments, lithofacies, and paleontological and sedimentological variation of Fossil Lake (Buchheim and Surdam 1981; Buchheim 1994; Grande and Buchheim 1994). Grande (1979, 1980a,b, 1982, 1984, 1985, 1987, 1989, 1991, 1998, 1999, 2001) has published extensively on the fossil fish faunas of Fossil Basin. The area surrounding Fossil Basin continues to be commercially mined for vertebrate fossils (primarily fish).

Numerous paleontological publications have focused on the fauna of the Wasatch Formation in the greater Green River Basin. This unit is particularly well exposed in the overthrust belt and in the Washakie Basin, and it intertongues with members of the Green River Formation. The Wasatch intertongues are of varying ages and fossil content. Early paleontological work in the Wasatch Formation in the greater Green River Basin includes that of Osborn and Wortman (1892) and Granger and Simpson (1928). A highly diverse mammalian fauna from the Sand Wash Basin in northwestern Colorado was described by McKenna $(1955,1958,1960)$. Examples of other studies of Wasatch Formation paleontology and geology include West and Dawson (1973) on the fossil mammals of the Cathedral Bluffs Tongue; Savage and Waters (1978) and Williams and Covert (1994) on new fossil primates; Gingerich and Dorr (1979) and Dorr and Gingerich (1980) on the mammalian paleontology and geology of the Chappo Member (middle-late Paleocene age) of the Wasatch Formation in the LaBarge area; Gauthier (1982) on early-Eocene lizards; Rich et al. (2001) on the fern Marsilea; and Zonneveld et al. (2000a) on early-Eocene fossil vertebrates of the southwestern Green River Basin. Recent work by Gunnell and colleagues has focused on the vertebrate paleontology, stratigraphy, and paleoecology of the Wasatch Formation in Fossil Butte National Monument (Gunnell et al. in press).

Early paleontological work in the Washakie Formation led to historically important but sometimes poorly documented fossil collections at the American Museum of Natural History, the Carnegie Museum, Yale Peabody Museum, and the University of California at Berkeley. Much of the paleontological work in the Washakie Formation in the Washakie Basin from the 1940s to the late 1970s was conducted by Rainer Zangerl and William Turnbull of the Field Museum of Natural History in Chicago and resulted in numerous publications (e.g., Turnbull 1972, 1978, 2004). These efforts led to a large and stratigraphically well-documented fossil collection. More recent paleontologic and stratigraphic work in the Washakie Formation was completed by Flynn (1986), McCarroll et al. (1996), and McCarroll and Turnbull (1996). Stucky et al. (1996) completed an important study on the magnetic stratigraphy, sedimentology, and mammalian paleontology of the Washakie Formation in the neighboring Sand Wash Basin. 
In general, the lithostratigraphic, biostratigraphic, and geochronologic interrelationships of the Eocene rock units and fossils within the greater Green River Basin of Wyoming and their stratigraphic correlation with Eocene rock units in the Uinta and Piceance Creek basins represent a complex problem that remains the subject of active investigation for geologists and paleontologists. Continued paleontologic and geologic work in the greater Green River Basin will greatly improve our understanding of this complex depositional system, as well as its preserved paleoenvironments and fossil remains.

\subsection{GEOLOGIC UNITS AND PALEONTOLOGICAL RESOURCES}

The portion of the Oil Shale and Tar Sands PEIS study area that lies within the greater Green River Basin in southwestern Wyoming and northwestern Colorado contains six mapped bedrock geologic units (Bradley 1945, 1961; Bryant 1992; Courtright and Braddock 1989; Dover and M'Gonigle 1993; Love and Christiansen 1985; M'Gonigle and Dover 1992; Nichols and Bryant 1990; Oriel and Platt 1980; Privrasky 1963; Roehler 1985; Rowley et al. 1985). These include, from oldest to youngest, and in approximate stratigraphic order, the Wasatch Formation, Green River Formation, Bridger Formation, Washakie Formation, Bishop Conglomerate, and Browns Park Formation. These bedrock units are locally mantled by younger surficial deposits of Holocene and Pleistocene age, which consist of alluvium, colluvium, landslide deposits, sand dune deposits, pediment deposits, and alluvial fan deposits.

In the following subsections (Sections 4.4.1 through 4.4.7), the geology and paleontology of the geologic units within the greater Green River Basin are discussed, and their paleontological sensitivities are evaluated. Previous and more-specific paleontological inventories of portions of southwestern Wyoming have been previously prepared for the BLM by McGrew and Bown (1976, 1977), Geo/Resource Consultants (1984), and Robinson et al. (2000). These documents are on file at the BLM Wyoming State Office. Additional fossil locality records may be on file at BLM field offices and at major museums throughout the United States.

\subsubsection{Wasatch Formation}

Within most of the greater Green River Basin exclusive of Fossil Basin, the early and early-middle Eocene Wasatch Formation has been subdivided into the following units: basal conglomerate, LaBarge Member, New Fork Tongue, Niland Tongue, Main Body, Upper Member, and Cathedral Bluffs Tongue (Dover and M'Gonigle 1993; M'Gonigle and Dover 1992; Roehler 1992b). An additional unit, the Hiawatha Member, occurs in the northern Sand Wash Basin of northwestern Colorado in the southeastern part of the greater Green River Basin. In the westernmost part of the Green River Basin and in Fossil Basin, the Wasatch Formation has been subdivided as follows: basal conglomerate, lower member, calcareous member, sandstone tongue, mudstone tongue, Bullpen Member, Tunp Member, and Main Body (McGrew and Casilliano 1975; M'Gonigle and Dover 1992).

The name Wasatch was originally applied to a sequence of variegated sand, clay, and conglomerate beds located on the east side of the Wasatch Mountains in Wyoming. As reported 
by Hayden (1869), "immediately west of Fort Bridger commences one of the most remarkable and extensive groups of Tertiary beds seen in the west. They are wonderfully variegated, some shade of red predominating. This group, to which I have given the name of Wasatch Group, is composed of variegated sands and clays. Very little calcareous matter is found in these beds." Currently, the USGS has extended the Wasatch Formation to include early (and some middle) Eocene-age fluvial deposits that interfinger with lacustrine deposits of the Green River Formation in Colorado, Utah, and Wyoming.

The Wasatch Formation is typically composed of variegated green, red, purple, and brown claystone, mudstone, siltstone, sandstone, and conglomerate (Franczyk et al. 1990; Tweto et al. 1978). In the central Green River Basin, it is approximately 1,718 ft thick including the Main Body (1,236 ft thick) and the Niland Tongue (482 ft thick) (Roehler 1992b). In the Washakie Basin, it is approximately 2,847 ft including the Main Body (1,691 ft thick), Niland Tongue (329 ft thick), and Cathedral Bluffs Tongue ( $827 \mathrm{ft}$ thick). Typical lithologies of the Main Body of the Wasatch Formation in the Washakie Basin include interbedded gray claystone; gray, green, and variegated mudstone; gray and brown fossiliferous limestone; gray fine- to medium-grained sandstone; gray calcareous siltstone; gray and brown carbonaceous shale; and coal (Roehler 1985, 1992b). The Niland Tongue of the Wasatch Formation consists of a lower part composed of interbedded fluvial sandstone, mudstone, and limestone, and an upper part composed of interbedded fluvial sandstone, mudstone, and limestone, with several thin beds of carbonaceous shale. The Cathedral Bluffs Tongue of the Wasatch Formation is typically composed of gray, green, and variegated mudstone; interbedded gray, fine- to coarse-grained, locally cross-bedded, sandstone; and minor thin beds of grayish-brown shale, algal limestone, oolitic limestone, and gray calcareous siltstone (Roehler 1985). The Cathedral Bluffs Tongue of the Wasatch Formation is laterally equivalent to most of the Wilkins Peak Member of the Green River Formation, which is thickest in the depositional center of the greater Green River Basin. East of the Rock Springs uplift, the Wilkins Peak Member thins progressively and in turn is replaced by rocks of the Cathedral Bluffs Tongue of the Wasatch Formation (Roehler 1992a).

Fossils collected from the various members of the Wasatch Formation that occur in the greater Green River Basin are housed in numerous institutions throughout the United States. They include the holotypes of most presently recognized early-Eocene mammalian taxa (Wasatchian NALMA). Across its distribution, the Wasatch Formation (also called the DeBeque Formation by paleontologists in the Piceance Creek Basin of Colorado) contains a high diversity of vertebrate, invertebrate, and plant fossils, which have collectively been the subject of many more paleontological publications than can be practically cited here. Representative contributions include the work of Black and Dawson (1966); Doi (1990); Gingerich and Dorr (1979); Granger and Simpson (1928); Kihm (1984); McKenna (1955, 1960); Osborn and Wortman (1892); and Savage and Russell (1983). Known fossils include ichnofossils (Zonneveld et al. 2000b), plants (Rich et al. 2001), and invertebrates (Kuchta 2000). Vertebrates include locally abundant and diverse fish, turtles, crocodilians, birds, and mammals (Dorr and Gingerich 1980; Gauthier 1982; Gunnell and Bartels 1999; Gunnell et al., in press; Hutchison 1984). Mammalian fossils include teeth and bones of multituberculates, marsupials, proteutheres, insectivores, chiropterans, primates, condylarths, carnivores, rodents, pantodonts, perissodactyls, artiodactyls, and taeniodonts (Dorr and Gingerich 1980; Gingerich and Dorr 1979; Savage and Waters 1978; West and Dawson 1973; Williams and Covert 1994; Zonneveld et al. 2000b). A 
high diversity of fossil vertebrate species has been described from the Wasatch Formation in the northern Sand Wash Basin of northwestern Colorado. McKenna $(1955,1960)$ identified more than 58 mammalian species from 4,700 teeth or tooth fragments, as well as at least 20 species of nonmammalian vertebrates.

Although fossils have been found in all members of the Wasatch Formation, their abundance in the unit is variable both geographically and stratigraphically. For example, the Cathedral Bluffs Tongue is less fossiliferous than the Main Body and contains fossils that are significantly younger. These are scientifically important, however, because they represent an important time interval (earliest Bridgerian NALMA). Cathedral Bluffs Tongue mammalian fossils include apatotheres, artiodactyls, carnivores, chiropterans, condylarths, dermopterans, insectivores, marsupials, pantolestids, perissodactyls, primates, rodents, taeniodonts, and tillodonts. Fossil remains of frogs, turtles, lizards, and crocodilians are also present in the tongue (West and Dawson 1973; unpublished paleontological data, University of Colorado Museum, compiled in 2002).

Because of the large number of vertebrate fossil localities known from the Wasatch Formation and the many publications based on its fossils, it is certain that additional scientifically significant fossils will be discovered in areas that have not yet been sufficiently prospected, and additional fossils will be collected from previously recorded localities. With the exception of the basal conglomerate beds for which no records of fossils were found, all members of the Wasatch Formation contain vertebrate fossils in varying abundances and are designated as BLM Condition 1 and PFYC Class 4/5. Future project-specific analyses of smaller geographic areas and more stratigraphically restricted intervals may necessitate a reevaluation and local redesignation.

\subsubsection{Green River Formation}

The transition from dominantly fluvial to dominantly lacustrine depositional environments and paleoenvironmental conditions in the Piceance Creek, Uinta, and Green River basins began in the late-early Eocene and is preserved in rocks of the early-to-middle Eoceneage Green River Formation. Exposures of the Green River Formation are present throughout a large geographic area encompassing southwestern Wyoming, northwestern Colorado, and northeastern Utah. Throughout its geographic distribution, the Green River Formation interfingers with several formations of fluvial origin. As discussed in Section 4.1, the Green River Formation was deposited in a vast lake system in a variety of open-water lacustrine and marginal-lacustrine environments that covered most of northeastern Utah, northwestern Colorado, and southwestern Wyoming (Cole and Picard 1978). On the basis of the modern distribution of Green River Formation rocks, it is not presently known if Lake Gosiute to the north and Lake Uinta to the south were ever physically connected (see discussion in Section 5.1).

Within most of the greater Green River Basin exclusive of Fossil Basin, the early- and middle-Eocene Green River Formation has been subdivided into the Luman Tongue, Fontenelle Tongue, Tipton Shale Member (Scheggs and Rife beds), Wilkins Peak Member, and Laney Member (LaClede, Sand Butte, and Hartt Cabin Beds) (M'Gonigle and Dover 1992; 
Roehler 1992b). In Fossil Basin, the Green River Formation has been subdivided into the Fossil Butte Member and the Angelo Member. Generalized stratigraphic correlation diagrams for the central part of the Green River Basin and Fossil Basin are provided in Figures 5 and 6.

The Green River Formation, named by Hayden (1869), is composed of beds of oil shale, marlstone, shale, siltstone, and sandstone; oolitic, algal, and ostracodal limestone; and tuff (Bradley 1964a; Cashion 1973; Rowley et al. 1985). In terms of lithofacies, it is characterized by thin, even, continuous beds of marlstone, oil shale, siltstone, and tuff deposited in deeper waters, and massive shallow-water deposited sandstone and limestone beds that are not laterally continuous (Bradley 1931; Cashion 1967, 1973; Cashion and Donnell 1974; Dane 1954; Duncan et al. 1974). In the center of the Green River Basin in Wyoming, the Green River Formation is composed of approximately 2,763 feet of lacustrine shale, oil shale, marl, sandstone, and limestone (Roehler 1992b). Here, the Luman Tongue is composed of approximately $229 \mathrm{ft}$ of gray, green, and red mudstone with minor thin beds of gray shale, graybrown oil shale, brown carbonaceous shale, and coal. The Tipton Shale Member consists of the Sheggs Bed, which is composed of approximately $98 \mathrm{ft}$ of mostly brown, fissile to papery oil

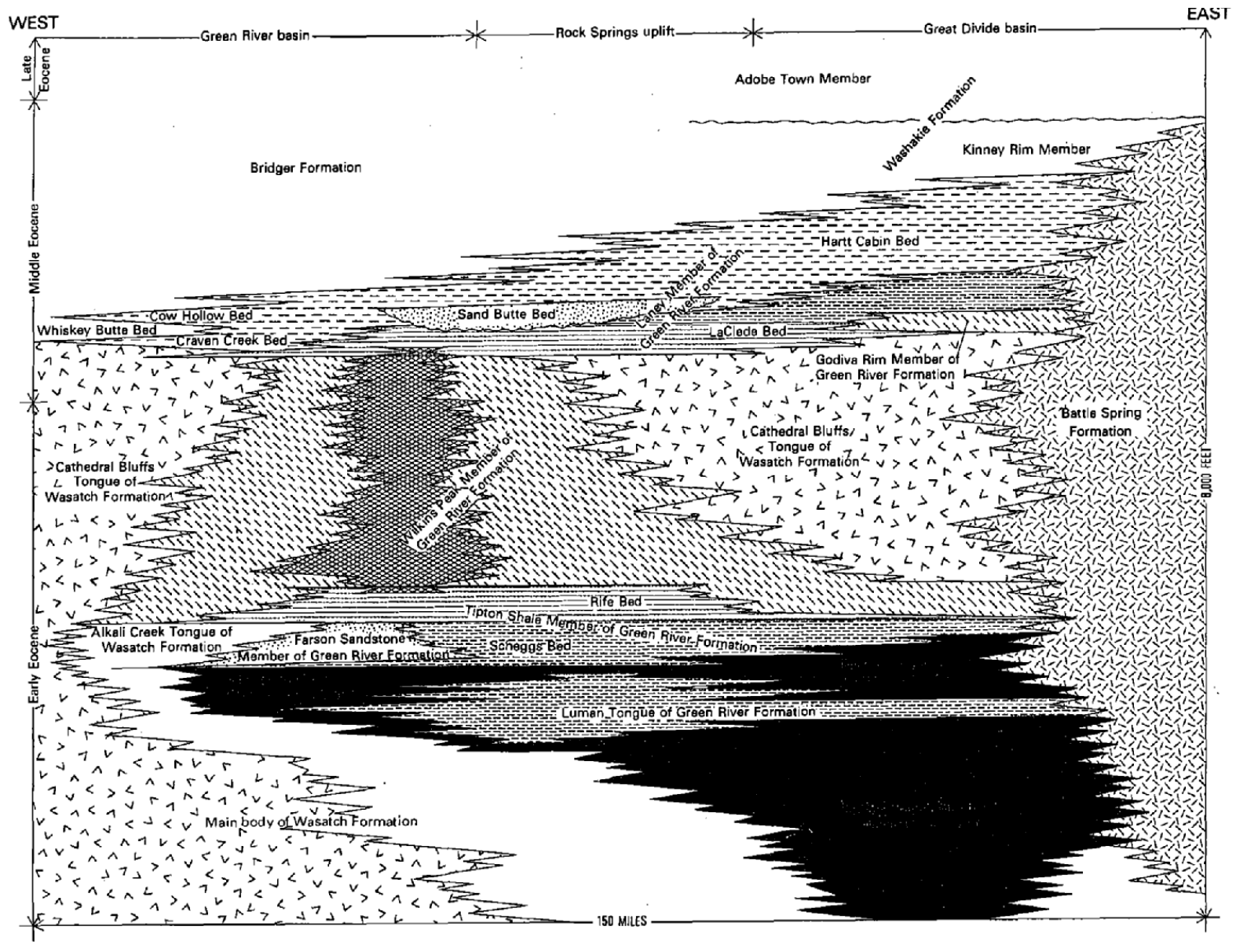

FIGURE 5 Generalized Stratigraphic Correlation of Eocene Rocks across the Central Part of the Greater Green River Basin (Source: Roehler 1992a) 


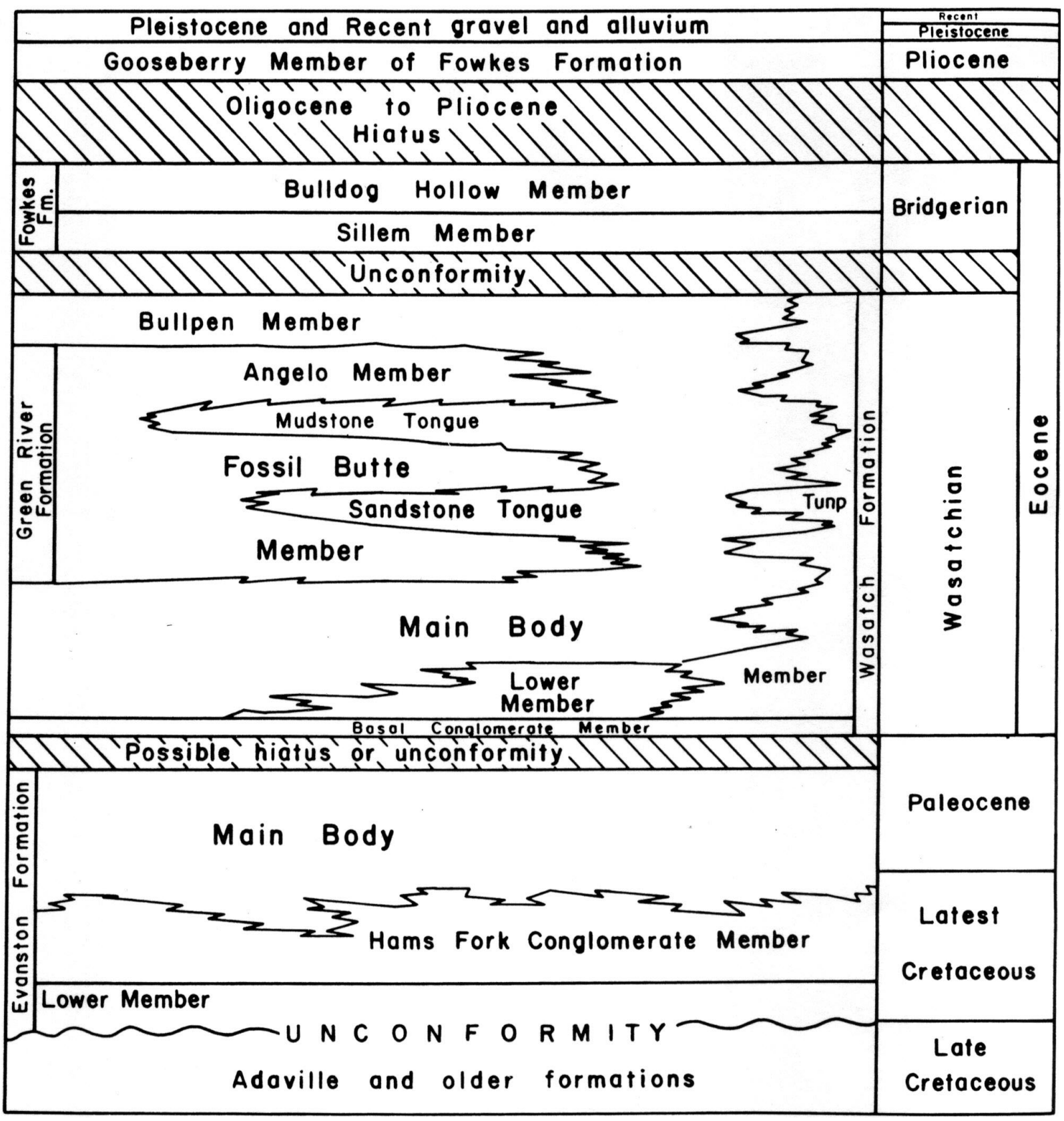

FIGURE 6 Generalized Stratigraphic Correlation Chart of Rock Units in Fossil Basin (Source: McGrew and Casilliano 1975)

shale and sparse, thin, gray sandstone, siltstone, dolomite, limestone, and tuff beds, and the Rife Bed. The latter is composed of approximately $69 \mathrm{ft}$ of medium-brown to dark-brown flaky dolomitic oil shale and very thin interbedded and interlaminated tan to brown dolomite and sparse thin beds of gray tuff. The Wilkins Peak Member consists of approximately 1,068 ft of interbedded tan-to-brown oil shale and clay shale, green mudstone, gray siltstone, tan-to-gray shale, and gray sandstone. Several interbeds of tan algal limestone, tuff, and brown clay pebble conglomerate are also present (Roehler 1992b). The Laney Member consists of the LaClede Bed, 
the Sand Butte Bed, and the Hartt Cabin Bed. The LaClede Bed is composed of approximately $259 \mathrm{ft}$ of mostly brown oil shale, clay shale, and occasional interbeds of gray siltstone, shale, and tuff. The Sand Butte Bed, formerly known as the Tower Sandstone Lentil, unconformably overlies the LaClede Bed and is composed of more than $225 \mathrm{ft}$ of tuffaceous sandstone, siltstone, and sandy mudstone that weathers to tan or brown cliffs. The Hartt Cabin Bed is more than $450 \mathrm{ft}$ thick and is composed of thin interbedded tan, brown, gray, and green mudstone, shale, clay shale, carbonaceous shale, dolomite, sandstone, and siltstone (Roehler 1992b).

In the Fossil Basin, the Fossil Butte Member of the Green River Formation consists of four lithostratigraphic units (McGrew and Casilliano 1975). The lowest consists of an approximately 45-ft-thick sequence of dominant mudstone with lesser amounts of light-gray calcareous mudstone and siltstone. This unit is overlain by approximately $75 \mathrm{ft}$ of dominant tanto-gray limestone with lesser amounts of shaley limestone, siltstone, and paper shale. The third unit consists of approximately $45 \mathrm{ft}$ of buff-weathering calcareous oil shale, organic-rich paper shale, and marlstone with several thin ash beds. Approximately $10 \mathrm{ft}$ below the top of this unit is an approximately 1-ft-thick shale bed rich in fossilized fish remains for which Fossil Butte National Monument was named. The uppermost unit consists of approximately $40 \mathrm{ft}$ of brown oil shale that weathers grayish-white, which is capped by an orange- to yellow-weathering limestone. The Angelo Member of the Green River Formation consists of white to bluish-whiteweathering limestone, marlstone, and mudstone, with interbedded lenticular beds of claystone, oil shale, and siliceous limestone. Both the Fossil Butte and Angelo members exhibit facies changes from deep water to littoral lacustrine environments. Laterally continuous thin beds of ash are common in the Green River Formation sequence in the Fossil Basin (McGrew and Casilliano 1975).

Accumulations of fossils are locally abundant in the Green River Formation throughout its distribution. Paleontological research on this formation has generated a wealth of information about Eocene paleoenvironments and the paleoecology of the intermontane basins of the Rocky Mountains. Green River Formation fossils include ichnofossils (Moussa 1968), an abundant and diverse flora (Bradley 1962; MacGinitie 1969), a large assemblage of arthropods, including insects (Coddington 1992a,b, 1993b; Leggitt and Cushman 2001; Hodgkins and Smith 2002), mollusks (Kuchta 2000), and abundant vertebrates, including fish (Grande 1980a,b, 1984, 2001; Carvalho et al. 2003); birds (Brodkorb 1965, 1970; Davis and Briggs 1998; Leggitt and Buchheim 1998a,b; Leggitt et al. 2001), and mammals (Froehlich and Breithaupt 1998; Gunnell 2003; McGrew and Casilliano 1975; Robinson et al. 2000; Black and Dawson 1966).

For more than 100 years, the Green River Formation has been the primary source of Eocene-age freshwater fishes in North America (Grande 1984). Tens to hundreds of thousands of complete and fully articulated skeletons of diverse freshwater bony and cartilaginous fish taxa have been recovered from quarries in the Fossil Basin of southwestern Wyoming. Included are beautifully preserved specimens of the stingray Xiphotrygon sp., paddlefish, gar, bowfin, perches, herrings, and others. Most of the fish quarries are located in Fossil Basin near Kemmerer, Wyoming, but many specimens have also been collected from other localities in Wyoming and Colorado. Exceptionally well-preserved and articulated skeletons of other vertebrates, including frogs, turtles, lizards, snakes, crocodiles, and birds, and mammals such as bats, condylarths, and others carnivores have also been recovered. Representative specimens are 
currently on display at Fossil Butte National Monument in Wyoming. The preservation of many fossil specimens discovered in the Green River Formation, especially the Fossil Butte Member, is extraordinary, sometimes including soft tissues such as the skin impressions of lizards, frogs, and crocodiles (McGrew and Casilliano 1975). The impressions of bird feathers have been found at a number of localities. A diverse and well-preserved assemblage of insect fossils has also been recovered. These fossils include horseflies, beetles, dragonflies, moths, and butterflies. Such specimens offer a unique opportunity to study organisms that are only rarely preserved as fossils because of their fragility. Other well-preserved invertebrates include mollusks, including both aquatic and land snails, several species of clams, and ostracods. Fossil arthropods, including crayfish, which are typically rare in continental deposits, have also been discovered. Plant fossils are locally abundant in certain parts of the Green River Formation and are also very well preserved (McGrew and Casilliano 1975). Leaves and other plant tissues, including beautifully preserved palm fronds from the Green River Formation, are housed in many museum collections. Fish fossils from the Green River and Washakie basins are known mostly from the Laney Member. Fossil fishes in these basins are reportedly smaller in size than those from the older and smaller Fossil Basin.

In the greater Green River Basin, the Laney and Fossil Butte members of the Green River Formation contain scientifically significant well-preserved vertebrate, invertebrate, and plant fossils, and are designated as BLM Condition 1 and PFYC Class 4/5. Future project-specific analyses of smaller geographic areas may necessitate a reevaluation and local redesignation. The Luman Tongue, Fontenelle Tongue, Tipton Shale Member, Wilkins Peak Member, and Angelo Member are less fossiliferous but do contain vertebrate fossils locally, and designated as BLM Condition 2 and PFYC Class 3.

\subsubsection{Bridger Formation}

With its abundant and diverse vertebrate fossils and extensive exposures, the Bridger Formation provides an excellent opportunity to study middle Eocene continental environments of North America. The dramatic and picturesque Bridger badlands are a thick sequence dominated by green-brown and red mudstone and claystone, with interbedded scattered ribbon and sheet sandstone, widespread beds of micritic, sparry, and silicified limestone, and thin but widespread beds of ash-fall tuff (Evanoff et al. 1998; Murphey and Evanoff 2007).

The Bridger Formation was named the Bridger Group by Hayden (1869). As discussed in Section 4.3, the first stratigraphic framework for the Bridger Formation was established by W.D. Matthew (1909) of the AMNH in the southern Green River Basin where the formation is thickest and best exposed. Matthew's (1909) stratigraphic subdivisions of the Bridger Formation were based primarily on five areally extensive limestones. These were named the Cottonwood, Sage Creek, Burnt Fork, Lonetree, and upper white layers, and some of them were used to subdivide the formation into five units: Bridger A, B, C, D, and E, from lowest to highest. Matthew's intent was to make it possible to stratigraphically locate the numerous known fossil localities in the formation. Because they are the most fossiliferous, the Bridger B, C, and D were further divided into five subunits corresponding to basal, lower, middle, upper, and top levels (e.g., B1, B2, B3, B4, B5). Because Matthew did not define the upper and lower boundaries of 
these subunits with stratigraphic markers or measured sections, correlations between them and the later subdivisions proposed by Evanoff et al. (1998), Murphey (2001), and Murphey and Evanoff (2007) are uncertain.

In his 1909 monograph, Matthew (1909:296) gave a brief description of his proposed five members and his white layers. "Horizon A" was $200 \mathrm{ft}$ thick, composed primarily of calcareous shales alternating with tuffs, and with rare fossils. "Horizon B" was $450 \mathrm{ft}$ thick, consisting of two benches separated by the Cottonwood white layer and containing abundant and varied fossils. He went on to note that the largest number of complete skeletons from the entire formation was found in the lower part of Horizon B (B2). "Horizon C" was $300 \mathrm{ft}$ thick, "defined inferiorly" by the Sage Creek white layer, with the Burntfork white layer occurring at about its middle, and with abundant and varied fossils. He also noted that the Sage Creek white layer was the "heavy and persistent calcareous stratum" at Sage Creek Spring, thus designating a type locality where this unit had been previously described and illustrated, but not named, by Sinclair (1906). "Horizon D" was $350 \mathrm{ft}$ thick, composed of harder gray and greenish-gray sandy and clayey tuffs, "defined inferiorly" by the Lonetree white layer, with the upper white layer about $75 \mathrm{ft}$ from the top, and with abundant and varied fossils. "Horizon E" was $500 \mathrm{ft}$ thick, composed of soft banded tuffs with heavy volcanic ash layers, with a high gypsum content and nearly barren of fossils. The total thickness of the Bridger reported by Matthew was 1,800 ft. Despite the lithologic descriptions of the five horizons made by Matthew (1909), subsequent workers have not been able to subdivide the Bridger Formation on the basis of lithologic differences (Bradley 1964a; Evanoff et al. 1998; Murphey 2001, Murphey and Evanoff 2007; Roehler 1992a). Furthermore, with the exception of the Bridger B-C and D-E boundaries, Matthew's subdivisions do not correspond to major faunal changes (Simpson 1933; Wood 1934; Murphey 2001; Murphey and Evanoff 2007).

Subsequent to the five informal subdivisions proposed by Matthew (1909), the Bridger Formation has formally been subdivided into three members. A detailed history of geologic and paleontologic investigations focusing on the Bridger Formation, and the history of stratigraphic nomenclature for this unit, can be found in Murphey (2001) and Murphey and Evanoff (2007). The Blacks Fork Member, or lower Bridger, is equivalent to Matthew's Bridger A and B; the Twin Buttes Member, or upper Bridger, is equivalent to Matthew's C and D; and the Turtle Bluff Member (renamed from Cedar Mountain Member of West and Hutchison 1981), also considered part of the upper Bridger, is equivalent to Matthew's Bridger E (Figure 7).

The first major stratigraphic revision of the Bridger Formation since Matthew's (1909) work was published in summary form by Evanoff et al. (1998). It was then expanded on with greater detail, geologic mapping, and stratigraphic data by Murphey (2001) and Murphey and Evanoff (2007). The latter publication is a detailed report on the stratigraphy, depositional environments, and distribution of fossils in the upper Bridger Formation and includes a 1:50,000-scale bedrock geologic map. The stratigraphic subdivisions proposed by these workers are based on widespread limestones, tuffs, and tuffaceous sheet sandstones, which are used as markers. Fifteen such units were described, and seven of these were considered major markers; these were used to subdivide the Bridger C and D (Twin Buttes Member) into lower, middle, and upper informal subdivisions (Figure 7). Two additional markers were used to redefine the base 


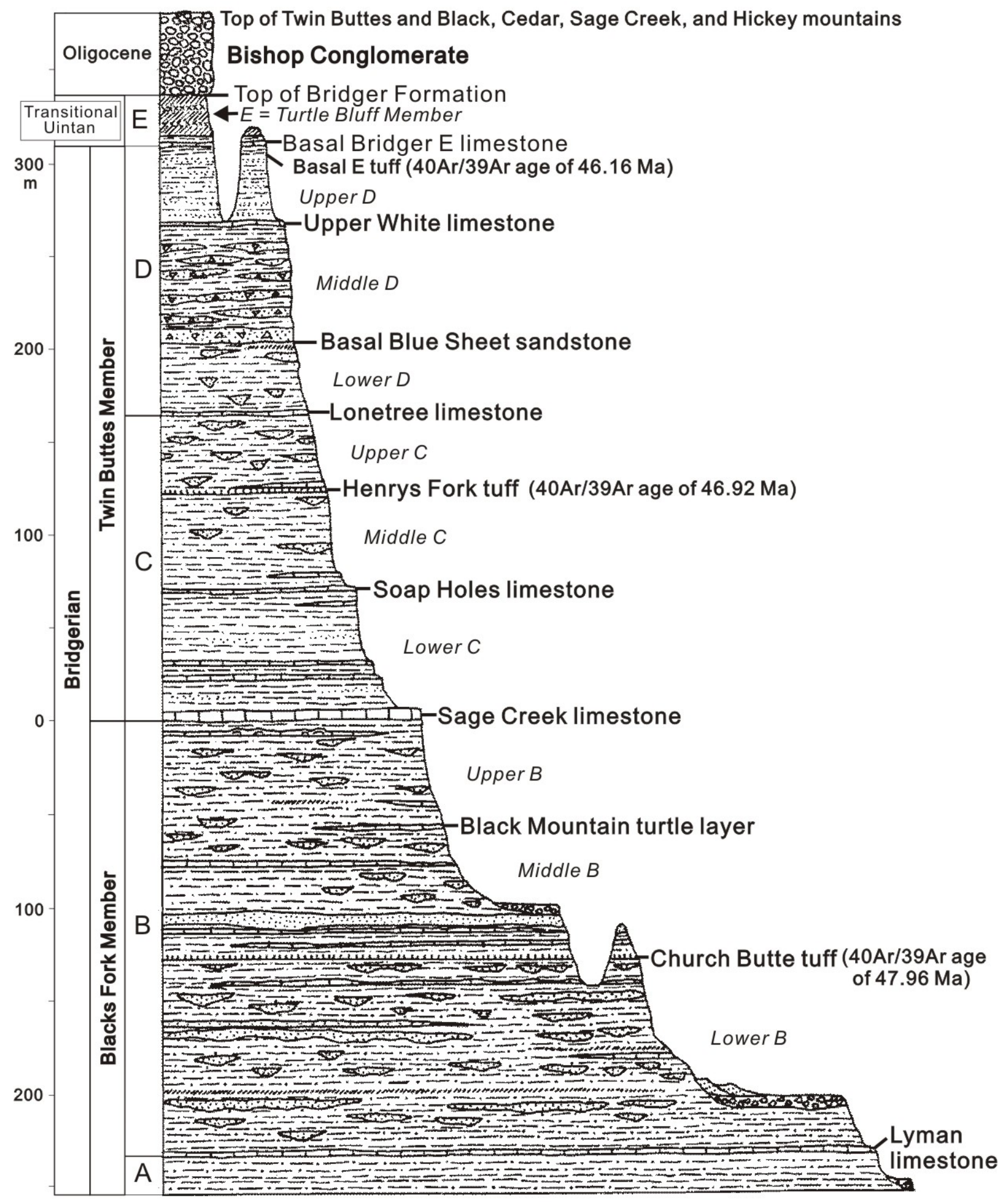

FIGURE 7 General Stratigraphic Features of the Bridger Formation (modified from Evanoff et al. 1998) 
and define the top of the Bridger E (Turtle Bluff Member). Four of Matthew's original "white layers" were included in the stratigraphy of the Bridger C and D, and these were mapped and redescribed in detail. Geologic mapping of 10 7.5-minute quadrangles, which cover the area encompassed by the upper Bridger Formation, was completed at the scale of 1:24,000 (Brand et al. 2007a,b; Evanoff et al. 2007; Murphey et al. 2007a-g). Because many marker's units were not continuously exposed or traceable across the entire basin (from Hickey Mountain, Sage Creek Mountain, and Cedar Mountain east to Twin Buttes and Black Mountain), a distance of approximately $40 \mathrm{mi}$, accurate correlation was made possible by using the mineralogically diagnostic Henrys Fork Tuff (Evanoff et al. 1998; Murphey 1995; Murphey et al. 1999; Murphey and Evanoff 2007) as a datum.

Rock accumulation rates, isotopic ages of ash-fall tuffs (Murphey et al. 1999), and fossils indicate that the Bridger Formation was deposited over an approximately 3.5-million-year interval from about 49.09 to $45.57 \mathrm{Ma}$, and that the faunal transition from the Bridgerian to the Uintan Land Mammal Age was underway by about $46 \mathrm{Ma}$ as indicated by fossils collected from the base of the Turtle Bluff Member (Evanoff et al. 1994; Murphey 2001; Murphey and Evanoff 2007; Robinson et al. 2004). Recognized depositional environments of the Bridger Formation include fluvial, lacustrine, playa lacustrine, paludal, marginal mudflat, basin margin, and volcanic. Murphey and Evanoff (2007) concluded that an influx of fluvially transported volcaniclastic sediment to the Green River Basin during middle Eocene time led to the filling of Lake Gosiute and the development of muddy floodplains of low topographic relief, which persisted for up to $85 \%$ of the time during which the upper Bridger was deposited. Occasional lapses in the flow of sediment to the basin permitted the development of shallow, mostly groundwater-fed lakes and ponds, which accumulated up to four times as slowly as floodplain deposits. These lapses decreased in frequency throughout deposition of the upper Bridger Formation. As indicated by fossil distribution and diversity, lakes and their margins provided favorable habitats for both aquatic and terrestrial organisms during deposition of the Bridger Formation. Murphey and Evanoff (2007) reported a total maximum thickness of the Bridger Formation of 2,765 ft. For more information about the Bridger Formation and ongoing stratigraphic and paleontologic research, see http://www.rockymountainpaleontology.com/ bridger.

One of the world's most abundant and diverse middle Eocene vertebrate faunas is preserved in the Bridger Formation. More than 86 species representing 67 genera, 30 families, and 13 orders of fossil mammals are recognized (Gazin 1976). Joseph Leidy's 1869 description of Omomys carteri was the first scientific description of a fossil from the Bridger Formation. Subsequently, Bridger fossils have been the subject of numerous publications, including many classic papers by pioneers of American vertebrate paleontology (Cope 1872, 1873; Granger 1908; Leidy 1869, 1871, 1872a; Marsh 1871, 1886; Matthew 1909; Osborn 1929). Other representative paleontological publications are cited in Section 4.3, although there are far too many to cite in this report. Like many other highly fossiliferous formations, the Bridger contains an abundance and diversity of fossils that make it well suited for paleontological research, most of which has focused on the phylogenetics, systematic paleontology, and biostratigraphy of the mammalian fauna (Covert et al. 1998; Evanoff et al. 1994; Gazin 1957, 1958, 1965, 1968, 1976; Krishtalka et al. 1987; McGrew and Sullivan 1970; Murphey and Walsh 2007; Robinson et al. 2004; West and Hutchison 1981). Preserved in a variety of 
sedimentary environments, preservational states, associations, and in locally varying abundances, these fossils include primarily vertebrates and mollusks, with less common plants and ichnofossils. Plant fossils include leaves, seeds, and wood, which is sometimes algal covered (see Murphey et al 2001). Ichnofossils include solitary bee cases, earthworm pellets, caddis fly larvae, and fish pellets (Hasiotis and Murphey 1997). Vertebrate fossils include fish, amphibians, reptiles (lizards, snakes, turtles, and crocodilians), a diversity of birds (see Murphey et al. 2001), and mammals. Mammalian fossils include apatotheres, artiodactyls, chiropterans, carnivores, condylarths, dermopterans, dinoceratans (uintatheres), edentates, insectivores, leptictids, marsupials, pantolestids, perissodactyls, primates, rodents, taeniodonts, and tillodonts (Gazin 1976; unpublished paleontological data, University of Colorado Museum, compiled in 2002). Despite the relative ease with which diverse and statistically significant fossil samples can be collected, and the large historical collections of Bridger vertebrates available in many museums, taphonomic and paleoecologic studies of Bridger vertebrate faunas are relatively few (Alexander and Burger 2001; Brand et al. 2000; Gunnell 1997; Gunnell and Bartels 1994; Murphey et al. 1999; Murphey and Townsend 2005; Townsend 2004).

The Bridger Formation contains locally abundant and well preserved vertebrate and invertebrate (mollusk) fossils, and less common but scientifically important plant fossils. All members of the Bridger Formation are designated as BLM Condition 1 and PFYC Class 4/5.

\subsubsection{Washakie Formation}

The name Washakie Group was first applied by Hayden (1869) to rock outcrops near Washakie Station (now Wamsutter) between Creston Station and Bitter Creek Station along the Union Pacific Railroad. Hayden designated no upper and lower contacts for the Washakie Group, and on the basis of his descriptions of lithologies and fossils, it is apparent that the Washakie Group as originally defined included rocks of the Wasatch and Green River formations in this area. In 1877, Hayden realized that his Washakie Group was stratigraphically equivalent to his Wasatch Group, and he abandoned the use of the name Washakie Group over which the Wasatch Group had nomenclatural priority. King (1877) assigned the beds overlying the "Green River Group" in the center of the Washakie Basin to the "Bridger series," correlating them with the Bridger Group of Hayden (1869). Osborn (1881) referred to the "Bridger series" in the Washakie Basin as the "Washakie beds." Granger (1909) reported that the name "Washakie Formation" was used in an orally presented paper by sedimentologist W.J. Sinclair.

Granger (1909) was the first to publish a detailed stratigraphic and paleontologic study of the Washakie Formation. He established mammalian faunal zones, and subdivided the formation at Haystack Mountain into Washakie A, or lower Washakie Formation, and Washakie B, or upper Washakie Formation. This interval now comprises a portion of the Adobe Town Member from Roehler's (1973) bed 569 to bed 675. Osborn (1929) provided a revised stratigraphic section of the Washakie Formation in the Haystack Mountain area, proposing "life zones" that were based on the work of Granger (1909). Bradley (1964a) applied the name Uinta Formation to the uppermost "Bridger beds" in the Washakie Basin because they are of similar ages. Wheeler (1961) concluded that the name Washakie Formation was most appropriate because (1) the post-Green River Formation strata in the Washakie Basin are lithologically and 
geographically distinct from both the Bridger and Uinta formations; (2) the Bridger and Uinta are both lithostratigraphic and chronostratigraphic names; and (3) there are both Bridgerian and Uintan elements to the mammalian faunas of the Washakie Formation. Roehler $(1973,1985$ 1992a, and other publications) has conducted the most detailed stratigraphic work in the Washakie Formation to date and formalized the use of the name Washakie Formation while providing ample justification. He defined the currently used stratigraphic nomenclature, including naming the Kinney Rim and Adobe Town members, in his 1973 publication.

As discussed previously, the definition of the Washakie Formation in this report is extended to include stratigraphically equivalent rocks (of latest Bridgerian and early Uintan age) that have been mapped by some workers as Bridger Formation in the Sand Wash Basin. In general, rocks of the Washakie Formation in the Sand Wash Basin have received less attention from paleontologists and geologists than those of the Washakie Formation in the Washakie Basin. Earl Douglas and J. LeRoy Kay of the Carnegie Museum collected the first fossils from the Washakie Formation in the Sand Wash Basin in the 1920s. Denver Museum field parties also collected in the area in the 1920s. Crews from the Carnegie Museum and University of Colorado Museum worked in the area in the 1960s, relocating old localities and discovering new ones. The Denver Museum returned to the area in the 1970s, and fieldwork conducted from 1989 to 1994 produced significant collections of fossil vertebrates (Stucky et al. 1996). Like the Washakie Formation in the Washakie Basin, the Washakie Formation in the Sand Wash Basin is particularly important because it apparently preserves fossils of earliest Uintan age, an interval of time that is not well represented in the type Uinta Formation and associated Eocene rocks in northeastern Utah. Flynn (1986) recognized the "Shoshonian" land mammal "subage" for the earliest Uintan faunas of the Washakie Basin, although the name and validity of the "Shoshonian" have not been universally accepted by paleontologists. Nevertheless, fossils from these early Uintan-aged rocks are of scientific importance because they represent a span of time that is not well represented in North America (Robinson et al. 2004).

The Washakie Formation in the Washakie Basin was formally subdivided into the Kinney Rim and Adobe Town members by Roehler (1973). The Adobe Town Member includes Granger's (1909) Lower Washakie (Washakie A) and Upper Washakie (Washakie B). The unconformable Kinney Rim and Adobe Town members are separated by Roehler's (1973) marker "bed 569," a 25 ft-thick light grayish-green sandstone, siltstone, and mudstone sequence referred to as the "lower brown sandstone" by Granger (1909). The base of the bed 569 sequence forms the base of the Adobe Town Member. The Adobe Town Member, approximately $984 \mathrm{ft}$ thick, is composed of interbedded gray to grayish-green, fine- to very coarse-grained, partly tuffaceous sandstone; gray and red calcareous, tuffaceous siltstone; gray, green, or variegated mudstone; brown and gray silty limestone; yellowish-brown silty dolomite; green, bluish-green, and gray tuff; and tan and gray conglomerate. The underlying Kinney Rim Member, approximately 0 to $984 \mathrm{ft}$ thick, is composed of interbedded gray, grayish-green, or variegated mudstone; gray to grayish-green very fine- to medium-grained sandstone; yellowish-gray, grayish-brown, and grayish-green tuff; tan-gray and grayish-brown limestone; gray and grayishgreen tuffaceous siltstone; algal limestone; and thin, lenticular conglomerate beds (Roehler 1985). The Kinney Rim Member conformably overlies the Laney Member of the Green River Formation. The Adobe Town Member is unconformably overlain in southern portions of the Washakie Basin by the Browns Park Formation. In the Sand Wash Basin, the Washakie 
Formation is composed of approximately $492 \mathrm{ft}$ of grayish-brown and purple tuffaceous mudstone, with green and lavender cross-bedded sandstone (Stucky et al. 1996).

Because many of the rocks overlying the Green River Formation in the Sand Wash Basin are lithologically similar to the type Bridger Formation in the southwestern Green River Basin, they have been mapped as Bridger Formation by some workers. However, Roehler $(1973,1992 a)$ distinguished the early Uintan-aged strata of the Washakie Basin from the Bridgerian strata of the older type Bridger Formation and formally named them the Washakie Formation following Granger (1909). More recent work suggests that the youngest subdivision of the Bridger Formation, the Turtle Bluff Member, may be transitional Uintan in age (Evanoff et al. 1994; Murphey et al. 1999; Murphey 2001; Murphey and Evanoff 2007; Robinson et al. 2004), and at least partly equivalent with part of the Adobe Town Member of the Washakie Formation. Roehler (1973, 1992a) did not rename the late Bridgerian- and Uintan-aged strata in the Sand Wash Basin as he did for the equivalent rocks in the Washakie Basin, although most paleontologists now refer to them as Washakie Formation. Indeed, until the uplift of the Cherokee Ridge, the Sand Wash Basin was part of the Washakie Basin; the stratigraphic sequences of the two areas are so similar that Roehler's $(1973,1992 \mathrm{~b}, \mathrm{c})$ marker-bed terminology for the Washakie Formation in Wyoming can be extended to parts of the Sand Wash Basin in Colorado (Stucky et al. 1996).

Fossils are locally abundant in both members of the Washakie Formation in the Washakie Basin and in equivalent strata in the Sand Wash Basin. Study of fossils and sedimentology reveal that these sediments were deposited in a marginal lacustrine-fluvial depositional environment. Mammalian fossils indicate a Bridgerian age for the Kinney Rim Member and lower part of the Adobe Town Member, and a Bridgerian and early Uintan age for the Adobe Town Member. Fossils collected from the Washakie Formation in both basins include a diverse assemblage of fishes; reptiles, including turtles, lizards, snakes, and crocodilians; and mammals, including marsupials, leptictids, pantolestids, insectivores, dinoceratans (uintatheres), dermopterans, primates, carnivores, rodents, condylarths, artiodactyls, mesonychids, and perissodactyls (McCarroll et al. 1996; McCarroll and Turnbull 1996; Roehler 1973; Stucky et al. 1996; Turnbull 1972, 1978, 2004; West and Dawson 1975; Wheeler 1961).

Both the Kinney Rim and Adobe Town members of the Washakie Formation contain locally abundant and well-preserved vertebrate and invertebrate (mollusk) fossils, and less common but scientifically important plant fossils. They are, therefore, designated as BLM Condition 1 and PFYC Class 4/5.

\subsubsection{Bishop Conglomerate}

The Green River, Bridger, and Washakie formations are locally and unconformably overlain by the Bishop Conglomerate. This unit, which was formerly referred to as the Wyoming Conglomerate (U.S. Geological and Geographic Survey of the Fortieth Parallel, 1867-1872), was first thought to be Pleistocene in age (Sinclair 1906). It is a very coarse conglomerate composed primarily of arkosic cobbles and boulders derived from the Proterozoic Uinta Mountain Group, with locally common cobbles and boulders of Paleozoic limestone 
(Bradley 1964a). It is as much as $131 \mathrm{ft}$ thick (Dover and M'Gonigle 1993). The Bishop Conglomerate is unfossiliferous, containing only scattered reworked invertebrates derived from Paleozoic rocks in the Uinta Mountains. Unidentified mammalian bone fragments were reported by Bradley (1964a:A55-A56), and it is possible that age-diagnostic fossils may be discovered in the future. The Bishop Conglomerate is currently believed to be of late Oligocene age (K/Ar $29.50 \pm 1.08 \mathrm{Ma}$, biotite) on the basis of isotopic ages obtained from a tuff that occurs within the unit on the south side of the Uinta Mountains (Hansen 1986). Chaotically bedded tuffaceous deposits also occur within the Bishop Conglomerate on Cedar Mountain in southwestern Sweetwater County (personal observation), and these may prove useful for determining the age of the unit on the north side of the Uinta Mountains.

Because no identifiable in situ fossils have been discovered within the Bishop Conglomerate, it is designated as BLM Condition 3 and PFYC Class 2.

\subsubsection{Browns Park Formation}

The Green River and Washakie formations are locally and unconformably overlain by the Browns Park Formation in the southern Washakie and Sand Wash basins. The Browns Park Formation is middle to late Miocene in age (Hemingfordian and Barstovian NALMA). It is composed predominantly of gray, fine- to coarse-grained, tuffaceous sandstone and interbedded gray-to-white tuff, gray siltstone, and gray and red mudstone (Roehler 1985). The unit also contains minor amounts of conglomerate (Honey and Izett 1988). It is approximately 1,800 ft thick in northwestern Colorado, where it crops out extensively.

Fossils are rare in the Browns Park Formation, and only a few published records exist (Bradley 1964a; Honey 1977; Honey and Izett 1988; McGrew 1951; Peterson 1924). Honey and Izett (1988) provide an overview of the paleontology and geology of the Browns Park Formation. They reported a low diversity mammalian fauna, with poor preservation, consisting of carnivores, perissodactyls, and artiodactyls. McGrew (1951) and Bradley (1964a) reported occurrences of the procyonid Bassariscops sp., an unidentified camelid, an unidentified oreodont, an unidentified antilocaprid, the rhinoceros Aphelops sp., the chalicothere Moropus sp., and the primitive mastodont Trilophodon sp. from the Browns Park Formation in Colorado. They also reported a new genus of mustelid and the camelid Gentilocamelus sp. from the Saratoga Basin in Wyoming. Unidentified fossil mammal tracks are also known from Round Butte in Moffat County, Colorado. Other geologic units of Miocene age in Colorado and Wyoming are more fossiliferous. It is possible that the Browns Park Formation has not been sufficiently prospected in Wyoming. For example, current fieldwork by the authors has resulted in the discovery of several new vertebrate localities in the Browns Park Formation in the Powder Rim area in the southern Washakie Basin, Wyoming; but thus far, all fossils (with the exception of turtles) are too poorly preserved to permit identification. Any new fossil discoveries would be of great scientific importance because they could provide new information to help constrain the relative age of this unit locally and regionally.

Because it contains few vertebrate fossils, the Browns Park Formation is designated as BLM Condition 2 and PFYC Class 3. 


\subsubsection{Pleistocene- and Holocene-Age Surficial Deposits}

The bedrock geologic units within the greater Green River Basin are locally mantled by younger surficial deposits of Pleistocene and Holocene age. These consist of alluvium, colluvium, landslide deposits, sand dune deposits, pediment deposits, and alluvial fan deposits. Holocene-age alluvium is composed primarily of poorly consolidated silt, sand, and cobbles derived from eroded bedrock and older alluvial and colluvial deposits. These sediments are deposited by rivers and streams in stream channels and on active alluvial floodplains. Pleistocene-age alluvium consists of gravel, sand, silt, mud, and clay that forms alluvial terraces and isolated remnants on dissected benches along stream drainages. Sand dune deposits consist of windblown silt and sand. Alluvial fan deposits consist of crudely stratified alluvium and colluvium forming well-defined fan-shaped deposits at mouths of tributary valleys. Colluvium and landslide deposits consist of rock material that has moved under the influence of gravity. Lithologies of these units vary and are dependent upon the type of source rock. They form on unstable slopes and on older colluvial deposits. In general, colluvium and landslide deposits are much less likely to contain well-preserved animal and plant remains than intact native sediments. Colluvium and landslide material is often subjected to increased groundwater percolation, which tends to have a negative effect on the preservation of organic material. Gravitationally induced movement of sediment can also destroy animal and plant remains through abrasion and breakage. Additionally, when the original stratigraphic position of the sediments is disturbed, there are varying degrees of information loss with the severity of changes to the slide mass.

Surficial deposits of Holocene age contain the unfossilized remains of modern taxa and are too young to contain in situ fossils. Pleistocene-age surficial deposits, particularly alluvium, may contain mineralized or partially mineralized animal bones, invertebrates, and plant remains of paleontological significance. With the exception of some caves, hot springs, and tar deposits, these fossils typically occur in low density and usually consist of scattered and poorly preserved remains. The most common Pleistocene vertebrate fossils include the bones of mammoth, bison, deer, and small mammals; however, other taxa, including horse, lion, cheetah, wolf, camel, antelope, peccary, mastodon, and giant ground sloth, have been reported from the Rocky Mountain region (Cook 1930, 1931; Emslie 1986; Gillette and Miller 1999; Gillette et al. 1999a,b; Heaton 1999; Hunt 1954; Lewis 1970; Scott 1963; Smith et al. 1999; unpublished paleontological data, Denver Museum of Nature and Science).

Generally, deposits of Holocene age contain the unfossilized remains of modern species of animals and plants and are not considered paleontologically sensitive. These are designated as BLM Condition 3 and PFYC Class 2 in this analysis. Few reports of Pleistocene age fossils from southwest Wyoming exist. Pleistocene-age surficial deposits within the greater Green River Basin are designated as BLM Condition 2 and PFYC Class 2.

\subsection{PALEONTOLOGICAL RESOURCE ASSESSMENT SUMMARY}

As discussed in Section 4.4, surface disturbance associated with commercial oil shale activities has the potential to impact six mapped bedrock geologic units and a variety of surficial deposits in the greater Green River Basin (Bradley 1945, 1961; Bryant 1992; Courtright and 
Braddock 1989; Dover and M'Gonigle 1993; Love and Christiansen 1985; M'Gonigle and Dover 1992; Nichols and Bryant 1990; Oriel and Platt 1980; Privrasky 1963; Roehler 1985; Rowley et al. 1985). The paleontological sensitivities of these units were evaluated by using both the BLM paleontological resource classification system (Conditions 1-3; BLM 1998) and the PFYC developed by the USFS and recently adopted by the BLM with modifications (see Sections 3.1 and 3.2; BLM 2007). Resource assessment designations for each geologic unit discussed in Section 4.4 are summarized in Table 3 using both classification systems.

TABLE 3 Summary of Programmatic-Level Paleontological Sensitivities of Geologic Units within the Greater Green River Basin in Southwestern Wyoming and Northwestern Colorado

\begin{tabular}{|c|c|c|c|c|}
\hline Geologic Unit & Age & Typical Fossils & $\begin{array}{c}\text { BLM } \\
\text { Designation } \\
\end{array}$ & $\begin{array}{c}\text { PFYC } \\
\text { Designation }\end{array}$ \\
\hline $\begin{array}{l}\text { Alluvium, colluvium, } \\
\text { landslide deposits, sand } \\
\text { dune deposits, pediment } \\
\text { deposits, and alluvial fan } \\
\text { deposits }\end{array}$ & Holocene & $\begin{array}{l}\text { None in deposits of Holocene } \\
\text { age unless reworked from } \\
\text { older sediments }\end{array}$ & Condition 3 & Class 2 \\
\hline $\begin{array}{l}\text { Alluvium, colluvium, } \\
\text { landslide deposits, sand } \\
\text { dune deposits, pediment } \\
\text { deposits, and alluvial fan } \\
\text { deposits }\end{array}$ & Pleistocene & $\begin{array}{l}\text { Scattered vertebrates, } \\
\text { invertebrates, and plants occur } \\
\text { locally }\end{array}$ & Condition 2 & Class 2 \\
\hline Browns Park Formation & $\begin{array}{l}\text { Middle and } \\
\text { late Miocene }\end{array}$ & $\begin{array}{l}\text { Vertebrates (mammals and } \\
\text { turtles) rare; mammal tracks } \\
\text { have also been reported; } \\
\text { silicified wood is locally } \\
\text { common }\end{array}$ & Condition 2 & Class 3 \\
\hline Bishop Conglomerate & $\begin{array}{l}\text { Late } \\
\text { Oligocene }\end{array}$ & $\begin{array}{l}\text { Rare unidentified mammal } \\
\text { bone fragments, reworked } \\
\text { Paleozoic invertebrates }\end{array}$ & Condition 3 & Class 2 \\
\hline $\begin{array}{l}\text { Washakie Formation: } \\
\text { Kinney Rim and Adobe } \\
\text { Town members }\end{array}$ & $\begin{array}{l}\text { Middle } \\
\text { Eocene }\end{array}$ & $\begin{array}{l}\text { Vertebrates (fishes, } \\
\text { amphibians, reptiles, and } \\
\text { mammals) locally abundant in } \\
\text { both members; invertebrates } \\
\text { (mollusks) and plants (wood) } \\
\text { locally common }\end{array}$ & Condition 1 & Class $4 / 5$ \\
\hline
\end{tabular}


TABLE 3 (Cont.)

\begin{tabular}{|c|c|c|c|c|}
\hline Geologic Unit & Age & Typical Fossils & $\begin{array}{c}\text { BLM } \\
\text { Designation }\end{array}$ & $\begin{array}{c}\text { PFYC } \\
\text { Designation }\end{array}$ \\
\hline $\begin{array}{l}\text { Bridger Formation: } \\
\text { Blacks Fork, Twin } \\
\text { Buttes, Turtle Bluff } \\
\text { members }\end{array}$ & $\begin{array}{l}\text { Middle } \\
\text { Eocene }\end{array}$ & $\begin{array}{l}\text { Vertebrates (fishes, } \\
\text { amphibians, reptiles, birds, } \\
\text { and mammals) locally } \\
\text { abundant; invertebrates } \\
\text { (mollusks) and plants (wood } \\
\text { and leaves) locally common; } \\
\text { insect and vertebrate } \\
\text { ichnofossils also present }\end{array}$ & Condition 1 & Class $4 / 5$ \\
\hline $\begin{array}{l}\text { Green River Formation: } \\
\text { Laney and Fossil Butte } \\
\text { members }\end{array}$ & $\begin{array}{l}\text { Early and } \\
\text { middle } \\
\text { Eocene }\end{array}$ & $\begin{array}{l}\text { Vertebrates (fishes, } \\
\text { amphibians, reptiles, birds, } \\
\text { and mammals) locally } \\
\text { abundant; invertebrates } \\
\text { (insects, arthropods, and } \\
\text { mollusks), plants, ichnofossils } \\
\text { locally abundant }\end{array}$ & Condition 1 & Class 4/5 \\
\hline $\begin{array}{l}\text { Green River Formation: } \\
\text { Luman Tongue, } \\
\text { Fontenelle Tongue, } \\
\text { Tipton Shale Member, } \\
\text { Wilkins Peak Member, } \\
\text { Angelo Member }\end{array}$ & $\begin{array}{l}\text { Early and } \\
\text { middle } \\
\text { Eocene }\end{array}$ & $\begin{array}{l}\text { Uncommon but locally present } \\
\text { vertebrates (fishes, reptiles, } \\
\text { and mammals), scattered } \\
\text { plants, locally common } \\
\text { invertebrates (mollusks and } \\
\text { ostracods) }\end{array}$ & Condition 2 & Class 3 \\
\hline $\begin{array}{l}\text { Wasatch Formation: } \\
\text { LaBarge Member, New } \\
\text { Fork Tongue, Niland } \\
\text { Tongue, Main Body, } \\
\text { Upper Member, } \\
\text { Cathedral Bluffs Tongue, } \\
\text { Hiawatha Member }\end{array}$ & $\begin{array}{l}\text { Mostly early } \\
\text { Eocene, } \\
\text { Cathedral } \\
\text { Bluffs } \\
\text { Tongue is } \\
\text { early and } \\
\text { early-middle } \\
\text { Eocene }\end{array}$ & $\begin{array}{l}\text { Locally abundant vertebrates } \\
\text { (fishes, amphibians, reptiles, } \\
\text { birds, and mammals), plants, } \\
\text { invertebrates (mollusks), and } \\
\text { ichnofossils }\end{array}$ & Condition 1 & Class 4/5 \\
\hline
\end{tabular}




\section{PICEANCE CREEK BASIN, COLORADO}

Deposits of oil shale are contained within sedimentary rocks of the Green River Formation. The Green River Formation was deposited in an ancient lake system that existed from the late Paleocene to the middle Eocene Epoch in what is now Colorado, Utah, and Wyoming. The smallest and oldest of these lakes, Fossil Lake, was deposited in Fossil Basin, which is located in the Wyoming overthrust belt just to the west of the Green River Basin in southwest Wyoming. Lake Gosiute was deposited in the greater Green River Basin, which includes the Green River and Washakie basins in southwest Wyoming, and the Sand Wash Basin in northwestern Colorado. Lake Uinta was deposited in the Uinta Basin in northeastern Utah and the Piceance Creek Basin in northwestern Colorado. It has been estimated that approximately $80 \%$ of the potential oil shale resource of the Green River Formation is located in the Piceance Creek Basin, although it is geographically much smaller than either the Uinta or greater Green River basins.

\subsection{GEOLOGIC SETTING AND DEPOSITIONAL HISTORY}

The Piceance Creek Basin occupies approximately 2,300 $\mathrm{mi}^{2}$ of northwestern Colorado and is located on the northeastern edge of the Colorado Plateau province. It lies immediately to the west of the Grand Hogback monocline, a north and northwest-trending feature that separates the Piceance Creek Basin from the White River Plateau of the Southern Rocky Mountain province to the east.

The Piceance Creek and Uinta basins are closely related early Cenozoic structural and sedimentary basins that were created by Laramide uplifts during latest Cretaceous and Paleocene time. The Piceance Creek Basin is bounded on the north by the Uinta uplift and the Axial Basin anticline, on the east by the White River uplift, and on the south by the Sawatch and Uncompahgre uplifts. Structurally, the Uinta and Piceance Creek basins are separated by the Douglas Creek arch, a broad north-south trending anticline that separated the two sedimentary basins until the early-middle Eocene, when the two basins coalesced across the top of the arch to form one large sedimentary basin (Johnson 1985, 1989; Moncure and Surdam 1980). Both the Piceance Creek and Uinta basins are highly asymmetrical. Strata of early Tertiary age in the Piceance Creek Basin generally dip gently toward the eastern margin of the basin, where the strata are upturned to near vertical dips along the Grand Hogback, which forms the western flank of the White River uplift (Johnson 1985).

The end of the Cretaceous Period and beginning of the Tertiary Period in the eastern Uinta Basin, Uinta Mountains, and northwestern Colorado is represented by a major unconformity (Fisher et al. 1960). This unconformity marks the period of initial subsidence within the region that occurred during the early part of the Laramide orogeny. As the Piceance Creek and Uinta basins initially formed during the latest Cretaceous Period and early Paleocene Epoch, a widespread beveling over the entire Piceance Creek Basin and the central and eastern portions of the Uinta Basin occurred. During the late Paleocene, widespread sedimentation occurred in most of both basins. Paleocene-age sediments, which accumulated shortly after the 
period of beveling, are highly variable lithologically but are commonly conglomeratic, reflecting active tectonism on nearby Laramide uplifts (Johnson 1985).

By the late Paleocene (Clarkforkian NALMA), large shallow lakes and ponds occupied a large portion of both the Piceance Creek and Uinta Basin. During the latest Paleocene and early Eocene (late Clarkforkian and early Wasatchian NALMA), there was a return to fluvial sedimentation in both basins, which is represented by rocks of the Wasatch (DeBeque) Formation. This was followed by a return to dominantly lacustrine conditions in the early Eocene with the establishment of two large freshwater lakes (one in each basin). These lakes may have been briefly connected over the Douglas Creek Arch during the early Eocene. Strata from this initial lacustrine interval in the Piceance Creek Basin were originally included in the lower part of the Douglas Creek Member of the Green River Formation (Bradley 1931). Johnson (1984) distinguished these rocks from the Douglas Creek Member and renamed them the Cow Ridge Member of the Green River Formation. Bradley (1931) named the tongue of the freshwater lacustrine unit, which was deposited during this brief time of maximum transgression, the "basal tongue" of the Green River Formation where it crops out in Indian Canyon in the western part of the Uinta Basin. The two early freshwater lakes in the Uinta and Piceance Creek basins appear to have been similar to the approximately contemporaneous Lake Luman, the early freshwater stage of Lake Gosiute, which existed in the greater Green River Basin in Wyoming. In the Piceance Creek Basin, marginal lacustrine deposits from this early lacustrine period consist of molluskand ostracod-rich sandstone and limestone and carbonaceous shale with thin coal interbeds. In the Uinta Basin, marginal lacustrine sediments from this time interval are mostly similar to those in the Piceance Creek Basin but include some oolites, oncolites, and stromatolites. Kerogen-rich, clay-bearing shales were deposited in the offshore areas of both lakes during the freshwater interval. In the western part of the Uinta Basin, Ryder at al. (1976) divided lacustrine rocks from this freshwater period into three gradational lithofacies, which represent deposition from lake margin to lake center environments. These include (1) ostracodal and oolitic grainstones with horizontal and low-angle cross stratification and minor amounts of sandstone; (2) gray, fossiliferous, mud-supported carbonate; and (3) brown, kerogenous ostracod-bearing mudsupported carbonate. The sediments from lacustrine maximums in both the Piceance and Uinta basins almost connect over the top of the Douglas Creek arch, suggesting that the two basins were hydrologically connected during at least part of the freshwater period. During this period, the two basins are believed to have drained externally since the lake waters in both basins remained fresh enough to support abundant freshwater mollusks (Johnson 1985).

At the end of the early Eocene (Wasatchian-Bridgerian NALMA boundary), a major transgression associated with expansion and deepening of lake water marked the beginning of Lake Uinta as an unbroken body of water across the Douglas Creek Arch in both the Piceance Creek and Uinta basins (Johnson 1985; Moncure and Surdam 1980). Johnson (1984) named this the Long Point transgression. Both lakes appear to have expanded at approximately the same time, and because the basal transgressive bed does not climb stratigraphically, it is believed that the transgression occurred relatively rapidly. After the maximum transgression, Lake Uinta extended close to the margins of the combined Piceance Creek and Uinta structural and sedimentary basins, and it covered a much larger area than that of the maximum transgression during the earlier freshwater stage of the lake. Five stages in the developmental history of the 
larger saline Lake Uinta have been identified on the basis of changes in water chemistry and depositional events (Johnson 1985):

Stage 1: After the Long Point transgression, low-grade clay-rich oil shale was deposited in large areas of both basins, including the Douglas Creek Arch.

Widespread and shallow marginal lacustrine shelves were rapidly reestablished once maximum transgression had been attained. Sandy shelves formed in areas of high clastic input, including the eastern margin of the Piceance Creek Basin and the south-central margins of the Uinta Basin. Carbonate shelves formed in areas with lower amounts of clastic input, including the Douglas Creek arch and the western Uinta Basin. Magadi-type chert was formed in shales along Evacuation Creek in the easternmost Uinta Basin. Freshwater mollusks that were intolerant of saline water died off during the first stage.

Stage 2: The beginning of this stage is marked by an abrupt increase in the oil shale richness in the depositional center of the Piceance Creek Basin. Stratigraphically, this occurs just above the widespread "orange marker," which approximately correlates with the widespread carbonate marker in the Uinta Basin. In the Piceance Creek Basin, sedimentation fluctuated dramatically between periods of rapid clastic sedimentation, which resulted in the formation of huge clastic wedges around the margins of the lake, and periods of low clastic input during which a relatively thin, stromatolite-rich sequence was deposited around the margins of the lake and rich oil shale deposited in the lake's center. Similar fluctuation has been identified in the eastern part of the Uinta Basin. The shores of Lake Uinta regressed during periods of rapid clastic sedimentation and transgressed during periods of oil shale deposition. These transgressions and regressions are evident in the southeastern Uinta Basin where the Wasatch and Green River formations intertongue (Cashion 1967).

Stage 3: The initiation of the third stage is marked by a shift to more carbonaterich deposition in both offshore and marginal areas of the lake. This stage includes the deposition of four oil shale zones in the Piceance Creek depositional center. It also includes the first appearance of the bicarbonate mineral nahcolite in the Piceance Creek Basin. By early in Stage 3, marginal shelves had prograded to such an extent that shallow-water deposition covered the entire Douglas Creek arch area, thus splitting the two oil shale depositional centers and creating a broad area of shallow water deposition. Individual stromatolites can be traced across the top of the arch, indicating that, at least during high-water periods, Lake Uinta remained a single lake. The stratigraphic interval represented by the third stage in the Piceance Creek Basin can be roughly correlated to the depositional center of the Uinta Basin, where it is represented by a thick sequence of interbedded clayrich and carbonate-rich rocks, including some oil shale beds. Stromatolites commonly compose as much as $50 \%$ of the interval deposited during Stage 3 . A new facies for the Lake Uinta sequence, which is transitional between the predominantly oil shale facies of the depositional center and the two marginal lacustrine facies, appears during Stage 3. This facies consists of carbonate-rich oil 
shale interbedded with barren laminated marlstone, as well as some sandstone and siltstone. Unlike the previous two stages, sediments deposited during Stage 3 thicken toward the oil shale depositional center and thin toward the marginal lacustrine facies.

Stage 4: The beginning of Stage 4 is marked by a relatively minor transgression that occurred across both basins. Stratigraphically, it occurs at about the base of the R-4 rich oil shale zone of Cashion and Donnell (1974). This transgression expanded the oil shale and marlstone facies over much of the outer marginal shelf areas, including the Douglas Creek arch, suggesting deeper average water depths than in Stage 3. Nearly continuous oil shale deposition in the Piceance Creek Basin occurs during this stage. In the Uinta Basin, oil shale from this stage is leaner and interbedded with mudstone, siltstone, and sandstone. This is possibly the result of dilution by clastics in the much-thicker Stage 4 Uinta Basin sequence. The majority of saline minerals deposited in the Piceance Creek Basin are found in Stage 4 strata and include nahcolite and halite. Fewer saline minerals were deposited during Stage 4 in the Uinta Basin.

Stage 5: The beginning of the fifth and final stage of saline Lake Uinta was marked by a major transgression, which occurred mostly during the deposition of the Mahogany oil shale bed. During peak transgression, rich oil shale deposition expanded to cover almost the entire area formerly occupied by the marginal shelves. The maximum extent of Lake Uinta at this time is unknown because most of the marginal lacustrine rocks from this period have been eroded. However, Lake Uinta may have extended close to the margins of the sedimentary basin. Infilling of the lake began almost immediately after deposition of the Mahogany bed, and shallow water-shelf deposition was once again reestablished in areas such as the southwestern Uinta Basin. Huge wedges of volcanic debris began to be deposited in the northern Piceance Creek Basin shortly after the maximum transgression, and these prograded south into the oil shale depositional center, eventually replacing oil shale deposition with shallow water lacustrine deposition (Johnson 1981). The shallow water facies consist of volcaniclastic sediments interbedded with marlstone and oil shale tongues. This suggests episodic volcaniclastic influx or periodic rises in water level. Surdam and Stanley (1979) have suggested that the volcaniclastics were derived from the Absaroka volcanic field in northwestern Wyoming and that Lake Gosiute in the greater Green River Basin in Wyoming may have started to drain to the south into Lake Uinta sometime before the arrival of the first volcanic sediments in the Piceance Creek Basin. They further suggest that this arrival of volcanics in Lake Uinta may represent the final infilling of Lake Gosiute, which had previously acted as a sediment trap. The infilling of the Piceance Creek and Uinta basin depositional centers took a relatively long time. Volcaniclastic wedges reached the southern Piceance Creek Basin and the eastern Uinta Basin at about the same time, depositing the Horse Bench Sandstone (see Cashion 1967) of the Parachute Creek Member in the eastern Uinta Basin and the Porcupine tuff in the southern Piceance Creek Basin. The influx of volcaniclastics appears to have stopped 
before reaching the central depositional center of the Uinta Basin. Lake Uinta persisted until roughly the end of the middle Eocene in the central and eastern Uinta Basin, when it was largely filled in with sediments derived from locally rejuvenated Laramide uplifts as Lake Uinta deposition was replaced by fluvial and minor lacustrine deposition (freshwater ponds). The volcaniclastic sedimentary rocks of Stage 5 were originally assigned to the Evacuation Creek Member of the Green River Formation by Bradley (1931). Later stratigraphic work (Cashion and Donnell 1974) demonstrated that at its type locality in the eastern Uinta Basin, the Evacuation Creek Member is equivalent to the upper part of the Parachute Creek Member at its type locality in the Piceance Creek Basin. Furthermore, the Evacuation Creek Member as previously used by most workers in the Piceance Creek Basin is equivalent to the lower part of the Uinta Formation in the Uinta Basin. Hence, the term Evacuation Creek was abandoned and replaced by the Parachute Creek Member in the eastern Uinta Basin, and by the Uinta Formation in the Piceance Creek Basin (Cashion and Donnell 1974).

Throughout most of these five stages, the salinity of Lake Uinta increased steadily. Ultimately, salinity increased to the point at which nahcolite and halite were precipitated during the fourth stage. Based on Green River Formation geometry and sedimentology, Lake Uinta appears to have had a broad shallow shelf area which surrounded a depositional center for oil shale in each of the two basins. In the Piceance Creek Basin, the oil shale depositional center was several hundred feet deep during most if its existence and received a much higher influx of saline minerals than did the depositional center of the Uinta Basin. In summary, the gradual filling of Lake Uinta during the middle Eocene was due to an influx of volcaniclastics from the Absaroka Volcanic Field in Wyoming to the north and from volcanic centers further to the west, and then later by an increase in sediment resulting from rejuvenated local Laramide uplifts. As discussed in Section 5.4.2, there is no direct geologic evidence that lakes Uinta and Gosiute were ever physically connected. However, fluvially deposited volcaniclastics in Lake Uinta deposits which were demonstrably derived from the Absaroka volcanic field in northwestern Wyoming would be a persuasive line of evidence, although it would not rule out the possibility of transport of volcaniclastic material from Lake Gosiute south to Lake Uinta via streams over the lowest drainage divides once the greater Green River Basin had been filled (Surdam and Stanley 1980a).

Marginal lacustrine rocks of middle-early to late-early Eocene age in the Uinta and Piceance Creek basins are generally included in the Douglas Creek and Anvil Points members of the Green River Formation, respectively. In the Piceance Creek Basin, deepwater lacustrine rocks of this time interval are assigned to the Garden Gulch Member of the Green River Formation (Tuttle 1991). Both the marginal and deep water lacustrine rocks of this age in the Piceance Creek and Uinta basins correlate with the Tipton Shale Member of the Green River Formation in the greater Green River Basin in Wyoming. Shortly after the beginning of the middle Eocene, the major transgression during which the Mahogany bed was deposited, took place. Deposition of the Mahogany bed of the Parachute Creek Member in the Piceance Creek and Uinta basins has been tentatively correlated with the Laney Member of the Green River Formation in the Green River Basin of Wyoming (Tuttle 1991). 
As lacustrine deposition in Lake Uinta diminished because of basin filling, fluvial sedimentation resulted in deposition of the Uinta Formation in the Piceance Creek and Uinta basins (Stokes 1986). At this time, fluvial deposition began to dominate in the basin as streams flowed into it from the north and east (Stokes 1986).

From the time basin subsidence began during the Paleocene until it ended in the late Eocene, as much as 12,000 ft of sediments accumulated in the deepest part of the Piceance Creek Basin, which is located to the west of the Grand Hogback (Johnson 1989). During the latest Tertiary and Quaternary, the major streams and their tributaries traversing the Piceance Creek and Uinta basins eroded much of the sediments and exhumed the Eocene strata in the basins. Stream erosion has exposed oil shale strata on cliff faces in many places such as the Roan Cliffs. Gentle folds and minor faults have locally deformed the deposits, but the sedimentary rocks of the Piceance Creek and Uinta basins as a whole are remarkably intact structurally, except in the areas where the strata are steeply tilted on the south flanks of the Uinta Mountains in Utah and along the Grand Hogback in Colorado.

\subsection{PALEOENVIRONMENTAL SUMMARY}

Before the middle Eocene, global climates were equable and dominantly tropical to warm temperate, forests were widespread across Asia and North America, and both continents shared a large number of plant species. Temperature declines and the rise of mountain ranges contributed to increasing floristic and eventually faunal provincialism (Storer 1990; Wing 1998). During the late Paleocene, early Eocene, and much of the middle Eocene, overall paleoenvironmental conditions in the Piceance Creek and Uinta basins were similar to those of the greater Green River Basin in Wyoming (see Section 4.2). Late Paleocene and early Eocene environments were characterized by mostly fluvial deposition in river channels and swamps and on floodplains, and by tropical to warm-temperate, humid climatic conditions, resulting in lush vegetation. Numerous comparatively short-lived small lakes and ponds developed on the low-relief basin floors. These depositional environments are preserved in rocks of the DeBeque (Wasatch) Formation.

With the onset of widespread freshwater lacustrine deposition in the early Eocene followed by the formation of Saline Lake Uinta in the Piceance Creek and Uinta basins, fluvial deposition was restricted to lake margins. Like Lake Gosiute on the north side of the Uinta Mountains, Lake Uinta, represented by the Green River Formation, had a long and complex history of transgressions and regressions associated with changes in climatic conditions, tectonics, and distal volcanic activity. As evidenced by desiccation features preserved in laminated lacustrine sediments, frequent subaerial exposure of lake margins occurred. This was caused by lake contractions resulting from an imbalance between evaporation and inflow of waters to the hydrographic basin (Moncure and Surdam 1980). Bradley (1929) estimated that Eocene lacustrine deposition in the Piceance Creek Basin lasted for approximately 6.5 million years. Picard (1963) concluded that lacustrine deposition in the Uinta Basin commenced earlier and persisted later than in the Piceance Creek Basin and estimated a timeframe of approximately 13.3 million years. However, both of these estimates are probably high given our present understanding of the biochronology of the mammalian faunal 
assemblages associated with the Eocene-age lacustrine and associated rocks in each basin. Mauger (1977) estimated that Lake Uinta persisted in the central part of the basin until about $41 \mathrm{Ma}$ (Uintan-Duchesnean NALMA boundary), although it was believed to have persisted for a longer duration in the western part of the basin. The Uinta Formation in the Piceance Creek and Uinta basins was deposited in river channels and on adjacent floodplains (Stokes 1986) and in river deltas (Townsend 2004).

Riparian environments and the floodplains adjacent to the shorelines of freshwater lakes and ponds were muddy and typically forested during deposition of the DeBeque (Wasatch), Green River, and Uinta formations. Insects of many varieties lived in the Eocene lakes, swamps, rivers, and forests, and are locally well preserved in lacustrine shales of the Parachute Creek Member of the Green River Formation. Many well-preserved specimens have been collected from localities in the Piceance Creek Basin in the Roan Cliffs and Douglas Pass area. Wellpreserved plant fossils reflective of tropical to warm-temperate climatic conditions are also locally present within the DeBeque (Wasatch), Green River, and Uinta formations in the Piceance Creek and Uinta basins. Seasonal aridity is reflected in some late Paleocene floras, as well as those of the Green River Formation, which is further evidence of increasing regionalism of floras in the western interior of North America. According to MacGinitie (1969), fossil plants of the Green River lakes are indicative of subtropical, dry, woodlands vegetation, and he referred to the assemblage as woodlands. The paleobotanical record indicates that there was a drying trend in the North American Eocene, but it was regional and subcontinental in effect. This regional variation in environments would directly affect vertebrate communities. A variety of aquatic mollusks (clams and snails) and arthropods (crayfish and ostracods) also inhabited Lake Uinta and the rivers and streams in the area and are locally abundant and well preserved, especially in the presaline lacustrine rocks of the Green River Formation and in pond and stream deposits of the DeBeque (Wasatch) and Uinta formations.

As evidenced by fossil distribution and sedimentology, fish diversity was high in freshwater lakes but low in saline lake waters. Crocodiles and turtles were common residents of rivers, lakes, and ponds deposited throughout the Eocene sequence. A diversity of other reptile species, including tortoise, lizards, and snakes, inhabited the floodplains and shoreward lake margins. Forests teemed with the primitive ancestors of many modern mammalian groups, including rodents, rabbits, insectivores, bats, primates, artiodactyls (oreodonts, camels), perissodactyls (horse, rhinoceros, and tapir), and carnivores, as well as more bizarre archaic forms such as creodonts, brontotheres, and massive six-horned uintatheres. The shift from dominantly tropical forest environments of the early and early-middle Eocene to more open, savanna-like conditions was underway by the middle Eocene (Uintan NALMA) in the Uinta and Green River basins, and the trend to more open habitats continued throughout the Uintan as reflected by mammalian faunas of the upper Bridger and Uinta formations (Townsend 2004; Murphey and Townsend 2005). This trend is notably reflected in the loss of diversity and abundance of primates over this time interval.

The fossil vertebrate, insect, mollusk, and plant assemblages of the Piceance Creek and Uinta basins provide an excellent opportunity to study Eocene paleocommunities and paleoenvironments. Studies of these fossils and the rocks in which they are preserved have contributed greatly to our knowledge of the Eocene of North America. The Tertiary vertebrate 
faunas of the Piceance Creek and Uinta basins are of particular scientific importance because, among other things, they represent an exceptional record of early Tertiary mammalian evolution and diversification during the late Paleocene and early and middle Eocene epochs.

\subsection{PREVIOUS PALEONTOLOGICAL WORK AND RELATED INVESTIGATIONS}

Northwestern Colorado, including the Piceance Creek Basin, has had a long history of paleontologic and geologic exploration and inquiry. The first fossils that were scientifically collected in Colorado were fossil insects discovered in rocks of what would later be recognized as the Green River Formation. These were collected by Professor W. Denton in 1865 in bluffs along the White River near the present location of the Colorado-Utah state line (Armstrong and Wolny 1989). Beginning in 1867, Samuel H. Scudder, the founder of American insect paleontology, one-time assistant to Louis Agassiz (1862-1864), and later USGS Paleontologist (1886-1892), confirmed Denton's discoveries and spent the following 30 years collecting and describing fossil insects of northwestern Colorado (Armstrong and Wolny 1989). Many of these specimens were included in Scudder's classic monograph, The Tertiary Insects of North America (1890).

The first scientifically collected vertebrate fossil reported from Colorado was discovered during the Hayden survey of 1869. This fossil, a broken caudal (tail) vertebra of a theropod dinosaur discovered in the late-Jurassic Morrison Formation in Middle Park, Colorado, was thought to be a "petrified horse hoof" by the field party that collected it. It was scientifically described by the well-known early North American paleontologist Joseph Leidy. Leidy later assigned the generic name genus Antrodemus to this specimen, but the name Antrodemus was subsequently synonymized with the genus Allosaurus, which had nomenclatural priority because it was based on a much more complete skeleton discovered by O.C. Marsh in 1877 in Fremont County, Colorado (Armstrong and Wolny 1989). According to now retired University of Colorado Paleontologist Professor Peter Robinson (personal communication 2000), the Antrodemus caudal vertebra may have been discovered near the Green Mountain Dam in Middle Park.

In 1909, Junius Henderson, founder of the University of Colorado Museum of Natural History, worked in northwestern Colorado, collecting and studying invertebrate fossils from the Cretaceous Mancos Shale. During a trip to Meeker, Colorado, in 1909, he recognized that the formation on the western flank of the Grand Hogback was the "Wasatch" (Henderson field notes 1909). Henderson, an invertebrate paleontologist, was in the same area later and collected fossil vertebrates, although his primary research interest was fossil mollusks. Professor T.D.A. Cockerell, a cofounder of the University of Colorado Museum, spent 30 years studying fossil insects from the Piceance Creek Basin and elsewhere in Colorado. Cockerell, a self-taught insect biologist and paleontologist with no college degrees, published prolifically throughout his long career.

Around 1900, paleontologist E.S. Riggs of the Field Museum of Natural History in Chicago excavated dinosaur fossils from the Morrison Formation just to the west of Grand Junction. In 1923, Earl Douglas of the Carnegie Museum apparently became the first vertebrate 
paleontologist to discover fossil vertebrates in the "Wasatch" Formation of the Piceance Creek Basin at the Blacks Gulch/Scenery Gulch area west of Meeker.

Paleontologist Bryan Patterson and a crew from the Field Museum of Natural History in Chicago worked in the Rifle area for several summers before 1940 and then again in 1946. These expeditions resulted in important fossil collections of late Paleocene and Eocene age from the Piceance Creek Basin. A number of specimens were also sent to the Denver Museum of Natural History, now the Denver Museum of Nature and Science. In 1961, William Turnbull of the Field Museum collected from a rich fossil locality near Silt, Colorado. Patterson's work resulted in a large number of paleontological publications based on the vertebrate faunal assemblages of the DeBeque (Wasatch) Formation (Patterson 1933, 1934, 1937, 1939, 1949; Patterson and West 1973).

In 1976, Allen Kihm began his fieldwork in the Piceance Creek Basin as a graduate student at the University of Colorado. His work culminated in his doctoral dissertation (Kihm 1984). Professor Peter Robinson, then Curator of Paleontology at the University of Colorado Museum, arranged for Bryan Patterson to return to the area and show Robinson and Kihm his collecting sites from the 1930s. Kihm's doctoral research, which has not yet been formally published, resulted in a large collection of stratigraphically positioned and biostratigraphically documented fossils of Tiffanian to Wasatchian (Lostcabinian) NALMA. Personnel from the University of Colorado Museum, including Professor Robinson who is now retired, periodically continue to collect fossils in the DeBeque and Green River formations in the Piceance Creek Basin. In recent years, these fossil-collecting efforts have been complemented by those of paleontologists contracted by commercial oil, gas, and mineral exploration companies to meet federal environmental requirements on BLM-administered lands. The known fossil record of the Piceance Creek Basin has been significantly augmented by these efforts.

As a result of its widespread exposures, wide variety of depositional environments and lithologies, diversity and abundance of fossils, and economic potential largely in the form of oil shale and evaporite minerals, the Green River Formation has served as a field laboratory for numerous geological studies for almost a century, many conducted by USGS geologists. Because depositional and paleoenvironmental conditions are directly correlated with the presence or absence of oil shale and other geologic resources of economic interest, a wealth of information about the paleoenvironments of Lake Uinta and the stratigraphy of the Green River Formation and associated rocks has been generated by these studies. Some notable examples include, but are not limited to, W.H. Bradley's (1929) study of the varves and climate of the Green River lakes, his 1931 study of the origin and microfossils of oil shale deposits, and his classic 1964 study of the Green River Formation and associated Eocene rocks in Wyoming, Colorado, and Utah; W.B. Cashion's (1967) classic study of the geology and fuel resources of the Green River Formation in the southeastern Uinta Basin in Utah and Colorado; Cashion and Donnell's (1974) revision of stratigraphic nomenclature of the upper part of the Green River Formation in the Piceance Creek and eastern Uinta basins; Cole and Picard's (1978) study of the comparative mineralogy of the nearshore and offshore facies of the Parachute Creek Member of the Green River Formation in the Piceance Creek and eastern Uinta basins; Dyni's (1981) geologic study of the nahcolite deposits and oil shale in the saline facies of the Green River Formation in the Piceance Creek Basin; Johnson's (1981) study on stratigraphic evidence for a deep water 
Lake Uinta in the Piceance Creek Basin and his 1985 study on the early Cenozoic history of the Uinta and Piceance Creek basins; and Surdam and Stanley's (1979) study on lacustrine sedimentation during the culminating phase of Lake Gosiute and its relations with Lake Uinta, and their 1980 study on the effects of changes in drainage-basin boundaries on sedimentation in Lakes Gosiute and Uinta in Wyoming, Utah, and Colorado.

\subsection{GEOLOGIC UNITS AND PALEONTOLOGICAL RESOURCES}

The portion of the Oil Shale and Tar Sands PEIS study area that lies within the Piceance Creek Basin in northwestern Colorado contains three mapped bedrock geologic units (Cashion 1973; Ellis and Freeman 1984; Ellis and Gabaldo 1989; Gualtieri 1988; Rowley et al. 1985; Tweto 1979; Tweto et al. 1978; Whitney 1981; and others-see Bibliography of Geologic Maps in Appendix B). These include, from oldest to youngest, and in approximate stratigraphic order, the DeBeque (Wasatch), Green River, and Uinta formations. On the basis of the geologic map review conducted for this study, older (and stratigraphically lower) bedrock units are not anticipated to be affected by oil shale development. The three potentially affected bedrock units are locally mantled by younger surficial deposits of Holocene and Pleistocene age, which consist of alluvium, colluvium, landslide deposits, and glacial drift. Generalized stratigraphic correlation diagrams for the northern Piceance Creek and eastern Uinta basins, and the southern Piceance Creek and southeastern Uinta basins, are provided in Figures 8 and 9, respectively.

In the following section of this report, the geology and paleontology of the geologic units within the Piceance Creek Basin are discussed, and the units' paleontological sensitivities are evaluated. Previous and more specific paleontological inventories of portions of northwestern Colorado have been previously prepared for the BLM by Lucas and Kihm (1982) and Armstrong and Wolny (1989). Armstrong and Wolny's (1989) regional analysis of the paleontological resources of northwestern Colorado (BLM Craig District) is a comprehensive study consisting of five volumes containing a history of paleontological work, an evaluation and analysis, an annotated bibliography, types of fossils found in each formation, and fossil locality records. These documents are on file at the BLM Colorado State Office. Additional analysis of paleontological resources within part of the study area in Colorado can be found in the White River Resource Management Plan (BLM 1997). Additional fossil locality records may be on file at BLM field offices and at major museums throughout the United States. 


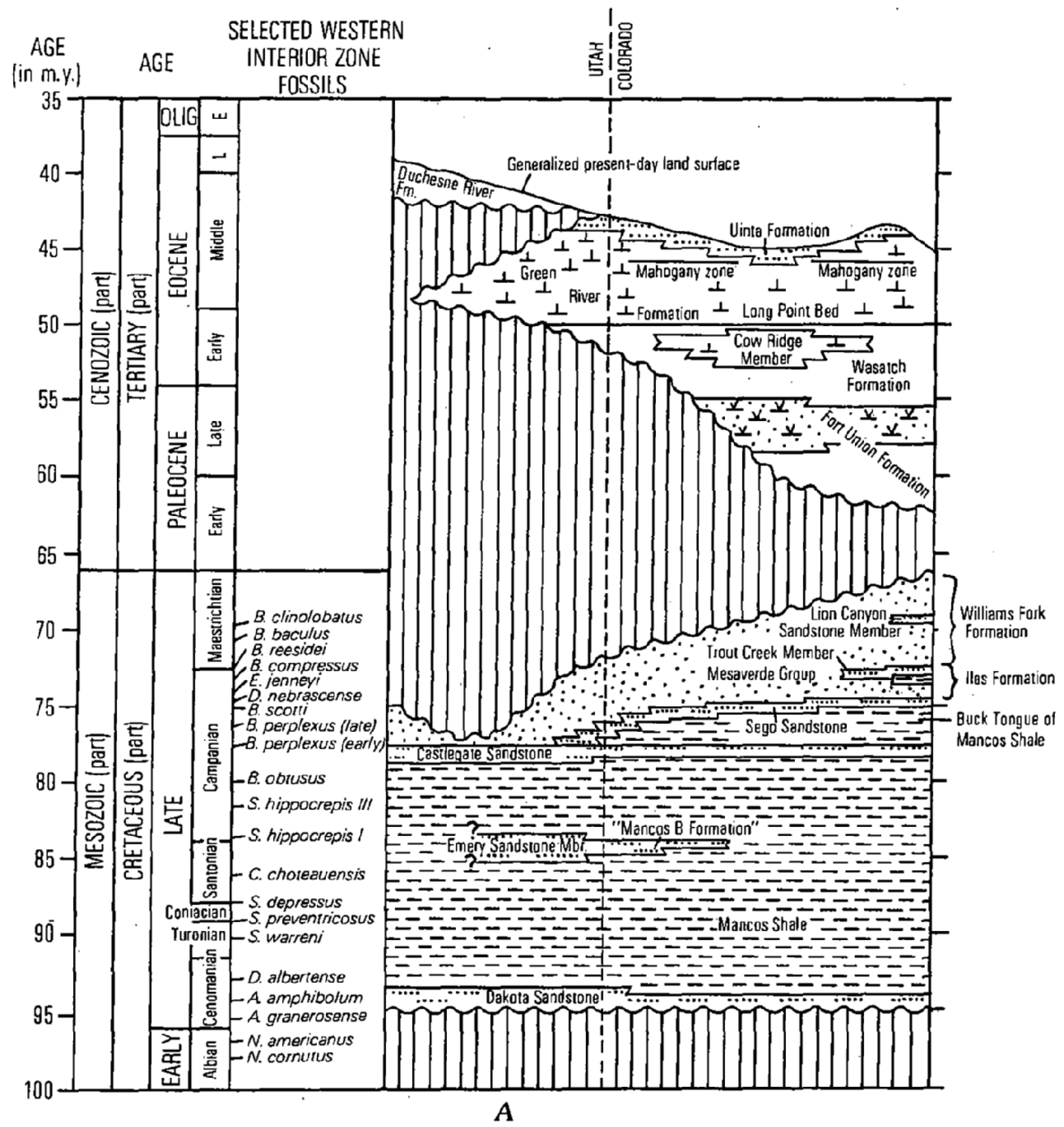

FIGURE 8 Generalized Stratigraphic Correlation Diagram for Late Cretaceous and Early Tertiary Rocks in the Northern Piceance Creek and Northeastern Uinta Basins (Source: Johnson 1989) 


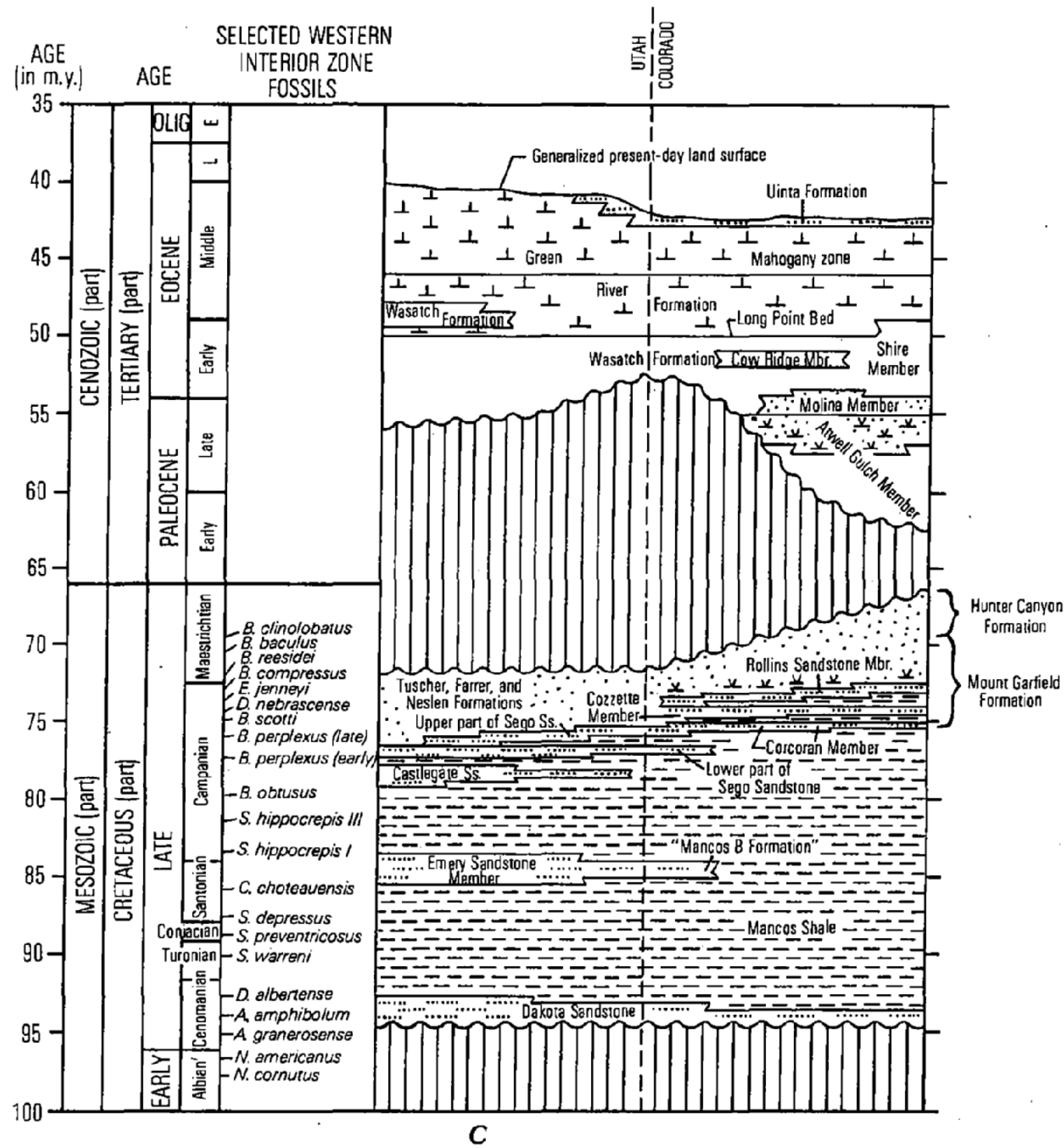

FIGURE 9 Generalized Stratigraphic Correlation Diagram for Late Cretaceous and Early Tertiary Rocks in the Southern Piceance Creek and Southeastern Uinta Basins (Source: Johnson 1989) 


\subsubsection{DeBeque Formation}

In the Piceance Creek Basin, the late Paleocene (Tiffanian) to early-middle Eocene (early Bridgerian) DeBeque (Wasatch) Formation is unconformably underlain by the lateCretaceous Mesaverde Group, and conformably overlain by the middle-Eocene Green River Formation. Although the name "DeBeque" has never been formally adopted by the USGS, it should be noted that the name "Wasatch Formation" for late Paleocene- and early Eocene-age fluvial rocks of the Piceance Creek Basin is not appropriate under the rules of stratigraphic nomenclature. The DeBeque Formation is similar in overall appearance, age, and fossil content to the Wasatch Formation. However, there is no direct evidence that the Piceance Creek Basin was ever part of the depositional basin in which the type Wasatch Formation of Wyoming accumulated. The name DeBeque Formation for early-Eocene rocks in the Piceance Creek Basin has been in informal use (mostly by vertebrate paleontologists) since Curator Bryan Patterson of the Field Museum of Natural History worked in the area during the 1930s and 1940s. Kihm (1984) proposed that the name be changed in his doctoral dissertation, but because this dissertation was never published, the name "DeBeque" has not been formally recognized. The name "DeBeque" for late Paleocene- and early Eocene-age dominantly fluvial rocks in the Piceance Creek Basin will be used henceforth in this report.

The DeBeque Formation includes three members: the Paleocene-age Atwell Gulch and Molina members and the early-Eocene Shire Member. Rocks of the DeBeque Formation are lithologically very similar to one another throughout the Piceance Creek Basin as heterogeneous continental fluvial deposits with interfingering channel sandstone beds and overbank deposits consisting of variegated claystone, mudstone, and siltstone beds (Franczyk et al. 1990). The underlying unconformable contact with the Mesaverde Group is locally difficult to distinguish because of similar lithologies. The DeBeque Formation is conformably overlain by the Green River Formation and is composed primarily of fluvial variegated green, red, purple, and brown claystone, mudstone, siltstone, sandstone, and conglomerate (Franczyk et al. 1990; Tweto et al. 1978). It is perhaps best exposed to the west of Rifle, where it outcrops as picturesque badlands at the base of the steep slopes of the Colorado River Valley to roughly onethird of the way up the Roan Cliffs ( 5,500 to 7,000 ft in elevation north of Sharrard Park). In the Roan Cliffs area, the DeBeque Formation sequence is mapped as the Shire Member of the Wasatch Formation (Yeend et al. 1988), which is described as variegated purple, lavender, red, gray, and brown claystone; there is some locally lenticular fine- to coarse-grained sandstone. It also contains minor conglomerate, limestone, coal, and carbonaceous shale (O'Sullivan 1986). The DeBeque Formation is reported to have a total thickness of 5,300 ft (Donnell 1961), although only the uppermost 1,500 ft is exposed in the Roan Cliffs area (O'Sullivan 1986).

The DeBeque Formation contains scientifically important continental fossil flora and fauna. The Paleocene portion (Atwell Gulch and Molina members) has produced vertebrate assemblages of Tiffanian and Clarkforkian age. The early-Eocene portion (Shire Member) has produced vertebrate assemblages that are taxonomically similar to the type Wasatch Formation of Wyoming. According to Robinson et al. (2004), the Eocene-age Shire Member of the DeBeque contains mammalian faunas of biochronologic zones Wa2 through Wa7. Numerous fossil mammal localities have been discovered in badlands near Parachute, Rifle, DeBeque, White River City, and other areas within the Piceance Creek Basin (see Armstrong and 
Wolny 1989). The University of Colorado Museum has more than 1,400 vertebrate specimens from approximately 235 recorded fossil localities from the DeBeque Formation (unpublished paleontological data, University of Colorado Museum, compiled in 2001). Included are fishes; reptiles, including turtles, lizards, and crocodiles; birds, including the enigmatic Presbyornis; and mammals including apatotheres, artiodactyls, carnivores, condylarths, creodonts, dermopterans, uintatheres, insectivores, leptictids, mesonychids, multituberculates, pantodonts, pantolestids, perissodactyls, primates, rodents, taeniodonts, and tillodonts. The vertebrate fossils of the DeBeque Formation have been included in numerous paleontological studies, many of which were conducted by Bryan Patterson of the Field Museum (Black and Dawson 1966; McKenna 1960; Patterson 1934, 1937, 1939, 1949; Patterson and West 1973; Savage and Russell 1983; Doi 1990). Kihm's (1984) dissertation remains the most comprehensive and stratigraphically controlled relatively recent paleontological study.

All members of the DeBeque Formation contain vertebrate fossils in varying abundances and are designated as BLM Condition 1 and PFYC Class 4/5. Future project-specific analyses of smaller geographic areas and more stratigraphically restricted intervals may necessitate a reevaluation and local redesignation.

\subsubsection{Green River Formation}

As discussed in detail in Section 5.1, the transition from dominantly fluvial to dominantly lacustrine depositional environments and paleoenvironmental conditions in the Piceance Creek Basin generally began in the late-early Eocene and is preserved in rocks of the early-to-middle Eocene lacustrine Green River Formation. In the Piceance Creek Basin, the Green River Formation is composed of approximately 3,800 ft of shale, oil shale, marl, sandstone, and limestone, and conformably overlies and intertongues with the DeBeque Formation. On the basis of vertebrate fossils found in the Piceance Creek Basin, the Green River Formation in this area interfingered with sedimentary deposits of the lateral and overlying Uinta Formation primarily during late Bridgerian time. Lake Uinta persisted throughout much of the middle Eocene in the central Piceance Creek Basin, with numerous transgressions and regressions expressed by widely fluctuating shoreline deposits. Evaporite accumulation during low-water intervals produced the thick beds of nahcolite that are currently being mined for sodium bicarbonate. Oil shale deposits within the formation, deposited in deep water lacustrine conditions, give the Green River Formation great economic importance. The Green River Formation has been assigned three members in ascending stratigraphic order: the Anvil Points Member, the Garden Gulch Member, and the Parachute Creek Member (Johnson 1985; 1989; Yeend et al. 1988). The Parachute Creek Member is conformably overlain by, and intertongues with, the Uinta Formation (Duncan et al. 1974).

In the Rifle/Roan Cliffs area, the Anvil Points Member of the Green River Formation is approximately $400 \mathrm{ft}$ (where Garden Gulch Member is present) to 1,700 ft thick. It grades westward into the Garden Gulch Member with a decrease in number and thickness of sandstone beds. Lithologically, the Anvil Points Member consists of brown and buff, massive, fine- to coarse-grained sandstone that forms conspicuous ledges, minor amounts of light-gray siltstone, marlstone, and several beds of low-grade oil shale (Yeend et al. 1988). The Garden Gulch 
Member is composed of light-gray marlstone, dark-brown to black locally fissile shale with some oil shale, light-gray oolitic limestone and sandstone, light-gray algal limestone, and some massive brown fine- to medium-grained sandstone. It has a maximum thickness of approximately 1,500 ft. The Parachute Creek Member consists of black, brown, and gray marlstone, which weathers gray (and includes cliff-forming oil shale); it also includes minor amounts of light-gray siltstone, light-gray and brown medium-grained sandstone, and numerous very thin beds of analcite and tuff. The base of the richest oil shale bed, the 2- to 4-ft-thick Mahogany bed (early Bridgerian NALMA), occurs approximately 40 to $80 \mathrm{ft}$ above the base of the Parachute Creek Member (Donnell 1964; O'Sullivan 1986; Yeend et al. 1988). The Mahogany bed is the lowest bed in the approximately 74-ft-thick "Mahogany Zone" (Yeend et al. 1988). Duncan et al. (1974) named four stratigraphically higher Green River Formation tongues, which interfinger with the Uinta Formation in the northern part of the Piceance Creek Basin. These include, in ascending order, the Yellow Creek, Dry Fork, Thirteenmile Creek, and Black Sulphur tongues.

Fossils are locally abundant in some of the Green River Formation strata in the Piceance Creek Basin. Large accumulations of terrestrial and aquatic vertebrates, mollusks, insects, and plants (MacGinitie 1969; Grande 1984; Johnson and Plumb 1995) occur, especially in the Parachute Creek Member. The University of Colorado Museum has more than 4,500 vertebrate fossil specimens from the general (member not recorded) Green River Formation in the Piceance Creek Basin. These include a diverse assemblage of fishes and amphibians (frogs); reptiles, including turtles, lizards, and crocodiles; birds, including the giant flightless carnivorous genus Diatryma; and mammals, including apatotheres, artiodactyls, carnivores, chiropterans (bats), condylarths, dermopterans, insectivores, marsupials, pantodonts, primates, and rodents (unpublished paleontological data, University of Colorado Museum, compiled in 2000). The Garden Gulch and Anvil Points members do contain fossil remains, but they are less abundant and typically less well preserved than those of the Parachute Creek Member. The most common fossils from the Anvil Points Member are moderately to poorly preserved plants (mostly leaves and stems) and invertebrates (ostracods, bivalves, gastropods, and insects).

In the Piceance Creek Basin, the Parachute Member of the Green River Formation is designated as BLM Condition 1 and PFYC Class 4/5. Future project-specific analyses of smaller geographic areas and stratigraphic intervals may necessitate a reevaluation and local redesignation. The Anvil Points and Garden Gulch members are designated as BLM Condition 2 and PFYC Class 3.

\subsubsection{Uinta Formation}

In the Piceance Creek Basin of Colorado, the Uinta Formation has been subdivided into Units 1 through 6, or Groups A through G, and is older than the type Uintan in the Uinta Basin of Utah on the basis of its fossils of Bridgerian age and superpositional relationships (Duncan 1976; Hail and Smith 1994, 1997). Strata of the Uinta Formation in the Piceance Creek Basin are composed largely of distributary channel sandstone complexes with interbedded overbank deposits. In the northern part of the Piceance Creek Basin, the distributary channels appear to have been draining into the eastern portion of Lake Uinta during Eocene time, and they 
interfinger extensively with Green River Formation rocks. Although lithologies and thicknesses of the Uinta Formation in the Piceance Creek Basin are highly variable, the unit is generally composed of approximately $850 \mathrm{ft}$ of light-brown, tan, and gray very fine- to medium-grained sandstone, light-gray siltstone, and marlstone.

Vertebrate fossils are not as common in the Uinta Formation in the Piceance Creek Basin as in parts of the Uinta Formation in the Uinta Basin, although this is at least in part reflective of the fact that it is more vegetated, difficult to access, and has not been as heavily prospected. Recent paleontological surveys associated with oil and gas development are adding significantly to the known fossil flora and fauna of this unit. Representative fossils collected include a jaw of a miacid carnivore, a tooth of the condylarthran mammal Hyopsodus, and four specimens of uintathere, including both Uintatherium and Tetheopsis (unpublished paleontological data, University of Colorado Museum, compiled in 2003). These fossils suggest a Bridgerian rather than a Uintan age. Plant fossils have been discovered in all Uinta Formation stratigraphic units in the Piceance Creek Basin, and they are considered scientifically significant because plants are relatively uncommon in the Uinta Formation (although locally abundant in the Green River Formation). Fossil insects are also known from the upper portion of the Uinta Formation Group C (Robinson 1978; Hail and Smith 1994, 1997).

In the Piceance Creek Basin, the Uinta Formation is designated as BLM Condition 1 and PFYC Class 4/5. Future project-specific analyses of smaller geographic areas and stratigraphic intervals may necessitate a reevaluation and local redesignation of the Uinta Formation in the Piceance Creek Basin.

\subsubsection{Pleistocene- and Holocene-Age Surficial Deposits}

The bedrock geologic units within the Piceance Creek Basin are locally mantled by younger surficial deposits of Pleistocene and Holocene age. These consist of alluvium, colluvium, landslide deposits, and glacial drift. Holocene-age alluvium is composed primarily of poorly consolidated silt, sand, and cobbles derived from eroded bedrock and older alluvial and colluvial deposits. These sediments are deposited by rivers and streams in stream channels and on active alluvial floodplains. Pleistocene-age alluvium consists of gravel, sand, silt, mud, and clay that forms alluvial terraces and isolated remnants on dissected benches along stream drainages. Glacial drift deposits, produced by glacial meltwater streams, are generally composed of stratified unconsolidated sand and gravel. Colluvium and landslide deposits consist of rock material that has moved under the influence of gravity. Lithologies of these units vary and are dependent upon the type of source rock. They form on unstable slopes and on older colluvial deposits. In general, colluvium and landslide deposits are much less likely to contain wellpreserved animal and plant remains than intact native sediments. Colluvium and landslide material is often subjected to increased groundwater percolation, which tends to have a negative effect on the preservation of organic material; gravitationally induced movement of sediment can also destroy animal and plant remains through abrasion and breakage. In addition, when the original stratigraphic position of the sediments is disturbed, there are varying degrees of information loss with the severity of changes to the slide mass. 
Surficial deposits of Holocene age contain the unfossilized remains of modern taxa and are too young to contain in situ fossils. Pleistocene-age surficial deposits, particularly alluvium, may contain mineralized or partially mineralized animal bones, invertebrates, and plant remains of paleontological significance. With the exception of some caves, hot springs, and tar deposits, these fossils typically occur in low density and usually consist of scattered and poorly preserved remains. The most common Pleistocene vertebrate fossils include the bones of mammoth, bison, deer, and small mammals, but other taxa, including horse, lion, cheetah, wolf, camel, antelope, peccary, mastodon, and giant ground sloth, have been reported from the Rocky Mountain region (Cook 1930, 1931; Emslie 1986; Gillette and Miller 1999; Gillette et al. 1999a,b; Heaton 1999; Hunt 1954; Lewis 1970; Scott 1963; Smith et al. 1999; unpublished paleontological data, Denver Museum of Nature and Science).

Generally, deposits of Holocene age contain the unfossilized remains of modern species of animals and plants and are not considered paleontologically sensitive. These are designated as BLM Condition 3 and PFYC Class 2 in this analysis. Relatively few reports of Pleistocene-age fossils from northwestern Colorado exist. Pleistocene-age surficial deposits within the Piceance Creek Basin are designated as BLM Condition 2 and PFYC Class 2.

\subsection{PALEONTOLOGICAL RESOURCE ASSESSMENT SUMMARY}

As discussed in Section 5.4, surface disturbance associated with commercial oil shale activities within the portion of the PEIS study area located in the Piceance Creek Basin in northwestern Colorado has the potential to affect four mapped bedrock geologic units, as well as a variety of surficial deposits (Cashion 1973; Ellis and Freeman 1984; Ellis and Gabaldo 1989; Gualtieri 1988; Rowley et al. 1985; Tweto 1979; Tweto et al. 1978; Whitney 1981; and otherssee Bibliography of Geologic Maps in Appendix B). The paleontological sensitivities of these units were evaluated by using both the BLM paleontological resource classification system (Conditions 1-3; BLM 1998) and the PFYC developed by the USFS and recently adopted with modifications by the BLM (see Sections 3.1 and 3.2; BLM 2007). Resource assessment designations for each geologic unit discussed in Section 5.4 are summarized in Table 4 using both classification systems. 
TABLE 4 Summary of Programmatic-Level Paleontological Sensitivities of Geologic Units within the Piceance Creek Basin in Northwestern Colorado

\begin{tabular}{|c|c|c|c|c|}
\hline Geologic Unit & Age & Typical Fossils & $\begin{array}{c}\text { BLM } \\
\text { Designation }\end{array}$ & $\begin{array}{c}\text { PFYC } \\
\text { Designation }\end{array}$ \\
\hline $\begin{array}{l}\text { Alluvium, colluvium, } \\
\text { landslide deposits, and } \\
\text { glacial drift }\end{array}$ & Holocene & $\begin{array}{l}\text { None in deposits of } \\
\text { Holocene age unless } \\
\text { reworked from older } \\
\text { sediments }\end{array}$ & Condition 3 & Class 2 \\
\hline $\begin{array}{l}\text { Alluvium, colluvium, } \\
\text { landslide deposits, and } \\
\text { glacial drift }\end{array}$ & Pleistocene & $\begin{array}{l}\text { Scattered vertebrates, } \\
\text { invertebrates, and plants } \\
\text { occur locally }\end{array}$ & Condition 2 & Class 2 \\
\hline Uinta Formation & Middle Eocene & $\begin{array}{l}\text { Localized occurrences of } \\
\text { vertebrates (mammals } \\
\text { and reptiles), } \\
\text { invertebrates (mollusks), } \\
\text { and plants (leaves and } \\
\text { wood) }\end{array}$ & Condition 1 & Class $4 / 5$ \\
\hline $\begin{array}{l}\text { Green River Formation: } \\
\text { Parachute Creek } \\
\text { Member }\end{array}$ & Middle Eocene & $\begin{array}{l}\text { Locally abundant } \\
\text { vertebrates (fishes, } \\
\text { amphibians, reptiles, } \\
\text { birds, and mammals), } \\
\text { invertebrates (insects and } \\
\text { arthropods, and } \\
\text { mollusks), plants (leaves, } \\
\text { flowers, and wood), and } \\
\text { ichnofossils }\end{array}$ & Condition 1 & Class 4/5 \\
\hline $\begin{array}{l}\text { Green River Formation: } \\
\text { Anvil Points and } \\
\text { Garden Gulch members }\end{array}$ & Early Eocene & $\begin{array}{l}\text { Vertebrates (mostly } \\
\text { fish), invertebrates } \\
\text { (mollusks), and plants } \\
\text { (leaves) }\end{array}$ & Condition 2 & Class 3 \\
\hline $\begin{array}{l}\text { DeBeque (Wasatch } \\
\text { Formation), Atwell } \\
\text { Gulch, Molina and } \\
\text { Shire members }\end{array}$ & $\begin{array}{l}\text { Paleocene and } \\
\text { early Eocene }\end{array}$ & $\begin{array}{l}\text { Locally abundant } \\
\text { vertebrates (fishes, } \\
\text { amphibians, reptiles, } \\
\text { birds, and mammals), } \\
\text { invertebrates (mollusks), } \\
\text { and plants }\end{array}$ & Condition 1 & Class $4 / 5$ \\
\hline
\end{tabular}




\section{UINTA BASIN, UTAH}

In the Uinta Basin of northeastern Utah, deposits of oil shale are contained within sedimentary rocks of the Green River Formation. The Green River Formation was deposited in an ancient lake system that existed from the late Paleocene to the middle Eocene Epoch in what is now Colorado, Utah, and Wyoming. The smallest and oldest of these lakes, Fossil Lake, was deposited in Fossil Basin, which is located in the Wyoming overthrust belt just to the west of the Green River Basin in southwestern Wyoming. Lake Gosiute was deposited in the greater Green River Basin, which includes the Green River and Washakie basins in southwestern Wyoming, and the Sand Wash Basin in northwestern Colorado. Lake Uinta was deposited in the Uinta Basin in northeastern Utah and the Piceance Creek Basin in northwestern Colorado.

Tar sands are locally present within Cretaceous and Eocene-age strata in the Uinta Basin. As defined in the Utah Combined Hydrocarbon Leasing EIS (BLM 1984) (see Table 1), deposits of tar sand in this area occur within strata of the Mesaverde Group, Wasatch Formation, Douglas Creek, and Parachute members of the Green River Formation, Uinta Formation, and Duchesne River Formation. Designated STSAs include Argyle Canyon-Willow Creek; Asphalt RidgeWhiterocks and Vicinity; Hill Creek; Pariette; P.R. Spring; Raven Ridge-Rim Rock and Vicinity; and Sunnyside and Vicinity (USGS 1980a-k).

\subsection{GEOLOGIC SETTING AND DEPOSITIONAL HISTORY}

The Uinta Basin and the highlands surrounding it define a region that is well known for its geologic history and paleontologic importance. Preserving a discontinuous but rich fossil record spanning at least 535 million years from the Cambrian Period to the Pleistocene Epoch, this region has produced many important fossil specimens, including numerous holotypes. Many specimens are now housed in museums throughout the United States. Predating this macrofossil record, isolated enigmatic trace fossils interpreted as tiny fossil algal globules have recently been reported from the 1.1 billion-year-old Precambrian Uinta Mountain Group (Gregson and Chure 2000).

Sediments that today compose the Uinta Mountains were first deposited in an east-west trending basin between 1,000 and $600 \mathrm{Ma}$. At this time, more than 25,000 ft of shallow-water sandstone and shale accumulated from westward-flowing stream deposits. The basin filled and major deposition was halted, although minor periodic subsidence allowed for thickening of sedimentary deposits (Stokes 1986). These deposits were eventually uplifted during the Rocky Mountain-forming Laramide orogeny in the latest Cretaceous Period and Paleocene Epoch to form the Uinta Mountains. In conjunction with this uplift, the southerly adjacent synclinal Uinta Basin formed (Rasmussen et al. 1999a).

The Uinta Basin occupies approximately $6,800 \mathrm{mi}^{2}$ of northeastern Utah. Structurally, it is an asymmetrical, elongate east-west trending synclinal basin bounded by the Uinta Mountains to the north, the Douglas Creek Arch and Roan Plateau to the east, the Book Cliffs/Tavaputs Plateau to the south, and the Wasatch Range to the west. Early Tertiary strata in the Uinta Basin 
dip gently from all directions to the northern margin of the basin, where the strata are sharply upturned and faulted along the southern flank of the Uinta Mountains uplift (Johnson 1985).

Like the greater Green River and Piceance Creek basins, the geology and paleontology of the Uinta Basin and adjacent Uinta Mountains are of great scientific importance. To cite several examples, the rock units and fossils preserved within them in this region record and provide a means to scientifically study (1) repeated marine transgressions and regressions during the Paleozoic and Mesozoic eras; (2) the development of savanna-like ecosystems inhabited by a high diversity of dinosaurs and primitive mammals during the late Jurassic Period; (3) the transition from tropical to more-open woodland ecosystems during the early and middle part of the Eocene Epoch; (4) the development and history of massive Lake Uinta during the early and middle part of the Eocene Epoch; and (5) the evolutionary radiation of mammals during the Wasatchian, Bridgerian, Uintan, and Duchesnean Eocene NALMAs.

The Mesaverde Group was deposited in nearshore and coastal plain environments during the late Cretaceous while the Cretaceous epeiric seaway was gradually being filled in. Blanketlike sandstone beds are common in the transgressive and regressive cycles in the lower part of the Mesaverde, while more lenticular sandstone beds dominate the coastal plain sediments of the upper part (Johnson 1989). Deposition of the Mesaverde Group mostly predates the Laramide orogeny that formed the Uinta and Piceance Creek basins. It was deposited in the Cretaceous Rocky Mountain foreland basin, a huge basin that covered much of central North America from northern Canada to the Gulf of Mexico. The western boundary of this foreland basin was the Sevier orogenic belt, an area of active uplift and eastward thrusting from the Jurassic until early Cenozoic times. During the Cretaceous Period, rapid subsidence in the foreland basin caused a major marine incursion and formation of the Cretaceous epeiric seaway, which existed in the area for most of the Cretaceous. Several thousand feet of marine Mancos Shale, which underlies the Mesaverde Group in this area, was deposited in what would later become the Uinta and Piceance Creek basins. For most of Cretaceous time, transgressions and regressions occurred within a fairly narrow area along the western margin of the seaway and appear to have been derived from the Sevier orogenic belt. During the late Cretaceous (Campanian), it is believed that pulses of orogenic activity on the Sevier orogenic belt created pulses of clastic sedimentation that began to push the shoreline of the seaway progressively farther to the east, and transgressions and regressions across the area now occupied by the Uinta and Piceance Creek basins occurred throughout much of the Campanian (Fouch et al. 1983). By the beginning of the latest Cretaceous (Maestrichtian), the shoreline of the seaway was located to the east of the present-day easternmost margin of the Piceance Creek Basin. Marginal marine sediments, deposited during the transgressions and regressions of the Campanian, and coastal plain sediments, deposited during the late Campanian and Maestrichtian, compose the Mesaverde Group.

The end of the Cretaceous Period and beginning of the Tertiary Period in the eastern Uinta Basin, Uinta Mountains, and northwestern Colorado is represented by a major unconformity (Fisher et al. 1960). This unconformity corresponds to a major period of regional uplift, and marks the period of initial subsidence within the region that occurred during the early part of the Laramide orogeny. As the Uinta and Piceance Creek basins initially formed during the latest Cretaceous Period and early Paleocene Epoch, a widespread beveling over the entire Piceance Creek Basin and the central and eastern portions of the Uinta Basin occurred. During 
the late Paleocene, widespread sedimentation occurred in most of both basins. Paleocene-age sediments, which were deposited shortly after the period of beveling, are highly variable lithologically, but are commonly conglomeratic, reflecting active tectonism on nearby Laramide uplifts (Johnson 1985).

The Uinta and Piceance Creek basins are closely related early Cenozoic structural and sedimentary basins that were created by Laramide uplifts during latest Cretaceous and Paleocene time. Structurally, the Uinta and Piceance Creek basins are separated by the Douglas Creek arch, a broad north-south trending anticline that separated the two sedimentary basins until the earlymiddle Eocene, when the two basins coalesced across the top of the arch to form one large sedimentary basin (Moncure and Surdam 1980; Johnson 1985, 1989). Both the Uinta and Piceance Creek basins are highly asymmetrical (Johnson 1985).

By the late Paleocene (Clarkforkian NALMA), large shallow lakes and ponds occupied a large portion of both the Uinta and Piceance Creek basins. During the latest Paleocene and early Eocene (late Clarkforkian and early Wasatchian NALMA), there was a return to fluvial sedimentation in both basins, which is represented by rocks of the Wasatch (DeBeque) Formation. This was followed by a return to dominantly lacustrine conditions in the early Eocene with the establishment of two large freshwater lakes (one in each basin). These lakes may have been briefly connected over the Douglas Creek Arch during the early Eocene (Johnson 1985). Bradley (1931) named the tongue of the freshwater lacustrine unit, which was deposited during this brief time of maximum transgression, the "basal tongue" of the Green River Formation where it crops out in Indian Canyon in the western part of the Uinta Basin. The two early freshwater lakes in the Uinta and Piceance Creek basins appear to have been similar to the approximately contemporaneous Lake Luman, the early freshwater stage of Lake Gosiute, which existed in the greater Green River Basin in Wyoming. In the Uinta Basin, marginal lacustrine sediments from this time interval are mostly similar to those in the Piceance Creek Basin but include some oolites, oncolites, and stromatolites. Kerogen-rich, clay-bearing shales were deposited in the offshore areas of both lakes during the freshwater interval. In the western part of the Uinta Basin, Ryder at al. (1976) divided lacustrine rocks from this freshwater period into three gradational lithofacies that represent deposition from lake-margin to lake-center environments. These include (1) ostracodal and oolitic grainstones with horizontal and low-angle cross stratification and minor amounts of sandstone; (2) gray, fossiliferous, mud-supported carbonate; and (3) brown, kerogenous, ostracod-bearing, mud-supported carbonate. The sediments from lacustrine maximums in both the Uinta and Piceance Creek basins almost connect over the top of the Douglas Creek arch, suggesting that during at least in part of the freshwater period the two basins were hydrologically connected. During this period, the two basins are believed to have drained externally since the lake waters in both basins remained fresh enough to support abundant freshwater mollusks (Johnson 1985).

At the end of the early Eocene (Wasatchian-Bridgerian NALMA boundary), a major transgression associated with expansion and deepening of lake water marked the beginning of Lake Uinta as an unbroken body of water across the Douglas Creek Arch in both the Piceance Creek and Uinta basins (Moncure and Surdam 1980; Johnson 1985). Johnson (1984) named this the Long Point transgression. Both lakes appear to have expanded at approximately the same time, and because the basal transgressive bed does not climb stratigraphically, it is believed that 
the transgression occurred relatively rapidly. After the maximum transgression, Lake Uinta extended close to the margins of the combined Uinta and Piceance Creek structural and sedimentary basins; it covered a much larger area than that of the maximum transgression during the earlier freshwater stage of the lake. Five stages in the developmental history of the larger saline Lake Uinta have been identified based on changes in water chemistry and depositional events (Johnson 1985):

Stage 1: After the Long Point transgression, low-grade, clay-rich oil shale was deposited in large areas of both basins, including the Douglas Creek Arch.

Widespread and shallow marginal lacustrine shelves were rapidly reestablished once maximum transgression had been attained. Sandy shelves formed in areas of high clastic input, including the south-central margins of the Uinta Basin and the eastern margin of the Piceance Creek Basin. Carbonate shelves formed in areas with lower amounts of clastic input, including the Douglas Creek Arch and the western Uinta Basin. Magadi-type chert was formed in shales along Evacuation Creek in the easternmost Uinta Basin. Freshwater mollusks that were intolerant of saline water died off during the first stage.

Stage 2: The beginning of Stage 2 is marked by an abrupt increase in the richness of the oil shale in the depositional center of the Piceance Creek Basin. Stratigraphically, this occurs just above the widespread "orange marker," which approximately correlates with the widespread "carbonate marker" in the Uinta Basin. In the Piceance Creek Basin, sedimentation fluctuated dramatically between periods of rapid clastic sedimentation, which resulted in the formation of huge clastic wedges around the margins of the lake. It also resulted in periods of low clastic input, during which a relatively thin, stromatolite-rich sequence was deposited around the margins of the lake and rich oil shale deposited in the lake's center. Similar fluctuation has been identified in the eastern part of the Uinta Basin. The shores of Lake Uinta regressed during periods of rapid clastic sedimentation and transgressed during periods of oil shale deposition. These transgressions and regressions are evident in the southeastern Uinta Basin where the Wasatch and Green River formations intertongue (Cashion 1967).

Stage 3: The initiation of the third stage is marked by a shift to more carbonaterich deposition in both offshore and marginal areas of the lake. This stage includes the deposition of four oil shale zones in the Piceance Creek depositional center. It also includes the first appearance of the bicarbonate mineral nahcolite in the Piceance Creek Basin. By early in Stage 3, marginal shelves had prograded to such an extent that shallow-water deposition covered the entire Douglas Creek Arch area, thus splitting the two oil shale depositional centers by a broad area of shallow water deposition. Individual stromatolites can be traced across the top of the arch, indicating that, at least during high-water periods, Lake Uinta remained a single lake. The stratigraphic interval represented by the third stage in the Piceance Creek Basin can be roughly correlated to the depositional center of the Uinta Basin, where it is represented by a thick sequence of interbedded clay-rich and carbonate-rich rocks, including some oil shale beds. Stromatolites commonly 
compose as much as $50 \%$ of the interval deposited during Stage 3. A new transitional facies for the Lake Uinta sequence appears during Stage 3, which is transitional between the predominantly oil shale facies of the depositional center and the two marginal lacustrine facies. This new facies consists of carbonate-rich oil shale interbedded with barren, laminated marlstone, as well as some sandstone and siltstone. Unlike the previous two stages, sediments deposited during Stage 3 thicken toward the oil shale depositional center and thin toward the marginal lacustrine facies.

Stage 4: The beginning of Stage 4 is marked by a relatively minor transgression that occurred across both basins. Stratigraphically, it occurs at about the base of the R-4 rich oil shale zone of Cashion and Donnell (1974). This transgression expanded the oil shale and marlstone facies over much of the outer marginal shelf areas, including the Douglas Creek arch, suggesting deeper average water depths than in Stage 3. Nearly continuous oil shale deposition occurred in the Piceance Creek Basin during this stage. In the Uinta Basin, oil shale from this stage is leaner and interbedded with mudstone, siltstone, and sandstone. This is possibly the result of dilution by clastics in the much-thicker Stage 4 Uinta Basin sequence. The majority of saline minerals deposited in the Piceance Creek Basin are found in Stage 4 strata and include nahcolite and halite. Fewer saline minerals were deposited during Stage 4 in the Uinta Basin.

Stage 5: The beginning of the fifth and final stage of saline Lake Uinta was marked by a major transgression that occurred mostly during the deposition of the Mahogany oil shale bed. During peak transgression, rich oil shale deposition expanded to cover almost the entire area formerly occupied by the marginal shelves. The maximum extent of Lake Uinta at this time is unknown because most of the marginal lacustrine rocks from this period have been eroded. However, Lake Uinta may have extended close to the margins of the sedimentary basin. Infilling of the lake began almost immediately after deposition of the Mahogany bed, and shallow-water-shelf deposition was once again reestablished in areas such as the southwestern Uinta Basin. Huge wedges of volcanic debris began to be deposited in the northern Piceance Creek Basin shortly after the maximum transgression, and these prograded south into the oil shale depositional center, eventually replacing oil shale deposition with shallow-water lacustrine deposition (Johnson 1981). The shallow water facies consist of volcaniclastic sediments interbedded with marlstone and oil shale tongues. This suggests episodic volcaniclastic influx or periodic rises in water level. Surdam and Stanley (1979) have suggested that the volcaniclastics were derived from the Absaroka volcanic field in northwestern Wyoming, and that Lake Gosiute in the greater Green River Basin in Wyoming may have started to drain to the south into Lake Uinta sometime before the arrival of the first volcanic sediments in the Piceance Creek Basin. They further suggest that this arrival of volcanics in Lake Uinta may represent the final infilling of Lake Gosiute, which had previously acted as a sediment trap. The infilling of the Piceance Creek and Uinta basin depositional centers took a relatively long time. Volcaniclastic wedges reached the southern 
Piceance Creek Basin and the eastern Uinta Basin at about the same time, depositing the Horse Bench Sandstone (see Cashion 1967) of the Parachute Creek Member in the eastern Uinta Basin and the Porcupine tuff in the southern Piceance Creek Basin. The influx of volcaniclastics appears to have stopped before reaching the central depositional center of the Uinta Basin. Lake Uinta persisted until roughly the end of the middle Eocene in the central and eastern Uinta Basin, when it was largely filled in with sediments derived from locally rejuvenated Laramide uplifts as Lake Uinta deposition was replaced by fluvial and minor lacustrine deposition (freshwater ponds). The volcaniclastic sedimentary rocks of Stage 5 were originally assigned to the Evacuation Creek Member of the Green River Formation by Bradley (1931). Later stratigraphic study (Cashion and Donnell 1974) demonstrated that at its type locality in the eastern Uinta Basin, the Evacuation Creek Member is equivalent to the upper part of the Parachute Creek Member at its type locality in the Piceance Creek Basin. Furthermore, the Evacuation Creek Member as previously used by most workers in the Piceance Creek Basin is equivalent to the lower part of the Uinta Formation in the Uinta Basin. Hence, the term Evacuation Creek was abandoned and replaced by the Parachute Creek Member in the eastern Uinta Basin and by the Uinta Formation in the Piceance Creek Basin (Cashion and Donnell 1974).

Throughout most of these five stages, the salinity of Lake Uinta increased steadily. Ultimately, salinity increased to the point at which nahcolite and halite were precipitated during the fourth stage. On the basis of Green River Formation geometry and sedimentology, Lake Uinta appears to have had a broad, shallow shelf area that surrounded a depositional center for oil shale in each of the two basins. In the Piceance Creek Basin, the oil shale depositional center was several hundred feet deep during most if its existence and received a much higher influx of saline minerals than did the depositional center of the Uinta Basin. In summary, the gradual filling of Lake Uinta during the middle Eocene was due to an influx of volcaniclastics from the Absaroka Volcanic Field in Wyoming to the north and from volcanic centers farther to the west, and then later by an increase in sediment resulting from rejuvenated local Laramide uplifts. As discussed in Section 4.4.2, there is no direct geologic evidence that Lakes Uinta and Gosiute were ever physically connected. However, fluvially deposited volcaniclastics in Lake Uinta, demonstrably derived from the Absaroka Volcanic Field in northwestern Wyoming, would be a persuasive line of evidence. This, however, would not rule out the possibility of transport of volcaniclastic material from Lake Gosiute south to Lake Uinta via streams over the lowest drainage divides after the greater Green River Basin had been filled (Surdam and Stanley 1980a).

Marginal lacustrine rocks of middle-early to late-early Eocene age in the Uinta and Piceance Creek basins are generally included in the Douglas Creek and Anvil Points members of the Green River Formation, respectively. Both the marginal and deep water lacustrine rocks of this age in the Uinta and Piceance Creek basins correlate with the Tipton Shale Member of the Green River Formation in the greater Green River Basin in Wyoming. Shortly after the beginning of the middle Eocene, the major transgression during which the Mahogany bed was deposited took place. Deposition of the Mahogany bed of the Parachute Creek Member in the Piceance Creek and Uinta basins has been tentatively correlated with the Laney Member of the Green River Formation in the Green River Basin of Wyoming (Tuttle 1991). 
As lacustrine deposition in Lake Uinta diminished because of basin filling, fluvial sedimentation resulted in deposition of the Uinta Formations in the Piceance Creek and Uinta basins (Stokes 1986). At this time, fluvial deposition began to dominate in the basin as streams flowed into it from the north and east (Stokes 1986). The east-west flow resulted in the formation of limey siltstone beds and fine-grained Uinta Formation shales in the eastern part of the Uinta Basin, contrasting with the red sandstone, shale, siltstone, conglomerate, and limestone beds in the west (Stokes 1986). Today, fluvial rocks of the middle Eocene Uinta Formation (Uintan NALMA) are preserved above Green River Formation strata only in the northern part of the Uinta Basin. The late-middle Eocene (Duchesnean NALMA) Duchesne River Formation overlies rocks of the Uinta Formation in the north-central and western parts of the Uinta Basin, and the Cretaceous-age Mesaverde Group on Asphalt Ridge. Both the Uinta and Duchesne River formations were deposited in river channels and on adjacent floodplains (Stokes 1986) and in river deltas (Townsend 2004). Riparian environments were forested, and the rivers and streams flowed through a savanna-type environment with some swampy and marshy areas and forested highlands (Hamblin 1987).

During the latest Tertiary and Quaternary, the major streams and their tributaries traversing the Uinta and Piceance Creek basins eroded much of the sediments and exhumed the Eocene strata in the basins. Stream erosion has exposed oil shale strata on cliff faces in many places. Gentle folds and minor faults have locally deformed the deposits, but the sedimentary rocks of the Uinta Basin as a whole are remarkably intact structurally.

\subsection{PALEOENVIRONMENTAL SUMMARY}

As discussed in Section 6.1, the rocks and fossils of the Mesaverde Group reflect deposition in nearshore, shallow marine environments, including offshore, littoral, shore margin, beach, swamp, estuary, and coastal plain. The warm, shallow sea waters were inhabited by a variety of marine animals, including mollusks (bivalves, gastropods, and cephalopods), sharks, rays and bony fishes, sea turtles, as well as large carnivorous marine reptiles, including mosasaurs and plesiosaurs. Pterosaurs, as well as primitive birds such as Icthyornis, hunted overhead. Teredo-bored logs also have been reported (ichnofossils). The coastal plains were tropical, lush, and forested. Plants included a diversity of palms, cycads, conifers, and ferns. Vertebrate inhabitants of the coastal plains included frogs, salamanders, pond turtles, lizards, and crocodilians, as well as typical late Cretaceous dinosaurs, including carnivorous theropods such as Albertosaurus sp. and the herbivorous ceratopsians and hadrosaurs. Primitive, mostly diminutive mammals inhabited the Cretaceous coastal forests of the Mesaverde Group in this area. These include several species of multituberculates and marsupials, and at least one species of proteuthere (eutherian mammal) (Archibald 1987). The end of the Cretaceous Period (the K-T Boundary) and the associated extinction of the dinosaurs are not represented in the stratigraphic sequence of the Uinta and Piceance Creek basins because of a widespread regional unconformity, which spanned from the latest Cretaceous Period through the middle Paleocene Epoch.

During the late Paleocene, early Eocene, and much of the middle Eocene, overall paleoenvironmental conditions in the Piceance Creek and Uinta basins were similar to those of 
the greater Green River Basin in Wyoming (see Section 4.2). Late Paleocene and early Eocene environments were characterized by mostly fluvial deposition in river channels and swamps and on floodplains and tropical to warm-temperate, humid climatic conditions and resulting lush vegetation. Numerous comparatively short-lived small lakes and ponds developed on the lowrelief basin floors. In the Uinta Basin, these depositional environments are preserved in rocks of the Wasatch and Colton formations. Before the middle Eocene, global climates were equable and dominantly tropical to warm temperate, forests were widespread across Asia and North America, and both continents shared a large number of plant species. Temperature declines and the rise of mountain ranges contributed to increasing floristic and eventually faunal provincialism (Storer 1990; Wing 1998).

With the onset of widespread freshwater lacustrine deposition in the early Eocene followed by the formation of Saline Lake Uinta in the Uinta and Piceance Creek basins, fluvial deposition was restricted to lake margins. Like Lake Gosiute on the north side of the Uinta Mountains, Lake Uinta, represented by the Green River Formation, had a long and complex history of transgressions and regressions associated with changes in climatic conditions, tectonics, and distal volcanic activity. As evidenced by desiccation features preserved in laminated lacustrine sediments, frequent subaerial exposure of lake margins occurred. This was caused by lake contractions resulting from an imbalance between evaporation and inflow of waters to the hydrographic basin (Moncure and Surdam 1980). Bradley (1929) estimated that Eocene lacustrine deposition in the Piceance Creek Basin lasted approximately 6.5 million years. Picard (1963), concluding that lacustrine deposition in the Uinta Basin commenced earlier and persisted later than in the Piceance Creek Basin, estimated a time frame of approximately 13.3 million years. However, both of these estimates are probably high given our present understanding of the biochronology of the mammalian faunal assemblages associated with the Eocene-age lacustrine and associated rocks in each basin. Mauger (1977) estimated that Lake Uinta persisted in the central part of the basin until about 41 Ma (Uintan-Duchesnean NALMA boundary), although it is believed to have persisted for a longer duration in the western part of the basin. The Uinta Formation in the Uinta and Piceance Creek basins was deposited in river channels and on adjacent floodplains (Stokes 1986) and in river deltas (Townsend 2004).

Riparian environments and the floodplains adjacent to the shorelines of freshwater lakes and ponds were muddy and typically forested during deposition of the Wasatch, Colton, Green River, and Uinta formations. Insects of many varieties lived in the Eocene lakes, swamps, rivers, and forests, and are locally well preserved in lacustrine shales of the Parachute Creek Member of the Green River Formation. Well-preserved plant fossils reflective of tropical to warm-temperate climatic conditions are also locally present within the Green River Formation in the Uinta Basin. Seasonal aridity is reflected in some late Paleocene floras, as well as those of the Green River Formation, which is further evidence of increasing regionalism of floras in the western interior of North America. According to MacGinitie (1969), fossil plants of the Green River lakes are indicative of subtropical dry woodlands vegetation, and he referred to the assemblage as woodlands. The paleobotanical record indicates that there was a drying trend in the North American Eocene, but it was regional and subcontinental in effect. This regional variation in environments would directly affect vertebrate communities. A variety of aquatic mollusks (clams and snails) and arthropods (crayfish and ostracods) also inhabited Lake Uinta and the rivers and streams in the area and are locally abundant and well preserved, especially in the 
presaline lacustrine rocks of the Green River Formation and in pond and stream deposits of the Wasatch and Uinta formations. As evidenced by fossil distribution and sedimentology, fish diversity was high in freshwater lakes but low in saline lake waters. Crocodiles and turtles were common residents of rivers, lakes, and ponds deposited throughout the Eocene sequence. A diversity of other reptile species, including tortoise, lizards, and snakes, inhabited the floodplains and shoreward lake margins. Forests teemed with the primitive ancestors of many modern mammalian groups, including rodents, rabbits, insectivores, bats, primates, artiodactyls (oreodonts, camels), perissodactyls (horse, rhinoceros, and tapir), and carnivores, as well as more bizarre archaic forms such as creodonts, brontotheres, and massive six-horned uintatheres. The shift from dominantly tropical forest environments of the early and early-middle Eocene to more open savanna-like conditions was underway by the middle Eocene (Uintan NALMA) in the Uinta Basin and continued into the late middle Eocene (Duchesnean NALMA), which is represented by the Duchesne River Formation. This trend correlates with a reduction in the abundance and diversity of arboreal mammals such as primates, as well as other aspects of the mammalian fauna (Townsend 2004; Murphey and Townsend 2005; Townsend et al. 2006).

The fossil vertebrate, insect, mollusk, and plant assemblages of the Uinta Basin provide an excellent opportunity to study Eocene paleocommunities and paleoenvironments. Studies of these fossils and the rocks in which they are preserved have contributed greatly to our knowledge of the Eocene of North America. The Tertiary vertebrate faunas of the Uinta Basin are of particular scientific importance because, among other things, they represent an exceptional record of early Tertiary mammalian evolution and diversification during the early Eocene to late middle Eocene epochs.

\subsection{PREVIOUS PALEONTOLOGICAL WORK AND RELATED INVESTIGATIONS}

For more than 135 years, scientists working in the Uinta basin and surrounding highlands have conducted studies in paleontology and geology, some of which are now considered classic works. Early paleontologists who either worked in the area or described fossils collected from Tertiary strata include a number of well-known pioneers of vertebrate paleontology in North America. O.C. Marsh of Yale University is usually credited with discovering the Uinta Basin in 1870 and naming the Uinta Formation in 1871. On the other hand, Wood (1934) credited Comstock (1875) with the first use of the name Uinta for rock units in the Uinta Basin (Cashion and Donnell 1974). The fossils collected by Marsh in 1870 were described by Joseph Leidy, whom many consider the father of American paleontology. E.D. Cope, in his classic monograph, The Vertebrata of the Tertiary Formation of the West, described fish and crocodilian fossils from what is now known as the Green River Formation (Cope 1884). Other paleontological expeditions of the late nineteenth century resulted in collections of fossil mammals from the Uinta and Duchesne River formations. These efforts were led by W.B. Scott, H.F. Osborn (1877-1878, 1886), and J.B. Hatcher (1895) from Princeton University, and later H.F. Osborn, O.A. Peterson (1893-1894), and W.D. Matthew (1899) of the American Museum of Natural History (AMNH). In 1909, Earl Douglass of the Carnegie Museum of Pittsburgh discovered the now world-renowned Carnegie Quarry in the Morrison Formation, at what is now Dinosaur National Monument, during an expedition to collect fossil mammals from the Uinta Formation. Douglass worked at the dinosaur quarry for the next 15 years while continuing to 
study Eocene fossil mammals collected from the Uinta Basin. Other paleontologists who studied fossil vertebrates of the Uinta and Duchesne River formations in the early-to-mid twentieth century included O.A. Peterson (AMNH), C.W. Gilmore (Smithsonian Institution), E.S. Riggs (Field Museum), J.L. Kay (Carnegie Museum), and J. Clark (then at the Carnegie Museum). The Uinta and Duchesne River formations in the Uinta Basin were designated the type localities for the Uintan and Duchesnean NALMAs (Wood et al. 1941).

\subsection{GEOLOGIC UNITS AND PALEONTOLOGICAL RESOURCES}

The portion of the Oil Shale and Tar Sands PEIS study area that lies within the Uinta Basin in northeastern Utah contains five mapped bedrock geologic units (Bryant 1992; Cashion 1973, 1974, 1977; Hansen et al. 1983; Hintze 2000; Keighin 1977a,b; Pantea 1987, 1993; Rowley et al. 1985; Weiss et al. 1990; Whitney 1981; Witkind 1988, 1995; Witkind and Weiss 1991). These include, from oldest to youngest, and in approximate ascending stratigraphic order, the Mesaverde Group, Wasatch Formation, Green River Formation, Uinta Formation, and Duchesne River Formation. For this report, the Colton Formation is combined with the Wasatch Formation. On the basis of the geologic map review conducted for this study, older (and stratigraphically lower) bedrock units in the Uinta Basin are not anticipated to be affected by oil shale and tar sands development. For example, the fossiliferous North Horn Formation is present in the Uinta Basin, but it does not contain oil shale or tar sands and is not present or stratigraphically relevant in any oil shale or STSAs. The five potentially affected bedrock units in the Uinta Basin are locally mantled by younger surficial deposits of Holocene and Pleistocene age, which consist of alluvium, colluvium, pediment deposits, landslide deposits, and glacial outwash and till. A generalized correlation chart for the east-central Uinta Basin and central Piceance Creek Basin is provided in Figure 10. A diagrammatic cross section of the Uinta Basin is provided in Figure 11.

In the following section of this report, the geology and paleontology of the geologic units within the Uinta Basin is discussed, and their paleontological sensitivities are evaluated. Paleontological locality records for BLM-administered lands in the State of Utah are on file at the BLM State Office, and are maintained in cooperation with the Utah State Geological Survey. Additional (and probably older) fossil locality records for oil shale and tar sands-bearing rocks units in the Uinta Basin may be on file at major museums throughout the United States.

\subsubsection{Mesaverde Group}

The Upper Cretaceous (late Santonian to late Campanian) Mesaverde Group is a stratigraphically complex sequence typically characterized by resistant, light gray, tan, yellow, and purplish-brown cross bedded sandstone; dark gray shale, and coal (Rowley et al. 1985). It is impregnated with oil on Asphalt Ridge just west of Vernal, Utah (USGS 1980b). The name Mesaverde was first used by Hayden (1875), although a type locality was not designated. Rocks of the Mesaverde Group and its composite units are widely distributed in seven states. As a result of its complex geometry caused by a depositional history of sedimentation occurring during the final transgressions and regressions of the Cretaceous epeiric seaway, and in a variety 


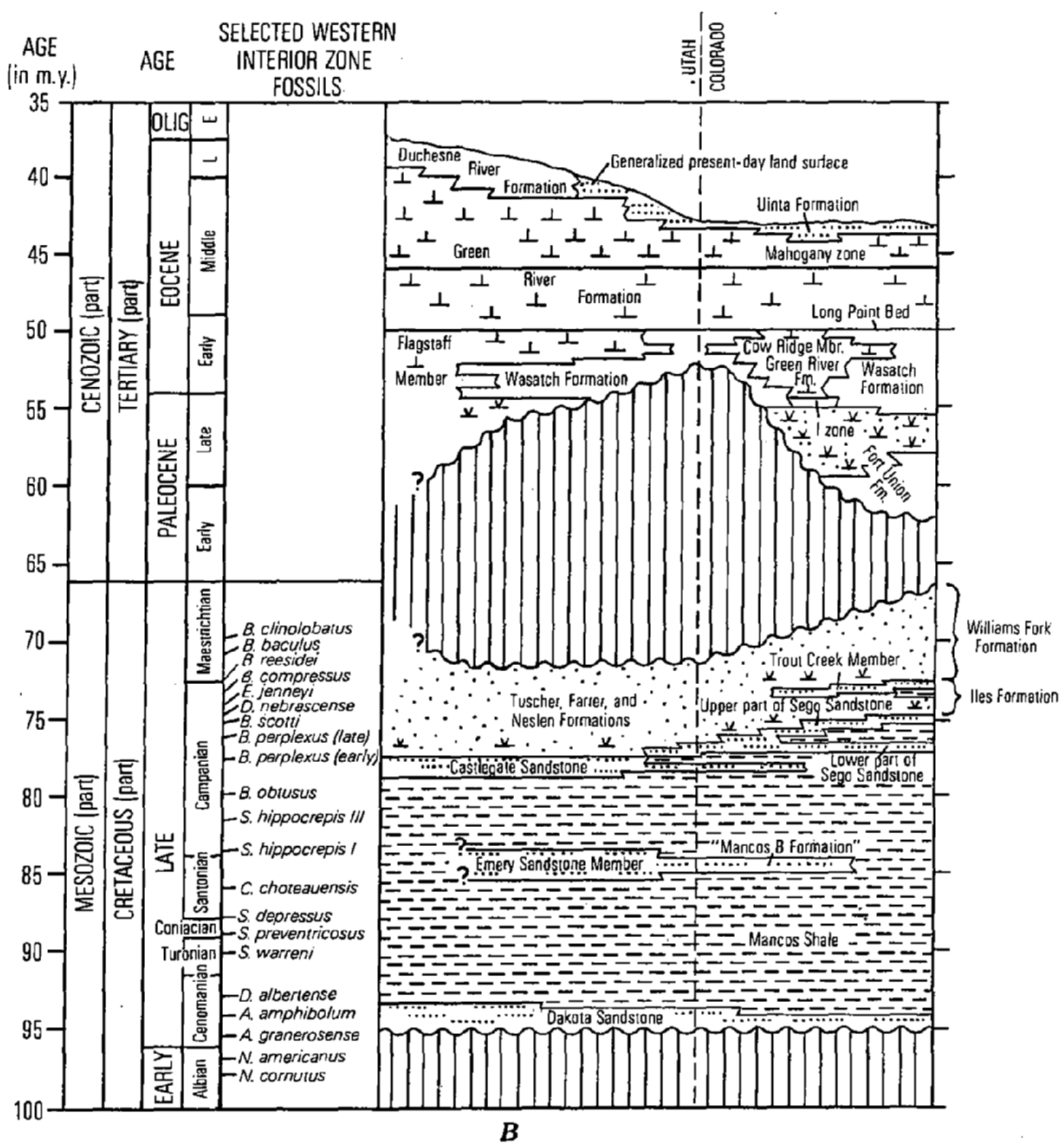

FIGURE 10 Generalized Correlation Chart for the Northern Piceance Creek and East-Central Uinta Basins (Source: Johnson 1989) 


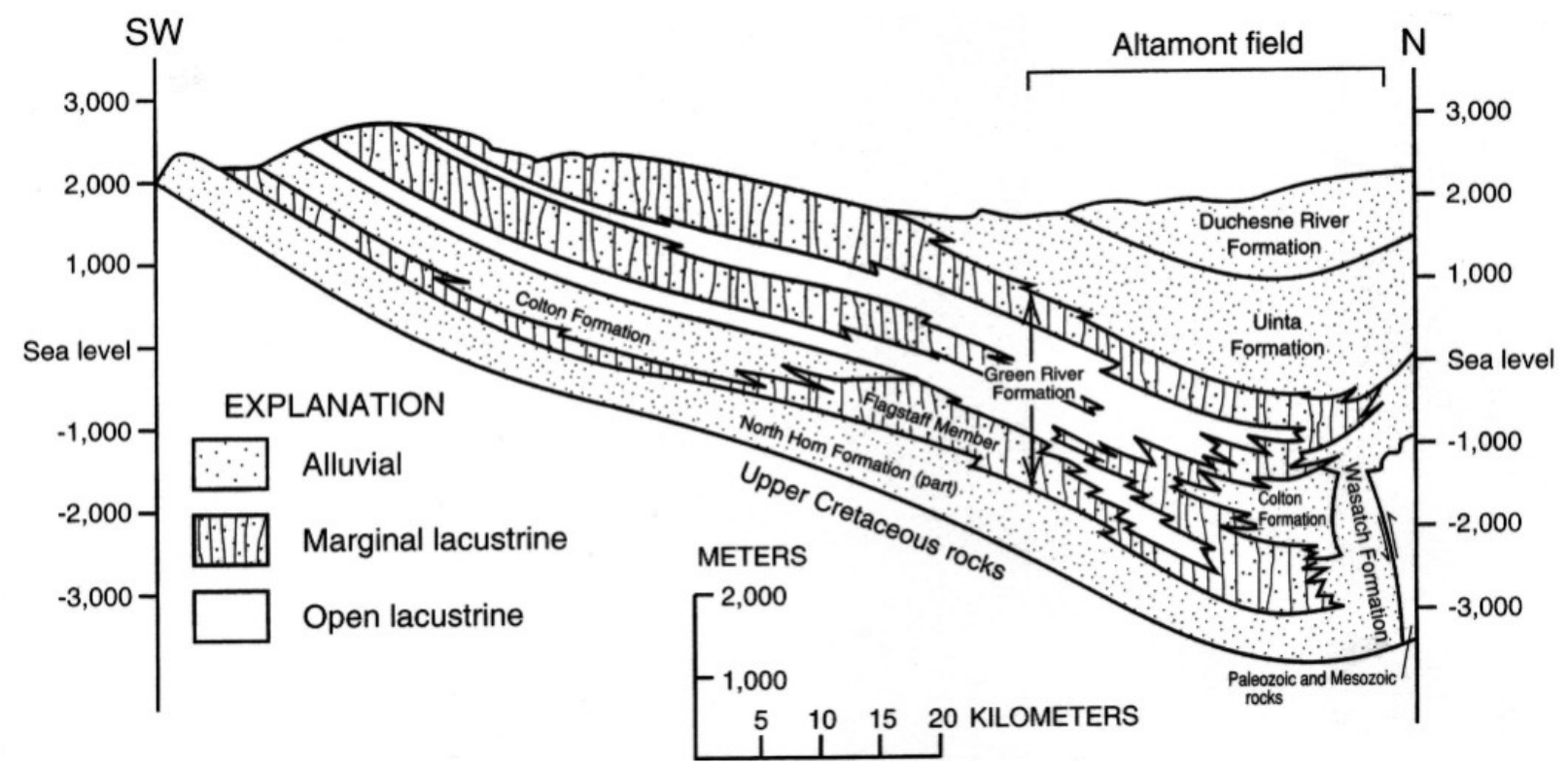

FIGURE 11 Lithologic Cross Section through the Central Part of the Uinta Basin from Southwest to North (Source: Wanty et al. 1991)

of coastal settings, the Mesaverde Group has a complicated and sometimes inconsistent history of stratigraphic nomenclature (see Cashion 1973; Johnson 1989; Rowley et al. 1985). Both the stratigraphic terminology and fossil content of the Mesaverde Group vary regionally (Demar and Breithaupt 2006).

Throughout most of its distribution in the Piceance Creek and Uinta basins, the Mesaverde Group is conformably underlain by the Mancos Shale and unconformably overlain by the DeBeque/Wasatch formations. However, it is directly and unconformably overlain by the Duchesne River Formation in the vicinity of Asphalt Ridge. The upper contact of the Mesaverde is locally difficult to distinguish from overlying strata because of similar lithologies and/or limited exposures. In the easternmost part of the Piceance Creek and Sand Wash basins in northwestern Colorado, the Mesaverde Group includes the Castlegate Sandstone, the Iles Formation, and the Williams Fork Formation, from lowest to highest. The Castlegate Sandstone is the oldest unit and separates the intertonguing Buck Tongue of the Mancos Shale from the underlying main body of the Mancos. Overlying the Buck Tongue are the Iles and Williams Forks formations. The Buck Tongue pinches out in eastern Utah, placing the Castlegate in direct contact with the overlying Mesaverde Group. The Castlegate is not always mapped as part of the Mesaverde Group (Hail 1990). The Iles Formation is composed of approximately 590 to 1,410 ft of resistant to moderately resistant, light-gray, tan and orange sandstone, shale, claystone, carbonaceous shale, and coal. Locally, it is capped by the Trout Creek Sandstone Member, a light-gray sandstone that is up to $98 \mathrm{ft}$ thick. The Williams Fork Formation is composed of approximately 1,312 to $2,952 \mathrm{ft}$ of moderately resistant, light- to medium-brown, orange-tan, and gray lenticular beds of sandstone, shale, claystone, carbonaceous shale, and coal (Rowley et al. 1985). 
In the vicinity of the Douglas Creek Arch on the eastern margin of the Uinta Basin, the Mesaverde Group contains five units, from lowest to highest stratigraphically (Rowley et al. 1985): the Castlegate Sandstone, Sego Sandstone, lower unit, coal unit, and upper unit. The Castlegate Sandstone and Sego Sandstone are locally divided stratigraphically by the intertonguing Buck Tongue of the Mancos Shale (Johnson 1989). The Castlegate Sandstone is composed of resistant, light-gray, yellow, and tan marine sandstone and minor amounts of shale with a thickness ranging from approximately 0 to $98 \mathrm{ft}$. The Sego Sandstone consists of resistant, light-gray, tan and buff and orange marine sandstone and shale with a thickness ranging from approximately 0 to $246 \mathrm{ft}$. The lower unit consists of moderately resistant, tan, light-gray to medium gray, and light-yellow cross-bedded sandstone with lesser amounts of shale, carbonaceous shale, and coal, with a thickness ranging from approximately 656 to $820 \mathrm{ft}$. The coal unit consists of moderately resistant, light- to medium gray, light-yellow, light-orange, and tan cross-bedded sandstone, carbonaceous shale, and coal with a thickness ranging from approximately 400 to $656 \mathrm{ft}$. The upper unit is composed of approximately 984 to $1,148 \mathrm{ft}$ of resistant tan, light-gray and yellow, lenticular cross-bedded sandstone with lesser amounts of shale, carbonaceous shale, and minor coal (Rowley et al. 1985).

In the Uinta Basin and Piceance Creek Basin, rocks of the Mesaverde Group are less fossiliferous than in other areas (such as parts of Wyoming, see Demar and Breithaupt 2006), but a fairly diverse fauna and flora consisting of terrestrial and marine vertebrates, invertebrates (marine and freshwater mollusks), and terrestrial plant fossils have been recovered. In Colorado, the Iles Formation has produced poorly preserved large bones (probably dinosaur), turtle, fish scales, freshwater and marine mollusks (bivalves, gastropods, and cephalopods), and wood and plant impressions (Armstrong and Wolny 1989). The Williams Fork Formation in the Piceance Creek Basin has produced a scientifically important assemblage of plants, including two species of cycads, at least nine species of conifers, three species of ferns, palms, bryophytes, and lycopsids. Freshwater gastropods (Goniobasis) and unionid bivalves also occur. Vertebrate fossils include several species of sharks, rays, and freshwater bony fishes; amphibians (frogs and salamanders); and a diverse reptilian assemblage of champsosaurs, turtles, lizards, crocodilians, and saurischian (Albertosaurus sp.) and ornithischian dinosaurs (ceratopsian and hadrosaur). Mammalian fossils include at least five species of multituberculates, two species of marsupials, and one species of eutherian mammal (Archibald 1987; Armstrong and Baker 1985; Armstrong and Wolny 1989; Lucas and Kihm 1982; unpublished paleontological data, University of Colorado Museum, compiled in 2000).

Rocks of the Mesaverde Group in the Uinta Basin are designated as BLM Condition 1 and PFYC Class 4/5. If distinguishable on the basis of local geologic mapping, terrestrial deposits of the Mesaverde Group are most likely to contain scientifically significant vertebrate fossils (on the basis of prior paleontological discoveries), and marine facies could be designated separately as Condition 2 and PFYC Class 3.

\subsubsection{Wasatch Formation}

The name "Wasatch" was originally applied to a sequence of variegated sand, clay, and conglomerate beds located on the east side of the Wasatch Mountains (Hayden 1869). The 
Wasatch Formation interfingers extensively with lacustrine deposits of the Green River Formation in Utah, Colorado, and Wyoming. The unit is currently defined to include late Paleocene to early Eocene sediments that were deposited mostly in fluvial environments. Thus, it was deposited on floodplains, in stream channels, and in deltas before and during the existence of the Green River lakes (Cashion 1967). The Colton Formation is a fluvial sequence underlying the Green River Formation that is equivalent to all or part of the Wasatch Formation in northeastern Utah; it is combined with the Wasatch Formation for the purpose of this report. As discussed in Section 5.4.1, rocks of the same age and lithology in the Piceance Creek Basin are also known as the DeBeque Formation. Tar sands have been discovered within the Wasatch Formation in the Uinta Basin (USGS 1980i).

In much of northeastern Utah, including the Uinta Basin, the Wasatch Formation is composed of soft, light-gray, red, green, white, yellow, and purple claystone, sandstone, siltstone, and conglomeratic sandstone (Cashion 1967; Rowley et al. 1985). It is approximately 4,600 ft thick at its maximum and thins northward, pinching out on Asphalt Ridge and Raven Ridge. Most Wasatch Formation strata are irregularly bedded and not laterally continuous. However, some interbedded zones of sandstone and shale can be traced for miles. Generally, the sandstones weather to buff, brown, and reddish-brown ledges, and the shales weather to steep red and gray slopes. In the Uinta Basin, the Wasatch Formation is subdivided into two units: the main body and the overlying Renegade Tongue. Both units intertongue with the Douglas Creek Member of the Green River Formation. The main body is composed of approximately 2,300 to 3,500 ft of soft, tan, gray-red, and yellow shale, claystone, sandstone, conglomeratic sandstone, and marly limestone (Rowley et al. 1985). The Renegade Tongue, named by Cashion (1967), is approximately $1,000 \mathrm{ft}$ thick at its type locality and thins progressively to the north and northeast as it intertongues with the Douglas Creek Member of the Green River Formation. Lithologically, it consists of massive, irregularly bedded, brown and gray sandstone beds and red and gray shale and siltstone beds. Cashion (1967) further subdivided the Renegade Tongue into Units X and W. The Renegade Tongue conformably overlies Tongue D of the Douglas Creek Member and is conformably overlain by Tongue A of the Douglas Creek Member. The Renegade Tongue is predominantly fluvial and the Douglas Creek Member predominantly lacustrine, but both units contain fluvial and lacustrine sediments. On the basis of middle-Eocene fossils that have been reported from Tongues B and C of the Douglas Creek Member, the Renegade Tongue of the Wasatch Formation is also believed to be middle Eocene in age (Cashion 1967).

Throughout its distribution, the Wasatch Formation and stratigraphically equivalent fluvial rocks have produced scientifically significant fossils, although the preservation and abundance of fossils vary regionally and stratigraphically. For example, north of the Book Cliffs Divide in the southern Uinta Basin, the Renegade Tongue contains numerous bone fragments and poorly preserved leaves and wood, but few identifiable well-preserved vertebrate fossils have been discovered. The paucity of fossils in this area may in part be reflective of limited exposures and insufficient prospecting by paleontologists. On the other hand, the main body of the Wasatch Formation at the Raven Ridge area has produced thousands of fossil vertebrate specimens of early Eocene (and possibly late Paleocene) to early-middle Eocene age (see Doi 1990). The main body of the Wasatch Formation in the Uinta Basin and elsewhere in Utah has produced a diverse fossil fauna and flora that are generally similar to those of the Wasatch Formation in Wyoming and Colorado (see Black and Dawson 1966; Kihm 1984; 
McKenna 1960; Savage and Russell 1983; Doi 1990). Typical fossils include ichnofossils (Zonneveld et al. 2000b), plants (Rich et al. 2001), and invertebrates (Kuchta 2000). Vertebrates include locally abundant and diverse fish, turtles, crocodiles, birds, and mammals (Dorr and Gingerich 1980; Gauthier 1982; Gunnell and Bartels 1999; Hutchison 1984). Mammalian fossils include teeth and bones of multituberculates, marsupials, proteutheres, insectivores, primates, condylarths, carnivores, rodents, pantodonts, perissodactyls, artiodactyls, and taeniodonts (unpublished data, University of Colorado Museum, compiled in 2001). The Wasatchian is an important NALMA as several mammalian orders make their first appearances, including the perissodactyls, artiodactyls, and primates (Robinson et al. 2004).

The main body of the Wasatch Formation in the Uinta Basin is designated as BLM Condition 1 and PFYC Class 4/5. Future project-specific analyses of smaller geographic areas and more stratigraphically restricted intervals may necessitate a reevaluation and local redesignation. The Renegade Tongue of the Wasatch Formation is less fossiliferous than the main body and is designated as BLM Condition 2 and PFYC Class 3.

\subsubsection{Green River Formation}

The lacustrine Green River Formation is present throughout a large geographic area encompassing northeastern Utah, northwestern Colorado, and southwestern Wyoming. Throughout its geographic distribution, it intertongues with several formations of fluvial origin. In the Uinta Basin, the Green River Formation conformably overlies and intertongues with the fluvial Wasatch Formation and is conformably overlain by and intertongues with the Uinta Formation (Hail 1990). Typical lithologies of the Green River Formation in the Uinta Basin include soft to moderately resistant, light-gray and buff marlstone, oil shale, limestone, siltstone, sandstone, conglomerate, and tuff (Rowley et al. 1985). In terms of facies, it is characterized by thin, even, continuous beds of marlstone, oil shale, siltstone, and tuff deposited in deeper waters, and massive shallow-water deposited sandstone and limestone beds that are not laterally continuous (Cashion 1967; Cole and Picard 1978). In the Uinta Basin, the Douglas Creek and Parachute Creek members of the Green River Formation are known to contain localized deposits of tar sand (USGS 1980a,d,f,g).

Although the stratigraphic nomenclature and subdivisions of the Green River Formation in the Uinta Basin are complex because of the formation's geometry, stratigraphy, and facies relationships, two members are recognized in this report: the Douglas Creek and Parachute Creek members (Cashion 1967; Cashion and Donnell 1974). As discussed in Section 6.1, rocks previously assigned to the uppermost member, the Evacuation Creek Member, have been reassigned to the Parachute Creek Member of the Green River Formation in the Uinta Basin, and the name Evacuation Creek has been formally abandoned (Cashion and Donnell 1974). The Douglas Creek, Parachute Creek, and Evacuation Creek members were all named by Bradley (1931). Some workers currently do not follow Bradley's terminology. However, the names Douglas Creek and Parachute Creek are used in this report because they are applicable to much of the Uinta and Piceance Creek basins, and most fossil collections with associated members utilize Bradley's stratigraphic nomenclature. In summary, Cashion (1967) used the Horse Bench Sandstone bed as the boundary between the Parachute Creek Member and overlying Evacuation 
Creek Member, and the Mahogany oil shale bed as the boundary between the Douglas Creek Member and overlying Parachute Creek Member. Bryant et al. (1989) and Witkind (1995) placed the Mahogany oil shale bed at the base of the Upper member of the Green River Formation, and the Horse Bench Sandstone in the approximate middle of the Upper member, making the Upper member roughly equivalent with the Parachute Creek and Evacuation Creek members of Bradley (1931) and Cashion (1967, 1973). The Sandstone and Limestone facies of Bryant et al. (1989) and Witkind (1995) is a transitional facies that lies in between the Uinta Formation and the underlying Saline facies. The Saline facies intertongues with the overlying Sandstone and Limestone facies (Witkind 1995).

The Douglas Creek Member of the Green River Formation conformably overlies and intertongues with the Renegade Tongue of the Wasatch Formation and conformably underlies the Parachute Creek Member of the Green River Formation. It is composed mostly of beds of sandstone, siltstone, and shale; oolitic, algal, and ostracodal limestone; and localized beds of oil shale. Approximately 1,060 ft thick at Raven Ridge, it attains a maximum thickness of approximately 1,180 ft along Evacuation Creek (Cashion 1967). The oil shale beds of the Douglas Creek Member are thinner and less widespread than those of the Parachute Creek Member. Bradley (1931) named the Parachute Creek Member after rocks of the Green River Formation along Parachute Creek in the Piceance Creek Basin, Garfield County, Colorado. In northeastern Utah, the Parachute Creek Member is composed of sediments that were mostly deposited in deep water facies, typically consisting of thin-bedded marlstone, oil shale, siltstone, sandstone, and tuff (Cashion 1967). Near the Utah-Colorado border, measured thicknesses of the Parachute Creek Member range from approximately $615 \mathrm{ft}$ along the White River to $365 \mathrm{ft}$ at Evacuation Creek. The Mahogany oil shale bed, the most widespread Green River Formation stratigraphic marker in the Piceance Creek and Uinta basins, occurs within the Parachute Creek Member.

Accumulations of fossils occur in the Green River Formation throughout its distribution, although quality of preservation, abundance, and diversity varies both geographically and stratigraphically. Paleontological research focused on the Green River Formation continues to document the paleoecology (paleoenvironments and paleocommunities) of the early and middle Eocene of the Rocky Mountain region, and newly discovered fossils continue to add to this important fossil record. Common fossil types known generally from this unit include ichnofossils (Moussa 1968); an abundant and diverse flora (MacGinitie 1969); a large assemblage of arthropods, including insects (Coddington 1993a,b; Leggitt and Cushman 2001; Hodgkins and Smith 2002); mollusks (Kuchta 2000); and abundant vertebrates, including fish (Grande 2001; Carvalho et al. 2003), birds (Leggitt and Buchheim 1998a,b; Leggitt et al. 2001), and mammals (Froehlich and Breithaupt 1998; Zonneveld et al. 2000a; Gunnell 2003).

According to Grande (1984), fossil insects and plants are the most common fossils from the Green River Formation in the Uinta Basin in Utah. Vertebrate fossils, including fishes from the Green River Formation in the Uinta Basin, are less studied (and less abundant) than those from the Green River Formation in Wyoming. Fossils of the Parachute Creek Member include a diversity of plants (leaves, fruits, seeds, and wood); an ichnofossil record consisting of bird, mammal, and insect tracks (Moussa 1968); an inferred spider web with spiders and insects (Coddington 1992a,b); bird feathers (unpublished paleontological data, University of Colorado 
Museum, compiled in 2002); and fish. Recently, researchers from the Denver Museum of Nature and Science have been collecting well-preserved plant fossils from Parachute Creek Member quarries in the southeastern Uinta Basin, some of which are on display in the Utah Field House of Natural History Museum in Vernal. Fossils are not as abundant or well preserved in the Douglas Creek Member as they are in the Parachute Creek Member. However, this may be at least partly an artifact of inadequate sampling. Records from this member include plants (leaves and wood); invertebrates (mollusks and ostracods); and vertebrates, including fishes, turtles, crocodiles, rodents, and primates (Cashion 1967; Dawson 1968; Langston and Rose 1978; unpublished paleontological data, University of Colorado Museum, compiled in 2002). In the 1930s, J.L. Kay of the Carnegie Museum collected a diverse vertebrate fossil assemblage from the Powder Wash Locality within rocks of the Douglas Creek Member on Raven Ridge.

The Parachute Creek Member of the Green River Formation in the Uinta Basin is designated as BLM Condition 1 and PFYC Class 4/5. Future project-specific analyses of smaller geographic areas and more stratigraphically restricted intervals may necessitate a reevaluation and local redesignation. The Douglas Creek Member of the Green River Formation is less fossiliferous than the Parachute Creek Member and is designated as BLM Condition 2 and PFYC Class 3. In the Raven Ridge and Nine Mile Canyon areas, where the Douglas Creek Member of the Green River Formation is known to be more fossiliferous, it is designated as BLM Condition 2 and PFYC Class 4/5.

\subsubsection{Uinta Formation}

In general terms, the Uinta Formation conformably overlies and interfingers with the Parachute Creek Member of the Green River Formation and is locally overlain by the Duchesne River Formation. However, despite its historical and scientific importance to vertebrate paleontology, the detailed stratigraphy of the Uinta Formation is fairly complex and has not yet been precisely documented. The stratigraphic nomenclature is also inconsistent. In general, the Uinta Formation consists of greenish-gray, dirty-yellow, grayish-orange, and purple fluvial- and lacustrine-deposited shale, marlstone, siltstone, and sandstone, and it is locally tuffaceous. In some places, the Uinta Formation has been divided into a lower and an upper part with a transitional contact (Cashion 1973; Dane 1954; Rowley et al. 1985). According to Rowley et al. (1985), the lower part of the Uinta Formation includes two units, which generally correspond to Horizons A and B of Osborn (1929), Peterson and Kay (1931), and Kay (1934). The lower unit of the lower part consists of typically resistant to moderately resistant, pale yellow, brown, or red sandstone and minor conglomerate and shale. The lower part (including lower and upper units) of the Uinta Formation has a maximum thickness of approximately $984 \mathrm{ft}$ and thins to the north. The upper unit of the lower part consists of soft, light-gray and lightpurple claystone and sandstone containing interbedded, resistant, greenish-gray, light-green, brown, and yellow cross-bedded ribbon sandstones and conglomerate beds. The upper part of the Uinta Formation consists of soft, light-gray, white, greenish-gray, maroon, grayish purple, red, tan, and yellow shale; mudstone; claystone; and minor sandstone, and includes most of Horizon C1 of Osborn (1929), Peterson and Kay (1931), and Kay (1934). It locally intertongues with the overlying Brennan Basin Member of the Duchesne River Formation and has a maximum thickness of approximately $820 \mathrm{ft}$, thinning to the north (Rowley et al. 1985). Measured 
thicknesses of the Uinta Formation vary widely across the Uinta Basin, and it pinches out locally in the vicinity of Asphalt Ridge and Raven Ridge. Tar sands have been reported from the Uinta Formation in the Pariette and Argyle Canyon areas (USGS 1980a,e)

Eocene mammals were first discovered in the Uinta Basin by O.C. Marsh during his expedition of 1870. Marsh and his field parties returned to the area for several subsequent years. A number of researchers have focused on the lithostratigraphy and biostratigraphy of the Uinta Formation since this unit and the Uinta Basin were named by O.C. Marsh (1871). O.A Peterson (in Osborn 1895:358) was the first worker to stratigraphically subdivide the Uinta Formation. His subdivisions were based on lithologic differences and included Horizon A, Horizon B, and Horizon C, from lowest to highest. Horizon C, which was the thickest, was later assigned to part of the Duchesne River Formation by Kay (1934).

E.S. Riggs (1912) assigned the names Lower Metarhinus zone and Upper Metarhinus zone to Uinta Horizons A and B, respectively. He measured a stratigraphic section and described the Amynodon sandstone as a laterally continuous marker bed that capped Horizon B, his Upper Metarhinus zone. E. Douglass (1914) also measured a stratigraphic section and questioned the division between Divisions B and C. Osborn (1929) further subdivided the formation and refined the tripartite scheme presented in his 1895 paper. He assigned the upper half of Uinta A to Uinta B1, which he called the Metarhinus zone and used a newly recognized marker unit, the Metarhinus sandstone, to define the top of Uinta B1. Riggs' Amynodon sandstone was used to divide Uinta B2 (the Eobasilieus-Dolichorhinus zone) from Uinta C. The lowest part of Uinta C was named the Diplacodon-Epihippus zone. Osborn's (1929) classic but flawed perissodactylbased biostratigraphy was dismissed by later workers.

As mentioned above, Kay (1934:358-359) named the Duchesne River Formation by removing the red beds of Osborn's "Upper Uinta," recognizing that these strata contained a distinctive and younger mammalian fauna. The Wood Committee (Wood et al. 1941) formally divided the Uinta Formation into the Wagonhound Member (Uinta A and B) and Myton Member (Uinta C), and discarded the older tripartite subdivision. However, the older terminology is still widely used because (1) the Wagonhound Member combined two lithologically distinct units, the sandstone-dominated Uinta A, which contains few fossils, and the mudstone and claystonedominated Uinta B, which contains locally abundant fossils, and (2) fossil collections made before the recommendations of the Wood Committee were made using the tripartite scheme.

Cashion (1982) measured a stratigraphic section from Wagonhound Canyon through Bonanza and the Coyote Basin. He defined the basal unit of the Uinta Formation as the lowest persistent sandstone bed and later published the geologic map of the Bonanza Quadrangle (Cashion 1986). Cashion did not map the boundary between Uinta B and C and noted that because of its limited aereal distribution, Riggs' (1912) Amynodon sandstone should not be used as a marker unit to divide Uinta B from Uinta C.

On the basis of paleomagnetic studies, Prothero and Emry (1996) concluded that the Uintan NALMA could be divided into five intervals based on magnetostratigraphy and biostratigraphy. These intervals include faunas from Uintan-aged localities across North America. They are the earliest Uintan, Uinta B1, Uinta B2, Uinta C, and the Randlett 
horizon, and they span 4.5 million years from about 46.5 to 42.0 Ma. Robinson et al. (2004) advocate subdividing the Uintan NALMA into three biochronologic zones: Ui1 (early = transitional Uintan, possibly Shoshonian of Flynn 1986), Ui2 (middle = early Uintan), and Ui3 (late = late Uintan). Recent stratigraphic and paleontologic work and fieldwork in progress in the Uinta Formation have included important efforts to better characterize and document the lithostratigraphy, biostratigraphy, paleoecology, and paleoenvironments of the Uinta Formation (see Rasmussen et al. 1999a; Townsend 2004; Townsend et al. 2006; Walsh 1996).

The Uinta Formation is paleontologically important for a number of reasons. It is the stratotype for the Uintan NALMA and represents nearly all of Uintan time (46.5-40.0 Ma) (Townsend 2004; Walsh 1996). Approximately $31 \%$ of modern mammalian families appear in the fossil record of North America during the Uintan NALMA (Black and Dawson 1966). Many of the new taxa are thought to have either originated in North America or emigrated in from Asia (Black and Dawson 1966; Stucky and Snyder 1992; Beard 1998). Faunally, the Uintan is important because it represents a transition from more climatically stable tropical conditions of the earlier Eocene to the more arid conditions of the later Eocene (Rasmussen et al. 1999a). Key mammalian evolutionary events of the Uintan include the origination and radiation of selenodont artiodactyls, a major family-level diversification of rodents, and the diversification of rhinoceratoid perissodactyls. The distinctive shift in the composition and diversity of mammalian communities that occurred during the Uintan is also marked by the disappearance or decline of some archaic groups. These include the uintatheres, north American primates, hyopsodontid condylarths, and oxyaenid creodonts (Rasmussen et al. 1999a; Robinson et al. 2004). Typical Uintan mammalian communities were dominated by selenodont artiodactyls Protoreodon and Leptotragulus, perissodactyls, including brontotheres, tapirs, both amynodont and hyracodont rhinos, and the horse Epihippus. Also included is a characteristic assemblage of rodents, including the cylindrodont Pareumys, the sciuravid Sciuravus, and the ischyromyids Leptotomus and Ischyrotomus (Rasmussen et al. 1999a). The primitive lagomorph Mytonolagus was also present.

Although the Wagonhound Member (especially the Uinta A) is less fossiliferous, both the Wagonhound and Myton members of the Uinta Formation in the Uinta Basin are designated as BLM Condition 1 and PFYC Class 4/5 because detailed geologic maps that differentiate between these two members or other proposed stratigraphic schemes of paleontological relevance have not been published. Future project-specific analyses of smaller geographic areas and more stratigraphically restricted intervals may necessitate a reevaluation and local redesignation.

\subsubsection{Duchesne River Formation}

The Duchesne River Formation occurs only in the northern part of the Uinta Basin in Utah, where it is widespread. Its definition and stratigraphic history are related to the underlying and apparently conformable Uinta Formation (see discussion in Section 6.4.4). In the northern part of its distribution, it unconformably overlies rocks of Triassic and Jurassic age. The Duchesne River Formation contains tar sands in the Asphalt Ridge area (USGS 1980b). 
The Duchesne River Formation was deposited under mostly fluvial conditions but includes some lacustrine deposits. It was originally subdivided into the Randlett, Halfway, and Lapoint members (horizons) by Kay (1934). However, the mammalian fauna of the Randlett Member was later found to be equivalent to that of Uinta $C$, and it was removed from the Duchesne River Formation (Gazin 1955). More recently, the stratigraphy of the Duchesne River Formation stratigraphy was revised, and this unit was subdivided into the following members in ascending stratigraphic order: Brennan Basin, Dry Gulch Creek, Lapoint, and Starr Flat (Anderson and Picard 1972; Rowley et al. 1985).

The Brennan Basin Member is composed of soft to moderately resistant, light-to-medium red, light-gray, light-brown, yellow, and tan ledgy sandstone, mudstone, conglomerate, shale, and siltstone, with a maximum thickness of about 1,970 ft south of Vernal. The member thins to the east and west. The Dry Gulch Creek Member consists of soft to moderately resistant, lightto-medium gray, medium red, purplish gray, and yellow sandstone, mudstone, shale, and conglomerate. It is approximately $490 \mathrm{ft}$ thick. The Lapoint Member consists of mostly soft, light red, tan, and yellow sandstone, siltstone, and mudstone with minor amounts of conglomerate. It contains diagnostic beds of light-gray to medium-gray or bluish-gray bentonite and ranges in thickness from approximately 390 to $980 \mathrm{ft}$. The Lapoint ash, which forms the base of the Lapoint Member (where most of the vertebrate fossils have been discovered), has been dated at 39.74 Ma $\pm 0.07 \mathrm{Ma}$ (Prothero and Swisher 1992). The Starr Flat Member consists of moderately resistant, light-to-medium red and tan sandstone, mudstone, with lesser amounts of conglomerate, and with a thickness of approximately $490 \mathrm{ft}$ (Rowley et al. 1985). It outcrops spottily along the southern flanks of the Uinta Mountains.

In comparison with the Uinta Formation, the Duchesne River Formation vertebrate fauna is sparse. However, it is just as important (Lucas 1992; Rasmussen et al. 1999b;

Robinson et al. 2004). Although it is the nominal stratotype for the Duchesnean NALMA (Wood et al. 1941), its validity has been the subject of some controversy among paleontologists (see Lucas 1992; Wilson 1978). Nevertheless, the Duchesnean NALMA has now been widely accepted by paleontologists (Rasmussen et al. 1999b; Robinson et al. 2004). Lucas (1992:88) made the observation that the Duchesne River Formation "has either been questioned, abandoned, subdivided, or defended." Scott (1945) regarded the Duchesne River Formation as Oligocene in age. Simpson (1946) and Gazin (1955) considered it Eocene. Faunally, the importance of the Duchesne River Formation and the Duchesnean NALMA is based on the fact that it records a major faunal replacement in North America, as demonstrated by its large number of first and last occurrences, as well as the small number of genera that are restricted to it (Black .and Dawson 1966; Robinson et al. 2004). Robinson et al. (2004) tentatively assigned Duchesnean first appearances to include Hyaenodon, Duchesneodus, Duchesnehippus intermedius, Amynodontopsis, and Eotylopus.

The fauna of the Brennan Basin Member, which was previously assigned to the Randlett horizon and lower part of the halfway horizon, includes an assemblage that is considered faunally intermediate between the mammalian faunas of the Uinta $\mathrm{C}$ (biochron Ui3) and the Lapoint Member of the Duschesne River Formation. The base of the Brennan Basin Member is reportedly of late Uintan Age. The Brennan Basin Member outcrops over a fairly large area, and several somewhat productive localities are known. The mammalian fauna of the Brennan Basin 
includes a reasonably diverse assemblage of artiodactyls, including Protoreodon, Pentacemylus, Diplobunops, and Leptotragulus. Perissodactyls include a mix of Uintan and Duchesnean brontotheres, as well as tapirs and rhinos. Specimens of the lagomorph Mytonolagus and the rodents Pareumys and Mytonomys have also been collected (Rasmussen et al. 1999b).

Until recently, only two published specimens had ever been reported from the Dry Gulch Creek Member, representing the "Halfway Fauna." This fauna included the holotype of Duchesnehippus intermedius, a genus of horse that is intermediate between the Uintan horse Epihippus and the Chadronian horse Mesohippus, and post-cranial elements tentatively identified as hyracodontid rhinoceros. In 2006, Steve Walsh and Paul Murphey of the San Diego Natural History Museum discovered a locality that produced a diversity of small mammals in the Dry Gulch Creek Member. This assemblage includes 14 additional small mammal taxa, and the diversity of the Dry Gulch Creek Member has been increased dramatically. The faunal assemblage is dominated by rodents and strongly suggests a Duchesnean age based on two genera (Walsh and Murphey 2007).

The mammalian fauna of the Lapoint Member is considered the type Duchesnean fauna, although misidentifications, data loss, and mistakes made by earlier workers have resulted in considerable confusion regarding what was actually collected at this horizon. Most of these problems seem to have been resolved by the efforts of Rasmussen et al. (1999b). The Lapoint fauna contains diverse assemblages of artiodactyls such as Protereodon, Agriochoerus, Simimeryx, and Brachyops, and perissodactyls (rhinos, brontotheres, horses) such as Colodon, Hyracodon, Duchesnehippus, and Duchesneodus. Also present are carnivores, the mesonychid Hessolestes, the creodont Hyaenodon, the insectivore Centetodon, and the rodents Pareumys and Protadjidaumo. No fossils have been reported from the stratigraphically highest Starr Flat Member.

Although the Lapoint and Brennan Basin members of the Duchesne River Formation are the most fossiliferous, fossils are generally scarce throughout the formation. On the other hand, any new discoveries would be highly significant, especially from the Dry Gulch Creek and Starr Flat members. On the basis of existing data, the Brennan Basin and Lapoint members of the Duchesne River Formation are designated as BLM Condition 2 and PFYC Class 4/5. The Dry Gulch Creek and Starr Flat members are designated as BLM Condition 2 and PFYC Class 3. Future project-specific analyses of smaller geographic areas and more stratigraphically restricted intervals may necessitate a reevaluation and redesignation of parts of the Duchesne River Formation.

\subsubsection{Pleistocene- and Holocene-Age Surficial Deposits}

The bedrock geologic units within the Uinta Basin are locally mantled by younger surficial deposits of Pleistocene and Holocene age. These consist of alluvium, colluvium, pediment deposits, landslide deposits, and glacial outwash and till. Holocene-age alluvium is composed primarily of poorly consolidated silt, sand, and cobbles derived from eroded bedrock and older alluvial and colluvial deposits. These sediments are deposited by rivers and streams in stream channels and on active alluvial floodplains. Pleistocene-age alluvium consists of gravel, 
sand, silt, mud, and clay that form alluvial terraces and isolated remnants on dissected benches along stream drainages. Pediment deposits consist of poorly stratified sand and silt that contain matrix-supported, angular- to subangular boulders, cobbles, and pebbles. Glacial outwash deposits consist of poorly sorted gravel and sand deposited by glacial meltwater. Glacial till deposits consist of angular unsorted sand and gravel deposited by glaciers. Colluvium and landslide deposits consist of rock material that has moved under the influence of gravity. Lithologies of these units vary and are dependent upon the type of source rock. They form on unstable slopes and on older colluvial deposits. In general, colluvium and landslide deposits are much less likely to contain well-preserved animal and plant remains than are intact native sediments. Colluvium and landslide material is often subjected to increased groundwater percolation, which tends to have a negative effect on the preservation of organic material; gravitationally induced movement of sediment can also destroy animal and plant remains through abrasion and breakage. Additionally, when the original stratigraphic position of the sediments is disturbed, there are varying degrees of information loss with the severity of changes to the slide mass.

Surficial deposits of Holocene age contain the unfossilized remains of modern taxa and are too young to contain in situ fossils. Pleistocene-age surficial deposits, particularly alluvium, may contain mineralized or partially mineralized animal bones, invertebrates, and plant remains of paleontological significance. With the exception of some caves, hot springs, and tar deposits, these fossils typically occur in low density and usually consist of scattered and poorly preserved remains. The most common Pleistocene vertebrate fossils include the bones of mammoth, bison, deer, and small mammals, but other taxa, including horse, lion, cheetah, wolf, camel, antelope, peccary, mastodon, and giant ground sloth, have been reported from the Rocky Mountain region (Cook 1930, 1931; Emslie 1986; Gillette and Miller 1999; Gillette et al. 1999a,b; Heaton 1999; Hunt 1954; Lewis 1970; Scott 1963; Smith et al. 1999; unpublished Denver Museum of Nature and Science paleontological data). Only one record of a Pleistocene-age fossil from the Uinta Basin was found during the research phase of this study. This specimen, a camel tibia collected from "near Bonanza," is on display at the Utah Field House Museum of Natural History in Vernal.

Generally, deposits of Holocene age contain the unfossilized remains of modern species of animals and plants and are not considered paleontologically sensitive. These are designated as BLM Condition 3 and PFYC Class 2. Occurrences of Pleistocene-age fossils from the Uinta Basin are rare. Pleistocene-age surficial deposits in this area are designated as BLM Condition 2 and PFYC Class 2.

\subsection{PALEONTOLOGICAL RESOURCE ASSESSMENT SUMMARY}

As discussed in Section 6.4, surface disturbance associated with commercial oil shale activities within the portion of the PEIS study area located in the Uinta Basin in northeastern Utah has the potential to affect five mapped bedrock geologic units, as well as a variety of surficial deposits (Bryant 1992; Cashion 1973, 1974, 1977; Hansen et al. 1983; Hintze 2000; Keighin 1977a,b; Pantea 1987, 1993; Rowley et al. 1985; Weiss et al. 1990; Whitney 1981; Witkind 1998, 1995; Witkind and Weiss 1991). The paleontological sensitivities of these units 
were evaluated by using both the BLM paleontological resource classification system (BLM 1998, Conditions 1-3) and the PFYC developed by the USFS, which was recently adopted with modifications by the BLM (BLM 2007). These two classification systems are presented in Sections 3.1 and 3.2, respectively. Resource assessment designations for each geologic unit discussed in Section 6.4 are summarized in Table 5 using both classification systems.

TABLE 5 Summary of Programmatic-Level Paleontological Sensitivities of Geologic Units within the Uinta Basin in Northeastern Utah

\begin{tabular}{|c|c|c|c|c|}
\hline Geologic Unit & Age & Typical Fossils & $\begin{array}{c}\text { BLM } \\
\text { Designation }\end{array}$ & $\begin{array}{c}\text { PFYC } \\
\text { Designation }\end{array}$ \\
\hline $\begin{array}{l}\text { Alluvium, colluvium, } \\
\text { landslide deposits, } \\
\text { pediment deposits, } \\
\text { glacial outwash, and till }\end{array}$ & Holocene & $\begin{array}{l}\text { None in deposits of Holocene } \\
\text { age unless reworked from } \\
\text { older sediments }\end{array}$ & Condition 3 & Class 2 \\
\hline $\begin{array}{l}\text { Alluvium, colluvium, } \\
\text { landslide deposits, } \\
\text { pediment deposits, } \\
\text { glacial outwash, and till }\end{array}$ & Pleistocene & $\begin{array}{l}\text { Scattered vertebrates, } \\
\text { invertebrates, and plants occur } \\
\text { locally }\end{array}$ & Condition 2 & Class 2 \\
\hline $\begin{array}{l}\text { Duchesne River } \\
\text { Formation: Brennan } \\
\text { Basin and Lapoint } \\
\text { members }\end{array}$ & $\begin{array}{l}\text { Middle } \\
\text { Eocene }\end{array}$ & $\begin{array}{l}\text { Vertebrate (mammal) fossil } \\
\text { accumulations occur locally } \\
\text { but are uncommon }\end{array}$ & Condition 2 & Class $4 / 5$ \\
\hline $\begin{array}{l}\text { Duchesne River } \\
\text { Formation: Dry Gulch } \\
\text { Creek and Starr Flat } \\
\text { members }\end{array}$ & $\begin{array}{l}\text { Middle } \\
\text { Eocene }\end{array}$ & $\begin{array}{l}\text { Vertebrate (mammal) fossils } \\
\text { rare in Dry Gulch Member; no } \\
\text { records of fossils in Starr Flat } \\
\text { Member }\end{array}$ & Condition 2 & Class 3 \\
\hline $\begin{array}{l}\text { Uinta Formation: } \\
\text { Wagonhound and } \\
\text { Myton members }\end{array}$ & $\begin{array}{l}\text { Middle } \\
\text { Eocene }\end{array}$ & $\begin{array}{l}\text { Locally abundant vertebrates } \\
\text { (mammals and reptiles), } \\
\text { invertebrates (mollusks), and } \\
\text { plants (leaves and wood) }\end{array}$ & Condition 1 & Class 4/5 \\
\hline $\begin{array}{l}\text { Green River Formation: } \\
\text { Parachute Creek } \\
\text { Member }\end{array}$ & $\begin{array}{l}\text { Middle } \\
\text { Eocene }\end{array}$ & $\begin{array}{l}\text { Locally abundant vertebrates } \\
\text { (fishes, amphibians, reptiles, } \\
\text { birds, and mammals), } \\
\text { invertebrates (insects, } \\
\text { arthropods, and mollusks), } \\
\text { plants (leaves, flowers, wood), } \\
\text { and (ichnofossils) }\end{array}$ & Condition 1 & Class $4 / 5$ \\
\hline
\end{tabular}


TABLE 5 (Cont.)

\begin{tabular}{|c|c|c|c|c|}
\hline Geologic Unit & Age & Typical Fossils & $\begin{array}{c}\text { BLM } \\
\text { Designation }\end{array}$ & $\begin{array}{c}\text { PFYC } \\
\text { Designation }\end{array}$ \\
\hline $\begin{array}{l}\text { Green River Formation: } \\
\text { Douglas Creek Member }\end{array}$ & $\begin{array}{l}\text { Early and } \\
\text { middle } \\
\text { Eocene }\end{array}$ & $\begin{array}{l}\text { Scarce vertebrates (mostly fish } \\
\text { but also reptiles and } \\
\text { uncommon mammals), } \\
\text { vertebrate trackways, locally } \\
\text { common invertebrates } \\
\text { (mollusks) and plants (leaves) }\end{array}$ & Condition 2 & $\begin{array}{l}\text { Class } 3 \\
\text { (Class } 4 / 5 \text { at } \\
\text { Raven Ridge and } \\
\text { Nine Mile } \\
\text { Canyon) }\end{array}$ \\
\hline $\begin{array}{l}\text { Wasatch Formation: } \\
\text { Renegade Tongue }\end{array}$ & $\begin{array}{l}\text { Middle } \\
\text { Eocene }\end{array}$ & $\begin{array}{l}\text { Scattered, poorly preserved } \\
\text { vertebrates and plants (leaves } \\
\text { and wood) }\end{array}$ & Condition 2 & Class 3 \\
\hline $\begin{array}{l}\text { Wasatch Formation: } \\
\text { main body }\end{array}$ & $\begin{array}{l}\text { Paleocene } \\
\text { and early } \\
\text { Eocene }\end{array}$ & $\begin{array}{l}\text { Locally abundant vertebrates } \\
\text { (fishes, amphibians, reptiles, } \\
\text { birds, and mammals), } \\
\text { invertebrates (mollusks), and } \\
\text { plants }\end{array}$ & Condition 1 & Class $4 / 5$ \\
\hline Mesaverde Group & $\begin{array}{l}\text { Late } \\
\text { Cretaceous } \\
\text { (Santonian } \\
\text { and } \\
\text { Campanian) }\end{array}$ & $\begin{array}{l}\text { Moderately abundant } \\
\text { terrestrial and marine } \\
\text { vertebrates (fish, amphibians, } \\
\text { reptiles, including dinosaurs } \\
\text { and mammals), invertebrates } \\
\text { (mollusks), and terrestrial } \\
\text { plants }\end{array}$ & Condition 1 & Class $4 / 5$ \\
\hline
\end{tabular}




\section{EAST-CENTRAL AND SOUTHEASTERN UTAH SPECIAL TAR SAND AREAS}

STSAs in Utah were defined in the Utah Combined Hydrocarbon EIS (BLM 1984) (see Figure 1). Those designated STSAs that occur in the Uinta Basin in northeastern Utah are included in Section 6 of this report. Four additional STSAs occur in central and east-central and southeastern Utah. These include the San Rafael Swell, Tar Sand Triangle, White Canyon, and Circle Cliffs East and West Flanks STSAs. The San Rafael Swell STSA encompasses approximately 130,292 ac on the San Rafael Swell in Emery County, east-central Utah. Tar sands source rocks in the San Rafael Swell include the Black Dragon and Torrey members of the Moenkopi Formation (USGS 1980h). The Tar Sand Triangle STSA encompasses approximately 157,339 ac north of the Colorado River, east of the Henry Mountains, and west of Canyonlands National Park (including part of the western portion of Canyonlands National Park) in Garfield and Wayne counties, southeast-central Utah. The tar sands source rock in the Tar Sand Triangle is primarily the White Rim Sandstone Formation of the Cutler Group, although oil has also seeped into permeable overlying and underlying beds of this unit (USGS 1980j; Huntoon et al. 1999). The White Canyon STSA encompasses approximately 10,469 ac, 3 to $5 \mathrm{mi}$ east of Glen Canyon National Recreation Area, and 5 mi south of Cataract Canyon on the Colorado River in San Juan County, southeastern Utah. The tar sands source rock in the White Canyon STSA is the Hoskinnini Member of the Moenkopi Formation (USGS 1980k). The Circle Cliffs East and West Flanks STSA encompasses approximately 91,080 ac in the Canyonlands section of the Colorado Plateau, approximately 30 mi east of the town of Escalante, just west of and including portions of Capitol Reef National Park in Garfield County, south-central Utah. Tar sands source rocks in the Circle Cliffs East and West Flanks STSA include the Kaibab Limestone, the Torrey Member of the Moenkopi Formation, and the Shinarump Member of the Chinle Formation (USGS 1980c).

Previous sections of this report subdivided oil shale and STSAs into three sections corresponding to three large sedimentary basins in Wyoming, Colorado, and Utah: the greater Green River, Piceance Creek, and Uinta basins. Generally, this section combines the geology and paleontology of each potentially affected geologic unit at the four STSAs in central and southern Utah to facilitate discussion of their depositional history, paleoenvironmental history, history of investigations, geology and stratigraphy, and paleontology. Thus, although members of the Moenkopi Formation occur at three of the four STSAs, there is only one discussion (Section 7.4.3) of the geology and paleontology of the Moenkopi Formation. Also, like the previous sections of this report, the discussions are focused only on the potentially affected geologic units within the four STSAs. These include, in ascending stratigraphic order, the late Pennsylvanian to Permian Cutler Group, the Upper Permian Kaibab Limestone, the Lower and Middle Triassic Moenkopi Formation, and the Upper Triassic Chinle Formation.

\subsection{GEOLOGIC SETTING AND DEPOSITIONAL HISTORY}

The San Rafael Swell, Tar Sand Triangle, White Canyon, and Circle Cliffs East and West Flanks STSAs are all located on the Colorado Plateau. The Colorado Plateau is a geographic and geologic province that includes approximately $140,000 \mathrm{mi}^{2}$ in the Four Corners region of 
Colorado, Utah, Arizona, and New Mexico. It is bordered by the Uinta Mountains to the north, the Wasatch Mountains to the west, and the Rocky Mountains to the east. It includes the area drained by the Colorado River and its tributaries, the Green, little Colorado, and San Juan, and ranges in elevation from 3,000 to $14,000 \mathrm{ft}$ with an average elevation of 5,200 ft. In Utah, the Colorado Plateau comprises much of the eastern and southern part of the state. Rigby (1977) subdivided the Colorado Plateau into six sections. The STSAs in central and southern Utah are located within the Canyonlands section and the High Plateaus section. The major structural features of the Colorado Plateau include broad flexures, monoclines, vertical faults, igneous laccoliths, and salt tectonic features (Foos 1999).

During early Paleozoic time (Cambrian through Mississippian), the Colorado Plateau was relatively stable tectonically, with sediment deposition occurring in shallow seas. These oldest rocks are well-exposed in the Grand Canyon. Because of a global lowering of sea level, Ordovician- and Silurian-age time is not represented on the Colorado Plateau due to major unconformities. The ancestral Rocky Mountains were uplifted from the Pennsylvanian through the Triassic, forming a series of northwest-trending broad uplifts and sedimentary basins. As these uplifts were eroded, they shed sediments into the adjacent basins. Seas with broad, shallow margins transgressed across parts of what would later become eastern Utah and southwestern Colorado, flooding basins and creating conditions suitable for the accumulation of thick evaporite deposits. During the early Jurassic, deposition of eolian sand dunes occurred over an area larger than the Sahara desert and covered the area that would later become the Colorado Plateau. During the Jurassic and Cretaceous, the Nevadan and Sevier orogenies to the west of the Colorado Plateau created uplifts that shed sediments into the Rocky Mountain Foreland Basin, including the Colorado Plateau. These sediments include bentonitic volcanic ash beds deposited during the Triassic, Jurassic, and Cretaceous. The youngest marine deposits on the Colorado Plateau, indicative of the last time the area was at sea level, are of late Cretaceous age. As the last Cretaceous sea regressed to the east, the latest Cretaceous and Paleogene Laramide orogeny commenced, forming the Rocky Mountains. Simultaneous tectonic deformation on the adjacent Colorado Plateau was relatively minor, resulting mostly in normal faulting and the formation of monoclines. During the Eocene, the Colorado Plateau was at a low elevation and surrounded by mountain ranges. As the mountains eroded, sediments were deposited in the adjacent basins, and Laramide structures were buried. Beginning in the early Pliocene, approximately five million years ago, a major uplift raised the elevations of the Rocky Mountain and Colorado Plateau regions approximately 4,000 to 6,000 ft, and the Colorado Plateau was tilted toward the north. As this uplift above base level occurred, the drainages of modern rivers and streams were established as they began to downcut actively and rapidly. Widespread erosion of the Colorado Plateau began at this time, accelerated during the colder and wetter climate of the Pleistocene, and continues to this day (Foos 1999).

The San Rafael Swell is located close to the western margin of the Colorado Plateau. It is a north-south trending anticline approximately $100 \mathrm{mi}$ long and $40 \mathrm{mi}$ wide that was uplifted during the Eocene. This dramatic anticline exposes some of the oldest strata in the Colorado Plateau, ranging in age from the Permian to the Cretaceous. From oldest to youngest, exposed rock units include the Permian-age littoral marine Coconino Sandstone and the open-water marine Kaibab Limestone, the Triassic-age interbedded marine and terrestrial Moenkopi and Chinle formations, the Jurassic-age eolian Wingate Sandstone, fluvial Kayenta Formation, eolian 
Navajo Sandstone, and marine Carmel Formation. The Moenkopi Formation contains the tar sands in this area (USGS 1980h).

The Tar Sand Triangle and White Canyon STSAs are located near the northern end of the Monument Upwarp, a broad anticline named for Monument Valley located to the south. Sedimentary rock units are well exposed in this area, with the oldest units generally outcropping near the confluence of the Green and Colorado rivers. Strata in this area typically dip gently across the anticline and include rocks of Pennsylvanian, Permian, Triassic, and Jurassic age. Local structural deformities have resulted from the upward movement of marine evaporite deposits of salt and gypsum, which become plastic under pressure, are less dense, and are therefore more buoyant than other rocks. During the Pennsylvanian, these evaporites accumulated in a shallow marine environment with restricted circulation. As the Pennsylvanian sea retreated, deposits of beach sand, eolian sand dunes, and alluvial fans accumulated; they are represented by rocks of the Permian-age Cedar Mesa Sandstone and Cutler Group. Rivers and streams transported sediments to the area during the Triassic, depositing them on floodplains and in deltas represented by the Moenkopi and Chinle formations. In the early Jurassic, massive sand dune deposits accumulated in a desert environment; they are represented by the Wingate and Navajo sandstones. These two units are stratigraphically separated by the Kayenta Formation, which was deposited fluvially. In the Tar Sand Triangle, tar sands are contained in the White Rim sandstone, the uppermost formation in the Cutler Group (USGS 1980j; Huntoon et al. 1999). In the White Canyon STSA, tar sands are trapped within the Hoskinnini Member of the Moenkopi Formation (USGS 1980k).

The dominant structural feature in the Circle Cliffs East and West Flanks STSA, located within and just to the west of Capitol Reef National Park, is Capitol Reef itself. This feature is part of Waterpocket Fold, a single large monocline of late Cretaceous age. Capitol Reef is a prominent part of this fold, and is composed of a sequence of steeply tilted sedimentary rocks of Jurassic age, including, from lowest to highest, the eolian Wingate Sandstone, fluvial Kayenta Formation, and Navajo Sandstone, which caps the crest of the Capitol Reef. Younger, Cretaceous-age strata are exposed to the east of the reef. Older Triassic- and Permian-age strata, including the Triassic Moenkopi Formation and Permian Kaibab Limestone, which are locally impregnated with tar sands, are exposed to the west of the reef (USGS 1980c).

\subsection{PALEOENVIRONMENTAL SUMMARY}

In contrast to the paleoenvironments and climates of the Eocene-age Green River lake system discussed in Chapters 4 through 6 of this report, less is known of late Paleozoic and early Mesozoic paleoenvironments of North America. This is at least in part reflective of the fact that the much older rocks of this age generally contain fewer fossils. Additionally, however, this ancient fossil biota is far more difficult to interpret in the context of today's world than that of the comparatively much younger Eocene Epoch. Our knowledge of the North American Paleozoic and Mesozoic has increased dramatically over the last several decades thanks in large part to the efforts of paleontologists and geologists working in Utah and adjacent parts of Arizona and Colorado. 
The Cutler Group, Kaibab Limestone, Moenkopi Formation, and Chinle Formation were deposited over an approximately 100-million-year interval, from about $300 \mathrm{Ma}$ to $200 \mathrm{Ma}$. This was important period in earth's biologic and geologic history. The fossils preserved in these rocks, together with the paleoenvironmental evidence found in the surrounding sediments, provide a record of a highly significant time in the evolution of vertebrates, invertebrates, and plants. This period is marked by the diversification of land vertebrates (tetrapods), a decline in the diversity and abundance of certain amphibian groups, the evolution and diversification of the amniotes (earliest reptiles and mammal-like reptiles), and the evolution of the earliest dinosaurs and mammals during the Triassic. Significant evolutionary changes also occurred in the floras and invertebrate faunas of the world. It is hypothesized that many of the ecological and evolutionary changes of this time were at least in part driven by global climatic shifts resulting from the tectonic movements of continental land masses. The largest known extinction in earth's history marks the boundary between the Permian and the Triassic periods approximately 250 million years ago. This event resulted in the loss of more than 90\% of marine invertebrate species and more than $70 \%$ of all terrestrial vertebrate species. Although a number of hypotheses have been proposed as explanations for the Permian-Triassic extinction, it is now commonly accepted that it occurred over a period of less than one million years, which is a brief period geologically.

A variety of back-beach, marine, fluvial, and eolian environments are preserved in sedimentary deposits of the late Pennsylvanian and early Permian Cutler Group. These environments were inhabited by a distinctive flora and fauna. The flora of the Cutler Group was apparently of low diversity and included mostly enigmatic forms with unclear taxonomic affinities. Floral evidence suggests a gradual drying throughout the Pennsylvanian, ultimately leading to relatively arid climatic conditions in the Permian. The vertebrate fauna was somewhat diverse based on the fossil record and included a variety of primitive sharks, actinopterygian and crossopterygian fishes, and lungfishes that inhabited the shallow seas, lakes, and rivers. In comparison to modern faunas, amphibians were highly diverse in terms of body shapes and sizes and included large land-dwelling forms such as Eryops, as well as aistopods, anthracosaurs, and the bizarre crescent-headed lepospondyl Diplocaulus. Terrestrial habitats of the Cutler Group were also inhabited by primitive amniotes, including early anapsid reptiles and synapsid pelycosaurs such as the sailbacked forms Dimetrodon and Edaphosaurus. The ancestors of mammals, therapsids (often informally referred to as "mammal-like reptiles"), were derived from the synapsids. On the basis of fossil evidence, late Pennsylvanian fish and amphibian faunas were considerably more diverse than those of Permian age, and amniote faunas of Permian age were apparently more diverse than those of Pennsylvanian age. Although this further suggests that gradual drying may have occurred throughout the Permian, it has also been interpreted as a possible collection bias (Sumida et al. 1999a).

During the late Permian, after deposition of the Cutler Group, the area known today as southern Utah, southern Nevada, and northern Arizona was flooded by a warm shallow sea. Irwin (1976) interpreted the paleoenvironment of the Kaibab Limestone in southeastern Utah as a shallow marine-shelf deposit that represents the time of maximum eastward transgression of the Kaibab Sea. Nearshore environments of the Kaibab Sea were inhabited by a dominantly molluscan faunal association composed mainly of bivalves, gastropods, and scaphopods with several species of brachiopods. Delta environments had a low-diversity molluscan fauna. 
Offshore environments were inhabited by a wide variety of sponges, corals, bryozoans, crinoids, and pectinid bivalves with a large number of brachiopod species (Cisne 1971). Trilobites also inhabited this sea and had an unusual pattern of distribution for the Paleozoic characterized by decreasing abundance and diversity from nearshore to offshore environments. Open-water environments were inhabited by chambered cephalopods such as nautiloids and ammonoids. Vertebrates such as sharks and bony fishes undoubtedly inhabited the Kaibab Sea but were only rarely preserved as fossils. Latest Permian and early Triassic time, including the massive Permian-Triassic extinction event, is not recorded in rocks of the Colorado Plateau due to a widespread regional unconformity (Gregory 1950).

In northern Arizona and southeastern Utah, the Moenkopi Formation was deposited in a succession of repeating marine and continental deposits in nearshore, shore (beach), tidal flat, deltaic, and fluvial environments that moved in a northwest to southeast direction as a warm, shallow sea transgressed and regressed over the area. Clastic sediments that were deposited in the Moenkopi sea were derived from source areas to the south and east (Morales 1987). The climate during Moenkopi time is interpreted to have been generally warm and seasonal, but semi-arid to arid on the basis of sedimentological and paleontological data (Repenning et al. 1969). Marine environments were inhabited by a wide variety of animals, including arthropods, ostracods, conodonts, worms, brachiopods, bivalves, gastropods, scaphopods, cephalopods, echinoderms, and cartilagenous fishes such as sharks and bony fishes, including coelacanths (Blakey 1974; McKee 1954; Morales 1987). Low rainfall may offer an explanation for the low abundance and diversity of plant fossils in the Moenkopi. The flora features primitive plants like the horsetail Neocalamites, tree ferns, and araucaria-like conifers. Sedimentological, paleontological, and taphonomic data suggest that most of the known Moenkopi land animals and plants were inhabitants of rivers and streams (riparian environments), ponds, and mud or tidal flats located near where their remains were buried (Morales 1987). However, McKee (1954) suggested that at least a portion of the terrestrial fauna probably lived in upland areas distant from the environment of deposition. Terrestrial animals thus probably gravitated toward wetter and/or cooler habitats and would have included labyrinthodont amphibians, archosaurian reptiles, dicynodont therapsids, and others.

Like the underlying Moenkopi Formation, deposition of the Chinle Formation in the late Triassic occurred in a variety of environments, but all were terrestrial. Regional upwarping ended deposition of the Moenkopi and caused the withdrawal of the Triassic seas. This upwarp created a generally northwest-flowing drainage system, and Chinle deposition occurred in rivers and streams (riparian habitats), in lakes and ponds, and on floodplains. Immediately before Chinle deposition, large eroding streams that mark one of the more conspicuous depositional hiatuses in the Mesozoic of the southwest cut valleys and stream channels more than $50 \mathrm{ft}$ deep into the underlying Moenkopi Formation. Later, beginning with deposition of the Chinle, the streams began to aggrade, and sediments filled the streams and valleys (Repenning et al. 1969). The climate of the Chinle is interpreted to have been monsoonal, with periods of high rainfall separated by dry seasons. Plant life was much more abundant than in Moenkopi times, as exemplified by the extensive fossil forests of Petrified Forest National Monument. Chinle floras were also taxonomically diverse, featuring horsetails, lycopods, ferns, conifers, cycads, and gingkos. The streams of the Chinle were inhabited by fishes, including freshwater sharks such as Xenacanthus, the lungfish Arganodus, coelacanths, semionotids, palaeoniscids, and others. Land 
and aquatic tetrapods included a diversity of forms, including labyrinthodont amphibians such as Metoposaurus and Apachesaurus; primitive reptiles, including aetosaurs, phytosaurs, and rauisuchians; the well-known small bipedal dinosaur Coelophysis; and cynodont mammal-like reptiles (Parker 2005).

\subsection{PREVIOUS PALEONTOLOGICAL WORK AND RELATED INVESTIGATIONS}

The first written account of fossils discovered in the area that would later become the state of Utah is from the journal of the 1776 Dominguez-Escalante expedition, led by two Spanish missionaries who were looking for a route between Catholic missions in New Mexico and California (Miller and Hall 1990). The journal entry concerns fossilized snails that are believed to have been collected from Pleistocene-age sediments from an area that was later named Lake Bonneville in northwestern Utah. The expedition report of U.S. Army Lt. John C. Fremont (1845) contains the first published reference to fossils from Utah. These "fossil ferns and invertebrates" were described and illustrated in an appendix to the expedition report by geologist James Hall. Fremont had led two prior expeditions to the southwest, and his favorable reports of the natural resources of the region were influential in the controversies that led to war with Mexico and in the Mormons' selection of Utah for colonization.

The expedition report of Captain John N. Macomb, published in 1876, contains the firstpublished reference to a vertebrate fossil from Utah. In 1859, Macomb's expedition, which had explored the Canyonlands area of southwestern Utah, had discovered and collected bones of a sauropod dinosaur in East Canyon, then called Cañon Pintado. This specimen, originally thought to be of Triassic age, was described and named Dystrophaeus viaemalae by paleontologist E.D. Cope (1877). It was later determined that the provenance of this fossil locality was the late Jurassic Morrison Formation.

In 1853, geologist Jules Marcou conducted the earliest dedicated geologic exploration of the Colorado Plateau, traversing western New Mexico and northern Arizona and dividing the strata into several broad units (Marcou 1856, 1858). One of these he named the "Trias," which approximately corresponds to the Moenkopi and Chinle formations. Commissioned by the U.S. Congress in 1867, the King, Hayden, and Powell surveys of the late 1860s and 1870s (see Section 4.3) formed the basis for the establishment of the USGS in 1879. In association with these expeditions, many geological and paleontological observations were made, and numerous fossils were collected. Many of these came from the Uinta Basin in northern Utah (see Section 5.3). Permian invertebrates from southern Utah are believed to have been collected along the Green River in 1871 by members of the Powell expedition (Miller and Hall 1990). Of the three above mentioned surveys, J.W. Powell (1876) made perhaps the most impressive stratigraphic observations that are relevant to this section of this report. He recognized four major groups of strata of "Jura" and "Trias" age. These groups were named, in ascending order: the Shinarump, Vermilion Cliff, White Cliff, and Flaming Gorge groups. Powell correlated these groups between the Uinta Mountains in the north and northwestern Arizona, and the accuracy of his work has been confirmed by more recent studies. Another expedition of the 1870s, commissioned by the U.S. Army, entered into and explored much of Utah. This expedition was led by Lt. George M. Wheeler, and although vertebrate fossils were discovered elsewhere, only 
fossil plants and invertebrates were reportedly found in Utah. Many well-known early American paleontologists, including J. Leidy, O.C. Marsh, E.D. Cope, W.B. Scott, H.F. Osborn, J.B. Hatcher, O.A. Peterson, W.D. Matthew, E. Douglass, E.S. Riggs, J.L. Kay, and C.W. Gilmore, collected and/or studied fossils discovered in Utah during the late nineteenth and early twentieth centuries (Lanham 1973; Miller and Hall 1990).

The first scientifically collected vertebrate fossils from late Paleozoic and Triassic rocks in the southwest, some of which were discovered in those geologic units that are now known to contain tar sands, were made during or immediately before the twentieth century. A number of important geologic studies also occurred at this time, establishing the stratigraphic framework for later researchers. The earliest work in rocks that included what would later be named the Cutler Formation was conducted by geologist W.H. Holmes $(1877,1878)$, who regarded these rocks as Jurassic and Triassic in age. The Cutler Formation and associated Permian rocks were described and named by geologist Whitman Cross and colleagues working in southwestern Colorado at the beginning of the twentieth century. Baker and Reeside (1929) defined the units of the Cutler Formation in southeastern Utah that are still in use today. A.S. Romer, S.J. Olsen, and A.D. Lewis of Harvard University collected vertebrate fossils from the Cutler Formation in southwestern Colorado in 1953. G.E. Lewis and P.P. Vaughn described additional vertebrate fossils from the Cutler Formation in southwestern Colorado in their 1965 publication. E.D. McKee (1938) was one of the first paleontologists to collect marine invertebrate fossils from the Kaibab Limestone, and he established the paleoenvironmental framework for the unit and its fossils. From 1938 to 1966, field crews under the direction Dr. Samuel Welles of the University of California Museum of Paleontology (UCMP) collected terrestrial vertebrate and plant fossils from the Moenkopi Formation. The most important discoveries were made in northeastern Arizona and southeastern Utah.

Most paleontological work on the Chinle Formation has taken place in northern Arizona, although important specimens have been collected in Utah. In 1899 and 1901, Lester Ward and Barnum Brown collected the first vertebrate fossils from the Chinle Formation from a locality in northern Arizona. John Muir made a small collection of fossil vertebrates from Petrified Forest National Park in 1906, and other collections in the general area were made by S.W. Williston in 1914 and M. Mehl in 1914 and 1922. Gregory (1917) established the first stratigraphic divisions of the Chinle Formation. Numerous vertebrate fossil localities were discovered in the Chinle Formation by A. Montague, L. Kellogg, and C.L. Camp in Petrified Forest National Park during the 1920s. B. Brown continued collecting fossils in the Chinle in the 1930s, and these specimens were the basis for several publications by E. Colbert of the AMNH. Colbert worked in the Chinle in the Petrified Forest area during the 1940s before discovering the famous Coelophysis Quarry at Ghost Ranch, New Mexico. Researchers from the Museum of Northern Arizona were active in the Chinle Formation during the 1970s. During the 1980s, researchers from the UCMP worked in Petrified Forest National Park, collecting hundreds of specimens from the Chinle Formation.

Additional important stratigraphic research that has focused on late Paleozoic and Mesozoic rocks in central and southern Utah includes the work of Gregory (1950) on the geology and geography of the Zion Park Region in Utah and Arizona; Stewart et al. (1959) on the Triassic and associated formations of the Colorado Plateau; Repenning et al. (1969) on the stratigraphy of the Chinle and Moenkopi formations on Indian reservations in Arizona, 
New Mexico, and Utah; O'Sullivan (1970) on the upper part of the Chinle Formation and related rocks in southeastern Utah; Stewart et al. (1972) on the stratigraphy and origin of the Moenkopi Formation and related strata in the Colorado Plateau Region; and Condon (1997) on the geology of the Cutler Group and Kaibab Limestone on the Paradox Basin in southeastern Utah and southwestern Colorado.

\subsection{GEOLOGIC UNITS AND PALEONTOLOGICAL RESOURCES}

As discussed in Section 7.1, STSAs of central and southern Utah contain four mapped geologic units (Hackman and Wyant 1973; Hintze 2000; Williams 1972; Witkind 1995). These include, from oldest to youngest, and in approximate ascending stratigraphic order, the Upper Pennsylvanian and Lower Permian Cutler Group, the Upper Permian Kaibab Limestone, the Lower and Middle Triassic Moenkopi Formation, and the Upper Triassic Chinle Formation. On the basis of the geologic map review conducted for this study, older (and stratigraphically lower) and younger bedrock units are not anticipated to be affected by tar sands development. The four potentially affected bedrock geologic units are locally mantled by younger surficial deposits of Holocene and Pleistocene age, which consist of alluvium, colluvium, slope wash, and landslide deposits.

Within the San Rafael Swell STSA, tar sands are contained within the Black Dragon and Torrey members of the Moenkopi Formation. Within the Tar Sand Triangle, tar sands are contained primarily within the White Rim Sandstone Formation of the Cutler Group, with lesser amounts in permeable, stratigraphically adjacent rocks. Within the White Canyon STSA, tar sands are contained within the Hoskinnini Member of the Moenkopi Formation. Within the Circle Cliffs East and West Flanks STSA, tar sands are contained within the Kaibab Limestone, the Torrey Member of the Moenkopi Formation, and the Shinarump Member of the Chinle Formation. A stratigraphic nomenclature and correlation chart for Triassic-aged strata in southern Utah, northeastern Arizona, and northwestern New Mexico is provided in Figure 12. A diagrammatic stratigraphic column for the San Rafael Swell area in east-central Utah is provided in Figure 13.

In Sections 7.4.2 through 7.4.5 of this report, the geology and paleontology of the potentially affected geologic units within the STSAs in central and southern Utah are discussed, and their paleontological sensitivities are evaluated. Paleontological locality records for BLMadministered lands in Utah are on file at the BLM Utah State Office and are maintained in cooperation with the Utah State Geological Survey. Additional (and probably older) fossil locality records for tar sands-bearing rocks units are on file at major museums throughout the United States.

\subsubsection{Cutler Group}

The Cutler Formation is composed predominantly of thick, arkosic sandstone beds that were shed southwestward from the Uncompahgre uplift into the Paradox Basin of southeastern 


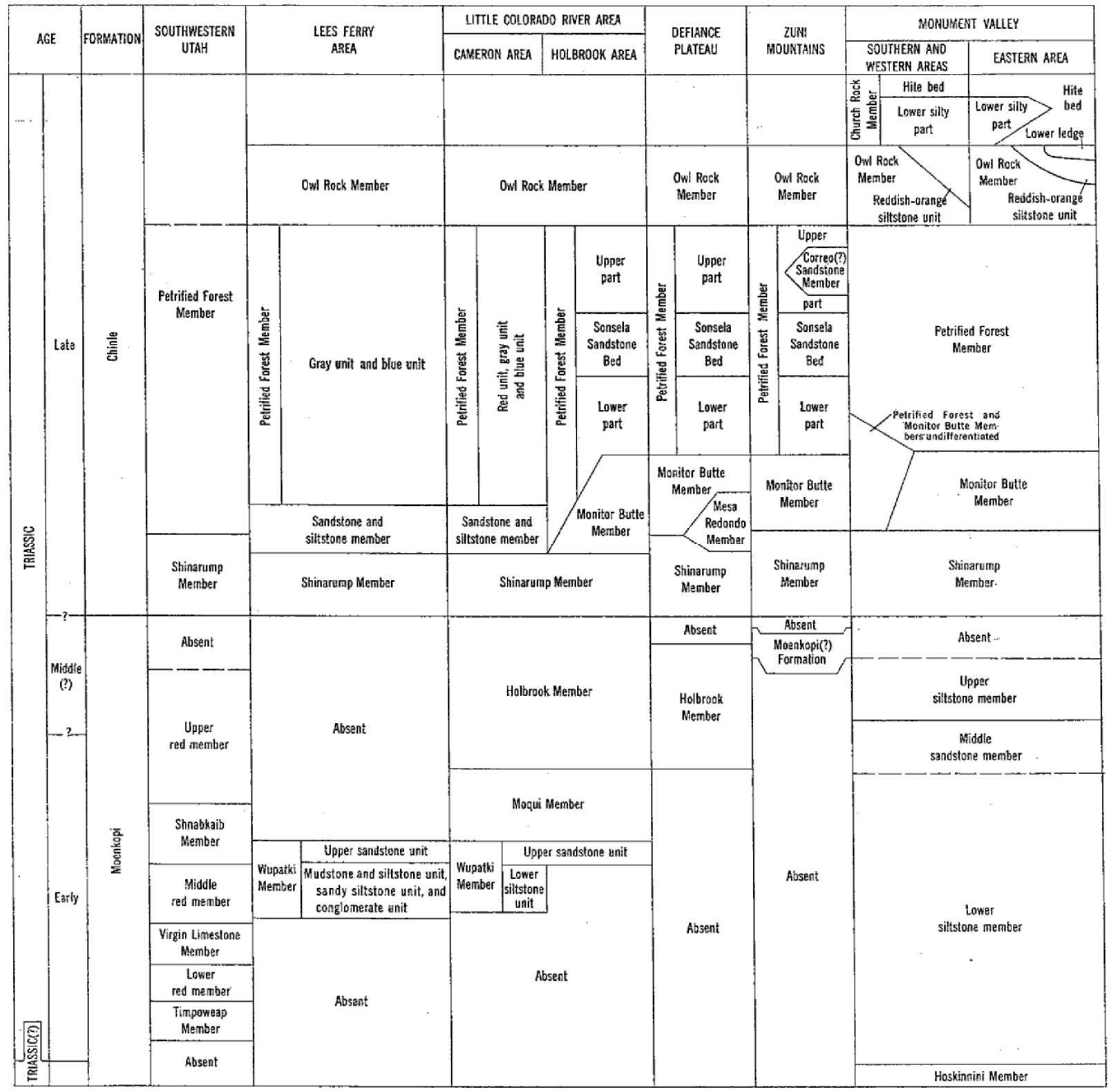

FIGURE 12 Stratigraphic Nomenclature and Correlation Chart of Triassic Strata in Southern Utah, Northeastern Arizona, and Northwestern New Mexico (Source: Repenning et al. 1969).

Utah and southwestern Colorado. In the southern and western parts of the basin, the Cutler Formation is recognized as a Group that has been divided into subunits on the basis of lithology (Condon 1997). In the eastern part of its distribution, on the western margin of the Uncompahgre uplift, the Cutler Formation is not divided into members or other subunits. Here it consists of a heterogeneous sequence of arkosic conglomerates with lesser amounts of arkosic sandstone, siltstone, and mudstone. Generally, the formation is dark red, purple, and maroon, with some greenish beds. Conglomerates are poorly sorted, with clasts ranging from sand size to 

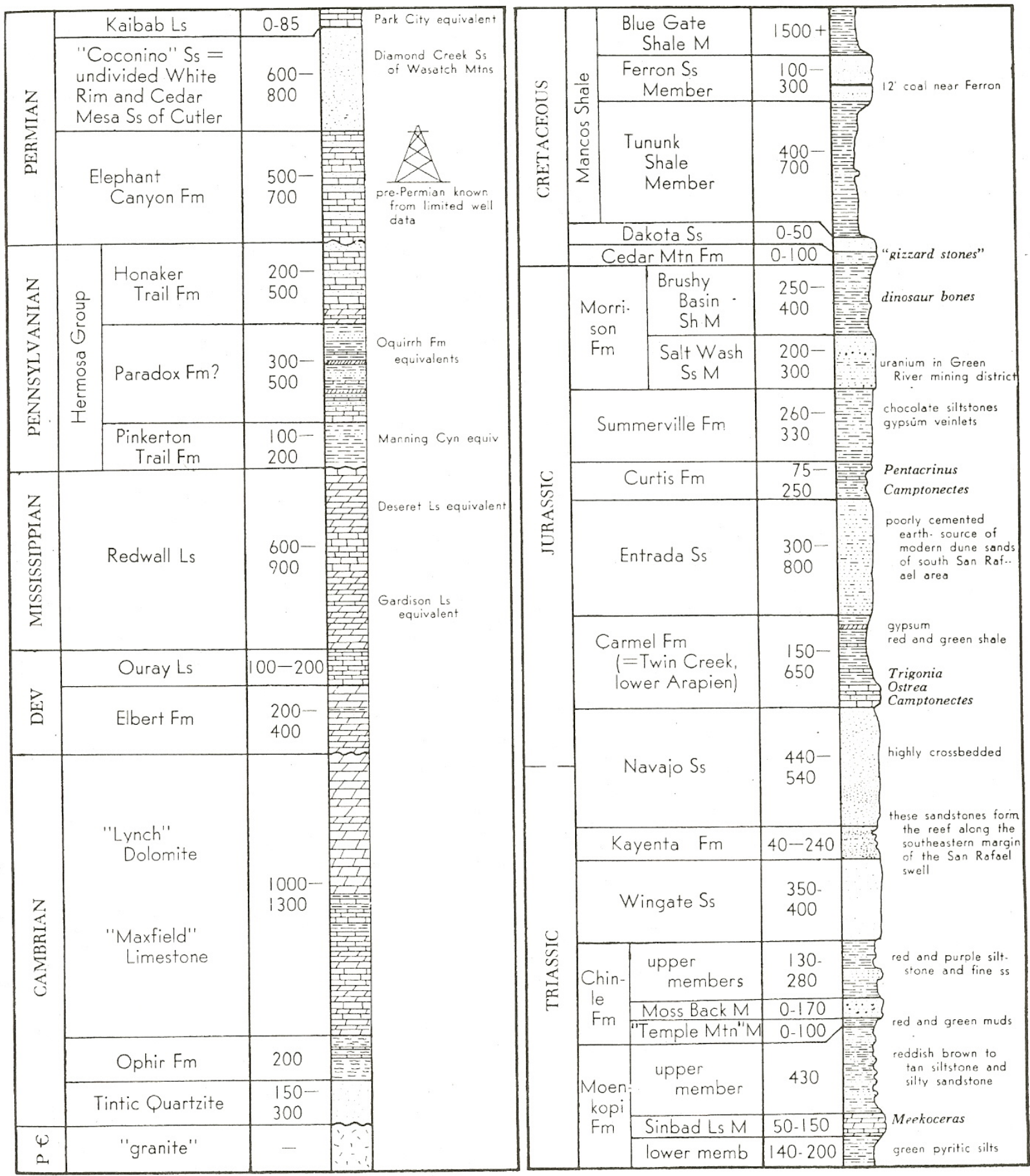

FIGURE 13 Stratigraphic Column for the San Rafael Swell Area, East-Central Utah (Source: Hintze 1973). 
boulders more than $25 \mathrm{ft}$ across (Shultz 1984). Salt tectonism played an important depositional role in some areas. In the northeast part of the Paradox Basin, as much as 15,000 ft of arkose was trapped between rising salt anticlines (Cutler Formation). The maximum thickness of the Cutler Group in the western and southern parts of the Paradox Basin is approximately 2,000 ft.

The Cutler Formation was named in 1905 by Whitman Cross for exposures along Cutler Creek, four miles north of Ouray, Colorado. The formations that comprise the Cutler Group were deposited in a complex system of alluvial, eolian, and marine environments and are characterized by abrupt vertical and lateral changes in lithologies (Condon 1997). The basal part of the Cutler Group is late Pennsylvanian in age, but most of the unit was deposited during the Permian. In much of the Paradox Basin in southeastern Utah and southwestern Colorado, the Cutler Group is conformably underlain by the Honaker Trail Formation of the Hermosa Group of Pennsylvanian age. In the western part of the Paradox Basin, the Cutler Group is unconformably overlain by the Kaibab Limestone. The Cutler Group or Kaibab limestone unconformably underlies the Lower Triassic Moenkopi Formation.

Like many rock units, the Cutler Group and its subunits have a complicated history of stratigraphic nomenclature due to an extensive area of outcrop, complex geometry, and diverse lithofacies. Baker and Reeside (1929) originally defined the units of the Cutler in southeastern Utah and introduced the stratigraphic terminology that is still mostly used today. From approximately lowest to highest, these units were named the Halgaito tongue, Cedar Mesa Sandstone Member, Organ Rock tongue, De Chelly Sandstone Member, White Rim Sandstone Member, and Hoskinnini tongue. The latter unit was later assigned as the basal unit of the Moenkopi Formation. Since that time, a large number of studies have focused on the Cutler Group and associated rocks, and knowledge of the age and stratigraphic relations of these rocks has been greatly refined. In a recent study by Condon (1997), the following lithostratigraphic units were recognized (1) a lower Cutler unit that contains part of the Elephant Canyon Formation of Baars (1962), the "lower Cutler beds" of Loope et al. (1990), the Rico Formation of some workers, and the Halgaito Formation; (2) the Cedar Mesa Sandstone; (3) the Organ Rock Formation; (4) the White Rim Sandstone; and (5) the De Chelly Sandstone. Where the Cutler Formation cannot be divided, it was named the Cutler Formation undivided. Figure 14 is a diagrammatic cross section showing the stratigraphic relationships and nomenclature for the Cutler Group in the Paradox Basin. The cross section extends from the San Rafael Swell in the west to the Uncompahgre uplift on the east; not all units listed above occur within this transect.

The White Rim Sandstone, which contains tar sands within the Tar Sand Triangle (Huntoon et al. 1999), is a large eolian sandstone that is present primarily west of the Colorado River in southeastern Utah. It forms a conspicuous white band along canyon rims. Locally, the Kaibab Limestone conformably overlies or grades into the White Rim Sandstone. Where the Kaibab Limestone is absent, the Moenkopi Formation unconformably overlies the White Rim Sandstone. Lithologically, typical exposures of the White Rim Sandstone consist of cliff-forming grayish-white to white, fine- to coarse-grained sandstone with large-scale, high-angle crossbeds and tabular beds. A major component of the unit is an eolian facies with high-angle crossbeds, wind-ripple laminae, and inversely graded laminae characteristic of eolian deposition. Transport directions were to the southeast and south-southwest (Steele 1987; Kamola and Chan 1988). 


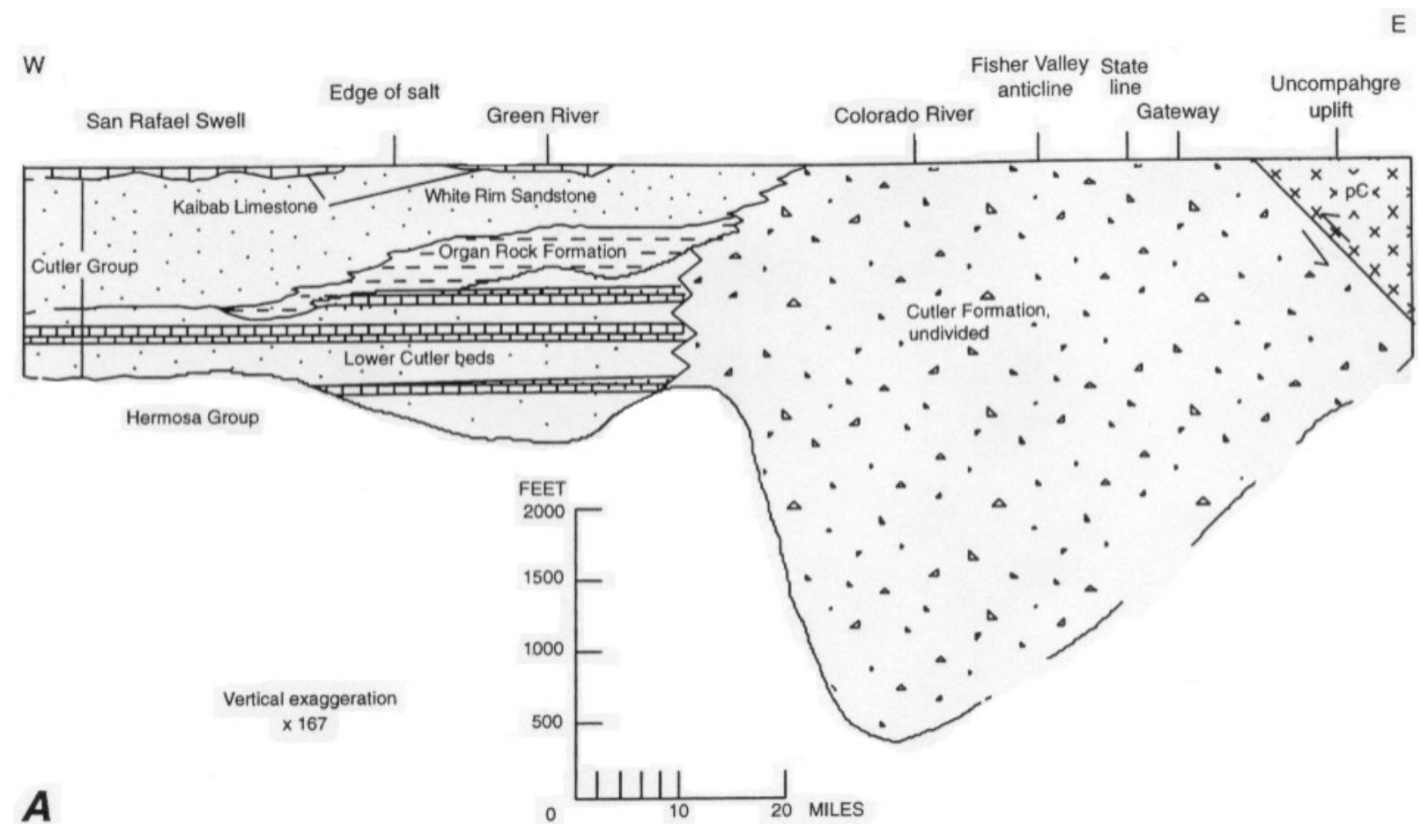

FIGURE 14 Cross Section Showing Stratigraphic Relationships and Nomenclature for the Cutler Group in the Paradox Basin (Source: Condon 1997) (The cross section extends from the San Rafael Swell [East-Central Utah] in the West to the Uncompahgre Uplift [Southwestern Colorado] on the East.)

Condon (1997) describes additional facies, sedimentological characteristics, and sedimentary features of the White Rim Sandstone.

The Cutler Group contains localized accumulations of vertebrate, plant, and invertebrate fossils and ichnofossils. The unit is important because it contains terrestrial vertebrate fossils of late Pennsylvanian and early Permian age, which are rare worldwide. The vast majority of fossilamphibians from the late Paleozoic of Utah come from the Cutler Group in the southeastern part of the state (Sumida et al. 1999a,b). The undivided Cutler Formation, as defined above, has produced a number of significant vertebrate fossils in southwestern Colorado (Lewis and Vaughn 1965). These include at least two genera of labyrinthodont amphibians, reptiles including four genera of cotylosaurs (now called captorhinids), and three genera of pelycosaurs. Previously considered to be of Permian age, the Halgaito Formation (Halgaito Shale) has now been shown to be of late Pennsylvanian age and has produced a diversity of vertebrate taxa, including fish, amphibians, and reptiles. The Cedar Mesa Sandstone has produced mostly tetrapod trackways; skeletal remains have been recovered from only one locality. The White Rim Sandstone has produced only invertebrate ichnofossils, including the shrimp burrow Ophiomorpha (Condon 1997). The Organ Rock Formation has produced a small but important assemblage of amniote fossils. The De Chelly Sandstone has produced no skeletal remains, but tetrapod trackways have been reported (Sumida et al. 1999b). In the Moab area, invertebrate and invertebrate ichnofossils of probable marine origin have been reported, but the member was not 
determined (Bilbey and Hall 2002). The Cutler Group has produced localized, low-diversity assemblages of taxonomically enigmatic primitive fossil plants, including Protoblechnum, Supaia, Taeniopteris, and Brongniart (Mamay and Breed 1970). Fossil sharks include Orthocanthus and Xenacanthus. Bony fishes include palaeoniscids, crossopterygians, and at least two genera of lungfish. Amphibians include aistopods, temnospondyls, anthracosaurs, and lepospondyls. Reptiles include diadectids, limnoscelids, captorhinids, and at least seven genera of pelycosaurs. It is likely that ongoing work in the Cutler Group will result in an increase in both the number of specimens recovered and the known diversity of the fossil fauna and flora.

On the basis of existing data for the Cutler Group, the Cutler Formation undivided, Halgaito Formation, and the Organ Rock Formation are designated as BLM Condition 2 and PFYC Class 3. The Cedar Mesa Sandstone, White Rim Sandstone, and De Chelly Sandstone are designated as BLM Condition 2 and PFYC Class 2. Future project-specific analyses of smaller geographic areas and more stratigraphically restricted intervals may necessitate a reevaluation and redesignation.

\subsubsection{Kaibab Limestone}

The Upper Permian Kaibab Limestone was named by Darton (1910). Marine in origin, the Kaibab Limestone composes one transgressive-regressive sequence of Permian-age (Leonardian) sediments, which were deposited in what is now southern Utah, southern Nevada, and northern Arizona (Cisne 1971; McKee 1938; Wagner 1932). In east-central and southeastern Utah, the limestone is exposed in the San Rafael Swell, Capitol Reef, and Circle Cliffs areas. Between these areas and outcrops of Permian-age rocks to the east along the Colorado River, the Kaibab Limestone either pinches out or grades laterally into the White Rim Sandstone Member of the Cutler Group. Throughout its distribution, the Kaibab Limestone unconformably underlies the Triassic-age Moenkopi Formation. At the San Rafael Swell and Circle Cliffs areas, the Kaibab Limestone overlies the Permian-age Coconino Sandstone (Stewart et al. 1959). In the Capitol Reef area, the Kaibab Limestone overlies the Pennsylvanian- and Permian-age Cutler Group. The Kaibab Limestone has also locally been referred to as the Black Box Dolomite (Condon 1997).

Gregory (1950) described five distinct subdivisions of the Kaibab Limestone but did not name them. Generally, the Kaibab is composed of yellowish-gray and light greenish-gray thinto-thick, horizontally bedded limestone and dolomite with interbedded sandstone, shale, gypsum, travertine, breccia, and conglomerate. The limestone and dolomite beds contain abundant interbeds and nodules of gray and brown chert (Stewart et al. 1959). Thick sets of yellowishgray, fine-grained, cross-bedded sandstone are locally interbedded with the limestone beds, and the limestone beds range in thickness from several inches to more than $20 \mathrm{ft}$. These sandstone beds have been interpreted as reworked White Rim Sandstone from the underlying Cutler Group. The Kaibab Limestone ranges in thickness from 0 to $360 \mathrm{ft}$. In the Circle Cliffs uplift, it is composed of thinly bedded, light-yellow dolomite containing geodes, chert nodules, and stringers of bedded chert. In this area, the underlying upper part of the White Rim Sandstone contains thin beds of fossiliferous dolomite, indicating a transgressive marine environment transitional to deposition of the Kaibab (Condon 1997). 
The Kaibab Limestone contains locally abundant marine invertebrate fossils throughout its distribution. The marine invertebrate fauna is diverse, including 5 genera of coral, 9 genera of bryozoans, 16 genera of brachiopods, 19 genera of bivalves, 1 genus of scaphopod, 10 genera of gastropods, 4 genera of cephalopods, 4 genera of trilobites, and 5 genera of conodonts (Cisne 1971; Gillette and Hayden 1997; Gregory 1950; Wagner 1932). Vertebrate fossils include only scattered unidentifiable fish scales and teeth.

On the basis of existing data, the Kaibab Limestone is designated as BLM Condition 3 and PFYC Class 2. Future project-specific analyses of smaller geographic areas and more stratigraphically restricted intervals may necessitate a reevaluation and redesignation, as would the discovery of identifiable vertebrate fossils in the unit.

\subsubsection{Moenkopi Formation}

The Lower and Middle Triassic Moenkopi Formation is a sequence of interfingering marine and continental deposits that accumulated in littoral marine, shoreline, deltaic, and fluvial environments during northwest-to-southeast transgressions and regressions of a shallow sea (Blakey 1973, 1974). The Moenkopi was named by Ward in 1901 for outcrops at the mouth of Moenkopi Wash in Cameron, Arizona (Morales 1987; Stewart et al. 1959). The name Moenkopi was first applied to southeastern Utah by Woodruff (1912) and Gregory $(1916,1917)$, but the strata to which these workers referred actually lie entirely above what is now recognized as the Moenkopi Formation. The miscorrelations of these and other early workers with regard to the stratigraphy of the Moenkopi and associated strata were corrected by Baker and Reeside (1929). The one exception was what Baker and Reeside (1929) referred to as the Hoskinnini tongue of the Cutler Formation. The Hoskinnini was assigned as the basal unit of the Moenkopi Formation (Stewart et al. 1959), but it was later elevated to formational rank by Blakey (1974). Not all workers have accepted the removal of the Hoskinnini Member from the Moenkopi Formation. Across most of its distribution, the Moenkopi Formation is unconformably underlain by the Kaibab Limestone or White Rim Sandstone Member of the Cutler Group and unconformably overlain by the Chinle Formation. The Moenkopi itself contains numerous unconformities. Thicknesses of the Moenkopi Formation range from more than 2,000 ft in the western part of its distribution (Morales 1987) to less than $100 \mathrm{ft}$ near the Colorado-Utah border (Stewart et al. 1972).

Terrestrial fossil-bearing sedimentary deposits of the Moenkopi Formation occur primarily in northern Arizona and southern Utah. Like many other rock units of the Colorado Plateau, the stratigraphic nomenclature of the Moenkopi varies regionally due to its complex geometry and facies relationships. This is illustrated in Figure 12 (which does not include the nomenclature for the Moenkopi Formation used by workers in southeastern Utah). Stewart et al. (1972) recognized six members of the Moenkopi Formation in southeastern Utah (including four informal members). These members, in ascending stratigraphic order, are the Hoskinnini, lower slope-forming, Sinbad Limestone, ledge-forming, upper slope-forming, and cliff-forming. The Hoskinnini Member consists of pale reddish-brown siltstone and very fine-grained sandstone with scattered coarser grains. The lower slope-forming member is composed of grayish-red, yellowish-gray, and light greenish-gray siltstone and sandy siltstone. The ledge-forming member 
consists of red siltstone and sandy siltstone or sandstone that weathers to form ledges as suggested by its name. The Sinbad Limestone Member is composed of gray limestone, which is marine in origin and pinches out to the east. The upper slope-forming member consists of grayish-red and pale reddish-brown siltstone. The cliff-forming member consists of pale reddishbrown and grayish-red siltstone with abundant ripple laminae (Stewart et al. 1972). Blakey's $(1973,1974)$ lowermost unit of the Moenkopi is the Black Dragon Member, and it is regarded as equivalent to the lower slope-forming member of Stewart et al. (1972). The Sinbad Limestone is recognized and was deemed equivalent by both workers. Blakey's $(1973,1974)$ Torrey Member is equivalent to the ledge-forming member and the lower part of the upper slope-forming member. Blakey's $(1973,1974)$ Moody Canyon Member is equivalent to the upper part of the upper slope-forming member and the cliff-forming member (Figure 15).

Three of the four STSAs discussed in this section of the report contain tar sands deposits within rocks of the Moenkopi Formation. The assignment of host members to tar sands-bearing rocks of the Moenkopi by the USGS (1980c,h,k) apparently used the stratigraphic terminology of both Blakey $(1973,1974)$ and Stewart et al. (1972) (Figure 15). Thus, tar sands are trapped in the Torrey Member at the Circle Cliffs East and West Flanks STSA, the Black Dragon and Torrey members at the San Rafael Swell STSA, and the Hoskinnini Member White Canyon STSA.

Although most vertebrate fossils discovered in rocks of the Moenkopi Formation were found in northern Arizona, important fossils have also been collected from this unit in southern Utah. Fossils from marine rocks of the Moenkopi are most abundant in limestone beds such as the Sinbad Limestone Member. These have produced a reasonably diverse invertebrate assemblage, including crustaceans, scaphopods, bivalves, gastropods, cephalopods, worms, echinoderms, conodonts, and one genus of brachiopod (Lingula) (Batten and Stokes 1986). Fish remains are also locally present in marine deposits of the Moenkopi. Fossils are generally less common in nearshore and terrestrial deposits. The flora of the Moenkopi is of fairly low diversity, consisting of only three genera. These include the giant horsetail Neocalamites, an unidentified filicophyte (fern), and the conifer Araucarioxylon. Fishes include the shark Hybodus, and bony fish including palaeoniscids, the crossopterygian genus Moenkopia, and unidentified lungfish teeth. Tetrapods from the Moenkopi include three temnospondyl amphibian genera: Paratosuchus, Eocyclotosaurus, and Hadrokkosaurus. Reptiles include the anapsid Procolophonia, a small lizard-like form traditionally believed by some workers to be ancestral to turtles, and diapsids including the enigmatic Anisodontosaurus, the rhynchosaur Ammorhynchus, the archosaur Arizonasaurus, and unidentified rauisuchians and poposaurs. Middle Triassic vertebrate faunas of the Moenkopi, as exemplified by the Holbrook Member in Northern Arizona (Morales 1987; Nesbitt and Angielczyk 2002, Nesbitt and Whatley 2004), contain a diverse assemblage of temnospondyl amphibians, poposaurs, basal archosaurs, rynchosaurs, and dicynodont therapsids (mammal-like reptiles). A highly diverse and locally well-preserved assemblage of ichnofossils has also been reported from many localities and levels of the Moenkopi. The fossil fauna and flora of the Moenkopi Formation was discussed in some detail by Stewart et al. (1972) and thoroughly reviewed by Morales (1987).

On the basis of existing data for southeastern Utah, all units of the Moenkopi Formation except for the Sinbad Limestone Member are designated as BLM Condition 2 and PFYC Class 3. 


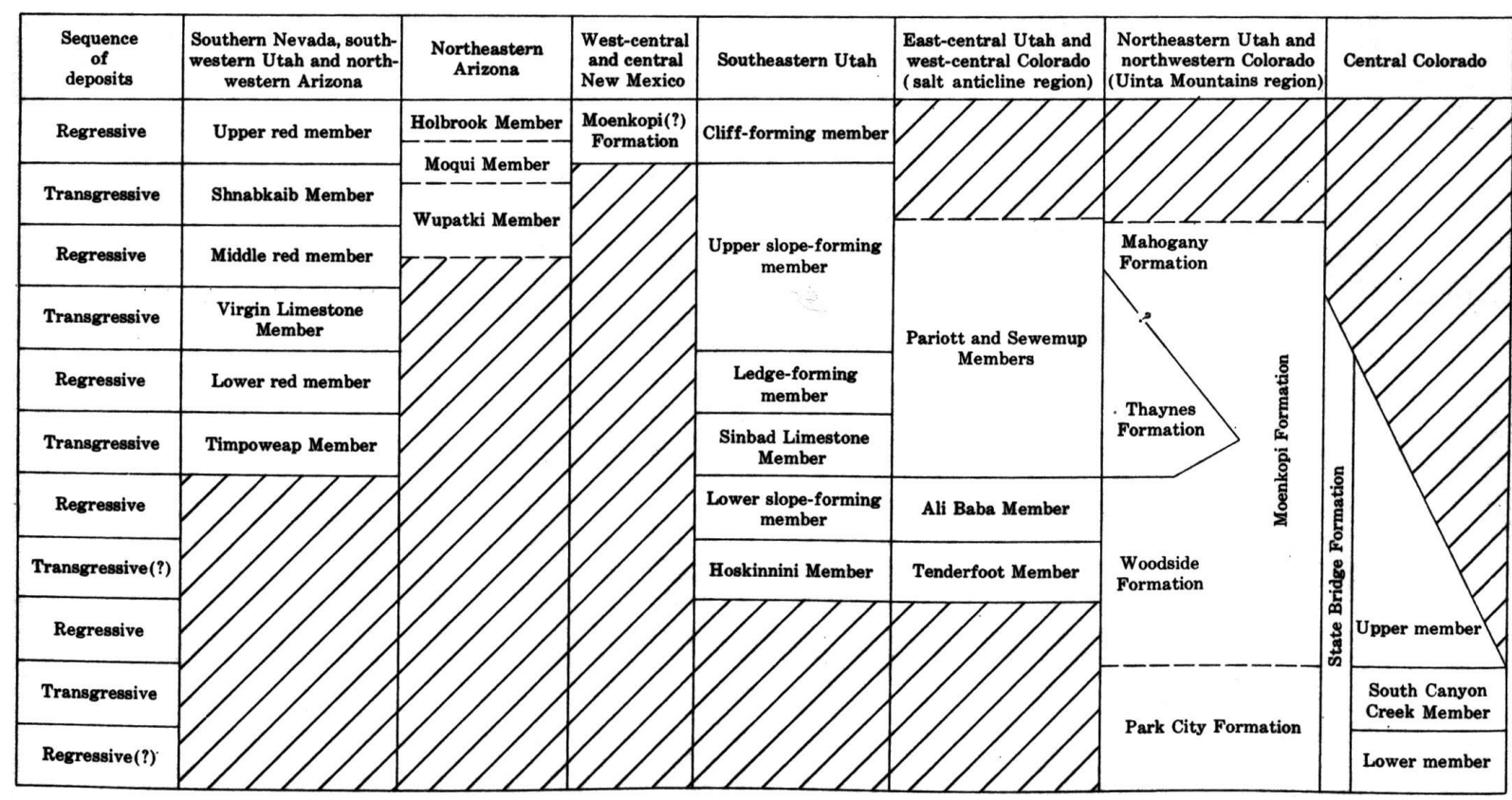

FIGURE 15 Stratigraphic Correlation Chart of Terrestrial Fossil-Bearing Units of the Moenkopi Formation (Source: Morales 1987).

This includes the Black Dragon, Torrey, and Moody Canyon members of Blakey $(1973,1974)$, and the lower slope-forming, ledge-forming, upper slope-forming, and cliff-forming members of Stewart et al. (1972). The Sinbad Limestone Member is designated as BLM Condition 3 and PFYC Class 2. Future project-specific analyses of smaller geographic areas and more stratigraphically restricted intervals may necessitate a reevaluation and redesignation.

\subsubsection{Chinle Formation}

The Upper Triassic Chinle Formation is predominantly fluvial in origin, with only minor amounts of lacustrine rocks. It was named by Gregory (1917) for exposures in the Chinle Valley in northeastern Arizona (Stewart et al. 1959). The Chinle Formation is one of the more conspicuous and well-known formations of the southwest, with its characteristic red beds, spectacular exposures in Arizona's Painted Desert, and the world-famous fossilized logs (and other fossils) of Petrified Forest National Park. The Chinle Formation outcrops throughout southeastern Utah and unconformably overlies the Moenkopi Formation. Where the Moenkopi Formation is absent in extreme east-central Utah, it unconformably overlies the Permian Cutler Group. The Chinle also contains several local intraformational unconformities. According to Stewart et al. (1959:500), the unconformity at the base of the Chinle is "the most conspicuous and widespread break in the sequence of the Permian and Triassic rocks and is marked by many channels that cut a few feet to several tens of feet into the Moenkopi surface."

Repenning et al. (1969) reported that this channelization of the Moenkopi surface actually has a relief of between 30 and $275 \mathrm{ft}$. The Chinle Formation is unconformably (and possibly locally conformably) overlain by the Wingate Sandstone. Typical lithologies of the Chinle Formation 
include variegated claystone, siltstone, sandstone, and conglomerate, with minor amounts of limestone and limestone-pebble conglomerate (Stewart et al. 1959). The Chinle Formation ranges in thickness from approximately 1,500 ft in the Zuni Mountains of Arizona to about $800 \mathrm{ft}$ near the Colorado and San Juan Rivers in southeastern Utah (Repenning et al. 1969).

Gregory (1917) established the first stratigraphic subdivisions of the Chinle Formation, which were called divisions D, C, B, and A, from lowest to highest. As first defined, the Chinle Formation did not include the underlying "Shinarump Conglomerate." In east-central and southeastern Utah and Arizona's Monument Valley, the Chinle Formation is presently divided into seven members. In ascending stratigraphic order, these are the Temple Mountain, Shinarump, Monitor Butte, Moss Back, Petrified Forest, Owl Rock, and Church Rock members (see Figure 12). The Temple Mountain Member is a thin unit that is restricted to the San Rafael Swell and composed largely of siltstone. The Shinarump and Moss Back members consist of widespread beds of sandstone and conglomerate. The Monitor Butte and Petrified Forest members are composed primarily of bentonitic claystone and clayey sandstone. The Monitor Butte Member contains lenticular sandstones. The Owl Rock and Church Rock members are primarily composed of reddish siltstone, although the Owl Rock Member contains minor amounts of limestone (Stewart et al. 1959). At most localities, the Shinarump and Moss Back members are lithologically distinctive. However, lithologic differences between the Monitor Butte, Petrified Forest, Owl Rock, and Church Rock members are slight at most localities, and locally these members are difficult to differentiate because they intertongue and intergrade. At the Circle Cliffs East and West Flanks STSA, tar sands are contained within the Shinarump Member of the Chinle Formation, which is the lowest member of the Chinle in this area (USGS 1980c).

The Chinle Formation has yielded a highly diverse late Triassic fossil fauna and flora, and the distribution and abundance of fossils within the Chinle has been commented on by a number of workers. According to Parrish (1999), although diverse and abundant vertebrate faunas have been discovered in Arizona and New Mexico, far fewer vertebrate fossils have been recovered from the Chinle in Utah. Parrish (1999) suggested that this is at least in part because in Utah, the Chinle tends to outcrop as vertical exposures instead of badlands, and inaccessibility has made it more difficult to prospect in many areas. Camp (1930) reported that the lower part of the Chinle (in Arizona) contains abundant wood and vertebrate remains, but that fossils are uncommon in the upper part of the Chinle (divisions A and B). O'Sullivan (1970) reported that fossils have been found throughout the Chinle Formation in southeastern Utah, including the Owl Rock Member in the upper part of the formation. Repenning et al. (1969) commented that vertebrate remains have been found in most places in the Chinle Formation in northeastern Arizona but are most common in the Petrified Forest Member. Colbert (1952) remarked that, with the exception of isolated fish scales and teeth, the almost all vertebrate fossils are from large animals, indicating a taphonomic bias against small animals. Foster et al. (2001) commented on the importance of the Chinle Formation because it contains some of North America's earliest dinosaurs.

The flora of the Chinle is diverse, featuring horsetails, lycopods, quillworts, 11 genera of primitive ferns, 2 genera of seed ferns, 16 genera of conifers, cycads, gingkos, and a number of unidentified taxa, as well as at least 16 forms of pollen (Ash 1972, 1978a,b,c, 2001, 2005). 
Coprolites have also been reported (Ash 1978d). Fossil invertebrates are locally abundant but are not taxonomically diverse in the Chinle, including only one genus of brachiopod and one genus of bivalve (Ash 2005). Fish fossils include at least 13 genera of sharks, palaeoniscids, semionotids, redfieldiids, colobontids, coelacanths, lungfish, and others (Ash 1978e: Parker 2005; Schaeffer and Dunkle 1950). Amphibians include the temnospodyls Buettneria, Apachesaurus, and Metoposaurus. Reptiles include an unidentified procolophonid and a diverse assemblage of archosauromorphs including Trilophosaurus, Rutiodon, Phytosaurus, Desmatosuchus, Coelophysis, and many others (Colbert 1952, 1972: Long and Padian 1986; Parker 2005). Mammal-like reptiles include an unidentified cynodont. Vertebrate and invertebrate ichnofossils including trackways have also been reported. Parker (2005) thoroughly reviewed the Chinle fauna, pointing out that it includes 18 vertebrate holotypes.

On the basis of existing data, all members of the Chinle Formation in southeastern Utah are designated as BLM Condition 2 and PFYC Class 4/5. Future project-specific analyses of smaller geographic areas and more stratigraphically restricted intervals may necessitate a reevaluation and redesignation.

\subsubsection{Pleistocene- and Holocene-Age Surficial Deposits}

Bedrock geologic units discussed in this section of the report are locally mantled by younger surficial deposits of Pleistocene and Holocene age. These consist of alluvium, colluvium, slope wash, and landslide deposits. Holocene-age alluvium is composed primarily of poorly consolidated silt, sand, and cobbles derived from eroded bedrock and older alluvial and colluvial deposits. These sediments are deposited by rivers and streams in stream channels and on active alluvial floodplains. Pleistocene-age alluvium consists of gravel, sand, silt, mud, and clay that forms alluvial terraces and isolated remnants on dissected benches along stream drainages. Colluvium, slope wash, and landslide deposits consist of rock material that has moved under the influence of gravity. Lithologies of these units vary and are dependent upon the type of source rock. They form on unstable slopes and on older colluvial deposits. In general, colluvium and landslide deposits are much less likely to contain well-preserved animal and plant remains than intact native sediments. Colluvium and landslide material are often subjected to increased groundwater percolation, which tends to have a negative effect on the preservation of organic material; gravitationally induced movement of sediment can also destroy animal and plant remains through abrasion and breakage. Additionally, when the original stratigraphic position of the sediments is disturbed, there are varying degrees of information loss with the severity of changes to the slide mass.

Surficial deposits of Holocene age contain the unfossilized remains of modern taxa and are too young to contain in situ fossils. Pleistocene-age surficial deposits, particularly alluvium, may contain mineralized or partially mineralized animal bones, invertebrates, and plant remains of paleontological significance. With the exception of some caves, hot springs, and tar deposits, these fossils typically occur in low density and usually consist of scattered and poorly preserved remains. The most common Pleistocene vertebrate fossils include the bones of mammoth, bison, deer, and small mammals, but other taxa, including horse, lion, cheetah, wolf, camel, antelope, peccary, mastodon, and giant ground sloth, have been reported from the Rocky Mountain region 
(Cook 1930, 1931; Emslie 1986; Gillette and Miller 1999; Gillette et al. 1999a,b; Heaton 1999; Hunt 1954; Lewis 1970; Scott 1963; Smith et al. 1999; unpublished paleontological data, Denver Museum of Nature and Science).

Generally, deposits of Holocene age contain the unfossilized remains of modern species of animals and plants, and are not considered paleontologically sensitive. These are designated as BLM Condition 3 and PFYC Class 2 in this analysis. There are few reports of Pleistocene-age fossils from southeastern Utah. Pleistocene-age surficial deposits in this area are designated as BLM Condition 2 and PFYC Class 2.

\subsection{PALEONTOLOGICAL RESOURCE ASSESSMENT SUMMARY}

As discussed in Section 7.4, surface disturbance associated with commercial tar sands development within the four STSAs located in east-central and southeastern Utah have the potential to impact four mapped bedrock geologic units, as well as a variety of surficial deposits (Hackman and Wyant 1973; Hintze 2000; Williams 1972; Witkind 1995). The paleontological sensitivities of these units were evaluated by using both the BLM system paleontological resource classification system (Conditions 1-3; BLM 1998) and the PFYC system developed by the USFS, which was recently adopted with modifications by the BLM (see Sections 3.1 and 3.2; BLM 2007). Resource assessment designations for each geologic unit discussed in Section 7.4 are summarized in Table 6 using both classification systems.

TABLE 6 Summary of Programmatic-Level Paleontological Sensitivities of Geologic Units within the STSAs Located in East-Central and Southeastern Utah

\begin{tabular}{|c|c|c|c|c|}
\hline Geologic Unit & Age & Typical Fossils & $\begin{array}{c}\text { BLM } \\
\text { Designation }\end{array}$ & $\begin{array}{c}\text { PFYC } \\
\text { Designation }\end{array}$ \\
\hline $\begin{array}{l}\text { Alluvium, colluvium, } \\
\text { slope wash, and } \\
\text { landslide deposits }\end{array}$ & Holocene & $\begin{array}{l}\text { None in deposits of Holocene } \\
\text { age unless reworked from } \\
\text { older sediments }\end{array}$ & Condition 3 & Class 2 \\
\hline $\begin{array}{l}\text { Alluvium, colluvium, } \\
\text { slope wash, and } \\
\text { landslide deposits }\end{array}$ & Pleistocene & $\begin{array}{l}\text { Scattered vertebrates, } \\
\text { invertebrates, and plants occur } \\
\text { locally }\end{array}$ & Condition 2 & Class 2 \\
\hline $\begin{array}{l}\text { Chinle Formation: } \\
\text { Temple Mountain, } \\
\text { Shinarump, Monitor } \\
\text { Butte, Moss Back, } \\
\text { Petrified Forest, Owl } \\
\text { Rock, and Church Rock } \\
\text { members }\end{array}$ & Upper Triassic & $\begin{array}{l}\text { Locally occurring vertebrates } \\
\text { (fishes, amphibians, and } \\
\text { reptiles), plants, and } \\
\text { invertebrates }\end{array}$ & Condition 2 & Class $4 / 5$ \\
\hline
\end{tabular}


TABLE 6 (Cont.)

\begin{tabular}{|c|c|c|c|c|}
\hline Geologic Unit & Age & Typical Fossils & $\begin{array}{c}\text { BLM } \\
\text { Designation } \\
\end{array}$ & $\begin{array}{c}\text { PFYC } \\
\text { Designation }\end{array}$ \\
\hline $\begin{array}{l}\text { Moenkopi Formation: } \\
\text { Black Dragon, and } \\
\text { Torrey, Moody Canyon } \\
\text { members }\end{array}$ & $\begin{array}{l}\text { Lower and } \\
\text { middle } \\
\text { Triassic }\end{array}$ & $\begin{array}{l}\text { Locally occurring vertebrates } \\
\text { (fishes, amphibians, and } \\
\text { reptiles), plants, and } \\
\text { invertebrates }\end{array}$ & Condition 2 & Class 3 \\
\hline $\begin{array}{l}\text { Moenkopi Formation: } \\
\text { Sinbad Limestone } \\
\text { Member }\end{array}$ & Lower Triassic & $\begin{array}{l}\text { Locally abundant marine } \\
\text { invertebrates }\end{array}$ & Condition 3 & Class 2 \\
\hline Kaibab Limestone & Upper Permian & $\begin{array}{l}\text { Locally abundant marine } \\
\text { invertebrates }\end{array}$ & Condition 3 & Class 2 \\
\hline $\begin{array}{l}\text { Cutler Group, Cutler } \\
\text { Formation undivided, } \\
\text { Halgaito Formation, } \\
\text { Organ Rock Formation }\end{array}$ & $\begin{array}{l}\text { Upper } \\
\text { Pennsylvanian } \\
\text { and Permian }\end{array}$ & $\begin{array}{l}\text { Locally occurring vertebrates } \\
\text { (fishes, amphibians, and } \\
\text { reptiles), plants, and } \\
\text { invertebrates }\end{array}$ & Condition 2 & Class 3 \\
\hline $\begin{array}{l}\text { Cutler Group, Cedar } \\
\text { Mesa Sandstone, White } \\
\text { Rim Sandstone, } \\
\text { De Chelly Sandstone }\end{array}$ & $\begin{array}{l}\text { Upper } \\
\text { Pennsylvanian } \\
\text { and Permian }\end{array}$ & $\begin{array}{l}\text { Uncommon vertebrate and } \\
\text { invertebrate ichnofossils }\end{array}$ & Condition 2 & Class 2 \\
\hline
\end{tabular}




\section{CONCLUSIONS AND RECOMMENDATIONS}

This report clearly demonstrates the paleontological and scientific significance of the study area for the Oil Shale and Tar Sands PEIS. At the formational level, each of the potentially affected bedrock geologic units is known to be fossiliferous. A total of 33 bedrock geologic formations and surficial deposits occur within the 4 geographic areas analyzed for this study, and most of these have been subdivided into members or other subunits. These fours areas, which include the greater Green River Basin in southwestern Wyoming and northwestern Colorado, the Piceance Creek Basin in northwestern Colorado, the Uinta Basin in northeastern Utah, and STSAs in east-central and southeastern Utah, have been studied by paleontologists for more than 135 years and have produced an estimated millions of fossil specimens from thousands of fossil localities. These fossils are currently housed in museums across the United States and throughout the world and have been the subject of enormous volumes of scientific research as exemplified by the bibliography in this report.

While the paleontological importance of the PEIS study area is well established based on past research, it is important to stress that the geologic formations within it, and the fossils they preserve, remain the focus of vigorous scientific inquiry. As fossils continue to be discovered by scientists working in the field, and the geologic context in which they were found is documented and analyzed, paleontological data are generated. Newly discovered fossils can be placed into two general categories: those taxa that have already been scientifically described and those are new to science. Both are vitally important to paleontological research. Augmentation of specimens of known taxa to paleontological collections greatly improves data sets by creating larger and more statistically valid samples. Newly discovered taxa increase the known taxonomic diversity of fossil assemblages. In both cases, vital evolutionary and paleoecological information contributes toward our understanding of the history and development of life. There is no doubt that future paleontological studies, aided by advancements in scientific methods and technologies, will be able to build upon existing data to test new hypotheses and help answer questions that we don't even know to ask at present. Importantly, this scientific process provides enormous educational opportunities at all levels.

In conclusion, depending upon the nature of the technology used and the extent of associated ground disturbance, in combination with the paleontological sensitivity of each affected geologic unit, commercial development of oil shale and tar sands could lead to the discovery of a vast number of scientifically significant fossils that would otherwise not have been available to science. Adverse impacts on these nonrenewable paleontological resources could be reduced to below the level of significance with carefully designed and properly implemented project-specific paleontological mitigation plans. Without mitigation, fossils uncovered by these ground-disturbing activities would be damaged or destroyed and associated contextual data lost, rendering them permanently unavailable for scientific research.

On the basis of the results of this study, the following programmatic recommendations are made: 
1. Geologic maps, including the large-scale paleontological sensitivity maps prepared for this report, reflect the distribution of geologic units at the surface within the study area. Commercial activities associated with development of oil shale and tar sands resources will also impact subsurface geologic units whose distribution is not mapped geologically. These impacts should be addressed on a project-specific basis.

2. A paleontological locality search of the PEIS study area was outside of the scope of this investigation. However, a thorough locality search should be conducted as a supplement to it. An inventory of previously recorded fossil localities within the PEIS study area would be useful for two reasons. First, it would allow land managers to identify specific sites that should be avoided, protected, monitored, excavated, and/or otherwise mitigated. Second, the density of fossil localities in a given geographic area and/or stratigraphic interval could be used as a quantitative measure of paleontological sensitivity. This is particularly true for areas and stratigraphic intervals that have already been systematically prospected. The locality search should include major regional and national museums, BLM state and field offices, and other pertinent state and federal agencies. Locality data should be organized in a confidential supplementary report and individual localities plotted on 7.5-minute topographic quadrangle maps (preferably digitized within a geographic information system [GIS]). The results of this search should also specifically identify areas of special paleontological concern such as localities with historical significance, interpretive sites, and/or those that have yielded fossils of particular scientific importance. In combination with this report, these locality data can then be used by BLM regional paleontologists and field office personnel in order to assist with project-specific analyses.

3. Project-specific analyses, including decisions regarding mitigation and other resource management issues, should be conducted in accordance with current BLM paleontological resource policies and guidelines. It is recommended that paleontological resource evaluations be based on the PFYC system, which the BLM has adopted through Instruction Memorandum No. 2008-009 (BLM 2007). Both the PFYC and the BLM Conditions 1-3 classification system (BLM 1998) were used in this report (see Chapter 3).

4. This study is intended to provide a baseline upon which more detailed analyses can build as the potential impacts on paleontological resources by commercial leasing and development of oil shale and tar sands become better understood. New data, such as the discovery of significant fossil remains in a formation and/or geographic area that was previously thought to be unfossiliferous, or the absence of fossils in a formation and/or geographic area that was previously believed to contain a high density of fossil remains (to cite just two examples), should be incorporated and considered in all future analyses. 
5. As technologies for the extraction of hydrocarbon resources from oil shale and tar sands are developed, it will become possible to design and test paleontological mitigation methods for their effectiveness both in terms of cost and resource preservation. However, without knowledge of the specific technologies that might be used, it is difficult to attempt to qualify or quantify direct impacts on paleontological resources. For example, strip mining of a fossiliferous rock unit such as the Parachute Creek Member of the Green River Formation in northwestern Colorado would unquestionably destroy large numbers of fossils unless they were salvaged by a paleontological monitor, and this monitoring could be designed to lower the adverse impacts to a less than significant level. On the other hand, drilling into the Parachute Creek Member of the Green River Formation would probably destroy some fossils, but adverse impacts would be far less than those resulting from strip mining because a much smaller geographic area would be affected. Furthermore, because of the nature of drilling, it is unlikely that it would be possible to quantify the impacts on paleontological resources because these impacts would occur underground and would, thus, be unobservable. In this case, paleontological monitoring would likely be pointless because salvage would not be feasible. It is recommended that a testing program be designed and implemented in order to determine quantitative and qualitative adverse impacts on paleontological resources. The purpose of this program would be to develop the most efficient and cost-effective mitigation strategies for reducing these impacts to below the level of significance. It should focus on members or other subunits of the Green River Formation that have been designated by the BLM as Condition 1 or 2, or PFYC Class 5.

6. In conjunction with other project-specific analyses, land managers should be encouraged to consult with paleontological researchers working locally in potentially affected geographic areas and rock units. These paleontologists can provide invaluable information and insights that should be taken into account when considering alternative actions and developing mitigation strategies. 


\section{REFERENCES}

Alexander, J.P. and B.J. Burger, 2001, Stratigraphy and taphonomy of Grizzly Buttes, Bridger Formation, and the middle Eocene of Wyoming; Eocene biodiversity; unusual occurrences and rarely sampled habitats: Topics in Geobiology, 18:165-196.

Anderson, D.W. and M.D. Picard, 1972, Stratigraphy of the Duchesne River Formation (EoceneOligocene), northern Uinta Basin, Northwestern Utah: Bulletin of the Utah Geological Mineralogical Survey, 97:1-29.

Archibald, J.D., 1987, Late Cretaceous (Judithian and Edmontonian) vertebrates and geology of the Williams Fork Formation, NW Colorado: Occasional Paper of the Tyrrell Museum of Palaeontology, 3:7-11.

Armstrong, H.J. and D.G. Wolny, 1989, Paleontological resources of Northwest Colorado: A regional analysis: Museum of Western Colorado, Grand Junction.

Armstrong, H.J. and S.G. Baker, 1985, A monitor and mitigation report for paleontological resources at the Chandler Locality (5 RB 2695), Rio Blanco County, Colorado: Unpublished Technical Report Prepared for the Colorado BLM.

Ash, S.R., 1972, Plant megafossil of the Chinle Formation. Museum of Northern Arizona Bulletin, 47:23-43.

Ash, S.R., 1978a, Geology, paleontology, and paleoecology of a Late Triassic lake, western New Mexico: Brigham Young University Research Studies, Geology Series, 25, Part 2:100 pp.

Ash, S.R., 1978b, Summary of the fossils in the Ciniza Lake Beds; Geology, paleontology, and paleoecology of a Late Triassic lake, western New Mexico: Brigham Young University Research Studies, Geology Series, 25, Part 2:21-22.

Ash, S.R., 1978c, Plant megafossils; Geology, paleontology, and paleoecology of a Late Triassic lake, western New Mexico: Brigham Young University Research Studies, Geology Series, 25, Part 2:23-43.

Ash, S.R., 1978d, Coprolites; Geology, paleontology, and paleoecology of a Late Triassic lake, western New Mexico: Brigham Young University Research Studies, Geology Series, 25, Part 2:69-73.

Ash, S.R., 1978e, Fish scales; Geology, paleontology, and paleoecology of a Late Triassic lake, western New Mexico: Brigham Young University Research Studies, Geology Series, 25, Part 2:67-68.

Ash, S.R., 2001, New cycadophytes from the Upper Triassic Chinle Formation of the Southwestern United States: PaleoBios, 21(1):15-28. 
Ash, S.R., 2005, A new Upper Triassic flora and associated invertebrate fossils from the basal beds of the Chinle Formation, near Cameron, Arizona: PaleoBios, 25(1):17-34.

Baars, D.L., 1962, Permian system of the Colorado Plateau: American Association of Petroleum Geologists Bulletin, v. 46, no. 2, pp. 149-218.

Baker, A.A., and Reeside, J.B., 1929, Correlation of the Permian of southern Utah, northern Arizona, and northwestern New Mexico, and southwestern Colorado: American Association of Petroleum Geologists Bulletin, v. 13, pp. 1413-1448.

Batten, R.L. and W.L. Stokes, 1986, Early Triassic gastropods from the Sinbad Member of the Moenkopi Formation, San Rafael Swell, Utah: American Museum Novitates, 2864:33 pp.

Beard, K.C., 1998, East of Eden; Asia as an important center of taxonomic origination in mammalian evolution; Dawn of the age of mammals in Asia: Symposium on Dawn of the age of mammals in Asia, Pittsburgh, PA, United States, Nov. 1, 1995, 34:5-39.

Bilbey, S.A. and E. Hall, 2002, Final paleontological report for the Rocky Mountain Expansion Loop Pipeline, Utah, Colorado and New Mexico: Unpublished technical report submitted to Williams Energy Co. and the Bureau of Land Management, Utah, Colorado and New Mexico, 126 pp.

Black, C.C. and M.R. Dawson, 1966, A review of late Eocene mammalian fauna from North America: American Journal of Science, 264:321-349.

Blakey, R.C., 1973, Stratigraphy, depositional environments, and economic geology of the Moenkopi Formation, southeastern Utah: Unpublished Ph.D. dissertation, University of Iowa, Iowa City, $269 \mathrm{pp}$.

Blakey, R.C., 1974, Stratigraphic depositional analysis of the Moenkopi Formation, southeastern Utah: Utah Geological and Mineralogical Survey, Bulletin, 104:1-81.

BLM (U.S. Bureau of Land Management), 1984, Utah combined hydrocarbon leasing EIS: Bureau of Land Management, Salt Lake City, UT.

BLM, 1997, White River: Record of Decision and Approved Resource Management Plan (July). Available at: http://www.co.blm.gov/nepa/rmpdocs/wrfodocs/White_River/Wrrr/Wrrr.pdf.

BLM, 1998, Paleontology Resources Management Manual, 8270, 12 pp., and Handbook, H-8270-1, 38 pp.

BLM, 2007, Instruction Memorandum No. 2008-009, Subject: "Potential Fossil Yield Classification (PFYC) System for Paleontological Resources on Public Lands," Washington, D.C., Oct. 15. 
Bradley, W.H., 1926a, Fossil rhizopods of the Green River oil shale: Geological Society of America Bulletin, 37(1):160 pp.

Bradley, W.H., 1926b, Shore fazes of the Green River Formation in northern Sweetwater County, Wyoming: U.S. Geological Survey Professional Paper 140-D:121-131.

Bradley, W.H., 1929, The varves and climate of the Green River epoch: U.S. Geological Survey Professional Paper 158-E:87-110.

Bradley, W.H., 1931, Origin and microfossils of the Green River Formation of Colorado and Utah: U.S. Geological Survey Professional Paper 168:58 pp.

Bradley, W.H., 1945, Geology of the Washakie Basin, Sweetwater and Carbon counties, Wyoming, and Moffat County, Colorado: U.S. Geological Survey Oil and Gas Investigations Map OM-0032, 1 Sheet.

Bradley, W.H., 1959, Revision of stratigraphic nomenclature of Green River Formation of Wyoming: American Association of Petroleum Geologists Bulletin, 43(5):1072-1075.

Bradley, W.H., 1961, Geologic map of a part of Southwestern Wyoming and adjacent states: U.S. Geological Survey Miscellaneous Investigations Series, 1 Sheet (Scale 1:250,000).

Bradley, W.H., 1962, Chloroplast in Spirogyra from the Green River Formation of Wyoming: American Journal of Science, 260(6):455-459.

Bradley, W.H., 1964a, Geology of Green River Formation and associated Eocene rocks in southwestern Wyoming and adjacent parts of Colorado and Utah: U.S. Geological Survey Professional Paper 496-A:1-86 pp.

Bradley, W.H., 1964b, Aquatic fungi from the Green River Formation of Wyoming: American Journal of Science, 262(3):413-416.

Bradley, W.H., 1969, Geochemistry and paleolimnology of the trona deposits and associated authigenic minerals of the Green River Formation of Wyoming: U.S. Geological Survey Professional Paper 496-B:71 pp.

Brand, L.R., H.T. Goodwin, P.D. Ambrose, and H.P. Buchheim, 2000, Taphonomy of turtles in the Middle Eocene Bridger Formation: Palaeogeography, Palaeoclimatology, Palaeoecology, 162:171-189.

Brand, L., P.C. Murphey, J.E. Haessig, and A.A. Smith, 2007a, Bedrock Geologic Map of the Linwood Canyon 7.5' Quadrangle, Sweetwater County, Wyoming: Wyoming State Geological Survey Open File Map, 1 Sheet (Scale 1:24,000). 
Brand, L., P.C. Murphey, J.E. Haessig and A.A. Smith, 2007b, Bedrock Geologic Map of the Antelope Wash 7.5' Quadrangle, Sweetwater County, Wyoming: Wyoming State Geological Survey Open File Map. 1, Sheet (Scale 1:24,000).

Brodkorb, P., 1965, New taxa of fossil birds: Florida Scientist, 28(2):197-198.

Brodkorb, P., 1970, An Eocene puffbird from Wyoming: Contributions to Geology, 9(1):13-15.

Bryant, B., C.W. Naeser, R.F. Marvin, and H.H. Mehnert, 1989, Upper Cretaceous and Paleogene sedimentary rocks and isotopic ages of Paleogene tuffs, Uinta Basin, Utah: U.S. Geological Survey Bulletin, 1787-J:22 pp.

Bryant, B.H., 1992, Geologic and structure maps of the Salt Lake City 1 degrees $\times 2$ degrees Quadrangle, Utah and Wyoming: U.S. Geological Survey Miscellaneous Investigations Series I-1997, 3 Sheets (Scale 1:125,000).

Buchheim, H.P., 1994, Paleoenvironments, lithofacies, and varves of the Fossil Butte Member of the Eocene Green River Formation, Southwestern Wyoming: Contributions to Geology, University of Wyoming, 30(1):3-14.

Buchheim, H.P. and R.C. Surdam, 1981, Paleoenvironments and fossil fishes of the Laney Member, Green River Formation, Wyoming, In: Communities of the Past (J. Gray, eds.), Hutchinson and Ross Publishing Company, PA, 415-452.

Buchheim, H.P., L.R. Brand, and H.T. Goodwin, 2000, Lacustrine to fluvial floodplain deposition in the Eocene Bridger Formation: Palaeogeography, Palaeoclimatology, Palaeoecology, 162:191-209.

Camp, C.L., 1930, A study of the phytosaurs with description of new material from western North America: California University Memoir, 10:174 pp.

Carroll, R.L., 1988, Vertebrate Paleontology and Evolution: W.H. Freeman and Company, $698 \mathrm{pp}$.

Carvalho, M., L. Grande, and J. Maisey, 2003, The evolution of stingrays (Chondrichthyes, Myliobatiformes), with special reference to the freshwater stingrays of the Green River Formation of Wyoming (early Eocene): Abstracts, Sixty-third annual meeting, Society of Vertebrate Paleontology, Science Museum of Minnesota, Saint Paul, MN, United States, Oct. 15-18, 2003, 23(3, Suppl.):39 pp.

Cashion, W.B., 1967, Geology and fuel resources of the Green River Formation, southeastern Uinta Basin Utah and Colorado: U.S. Geological Survey Professional Paper 548:48 pp.

Cashion, W.B., 1973, Geologic and structure map of the Grand Junction Quadrangle, Colorado and Utah: U.S. Geological Survey Miscellaneous Investigations Series I-0736, 1 Sheet (Scale 1:250,000). 
Cashion, W.B., 1974, Geologic map of the Southam Canyon Quadrangle, Uintah County, Utah: U.S. Geological Survey Miscellaneous Field Studies Map MF-0579, 1 Sheet (Scale 1:24,000).

Cashion, W.B., 1977, Geologic map of the Weaver Ridge Quadrangle, Uintah County, Utah, and Rio Blanco County, Colorado: U.S. Geological Survey Miscellaneous Field Studies Map MF-0824, 1 Sheet (Scale 1:24,000).

Cashion, W.B., 1982, Descriptions of Four Stratigraphic Sections of Parts of the Green River and Uinta Formations in the Eastern Uinta Basin, Uintah County, Utah, and Rio Blanco Count, Colorado: Open-File Report 83-17, U.S. Geological Survey:42 pp.

Cashion, W.B., 1986, Geologic map of the Bonanza Quadrangle, Uintah County, Utah: U.S. Geological Survey Miscellaneous Field Studies Map MF-1865 (Scale 1:24,000).

Cashion, W.B. and J.R. Donnell, 1974, Revision of nomenclature of the upper part of the Green River Formation, Piceance Creek Basin, Colorado, and eastern Uinta Basin, Utah: U.S. Geological Survey Bulletin, 1394-G:G1-G9.

Chadey, H.F., 1973, Historical Aspects of the Green River Basin, Wyoming: Wyoming Geological Association, 25th Field Conference on the geology and mineral resources of the greater Green River Basin, Wyoming:27-33.

Cisne, J.L., 1971, Paleoecology of trilobites of the Kaibab limestone (Permian) in Arizona, Utah, and Nevada: Journal of Paleontology, 45(3):525-533.

Codington, L.A., 1992a, Fossil spider web from the Eocene of western Colorado: 124th annual meeting of the Kansas Academy of Science, Hutchinson, KS, United States, March 26-27, 1992, 11:6.

Codington, L.A., 1992b, Fossil spider web from the Eocene of western Colorado: Geological Society of America, 1992 annual meeting, Cincinnati, OH, United States, Oct. 26-29, 1992, 24(7):344 pp.

Codington, L.A., 1993a, Climatic implications of terrestrial arthropods from the Parachute Creek Member (middle Eocene), Green River Formation, Garfield County, Colorado: Fort Hays State University, Hays, KS, United States (USA) Master's.

Codington, L.A., 1993b, New locality for fossil insects in the Green River Formation, western Colorado: The Compass, 70(3):90-91.

Colbert, E.H., 1952, A pseudosuchian reptile from Arizona: Bulletin of the American Museum of Natural History, 99:561-592.

Colbert, E.H., 1972, Vertebrates from the Chinle Formation; Investigations in the Triassic Chinle Formation: Museum of Northern Arizona Bulletin, 47:1-11. 
Cole, R.D. and M.D. Picard, 1978, Comparative mineralogy of nearshore and offshore lacustrine lithofacies, Parachute Creek Member of the Green River Formation, Piceance Creek Basin, Colorado, and eastern Uinta Basin, Utah: Geological Society of America Bulletin, 89:1441-1454.

Comstock, T.B., 1875, Geological report: In: Jones, W.A., Report upon the reconnaissance of northwestern Wyoming, including Yellowstone National Park, for 1873 (2nd ed.): U.S. Cong., 43rd, 1st sass., House of Representatives Executive Doc. 285, pp. 85-292 (1st ed., pp. 85-184, 1874).

Condon, S.M., 1997, Geology of the Pennsylvanian and Permian Cutler Group and Permian Kaibab Limestone in the Paradox Basin, southeastern Utah and southwestern Colorado: U.S. Geological Survey Bulletin, B 2000-P:P1-P46.

Cook, H.J., 1930, Occurrence of mammoth and giant bison in glacial moraines in the high mountains of Colorado: Science, 72, no. 1885:68 pp.

Cook, H.J., 1931, More evidence of mammoths in the high mountains of Colorado: Science, 73, no. 1889:283-284.

Cope, E.D., 1872, Descriptions of some new Vertebrata from the Bridger Group of the Eocene: Proceedings of the American Philosophical Society, 12:460-465.

Cope, E.D., 1873, On the extinct Vertebrata of the Eocene of Wyoming, observed by the expedition of 1872, with notes on the geology, In: Sixth Annual Report of the United States Geological Survey of the Territories for 1872 (F.V. Hayden, ed.), pp. 545-649.

Cope, E.D., 1877, On a Dinosaurian from the Trias of Utah: Proceedings of the American Philosophical Society, 16:579-587.

Cope, E.D., 1884, Vertebrata of the Tertiary Formations of the West: Report of the U.S. Geological Survey of the Territories, Vol. 3.

Courtright, T.R. and W.A. Braddock, 1989, Geologic map of the Table Mountain Quadrangle and adjacent parts of the Round Butte and Buckeye quadrangles, Larimer County, Colorado and Laramie County, Wyoming: U.S. Geological Survey Miscellaneous Investigations Series I-1805, 1 Sheet (Scale 1:24,000).

Covert, H.H., P. Robinson, and J.R. Harris, 1998, Evidence for two lineages of Notharctus during the Bridger C and D: Journal of Vertebrate Paleontology, Supplement to 18:3.

Dane, C.H., 1954, Stratigraphic and facies relationships of upper part of Green River Formation and lower part of Uinta Formation in Duchesne, Uintah, Wasatch Counties, Utah: American Association of Petroleum Geologists Bulletin, 38:405-425.

Darton, N.H., 1910, A reconnaissance of parts of northwestern New Mexico and northern Arizona: U.S. Geological Survey Bulletin, 435:88 pp. 
Davis, P.G. and D.E.G. Briggs, 1998, The impact of decay and disarticulation on the preservation of fossil birds: Palaios, 13(1):3-13.

Dawson, M.R., 1968, Middle Eocene rodents (Mammalia) from northeastern Utah: Annals of Carnegie Museum, 39:327-370.

DeMar, D.G. and B.H. Breithaupt, 2006, The nonmammalian vertebrate microfossil assemblages of the Mesaverde Formation (Upper Cretaceous, Campanian) of the Wind River and Bighorn Basins, Wyoming, In: Late Cretaceous Vertebrates from the Western Interior (S.G. Lucas and R.M. Sullivan, eds.), New Mexico Museum of Natural History and Science Bulletin, 35:33-54.

Doi, K., 1990, Geology, and paleontology of two primate families of the Raven Ridge, northwestern Colorado and northeastern Utah: University of Colorado, Boulder, CO, United States (USA) Master's Thesis.

Donnell, J.R., 1961, Tertiary geology and oil-shale resources of the Piceance Creek Basin between the Colorado and White Rivers, northwest Colorado: U.S. Geological Survey Bulletin, 1082-L:835-891.

Donnell, J.R., 1964, Geology and oil-shale resources of the Green River Formation; First symposium on oil shale: Quarterly of the Colorado School of Mines, 59(3):153-163.

Dorr, J.A., Jr. and P.D. Gingerich, 1980, Early Cenozoic mammalian paleontology, geologic structure, and tectonic history in the overthrust belt near LaBarge, western Wyoming: Contributions to Geology, University of Wyoming, 18(2):101-115.

Douglass, E., 1914, Geology of the Uinta Formation: Geological Society of America Bulletin:417-420.

Dover, J.H. and J.W. McGonigle, 1993, Geologic map of the Evanston 30' × 60' Quadrangle, Uinta and Sweetwater counties, Wyoming: U.S. Geological Survey Miscellaneous Investigations Series I-2168, 1 Sheet (Scale 1:100,000).

Duncan, D.C., 1976, Preliminary geologic map of Yankee Gulch Quadrangle, Rio Blanco County, Colorado: U.S. Geological Survey Miscellaneous Field Studies Map MF-758, 1 Sheet (Scale 1:24,000).

Duncan, D.C., W.J. Hail, Jr., R.B. O’Sullivan, and G.N. Pipiringos, 1974, Four newly named tongues of the Eocene Green River Formation, northern Piceance Creek Basin, Colorado: U.S. Geological Survey Bulletin, 1394-F:F1-F13.

Dyni, J.R., 1981, Geology of the nahcolite deposits and associated oil shales of the Green River Formation in the Piceance Creek basin, Colorado: University of Colorado, Boulder, CO, United States (USA) Doctoral Dissertation. 
Ellis, M.S. and V.L. Freeman, 1984, Geologic map and cross sections of the Carbondale 30' $\times$ 60' Quadrangle, west-central Colorado: U.S. Geological Survey Coal Investigations Map $C$-0097-A, 1 Sheet (Scale 1:100,000).

Ellis, M.S. and V. Gabaldo, 1989, Geologic map and cross sections of parts of the Grand Junction and Delta 30' $\times$ 60' quadrangles, west-central Colorado: U.S. Geological Survey Coal Investigations Map C-0124, 1 Sheet (Scale 1:100,000).

Emslie, S.D., 1986, Late Pleistocene vertebrates from Gunnison County, Colorado: Journal of Paleontology, 60:170-176.

Evanoff, E., P. Robinson, P.C. Murphey, D. Kron, and D. Engard, 1994, An early Uintan fauna from the Bridger "E": Journal of Vertebrate Paleontology, Supplement to Vol. 13, No. 3.

Evanoff, E., P.C. Murphey, and L.R. Brand, 1998, Widespread stratigraphic marker units and subdivisions of Bridger B through D (middle Eocene), southwest Wyoming: Journal of Vertebrate Paleontology, Abstracts with Programs.

Evanoff, E., P.C. Murphey, J.E. Haessig, A.A. Smith, and N. Matthews, 2007, Bedrock geologic map of the Reed Reservoir 7.5' Quadrangle, Sweetwater County, Wyoming: Wyoming State Geological Survey Open File Map, 1 Sheet (Scale 1:24,000).

Fisher, E.J., C.E. Erdman, and J.B. Reeside, Jr., 1960, Cretaceous and Tertiary Formations of the Book Cliffs: Carbon, Emery, and Grand counties, Utah, and Garfield and Mesa counties, Colorado: U.S. Geological Survey Professional Paper 332:80 pp.

Flynn, J.J., 1986, Correlation and geochronology of middle Eocene strata from the western United States: Palaeogeography, Palaeoclimatology, Palaeoecology, 55:335-406.

Foos, A.F., 1999, Geology of the Colorado Plateau, Internet publication copyrighted by author, 6 pp. Available at www2.nature.nps.gov/geology/education/foos/plateau.pdf.

Foster, J., A.L. Titus, G.F. Winterfeld, M.C. Hayden, and A.H. Hamblin, 2001, Paleontological survey of the Grand Staircase-Escalante National Monument, Garfield and Kane counties, Utah: Utah Geological Survey Special Study 99:98 pp.

Fouch, T.D., T.F. Lawton, D.J. Nichols, W.B. Cashion, and W.A. Cobban, 1983, Patterns and timing of synorogenic sedimentation in Upper Cretaceous rocks of central and northeast Utah, In: Mesozoic Paleogeography of the west-central United States (M.W. Reynolds and E.D. Dolly, eds.), Society of Economic Paleontologists and Mineralogists, Rocky Mountain Paleogeography Symposium 2, Denver, CO, 305-336.

Franczyk, K.J., J.K. Pitman, and D.J. Nichols, 1990, Sedimentology, mineralogy, and depositional history of some Uppermost Cretaceous Lowermost Tertiary rocks along the Utah Book and Roan Cliffs east of the Green River: U.S. Geological Survey Bulletin, 1787:27 pp. 
Fremont, J. C., 1845, Report of the exploring expedition through the Rocky Mountains in the year 1842 and to Oregon and California in the years 1843-1844: Senate Document No. 174 and House Document No. 166, 28th Congress, 2nd session.

Froehlich, D.J. and B.H. Breithaupt, 1998, Mammals from the Eocene epoch Fossil Butte Member of the Green River Formation, Fossil Basin, Wyoming: Abstracts, Fifty-eighth annual meeting, Society of Vertebrate Paleontology, Snowbird, UT, United States, Sept. 30-Oct. 3, 1998, 18(3, Suppl):43-44 .

Gauthier, J.A., 1982, Fossil xenosaurid and anguid lizards from the early Eocene Wasatch Formation, Southeast Wyoming, and a revision of the Anguioidea: Contributions to Geology, 21(1):7-54.

Gazin, C.L., 1934, On the priority of specific names for the upper Bridger Notharctus: Journal of mammalogy, 15(1):71 pp.

Gazin, C.L., 1946, Machaeroides eothen Matthew, the saber tooth creodont of the Bridger Eocene [Wyoming]: Proceedings of the United States National Museum, 96(3203):335-347.

Gazin, C.L., 1949, A leptictid insectivore from the middle Eocene Bridger Formation of Wyoming: Journal of the Washington Academy of Sciences, 39(7):220-223.

Gazin, C.L., 1955, A review of the Upper Eocene Artiodactyla of North America: Smithsonian Miscellaneous Collections, 281(8):96 pp.

Gazin, C.L., 1957, A skull of the Bridger middle Eocene creodont, Patriofelis ulta Leidy [Wyoming]: Smithsonian Miscellaneous Collections, 134(8):20 pp.

Gazin, C.L., 1958, A review of the middle and upper Eocene primates of North America: Smithsonian Miscellaneous Collections, 136(1):1-112.

Gazin, C.L., 1965, An endocranial cast of the Bridger middle Eocene primate Smilodectes gracilis: Smithsonian Miscellaneous Collections, 149(4):1-14.

Gazin, C.L., 1968, A study of the Eocene condylarthran mammal Hyopsodus: Smithsonian Miscellaneous Collections, 153(4):1-90.

Gazin, C.L., 1976, Mammalian faunal zones of the Bridger middle Eocene: Smithsonian Contributions to Paleobiology,(26):25-25.

Geo/Resource Consultants, 1984, Green River Basin geologic resources inventory: Unpublished Technical Report prepared for the Wyoming BLM.

Gillette, D.D. and M.C. Hayden, 1997, A preliminary inventory of paleontological resources within the Grand Staircase-Escalante National Monument, Utah: Circular-Utah Geological Survey, 96:34 pp. 
Gillette, D.D. and W.E. Miller, 1999, Catalogue of new Pleistocene mammalian sites and recovered fossils from Utah In: Vertebrate paleontology in Utah: Miscellaneous Publication-Utah Geological Survey, 99-1:523-530.

Gillette, D.D., H.G. McDonald, and M.C. Hayden, 1999a, The first record of Jefferson's Ground Sloth, Megalonyx Jeffersonii, in Utah (Pleistocene, Rancholabrean Land Mammal Age): In: Vertebrate paleontology in Utah: Miscellaneous Publication-Utah Geological Survey, 99-1:509-522.

Gillette, D.D., C.J. Bell, and M.C. Hayden, 1999b, Preliminary report of the Little Dell Dam fauna, Salt Lake County, Utah (Middle Pleistocene, Irvingtonian Land mammal Age): In: Vertebrate paleontology in Utah: Miscellaneous Publication-Utah Geological Survey, 99-1:495-500.

Gingerich, P.D. and J.A. Dorr, Jr., 1979, Mandible of Chiromyoides minor (Mammalia, Primates) from the upper Paleocene Chappo Member of the Wasatch Formation, Wyoming: Journal of Paleontology, 53(3):550-552.

Grande, L., 1979, Eohiodon falcatus, a new species of hiodontid (Pisces) from the late early Eocene Green River Formation of Wyoming: Journal of Paleontology, 53(1):103-111.

Grande, L., 1980a, Paleontology of the Green River Formation, with a review of the fish fauna: Bulletin-Geological Survey of Wyoming, 63:333 pp.

Grande, R.L., 1980b, Paleontology of the Green River Formation, with a review of the fish fauna: University of Minnesota, Minneapolis, Minneapolis, MN, United States (USA) Master's. Thesis.

Grande, L., 1982, A revision of the fossil genus Knightia, with a description of a new genus from the Green River Formation (Teleostei, Clupeidae): American Museum Novitates, 2731:22 pp.

Grande, L., 1984, Paleontology of the Green River Formation, with a review of the fish fauna; second edition: Bulletin - Geological Survey of Wyoming, 63:333 pp.

Grande, L., 1985, Fish fossils in the Eocene Green River Formation of southwestern Wyoming; On research and exploration projects supported by the National Geographic Society, for which an initial grant or continuing support was provided in the years 1980-1983: Research Reports-National Geographic Society, 21:201-207.

Grande, L., 1987, Redescription of Hypsidoris farsonensis (Teleostei: Siluriformes), with a reassessment of its phylogenetic relationships: Journal of Vertebrate Paleontology, 7(1):24-54.

Grande, L., 1989, Fossil fauna of the Green River Formation; Conservation and the future of humanity: 82nd annual meeting of the Illinois State Academy of Science, Chicago, IL, United States, Oct. 20-21, 1989, 82, Suppl:66 pp. 
Grande, L., 1991, Transferred type specimens of well-preserved Eocene fishes from the Green River Formation: Journal of Paleontology, 65(5):889-890.

Grande, L., 1998, The first pickerel (Teleostei, Esocidae) from the Green River Formation, and a review of the world's most productive freshwater Lagerstatten; Abstracts of papers; Society of Vertebrate Paleontology Fifty-Eighth Annual Meeting, Snowbird, UT, United States, Sept. 30-Oct. 3, 1998, 18(3, Suppl):47 pp.

Grande, L., 1999, The first Esox (Esocidae, Teleostei) from the Eocene Green River Formation, and a brief review of esocid fishes: Journal of Vertebrate Paleontology, 19(2):271-292.

Grande, L., 2001, An updated review of the fish faunas from the Green River Formation, the world's most productive freshwater Lagerstatten; Eocene biodiversity; unusual occurrences and rarely sampled habitats: Topics in Geobiology, 18:1-38.

Grande, L. and H.P. Buchheim, 1994, Paleontological and sedimentological variation in early Eocene Fossil Lake: Contributions to Geology, University of Wyoming, 30(1):33-56.

Granger, W., 1908, A revision of the American Eocene horses: Bulletin of the American Museum of Natural History, 24:221-264.

Granger, W., 1909, Faunal horizons of the Washakie Formation of southern Wyoming: Bulletin of the American Museum of Natural History, 26:13-23.

Granger, W. and G.G. Simpson, 1928, Multituberculates in the Wasatch Formation: American Museum Novitates, 312:4 pp.

Gregory, H.E., 1916, The Navajo country, a geographic and hydrographic reconnaissance of parts of Arizona, New Mexico, and Utah: U.S. Geological Survey Water Supply Paper 380:219 pp.

Gregory, H.E., 1917, Geology of the Navajo Country: U.S. Geological Survey Professional Paper 93:161 pp.

Gregory, H.E., 1950, Geology and geography of the Zion [National] Park region, Utah and Arizona: U.S. Geological Survey Professional Paper P 0220:200 pp.

Gregson, J.D. and D.J. Chure, 2000, Geology and Paleontology of Dinosaur National Monument, Utah-Colorado, In: Geology of Utah's Parks and Monuments (D.A. Sprinkel, T.C. Chidsey. Jr., and P.B. Anderson, eds.), Utah Geological Association Publication, 28:155-188.

Gualtieri, J.L., 1988, Geologic map of the Westwater 30' $\times$ 60' Quadrangle, Grand and Uintah counties, Utah and Garfield and Mesa counties, Colorado: U.S. Geological Survey Miscellaneous Investigations Series I-1765, 1 Sheet (Scale 1:100,000). 
Gunnell, G.F., 1997, Wasatchian-Bridgerian (Eocene) paleoecology of the western interior of North America: changing paleoenvironments and taxonomic composition of omomyid (Tarsiiformes) primates: Journal of Human Evolution, 32:105-132.

Gunnell, G.F. and W.S. Bartels, 1994, Early Bridgerian (middle Eocene) vertebrate paleontology and paleoecology of the southern Green River Basin Wyoming: Contributions to Geology, University of Wyoming, 30(1):57-70.

Gunnell, G. and W.S. Bartels, 1999, Middle Eocene vertebrates from the Uinta Basin, Utah, and their relationship with faunas from the southern Green River Basin, Wyoming: Utah Geological Survey Misc. Publications, 99-1:429-442.

Gunnell, G., 2003, New primitive microbat (Chiroptera) from the Green River Formation (upper lower Eocene), Fossil Basin, southwestern Wyoming: Sixty-third annual meeting, Society of Vertebrate Paleontology, Oct. 15-18, 2003, 23(3, Suppl.):58.

Gunnell, G.F., J.P. Zonneveld, and W.S. Bartels, (in press), Stratigraphy, vertebrate paleontology, and paleoecology of the Wasatch Formation, Fossil Butte National Monument, Wyoming Part 2: mammalian paleontology and age correlation: Wyoming State Geological Survey.

Hackman, R.J. and D.G. Wyant, 1973, Geology, structure, and uranium deposits of the Escalante Quadrangle, Utah and Arizona: U.S. Geological Survey Miscellaneous Investigations Series I-744, 1 Sheet (Scale 1:250,000).

Hail, W.J., Jr., 1990, Geology of the Lower Yellow Creek area, northwestern Colorado: U.S. Geological Survey Bulletin 1787-O:45 pp.

Hail, W.J., Jr. and M.C. Smith, 1994, Geologic map of the northern part of the Piceance Creek basin, northwestern Colorado: U.S. Geological Survey Miscellaneous Investigation Map I-2400.

Hail, W.J., Jr. and M.C. Smith, 1997, Geologic map of the southern part of the Piceance Creek basin, northwestern Colorado: U.S. Geological Survey Miscellaneous Investigation Map I-2529.

Hamblin, A.H., 1987, Paleogeography and paleoecology of the Myton Pocket, Uinta Basin, Utah (Uinta Formation-Upper Eocene): Brigham Young University Studies, 34:33-60.

Hanley, J.H., 1974, Systematics, paleoecology, and biostratigraphy of nonmarine Mollusca from the Green River and Wasatch formations (Eocene), southwestern Wyoming and northwestern Colorado: University of Wyoming, Laramie, WY, United States (USA) Doctoral Dissertation.

Hansen, W.R., P.D. Rowley, and P.E. Carrara, 1983, Geologic map of Dinosaur National Monument and vicinity, Utah and Colorado: U.S. Geological Survey Miscellaneous Investigations Series I-1407, 1 Sheet (Scale 1:50,000). 
Hansen, W.R., 1986, Neogene tectonics and geomorphology of the eastern Uinta Mountains in Utah, Colorado, and Wyoming: U.S. Geological Survey Professional Paper 1506-A, 1356:1-78.

Hasiotis, S.T. and P.C. Murphey, 1997, Preliminary report of aquatic plant and invertebrate ichnofossils from the middle Eocene Bridger Formation, southwest Wyoming: Geological Society of America Abstracts with Programs, Vol. 29, No. 2.

Hayden, F.V., 1869, Preliminary field report (3rd Annual Report) of the U.S. Geological Survey of Colorado and New Mexico: U.S. Government Printing Office, Washington, D.C. 155 pp.

Hayden, F.V., 1871, Preliminary report of the United States Geological Survey of Wyoming and portions of contiguous territories (2nd Annual Report): U.S. Government Printing Office, Department of the Interior, Washington, D.C., 155 pp.

Hayden, F.V., 1873, First, Second, and Third Annual Reports of the U.S. Geological and Geographic Survey of the Territories, for the years 1867, 1868, and 1869: U.S. Government Printing Office, Washington, $261 \mathrm{pp}$.

Hayden, F.V., 1875, Report on the San Juan district, Colorado: U.S. Geological Survey Annual Report, 9:245-248.

Heaton, T.H., 1999, Late Quaternary vertebrate history of the Great Basin: In: Vertebrate paleontology in Utah: Miscellaneous Publication-Utah Geological Survey, 99-1:501-508.

Henderson, J., 1909, Field Notes, University of Colorado Museum, transcribed by Professor Peter Robinson.

Hintze, L.F., 1973, Lower and Middle Ordovician stratigraphic sections in the Ibex area, Millard County, Utah: Brigham Young University Geology Studies, 20:3-36.

Hintze, L.F., 2000, Digital Geologic Map of Utah: U.S. Geological Survey Map (Scale 1:500,000).

Hodgkins, J.M. and D.M. Smith, 2002, A record of evolutionary change in an Eocene plantherbivore assemblage: Geological Society of America Abstracts with Programs, 34:4.

Holmes, W.H., 1877, Report of William H. Holmes, Geologist of the San Juan Division: U.S. Geological and Geographical Survey of the Territories (Hayden), 9th Annual Report:237-276.

Holmes, W.H., 1878, Report of the geology of the Sierra Abajo and west San Miguel Mountains: U.S. Geological and Geographical Survey of the Territories (Hayden), 10th Annual Report:187-195. 
Honey, J.G., 1977, The paleontology of the Brown's Park Formation in the Maybell, Colorado area, and a taphonomic study of two fossil quarries Colorado and Arizona: University of Arizona, Tucson, AZ, United States (USA) Master's Thesis.

Honey, J.G. and G.A. Izett, 1988, Paleontology, taphonomy, and stratigraphy of the Browns Park Formation (Oligocene and Miocene) near Maybell, Moffat County, Colorado: U.S. Geological Survey Professional Paper 1358:52 pp.

Hunt, C.B., 1954, Pleistocene and Recent deposits in the Denver area, Colorado: U.S. Geological Survey Bulletin, 996-C:91-140.

Huntoon, J.E., P.L. Hansley, and N.D. Naeser, 1999, The search for a source rock for the giant Tar Sand Triangle accumulation, southeastern Utah: AAPG Bulletin, 83(3):467-495.

Hutchison, J.H., 1984, Determinate growth in the Baenidae (Testudines); taxonomic, ecologic and stratigraphic significance: Journal of Vertebrate Paleontology, 3(3):148-151.

Irwin, C.D., 1976, Permian and Lower Triassic reservoir rocks of central Utah, In: Symposium on Geology of the Cordilleran Hingeline (J.G. Hill, eds.), Rocky Mountain Associate of Geologists Field Conference, pp. 193-202.

Johnson, R.C., 1981, Stratigraphic evidence for a deep Eocene Lake Uinta, Piceance Creek Basin, Colorado: Geology, v. 9, no. 5, pp. 55-62.

Johnson, R.C., 1984, New names for units in the lower part of the Green River Formation, Piceance Creek Basin, Colorado: U.S. Geological Survey Bulletin, B 1529-I, 20 pp.

Johnson, R.C., 1985, Early Cenozoic history of the Uinta and Piceance Creek basins, Utah and Colorado, with special reference to the development of Eocene Lake Uinta, In: Cenozoic Paleogeography of West-Central United States (R.M. Flores and S.S. Kaplan, eds.), Society for Sedimentary Geology, pp. 247-276.

Johnson, R.C., 1989, Geologic history and hydrocarbon potential of late Cretaceous-age, lowpermeability reservoirs, Piceance Basin, western Colorado: U.S. Geological Survey Bulletin, B 1787-E:51 pp.

Johnson, K.R. and C. Plumb, 1995, Common plant fossils from the Green River Formation at Douglas Pass, Colorado, and Bonanza, Utah, In: The Green River Formation in Piceance Creek and eastern Uinta basins, Grand Junction Geol. Society Guidebook, pp. 121-130.

Kamola, D.L., and Chan, M.A., 1988, Coastal dune facies, Permian Cutler Formation (White Rim Sandstone), Capitol Reef National Park area, southern Utah, In: Late Paleozoic and Mesozoic Eolian Deposits of the Western interior of the United States (G. Kocurek, ed.), Sedimentary Geology, 56:341-356. 
Kay, J.L., 1934, The Tertiary formations of the Uinta Basin, Utah: Annals of the Carnegie Museum, 23:357-371.

Keighin, C.W., 1977a, Preliminary geologic map of the Burnt Timber Canyon Quadrangle, Uintah County, Utah: U.S. Geological Survey Miscellaneous Field Studies Map MF-0875, 1 Sheet (Scale 1:24,000).

Keighin, C.W., 1977b, Preliminary geologic map of the Cooper Canyon Quadrangle, Uintah County, Utah: U.S. Geological Survey Miscellaneous Field Studies Map MF-0874, 1 Sheet (Scale 1:24,000).

Kihm, A.J., 1984, Early Eocene mammalian faunas of the Piceance Creek basin, northwestern Colorado: University of Colorado, Boulder, CO, United States (USA) Doctoral Dissertation.

King, C., 1877, Descriptive geology: U.S. Geological Exploration of the 40th Parallel, 2:202-277.

Koenig, K.J., 1960, Bridger Formation in the Bridger Basin, Wyoming: Wyoming Geol. Assoc. Guidebook, Fifteenth Annual Field Conference:163-168.

Krishtalka, L., R.M. West, C.C. Black, M.R. Dawson, J.J. Flynn, W.D. Turnbull, R.K. Stucky, M.M.C., T.M. Bown, D.J. Golz, and J.A. Lillegraven, 1987, Eocene (Wasatchian through Duchesnean) biochronology of North America, In: Cenozoic Mammals of North America: Geochronology and Biostratigraphy (M.O. Woodburne, ed.), University of California Press, Berkeley, pp. 77-117.

Kuchta, M.A., 2000, Paleoenvironmental significance of nonmarine Mollusca in the Luman Tongue of the Green River Formation, Wyoming: Master's Thesis, University of Wisconsin, $63 \mathrm{pp}$.

Langston, W., Jr. and H. Rose, 1978, A yearling crocodilian from the middle Eocene Green River Formation of Colorado: Journal of Paleontology, 52(1):122-125.

Lanham, U., 1973, The Bone Hunters: The Historic Age of Paleontology in the American West: Dover Publications, 285 pp.

Leggitt, V.L. and H.P. Buchheim, 1998a, Avian eggshell identified from a Presbyornis (Aves; Anseriformes) rookery; Eocene Lake Gosiute, Sweetwater County, Wyoming: Geological Society of America, 1998 annual meeting, Toronto, ON, Canada, Oct. 26-29, 1998, 30(7):32 pp.

Leggitt, V.L. and H.P. Buchheim, 1998b, A new Presbyornis (Aves, Anseriformes) nesting site with abundant eggshell; Eocene Fossil Lake, Lincoln County, Wyoming: Abstracts, Fifty-eighth annual meeting, Society of Vertebrate Paleontology, Snowbird, UT, United States, Sept. 30 Oct. 3, 1998, 18(3, Suppl):p. 58. 
Leggitt, V.L. and R.A. Cushman, 2001, Complex caddisfly-dominated bioherms from the Eocene Green River Formation: Sedimentary Geology, 145:377-396.

Leggitt, V.L., H.P. Buchheim, and R.E. Biaggi, 2001, Avian eggshell from caddisfly (Insecta, Trichoptera) mounds; Tipton Shale Member, Eocene Green River Formation: Abstracts, Sixtyfirst annual meeting, Society of Vertebrate Paleontology, Bozeman, MT, United States, Oct. 3-6, 2001, 21(3, Suppl):p. 72.

Leidy, J., 1869, Notice of some extinct vertebrates from Wyoming and Dakota: Proceedings of the Academy of Natural Sciences of Philadelphia, pp. 63-67.

Leidy, J., 1871, Notice of some extinct rodents: Proceedings of the Academy of Natural Sciences of Philadelphia, pp. 230-232.

Leidy, J., 1872a, On the fossil vertebrates of the early Tertiary of Wyoming: United States Geological Survey of Montana and Portions of Adjacent Territories, Fifth Annual Report on the Fossil Vertebrates of the Early Tertiary of Wyoming, pp. 353-372.

Leidy, J., 1872b, On some new species of fossil mammalia from Wyoming: Proceedings of the Academy of Natural Sciences of Philadelphia, pp. 167-169.

Leidy, J., 1873, Contributions to the extinct vertebrate fauna of the western territories, Part I: Report of the United States Geological Survey of the Territories, F.V. Hayden, 358 pp.

Leopold, E.B. and H.D. MacGinitie, 1972, Development and affinities of Tertiary floras in the Rocky Mountains, In: Floristics and Paleofloristics of Asia and Eastern North America, Elsevier, Amsterdam, pp. 147-200.

Lewis, G.E., 1970, New discoveries of Pleistocene bison and peccaries in Colorado: U.S. Geological Survey Professional Paper 700-B:B137-B140.

Lewis, G.E. and P.P. Vaughn, 1965, Early Permian vertebrates from the Cutler Formation of the Placerville area, Colorado: U.S. Geological Survey Professional Paper P 0503-C: pp. C1-C50.

Long, R.A. and K. Padian, 1986, Vertebrate biostratigraphy of the Late Triassic Chinle Formation, Petrified Forest National Park, Arizona: preliminary results, In: The Beginning of the Age of Dinosaurs (K. Padian, ed.), London, Cambridge University Press, pp. 161-169.

Loope, D.B., G.A. Sanderson, and G.J. Verville, 1990, Abandonment of the name Elephant Canyon Formation in southeastern Utah: physical and temporal implications: Mountain Geologist, 27(4):119-130.

Love, J.D. and Christiansen, A.C., 1985, Geologic Map of Wyoming: U.S. Geological Survey Map, 3 Sheets (Scale 1:500,000). 
Lucas, S.G., 1992, Redefinition of the Duchesnean Land Mammal "Age," late Eocene of western North America, In: Eocene-Oligocene Climatic and Biotic Evolution (D.R. Prothero and W.A. Berggren, eds.), Princeton University Press, Princeton, NJ, pp. 46-73.

Lucas, S.G. and A.J. Kihm, 1982, Paleontological resource study and inventory of part of the White River Resource Area and vicinity, Piceance Creek Basin, Colorado: Unpublished Technical Report Prepared for the Colorado BLM, 435 pp.

M'Gonigle, J.W. and J.H. Dover, 1992, Geologic map of the Kemmerer 30' × 60' Quadrangle, Lincoln, Uinta, and Sweetwater counties, Wyoming: U.S. Geological Survey Miscellaneous Investigations Series I-2079, 1 Sheet (Scale 1:100,000).

MacGinitie, H.D., 1969, The Eocene Green River flora of northwestern Colorado and northeastern Utah: University of California Publications in Geological Sciences, 83:202 pp.

Mamay, S.H. and W.J. Breed, 1970, Early Permian plants from the Cutler Formation in Monument Valley, Utah: U.S. Geological Survey Professional Paper P 0700-B:B109-B117.

Marcou, J., 1856, Resume of a geological reconnaissance extending from Napoleon at the junction of the Arkansas with the Mississippi to the Pueblo de Los Angeles in California, In: Report of Explorations for a Railway Route near the Thirty-Fifth Parallel of Latitude from the Mississippi River to the Pacific Ocean (A.D. Whipple, eds.), U.S. Pacific R.R. Explor. (U.S. 33rd Congress, 2nd Session, S. Ex. Doc. 78 and H. Ex. Doc. 91), v. 3, pt. 4:165-171.

Marcou, J., 1858, Geology of North America, with two reports on the prairies of Arkansas and Texas, and the Sierra Nevada of California: Zurich, 144 pp. (Reviewed by J.D. Dana, Am Jour. Sci. 2nd ser., v. 26, pp. 323-333).

Marsh, O.C., 1871, Notice of some new fossil mammals from the Tertiary formation: American Journal of Science, 2:35-44.

Marsh, O.C., 1886, Dinocerata, a monograph of an extinct order of gigantic mammals: U.S. Geological Survey Monograph M0010:243 pp.

Matthew, W.D., 1909, The Carnivora and Insectivora of the Bridger Basin, middle Eocene: Memoirs of the American Museum of Natural History, 9(6):291-567.

Mauger, R.L., 1977, K-Ar ages of biotites from tuffs in Eocene rocks of the Green River Formation, Piceance Creek Basin, Colorado: Geology, 3:493-497.

McCarroll, S.M. and W.D. Turnbull, 1996, A late Bridgerian fauna from the Kinney Rim Member of the Washakie Formation, Washakie Basin, Wyoming: Abstract, Fifty-sixth annual meeting, Society of Vertebrate Paleontology, New York, NY, United States, Oct. 16-19, 1996, 16(3, Suppl): 51-52. 
McCarroll, S.M., J.J. Flynn, and W.D. Turnbull, 1996, The mammalian faunas of the Washakie Formation, Eocene age, of southern Wyoming; Part III, The perissodactyls: Fieldiana: Geology (New Series), 33:38 pp.

McGrew, E.J., 1951, Tertiary stratigraphy and paleontology of south-central Wyoming: Wyoming Geological Association Guidebook, Sixth Annual Field Conference, South-central Wyoming, pp. 54-57.

McGrew, P.O., 1959, The geology and paleontology of the Elk Mountain and Tabernacle Butte area, Wyoming: Bulletin of the American Museum of Natural History, 117 (Article 3):123-174.

McGrew, P.O. and M. Casilliano, 1975, The geological history of Fossil Butte National Monument and Fossil Basin: National Park Service Occasional Paper, (3):37 pp.

McGrew, P.O. and T.M. Bown, 1976, Fossil vertebrate faunas: Green Mountain, Ferris-Seven Lakes, and Sandy EIS areas, and Sweetwater County, Wyoming: Unpublished technical report prepared for the Wyoming BLM, $422 \mathrm{pp}$.

McGrew, P.O. and T.M. Bown, 1977, Fossil vertebrate faunas: Carbon, Lincoln, and Uinta counties, Wyoming: Unpublished technical report prepared for the Wyoming BLM, $251 \mathrm{pp}$.

McGrew, P.O. and R. Sullivan, 1970, The stratigraphy and paleontology of Bridger A: Contributions to Geology, University of Wyoming, 9(2):66-85.

McKee, E.D., 1938, The environment and history of the Toroweap and Kaibab formations of northern Arizona and southern Utah: Carnegie Institution of Washington Publication, pp. 268-268.

McKee, E.D., 1954, Relationship between fauna and lithology in the Moenkopi Formation [Arizona-Utah]: Journal of Sedimentary Petrology, 24(2):136 pp.

McKenna, M.C., 1955, Age of the Four Mile Local Fauna, northeast Sand Wash Basin, Colorado: Wyoming Geological Association Guidebook, pp. 105-107.

McKenna, M.C., 1958, Fossil Mammalia from the early Wasatchian Four Mile fauna, Eocene of Northwest Colorado: University of California, Berkeley, Berkeley, CA, United States (USA) Doctoral Dissertation.

McKenna, M.C., 1960, Fossil Mammalia from the early Wasatchian Four Mile fauna, Eocene of northwest Colorado: University of California Publications in Geological Sciences, 37(1):1-130.

McKenna, M.C., P. Robinson, and D.W. Taylor, 1962, Notes on Eocene Mammalia and Mollusca from Tabernacle Butte, Wyoming: American Museum Novitates, 2102:33 pp.

McKenna, M.C. and S.K. Bell, 1997, Classification of Mammals above the Species Level: Columbia University Press, 631 pp. 
Miller, W.E. and D.A. Hall, 1990, Earliest history of vertebrate paleontology in Utah: Last half of the 19th Century: Earth Sciences History, 9(1):28-33.

Moncure, G. and R.C. Surdam, 1980, Depositional environment of the Green River Formation in the vicinity of the Douglas Creek Arch, Colorado and Utah: Contributions to Geology, University of Wyoming, 19(1):9-24.

Morales, M., 1987, Terrestrial fauna and flora from the Triassic Moenkopi Formation of the southwestern United States: Journal of the Arizona-Nevada Academy of Science, 22(1):1-19 pp.

Moussa, M.T., 1968, Fossil tracks from the Green River Formation (Eocene) near Soldier Summit, Utah: Journal of Paleontology, 42(6):1433-1438.

Murphey, P.C., 1995, Paleontology, sedimentology, and depositional history of a middle Eocene lacustrine deposit in the Bridger Formation, southwest Wyoming: University of Colorado unpublished Masters Thesis, 121 pp.

Murphey, P.C., 2001, Stratigraphy, fossil distribution, and depositional environments of the upper Bridger Formation (middle Eocene) of southwestern Wyoming, and the taphonomy of an unusual Bridger microfossil assemblage: University of Colorado Doctoral Dissertation, 345 pp.

Murphey, P.C., A. Lester, B. Bohor, P. Robinson, E. Evanoff, and E. Larson, 1999, 40Ar/39Ar dating of volcanic ash deposits in the Bridger Formation (middle Eocene) of southwestern Wyoming: Geological Society of America Abstracts with Programs, 1999 Annual Meeting Issue.

Murphey, P.C., L.L. Torick, E.S. Bray, R. Chandler, and E. Evanoff, 2001, Taphonomy, fauna, and depositional environment of the Omomys Quarry, an unusual accumulation from the Bridger Formation (middle Eocene) of southwestern Wyoming (USA); Eocene biodiversity; unusual occurrences and rarely sampled habitats: Topics in Geobiology, 18:361-402.

Murphey, P.C. and K.E. Townsend, 2005, Ecological Diversity Analysis applied to facies faunas in the Twin Buttes Member, middle Eocene Bridger Formation, southwestern Wyoming, USA: Society of Vertebrate Paleontology, 25(3, Suppl).

Murphey, P.C. and E. Evanoff, 2007, Stratigraphy, fossil distribution and depositional environments of the upper Bridger Formation (middle Eocene), southwestern Wyoming: Wyoming State Geological Report of Investigation, 56.

Murphey, P.C. and S.L. Walsh, 2007, Shoshonian revisited: Documenting the Bridgerian-Uintan faunal transition in the Turtle Bluff Member of the Bridge Formation (middle Eocene), southwestern Wyoming: Geological Society of America Abstracts with Program, 39(6):418.

Murphey, P.C., J.E. Haessig, L. Brand, and N. Matthews, 2007a, Bedrock geologic map of the Soap Holes Reservoir 7.5' Quadrangle, Sweetwater County, Wyoming: Wyoming State Geological Survey Open File Map, 1 Sheet (Scale 1:24,000). 
Murphey, P.C., J.E. Haessig, L. Brand, and N. Matthews, 2007b, Bedrock geologic map of the McKinnon 7.5' Quadrangle, Sweetwater County, Wyoming: Wyoming State Geological Survey Open File Map, 1 Sheet (Scale 1:24,000).

Murphey, P.C., J.E. Haessig, and L. Brand, 2007c, Bedrock geologic map of the Horse Ranch 7.5' Quadrangle, Sweetwater County, Wyoming: Wyoming State Geological Survey Open File Map, 1 Sheet (Scale 1:24,000).

Murphey, P.C., E. Evanoff, J.E. Haessig, and N. Matthews, 2007d, Bedrock geologic map of the Lonetree 7.5' Quadrangle, Sweetwater County, Wyoming: Wyoming State Geological Survey Open File Map, 1 Sheet (Scale 1:24,000).

Murphey, P.C., E. Evanoff, J.E. Haessig, and N. Matthews, 2007e, Bedrock geologic map of the Burntfork 7.5' Quadrangle, Sweetwater County, Wyoming: Wyoming State Geological Survey Open File Map, 1 Sheet (Scale 1:24,000).

Murphey, P.C., L. Brand, J.E. Haessig, and A.A. Smith, 2007f, Bedrock geologic map of the Devils Playground 7.5' Quadrangle, Sweetwater County, Wyoming: Wyoming State Geological Survey Open File Map, 1 Sheet (Scale 1:24,000).

Murphey, P.C., L. Brand, and J.E. Haessig, 2007g, Bedrock geologic map of the Black Spring Reservoir 7.5' Quadrangle, Sweetwater County, Wyoming: Wyoming State Geological Survey Open File Map, 1 Sheet (Scale 1:24,000).

Nesbitt, S.J. and K.D. Angielczyk, 2002, New evidence of large dicynodonts in the upper Moenkopi Formation (Middle Triassic) of northern Arizona: PaleoBios, 22(2):10-17.

Nesbitt, S.J. and R.L. Whatley, 2004, The first discovery of a rhynchosaur from the upper Moenkopi Formation (Middle Triassic) of northern Arizona: PaleoBios, 24(3):1-10.

Nichols, D.J., 1987, Palynology of the Vermillion Creek coal bed and associated strata: U.S. Geological Survey Professional Paper 1314-D:47-73.

Nichols, D.J. and B. Bryant, 1990, Geologic map of the Salt Lake City 30' × 60' Quadrangle, north-central Utah, and Uinta County, Wyoming: U.S. Geological Survey Miscellaneous Investigations Series I-1944, 2 Sheets (Scale 1:100,000).

Oriel, S.F. and J.I. Tracey, 1970, Uppermost Cretaceous and Tertiary stratigraphy of Fossil Basin, southwest Wyoming: U.S. Geological Survey Professional Paper 635:53 pp.

Oriel, S.S. and L.B. Platt, 1980, Geologic map of the Preston 1 degree by 2 degrees quadrangle, southeastern Idaho and western Wyoming: U.S. Geological Survey Miscellaneous Investigations Series I- 1127, 1 Sheet (Scale 1:250,000). 
O'Sullivan, R.B., 1970, The upper part of the Upper Triassic Chinle Formation and related rocks, southeastern Utah and adjacent areas: U.S. Geological Survey Professional Paper $P$ 0644-E:E1-E22.

O’Sullivan, R.B., 1986, Preliminary geologic map of the Anvil Points Quadrangle, Garfield County, Colorado: U.S. Geological Survey Miscellaneous Field Studies Map MF-1882, 1 Sheet (Scale 1:24,000).

Osborn, H.F., 1881, A memoir upon Loxolophodon and Uintatherium: E.M. Museum of Geology and Archaeology of the College of New Jersey Contributions, 1(1):1-44.

Osborn, H.F., 1895, Fossil mammals of the Uinta beds [Utah]: Bulletin of the American Museum of Natural History:71-106.

Osborn, H.F., 1929, The Titanotheres of ancient Wyoming, Dakota, and Nebraska: U.S. Geological Survey Monograph 1(55):1-701.

Osborn, H.F. and J.L. Wortman, 1892, Fossil mammals of the Wasatch and Wind River beds: Bulletin of the American Museum of Natural History, 4:81-147.

Pantea, M.P., 1987, Preliminary geologic map of the Davis Canyon Quadrangle, Uintah County, Utah and Garfield and Rio Blanco counties, Colorado: U.S. Geological Survey Miscellaneous Field Studies Map MF-1933, 1 Sheet (Scale 1:24,000).

Pantea, M.P., 1993, Preliminary geologic map of the East Evacuation Creek Quadrangle, Garfield and Rio Blanco counties, Colorado: U.S. Geological Survey Miscellaneous Investigations Series, 1 Sheet (Scale 1:24,000).

Parker, W.G., 2005, Faunal review of the Upper Triassic Chinle Formation of Arizona, In: Vertebrate Paleontology of Arizona (R.D. McCord, ed.), Mesa Southwest Museum Bulletin 21.

Parrish, J.M., 1999, Small fossil vertebrates from the Chinle Formation (Upper Triassic) of southern Utah; Vertebrate paleontology in Utah: Miscellaneous Publication - Utah Geological Survey, 99-1:45-50.

Patterson, B., 1933, A new species of the amblypod Titanoides from Western Colorado: American Journal of Science, 25(149):415-425.

Patterson, B., 1934, A contribution to the osteology of Titanoides and the relationships of the Amblypoda: Proceedings of the American Philosophical Society, 73:71-102.

Patterson, B., 1937, A new genus, Barylambda, for Titanoides faberi, Paleocene amblypod: Geological Series Field Museum of Natural History, 6:229-231. 
Patterson, B., 1939, New Pantodonta and Dinocerata from the Upper Paleocene of western Colorado: Geological Series Field Museum of Natural History, 6:351-384.

Patterson, B., 1949, A new genus of taeniodont from the late Paleocene: Fieldiana: Geology, 10:41-42.

Patterson, B. and R.M. West, 1973, A new late Paleocene phenacodont (Mammalia, Condylarthra) from western Colorado: Breviora, 403:1-7.

Peale, A.C., 1879, Report on the geology of the Green River district: 11th Annual Report, U.S. Geological Survey of the Territories Report on the geology of the Green River district.

Peterson, O.A., 1924, Discovery of fossil mammals in the Browns Park Formation of Moffat County, Colorado: Annals of Carnegie Museum, 15(2-3):299-304.

Peterson, O.A. and J.L. Kay, 1931, The upper Uinta Formation of northeastern Utah: Annals of Carnegie Museum, 20(3-4):293-306.

Picard, M.D., 1963, Duration of Eocene Lake Uinta, Uinta Basin, Utah: Geological Society of America Bulletin, 74:89-90.

Powell, J.W., 1876, Report on the geology of the eastern portion of the Uinta Mountains and a region of country adjacent thereto: U.S. Geological and Geographical Survey of the Territiories, $218 \mathrm{pp}$.

Privrasky, N.C., 1963, Geology of the Big Piney area, Sublette County, Wyoming: U.S. Geological Survey Oil and Gas Investigations Map OM-0205, 2 Sheets $(1: 31,680)$.

Prothero, D.R. and C.C. Swisher, III, 1992, Magnetostratigraphy and geochronology of the terrestrial Eocene-Oligocene transition in North America, In: Eocene-Oligocene Climatic and Biotic Evolution (D.R. Prothero and W.A. Berggren, eds.), Princeton University Press, Princeton, N.J., pp. 46-73.

Prothero, D.R. and R.J. Emry, 1996, Magnetic stratigraphy and biostratigraphy of the middle Eocene Uinta Formation, Uinta Basin, Utah, In: The terrestrial Eocene-Oligocene transition in North America (D.R. Prothero, ed.), United States (USA), Cambridge University Press, United States (USA).

Rasmussen, D.T., G.C. Conroy, A.R. Friscia, K.E. Townsend, and M.D. Kinkel, 1999a, Mammals of the middle Eocene Uinta Formation; Vertebrate paleontology in Utah: Miscellaneous Publication-Utah Geological Survey, 99-1:401-420.

Rasmussen, D.T., A.H. Hamblin, and A.R. Tabrum, 1999b, The mammals of the Eocene Duchesne River Formation; Vertebrate paleontology in Utah: Miscellaneous Publication-Utah Geological Survey, 99-1:421-427. 
Repenning, C.A., M.E. Cooley, and J.P. Akers, 1969, Stratigraphy of the Chinle and Moenkopi formations, Navajo and Hopi Indian reservations; Arizona, New Mexico, and Utah:

U.S. Geological Survey Professional Paper P 521-B:B1-B34.

Rich, F.J., D.M. Johnson, and T.V. Durkin, 2001, Occurrence and paleoecology of Marsilea from the Eocene Wasatch: Palaios, 16:608-613.

Rigby, J.K., 1977, Southern Colorado Plateau: K/H Geology Field Guide Series: Kendall Hunt Publishing Co., Dubuque, IA, 148 pp.

Riggs, E. S., 1912, New or Little Known Titanotheres from the Lower Uintah Formations. Field Museum of Natural History Geological Series, 159:17--41.

Robinson, P., 1978, Paleontological resources inventory and evaluation, Bureau of Mines Experimental Oil Shale Mine, Rio Blanco County, Colorado: prepared for VTN Colorado, Inc. 2600 S. Parker Rd., Aurora, CO, 22 pp.

Robinson, P., D.J. Daitch, and J.E. Haessig, 2000, Fossil vertebrate localities of southwestern Wyoming: a literature search, locality record, and formation evaluation: Unpublished technical report prepared for the Wyoming BLM.

Robinson, P., G.F. Gunnell, S.L. Walsh, W.C. Clyde, J.E. Storer, R.K. Stucky, D.J. Froehlich, I.F. Villafranca, and M.C. McKenna, 2004, Wasatchian through Duschesnean biochronology, In: Late Cretaceous and Cenozoic Mammals of North America (M.O. Woodburne, ed.), Columbia University Press, pp. 106-155.

Roehler, H.W., 1973, Stratigraphy of the Washakie Formation in the Washakie Basin, Wyoming: U.S. Geological Survey Bulletin, Report B 1369:40 pp.

Roehler, H.W., 1985, Geologic map of the Kinney Rim 30 by 60 minute Quadrangle, Wyoming and Colorado: U.S. Geological Survey Miscellaneous Investigations Series I-1615, 1 Sheet (Scale 1:100,000).

Roehler, H.W., 1992a, Geology of the Eocene Wasatch, Green River, and Bridger (Washakie) Formations, Greater Green River Basin, Wyoming, Utah and Colorado: Introduction to Greater Green River Basin Geology, Physiography, and History of Investigations: U.S. Geological Survey Professional Paper 1506-A:14 pp.

Roehler, H.W., 1992b, Geology of the Eocene Wasatch, Green River, and Bridger (Washakie) Formations, Greater Green River Basin, Wyoming, Utah and Colorado: Description and Correlation of Eocene Rocks in Stratigraphic Reference Sections for the Green River and Washakie Basin, Southwest Wyoming: U.S. Geological Survey Professional Paper 1506-D:83 pp. 
Roehler, H.W., 1992c, Geology of the Eocene Wasatch, Green River, and Bridger (Washakie) Formations, Greater Green River Basin, Wyoming, Utah and Colorado: Correlation, Composition, Areal Distribution, and Thickness of Eocene Stratigraphic Units, Greater Green River Basin, Wyoming, Utah, and Colorado: U.S. Geological Survey Professional Paper 1506-E:49 pp.

Roehler, H.W., 1993, Geology of the Eocene Wasatch, Green River, and Bridger (Washakie) Formations, Greater Green River Basin, Wyoming, Utah and Colorado: Eocene Climates, Depositional Environments, and Geography, Greater Green River Basin, Wyoming, Utah and Colorado: U.S. Geological Survey Professional Paper 1506-F:74 pp.

Rowley, P.D., W.R. Hansen, O. Tweto, and P.E. Carrara, 1985, Geologic map of the Vernal 1 degree by 2 degrees Quadrangle, Colorado, Utah, and Wyoming: U.S. Geological Survey Miscellaneous Investigations Series I-1526, 1 Sheet (Scale 1:250,000).

Rubey, W.W., 1968a, Preliminary geologic map of the Kemmerer quadrangle, Lincoln County, Wyoming: U.S. Geological Survey Open File Map.

Rubey, W.W., 1968b, Preliminary map of the Sage quadrangle, Lincoln County, Wyoming: U.S. Geological Survey Open File Map.

Ryder, R.T., T.D. Fouch, and J.H. Elison, 1976, Early Tertiary sedimentation in the western Uinta Basin, Utah: Geological Society of America Bulletin, 87(4):496-512.

Savage, D.E. and B.T. Waters, 1978, A new omomyid primate from the Wasatch Formation of southern Wyoming: Folia Primatologica, 30(1):1-29.

Savage, D.E. and D.E. Russell, 1983, Mammalian Paleofauna of the World: Addison-Wesley Publ. Co., 432 pp.

Schaeffer, B. and D.H. Dunkle, 1950, A semionotid fish from the Chinle Formation [Utah], with consideration of its relationships: American Museum Novitates, 1457:29 pp.

Schultz, A.R., 1914, Geology and geography of a portion of Lincoln County, Wyoming: U.S. Geological Survey Bulletin, 543:1-141.

Schultz, A.W., 1984, Subaerial debris-flow deposition in the upper Paleozoic Cutler Formation, western Colorado: Journal of Sedimentary Petrology, 54(3):759-772.

Scott, W.B., 1945, Mammalia of the Duchesne River Oligocene: Transactions of the American Philosophical Society, 34:209-253.

Scott, G.R., 1963, Quaternary geology and geomorphic history of the Kassler Quadrangle, Colorado: U.S. Geological Survey Professional Paper 421-A:70 pp. 
Scudder, S.H., 1890, The Tertiary Insects of North America: Report of the United States Geological Survey of the Territories: 13:1-734, 28 plates.

Simpson, G.G., 1933, Glossary and correlation charts of North American Tertiary mammalbearing formations: American Museum of Natural History Bulletin, 47:91 pp.

Simpson, G.G., 1946, The Duchesnean fauna and the Eocene-Oligocene boundary: American Journal of Science, 244:52-57.

Sinclair, W.J., 1906, Volcanic ash in the Bridger beds of Wyoming: American Museum of Natural History Bulletin, vol. 22, article 15, pp. 273-280.

Smith, M.E., 2001, Precise 40Ar/39Ar laser fusion geochronology of the Green River Formation, Wyoming: Geological Society of America Abstracts with Programs, annual meeting issue.

Smith, K.S., R.L. Cifelli, and N.J. Czaplewski, 1999, An early Holocene, high-altitude vertebrate faunule from central Utah: In: Vertebrate paleontology in Utah: Miscellaneous PublicationUtah Geological Survey, 99-1:537-543.

Steele, B.A., 1987, Depositional environments of the White Rim Sandstone Member of the Permian Cutler Formation, Canyonlands National Park, Utah: U.S. Geological Survey Bulletin, 1592:20 pp.

Stewart, J.H., G.A. Williams, H.F. Albee, and O.B. Raup, 1959, Stratigraphy of Triassic and associated formations in part of the Colorado Plateau Region: U.S. Geological Survey Bulletin, 1046-Q:576 pp.

Stewart, J.H., F.G. Poole, and R.F. Wilson, 1972, Stratigraphy and origin of the Chinle Formation and related Upper Triassic strata in the Colorado Plateau region: U.S. Geological Survey Professional Paper P 0690:336 pp.

Stokes, W.L., 1986, Geology of Utah: Utah Museum of Natural History, University of Utah and Utah Geological and Mineral Survey, Department of Natural Resources.

Storer, J.E., 1990, Primates of the Lac Pelletier Lower Fauna (Eocene: Duchesnean), Saskatchewan: Canadian Journal of Earth Sciences, 27:520-524.

Stucky, R.K. and J.R. Snyder, 1992, Mammalian fauna of the Sand Wash Basin, Colorado (Washakie Formation, middle Eocene, earliest Uintan): Abstracts, Fifty-Second Annual Meeting, Society of Vertebrate Paleontology, Toronto, ON, Canada, October 28-31, 1992, 12(3, Suppl):54A.

Stucky, R.K., D.R. Prothero, W.G. Lohr, and J.R. Snyder, 1996, Magnetic stratigraphy, sedimentology, and mammalian faunas of the early Uintan Washakie Formation, Sand Wash Basin, Colorado, In: The Terrestrial Eocene-Oligocene Transition in North America (D.R. Prothero and R.J. Emry, eds.), Cambridge University Press, pp. 40-51. 
Sumida, S.S., J.B. Walliser, and R.E. Lombard, 1999a, Late Paleozoic Amphibian-Grade tetrapods of Utah: In: Vertebrate Paleontology in Utah (D. Gillette, ed.)-Miscellaneous Publication, Utah Geological Survey, 99-1:21-30.

Sumida, S.S., R.E. Lombard, D.S. Berman, and A.C. Henrici, 1999b, Late Paleozoic amniotes and their near relatives from Utah and northeastern Arizona, with comments on the PermianPennsylvanian boundary in Utah and northern Arizona: In: Vertebrate Paleontology in Utah (D. Gillette, ed.)—Miscellaneous Publication, Utah Geological Survey, 99-1:31-43.

Surdam, R.C., and K.O. Stanley, 1979, Lacustrine sedimentation during the culminating phase of Eocene Lake Gosiute Wyoming (Green River Formation): Geological Society of America Bulletin, part 1, v. 90, no. 1, pp. 93-110.

Surdam, R.C., and K.O. Stanley, 1980a, Effects on changes in drainage basin boundaries on sedimentation in Eocene Lakes Gosiute and Uinta of Wyoming, Utah, and Colorado: Geology, 8:135-139.

Surdam, R.C. and K.O. Stanley, 1980b, The stratigraphic and sedimentologic framework of the Green River Formation, Wyoming: Wyoming Geological Association, 31 st Field Conference Guidebook, pp. 205-221.

Townsend, K.E., 2004, Stratigraphy, paleoecology, and habitat change in the middle Eocene of North America: Washington University, Saint Louis, MO, United States (USA) Doctoral Dissertation.

Townsend, K.E., A.R. Fricia, and D.T. Rasmussen, 2006, Stratigraphic distribution of upper middle Eocene fossil vertebrate localities in the eastern Uinta Basin, Utah, with comments on Uintan biostratigraphy: The Mountain Geologist, 45(2):115-134.

Turnbull, W.D., 1972, The Allen Titanothere Quarry: Society of Vertebrate Paleontology, 32nd Annual Meeting, University of Nebraska, Lincoln, NE, United States (USA).

Turnbull, W.D., 1978, The mammalian faunas of the Washakie Formation, Eocene age, of southern Wyoming: Part I-Introduction: the geology, history, and setting: Fieldiana: Geology, 33(30):569-601.

Turnbull, W.D., 2004, Taenidonta of the Washakie Formation, southwestern Wyoming; Fanfare for an uncommon paleontologist; papers in honor of Malcolm C. McKenna: Bulletin of Carnegie Museum of Natural History, 36:302-333.

Tuttle, M.L., 1991, Introduction, In: Geochemical, Biogeochemical, and Sedimentological Studies of the Green River Formation, Wyoming, Utah, and Colorado (M.L. Tuttle, ed.), U.S. Geological Survey Bulletin, 1973-A-G:A1-A6.

Tweto, O., 1979, Geologic Map of Colorado: U.S. Geological Survey Map, 3 Sheets (Scale 1:500,000). 
Tweto, O., R.H. Moench, and J.C. Reed, Jr., 1978, Geologic map of the Leadville 1 degree by 2 degrees quadrangle, northeastern Colorado: U.S. Geological Survey Miscellaneous Investigations Series I-999, 1 Sheet (Scale 1:250,000).

USFS (U.S. Forest Service), 1996, Potential fossil yield classification (PFYC): Developed by the Paleontology Center of Excellence and the Region 2 (USFS) Paleo Initiative.

USGS (U.S. Geological Survey), 1980a, Argyle Canyon-Willow Creek, Utah tar sand leasing minutes no. 9: Minutes of the Mineral Land Evaluation Committee, 7 pp.

USGS, 1980b, Asphalt Ridge-Whiterocks and Vicinity, Utah tar sand leasing minutes no. 3: Minutes of the Mineral Land Evaluation Committee, 28 pp.

USGS, 1980c, Circle Cliffs East and West Flanks, Utah tar sand leasing minutes no. 5: Minutes of the Mineral Land Evaluation Committee, 15 pp.

USGS, 1980d, Hill Creek, Utah tar sand leasing minutes no. 6: Minutes of the Mineral Land Evaluation Committee, 12 pp.

USGS, 1980e, Pariette, Utah tar sand leasing minutes: Minutes of the Mineral Land Evaluation Committee, 8 pp.

USGS, 1980f, P.R. Spring, Utah tar sand leasing minutes: Minutes of the Mineral Land Evaluation Committee, 17 pp.

USGS, 1980g, Raven Ridge-Rim Rock and Vicinity, Utah tar sand leasing minutes no. 8: Minutes of the Mineral Land Evaluation Committee, 12 pp.

USGS, 1980h, San Rafael Swell, Utah tar sand leasing minutes no. 7: Minutes of the Mineral Land Evaluation Committee, 27 pp.

USGS, 1980i, Sunnyside and Vicinity, Utah tar sand leasing minutes no. 4: Minutes of the Mineral Land Evaluation Committee, 16 pp.

USGS, 1980j, Tar Sand Triangle, Utah tar sand leasing minutes no. 2: Minutes of the Mineral Land Evaluation Committee, 14 pp.

USGS, 1980k, White Canyon, Utah tar sand leasing minutes no. 11: Minutes of the Mineral Land Evaluation Committee, 11 pp.

Vaughn, P.P., 1962, Vertebrates from the Halgaito tongue of the Cutler Formation, Permian of San Juan County, Utah: Journal of Paleontology, 36(3):529-539.

Veatch, A.C., 1907, Geography and geology of a portion of southwestern Wyoming: U.S. Geological Survey Professional Paper 56:163 pp. 
Wagner, O.E., 1932, The paleontology and stratigraphy of the Kaibab Limestone: University of Illinois, Chicago, Chicago, IL, United States (USA) Doctoral Dissertation.

Walsh, S.L., 1996, The Bridgerian/Uintan boundary and the status of the "Shoshonian" (earliest Uintan) land mammal "subage," In: The Terrestrial Eocene-Oligocene Transition in

North America (D.R. Prothero and R.J. Emry, eds.), New York, Cambridge University Press, pp. 52-59.

Walsh, S.L. and P.C. Murphey, 2007, Documenting the Uintan-Duchesnean Transition in the Duchesne River Formation, Utah, Journal of Vertebrate Paleontology, 27

(Suppl. to No. 3):p. 163a).

Wanty, R.B., J.K. Pitman, and T.D. Fouch, 1991, Ground-water chemistry and diagenetic reactions in Tertiary sandstones of the Green River and Wasatch formations, Uinta Basin, Utah: U.S. Geological Survey Bulletin, 1787-X:21 pp.

Weiss, M.P., I.J. Witkind, and W.B. Cashion, 1990, Geologic map of the Price 30' $\times 60$ ' Quadrangle, Carbon, Duchesne, Uintah, Utah, and Wasatch counties, Utah: U.S. Geological Survey Miscellaneous Investigations Series I-1981, 1 Sheet (Scale 1:100,000).

West, R.M., 1976, Paleontology and geology of the Bridger Formation, southern Green River basin, southwestern Wyoming; Part 1, History of field work and geological setting:

Contributions in Biology and Geology,(7):12-12.

West, R.M., 1990, Vertebrate paleontology of the Green River Basin, Wyoming, 1840-1910: Earth Sciences History, 9(1):45-56.

West, R.M. and E.G. Atkins, 1970, Additional middle Eocene (Bridgerian) mammals from Tabernacle Butte, Sublette County, Wyoming: American Museum Novitates, 2404:26 pp.

West, R.M. and J.H. Hutchison, 1981, Geology and paleontology of the Bridger Formation, southern Green River basin, southwestern Wyoming; Part 6, The fauna and correlation of Bridger E: Contributions in Biology and Geology, 46:8 pp.

West, R.M. and M.R. Dawson, 1973, Fossil mammals from the upper part of the Cathedral Bluffs Tongue of the Wasatch Formation (early Bridgerian), northern Green River basin, Wyoming: Contributions to Geology, 12(1):33-41.

West, R.M. and M.R. Dawson, 1975, Eocene fossil Mammalia from the Sand Wash Basin, northwestern Moffat County, Colorado: Annals of Carnegie Museum, 45(Article 11):231-253.

Wheeler, W.H., 1961, Revision of the Uintatheres: Bulletin-Peabody Museum of Natural History: 93-93. 
Whitney, J.W., 1981, Surficial geologic map of the Grand Junction, 1 degree by 2 degrees quadrangle, Colorado and Utah: U.S. Geological Survey Miscellaneous Investigations Series I-1289, 1 Sheet (Scale 1:00,000).

Williams, B.A. and H.H. Covert, 1994, New Early Eocene anaptomorphine primate (Omomyidae) from the Washakie Basin, Wyoming, with comments on the phylogeny and paleobiology of anaptomorphines: American Journal of Physical Anthropology, 93:323-340.

Williams, P.L., 1972, Map showing types of bedrock and surficial deposits, Salina Quadrangle, Utah: U.S. Geological Survey Miscellaneous Investigations Series I-0591-H, 1 Sheet (Scale 1:250,000).

Wilson, J.A., 1978, Stratigraphic occurrence and correlation of early Tertiary vertebrate faunas, Trans-Pecos, Texas Part 1-Vieja area: Texas Memorial Museum Bulletin 25:1-42.

Wing, S.L., 1998, Tertiary vegetation of North America as a context for mammalian evolution, In: Evolution of Tertiary Mammals of North America (C.M. Janis, K.M. Scott and L.L. Jacobs, eds.), Cambridge University Press.

Witkind, I.J., 1988, Geologic map of the Huntington 30' $\times$ 60' Quadrangle, Carbon, Emery, Grand, and Uintah counties, Utah: U.S. Geological Survey Miscellaneous Investigations Series I-1764, 1 Sheet (Scale 1:100,000).

Witkind, I.J., 1995, Geologic map of the Price 1 degree $\times 2$ degrees Quadrangle, Utah: U.S. Geological Survey Miscellaneous Investigations Series I-2462, 1 Sheet (Scale 1:250,000).

Witkind, I.J. and M.P. Weiss, 1991, Geologic map of the Nephi 30' × 60' Quadrangle, Carbon, Emery, Juab, Sanpete, Utah, and Wasatch counties, Utah: U.S. Geological Survey Miscellaneous Investigations Series I-1937, 1 Sheet plus Pamphlet (Scale 1:100,000).

Wood, H.E., 1934, Revision of the Hyrachyidae: American Museum of Natural History Bulletin, 67(5):181-295.

Wood, H.E., R.W. Chaney, J.Clark, E.H. Colbert, G.L. Jepsen, J.J.B. Reeside, and C. Stock, 1941, Nomenclature and correlation of the North American continental Tertiary: Bulletin of the Geological Society of America, 52:1-48.

Woodburne, M.O. and C.C.I. Swisher, 1995, Land mammal high-resolution geochronology, intercontinental overland dispersals, sea level, climate, and vicariance, In: Geochronology, Time Scales, and Global Stratigraphic Correlations: Unified Temporal Framework for an Historical Geology (W.A. Berggren, D.V. Kent, M.P. Aubry, and J. Hardenbol, eds.), SEPM Special Publication No. 54. 337-364.

Woodruff, E.G., 1912, Geology of the San Juan oil field, Utah: U.S. Geological Survey Bulletin, 471-A:76-104. 
Yeend, W.E., J.R. Donnell, and M.C. Smith, 1988, Geologic map of the Rulison Quadrangle, Garfield County, Colorado: U.S. Geological Survey Miscellaneous Field Studies Map MF-2060, 1 Sheet (Scale 1:24,000).

Zonneveld, J.-P., G.F. Gunnell, and W.S. Bartels, 2000a, Early Eocene fossil vertebrates from the southwestern Green River basin, Lincoln and Uinta counties, Wyoming: Journal of Vertebrate Paleontology, 20(2):369-386.

Zonneveld, J.-P., J.M. Lavigne, and W.S. Bartels, 2000b, Ichnology of an early Eocene meandering fluvial system, Wasatch Formation, Fossil Butte National Monument, Wyoming: Geological Society of America Abstracts, 32(7):309. 


\section{GLOSSARY}

Amniote: Tetrapod vertebrate animals that lay shelled eggs (e.g., reptiles and birds).

Biochronology: The relative dating of geologic events on the basis of fossil evidence.

Biogeography: The geographic distributions of animal and plant species.

Biostratigraphy: The science of dating rocks by using the fossils contained within them. Usually the aim is correlation, that is, demonstrating that a particular horizon in one geological section represents the same period of time as another horizon at some other section. The fossils are useful because sediments of the same age can look completely different because of local variations in the sedimentary environment.

Diagenesis: With regard to the earth sciences, diagenesis refers to all the chemical, physical, and biological changes undergone by a sediment after its initial deposition, and during and after its lithification, exclusive of surface alteration (weathering). Diagenesis is the lowest grade of metamorphism.

Evolution: The sequence of events involved in the evolutionary development of a species or taxonomic group of organisms. In the context of the life sciences, evolution is change in the genetic makeup of a group - a population of interbreeding individuals within a species. Such a population shares a common gene pool, and members exhibit a degree of genetic relatedness.

Extinction: The disappearance of a species or group of species. The moment of extinction is generally considered to be the death of the last individual of that species.
Facies: Every depositional environment puts its own distinctive imprint on the sediment, making a particular facies. Thus, a facies is a distinct kind of rock for that area or environment.

Fluvial: Pertaining to rivers, streams, and floodplains.

Holotype: A holotype (sometimes simply type) is the single physical example or illustration of an organism that defines the characteristics of the whole species. It is the definitive member of that species. Other specimens can be compared with the holotype to determine whether they are actually a member of that species.

Ichnofossil: Trace fossil. A fossil that preserves animal behavior (footprints, burrows, bite marks, scratches, etc.).

Invertebrate: Animals without backbones (e.g., mollusks, sea urchins, insects, and spiders).

Lacustrine: Pertaining to lakes.

Ma: Megannum $=$ millions of years before present.

Paleoecology: The study of the interactions between ancient organisms and their environments, including their life cycles, interactions, natural environment, and manner of death and burial. Paleoecology's aim is to build the most detailed model possible of the life environment of those organisms found today as fossils.

Paleoenvironment: Pertaining to ancient environments. 
Phylogenetics: The study of the evolutionary interrelationships of living things in order to interpret the way life has diversified and changed over time.

Provenance: The area from which the constitutent particles of sedimentary rock or sedimentary lithofacies were derived; the stratigraphic and geographic origin (locality) of a fossil.

Speciation: The process leading to the creation of new species; it is one form of biological evolution. Speciation occurs when a parent species splits into two (or more) reproductively isolated populations, each of which then accumulates changes from sexual reproduction and/or random mutation until the populations are no longer capable of interbreeding.

Stromatolite: Stromatolites are commonly thought to have been formed by the trapping, binding, and cementation of sedimentary grains by microorganisms, especially blue-green algae (cyanobacteria).

Surficial: Pertaining to or lying in or on the surface. Sediments covering bedrock.
Taphonomy: The study of what happens to an organism's remains from the time of death until discovery by a paleontologist in an attempt to better interpret the fossil record and conditions responsible for fossil preservation. It includes processes such as scavenging, weathering, transport, and diagenesis.

Temporal: Refers to geologic time for the purposes of this report.

Tectonic: Tectonics is a field of study within geology concerned generally with the structure of the earth's crust and particularly with the forces and movements that have operated in a region to create geomorphic features.

Tetrapod: A four-legged vertebrate animal. The term commonly applies to late Paleozoic terrestrial vertebrates (amphibians and reptiles).

Vertebrate: Animals with vertebrae (back bones), including fish, amphibians, reptiles, birds, and mammals. 


\section{APPENDIX A:}

BIBLIOGRAPHY OF RELEVANT LITERATURE AND TECHNICAL REPORTS FOR THE

OIL SHALE AND TAR SANDS PEIS STUDY AREA 


\section{APPENDIX A:}

\section{BIBLIOGRAPHY OF RELEVANT LITERATURE AND TECHNICAL REPORTS FOR THE OIL SHALE AND TAR SANDS PEIS STUDY AREA}

\section{A.1 GREATER GREEN RIVER BASIN, WYOMING AND COLORADO}

\section{A.1.1 Wasatch Formation}

Ambrose, P., W. S. Bartels, G. F. Gunnell, E. M. Williams, J. Bolt and L. Grande, 1997, Stratigraphy and vertebrate paleontology of the Wasatch Formation, Fossil Butte National Monument, Wyoming: Abstract, Fifty-seventh annual meeting, Society of Vertebrate Paleontology, Chicago, IL, United States, Oct. 8-11, 1997, 17(3, Suppl.):29.

Anemone, R. L., D. Bowen, L.-J. Davignon, D. Koepfer and D. J. Over, 1998, The Red Desert Basin Project; vertebrate paleontology and geology of an intermontane basin in southwestern Wyoming: Twenty-first annual fall scientific paper session, Rochester, NY, United States, Nov. 5, 1994, 18(3):71.

Beasley, B. A., 1991, A late Pleistocene avifauna from the Blonquist Rockshelter, Summit County, Utah: 123rd annual meeting, Kansas Academy of Science, Lindsborg, KS, United States, Apr. 11-12, 1991, 123:3.

Beasley, B. A., M. E. Nelson, G. A. Liggett, J. C. Pugh and S. R. Ash, 1992, Paleontological investigation at the Blonquist rockshelter, Summit County, Utah: Geological Society of America, Rocky Mountain Section and associated societies, 45th annual meeting, Ogden, UT, United States, May 13-15, 1992, 24(6):2.

Black, C. C. and M. R. Dawson, 1966, A review of late Eocene mammalian fauna from North America: American Journal of Science, 264:321-349.

Breithaupt, B. H., 1990, Early Tertiary fossils and environments of Wyoming; Jackson to Fossil Butte National Monument; Geologic field tours of western Wyoming and parts of adjacent Idaho, Montana, and Utah: Public Information Circular - Geological Survey of Wyoming, 29:57-72.

Bryant, B., C. W. Naeser, R. F. Marvin and H. H. Mehnert, 1989, Upper Cretaceous and Paleogene sedimentary rocks and isotopic ages of Paleogene tuffs, Uinta Basin, Utah: U.S. Geological Survey Bulletin, 1787-J:22 pp.

Cope, E. D., 1884, Vertebrata of the Tertiary Formations of the West: Report of the U.S. Geological Survey of the Territories, vol. 3. 


\section{A.1 GREATER GREEN RIVER BASIN, WYOMING AND COLORADO}

\section{A.1.1 Wasatch Formation (Cont.)}

Dawson, M. R., 1968, Middle Eocene rodents (Mammalia) from northeastern Utah: Annals of Carnegie Museum, 39:327-370.

Doi, K., 1990, Geology, and paleontology of two primate families of the Raven Ridge, northwestern Colorado and northeastern Utah: University of Colorado, Boulder, CO, United States (USA) Master's.

Dorr, J. A., Jr., 1978, Revised and amended fossil vertebrate faunal lists, early Tertiary, Hoback Basin, Wyoming: Contributions to Geology, 16(2):79-84.

Dorr, J. A., Jr. and P. D. Gingerich, 1980, Early Cenozoic mammalian paleontology, geologic structure, and tectonic history in the overthrust belt near LaBarge, western Wyoming: Contributions to Geology, University of Wyoming, 18(2):101-115.

Eaton, J. G., J. I. Kirkland and K. Doi, 1989, Evidence of reworked Cretaceous fossils and their bearing on the existence of Tertiary dinosaurs: Palaios, 4(3):281-286.

Fisher, E. J., C. E. Erdman and J. B. Reeside, Jr. , 1960, Cretaceous and Tertiary Formations of the Book Cliffs: Carbon, Emery, and Grand counties, Utah, and Garfield and Mesa counties, Colorado: U.S. Geological Survey Professional Paper, 332:80 pp.

Foster, J. R., 2000, Amphibian tracks (Ambystomichnus?) from the Cathedral Bluffs Tongue of the Wasatch Formation (Eocene), southwestern Wyoming: Geological Society of America, Rocky Mountain Section, 52nd annual meeting, Missoula, MT, United States, April 17-18, 2000, 32(5):8-9.

Foster, J. R., 2001, Salamander tracks (Ambystomichnus?) from the Cathedral Bluffs Tongue of the Wasatch Formation (Eocene), northeastern Green River basin, Wyoming: Journal of Paleontology, 75(4):901-904.

Gauthier, J. A., 1982, Fossil xenosaurid and anguid lizards from the early Eocene Wasatch Formation, Southeast Wyoming, and a revision of the Anguioidea: Contributions to Geology, 21(1):7-54.

Geo/Resource, 1984, Green River Basin geologic resources inventory: Unpublished Technical Report prepared for the Wyoming BLM.

Gingerich, P. D. and J. A. Dorr, Jr., 1979, Mandible of Chiromyoides minor (Mammalia, Primates) from the upper Paleocene Chappo Member of the Wasatch Formation, Wyoming: Journal of Paleontology, 53(3):550-552. 


\section{A.1 GREATER GREEN RIVER BASIN, WYOMING AND COLORADO}

\section{A.1.1 Wasatch Formation (Cont.)}

Granger, W. and G. G. Simpson, 1928, Multituberculates in the Wasatch Formation: American Museum Novitates, 312:4.

Gregson, J. D. and D. J. Chure, 2000, Geology and Paleontology of Dinosaur National Monument, Utah-Colorado, In: Geology of Utah's Parks and Monuments (D. A. Sprinkel, T. C. Chidsey Jr., and P. B. Anderson, eds.), Utah Geological Association Publication. 155-188.

Gunnell, G. F., 1994, Paleocene mammals and faunal analysis of the Chappo type locality (Tiffanian), Green River Basin, Wyoming: Journal of Vertebrate Paleontology, 14(1):81-104.

Gunnell, G. F., W. S. Bartels, J. Bolt and L. Grande, 1997, Basin-margin mammalian assemblages from the Wasatch Formation (Bridgerian) of the northeastern Green River Basin, Wyoming; anachronistic taxa and the origin of new genera: Abstracts, Fifty-seventh annual meeting, Society of Vertebrate Paleontology, Chicago, IL, United States, Oct. 8-11, 1997, 17(3, Suppl):51.

Gunnell, G. F., W. S. Bartels and J.-P. Zonneveld, 2004, A late Wasatchian (late early Eocene) vertebrate assemblage preserved in meandering stream channel deposits, northern Red Desert, Wyoming: Geological Society of America, 2004 annual meeting, Denver, CO, United States, Nov. 7-10, 2004, 36(5):92.

Gunnell, G. F., W. S. Bartels and J. P. Zonneveld, 2002, Stratigraphy, vertebrate paleontology, and paleoecology of the Wasatch Formation, Fossil Butte National Monument, Wyoming: Geological Society of America, 2002 annual meeting, Denver, CO, United States, Oct. 27-30, 2002, 34(6):557.

Gunnell, G. F. and V. L. Yarborough, 2000, Brontotheriidae (Perissodactyla) from the late early and middle Eocene (Bridgerian), Wasatch and Bridger formations, southern Green River basin, southwestern Wyoming: Journal of Vertebrate Paleontology, 20(2):349-368.

Gunnell, G. F., J. P. Zonneveld and W. S. Bartels, In Press, Stratigraphy, vertebrate paleontology, and paleoecology of the Wasatch Formation, Fossil Butte National Monument, Wyoming Part 2: mammalian paleontology and age correlation: Wyoming State Geological Survey.

Hail, W. J., Jr., 1990, Geology of the Lower Yellow Creek area, northwestern Colorado: U.S. Geological Survey Bulletin 1787-O:45 pp.

Haist, B., V. Santucci and A. Aase, 2002, The history of vertebrate paleontological fieldwork in Fossil Basin, Wyoming: Abstracts, Sixty-second annual meeting, Society of Vertebrate Paleontology, Norman, OK, United States, Oct. 9-12, 2002, 22(3, Suppl):62A. 


\section{A.1 GREATER GREEN RIVER BASIN, WYOMING AND COLORADO}

\section{A.1.1 Wasatch Formation (Cont.)}

Hamrick, M. W. and H. H. Covert, 1991, A late Wasatchian mammalian fauna from the Washakie Basin, Wyoming: Abstracts, Fifty-first annual meeting, Society of Vertebrate Paleontology, San Diego, CA, United States, Oct. 24-26, 1991, 11(3, Suppl):33.

Hanley, J. H., 1974, Systematics, paleoecology, and biostratigraphy of nonmarine Mollusca from the Green River and Wasatch formations (Eocene), southwestern Wyoming and northwestern Colorado: University of Wyoming, Laramie, WY, United States (USA) Doctoral.

Hanley, J. H., R. W. Scott and R. R. West, 1976, Paleosynecology of nonmarine Mollusca from the Green River and Wasatch formations (Eocene), southwestern Wyoming and northwestern Colorado, In: Structure and classification of paleocommunities (Anonymous, eds.), Dowden, Hutchinson \& Ross, Inc., Stroudsburg, Pa., United States (USA).

Hartman, J. H., 1993, The Paleocene-Eocene nonmarine molluscan transition in the United States: Abstracts, Fifty-third annual meeting, Society of Vertebrate Paleontology, Albuquerque, NM, United States, Oct. 13-16, 1993, 13(3, Suppl):41.

Hayden, F. V., 1873, First, Second, and Third Annual Reports Report of the U.S. Geological and Geographic Survey of the Territories, for the years 1867, 1868, and 1869: U.S. Government Printing Office, Washington. 261 pp.

Holbrook, L., S. Lucas, S. Ting, P. Gingerich, P. Higgins, B. Small and M. Fox, 2004, The skull of Lambdotherium (Mammalia, Perissodactyla) and its phylogenetic implications: Abstracts, Sixty-fourth annual meeting, Society of Vertebrate Paleontology, Denver, CO, United States, Nov. 3-6, 2004, 24(3, Suppl):71.

Holroyd, P. A., 2001, Contrasting early Eocene mammalian diversity and turnover in two contemporaneous Wyoming basins: Abstracts, Sixty-first annual meeting, Society of Vertebrate Paleontology, Bozeman, MT, United States, Oct. 3-6, 2001, 21(3, Suppl):62.

Holroyd, P. A., D. M. Erwin and J. H. Hutchison, 1997, Non-mammalian paleontology of the Wasatch Formation in the northern Green River basin, Wyoming: Geological Society of America, 1997 annual meeting, Salt Lake City, UT, United States, Oct. 20-23, 1997, 29(6):104-105.

Holroyd, P. A. and K. T. Smith, 2000, Preliminary biostratigraphic evidence for age of the Wasatch and Green River formations, Washakie Basin, southwestern Wyoming: Geological Society of America, 2000 annual meeting, Reno, NV, United States, Nov. 9-18, 2000, 32(7):498. 


\section{A.1 GREATER GREEN RIVER BASIN, WYOMING AND COLORADO}

\section{A.1.1 Wasatch Formation (Cont.)}

Honey, J. G., H. W. Roehler, J. H. Hanley and J. G. Honey, 1988, A mammalian fauna from the base of the Eocene Cathedral Bluffs Tongue of the Wasatch Formation, Cottonwood Creek area, Southeast Washakie Basin, Wyoming, In: Geology and paleoecology of the Cottonwood Creek delta in the Eocene Tipton Tongue of the Green River Formation and a mammalian fauna from the Eocene Cathedral Bluffs Tongue of the Wasatch Formation, Southeast Washakie Basin, Wyoming: U.S. Geological Survey Bulletin B 1669 A-C, p. C1-C14.

Kester, P. R. and A. K. Aase, 2002, Stratigraphic correlation of the early Cenozoic intermontane lacustrine deposits of Wyoming, Colorado, and Utah: Geological Society of America, 2002 annual meeting, Denver, CO, United States, Oct. 27-30, 2002, 34(6):558.

Kihm, A. J., 1984, Early Eocene mammalian faunas of the Piceance Creek basin, northwestern Colorado: University of Colorado, Boulder, CO, United States (USA) Doctoral.

Krishtalka, L., 1976, Early Tertiary Adapisoricidae and Erinaceidae (Mammalia, Insectivora) of North America: Bulletin of Carnegie Museum of Natural History,(1):40-40.

Leggitt, V. L., H. Buchheim and M. A. Loewen, 1999, First report of a fully articulated Presbyornis (Aves; Anseriformes) wing from a Colorado Presbyornis nesting site: Abstracts, Fifty-ninth annual meeting of the Society of Vertebrate Paleontology, Denver, CO, United States, Oct. 20-23, 1999, 19(3, Suppl):59.

Leggitt, V. L., R. Cushman, J., 2003, Flamingo nest mounds from a crocodilian nesting site in the Eocene Wasatch Formation; Lincoln County, Wyoming: Abstracts, Sixty-third annual meeting, Society of Vertebrate Paleontology, Science Museum of Minnesota, Saint Paul, MN, United States, Oct. 15-18, 2003, 23(3, Suppl):71.

Loewen, M. A., V. L. Leggitt, R. E. Biaggi, H. P. Buchheim and R. A. Cushman, Jr., 1999, Morphologic variation in caddisfly (Trichoptera) larval case architecture from the Eocene Green River and Wasatch formations of Wyoming: Geological Society of America, 1999 annual meeting, Denver, CO, United States, Oct. 25-28, 1999, 31(7):470.

Lucas, S. G. and L. T. Holbrook, 2004, The skull of the Eocene perissodactyl Lambdotherium and its phylogenetic significance; Paleogene mammals: Bulletin - New Mexico Museum of Natural History and Science, 26:81-87.

Lucas, S. G. and R. M. Schoch, 1990, Ontogenetic studies of early Cenozoic Coryphodon (Mammalia, Pantodonta): Journal of Paleontology, 64(5):831-841.

Matthew, W. D. and W. Granger, 1918, Fossil mammals of the Tiffany beds: Geological Society of America Bulletin, 29:152. 


\section{A.1 GREATER GREEN RIVER BASIN, WYOMING AND COLORADO}

\section{A.1.1 Wasatch Formation (Cont.)}

McGee, E., 2001, A mass death accumulation of Coryphodon anthracoideus (Mammalia, Pantodonta) at Roehler's Coryphodon Catastrophe Quarry (lower Eocene, Wasatch Formation), Washakie Basin, Wyoming; Eocene biodiversity; unusual occurrences and rarely sampled habitats: Topics in Geobiology, 18:317-333.

McGee, E. M., 1993, The taphonomy of Roehler's Coryphodon Catastrophe Quarry (lower Eocene, Wasatch Formation, Washakie Basin, Wyoming): Abstracts, Fifty-third annual meeting, Society of Vertebrate Paleontology, Albuquerque, NM, United States, Oct. 13-16, 1993, 13(3, Suppl):49.

McGee, E. M., 2002, Intraspecific dental variability in cf. Coryphodon anthracoideus (Mammalia, Pantodonta) from Roehler's Coryphodon Catastrophe Quarry, Washakie Basin, Wyoming: Rocky Mountain Geology, 37(1):61-73.

McGrew, P. O. and T. M. Bown, 1976, Fossil vertebrate faunas: Green Mountain, Ferris-Seven Lakes, and Sandy EIS areas, and Sweetwater County, Wyoming: Unpublished technical report prepared for the Wyoming BLM. $422 \mathrm{pp}$.

McGrew, P. O. and T. M. Bown, 1977, Fossil vertebrate faunas: Carbon, Lincoln, and Uinta Counties, Wyoming: Unpublished technical report prepared for the Wyoming BLM. $251 \mathrm{pp}$.

McKenna, M. C., 1955, Age of the Four Mile Local Fauna, northeast Sand Wash Basin, Colorado: Wyoming Geological Association Guidebook:105-107.

McKenna, M. C., 1958, Fossil Mammalia from the early Wasatchian Four Mile fauna, Eocene of Northwest Colorado: University of California, Berkeley, Berkeley, CA, United States (USA) Doctoral.

McKenna, M. C., 1960, Fossil Mammalia from the early Wasatchian Four Mile fauna, Eocene of northwest Colorado: University of California Publications in Geological Sciences, 37(1):1-130.

Mellett, J. S., 1982, Paleontologic resource inventory, Bookcliffs and Grand Hogback areas, western Colorado, Vols. 1 and 2: Unpublished BLM Report.

Nachman, B. A., 1998, Geology and vertebrate paleontology of the Great Divide Basin, SW Wyoming; Twenty-third annual fall scientific paper session [modified]: Twenty-third annual fall scientific paper session, Brockport, NY, United States, Nov. 23, 1996, 18(3):101.

Novacek, M., 1977, A review of Paleocene and Eocene Leptictidae (Eutheria; Mammalia) from North America: PaleoBios,(24):42-42. 


\section{A.1 GREATER GREEN RIVER BASIN, WYOMING AND COLORADO}

\section{A.1.1 Wasatch Formation (Cont.)}

Oriel, S. F. and J. I. Tracey 1970, Uppermost Cretaceous and Tertiary stratigraphy of Fossil Basin, southwest Wyoming: U.S. Geological Survey Professional Paper 635:53 pp.

Osborn, H. F. and J. L. Wortman, 1892, Fossil mammals of the Wasatch and Wind River beds: Bulletin of the American Museum of Natural History, 4:81-147.

Podorsky, R. A., 1981, The stratigraphy and mammalian paleontology of the Wasatch Formation (Eocene), Fossil Butte National Monument, Lincoln County, Wyoming: Fort Hays State University, Hays, KS, United States (USA) Master's.

Rich, F. J., D. M. Johnson and T. V. Durkin, 2001, Occurrence and paleoecology of Marsilea from the Eocene Wasatch: Palaios, 16:608-613.

Robinson, P., 1978, Paleontological resources inventory and evaluation, Bureau of Mines Experimental Oil Shale Mine, Rio Blanco County, Colorado: Prepared for VTN Colorado, Inc. 2600 S. Parker Rd., Aurora, Colorado. 22 pp.

Robinson, P., D. J. Daitch and J. E. Haessig, 2000, Fossil vertebrate localities of southwestern Wyoming: a literature search, locality record, and formation evaluation: Unpublished technical report prepared for the Wyoming BLM.

Robinson, P., G. F. Gunnell, S. L. Walsh, W. C. Clyde, J. E. Storer, R. K. Stucky, D. J. Froehlich, I. F. Villafranca and M. C. McKenna, 2004, Wasatchian though Duschesnean biochronology, In: Late Cretaceous and Cenozoic Mammals of North America (M. O. Woodburne, ed.), Columbia University Press. 106-155.

Roehler, H. W., 1992a, Geology of the Eocene Wasatch, Green River, and Bridger (Washakie) Formations, Greater Green River Basin, Wyoming, Utah and Colorado: Introduction to Greater Green River Basin Geology, Physiography, and History of Investigations: U.S. Geological Survey Professional Paper 1506-A:14.

Roehler, H. W., 1992b, Geology of the Eocene Wasatch, Green River, and Bridger (Washakie) Formations, Greater Green River Basin, Wyoming, Utah and Colorado: Description and Correlation of Eocene Rocks in Stratigraphic Reference Sections for the Green River and Washakie Basin, Southwest Wyoming: U.S. Geological Survey Professional Paper 1506-D:83 pp.

Roehler, H. W., 1992c, Geology of the Eocene Wasatch, Green River, and Bridger (Washakie) Formations, Greater Green River Basin, Wyoming, Utah and Colorado: Correlation, Composition, Areal Distribution, and Thickness of Eocene Stratigraphic Units, Greater Green River Basin, Wyoming, Utah, and Colorado: U.S. Geological Survey Professional Paper 1506-E:49 pp. 


\section{A.1 GREATER GREEN RIVER BASIN, WYOMING AND COLORADO}

\section{A.1.1 Wasatch Formation (Cont.)}

Roehler, H. W., 1993, Geology of the Eocene Wasatch, Green River, and Bridger (Washakie) Formations, Greater Green River Basin, Wyoming, Utah and Colorado: Eocene Climates, Depositional Environments, and Geography, Greater Green River Basin, Wyoming, Utah and Colorado: U.S. Geological Survey Professional Paper 1506-F:74 pp.

Rose, K. D., 1977, Evolution of carpolestid primates and chronology of the North American middle and late Paleocene: Journal of Paleontology, 51(3):536-542.

Rose, K. D., T. M. Bown and E. L. Simons, 1977, An unusual new mammal from the early Eocene of Wyoming: Postilla,(172):10-10.

Savage, D. E. and D. E. Russell, 1983, Mammalian Paleofauna of the World: Addison-Wesley Publ. Co. 432 pp.

Savage, D. E. and B. T. Waters, 1978, A new omomyid primate from the Wasatch Formation of southern Wyoming: Folia Primatologica, 30(1):1-29.

Simnacher, F., 1970, Stratigraphy, depositional environments and paleontology of the Cathedral Bluffs tongue of the Wasatch Formation (Eocene), Parnell Creek area, Sweetwater County, Wyoming: University of Wyoming, Laramie, WY, United States (USA) Master's.

Simpson, G. G., 1935, The Tiffany fauna, upper Paleocene; 2, Structure and relationships of Plesiadapis: American Museum Novitates, 816:30.

Stidham, T. A., 1998, Phylogenetic and ecological diversification of waterfowl (Anseriformes) in the Late Cretaceous and Paleogene: Abstracts, Fifty-eighth annual meeting, Society of Vertebrate Paleontology, Snowbird, UT, United States, Sept. 30-Oct. 3, 1998, 18(3, Suppl):80.

Stidham, T. A., 2000, Morphometrics and the paleobiology of Presbyornithidae (Neornithes, Anseriformes): Geological Society of America, 2000 annual meeting, Reno, NV, United States, Nov. 9-18, 2000, 32(7):15.

Stokes, W. L., 1986, Geology of Utah: Utah Museum of Natural History, University of Utah and Utah Geological and Mineral Survey, Department of Natural Resources.

Stucky, R. K., 1984, The Wasatchian-Bridgerian land mammal age boundary (Early to Middle Eocene) in western North America: Annals of the Carnegie Museum of Natural History, 53:347-382. 


\section{A.1 GREATER GREEN RIVER BASIN, WYOMING AND COLORADO}

\section{A.1.1 Wasatch Formation (Cont.)}

Townsend, K. and C. Harrisville-Wolff, 1993, A new species of Hyopsodus from the upper Graybull Beds of the Wasatchian from the Washakie Basin, Wyoming: Abstracts, Fifty-third annual meeting, Society of Vertebrate Paleontology, Albuquerque, NM, United States, Oct. 13-16, 1993, 13(3, Suppl):60.

Veatch, A. C., 1907, Geography and geology of a portion of southwestern Wyoming: U.S. Geological Survey Professional Paper 56:163 pp.

West, R. M., 1973, Geology and mammalian paleontology of the New Fork-Big Sandy area, Sublette County, Wyoming: Fieldiana: Geology (New Series), 29:193.

West, R. M. and M. R. Dawson, 1973, Fossil mammals from the upper part of the Cathedral Bluffs Tongue of the Wasatch Formation (early Bridgerian), northern Green River basin, Wyoming: Contributions to Geology, 12(1):33-41.

Wideman, N. K. and P. A. Holroyd, 1998, Coryphodon in the greater Green River basin, SW Wyoming; possible climatic \& taphonomic factors influencing distribution: Abstracts, Fifty eighth annual meeting, Society of Vertebrate Paleontology, Snowbird, UT, United States, Sept. 30-Oct. 3, 1998, 18(3, Suppl):86.

Williams, B. A. and H. H. Covert, 1994, New Early Eocene anaptomorphine primate (Omomyidae) from the Washakie Basin, Wyoming, with comments on the phylogeny and paleobiology of anaptomorphines: American Journal of Physical Anthropology, 93:323-340.

Williamson, C., S. Strait, P. Holroyd, S. Ting, P. Gingerich, P. Higgins, B. Small and M. Fox, 2004, Rodents from a catastrophic assemblage in the early Eocene main body of the Wasatch Formation, Washakie Basin, Wyoming: Abstracts, Sixty-fourth annual meeting, Society of Vertebrate Paleontology, Denver, CO, United States, Nov. 3-6, 2004, 24(3, Suppl):129.

Williamson, T. E., 1998, Meniscotherium mass-death assemblages; Abstracts of papers: Abstracts, Fifty-eighth annual meeting, Society of Vertebrate Paleontology, Snowbird, UT, United States, Sept. 30-Oct. 3, 1998, 18(3, Suppl):86.

Williamson, T. E., 2001, Meniscotherium mass-death assemblages; Eocene biodiversity; unusual occurrences and rarely sampled habitats: Topics in Geobiology, 18:335-360.

Winterfeld, G. F., 1982, Mammalian paleontology of the Fort Union Formation (Paleocene), eastern Rock Springs Uplift, Sweetwater County, Wyoming: Contributions to Geology, 21(1):73-111. 


\section{A.1 GREATER GREEN RIVER BASIN, WYOMING AND COLORADO}

\section{A.1.1 Wasatch Formation (Cont.)}

Wood, H. E., R. W. Chaney, J. Clark, E. H. Colbert, G. L. Jepsen, J. J. B. Reeside and C. Stock, 1941, Nomenclature and correlation of the North American continental Tertiary: Bulletin of the Geological Society of America, 52:1-48.

Woodburne, M. O. and C. C. I. Swisher, 1995, Land mammal high-resolution geochronology, intercontinental overland dispersals, sea level, climate, and vicariance, In: Geochronology, Time Scales, and Global Stratigraphic Correlations: Unified Temporal Framework for an Historical Geology (W. A. Berggren, D. V. Kent, M. P. Aubry and J. Hardenbol, eds.), SEPM Special Publication no. 54. 337-364.

Zack, S. P., 2004, An early Eocene arctostylopid (Mammalia, Arctostylopida) from the Green River basin, Wyoming: Journal of Vertebrate Paleontology, 24(2):498-501.

Zonneveld, J.-P. and G. F. Gunnell, 2003, A new species of cf. Dilophodon (Mammalia, Perissodactyla) from the early Bridgerian of southwestern Wyoming: Journal of Vertebrate Paleontology, 23(3):652-658.

Zonneveld, J.-P., G. F. Gunnell and W. S. Bartels, 2000, Early Eocene fossil vertebrates from the southwestern Green River basin, Lincoln and Uinta counties, Wyoming: Journal of Vertebrate Paleontology, 20(2):369-386.

Zonneveld, J. P., W. S. Bartels, S. D. Wolfe, G. F. Gunnell and J. I. Bloch, 2001, The occurrence of fossil vertebrates along strandlines of Paleolake Gosiute, Wasatch Formation, South Pass, Wyoming: Abstracts, Sixty-first annual meeting, Society of Vertebrate Paleontology, Bozeman, MT, United States, Oct. 3-6, 2001, 21(3, Suppl):117.

Zonneveld, J. P., J. M. Lavigne and W. S. Bartels, 2000, Ichnology of an early Eocene meandering fluvial system, Wasatch Formation, Fossil Butte National Monument, Wyoming: Geologic Society of America Abstracts with Programs, 32(7):309. 


\section{A.1 GREATER GREEN RIVER BASIN, WYOMING AND COLORADO}

\section{A.1.2 Green River Formation}

Allmon, W. D., 2005, Paleontology of "turritella agate", a pleurocerid gastropod-dominated assemblage from the Eocene Green River Formation of Wyoming: Geological Society of America, Northeastern Section, 40th annual meeting, Saratoga Springs, NY, United States, March 14-16, 2005, 37(1):19.

Amato, T. J., H. P. Buchheim, R. A. Cushman and R. E. Biaggi, 2002, Climate change, salinity gradient or marginal freshwater lagoon? The story behind a unique fossiliferous unit of the Green River Formation in Fossil Basin, Wyoming: Geological Society of America, 2002 annual meeting, Denver, CO, United States, Oct. 27-30, 2002, 34(6):555.

Armstrong, H., 1991, Class I paleontological data inventory along a proposed highway route with alternates from Ouray to Cisco, Uintah and Grand Counties, Utah: Unpublished BLM Report. 1-211.

Armstrong, H. J. and D. G. Wolny, 1989, Paleontological resources of Northwest Colorado: A regional analysis: Museum of Western Colorado, Grand Junction.

Barclay, R. S., W. D. Bateman, K. R. Johnson, S. B. Wagner and M. L. Graham, 2003, The Parachute Creek Atlas Project; deciphering the floral diversity of the Green River Formation of Colorado and Utah: Geological Society of America, 2003 annual meeting, Seattle, WA, United States, Nov. 2-5, 2003, 35(6):588.

Bartels, W. S., 1993, Niche separation of fluvial and lacustrine reptiles from the Eocene Green River and Bridger formations of Wyoming: Abstracts, Fifty-third annual meeting, Society of Vertebrate Paleontology, Albuquerque, NM, United States, Oct. 13-16, 1993, 13(3, Suppl):25. Benton, R., 1993, Fossil Butte National Monument, Kemmerer, Wyoming: Rocks and Minerals, 68(3):180-182.

Benton, R. C., 1999, Comparative taphonomy of Holocene microvertebrate faunas preserved in fissure fill versus shelter cave deposits: University of Iowa, Iowa City, IA, United States (USA) Doctoral.

Biaggi, R. E., H. P. Buchheim and R. A. Cushman, Jr., 2000, Deposition of a laminated, fossil rich facies in a nearshore oxic paleoenvironment, Eocene Lake Gosiute, Wyoming: Geological Society of America, 2000 annual meeting, Reno, NV, United States, Nov. 9-18, 2000, 32(7):415.

Biaggi, R. E., V. L. Leggitt and H. P. Buchheim, 1999, Caddisfly (Insecta; Trichoptera) larvae mounds from the Eocene Tipton Member, Green River Formation, Wyoming: Geological Society of America, 1999 annual meeting, Denver, CO, United States, Oct. 25-28, 1999, 31(7):242. 


\section{A.1 GREATER GREEN RIVER BASIN, WYOMING AND COLORADO}

\section{A.1.2 Green River Formation (Cont.)}

Bilbey, S. A., 2001, Final Paleontologic Report for the American Soda LLP Yankee Gulch Sodium Minerals Project, Parachute to Piceance Creek, Pipeline, Well Sites, Processing Plant, Garfield and Rio Blanco Counties, Colorado:81 pp.

Black, C. C. and M. R. Dawson, 1966, A review of late Eocene mammalian fauna from North America: American Journal of Science, 264:321-349.

Black, C. C. and M. R. Dawson, 1966, A review of late Eocene mammalian faunas from North America: American Journal of Science, 264:321-349.

Black, C. C. and J. F. Sutton, 1984, Paleocene and Eocene rodents of North America; Papers in vertebrate paleontology honoring Robert Warren Wilson: Special Publication of Carnegie Museum of Natural History, 9:67-84.

Bradley, W. H., 1924, Fossil caddice fly cases from the Green River Formation of Wyoming: American Journal of Science, 7:310-312.

Bradley, W. H., 1926a, Fossil rhizopods of the Green River oil shale: Geological Society of America Bulletin, 37(1):160.

Bradley, W. H., 1926b, Shore fazes of the Green River Formation in northern Sweetwater County, Wyoming: U.S. Geological Survey Professional Paper 140-D:121-131.

Bradley, W.H., 1929, The varves and climate of the Green River epoch: U.S. Geological Survey Professional Paper 158-E, p. 87-110.

Bradley, W. H., 1931, Origin and microfossils of the Green River Formation of Colorado and Utah: U.S. Geological Survey Professional Paper 168:58.

Bradley, W. H., 1959, Revision of stratigraphic nomenclature of Green River Formation of Wyoming: American Association of Petroleum Geologists Bulletin, 43(5):1072-1075.

Bradley, W. H., 1962, Chloroplast in Spirogyra from the Green River Formation of Wyoming: American Journal of Science, 260(6):455-459.

Bradley, W. H., 1964a, Geology of Green River Formation and associated Eocene rocks in southwestern Wyoming and adjacent parts of Colorado and Utah: U.S. Geological Survey Professional Paper 496-A:1-86.

Bradley, W. H., 1964b, Aquatic fungi from the Green River Formation of Wyoming: American Journal of Science, 262(3):413-416. 


\section{A.1 GREATER GREEN RIVER BASIN, WYOMING AND COLORADO}

\section{A.1.2 Green River Formation (Cont.)}

Bradley, W. H., 1967, Two aquatic fungi (Chytridiales) of Eocene age from the Green River Formation of Wyoming: American Journal of Botany, 54(5, Part 1):577-582.

Bradley, W. H., 1969, Geochemistry and paleolimnology of the trona deposits and associated authigenic minerals of the Green River Formation of Wyoming: U.S. Geological Survey Professional Paper 496-B:71 pp.

Bradley, W. H., 1974, Oocardium tufa from the Eocene Green River Formation of Wyoming: Journal of Paleontology, 48(6):1289-1290.

Breithaupt, B. H., 1990, Early Tertiary fossils and environments of Wyoming; Jackson to Fossil Butte National Monument; Geologic field tours of western Wyoming and parts of adjacent Idaho, Montana, and Utah: Public Information Circular - Geological Survey of Wyoming, 29:57-72.

Brodkorb, P., 1965, New taxa of fossil birds: Florida Scientist, 28(2):197-198.

Brodkorb, P., 1970, An Eocene puffbird from Wyoming: Contributions to Geology, 9(1):13-15.

Bruner, J. C., 1991, Comments on the genus Amyzon (family Catostomidae): Journal of Paleontology, 65(4):678-686.

Bryant, B., C. W. Naeser, R. F. Marvin and H. H. Mehnert, 1989, Upper Cretaceous and Paleogene sedimentary rocks and isotopic ages of Paleogene tuffs, Uinta Basin, Utah: U.S. Geological Survey Bulletin, 1787-J:22 pp.

Buchheim, H. P., 1986, Paleoenvironments and sediment-fossil fish relationships; a case study from the Eocene Green River Formation, Wyoming; Fourth North American paleontological convention: Fourth North American paleontological convention, Boulder, CO, United States, Aug. 12-15, 1986, 4:A7.

Buchheim, H. P., 1994, Paleoenvironments, lithofacies, and varves of the Fossil Butte Member of the Eocene Green River Formation, Southwestern Wyoming: Contributions to Geology, University of Wyoming, 30(1):3-14.

Buchheim, H. P. and R. C. Surdam (1977). Paleoenvironments and fossil fishes of the Laney Member, Green River Formation, Wyoming; Communities of the past: Second North American paleontology convention, Lawrence, KS, United States (USA), Hutchinson Ross Publ. Co., Stroudsburg, PA, United States (USA). 


\section{A.1 GREATER GREEN RIVER BASIN, WYOMING AND COLORADO}

\section{A.1.2 Green River Formation (Cont.)}

Buchheim, H. P. and R. C. Surdam, 1981, Paleoenvironments and fossil fishes of the Laney Member, Green River Formation, Wyoming, In: Communities of the Past (J. Gray, ed.), Hutchinson and Ross Publishing Company, Pennsylvania. 415-452.

Buchheim, H. P. and R. C. Surdam, 1984, Fossil catfish in the Green River Formation, Wyoming; new discoveries and implications to depositional models; On research and exploration projects supported by the National Geographic Society for which an initial grant or continuing support was provided in the year 1976: Research Reports - National Geographic Society, $17: 245-255$.

Carpenter, F. M., 1928, A scorpion-fly from the Green River Eocene: Annals of Carnegie Museum, 18, Part 1(1):241-248.

Carvalho, M., L. Grande, J. Maisey, 2003, The evolution of stingrays (Chondrichthyes, Myliobatiformes), with special reference to the freshwater stingrays of the Green River Formation of Wyoming (early Eocene): Abstracts, Sixty-third annual meeting, Society of Vertebrate Paleontology, Science Museum of Minnesota, Saint Paul, MN, United States, Oct. 15-18, 2003, 23(3, Suppl):39.

Cashion, W. B., 1967, Geology and fuel resources of the Green River Formation, southeastern Uinta Basin Utah and Colorado: U.S. Geological Survey Professional Paper 548:48.

Cashion, W. B. and J. R. Donnell, 1974, Revision of nomenclature of the upper part of the Green River Formation, Piceance Creek Basin, Colorado, and eastern Uinta Basin, Utah: U.S. Geological Survey Bulletin 1394-G:G1-G9.

Chadey, H. F., 1973, Historical Aspects of the Green River Basin, Wyoming: Wyoming Geological Association, 25th Field Conference on the geology and mineral resources of the greater Green River Basin, Wyoming:27-33.

Cockerell, T. D. A., 1922, An ancient wasp [Hoplisus archorytes, Bear Gulch, Green River Formation, Colorado]: Nature (London), 110:313.

Cockerell, T. D. A., 1925, Plant and insect fossils from the Green River Eocene of Colorado: Proceedings of the United States National Museum, 66(19):13.

Cockerell, T. D. A., 1926, Plant and Insect Fossils from the Green River Eocene of Colorado: Proceedings of the United States National Museum, 66:1-13.

Cockerell, T. D. A., 1936, Tertiary floras: Science, 83(2154):350-351. 


\section{A.1 GREATER GREEN RIVER BASIN, WYOMING AND COLORADO}

\section{A.1.2 Green River Formation (Cont.)}

Codington, L. A., 1992a, Fossil spider web from the Eocene of western Colorado: 124th annual meeting of the Kansas Academy of Science, Hutchinson, KS, United States, March 26-27, 1992, 11:6.

Codington, L. A., 1992b, Fossil spider web from the Eocene of western Colorado: Geological Society of America, 1992 annual meeting, Cincinnati, OH, United States, Oct. 26-29, 1992, 24(7):344.

Codington, L. A., 1993, Climatic implications of terrestrial arthropods from the Parachute Creek Member (middle Eocene), Green River Formation, Garfield County, Colorado: Fort Hays State University, Hays, KS, United States (USA) Master's.

Codington, L. A., 1993, New locality for fossil insects in the Green River Formation, western Colorado: The Compass, 70(3):90-91.

Cole, R. D. and M. D. Picard, 1978, Comparative mineralogy of nearshore and offshore lacustrine lithofacies, Parachute Creek Member of the Green River Formation, Piceance Creek Basin, Colorado, and eastern Uinta Basin, Utah: Geological Society of America Bulletin, 89:1441-1454.

Conrad, J. L., 2002, First fossil relative of Shinisaurus (Anguimorpha, Squamata) and the phylogenetic importance of Shinisauridae: Abstracts, Sixty-second annual meeting, Society of Vertebrate Paleontology, Norman, OK, United States, Oct. 9-12, 2002, 22(3, Suppl):46A.

Cope, E. D., 1884, Vertebrata of the Tertiary Formations of the West: Report of the U.S. Geological Survey of the Territories, vol. 3.

Crepet, W. L., D. L. Dilcher and W. L. Crepet, 1984, Advanced (constant) insect pollination mechanisms; pattern of evolution and implications vis-a-vis angiosperm diversity; Historical perspectives of angiosperm evolution: Thirtieth annual symposium, St. Louis, MO, United States, 1984, 71(2):607-630.

Dane, C. H., 1954, Stratigraphic and facies relationships of upper part of Green River Formation and lower part of Uinta Formation in Duchesne, Uintah, Wasatch Counties, Utah: American Association of Petroleum Geologists Bulletin, 38:405-425.

Davis, P. G. and D. E. G. Briggs, 1998, The impact of decay and disarticulation on the preservation of fossil birds: Palaios, 13(1):3-13.

Dawson, M. R., 1968, Middle Eocene rodents (Mammalia) from northeastern Utah: Annals of Carnegie Museum, 39:327-370. 


\section{A.1 GREATER GREEN RIVER BASIN, WYOMING AND COLORADO}

\section{A.1.2 Green River Formation (Cont.)}

Dayvault, R. and A. Gorski, 1989, Fossils from the Green River Formation, Douglas Pass area, Colorado: Rocks and Minerals, 64(2):134-139.

Dayvault, R. D., 1992, The Green River Formation fossil quarries of Wyoming: Rocks and Minerals, 67(4):256-261.

de Carvalho, M. R., J. G. Maisey and L. Grande, 2004, Freshwater stingrays of the Green River Formation of Wyoming (early Eocene), with the description of a new genus and species and an analysis of its phylogenetic relationships (Chondrichthyes, Myliobatiformes): Bulletin of the American Museum of Natural History, 284:136.

Dlussky, G. M. and K. S. Perfilieva, 2003, Paleogene ants of the genus Archimyrmex Cockerell, 1923 (Hymenoptera, Formicidae, Myrmeciinae): Paleontological Journal, 37(1):39-47.

Doi, K., 1990, Geology, and paleontology of two primate families of the Raven Ridge, northwestern Colorado and northeastern Utah: University of Colorado, Boulder, CO, United States (USA) Master's.

Dorr, J. A., Jr. and P. D. Gingerich, 1980, Early Cenozoic mammalian paleontology, geologic structure, and tectonic history in the overthrust belt near LaBarge, western Wyoming Contributions to Geology, University of Wyoming, 18(2):101-115.

Duncan, D. C., W. J. Hail, Jr., R. B. O’Sullivan and G. N. Pipiringos, 1974, Four newly named tongues of the Eocene Green River Formation, northern Piceance Creek Basin, Colorado: U.S. Geological Survey Bulletin 1394-F:F1-F13.

Durden, C. J. and H. Rose, 1978, Butterflies from the middle Eocene; the earliest occurrence of fossil Papilionoidea (Lepidoptera): The Pearce-Sellards Series,(29):25-25.

Eastman, J. T., 1980, The caudal skeletons of catostomid fishes: American Midland Naturalist, 103(1):133-148.

Edwards, P., 1976, Fish coprolites from Fossil Butte, Wyoming: Contributions to Geology, 14(2):115-117.

Edwards, P. D., 1975, Preliminary notes on fish coprolites from the Green River Formation (Eocene) of Wyoming: Proceedings of the Nebraska Academy of Sciences and Affiliated Societies, 85:40.

Erickson, B. R., 1967, Fossil bird tracks from Utah: Museum Observer, 5(1):6-12.

Feduccia, A., 1973, A new Eocene Zygodactyl bird: Journal of Paleontology, 47(3):501-503. 


\section{A.1 GREATER GREEN RIVER BASIN, WYOMING AND COLORADO}

\section{A.1.2 Green River Formation (Cont.)}

Feduccia, A., 1976, Neanis schucherti restudied; another Eocene piciform bird: Smithsonian Contributions to Paleobiology, no.27, Coll. .pap. avian paleontol. honoring 90th birthday A.Wetmore:95-99.

Feduccia, A., 1978, Presbyornis and the evolution of ducks and flamingos: American Scientist, 66(3):298-304.

Feduccia, A. and L. D. Martin, 1976, The Eocene zygodactyl birds of North America (Aves; Piciformes): Smithsonian Contributions to Paleobiology, no.27, Coll. pap. avian paleontol. honoring 90th birthday A. Wetmore:101-110.

Feduccia, A. and P. O. McGrew, 1984, The rediscovery of the avian fossil Presbyornis from the Eocene of Wyoming; On research and exploration projects supported by the National Geographic Society, for which an initial grant or continuing support was provided in the year 1975: Research Reports - National Geographic Society, 16:481-485.

Feldmann, R. M., L. Grande, C. P. Birkhimer, J. T. Hannibal and D. L. McCoy, 1981, Decapod fauna of the Green River Formation (Eocene) of Wyoming: Journal of Paleontology, 55(4):788-799.

Ferber, C. T., 1987, Environmental interpretation of fish deposits in the Eocene Green River Formation of Utah and Wyoming: Kent State University, Kent, Kent, OH, United States (USA) Master's.

Ferber, C. T. and N. A. Wells, 1986, Fish taphonomy and environmental interpretation of parts of the Eocene Green River Formation, Utah; SEPM, annual midyear meeting; abstracts: SEPM annual midyear meeting, Raleigh, NC, United States, Sept. 26-28, 1986, 1986, Vol. 3:35-36.

Ferber, C. T. and N. A. Wells, 1995, Paleolimnology and taphonomy of some fish deposits in "Fossil" and "Uinta" Lakes of the Eocene Green River Formation, Utah and Wyoming: Palaeogeography, Palaeoclimatology, Palaeoecology, 117(3-4):185-210.

Fisher, E. J., C. E. Erdman and J. B. Reeside, Jr. , 1960, Cretaceous and Tertiary Formations of the Book Cliffs: Carbon, Emery, and Grand counties, Utah, and Garfield and Mesa counties, Colorado: U.S. Geological Survey Professional Paper, 332:80 pp.

Fouch, T. D., J. H. Hanley, R. M. Forester, C. W. Keighin, J. K. Pitman and D. J. Nichols, 1987, Chart showing lithology, mineralogy, and paleontology of the nonmarine North Horn Formation and Flagstaff Member of the Green River Formation, Price Canyon, central Utah; a principal reference section: U.S. Geological Survey, Miscellaneous Investigations Series, Map I-1797-A, 1 sheet. 


\section{A.1 GREATER GREEN RIVER BASIN, WYOMING AND COLORADO}

\section{A.1.2 Green River Formation (Cont.)}

Franczyk, K. J., J. K. Pitman, and D. J. Nichols, 1990, Sedimentology, mineralogy, and depositional history of some Uppermost Cretaceous Lowermost Tertiary rocks along the Utah Book and Roan Cliffs east of the Green River: U.S. Geological Survey Bulletin 1787:27 pp.

Fremont, J. C., 1845, Report of the exploring expedition through the Rocky Mountains in the year 1842 and to Oregon and California in the years 1843-1844: Senate Document No. 174 and House Document No. 166, 28th Congress, 2nd session.

Froehlich, D. J. and B. H. Breithaupt, 1998, Mammals from the Eocene epoch Fossil Butte Member of the Green River Formation, Fossil Basin, Wyoming: Abstracts, Fifty-eighth annual meeting, Society of Vertebrate Paleontology, Snowbird, UT, United States, Sept. 30-Oct. 3, 1998, 18(3, Suppl):43-44.

Froehlich, D. J. and B. H. Breithaupt, 2002, Biostratigraphic and paleoenvironmental utility of Lambdotherium; tying down the Lagerstatten of the Green River Formation: Geological Society of America, 2002 annual meeting, Denver, CO, United States, Oct. 27-30, 2002, 34(6):556-557.

Froehlich, D. J., B. H. Breithaupt, J. Bolt and L. Grande, 1997, A Lambdotherium specimen from the Fossil Butte Member of the Green River Formation, with comments on its biostratigraphic and paleoenvironmental importance and the phylogenetic significance of its postcrania: Abstracts, Fifty-seventh annual meeting, Society of Vertebrate Paleontology, Chicago, IL, United States, Oct. 8-11, 1997, 17(3, Suppl):47.

Froehlich, J. W. and D. J. Froehlich, 2002, Using mammal fossils to locate the edge of the Green River lake in the Piceance Creek basin during the late-early Eocene: Geological Society of America, 2002 annual meeting, Denver, CO, United States, Oct. 27-30, 2002, 34(6):480-481.

Gardner, J. D., 1999, Comments on amphibians from the Green River Formation, with a description of a fossil tadpole; Vertebrate paleontology in Utah: Miscellaneous Publication Utah Geological Survey, 99-1:455-461.

Gauthier, J. A., 1982, Fossil xenosaurid and anguid lizards from the early Eocene Wasatch Formation, southeast Wyoming, and a revision of the Anguioidea: Contributions to Geology, 21:7-54.

Geo/Resource, 1984, Green River Basin geologic resources inventory: Unpublished Technical Report prepared for the Wyoming BLM.

Gnidovec, D. M., 1978, Taphonomy of the Powder Wash vertebrate quarry, Green River Formation; Eocene, Uintah County, Utah: Fort Hays State University, Hays, KS, United States (USA) Master's. 


\section{A.1 GREATER GREEN RIVER BASIN, WYOMING AND COLORADO}

\section{A.1.2 Green River Formation (Cont.)}

Grande, L., 1979, Eohiodon falcatus, a new species of hiodontid (Pisces) from the late early Eocene Green River Formation of Wyoming: Journal of Paleontology, 53(1):103-111.

Grande, L., 1980, Paleontology of the Green River Formation, with a review of the fish fauna: Bulletin - Geological Survey of Wyoming, 63:333.

Grande, L., 1982, A revision of the fossil genus Knightia, with a description of a new genus from the Green River Formation (Teleostei, Clupeidae): American Museum Novitates, 2731:22.

Grande, L., 1984, Paleontology of the Green River Formation, with a review of the fish fauna; second edition: Bulletin - Geological Survey of Wyoming, 63:333.

Grande, L., 1985, Fish fossils in the Eocene Green River Formation of southwestern Wyoming; On research and exploration projects supported by the National Geographic Society, for which an initial grant or continuing support was provided in the years 1980-1983: Research Reports National Geographic Society, 21:201-207.

Grande, L., 1987, Redescription of Hypsidoris farsonensis (Teleostei: Siluriformes), with a reassessment of its phylogenetic relationships: Journal of Vertebrate Paleontology, 7(1):24-54.

Grande, L., 1989, Fossil fauna of the Green River Formation; Conservation and the future of humanity: 82nd annual meeting of the Illinois State Academy of Science, Chicago, IL, United States, Oct. 20-21, 1989, 82, Suppl:66.

Grande, L., 1991, Transferred type specimens of well-preserved Eocene fishes from the Green River Formation: Journal of Paleontology, 65(5):889-890.

Grande, L., 1998, The first pickerel (Teleostei, Esocidae) from the Green River Formation, and a review of the world's most productive freshwater Lagerstatten; Abstracts of papers; fifty-eighth annual meeting; Society of Vertebrate Paleontology: Society of Vertebrate Paleontology fifty eighth annual meeting, Snowbird, UT, United States, Sept. 30-Oct. 3, 1998, 18(3, Suppl):47.

Grande, L., 1999, The first Esox (Esocidae, Teleostei) from the Eocene Green River Formation, and a brief review of esocid fishes: Journal of Vertebrate Paleontology, 19(2):271-292.

Grande, L., 2001, An updated review of the fish faunas from the Green River Formation, the world's most productive freshwater Lagerstaetten; Eocene biodiversity; unusual occurrences and rarely sampled habitats: Topics in Geobiology, 18:1-38.

Grande, L. and W. E. Bemis, 1991, Osteology and phylogenetic relationships of fossil and Recent paddlefishes (Polyodontidae) with comments on the interrelationships of Acipenseriformes: Journal of Vertebrate Paleontology, 11(1, Supplement):121. 


\section{A.1 GREATER GREEN RIVER BASIN, WYOMING AND COLORADO}

\section{A.1.2 Green River Formation (Cont.)}

Grande, L. and H. P. Buchheim, 1994, Paleontological and sedimentological variation in early Eocene Fossil Lake: Contributions to Geology, University of Wyoming, 30(1):33-56.

Grande, L., J. T. Eastman and T. M. Cavender, 1982, Amyzon gosiutensis, a new catostomid fish from the Green River Formation: Copeia, 1982(3):523-532.

Grande, R. L., 1980b, Paleontology of the Green River Formation, with a review of the fish fauna: University of Minnesota, Minneapolis, Minneapolis, MN, United States (USA) Master's.

Grande, L., 1989, The Eocene Green River lake system, Fossil Lake, and the history of the North American fish fauna, In: Mesozoic/Cenozoic vertebrate paleontology; classic localities, contemporary approaches (J. J. Flynn, ed.), United States (USA), Am. Geophys. Union, Washington, DC, United States (USA).

Gregson, J. D. and. D. J. Chure, 2000, Geology and Paleontology of Dinosaur National Monument, Utah-Colorado, In: Geology of Utah's Parks and Monuments (D. A. Sprinkel, T. C. Chidsey Jr., and P. B. Anderson, eds.), Utah Geological Association Publication. 155-188.

Gulas-Wroblewski, 2003, Limnofregata; not a frigatebird any more: Abstracts, Sixty-third annual meeting, Society of Vertebrate Paleontology, Science Museum of Minnesota, Saint Paul, MN, United States, Oct. 15-18, 2003, 23(3, Suppl):58.

Gulas-Wroblewski, B. E., 2003, New evidence for pelecaniform (Aves, Pelecaniformes) diversity during the Eocene of Wyoming: Geological Society of America, Rocky Mountain Section, 55th annual meeting, Durango, CO, United States, May 7-9, 2003, 35(5):16.

Gulas-Wroblewski, B. E. and S. Uibreaslain, 2002, A new pelecaniform bird from the Green River Formation (Eocene) of Wyoming: Geological Society of America, 2002 annual meeting, Denver, CO, United States, Oct. 27-30, 2002, 34(6):425.

Gunnell, G., 2003, New primitive microbat (Chiroptera) from the Green River Formation (upper lower Eocene), Fossil Basin, southwestern Wyoming: Abstracts, Sixty-third annual meeting, Society of Vertebrate Paleontology, Science Museum of Minnesota, Saint Paul, MN, United States, Oct. 15-18, 2003, 23(3, Suppl):58.

Gunnell, G. and W. S. Bartels, 1999, Middle Eocene vertebrates from the Uinta Basin, Utah, and their relationship with faunas from the southern Green River Basin, Wyoming: Utah Geological Survey Misc. Publications, 99-1:429-442. 


\section{A.1 GREATER GREEN RIVER BASIN, WYOMING AND COLORADO}

\section{A.1.2 Green River Formation (Cont.)}

Gunnell, G. F. and W. S. Bartels, 1994, Early Bridgerian (middle Eocene) vertebrate paleontology and paleoecology of the southern Green River Basin Wyoming: Contributions to Geology, University of Wyoming, 30(1):57-70.

Gunnell, G. F. and W. S. Bartels, 2001, Basin margins, biodiversity, evolutionary innovation, and the origin of new taxa; Eocene biodiversity; unusual occurrences and rarely sampled habitats: Topics in Geobiology, 18:403-432.

Gunnell, G. F., W. S. Bartels and J.-P. Zonneveld, 2004, A late Wasatchian (late early Eocene) vertebrate assemblage preserved in meandering stream channel deposits, northern Red Desert, Wyoming: Geological Society of America, 2004 annual meeting, Denver, CO, United States, Nov. 7-10, 2004, 36(5):92.

Gunnell, G. F., W. S. Bartels and J. P. Zonneveld, 2002, Stratigraphy, vertebrate paleontology, and paleoecology of the Wasatch Formation, Fossil Butte National Monument, Wyoming: Geological Society of America, 2002 annual meeting, Denver, CO, United States, Oct. 27-30, 2002, 34(6):557.

Hail, W. J., Jr., 1990, Geology of the Lower Yellow Creek area, northwestern Colorado: U.S. Geological Survey Bulletin 1787-O:45 pp.

Haist, B., V. Santucci and A. Aase, 2002, The history of vertebrate paleontological fieldwork in Fossil Basin, Wyoming: Abstracts, Sixty-second annual meeting, Society of Vertebrate Paleontology, Norman, OK, United States, Oct. 9-12, 2002, 22(3, Suppl):62A.

Hanley, J. H., 1974, Systematics, paleoecology, and biostratigraphy of nonmarine Mollusca from the Green River and Wasatch formations (Eocene), southwestern Wyoming and northwestern Colorado: University of Wyoming, Laramie, WY, United States (USA) Doctoral.

Hanley, J. H., 1979, Reproduction of glochidium larva in an Eocene nonmarine bivalve: U.S. Geological Survey Professional Paper P-1150.

Hanley, J. H., R. W. Scott and R. R. West, 1976, Paleosynecology of nonmarine Mollusca from the Green River and Wasatch formations (Eocene), southwestern Wyoming and northwestern Colorado, In: Structure and classification of paleocommunities (Anonymous, eds.), United States (USA), Dowden, Hutchinson \& Ross, Inc., Stroudsburg, Pa., United States (USA).

Hartman, J. H., 2004, The collections of J. C. Fremont and the type locality and record of Viviparus paludinaeformis (Hall) (Gastropoda) from the Eocene of Wyoming; Fanfare for an uncommon paleontologist; papers in honor of Malcolm C. McKenna: Bulletin of Carnegie Museum of Natural History, 36:31-42. 


\section{A.1 GREATER GREEN RIVER BASIN, WYOMING AND COLORADO}

\section{A.1.2 Green River Formation (Cont.)}

Hayden, F. V., 1869, Preliminary field report (3rd ann.) of the U.S. Geological Survey of Colorado and New Mexico: U.S. Government, Washington. 155 pp.

Hayden, F. V., 1871, Preliminary report of the United States Geological Survey of Wyoming and portions of contiguous territories (2nd Annual Report): U.S. Government Printing Office, Department of the Interior. $155 \mathrm{pp}$.

Hayden, F. V., 1873, First, Second, and Third Annual Reports Report of the U.S. Geological and Geographic Survey of the Territories, for the years 1867, 1868, and 1869: U.S. Government Printing Office, Washington. 261 pp.

Hayden, F. V., 1877, Notes on some artesian borings along the line of the Union Pacific Railroad in Wyoming Territory: U.S. Geological and Geographical Survey of the Territories, 3(1):181-185.

Henderson, J., 1924, The origin of the Green River Formation: Bulletin of the American Association of Petroleum Geologists, 8(5):662-668.

Hesse, A., 1992, A new species of Messelornis (Aves; Gruiformes; Messelornithidae) from the middle Eocene Green River Formation; Papers in avian paleontology; honoring Pierce Brodkorb: II International symposium of the Society of Avian Paleontology and Evolution, Los Angeles, CA, United States, Sept. 28-30, 1988, 36:171-178.

Hilton, E. J. and L. Grande, 2001, Osteology of Eohiodon (Teleostei, Hiodontiformes), based on new acid-prepared specimens from the Green River Formation (Eocene), Wyoming: Abstract, Sixty-first annual meeting, Society of Vertebrate Paleontology, Bozeman, MT, United States, Oct. 3-6, 2001, 21(3, Suppl):61-62.

Hodgkins, J. M. and D. M. Smith, 2002, A record of evolutionary change in an Eocene plantherbivore assemblage: Geological Society of America Abstracts with Programs. 34:4.

Holroyd, P. A., 2001, Contrasting early Eocene mammalian diversity and turnover in two contemporaneous Wyoming basins: Abstracts, Sixty-first annual meeting, Society of Vertebrate Paleontology, Bozeman, MT, United States, Oct. 3-6, 2001, 21(3, Suppl):62.

Holroyd, P. A., D. M. Erwin and J. H. Hutchison, 1997, Non-mammalian paleontology of the Wasatch Formation in the northern Green River basin, Wyoming: Geological Society of America, 1997 annual meeting, Salt Lake City, UT, United States, Oct. 20-23, 1997, 29(6):104-105. 


\section{A.1 GREATER GREEN RIVER BASIN, WYOMING AND COLORADO}

\section{A.1.2 Green River Formation (Cont.)}

Holroyd, P. A. and K. T. Smith, 2000, Preliminary biostratigraphic evidence for age of the Wasatch and Green River formations, Washakie Basin, southwestern Wyoming: Geological Society of America, 2000 annual meeting, Reno, NV, United States, Nov. 9-18, 2000, 32(7):498.

Honey, J. G., 1990, New Washakiin Primates (Omomyidae) from the Eocene of Wyoming and Colorado, and comments on the evolution of the Washakiini: Journal of Vertebrate Paleontology, 10(2):206-221.

Houde, P. and S. L. Olson, 1981, Paleognathous carinate birds from the early Tertiary of North America: Science, 214(4526):1236-1237.

Hutchinson, J. H., 1984, Determinate growth in the Baenidae (Testudines); taxonomic, ecologic and stratigraphic significance: Journal of Vertebrate Paleontology, 3:148-151.

Ingalls, B. and L. E. Park, 2005, Paleoecology and taphonomy of an ostracode fauna from the Laney Member, Green River Formation, Wyoming: Geological Society of America, 2005 annual meeting, Salt Lake City, UT, United States, Oct. 16-19, 2005, 37(7):64.

Jennings, D. S., V. L. Santucci, H. P. Buchheim and S. T. Hasiotis, 2002, A preliminary inventory and assessment of ichnofossils from the Green River Formation: Geological Society of America, 2002 annual meeting, Denver, CO, United States, Oct. 27-30, 2002, 34(6):556.

Jepsen, G. L., 1966, Early Eocene bat from Wyoming: Science, 154(3754):1333-1339.

Johnson, K. R., W. Bateman, M. Graham, S. R. Manchester and B. Handley, 2002, The Parachute Creek atlas project; an overview of the megaflora of the Green River Formation from Colorado and Utah: Geological Society of America, 2002 annual meeting, Denver, CO, United States, Oct. 27-30, 2002, 34(6):480.

Johnson, K. R. and C. Plumb, 1995, Common plant fossils from the Green River Formation at Douglas Pass, Colorado and Bonanza, Utah, In: The Green River Formation in Piceance Creek and eastern Uinta basins, Grand Junction Geol. Society Guidebook. 121-130.

Johnson, R. C., 1981, Stratigraphic evidence for a deep Eocene Lake Uinta, Piceance Creek Basin, Colorado: Geology, v. 9, no. 5, pp. 55-62.

Johnson, R. C., 1984, New names for units in the lower part of the Green River Formation, Piceance Creek Basin, Colorado: U.S. Geological Survey Bulletin, B 1529-I. 


\section{A.1 GREATER GREEN RIVER BASIN, WYOMING AND COLORADO}

\section{A.1.2 Green River Formation (Cont.)}

Johnson, R. C., 1985, Early Cenozoic history of the Uinta and Piceance Creek basins, Utah and Colorado, with special reference to the development of Eocene Lake Uinta, In: Cenozoic Paleogeography of West-Central United States (R. M. Flores and S. S. Kaplan, eds.), Society for Sedimentary Geology. 247-276.

Johnson, R. C., 1989, Geologic history and hydrocarbon potential of late Cretaceous-age, lowpermeability reservoirs, Piceance Basin, western Colorado: U.S. Geological Survey Bulletin, B1787-E, 51 pp.

Kester, P. R. and A. K. Aase, 2002, Stratigraphic correlation of the early Cenozoic intermontane lacustrine deposits of Wyoming, Colorado, and Utah: Geological Society of America, 2002 annual meeting, Denver, CO, United States, Oct. 27-30, 2002, 34(6):558.

Kihm, A. J., 1984, Early Eocene mammalian faunas of the Piceance Creek basin, northwestern Colorado: University of Colorado, Boulder, CO, United States (USA) Doctoral.

King, C., 1877, Descriptive geology: U.S. Geological Exploration of the 40th Parallel, 2:202-277.

Krishtalka, L., 1976, Early Tertiary Adapisoricidae and Erinaceidae (Mammalia, Insectivora) of North America: Bulletin of Carnegie Museum of Natural History,(1):40-40.

Krishtalka, L., 1976, North American Nyctitheriidae; Mammalia, Insectivora: Annals of Carnegie Museum, 46(Article 2):7-28.

Krishtalka, L. and R. K. Stucky, 1984, Middle Eocene marsupials (Mammalia) from northeastern Utah and the mammalian fauna from Powder Wash: Annals of Carnegie Museum, 53(2):31-45.

Kuchta, M. A., 2000, Paleoenvironmental significance of nonmarine Mollusca in the Luman Tongue of the Green River Formation, Wyoming: Master's Thesis, University of Wisconsin, $63 \mathrm{pp}$.

Langston, W., Jr. and H. Rose, 1978, A yearling crocodilian from the middle Eocene Green River Formation of Colorado: Journal of Paleontology, 52(1):122-125.

Leggitt, V. L., R. Biaggi, H. P. Buchheim, 2004, Avian eggshell fragments confirm lake margin fluctuation; Tipton Shale Member, Eocene Lake Gosiute: Abstracts, Sixty-fourth annual meeting, Society of Vertebrate Paleontology, Denver, CO, United States, Nov. 3-6, 2004, 24(3, Suppl):82.

Leggitt, V. L. and H. P. Buchheim, 1993, Radiograph aided taphonomic analysis of an avian fossil quarry; insights into the paleohabitat of the Tertiary bird, Presbyornis: Geological Society of America, 1993 annual meeting, Boston, MA, United States, Oct. 25-28, 1993, 25(6):58. 


\section{A.1 GREATER GREEN RIVER BASIN, WYOMING AND COLORADO}

\section{A.1.2 Green River Formation (Cont.)}

Leggitt, V. L. and H. P. Buchheim, 1996, An avian botulism epizootic affecting a nesting site population of Presbyornis on a carbonate mudflat shoreline of Eocene Fossil Lake: Sixth North American paleontological convention, Washington, DC, United States, June 9-12, 1996, $8: 234$.

Leggitt, V. L. and H. P. Buchheim, 1998a, Avian eggshell identified from a Presbyornis (Aves; Anseriformes) rookery; Eocene Lake Gosiute, Sweetwater County, Wyoming: Geological Society of America, 1998 annual meeting, Toronto, ON, Canada, Oct. 26-29, 1998, 30(7):32.

Leggitt, V. L. and H. P. Buchheim, 1998b, A new Presbyornis (Aves, Anseriformes) nesting site with abundant eggshell; Eocene Fossil Lake, Lincoln County, Wyoming: Abstracts, Fifty-eighth annual meeting, Society of Vertebrate Paleontology, Snowbird, UT, United States, Sept. 30Oct. 3, 1998, 18(3, Suppl):58.

Leggitt, V. L., H. P. Buchheim and R. E. Biaggi, 2001, Avian eggshell from caddisfly (Insecta, Trichoptera) mounds; Tipton Shale Member, Eocene Green River Formation: Abstracts, Sixtyfirst annual meeting, Society of Vertebrate Paleontology, Bozeman, MT, United States, Oct. 3-6, 2001, 21(3, Suppl):72.

Leggitt, V. L., H. P. Buchheim, J. Bolt and L. Grande, 1997, Presbyornis (Aves, Anseriformes) eggshell from three avian mass mortality sites; Eocene Fossil Lake, Lincoln County, Wyoming: Abstracts, Fifty-seventh annual meeting, Society of Vertebrate Paleontology, Chicago, IL, United States, Oct. 8-11, 1997, 17(3, Suppl):60.

Leggitt, V. L. and R. A. Cushman, 2001, Complex caddisfly-dominated bioherms from the Eocene Green River Formation: Sedimentary Geology, 145:377-396.

Leopold, E. B. and H. D. MacGinitie, 1972, Development and affinities of Tertiary floras in the Rocky Mountains, In: Floristics and Paleofloristics of Asia and Eastern North America, Elsevier, Amsterdam. pp. 147-200.

Li, G.-Q., L. Grande and M. V. H. Wilson, 1997, The species of Phareodus (Teleostei, Osteoglossidae) from the Eocene of North America and their phylogenetic relationships: Journal of Vertebrate Paleontology, 17(3):487-505.

Loewen, M. A. and H. P. Buchheim, 1998, Paleocommunities and trophic relationships during the latter stages of Eocene Fossil Lake, SW Wyoming: Abstracts, Fifty-eighth annual meeting, Society of Vertebrate Paleontology, Snowbird, UT, United States, Sept. 30-Oct. 3, 1998, 18(3, Suppl):59. 


\section{A.1 GREATER GREEN RIVER BASIN, WYOMING AND COLORADO}

\section{A.1.2 Green River Formation (Cont.)}

Loewen, M. A. and J. M. Gibert, 1999, The first occurrence of Cenozoic fish trails (Undichna) from Eocene Fossil Lake, Wyoming: Abstracts, Fifty-ninth annual meeting, Society of Vertebrate Paleontology, Denver, CO, United States, Oct. 20-23, 1999, 19(3, Suppl):59.

Loewen, M. A., V. L. Leggitt, R. E. Biaggi, H. P. Buchheim and R. A. Cushman, Jr., 1999, Morphologic variation in caddisfly (Trichoptera) larval case architecture from the Eocene Green River and Wasatch formations of Wyoming: Geological Society of America, 1999 annual meeting, Denver, CO, United States, Oct. 25-28, 1999, 31(7):470.

Lundberg, J. G. and G. R. Case, 1970, A new catfish from the Eocene Green River Formation, Wyoming: Journal of Paleontology, 44(3):451-457.

MacGinitie, H. D., 1969, The Eocene Green River flora of northwestern Colorado and northeastern Utah: University of California Publications in Geological Sciences, 83:202.

Martin, L. D. and A. Feduccia, 2002, Avifauna of the Green River deposits and the early radiation of modern birds: Geological Society of America, 2002 annual meeting, Denver, CO, United States, Oct. 27-30, 2002, 34(6):480.

Mayr, G. and M. Daniels, 2001, A new short-legged landbird from the early Eocene of Wyoming and contemporaneous European sites: Acta Palaeontologica Polonica, 46(3):393-402.

McGrew, P. O., 1971, Early and middle Eocene faunas of the Green River basin; Trona issue: Contributions to Geology, 10(1):65-68.

McGrew, P. O., 1975, Taphonomy of Eocene fish from Fossil Basin, Wyoming: Fieldiana: Geology 33(14):257-270.

McGrew, P. O., 1980, An Eocene flamingo nesting area, Sweetwater County, Wyoming: Research Reports - National Geographic Society, 12:473-478.

McGrew, P. O. and T. M. Bown, 1976, Fossil vertebrate faunas: Green Mountain, Ferris-Seven Lakes, and Sandy EIS areas, and Sweetwater County, Wyoming: Unpublished technical report prepared for the Wyoming BLM. $422 \mathrm{pp}$.

McGrew, P. O. and T. M. Bown, 1977, Fossil vertebrate faunas: Carbon, Lincoln, and Uinta Counties, Wyoming: Unpublished technical report prepared for the Wyoming BLM. 251 pp.

McGrew, P. O. and M. Casilliano, 1975, The geological history of Fossil Butte National Monument and Fossil Basin: National Park Service Occasional Paper,(3):37-37. 


\section{A.1 GREATER GREEN RIVER BASIN, WYOMING AND COLORADO}

\section{A.1.2 Green River Formation (Cont.)}

Metz, R., 1987, Sinusoidal trail formed by a Recent biting midge (family Ceratopogonidae); trace fossil implications: Journal of Paleontology, 61(2):312-314.

Moncure, G. and R. C. Surdam, 1980, Depositional environment of the Green River Formation in the vicinity of the Douglas Creek Arch, Colorado and Utah: Contributions to Geology, University of Wyoming, 19(1):9-24.

Mook, C. C., 1959, A new species of fossil crocodile of the genus Leidyosuchus from the Green River beds [Wyoming]: American Museum Novitates, 1933:6.

Moussa, M. T., 1968, Fossil tracks from the Green River Formation (Eocene) near Soldier Summit, Utah: Journal of Paleontology, 42(6):1433-1438.

Moussa, M. T., 1970, Nematode fossil trails from the Green River Formation (Eocene) in the Uinta Basin, Utah: Journal of Paleontology, 44(2):304-307.

Nelson, M. E., J. H. Madsen, Jr. and W. L. Stokes, 1980, A titanothere from the Green River Formation, central Utah; Teleodus uintensis (Perissodactyla; Brontotheriidae): Contributions to Geology, 18(2):127-134.

Nichols, D. J., 1987, Palynology of the Vermillion Creek coal bed and associated strata: U.S. Geological Survey Professional Paper 1314-D:47-73.

Olson, S. L., 1977, A lower Eocene frigatebird from the Green River Formation of Wyoming (Pelecaniformes; Fregatidae): Smithsonian Contributions to Paleobiology,(35):33-33.

Olson, S. L., 1987, An early Eocene oilbird from the Green River Formation of Wyoming (Caprimulgiformes; Steatornithidae): The evolution of birds based on fossil evidence: Documents des Laboratoires de Geologie, Lyon, 99:57-69.

Olson, S. L., 1992, A new family of primitive landbirds from the lower Eocene Green River Formation of Wyoming; Papers in avian paleontology; honoring Pierce Brodkorb: II International symposium of the Society of Avian Paleontology and Evolution, Los Angeles, CA, United States, Sept. 28-30, 1988, 36:127-136.

Oriel, S. F. and J. I. Tracey 1970, Uppermost Cretaceous and Tertiary stratigraphy of Fossil Basin, southwest Wyoming: U.S. Geological Survey Professional Paper 635:53 pp.

Parker, L. R., 1970, A titanothere from the Eocene Green River Formation of Utah: Abstracts with Programs - Geological Society of America, 2(6):400. 


\section{A.1 GREATER GREEN RIVER BASIN, WYOMING AND COLORADO}

\section{A.1.2 Green River Formation (Cont.)}

Peale, A. C., 1879, Report on the geology of the Green River district: 11th Annual Report, U.S. Geological Survey of the Territories Report on the geology of the Green River district.

Perry, M. L., 2003, Preliminary description of a new fossil scorpion from the middle Eocene, Green River Formation, Rio Blanco, Colorado: Abstracts, 74th annual meeting of the ColoradoWyoming Academy of Science, Greeley, CO, United States, April 26, 2003, 35(1):22.

Prothero, D. R. and C. C. Swisher, III, 1992, Magnetostratigraphy and geochronology of the terrestrial Eocene-Oligocene transition in North America, In: Eocene-Oligocene Climatic and Biotic Evolution (D. R. Prothero and W. A. Berggren, eds.), Princeton University Press, Princeton, New Jersey. 46-73.

Rieppel, O. and L. Grande, 1998, A well-preserved fossil amphiumid (Lissamphibia; Caudata) from the Eocene Green River Formation of Wyoming: Journal of Vertebrate Paleontology, 18(4):700-708.

Robinson, P., 1978, Paleontological resources inventory and evaluation, Bureau of Mines Experimental Oil Shale Mine, Rio Blanco County, Colorado: Prepared for VTN Colorado, Inc. 2600 S. Parker Rd., Aurora, Colorado. 22 pp.

Robinson, P., D. J. Daitch and J. E. Haessig, 2000, Fossil vertebrate localities of southwestern Wyoming: a literature search, locality record, and formation evaluation: Unpublished technical report prepared for the Wyoming BLM.

Robinson, P., G. F. Gunnell, S. L. Walsh, W. C. Clyde, J. E. Storer, R. K. Stucky, D. J. Froehlich, I. F. Villafranca and M. C. McKenna, 2004, Wasatchian though Duschesnean biochronology, In: Late Cretaceous and Cenozoic Mammals of North America (M. O. Woodburne, ed.), Columbia University Press. 106-155.

Roehler, H. W., 1973, Stratigraphy of the Washakie Formation in the Washakie Basin, Wyoming: U.S. Geological Survey Bulletin, Report: B 1369:40.

Roehler, H. W., 1992a, Geology of the Eocene Wasatch, Green River, and Bridger (Washakie) Formations, Greater Green River Basin, Wyoming, Utah and Colorado: Introduction to Greater Green River Basin Geology, Physiography, and History of Investigations: U.S. Geological Survey Professional Paper 1506-A:14.

Roehler, H. W., 1992b, Geology of the Eocene Wasatch, Green River, and Bridger (Washakie) Formations, Greater Green River Basin, Wyoming, Utah and Colorado: Description and Correlation of Eocene Rocks in Stratigraphic Reference Sections for the Green River and Washakie Basin, Southwest Wyoming: U.S. Geological Survey Professional Paper 1506-D:83 pp. 


\section{A.1 GREATER GREEN RIVER BASIN, WYOMING AND COLORADO}

\section{A.1.2 Green River Formation (Cont.)}

Roehler, H. W., 1992c, Geology of the Eocene Wasatch, Green River, and Bridger (Washakie) Formations, Greater Green River Basin, Wyoming, Utah and Colorado: Correlation, Composition, Areal Distribution, and Thickness of Eocene Stratigraphic Units, Greater Green River Basin, Wyoming, Utah, and Colorado: U.S. Geological Survey Professional Paper 1506-E:49 pp.

Roehler, H. W., 1993, Geology of the Eocene Wasatch, Green River, and Bridger (Washakie) Formations, Greater Green River Basin, Wyoming, Utah and Colorado: Eocene Climates, Depositional Environments, and Geography, Greater Green River Basin, Wyoming, Utah and Colorado: U.S. Geological Survey Professional Paper 1506-F:74 pp.

Savage, D. E. and D. E. Russell, 1983, Mammalian Paleofauna of the World: Addison-Wesley Publ. Co. 432 pp.

Savage, D. E., B. T. Waters and J. H. Hutchison, 1972, Early Eocene fossiliferous strata, northwest Washakie Basin, Sweetwater County, Wyoming: Abstracts, Thirty-second annual meeting, Society of Vertebrate Paleontology, pp. 7-8.

Schultz, A. R., 1914, Geology and geography of a portion of Lincoln County, Wyoming: U.S. Geological Survey Bulletin 543:1-141.

Scudder, S. H., 1868, The insects of the ancient American Tertiary beds of Green River: The American Naturalist, 1:625-634.

Scudder, S.H., 1890, The Tertiary Insects of North America: Report of the United States Geological Survey of the Territories: 13:1-734, 28 plates.

Smith, M. E., 2001, Precise 40Ar/39Ar laser fusion geochronology of the Green River Formation, Wyoming: Geological Society of America Abstracts with Programs, annual meeting issue.

Smith, M. E., B. Singer and A. R. Carroll, 2003, 40Ar/39Ar geochronology of the Eocene Green River Formation, Wyoming: Geological Society of America Bulletin, 115(5):545-565.

Spangler, C. L., J. D. Miller and R. J. Cuffey, 2005, Fishes from the Eocene Green River Formation around Fossil Butte, Wyoming; effect of small versus large sample size on species recovered and proportions observed: Geological Society of America, North-Central Section, 39th annual meeting, Minneapolis, MN, United States, May 19-20, 2005, 37(5):80-81.

Stidham, T. A., 1998, Phylogenetic and ecological diversification of waterfowl (Anseriformes) in the Late Cretaceous and Paleogene: Abstract, Fifty-eighth annual meeting, Society of Vertebrate Paleontology, Snowbird, UT, United States, Sept. 30-Oct. 3, 1998, 18(3, Suppl):80. 


\section{A.1 GREATER GREEN RIVER BASIN, WYOMING AND COLORADO}

\section{A.1.2 Green River Formation (Cont.)}

Stidham, T. A., 2000, Morphometrics and the paleobiology of Presbyornithidae (Neornithes, Anseriformes): Geological Society of America, 2000 annual meeting, Reno, NV, United States, Nov. 9-18, 2000, 32(7):15.

Stokes, W. L., 1978, Impressions of lizard scales from the Green River Formation (Eocene), Uinta Basin, Utah: Journal of Paleontology, 52(2):407-410.

Stokes, W. L., 1986, Geology of Utah: Utah Museum of Natural History, University of Utah and Utah Geological and Mineral Survey, Department of Natural Resources.

Surdam, R.C., and Stanley, K.O., 1979, Lacustrine sedimentation during the culminating phase of Eocene Lake Gosiute Wyoming (Green River Formation): Geological Society of America Bulletin, part 1, v. 90, no. 1, pp. 93-110.

Surdam, R. C. and K. O. Stanley, 1980a, Effects on changes in drainage basin boundaries on sedimentation in Eocene Lakes Gosiute and Uinta of Wyoming, Utah, and Colorado: Geology, 8:135-139.

Surdam, R. C. and K. O. Stanley, 1980b, The stratigraphic and sedimentologic framework of the Green River Formation, Wyoming: Wyoming Geological Association, 31 st Field Conference Guidebook:205-221.

Swain, F. M., 1964, Early Tertiary freshwater Ostracoda from Colorado, Nevada and Utah and their stratigraphic distribution: Journal of Paleontology, 38(2):256-280.

Taylor, R. S., 1972, Paleoecology of ostracodes from the Luman Tongue and Tipton Member (early Eocene) of the Green River Formation, Wyoming: University of Kansas, Lawrence, KS, United States (USA) Doctoral.

Tevesz, M. J. S., P. L. McCall, P. L. McCall, M. J. S. Tevesz and F. G. Stehli, 1982, Geological significance of aquatic nonmarine trace fossils, In: Animal-sediment relations; the biogenic alteration of sediments (Anonymous, eds.), United States (USA), Plenum Press, New York, NY, United States (USA).

Tuttle, M. L., 1991, Introduction, In: Geochemical, Biogeochemical, and Sedimentological Studies of the Green River Formation, Wyoming, Utah, and Colorado (M. L. Tuttle, ed.), U.S. Geological Survey Bulletin 1973-A-G. A1-A6.

Veatch, A. C., 1907, Geography and geology of a portion of southwestern Wyoming: U.S. Geological Survey Professional Paper 56:163 pp. 


\section{A.1 GREATER GREEN RIVER BASIN, WYOMING AND COLORADO}

\section{A.1.2 Green River Formation (Cont.)}

Von Koenigswald, W., K. Rose, L. Grande, R. Martin, 2004, Apatemyid and pantolestid skeletons from the Eocene Fossil Butte Member (Wyoming) compared to those from Messel (Germany): Abstracts, Sixty-fourth annual meeting, Vertebrate Paleontology, Denver, CO, United States, Nov. 3-6, 2004, 24(3, Suppl):125.

Waterhouse, D., G. Dyke, 2003, A new fossil charadriiform bird from the lower Eocene Green River Formation of Wyoming: Abstracts, Sixty-third annual meeting, Society of Vertebrate Paleontology, Science Museum of Minnesota, Saint Paul, MN, United States, Oct. 15-18, 2003, 23(3, Suppl):108.

Wehr, W. C. and L. L. Barksdale, 1995, Implications of middle Eocene feathers and crayfish from Republic, Washington: Washington Geology, 23(4):6-10.

West, R. M., 1973, Geology and mammalian paleontology of the New Fork-Big Sandy area, Sublette County, Wyoming: Fieldiana: Geology, 29:193.

West, R. M., 1990, Vertebrate paleontology of the Green River Basin, Wyoming, 1840-1910: Earth Sciences History, 9(1):45-56.

West, R. M. and M. R. Dawson, 1975, Eocene fossil Mammalia from the Sand Wash Basin, northwestern Moffat County, Colorado: Annals of Carnegie Museum, 45(Article 11):231-253.

Whitmore, J. H., L. R. Brand and H. P. Buchheim, 2002, Implications of modern fish taphonomy for the preservation states and depositional environments of fossil fish, Fossil Butte Member, Green River Formation, southwestern Wyoming: Geological Society of America, 2002 annual meeting, Denver, CO, United States, Oct. 27-30, 2002, 34(6):556.

Wood, H. E., R. W. Chaney, J. Clark, E. H. Colbert, G. L. Jepsen, J. J. B. Reeside and C. Stock, 1941, Nomenclature and correlation of the North American continental Tertiary: Bulletin of the Geological Society of America, 52:1-48.

Woodburne, M. O. and C. C. I. Swisher, 1995, Land mammal high-resolution geochronology, intercontinental overland dispersals, sea level, climate, and vicariance, In: Geochronology, Time Scales, and Global Stratigraphic Correlations: Unified Temporal Framework for an Historical Geology (W. A. Berggren, D. V. Kent, M. P. Aubry and J. Hardenbol, eds.), SEPM Special Publication no. 54. 337-364.

Yang, S.-Y., M. G. Lockley, R. Greben, B. R. Erickson and S.-K. Lim, 1995, Flamingo and duck-like bird tracks from the Late Cretaceous and early Tertiary; evidence and implications: Ichnos, 4(1):21-34. 


\section{A.1 GREATER GREEN RIVER BASIN, WYOMING AND COLORADO}

\section{A.1.2 Green River Formation (Cont.)}

Zonneveld, J.-P., G. F. Gunnell and W. S. Bartels, 2000a, Early Eocene fossil vertebrates from the southwestern Green River Basin, Lincoln and Uinta counties, Wyoming: Journal of Vertebrate Paleontology, 20(2):369-386.

Zonneveld, J.-P., J. M. Lavigne and W. S. Bartels, 2000b, Ichnology of an early Eocene meandering fluvial system, Wasatch Formation, Fossil Butte National Monument, Wyoming: Geological Society of America Abstracts, 32(7):309. 


\section{A.1 GREATER GREEN RIVER BASIN, WYOMING AND COLORADO}

\section{A.1.3 Bridger Formation}

Alexander, J. P., 1996, New extraction and preparation techniques for well preserved Bridger Formation fossils: Abstracts, Sixty-fourth annual meeting, Society of Vertebrate Paleontology, New York, NY, United States, Oct. 16-19, 1996, 16(3, Suppl):19.

Alexander, J. P. and B. J. Burger, 1998, Stratigraphy and taphonomy of Grizzly Buttes, Wyoming: Abstracts, Fifty-eighth annual meeting, Society of Vertebrate Paleontology, Snowbird, UT, United States, Sept. 30-Oct. 3, 1998, 18(3, Suppl):23.

Alexander, J. P. and B. J. Burger, 2001, Stratigraphy and taphonomy of Grizzly Buttes, Bridger Formation, and the middle Eocene of Wyoming; Eocene biodiversity; unusual occurrences and rarely sampled habitats: Topics in Geobiology, 18:165-196.

Alexander, J. P. and R. D. E. MacPhee, 1999, Skull morphology of Omomys carteri: Abstracts, Fifty-ninth annual meeting, Society of Vertebrate Paleontology, Denver, CO, United States, October 20-23, 1999, 19(3, Suppl):29.

Alexander, J. P., 1994, Sympatry of two species of Notharctus in the Bridger Basin, Wyoming: Abstracts, Fifty-fourth annual meeting, Society of Vertebrate Paleontology, Seattle, WA, United States, Oct. 19-22, 1994, 14(3, Suppl):14.

Ambrose, P. D., 1992, Taphonomy and paleoenvironments of a turtle-bearing unit of the Bridger Formation, southwestern Wyoming: Abstracts, Fifty-second annual meeting, Society of Vertebrate Paleontology, Toronto, ON, Canada, October 28-31, 1992, 12(3, Suppl):16A.

Anderson, D., 2004, Evidence for directional selection in Leptotomus parvus (Rodentia; Ischyromyidae), Bridger Formation (middle Eocene), Green River basin, Wyoming: Abstracts, Sixty-fourth annual meeting, Society of Vertebrate Paleontology, Denver, CO, United States, Nov. 3-6, 2004, 24(3, Suppl):34.

Anderson, D. K., 2000, Revision of the genus Leptotomus (Rodentia, Paramyidae): Abstracts, Sixtieth annual meeting, Society of Vertebrate Paleontology, Mexico City, Mexico, Oct. 25-28, 2000, 20(3, Suppl):26.

Anemone, R. L. and B. A. Nachman, 1999, Extraordinary assemblage of Omomys fossils from the Bridger C, Uinta Co, WY; hindlimb morphology and positional behavior: Geological Society of America, North-Central Section, 33rd annual meeting, Champaign, IL, United States, April 22-23, 1999, 31(5):2.

Barker, S. W., 1975, A preliminary study of the paleontology of a part of Bridger Basin near Lonetree, Wyoming: Proceedings of the Utah Academy of Sciences, Arts and Letters, 52(1):77. 


\section{A.1 GREATER GREEN RIVER BASIN, WYOMING AND COLORADO}

\section{A.1.3 Bridger Formation (Cont.)}

Bartels, W. S., 1993, Niche separation of fluvial and lacustrine reptiles from the Eocene Green River and Bridger formations of Wyoming: Abstracts, Fifty-third annual meeting, Society of Vertebrate Paleontology, Albuquerque, NM, United States, Oct. 13-16, 1993, 13(3, Suppl):25.

Berman, D. S., 1973, Spathorhynchus fossorium, a middle Eocene amphisbaenian (Reptilia) from Wyoming: Copeia,(4):704-721.

Bradley, W. H., 1946, Coprolites from the Bridger Formation of Wyoming, their composition and microorganisms: American Journal of Science, 244(3):215-239.

Bradley, W. H., 1964, Geology of Green River Formation and associated Eocene rocks in southwestern Wyoming and adjacent parts of Colorado and Utah: U.S. Geological Survey Professional Paper 496-A:1-86.

Brand, L. R., 2002, Lacustrine deposition in the Bridger Formation: Lake Gosiute extended: Geological Society of America Abstracts with Programs, Annual Meeting Issue.

Brand, L. R., H. T. Goodwin, P. D. Ambrose and H. P. Buchheim, 2000, Taphonomy of turtles in the Middle Eocene Bridger Formation: Palaeogeography, Palaeoclimatology, Palaeoecology, 162:171-189.

Brand, L. R., H. T. Goodwin and H. P. Buchheim, 1993, Density of turtles in three stratigraphic units of the Eocene Bridger Formation in Wyoming: Abstracts, Fifty-third annual meeting, Society of Vertebrate Paleontology, Albuquerque, NM, United States, Oct. 13-16, 1993, 13(3, Suppl):27.

Brand, L. R., P. C. Murphey, E. Evanoff, N. Matthews and S. Gregonis, 1998, Mapping of the widespread marker units in the middle Eocene Bridger Formation, southwestern Wyoming: Fifth Annual Conference on Fossil Resources, p. SP-01.

Buchheim, H. P., L. R. Brand and H. T. Goodwin, 2000, Lacustrine to fluvial floodplain deposition in the Eocene Bridger Formation: Palaeogeography, Palaeoclimatology, Palaeoecology, 162:191-209.

Burger, B. J., 1998, A new skeleton of Hyopsodus from the Eocene of Wyoming: Abstracts, Fifty-eighth annual meeting, Society of Vertebrate Paleontology, Snowbird, UT, United States, Sept. 30-Oct. 3, 1998, 18(3, Suppl):30.

Caldwell, M. W., 2003, Holotype snout elements of Saniwa ensidens reassigned to cf. Restes sp. indet. (Xenosauridae): Journal of Paleontology, 77(2):393-396. 


\section{A.1 GREATER GREEN RIVER BASIN, WYOMING AND COLORADO}

\section{A.1.3 Bridger Formation (Cont.)}

Clyde, W. C., N. D. Sheldon, P. L. Koch, G. F. Gunnell and W. S. Bartels, 2001, Linking the Wasatchian/Bridgerian boundary to the Cenozoic global climate optimum: new magnetostratigraphic and isotopic results from South Pass, Wyoming: Palaeogeography, Palaeoclimatology, and Palaeoecology, 167:175-199.

Clyde, W. C., J. P. Zonneveld, J. Stamatakos, G. Gunnell and W. S. Bartels, 1997, Magnetostratigraphy across the Wasatchian/Bridgerian NALMA boundary (early to middle Eocene) in the western Green River Basin, Wyoming: Journal of Geology, 105:657-669.

Coombs, M. C. and W. P. Coombs, Jr., 1982, Anatomy of the ear region of four Eocene artiodactyls; Gobiohyus, ?Helohyus, Diacodexis and Homacodon: Journal of Vertebrate Paleontology, 2(2):219-236.

Covert, H. H. and P. C. Murphey, 1994, New middle Eocene omomyine skeletal material: American Journal of Physical Anthropology, Supplement to no. 18, Annual Meeting Issue.

Covert, H. H., P. Robinson and J. R. Harris, 1998, Evidence for two lineages of Notharctus during the Bridger C and D: Journal of Vertebrate Paleontology, Supplement to 18:3.

Dawson, M. R., 1962, A sciuravid rodent from the middle Eocene of Wyoming: American Museum Novitates, 2075:5.

Evanoff, E., L. R. Brand and P. C. Murphey, 1998a, The lower Bridger Formation (middle Eocene) of southwest Wyoming: Widespread marker units and subdivisions of Bridger B: Dakoterra, 5:115-122.

Evanoff, E., L. R. Brand and P. C. Murphey, 1998b, The Bridger Formation (middle Eocene) of southwest Wyoming: Widespread marker units and subdivisions of Bridger B through D: Society of Vertebrate Paleontology, Supplement to No. 3, p. 40 A.

Evanoff, E. and P. C. Murphey, 1996, The end of Laramide tectonism as recorded by middle Eocene basinal rocks of Wyoming and adjacent states: Geological Society of America Abstracts with Programs, Vol. 28, no. 7, p. A-373.

Evanoff, E. and P. C. Murphey, 1999, High-resolution stratigraphy of terrestrial sequences: Examples from the White River and Bridger Formations of Wyoming: Geological Society of America Abstracts with Programs, 1999 Annual Meeting Issue.

Evanoff, E., P. C. Murphey and L. R. Brand, 1998, Widespread stratigraphic marker units and subdivisions of Bridger B through D (middle Eocene), southwest Wyoming: Journal of Vertebrate Paleontology, Abstracts with Programs. 


\section{A.1 GREATER GREEN RIVER BASIN, WYOMING AND COLORADO}

\section{A.1.3 Bridger Formation (Cont.)}

Evanoff, E., P. Robinson, P. C. Murphey, D. G. Kron, D. Engard, P. Monaco, 1994, An early Uintan fauna from Bridger E: Abstracts, Fifty-fourth annual meeting, Society of Vertebrate Paleontology, Seattle, WA, United States, Oct. 19-22, 1994, 14(3, Suppl):24.

Evanoff, E. and D. F. Rosetti, 1992, A tale of two volcanic sequences I: The fluvial-lacustrine Bridger Formation of southwestern Wyoming: Society of Economic Paleontology and Mineralogy Theme Meeting Abstracts, p. 25.

Evanoff, E. E., P. C. Murphey and P. Robinson, 1996, The middle Eocene Bridger Formation of southwestern Wyoming: Geological Society of America Abstracts with Programs, Vol. 28, no. 4, p. 27.

Evernden, J. F., D. E. Savage, G. H. Curtis and J. T. James, 1964, Potassium-Argon dates and the Cenozoic mammalian chronology of North America: American Journal of Science, 262:145-198.

Feduccia, A. and L. D. Martin, 1976, The Eocene zygodactyl birds of North America (Aves; Piciformes): Smithsonian Contributions to Paleobiology, no.27, Coll. pap. avian paleontol. honoring 90th birthday A. Wetmore:101-110.

Flynn, J. J., 1986, Correlation and geochronology of middle Eocene strata from the western United States: Palaeogeography, Palaeoclimatology, Palaeoecology, 55:335-406.

Gaffney, E. S., 1979, Description of a large trionychid turtle shell from the Eocene Bridger Formation of Wyoming: Contributions to Geology, 17(1):53-57.

Gazin, C. L., 1934, On the priority of specific names for the upper Bridger Notharctus: Journal of mammalogy, 15(1):71.

Gazin, C. L., 1946, Machaeroides eothen Matthew, the saber tooth creodont of the Bridger Eocene [Wyoming]: Proceedings of the United States National Museum, 96(3203):335-347.

Gazin, C. L., 1949, A leptictid insectivore from the middle Eocene Bridger Formation of Wyoming: Journal of the Washington Academy of Sciences, 39(7):220-223.

Gazin, C. L., 1957, A skull of the Bridger middle Eocene creodont, Patriofelis ulta Leidy [Wyoming]: Smithsonian Miscellaneous Collections, 134(8):20.

Gazin, C. L., 1958, A review of the middle and upper Eocene primates of North America: Smithsonian Miscellaneous Collections, 136(1):1-112.

Gazin, C. L., 1965, An endocranial cast of the Bridger middle Eocene primate Smilodectes gracilis: Smithsonian Miscellaneous Collections, 149(4):1-14. 


\section{A.1 GREATER GREEN RIVER BASIN, WYOMING AND COLORADO}

\section{A.1.3 Bridger Formation (Cont.)}

Gazin, C. L., 1968, A study of the Eocene condylarthran mammal Hyopsodus: Smithsonian Miscellaneous Collections, 153(4):1-90.

Gazin, C. L., 1976, Mammalian faunal zones of the Bridger middle Eocene: Smithsonian Contributions to Paleobiology,(26):25-25.

Geo/Resource, 1984, Green River Basin geologic resources inventory: Unpublished Technical Report prepared for the Wyoming BLM.

Gingerich, P. D., 1979, Phylogeny of middle Eocene Adapidae (Mammalia, Primates) in North America; Smilodectes and Notharctus: Journal of Paleontology, 53(1):153-163.

Gulas-Wroblewski, B. E. and A. F. J. Wroblewski, 2003, A crown-group galliform bird from the middle Eocene Bridger Formation of Wyoming: Palaeontology, 46, Part 6:1269-1280.

Gulas, B. E. and A. F.-J. Wroblewski, 2002, A new fossil galliform from the Bridger Formation (Eocene, 50-48 ma), southwestern Wyoming: Geological Society of America, Northeastern Section, 37th annual meeting, Springfield, MA, United States, March 25-27, 2002, 34(1):58.

Gunnell, G. F., 1998, Mammalian fauna from the lower Bridger Formation (Bridger A, early middle Eocene) of the southern Green River basin, Wyoming: Contributions from the Museum of Paleontology, University of Michigan, 30(3):83-130.

Gunnell, G. F. and W. S. Bartels, 1990, Early Bridgerian vertebrate paleontology and paleoecology of the southern Green River basin: Geological Society of America, Rocky Mountain Section, 43rd annual meeting, Jackson, WY, United States, May 21-23, 1990, 22(6):13.

Gunnell, G. F. and W. S. Bartels, 1999, Middle Eocene vertebrates from the Uinta Basin, Utah, and their relationship with faunas from the southern Green River Basin, Wyoming, In: Vertebrate Paleontology in Utah (D. D. Gillette, ed.), Utah Geological Survey Miscellaneous Publications. 429-442.

Gunnell, G. F. and H.-P. Schultze, 1990, Cenogram analysis of the Bridger B mammalian fauna (middle Eocene): Abstracts, Fiftieth annual meeting, Society of Vertebrate Paleontology, Lawrence, KS, United States, Oct. 11-13, 1990, 10(3, Suppl):26A.

Gunnell, G. F. and V. L. Yarborough, 2000, Brontotheriidae (Perissodactyla) from the late early and middle Eocene (Bridgerian), Wasatch and Bridger formations, southern Green River basin, southwestern Wyoming: Journal of Vertebrate Paleontology, 20(2):349-368.

Gustav, S., 1974, The sedimentology and paleogeography of the Bridger Formation (Eocene) of southwestern Wyoming: Master's thesis, University of Massachusetts. 82 pp. 


\section{A.1 GREATER GREEN RIVER BASIN, WYOMING AND COLORADO}

\section{A.1.3 Bridger Formation (Cont.)}

Hamrick, M. W. and J. P. Alexander, 1996, The hand skeleton of Notharctus tenebrosus (Primates, Notharctidae) and its significance for the origin of the primate hand: American Museum Novitates, 3182:20.

Hansen, W. R., 1986, Neogene tectonics and geomorphology of the eastern Uinta Mountains in Utah, Colorado, and Wyoming: U.S. Geological Survey Professional Paper 1506-A, 1356:1-78.

Hasiotis, S. T. and P. C. Murphey, 1997, Preliminary report of aquatic plant and invertebrate ichnofossils from the middle Eocene Bridger Formation, southwest Wyoming: Geological Society of America Abstracts with Programs, Vol. 29, no. 2.

Hasiotis, S. T. and P. R. Murphey, 1997, Preliminary report on aquatic insect and plant ichnofossils from the middle Eocene Bridger Formation, Sweetwater County, Wyoming: Geological Society of America, South-Central Section, 31 st annual meeting and Rocky Mountain Section, 50th annual meeting, El Paso, TX, United States, March 20-21, 1997, 29(2):13.

Hayden, F. V., 1871, Preliminary report of the United States Geological Survey of Wyoming and portions of contiguous territories (2nd Annual Report): U.S. Government Printing Office, Department of the Interior. $155 \mathrm{pp}$.

Hayden, F. V., 1873, First, Second, and Third Annual Reports Report of the U.S. Geological and Geographic Survey of the Territories, for the years 1867, 1868, and 1869: U.S. Government Printing Office, Washington, $261 \mathrm{p}$.

Hembree, D. I. and S. T. Hasiotis, 2003, The fossil record and paleoecological significance of North American amphisbaenians and their burrows; the interaction of fossorial reptiles with the substrate: Geological Society of America, 2003 annual meeting, Seattle, WA, United States, Nov. 2-5, 2003, 35(6):499.

Hirsch, K. F. and R. Kohring, 1992, Crocodilian eggs from the middle Eocene Bridger Formation, Wyoming: Journal of Vertebrate Paleontology, 12(1):59-65.

Hutchison, J. H., 1984, Determinate growth in the Baenidae (Testudines); taxonomic, ecologic and stratigraphic significance: Journal of Vertebrate Paleontology, 3(3):148-151.

Ivy, L.D., 1993, Systematic revision of early to middle Eocene North American Hyaenodontidae (Mammalia, Creodonta): University of Colorado at Boulder, Boulder, CO, United States, Doctoral Dissertation.

Jerskey, R. G., 1981, A paleomagnetic study of the Bridger Formation, southern Green River Basin, Wyoming: Master's thesis, University of Wisconsin-Milwaukee, 113 pp. 


\section{A.1 GREATER GREEN RIVER BASIN, WYOMING AND COLORADO}

\section{A.1.3 Bridger Formation (Cont.)}

Kistner, F. B., 1973, Stratigraphy of the Bridger Formation in the Big Island-Blue Rim area, Sweetwater County, Wyoming: Master's thesis, University of Wyoming-Laramie, 174 pp.

Kitts, D. B., 1957, A revision of the genus Orohippus (Perissodactyla, Equidae) [Wyoming]: American Museum Novitates, 1864:40.

Koenig, K. J., 1949, Bridger Formation in the Bridger Basin, Wyoming: Ph.D. dissertation, University of Illinois, $119 \mathrm{p}$.

Koenig, K. J., 1960, Bridger Formation in the Bridger Basin, Wyoming: Wyoming Geol. Assoc. Guidebook, Fifteenth Annual Field Conference:163-168.

Korth, W. W., 1985, The rodents Pseudotomus and Quadratomus and the content of the tribe Manitshini (Paramyinae, Ischyromyidae): Journal of Vertebrate Paleontology, 5(2):139-152.

Krishtalka, L., 1976, Early Tertiary Adapisoricidae and Erinaceidae (Mammalia, Insectivora) of North America: Bulletin of Carnegie Museum of Natural History,(1):40-40.

Krishtalka, L., 1976, North American Nyctitheriidae; Mammalia, Insectivora: Annals of Carnegie Museum, 46(Article 2):7-28.

Krishtalka, L. and R. M. West, 1977, Paleontology and geology of the Bridger Formation, southern Green River basin, southwestern Wyoming; Part 2, The Bridgerian insectivore Entomolestes grangeri: Contributions in Biology and Geology,(14):11-11.

Krishtalka, L. and R. M. West, 1979, Paleontology and geology of the Bridger Formation, southern Green River basin, southwestern Wyoming; Part 4, The Geolabididae (Mammalia, Insectivora): Contributions in Biology and Geology,(27):10-10.

Krishtalka, L., R. M. West, C. C. Black, M. R. Dawson, J. J. Flynn, W. D. Turnbull, R. K. Stucky, M. M.C., T. M. Bown, D. J. Golz and J. A. Lillegraven, 1987, Eocene (Wasatchian through Duchesnean) biochronology of North America, In: Cenozoic Mammals of North America: Geochronology and Biostratigraphy (M. O. Woodburne, ed.), University of California Press, Berkeley. 77-117

Lanham, U., 1973, The Bone Hunters: The Historic Age of Paleontology in the American West: Dover Publications. 285 pp.

Leidy, J., 1869, Notice of some extinct vertebrates from Wyoming and Dakota: Proceedings of the Academy of Natural Sciences of Philadelphia:63-67. 


\section{A.1 GREATER GREEN RIVER BASIN, WYOMING AND COLORADO}

\section{A.1.3 Bridger Formation (Cont.)}

Leidy, J., 1871, Notice of some extinct rodents: Proceedings of the Academy of Natural Sciences of Philadelphia:230-232.

Leidy, J., 1872a, On the fossil vertebrates of the early Tertiary of Wyoming: United States Geological Survey of Montana and Portions of Adjacent Territories, Fifth Annual Report On the fossil vertebrates of the early Tertiary of Wyoming. pp. 353-372.

Leidy, J., 1872b, On some new species of fossil mammalia from Wyoming: Proceedings of the Academy of Natural Sciences of Philadelphia:167-169.

Leidy, J., 1873, Contributions to the extinct vertebrate fauna of the western territories, Part I: Report of the United States Geological Survey of the Territories, F.V. Hayden, 358 pp.

Love, J. D., 1939, Geology along the southern margin of the Absaroka Range, Wyoming: Geological Society of America Special Paper, 39:1-134.

Mader, B. J., 1989, The Brontotheriidae: a systematic revision and preliminary phylogeny of North American genera, In: The Evolution of Perissodactyls (D. R. Prothero and R. M. Schoch, eds.), New York, Oxford University Press. 458-484

Matthew, W. D., 1909, The Carnivora and Insectivora of the Bridger Basin, middle Eocene: Memoirs of the American Museum of Natural History, 9(6):291-567.

Matthew, W. D., 1920, A new genus of rodents [Reithroparamys] from the middle Eocene: Journal of mammalogy, 1(4):168-169.

Matthew, W. D. and W. Granger, 1903-1906, field notes: Frick Archives, American Museum of Natural History.

McGrew, P. O., 1959, The geology and paleontology of the Elk Mountain and Tabernacle Butte area, Wyoming: Bulletin of the American Museum of Natural History, 117 (Article 3):123-174.

McGrew, P. O. and T. M. Bown, 1976, Fossil vertebrate faunas: Green Mountain, Ferris-Seven Lakes, and Sandy EIS areas, and Sweetwater County, Wyoming: Unpublished technical report prepared for the Wyoming BLM. $422 \mathrm{pp}$.

McGrew, P. O. and T. M. Bown, 1977, Fossil vertebrate faunas: Carbon, Lincoln, and Uinta Counties, Wyoming: Unpublished technical report prepared for the Wyoming BLM. $251 \mathrm{pp}$.

McGrew, P. O. and R. Sullivan, 1970, The stratigraphy and paleontology of Bridger A: Contributions to Geology, University of Wyoming, 9(2):66-85. 


\section{A.1 GREATER GREEN RIVER BASIN, WYOMING AND COLORADO}

\section{A.1.3 Bridger Formation (Cont.)}

McKenna, M. C., P. Robinson and D. W. Taylor, 1962, Notes on Eocene Mammalia and Mollusca from Tabernacle Butte, Wyoming: American Museum Novitates, 2102:33.

McKenna, M. C., D. E. Russell, R. M. West, C. C. Black, T. D. Turnbull, M. R. Dawson and J. A. Lillegraven, 1973, K-Ar recalibration of Eocene North American land mammal "ages" and European ages: Geological Society of America Abstracts with Programs, 1999 Annual Meeting Issue., 5:733.

McKenna, M. C. and G. G. Simpson, 1959, A new insectivore from the middle Eocene of Tabernacle Butte, Wyoming: American Museum Novitates, 1952:12.

Miyata, K. and R. J. Emry, 2002, New information on the dental morphology of Trogosus material from the Bridger Formation, Uinta County, Wyoming, and its implication to the evolutionary history of tillodonts: Sixty-second annual meeting, Abstracts of papers, Norman, OK, United States, Oct. 9-12, 2002, 22(3, Suppl):89.

Mook, C. C., 1960, Diplocynodon remains from the Bridger beds of Wyoming: American Museum Novitates, 2007(2007):4.

Mook, C. C., 1961, Notes on the skull characters of Allognathosuchus polyodon: American Museum Novitates, 2072:1-5.

Mook, C. C., 1962, A new species of Brachyuranochampsa (Crocodilia) from the Bridger Beds of Wyoming: American Museum Novitates, 2079:6.

Morlo, M. and G. F. Gunnell, 2005, New species of Limnocyon (Mammalia, Creodonta) from the Bridgerian (middle Eocene): Journal of Vertebrate Paleontology, 25(1):251-255.

Morlo, M., G. F. Gunnell, 2003, New species of Limnocyon (Limnocyoninae, Hyaenodontidae, Mammalia) from the middle Bridgerian (middle Eocene) of southwestern Wyoming: Abstracts, Sixty-third annual meeting, Society of Vertebrate Paleontology, Science Museum of Minnesota, Saint Paul, MN, United States, Oct. 15-18, 2003, 23(3, Suppl):80.

Murphey, P. C., 1995, Paleontology, sedimentology, and depositional history of a middle Eocene lacustrine deposit in the Bridger Formation, southwest Wyoming: University of Colorado unpublished Masters Thesis. 121 p.

Murphey, P. C., 1996, Depositional setting and fauna of the Omomys Quarry; a possible owl site in the Bridger Formation (middle Eocene) of southwestern Wyoming: Abstracts, Fifty-sixth annual meeting, Society of Vertebrate Paleontology, New York, NY, United States, Oct. 16-19, 1996, 16(3, Suppl):55. 


\section{A.1 GREATER GREEN RIVER BASIN, WYOMING AND COLORADO}

\section{A.1.3 Bridger Formation (Cont.)}

Murphey, P. C., 1996, The Henrys Fork white layer, a fossil bearing lacustrine deposit within the middle Eocene Bridger Formation, southwestern Wyoming: Geological Society of America Abstracts with Programs, Vol. 28, no. 4, p. 33.

Murphey, P. C., L. Torick, E. Bray, R. Chandler and E. Evanoff, 1998, Taphonomy and paleoecology of the Omomys Quarry, an unusual fossil accumulation from the Bridger Formation, Wyoming: Abstracts, Fifty-eighth annual meeting, Society of Vertebrate Paleontology, Snowbird, UT, United States, Sept. 30-Oct. 3, 1998, 18(3, Suppl):65.

Murphey, P. C., A. Lester, B. Bohor, P. Robinson, E. Evanoff and E. Larson, 1999, 40Ar/39Ar dating of volcanic ash deposits in the Bridger Formation (middle Eocene) of southwestern Wyoming: Geological Society of America Abstracts with Programs, 1999 Annual Meeting Issue.

Murphey, P. C., 2001, Stratigraphy, fossil distribution, and depositional environments of the upper Bridger Formation (middle Eocene) of southwestern Wyoming, and the taphonomy of an unusual Bridger microfossil assemblage: University of Colorado Doctoral Dissertation. 345 pp.

Murphey, P. C., L. L. Torick, E. S. Bray, R. Chandler and E. Evanoff, 2001, Taphonomy, fauna, and depositional environment of the Omomys Quarry, an unusual accumulation from the Bridger Formation (middle Eocene) of southwestern Wyoming (USA); Eocene biodiversity; unusual occurrences and rarely sampled habitats (G. F. Gunnell and J. P. Alexander, eds.), Topics in Geobiology, 18:361-402.

Murphey, P. C. and K. E. Townsend, 2005, Ecological Diversity Analysis applied to facies faunas in the Twin Buttes Member, middle Eocene Bridger Formation, southwestern Wyoming, USA: Society of Vertebrate Paleontology, 25(3, Suppl).

Murphey, P. C. and E. Evanoff, 2006, Stratigraphy, fossil distribution and depositional environments of the upper Bridger Formation (middle Eocene), southwestern Wyoming: Wyoming State Geological Survey Report of Investigation, 56.

Novacek, M., 1977, A review of Paleocene and Eocene Leptictidae (Eutheria; Mammalia) from North America: PaleoBios,(24):42-42.

Osborn, H. F., 1904, An armadillo from the middle Eocene (Bridger) of North America: Bulletin of the American Museum of Natural History:163-165.

Osborn, H. F., 1929, The Titanotheres of ancient Wyoming, Dakota, and Nebraska: United States Geological Survey Monograph 1(55):1-701. 


\section{A.1 GREATER GREEN RIVER BASIN, WYOMING AND COLORADO}

\section{A.1.3 Bridger Formation (Cont.)}

Powell, J. W., 1876, Report on the geology of the eastern portion of the Uinta Mountains and a region of country adjacent thereto: U.S. Geological and Geographical survey of the Territiories:218 pp.

Prothero, D. R., 1995, Geochronology and magnetostratigraphy of Paleogene North American Land Mammal "ages": an update, In: Geochronology Time Scales and Global Stratigraphic Correlation, SEPM Special Publication 305-315.

Prothero, D. R. and C. C. Swisher, III, 1992, Magnetostratigraphy and geochronology of the terrestrial Eocene-Oligocene transition in North America, In: Eocene-Oligocene Climatic and Biotic Evolution (D. R. Prothero and W. A. Berggren,eds.), Princeton University Press, Princeton, New Jersey. 46-73.

Radinsky, L. B., 1967, Hyrachyus, Chasmotherium, and the early evolution of Helaletid tapiroids: American Museum Novitates, 2313:23.

Robinson, P., 1963, Fused cervical vertebrae from the Bridger Formation (Eocene) of Wyoming: Colorado Univ. Studies Ser. Geology, 1:6-9.

Robinson, P., D. J. Daitch and J. E. Haessig, 2000, Fossil vertebrate localities of southwestern Wyoming: a literature search, locality record, and formation evaluation: Unpublished technical report prepared for the Wyoming BLM.

Robinson, P., G. F. Gunnell, S. L. Walsh, W. C. Clyde, J. E. Storer, R. K. Stucky, D. J. Froehlich, I. F. Villafranca and M. C. McKenna, 2004, Wasatchian though Duschesnean biochronology, In: Late Cretaceous and Cenozoic Mammals of North America (M. O. Woodburne, ed.), Columbia University Press. 106-155.

Roehler, H. W., 1992a, Geology of the Eocene Wasatch, Green River, and Bridger (Washakie) Formations, Greater Green River Basin, Wyoming, Utah and Colorado: Introduction to Greater Green River Basin Geology, Physiography, and History of Investigations: U.S. Geological Survey Professional Paper 1506-A:14.

Roehler, H. W., 1992b, Geology of the Eocene Wasatch, Green River, and Bridger (Washakie) Formations, Greater Green River Basin, Wyoming, Utah and Colorado: Description and Correlation of Eocene Rocks in Stratigraphic Reference Sections for the Green River and Washakie Basin, Southwest Wyoming: U.S. Geological Survey Professional Paper 1506-D:83 pp. 


\section{A.1 GREATER GREEN RIVER BASIN, WYOMING AND COLORADO}

\section{A.1.3 Bridger Formation (Cont.)}

Roehler, H. W., 1992c, Geology of the Eocene Wasatch, Green River, and Bridger (Washakie) Formations, Greater Green River Basin, Wyoming, Utah and Colorado: Correlation, Composition, Areal Distribution, and Thickness of Eocene Stratigraphic Units, Greater Green River Basin, Wyoming, Utah, and Colorado: U.S. Geological Survey Professional Paper 1506-E:49 pp.

Roehler, H. W., 1993, Geology of the Eocene Wasatch, Green River, and Bridger (Washakie) Formations, Greater Green River Basin, Wyoming, Utah and Colorado: Eocene Climates, Depositional Environments, and Geography, Greater Green River Basin, Wyoming, Utah and Colorado: U.S. Geological Survey Professional Paper 1506-F:74 pp.

Royse, F. R. J., 1993, An overview of the geologic structure of the thrust belt in Wyoming, northern Utah, and eastern Idaho, In: Geology of Wyoming, Memoir no. 5, The Geological Survey of Wyoming, pp. 272-311.

Schafer, A. R., H. T. Goodwin, L. Brand, H. Moon, S. Ting, P. Gingerich, P. Higgins, B. Small and M. Fox, 2004, Taphonomy of microfossils from the Black Mountain turtle layer, Eocene Bridger Formation, southwestern Wyoming: Abstracts, Sixty-fourth annual meeting, Society of Vertebrate Paleontology, Denver, CO, United States, Nov. 3-6, 2004, 24(3, Suppl):110.

Schminke, H. U. and P. van den Bogaard, 1991, Tephra layers and tephra events, In: Cycles and Events in Stratigraphy (G. Einsele, W. Ricken and A. Seilacher, eds.), Springer-Verlag, Berlin. 392-429.

Schoch, R. M., 1983, A new species of Isectolophus (Mammalia, Tapiroidea) from the middle Eocene of Wyoming: Postilla, 188:4.

Simpson, G. G., 1933, Glossary and correlation charts of North American Tertiary mammalbearing formations: American Museum of Natural History Bulletin, 47:91.

Simpson, G. G., 1959a, Two new records from the Bridger middle Eocene of Tabernacle butte, Wyoming: American Museum Novitates, 1966:5.

Simpson, G. G., 1959b, A new middle Eocene edentate from Wyoming: American Museum Novitates, 1950:8.

Sinclair, W. J., 1906, Volcanic ash in the Bridger beds of Wyoming: American Museum of Natural History Bulletin, vol. 22, article 15, pp. 273-280.

Slattengren, B. A., 1988, Paramyid rodents from a single layer in the middle Eocene Bridger Formation: Abstracts, Forty-eighth annual meeting, Society of Vertebrate Paleontology, Drumheller, AB, Canada, Oct. 13-15, 1988, 8(3, Suppl):26A. 


\section{A.1 GREATER GREEN RIVER BASIN, WYOMING AND COLORADO}

\section{A.1.3 Bridger Formation (Cont.)}

Smith, M. E., 2001, Precise 40Ar/39Ar laser fusion geochronology of the Green River Formation, Wyoming: Geological Society of America Abstracts with Programs, annual meeting issue.

Smith, M. E., B. Singer and A. R. Carroll, 2003, 40Ar/39Ar geochronology of the Eocene Green River Formation, Wyoming: Geological Society of America Bulletin, 115(5):545-565.

Socci, A., 1978, The sedimentary petrology of the Bridger C in the southern Green River Basin, southern Wyoming: Master's thesis, University of Wisconsin-Milwaukee.

Sullivan, R. M., 1979, Revision of the Paleogene genus Glyptosaurus; Reptilia, Anguidae: Bulletin of the American Museum of Natural History, 163, Article 1:72.

Sullivan, R. M., 1986, The skull of Glyptosaurus sylvestris Marsh, 1871 (Lacertilia: Anguidae): Journal of Vertebrate Paleontology, 6(1):28-37.

Townsend, K. E., 2004, Stratigraphy, paleoecology, and habitat change in the middle Eocene of North America: Washington University, Saint Louis, MO, United States (USA) Doctoral.

Troxell, E. L., 1923, American rhinoceroses and the evolution of Diceratherium: Geological Society of America Bulletin, 34(1):134.

Troxell, E. L., 1923, Pauromys perditus, a small rodent [Bridger formation, Wyoming]: American Journal of Science, 5:155-156.

Vallentyne, J. R., 1960, On fish remains in lacustrine sediments: American Journal of Science, Bradley Volume, 258-A:344-349.

Wallace, S. M., 1980, A revision of North American early Eocene Brontotheriidae (Mammalia, Perissodactyla): University of Colorado, Boulder, CO, United States (USA) Master's.

Walsh, S. A., 1996, The Bridgerian/Uintan boundary and the status of the "Shoshonian" (earliest Uintan) land mammal "subage," In: The Terrestrial Eocene-Oligocene Transition in

North America (D. R. Prothero and R. J. Emry, eds.), New York, Cambridge University Press. 52-59.

West, R. M., 1970, Additional Middle Eocene (Bridgerian) mammals from Tabernacle Butte, Sublette County, Wyoming: American Museum Novitates, 2404:26 pp.

West, R. M., 1972, The North American Eocene apatemyid insectivores: Year Book - American Philosophical Society, 1971(71):357. 


\section{A.1 GREATER GREEN RIVER BASIN, WYOMING AND COLORADO}

\section{A.1.3 Bridger Formation (Cont.)}

West, R. M., 1973, An early middle Eocene epoicotheriid (Mammalia) from southwestern Wyoming: Journal of Paleontology, 47(5):929-931.

West, R. M., 1974, New North American Middle Eocene nyctithere (Mammalia, Insectivora): Journal of Paleontology, 48(5):983-987.

West, R. M., 1976, Paleontology and geology of the Bridger Formation, southern Green River basin, southwestern Wyoming; Part 1, History of field work and geological setting: Contributions in Biology and Geology,(7):12-12.

West, R. M., 1979, Paleontology and geology of the Bridger Formation, southern Green River basin, southwestern Wyoming; Part 3, Notes on Hyopsodus: Contributions in Biology and Geology,(25):52-52.

West, R. M., 1981, Geology and paleontology of the Bridger Formation, southern Green River basin, southwestern Wyoming; Part 5, Harpagolestes macrocephalus and comments on structure, function and diversity of middle Eocene to early Oligocene large mesonychids: Contributions in Biology and Geology,(43):17-17.

West, R. M., 1984, Paleontology and geology of the Bridger Formation, southern Green River basin, southwestern Wyoming; Part 7, Survey of Bridgerian Artiodactyla, including description of a skull and partial skeleton of Antiacodon pygmaeus: Contributions in Biology and Geology, $56: 47$.

West, R. M., 1990, Vertebrate paleontology of the Green River Basin, Wyoming, 1840-1910: Earth Sciences History, 9(1):45-56.

West, R. M. and M. R. Dawson, 1975, Eocene fossil Mammalia from the Sand Wash Basin, northwestern Moffat County, Colorado: Annals of Carnegie Museum, 45(Article 11):231-253.

West, R. M. and J. H. Hutchison, 1981, Geology and paleontology of the Bridger Formation, southern Green River basin, southwestern Wyoming; Part 6, The fauna and correlation of Bridger E: Contributions in Biology and Geology, 46:8.

Wetmore, A., 1922, A fossil owl from the Bridger Eocene: Proceedings of the Academy of Natural Sciences of Philadelphia, 73, Part 3:455-458.

Wilson, M. V., 1987, Predation as a source of fish fossils in Eocene lake sediments: Palaios, 2:497-504.

Wilson, R. W., 1938, Review of some rodent genera from the Bridger Eocene; Part III: American Journal of Science, 35(208):297-304. 


\section{A.1 GREATER GREEN RIVER BASIN, WYOMING AND COLORADO}

\section{A.1.3 Bridger Formation (Cont.)}

Wood, A. E., 1959, A new sciuravid rodent of the genus Pauromys from the Eocene of Wyoming: American Museum Novitates, 1978:6.

Wood, C. B., 1966, Stratigraphy and paleontology of the Bridger Formation northeast of Opal, Lincoln County, Wyoming: University of Wyoming, Laramie, WY, United States (USA) Master's.

Wood, H. E., 1934, Revision of the Hyrachyidae: American Museum of Natural History Bulletin, 67(5):181-295.

Wood, H. E., R. W. Chaney, J. Clark, E. H. Colbert, G. L. Jepsen, J. B. Reeside and C. Stock, 1941, Nomenclature and correlation of the North American continental Tertiary: Geological Society of America Bulletin, 52:1-48.

Woodburne, M. O. and C. C. I. Swisher, 1995, Land mammal high-resolution geochronology, intercontinental overland dispersals, sea level, climate, and vicariance, In: Geochronology, Time Scales, and Global Stratigraphic Correlations: Unified Temporal Framework for an Historical Geology (W. A. Berggren, D. V. Kent, M. P. Aubry and J. Hardenbol, eds.), SEPM Special Publication no. 54. 337-364.

Zangerl, R., 1944, Aspideretes annae n. sp., a new species of soft shell turtle from the Bridger Eocene of Wyoming: American Midland Naturalist, 31(3):583-591. 


\section{A.1 GREATER GREEN RIVER BASIN, WYOMING AND COLORADO}

\section{A.1.4 Washakie Formation}

Black, C. C. and M. R. Dawson, 1966, A review of late Eocene mammalian faunas from North America: American Journal of Science, 264:321-349.

Covey, D. S. G. and S. M. McCarroll, 1996, The artiodactyl fauna of the Washakie Formation, Eocene age, of southern Wyoming: Abstracts, Fifty-sixth annual meeting, Society of Vertebrate Paleontology, New York, NY, United States, Oct. 16-19, 1996, 16(3, Suppl):29.

Ericson, P. G. P., 1999, New material of Juncitarsus (Phoenicopteriformes), with a guide for differentiating that genus from the Presbyornithidae (Anseriformes), In: Avian paleontology at the close of the 20th century: 4th international meeting of the Society of Avian Paleontology and Evolution, Washington, DC, United States, June 4-7, 1996, 89:245-251.

Flynn, J. J., 1986, Correlation and geochronology of middle Eocene strata from the western United States: Palaeogeography, Palaeoclimatology, Palaeoecology, 55:335-406.

Foss, S. E., W. D. Turnbull and L. Barber, 2001, Observations on a new specimen of Achaenodon (Mammalia, Artiodactyla) from the Eocene Washakie Formation of southern Wyoming: Abstracts, Sixty-first annual meeting, Society of Vertebrate Paleontology, Bozeman, MT, United States, Oct. 3-6, 2001, 21(3, Suppl):51.

Granger, W., 1909, Faunal horizons of the Washakie Formation of southern Wyoming: Bulletin of the American Museum of Natural History:13-23.

Holbrook, L. T. and S. G. Lucas, 1997, A new genus of rhinocerotoid from the Eocene of Utah and the status of North American "Forstercooperia": Journal of Vertebrate Paleontology, 17(2):384-396.

Hutchison, J. H., 1984, Determinate growth in the Baenidae (Testudines); taxonomic, ecologic and stratigraphic significance: Journal of Vertebrate Paleontology, 3(3):148-151.

Lucas, S. G. and R. M. Schoch, 1989, Taxonomy and biochronology of Eomoropus and Grangeria, Eocene chalicotheres from the Western United States and China, In: The evolution of perissodactyls: Fourth International Theriological Congress; Workshop on the evolution of perissodactyls, Edmonton, AB, Canada, August 16, 1985, 15:422-437.

McCarroll, S. M., 1995, An early Uintan fauna from the upper unit of the Adobe Town Member, Washakie Formation, Washakie Basin, Wyoming: Abstracts, Fifty-fifth annual meeting, Society of Vertebrate Paleontology, Pittsburgh, PA, United States, Nov. 1-4, 1995, 15(3, Suppl):42.

McCarroll, S. M., J. J. Flynn and W. D. Turnbull, 1996a, The mammalian faunas of the Washakie Formation, Eocene age, of southern Wyoming; Part III, The perissodactyls: Fieldiana: Geology (New Series), 33:38. 


\section{A.1 GREATER GREEN RIVER BASIN, WYOMING AND COLORADO}

\section{A.1.4 Washakie Formation (Cont.)}

McCarroll, S. M. and K. Padian, 1994, Perissodactyls from the Washakie Formation (middle-late Eocene), Washakie Basin, Wyoming: Abstracts, Fifty-fourth annual meeting, Society of Vertebrate Paleontology, Seattle, WA, United States, Oct. 19-22, 1994, 14(3, Suppl):37.

McCarroll, S. M. and W. D. Turnbull, 1996b, A late Bridgerian fauna from the Kinney Rim Member of the Washakie Formation, Washakie Basin, Wyoming: Abstract, Fifty-sixth annual meeting, Society of Vertebrate Paleontology, New York, NY, United States, Oct. 16-19, 1996, 16(3, Suppl):51-52.

Osborn, H. F., 1881, A memoir upon Loxolophodon and Uintatherium: E.M. Museum of Geology and Archaeology of the College of New Jersey Contributions, 1(1):1-44.

Osborn, H. F., 1929, The titanotheres of ancient Wyoming, Dakota, and Nebraska: U.S. Geologic Survey Monograph 1:1-701.

Prothero, D. R. and C. C. Swisher, III, 1992, Magnetostratigraphy and geochronology of the terrestrial Eocene-Oligocene transition in North America, In: Eocene-Oligocene Climatic and Biotic Evolution (D. R. Prothero and W. A. Berggren,eds.), Princeton University Press, Princeton, New Jersey. 46-73.

Robinson, P., G. F. Gunnell, S. L. Walsh, W. C. Clyde, J. E. Storer, R. K. Stucky, D. J. Froehlich, I. F. Villafranca and M. C. McKenna, 2004, Wasatchian though Duschesnean biochronology, In: Late Cretaceous and Cenozoic Mammals of North America (M. O. Woodburne, ed.), Columbia University Press. 106-155.

Roehler, H. W., 1992, Description and correlation of Eocene rocks in stratigraphic reference sections for the Green River and Washakie basins, Southwest Wyoming: U.S. Geological Survey Professional Paper P 1506-D, p. D1-D83.

Roehler, H. W., 1992a, Geology of the Eocene Wasatch, Green River, and Bridger (Washakie) Formations, Greater Green River Basin, Wyoming, Utah and Colorado: Introduction to Greater Green River Basin Geology, Physiography, and History of Investigations: U.S. Geological Survey Professional Paper 1506-A:14 pp.

Roehler, H. W., 1992b, Geology of the Eocene Wasatch, Green River, and Bridger (Washakie) Formations, Greater Green River Basin, Wyoming, Utah and Colorado: Description and Correlation of Eocene Rocks in Stratigraphic Reference Sections for the Green River and Washakie Basin, Southwest Wyoming: U.S. Geological Survey Professional Paper 1506-D, $83 \mathrm{pp}$. 


\section{A.1 GREATER GREEN RIVER BASIN, WYOMING AND COLORADO}

\section{A.1.4 Washakie Formation (Cont.)}

Roehler, H. W., 1992c, Geology of the Eocene Wasatch, Green River, and Bridger (Washakie) Formations, Greater Green River Basin, Wyoming, Utah and Colorado: Correlation, Composition, Areal Distribution, and Thickness of Eocene Stratigraphic Units, Greater Green River Basin, Wyoming, Utah, and Colorado: U.S. Geological Survey Professional Paper 1506-E:49 pp.

Roehler, H. W., 1993, Geology of the Eocene Wasatch, Green River, and Bridger (Washakie) Formations, Greater Green River Basin, Wyoming, Utah and Colorado: Eocene Climates, Depositional Environments, and Geography, Greater Green River Basin, Wyoming, Utah and Colorado: U.S. Geological Survey Professional Paper 1506-F:74 pp.

Snyder, J. R., 1993, A new genus of Helohyidae (Mammalia, Artiodactyla) from the Sand Wash Basin, Colorado (Washakie Formation, Eocene, earliest Uintan): Abstracts, Fifty-third annual meeting, Society of Vertebrate Paleontology, Albuquerque, NM, United States, Oct. 13-16, 1993, 13(3, Suppl):58.

Stucky, R. K., D. R. Prothero, W. G. Lohr and J. R. Snyder, 1996, Magnetic stratigraphy, sedimentology, and mammalian faunas of the early Uintan Washakie Formation, Sand Wash Basin, Colorado, In: The Terrestrial Eocene-Oligocene Transition in North America (D. R. Prothero and R. J. Emry, eds.), Cambridge University Press. 40-51.

Stucky, R. K. and J. R. Snyder, 1992, Mammalian fauna of the Sand Wash Basin, Colorado (Washakie Formation, middle Eocene, earliest Uintan): Abstracts, Fifty-second annual meeting, Society of Vertebrate Paleontology, Toronto, ON, Canada, October 28-31, 1992, 12(3, Suppl):54A.

Turnbull, W. D., 1972a, The Allen Titanothere Quarry: Abstracts, Thirty-second annual meeting, Society of Vertebrate Paleontology:8.

Turnbull, W. D., 1972b, The Washakie Formation of Bridgerian-Uintan ages, and the related faunas: Field Conference on Tertiary Biostratigraphy of Southern and Western Wyoming, Adelphi University, Department of Biology:20-31.

Turnbull, W. D., 1978, The mammalian faunas of the Washakie Formation, Eocene age, of southern Wyoming: Part I- Introduction: the geology, history, and setting: Fieldiana: Geology, 33(30):569-601.

Turnbull, W. D., 1993, Addition to knowledge of the uintatheres of the Washakie Formation and aspects of their biology: Abstracts, Fifty-third annual meeting, Society of Vertebrate Paleontology, Albuquerque, NM, United States, Oct. 13-16, 1993, 13(3, Suppl):60. 


\section{A.1 GREATER GREEN RIVER BASIN, WYOMING AND COLORADO}

\section{A.1.4 Washakie Formation (Cont.)}

Turnbull, W. D., 2004, Taenidonta of the Washakie Formation, southwestern Wyoming; Fanfare for an uncommon paleontologist; papers in honor of Malcolm C. McKenna: Bulletin of Carnegie Museum of Natural History, 36:302-333.

Turnbull, W. D. and D. M. Martill, 1988, Taphonomy and preservation of a monospecific titanothere assemblage from the Washakie Formation (late Eocene), southern Wyoming;, an ecological accident in the fossil record; Ecological and evolutionary implications of taphonomic processes: Palaeogeography, Palaeoclimatology, Palaeoecology, 63(1-3):91-108.

Wood, H. E., R. W. Chaney, J. Clark, E. H. Colbert, G. L. Jepsen, J. J. B. Reeside and C. Stock, 1941, Nomenclature and correlation of the North American continental Tertiary: Bulletin of the Geological Society of America, 52:1-48.

Woodburne, M. O. and C. C. I. Swisher, 1995, Land mammal high-resolution geochronology, intercontinental overland dispersals, sea level, climate, and vicariance, In: Geochronology, Time Scales, and Global Stratigraphic Correlations: Unified Temporal Framework for an Historical Geology (W. A. Berggren, D. V. Kent, M. P. Aubry and J. Hardenbol, eds.), SEPM Special Publication no. 54. 337-364. 


\section{A.1 GREATER GREEN RIVER BASIN, WYOMING AND COLORADO}

\section{A.1.5 Bishop Conglomerate}

Bradley, W. H., 1964, Geology of Green River Formation and associated Eocene rocks in southwestern Wyoming and adjacent parts of Colorado and Utah: U.S. Geological Survey Professional Paper 496-A:1-86.

Geo/Resource, 1984, Green River Basin geologic resources inventory: Unpublished Technical Report prepared for the Wyoming BLM.

Hansen, W. R., 1986, Neogene tectonics and geomorphology of the eastern Uinta Mountains in Utah, Colorado, and Wyoming: U.S. Geological Survey Professional Paper 1356:1-78.

McGrew, P. O. and T. M. Bown, 1976, Fossil vertebrate faunas: Green Mountain, Ferris-Seven Lakes, and Sandy EIS areas, and Sweetwater County, Wyoming: Unpublished technical report prepared for the Wyoming BLM. $422 \mathrm{pp}$.

McGrew, P. O. and T. M. Bown, 1977, Fossil vertebrate faunas: Carbon, Lincoln, and Uinta Counties, Wyoming: Unpublished technical report prepared for the Wyoming BLM. 251 pp.

Robinson, P., D. J. Daitch and J. E. Haessig, 2000, Fossil vertebrate localities of southwestern Wyoming: a literature search, locality record, and formation evaluation: Unpublished technical report prepared for the Wyoming BLM.

Sinclair, W. J., 1906, Volcanic ash in the Bridger beds of Wyoming: American Museum of Natural History Bulletin, vol. 22, article 15, p. 273-280.

Wood, H. E., R. W. Chaney, J. Clark, E. H. Colbert, G. L. Jepsen, J. J. B. Reeside and C. Stock, 1941, Nomenclature and correlation of the North American continental Tertiary: Bulletin of the Geological Society of America, 52:1-48.

Woodburne, M. O. and C. C. I. Swisher, 1995, Land mammal high-resolution geochronology, intercontinental overland dispersals, sea level, climate, and vicariance, In: Geochronology, Time Scales, and Global Stratigraphic Correlations: Unified Temporal Framework for an Historical Geology (W. A. Berggren, D. V. Kent, M. P. Aubry and J. Hardenbol, eds.), SEPM Special Publication no. 54. 337-364. 


\section{A.1 GREATER GREEN RIVER BASIN, WYOMING AND COLORADO}

\section{A.1.6 Browns Park Formation}

Bradley, W. H., 1964, Geology of Green River Formation and associated Eocene rocks in southwestern Wyoming and adjacent parts of Colorado and Utah: U.S. Geological Survey Professional Paper 496-A:1-86.

Geo/Resource, 1984, Green River Basin geologic resources inventory: Unpublished Technical Report prepared for the Wyoming BLM.

Honey, J. G., 1977, The paleontology of the Brown's Park Formation in the Maybell, Colorado area, and a taphonomic study of two fossil quarries Colorado and Arizona: University of Arizona, Tucson, AZ, United States (USA) Master's.

Honey, J. G. and G. A. Izett, 1988, Paleontology, taphonomy, and stratigraphy of the Browns Park Formation (Oligocene and Miocene) near Maybell, Moffat County, Colorado: U.S. Geological Survey Professional Paper 1358, 52 pp.

McGrew, E. J., 1951, Tertiary stratigraphy and paleontology of south-central Wyoming: Wyoming Geological Association Guidebook, Sixth Annual Field Conference, South-central Wyoming:54-57.

McGrew, P. O. and T. M. Bown, 1976, Fossil vertebrate faunas: Green Mountain, Ferris-Seven Lakes, and Sandy EIS areas, and Sweetwater County, Wyoming: Unpublished technical report prepared for the Wyoming BLM. $422 \mathrm{pp}$.

McGrew, P. O. and T. M. Bown, 1977, Fossil vertebrate faunas: Carbon, Lincoln, and Uinta Counties, Wyoming: Unpublished technical report prepared for the Wyoming BLM. 251 pp.

Peterson, O. A., 1924, Discovery of fossil mammals in the Browns Park Formation of Moffat County, Colorado: Annals of Carnegie Museum, 15(2-3):299-304.

Robinson, P., D. J. Daitch and J. E. Haessig, 2000, Fossil vertebrate localities of southwestern Wyoming: a literature search, locality record, and formation evaluation: Unpublished technical report prepared for the Wyoming BLM.

Rowley, P. D. and W. R. Hansen, 1982, Relation of Bishop Conglomerate to Browns Park Formation in eastern Uinta Mountains, Colorado and Utah; Geological Survey research 1982: U.S. Geological Survey Professional Paper P 1375, p. 57-58.

Wood, H. E., R. W. Chaney, J. Clark, E. H. Colbert, G. L. Jepsen, J. J. B. Reeside and C. Stock, 1941, Nomenclature and correlation of the North American continental Tertiary: Bulletin of the Geological Society of America, 52:1-48. 


\section{A.1 GREATER GREEN RIVER BASIN, WYOMING AND COLORADO}

\section{A.1.6 Browns Park Formation (Cont.)}

Woodburne, M. O. and C. C. I. Swisher, 1995, Land mammal high-resolution geochronology, intercontinental overland dispersals, sea level, climate, and vicariance, In: Geochronology, Time Scales, and Global Stratigraphic Correlations: Unified Temporal Framework for an Historical Geology (W. A. Berggren, D. V. Kent, M. P. Aubry and J. Hardenbol, eds.), SEPM Special Publication no. 54. 337-364. 


\section{A.1 GREATER GREEN RIVER BASIN, WYOMING AND COLORADO}

\section{A.1.7 Quaternary Units}

Cook, H. J., 1930, Occurrence of mammoth and giant bison in Glacial moraines in the high mountains of Colorado: Science, 72, no. 1885:68.

Cook, H. J., 1931, More evidence of mammoths in the high mountains of Colorado: Science, 73, no. 1889:283-284.

Emslie, S. D., 1986, Late Pleistocene vertebrates from Gunnison County, Colorado: Journal of Paleontology, 60:170-176.

Geo/Resource, 1984, Green River Basin geologic resources inventory: Unpublished Technical Report prepared for the Wyoming BLM.

Gillette, D. D., C. J. Bell and M. C. Hayden, 1999b, Preliminary report of the Little Dell Dam fauna, Salt Lake County, Utah (Middle Pleistocene, Irvingtonian Land mammal Age):

In: Vertebrate paleontology in Utah: Miscellaneous Publication - Utah Geological Survey, 99-1:495-500.

Gillette, D. D., H. G. McDonald and M. C. Hayden, 1999a, The first record of Jefferson's Ground Sloth, Megalonyx Jeffersonii, in Utah (Pleistocene, Rancholabrean Land Mammal Age): In: Vertebrate paleontology in Utah Miscellaneous Publication - Utah Geological Survey, 99-1:509-522.

Gillette, D. D. and W. E. Miller, 1999, Catalogue of new Pleistocene mammalian sites and

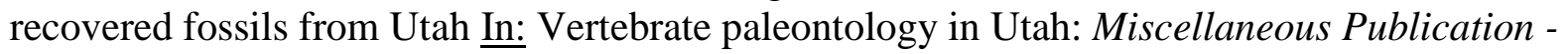
Utah Geological Survey, 99-1:523-530.

Heaton, T. H., 1999, Late Quaternary vertebrate history of the Great Basin: In: Vertebrate paleontology in Utah: Miscellaneous Publication - Utah Geological Survey, 99-1:501-508.

Hunt, C. B., 1954, Pleistocene and Recent deposits in the Denver area, Colorado: U.S. Geological Survey Bulletin 996-C: 91-140.

Larson, P. R., 1999, The Columbian mammoth (Mammuthus columbi) from Escalante Valley, Iron County, Utah--discovery and implications: In: Vertebrate paleontology in Utah: Miscellaneous Publication - Utah Geological Survey, 99-1:531-537.

Lewis, G. E., 1970, New discoveries of Pleistocene bison and peccaries in Colorado: U.S. Geological Survey Professional Paper 700-B:B137-B140.

McGrew, P. O. and T. M. Bown, 1976, Fossil vertebrate faunas: Green Mountain, Ferris-Seven Lakes, and Sandy EIS areas, and Sweetwater County, Wyoming: Unpublished technical report prepared for the Wyoming BLM. $422 \mathrm{pp}$. 


\section{A.1 GREATER GREEN RIVER BASIN, WYOMING AND COLORADO}

\section{A.1.7 Quaternary Units (Cont.)}

McGrew, P. O. and T. M. Bown, 1977, Fossil vertebrate faunas: Carbon, Lincoln, and Uinta Counties, Wyoming: Unpublished technical report prepared for the Wyoming BLM. $251 \mathrm{pp}$.

Robinson, P., D. J. Daitch and J. E. Haessig, 2000, Fossil vertebrate localities of southwestern Wyoming: a literature search, locality record, and formation evaluation: Unpublished technical report prepared for the Wyoming BLM.

Scott, G. R., 1963, Quaternary geology and geomorphic history of the Kassler Quadrangle, Colorado: U.S. Geological Survey Professional Paper 421-A:70 pp.

Smith, K. S., R. L. Cifelli and N. J. Czaplewski, 1999, An early Holocene, high-altitude vertebrate faunule from central Utah: In: Vertebrate paleontology in Utah: Miscellaneous Publication - Utah Geological Survey, 99-1:537-543. 


\section{A.2 PICEANCE CREEK BASIN, COLORADO}

\section{A.2.1 DeBeque Formation ( = Wasatch Formation)}

Ambrose, P., W. S. Bartels, G. F. Gunnell, E. M. Williams, J. Bolt and L. Grande, 1997, Stratigraphy and vertebrate paleontology of the Wasatch Formation, Fossil Butte National Monument, Wyoming: Abstract, Fifty-seventh annual meeting, Society of Vertebrate Paleontology, Chicago, IL, United States, Oct. 8-11, 1997, 17(3, Suppl):29.

Anemone, R. L., D. Bowen, L.-J. Davignon, D. Koepfer and D. J. Over, 1998, The Red Desert Basin Project; vertebrate paleontology and geology of an intermontane basin in southwestern Wyoming: Twenty-first annual fall scientific paper session, Rochester, NY, United States, Nov. 5 , 1994, 18(3):71.

Beasley, B. A., 1991, A late Pleistocene avifauna from the Blonquist Rockshelter, Summit County, Utah: 123rd annual meeting, Kansas Academy of Science, Lindsborg, KS, United States, Apr. 11-12, 1991, 123:3.

Beasley, B. A., M. E. Nelson, G. A. Liggett, J. C. Pugh and S. R. Ash, 1992, Paleontological investigation at the Blonquist rockshelter, Summit County, Utah: Geological Society of America, Rocky Mountain Section and associated societies, 45th annual meeting, Ogden, UT, United States, May 13-15, 1992, 24(6):2.

Black, C. C. and M. R. Dawson, 1966, A review of late Eocene mammalian fauna from North America: American Journal of Science, 264:321-349.

Breithaupt, B. H., 1990, Early Tertiary fossils and environments of Wyoming; Jackson to Fossil Butte National Monument; Geologic field tours of western Wyoming and parts of adjacent Idaho, Montana, and Utah: Public Information Circular - Geological Survey of Wyoming, 29:57-72.

Bryant, B., C. W. Naeser, R. F. Marvin and H. H. Mehnert, 1989, Upper Cretaceous and Paleogene sedimentary rocks and isotopic ages of Paleogene tuffs, Uinta Basin, Utah: U.S. Geological Survey Bulletin, 1787-J:22 pp.

Cope, E. D., 1884, Vertebrata of the Tertiary Formations of the West: Report of the U.S. Geological Survey of the Territories, vol. 3.

Dawson, M. R., 1968, Middle Eocene rodents (Mammalia) from northeastern Utah: Annals of Carnegie Museum, 39:327-370.

Doi, K., 1990, Geology, and paleontology of two primate families of the Raven Ridge, northwestern Colorado and northeastern Utah: University of Colorado, Boulder, CO, United States (USA) Master's. 


\section{A.2 PICEANCE CREEK BASIN, COLORADO}

\section{A.2.1 DeBeque Formation ( = Wasatch Formation) (Cont.)}

Dorr, J. A., Jr., 1978, Revised and amended fossil vertebrate faunal lists, early Tertiary, Hoback Basin, Wyoming: Contributions to Geology, 16(2):79-84.

Dorr, J. A., Jr. and P. D. Gingerich, 1980, Early Cenozoic mammalian paleontology, geologic structure, and tectonic history in the overthrust belt near LaBarge, western Wyoming:

Contributions to Geology, University of Wyoming, 18(2):101-115.

Eaton, J. G., J. I. Kirkland and K. Doi, 1989, Evidence of reworked Cretaceous fossils and their bearing on the existence of Tertiary dinosaurs: Palaios, 4(3):281-286.

Fisher, E. J., C. E. Erdman and J. B. Reeside, Jr. , 1960, Cretaceous and Tertiary Formations of the Book Cliffs: Carbon, Emery, and Grand counties, Utah, and Garfield and Mesa counties, Colorado: U.S. Geological Survey Professional Paper, 332:80 pp.

Foster, J. R., 2000, Amphibian tracks (Ambystomichnus?) from the Cathedral Bluffs Tongue of the Wasatch Formation (Eocene), southwestern Wyoming: Geological Society of America, Rocky Mountain Section, 52nd annual meeting, Missoula, MT, United States, April 17-18, 2000, 32(5):8-9.

Foster, J. R., 2001, Salamander tracks (Ambystomichnus?) from the Cathedral Bluffs Tongue of the Wasatch Formation (Eocene), northeastern Green River basin, Wyoming: Journal of Paleontology, 75(4):901-904.

Gauthier, J. A., 1982, Fossil xenosaurid and anguid lizards from the early Eocene Wasatch Formation, Southeast Wyoming, and a revision of the Anguioidea: Contributions to Geology, 21(1):7-54.

Geo/Resource, 1984, Green River Basin geologic resources inventory: Unpublished Technical Report prepared for the Wyoming BLM.

Gingerich, P. D. and J. A. Dorr, Jr., 1979, Mandible of Chiromyoides minor (Mammalia, Primates) from the upper Paleocene Chappo Member of the Wasatch Formation, Wyoming: Journal of Paleontology, 53(3):550-552.

Granger, W. and G. G. Simpson, 1928, Multituberculates in the Wasatch Formation: American Museum Novitates, 312:4.

Gregson, J. D. and D J. Chure, 2000, Geology and Paleontology of Dinosaur National Monument, Utah-Colorado, In: Geology of Utah's Parks and Monuments (D. A. Sprinkel, T. C. Chidsey Jr., and P. B Anderson, eds.), Utah Geological Association Publication. 155-188. 


\section{A.2 PICEANCE CREEK BASIN, COLORADO}

\section{A.2.1 DeBeque Formation ( = Wasatch Formation) (Cont.)}

Gunnell, G. F., 1994, Paleocene mammals and faunal analysis of the Chappo type locality (Tiffanian), Green River Basin, Wyoming: Journal of Vertebrate Paleontology, 14(1):81-104.

Gunnell, G. F., W. S. Bartels, J. Bolt and L. Grande, 1997, Basin-margin mammalian assemblages from the Wasatch Formation (Bridgerian) of the northeastern Green River Basin, Wyoming; anachronistic taxa and the origin of new genera: Abstracts, Fifty-seventh annual meeting, Society of Vertebrate Paleontology, Chicago, IL, United States, Oct. 8-11, 1997, 17(3, Suppl):51.

Gunnell, G. F., W. S. Bartels and J.-P. Zonneveld, 2004, A late Wasatchian (late early Eocene) vertebrate assemblage preserved in meandering stream channel deposits, northern Red Desert, Wyoming: Geological Society of America, 2004 annual meeting, Denver, CO, United States, Nov. 7-10, 2004, 36(5):92.

Gunnell, G. F., W. S. Bartels and J. P. Zonneveld, 2002, Stratigraphy, vertebrate paleontology, and paleoecology of the Wasatch Formation, Fossil Butte National Monument, Wyoming: Geological Society of America, 2002 annual meeting, Denver, CO, United States, Oct. 27-30, 2002, 34(6):557.

Gunnell, G. F. and V. L. Yarborough, 2000, Brontotheriidae (Perissodactyla) from the late early and middle Eocene (Bridgerian), Wasatch and Bridger formations, southern Green River basin, southwestern Wyoming: Journal of Vertebrate Paleontology, 20(2):349-368.

Gunnell, G. F., J. P. Zonneveld and W. S. Bartels, In Press, Stratigraphy, vertebrate paleontology, and paleoecology of the Wasatch Formation, Fossil Butte National Monument, Wyoming Part 2: mammalian paleontology and age correlation: Wyoming State Geological Survey.

Hail, W. J., Jr., 1990, Geology of the Lower Yellow Creek area, northwestern Colorado: U.S. Geological Survey Bulletin 1787-O:45 pp.

Haist, B., V. Santucci and A. Aase, 2002, The history of vertebrate paleontological fieldwork in Fossil Basin, Wyoming: Abstracts, Sixty-second annual meeting, Society of Vertebrate Paleontology, Norman, OK, United States, Oct. 9-12, 2002, 22(3, Suppl):62A.

Hamrick, M. W. and H. H. Covert, 1991, A late Wasatchian mammalian fauna from the Washakie Basin, Wyoming: Abstracts, Fifty-first annual meeting, Society of Vertebrate Paleontology, San Diego, CA, United States, Oct. 24-26, 1991, 11(3, Suppl):33.

Hanley, J. H., 1974, Systematics, paleoecology, and biostratigraphy of nonmarine Mollusca from the Green River and Wasatch formations (Eocene), southwestern Wyoming and northwestern Colorado: University of Wyoming, Laramie, WY, United States (USA) Doctoral. 


\section{A.2 PICEANCE CREEK BASIN, COLORADO}

\section{A.2.1 DeBeque Formation ( = Wasatch Formation) (Cont.)}

Hanley, J. H., R. W. Scott and R. R. West, 1976, Paleosynecology of nonmarine Mollusca from the Green River and Wasatch formations (Eocene), southwestern Wyoming and northwestern Colorado, In: Structure and classification of paleocommunities (Anonymous, eds.), Dowden, Hutchinson \& Ross, Inc., Stroudsburg, Pa., United States (USA).

Hartman, J. H., 1993, The Paleocene-Eocene nonmarine molluscan transition in the United States: Abstracts, Fifty-third annual meeting, Society of Vertebrate Paleontology, Albuquerque, NM, United States, Oct. 13-16, 1993, 13(3, Suppl):41.

Hayden, F. V., 1873, First, Second, and Third Annual Reports Report of the U.S. Geological and Geographic Survey of the Territories, for the years 1867, 1868, and 1869: U.S. Government Printing Office, Washington. 261 pp.

Henderson, J., 1909, Field Notes, University of Colorado Museum, transcribed by Professor Peter Robinson.

Holbrook, L., S. Lucas, S. Ting, P. Gingerich, P. Higgins, B. Small and M. Fox, 2004, The skull of Lambdotherium (Mammalia, Perissodactyla) and its phylogenetic implications: Abstracts, Sixty-fourth annual meeting, Society of Vertebrate Paleontology, Denver, CO, United States, Nov. 3-6, 2004, 24(3, Suppl):71.

Holroyd, P. A., 2001, Contrasting early Eocene mammalian diversity and turnover in two contemporaneous Wyoming basins: Abstracts, Sixty-first annual meeting, Society of Vertebrate Paleontology, Bozeman, MT, United States, Oct. 3-6, 2001, 21(3, Suppl):62.

Holroyd, P. A., D. M. Erwin and J. H. Hutchison, 1997, Non-mammalian paleontology of the Wasatch Formation in the northern Green River basin, Wyoming: Geological Society of America, 1997 annual meeting, Salt Lake City, UT, United States, Oct. 20-23, 1997, 29(6):104-105.

Holroyd, P. A. and K. T. Smith, 2000, Preliminary biostratigraphic evidence for age of the Wasatch and Green River formations, Washakie Basin, southwestern Wyoming: Geological Society of America, 2000 annual meeting, Reno, NV, United States, Nov. 9-18, 2000, 32(7):498.

Honey, J. G., 1988, A mammalian fauna from the base of the Eocene Cathedral Bluffs Tongue of the Wasatch Formation, Cottonwood Creek area, Southeast Washakie Basin, Wyoming, U.S. Geological Survey Bulletin B 1669 A-C, p. C1-C14.

Kester, P. R. and A. K. Aase, 2002, Stratigraphic correlation of the early Cenozoic intermontane lacustrine deposits of Wyoming, Colorado, and Utah: Geological Society of America, 2002 annual meeting, Denver, CO, United States, Oct. 27-30, 2002, 34(6):558. 


\section{A.2 PICEANCE CREEK BASIN, COLORADO}

\section{A.2.1 DeBeque Formation ( = Wasatch Formation) (Cont.)}

Kihm, A. J., 1984, Early Eocene mammalian faunas of the Piceance Creek basin, northwestern Colorado: University of Colorado, Boulder, CO, United States (USA) Doctoral.

Krishtalka, L., 1976, Early Tertiary Adapisoricidae and Erinaceidae (Mammalia, Insectivora) of North America: Bulletin of Carnegie Museum of Natural History,(1):40-40.

Leggitt, V. L., H. Buchheim and M. A. Loewen, 1999, First report of a fully articulated Presbyornis (Aves; Anseriformes) wing from a Colorado Presbyornis nesting site: Abstracts, Fifty-ninth annual meeting of the Society of Vertebrate Paleontology, Denver, CO, United States, Oct. 20-23, 1999, 19(3, Suppl):59.

Leggitt, V. L., R. Cushman, J. Anderson, H.-D. Sues, M. Fox, J. A. Case, J. Eberle, M. Goodwin and S. Carlson, 2003, Flamingo nest mounds from a crocodilian nesting site in the Eocene Wasatch Formation; Lincoln County, Wyoming: Abstracts, Sixty-third annual meeting, Society of Vertebrate Paleontology, Science Museum of Minnesota, Saint Paul, MN, United States, Oct. 15-18, 2003, 23(3, Suppl):71.

Loewen, M. A., V. L. Leggitt, R. E. Biaggi, H. P. Buchheim and R. A. Cushman, Jr., 1999, Morphologic variation in caddisfly (Trichoptera) larval case architecture from the Eocene Green River and Wasatch formations of Wyoming: Geological Society of America, 1999 annual meeting, Denver, CO, United States, Oct. 25-28, 1999, 31(7):470.

Lucas, S. G. and L. T. Holbrook, 2004, The skull of the Eocene perissodactyl Lambdotherium and its phylogenetic significance; Paleogene mammals: Bulletin - New Mexico Museum of Natural History and Science, 26:81-87.

Lucas, S. G. and R. M. Schoch, 1990, Ontogenetic studies of early Cenozoic Coryphodon (Mammalia, Pantodonta): Journal of Paleontology, 64(5):831-841.

Matthew, W. D. and W. Granger, 1918, Fossil mammals of the Tiffany beds: Geological Society of America Bulletin, 29:152.

McGee, E., 2001, A mass death accumulation of Coryphodon anthracoideus (Mammalia, Pantodonta) at Roehler's Coryphodon Catastrophe Quarry (lower Eocene, Wasatch Formation), Washakie Basin, Wyoming; Eocene biodiversity; unusual occurrences and rarely sampled habitats: Topics in Geobiology, 18:317-333.

McGee, E. M., 1993, The taphonomy of Roehler's Coryphodon Catastrophe Quarry (lower Eocene, Wasatch Formation, Washakie Basin, Wyoming): Abstracts, Fifty-third annual meeting, Society of Vertebrate Paleontology, Albuquerque, NM, United States, Oct. 13-16, 1993, 13(3, Suppl):49. 


\section{A.2 PICEANCE CREEK BASIN, COLORADO}

\section{A.2.1 DeBeque Formation ( = Wasatch Formation) (Cont.)}

McGee, E. M., 2002, Intraspecific dental variability in cf. Coryphodon anthracoideus (Mammalia, Pantodonta) from Roehler's Coryphodon Catastrophe Quarry, Washakie Basin, Wyoming: Rocky Mountain Geology, 37(1):61-73.

McGrew, P. O. and T. M. Bown, 1976, Fossil vertebrate faunas: Green Mountain, Ferris-Seven Lakes, and Sandy EIS areas, and Sweetwater County, Wyoming: Unpublished technical report prepared for the Wyoming BLM. $422 \mathrm{pp}$.

McGrew, P. O. and T. M. Bown, 1977, Fossil vertebrate faunas: Carbon, Lincoln, and Uinta Counties, Wyoming: Unpublished technical report prepared for the Wyoming BLM. $251 \mathrm{pp}$.

McKenna, M. C., 1955, Age of the Four Mile Local Fauna, northeast Sand Wash Basin, Colorado: Wyoming Geological Association Guidebook:105-107.

McKenna, M. C., 1958, Fossil Mammalia from the early Wasatchian Four Mile fauna, Eocene of Northwest Colorado: University of California, Berkeley, Berkeley, CA, United States (USA) Doctoral.

McKenna, M. C., 1960, Fossil Mammalia from the early Wasatchian Four Mile fauna, Eocene of northwest Colorado: University of California Publications in Geological Sciences, 37(1):1-130.

Mellett, J. S., 1982, Paleontologic resource inventory, Bookcliffs and Grand Hoback areas, western Colorado, Vols. 1 and 2: Unpublished BLM Report.

Nachman, B. A., 1998, Geology and vertebrate paleontology of the Great Divide Basin, SW Wyoming; Twenty-third annual fall scientific paper session [modified]: Twenty-third annual fall scientific paper session, Brockport, NY, United States, Nov. 23, 1996, 18(3):101.

Novacek, M., 1977, A review of Paleocene and Eocene Leptictidae (Eutheria; Mammalia) from North America: PaleoBios,(24):42-42.

Oriel, S. F. and J. I. Tracey 1970, Uppermost Cretaceous and Tertiary stratigraphy of Fossil Basin, southwest Wyoming: U.S. Geological Survey Professional Paper 635:53 pp.

Osborn, H. F. and J. L. Wortman, 1892, Fossil mammals of the Wasatch and Wind River beds: Bulletin of the American Museum of Natural History, 4:81-147.

Patterson, B., 1933, A new species of the amblypod Titanoides from Western Colorado: American Journal of Science, 25(149):415-425.

Patterson, B., 1934, A contribution to the osteology of Titanoides and the relationships of the Amblypoda: Proceedings of the American Philosophical Society, 73:71-102. 


\section{A.2 PICEANCE CREEK BASIN, COLORADO}

\section{A.2.1 DeBeque Formation ( = Wasatch Formation) (Cont.)}

Patterson, B., 1937, A new genus, Barylambda, for Titanoides faberi, Paleocene amblypod: Geological Series Field Museum of Natural History, 6:229-231.

Patterson, B., 1939, New Pantodonta and Dinocerata from the Upper Paleocene of western Colorado: Geological Series Field Museum of Natural History, 6(351-384).

Patterson, B., 1949, A new genus of taeniodonts from the late Paleocene: Fieldiana: Geology, 10(41-42).

Patterson, B. and R. M. West, 1973, A new late Paleocene phenacodont (Mammalia, Condylarthra) from western Colorado: Breviora, 403(1-7).

Picard, M. D., 1963, Duration of Eocene Lake Uinta, Uinta Basin, Utah: Geological Society of America Bulletin, 74:89-90.

Podorsky, R. A., 1981, The stratigraphy and mammalian paleontology of the Wasatch Formation (Eocene), Fossil Butte National Monument, Lincoln County, Wyoming: Fort Hays State University, Hays, KS, United States (USA) Master's.

Rich, F. J., D. M. Johnson and T. V. Durkin, 2001, Occurrence and paleoecology of Marsilea from the Eocene Wasatch: Palaios, 16:608-613.

Robinson, P., 1978, Paleontological resources inventory and evaluation, Bureau of Mines Experimental Oil Shale Mine, Rio Blanco County, Colorado: Prepared for VTN Colorado, Inc. 2600 S. Parker Rd., Aurora, Colorado. 22 pp.

Robinson, P., D. J. Daitch and J. E. Haessig, 2000, Fossil vertebrate localities of southwestern Wyoming: a literature search, locality record, and formation evaluation: Unpublished technical report prepared for the Wyoming BLM.

Robinson, P., G. F. Gunnell, S. L. Walsh, W. C. Clyde, J. E. Storer, R. K. Stucky, D. J. Froehlich, I. F. Villafranca and M. C. McKenna, 2004, Wasatchian though Duschesnean biochronology, In: Late Cretaceous and Cenozoic Mammals of North America (M. O. Woodburne, ed.), Columbia University Press. 106-155.

Roehler, H. W., 1992a, Geology of the Eocene Wasatch, Green River, and Bridger (Washakie) Formations, Greater Green River Basin, Wyoming, Utah and Colorado: Introduction to Greater Green River Basin Geology, Physiography, and History of Investigations: U.S. Geological Survey Professional Paper 1506-A:14. 


\section{A.2 PICEANCE CREEK BASIN, COLORADO}

\section{A.2.1 DeBeque Formation ( = Wasatch Formation) (Cont.)}

Roehler, H. W., 1992b, Geology of the Eocene Wasatch, Green River, and Bridger (Washakie) Formations, Greater Green River Basin, Wyoming, Utah and Colorado: Description and Correlation of Eocene Rocks in Stratigraphic Reference Sections for the Green River and Washakie Basin, Southwest Wyoming: U.S. Geological Survey Professional Paper 1506-D:83 pp.

Roehler, H. W., 1992c, Geology of the Eocene Wasatch, Green River, and Bridger (Washakie) Formations, Greater Green River Basin, Wyoming, Utah and Colorado: Correlation, Composition, Areal Distribution, and Thickness of Eocene Stratigraphic Units, Greater Green River Basin, Wyoming, Utah, and Colorado: U.S. Geological Survey Professional Paper 1506-E:49 pp.

Roehler, H. W., 1993, Geology of the Eocene Wasatch, Green River, and Bridger (Washakie) Formations, Greater Green River Basin, Wyoming, Utah and Colorado: Eocene Climates, Depositional Environments, and Geography, Greater Green River Basin, Wyoming, Utah and Colorado: U.S. Geological Survey Professional Paper 1506-F:74 pp.

Rose, K. D., 1977, Evolution of carpolestid primates and chronology of the North American middle and late Paleocene: Journal of Paleontology, 51(3):536-542.

Rose, K. D., T. M. Bown and E. L. Simons, 1977, An unusual new mammal from the early Eocene of Wyoming: Postilla,(172):10-10.

Savage, D. E. and D. E. Russell, 1983, Mammalian Paleofauna of the World: Addison-Wesley Publ. Co. 432 pp.

Savage, D. E. and B. T. Waters, 1978, A new omomyid primate from the Wasatch Formation of southern Wyoming: Folia Primatologica, 30(1):1-29.

Simnacher, F., 1970, Stratigraphy, depositional environments and paleontology of the Cathedral Bluffs tongue of the Wasatch Formation (Eocene), Parnell Creek area, Sweetwater County, Wyoming: University of Wyoming, Laramie, WY, United States (USA) Master's.

Simpson, G. G., 1935, The Tiffany fauna, upper Paleocene; 2, Structure and relationships of Plesiadapis: American Museum Novitates, 816:30.

Stidham, T. A., 1998, Phylogenetic and ecological diversification of waterfowl (Anseriformes) in the Late Cretaceous and Paleogene: Abstracts, Fifty-eighth annual meeting, Society of Vertebrate Paleontology, Snowbird, UT, United States, Sept. 30-Oct. 3, 1998, 18(3, Suppl):80. 


\section{A.2 PICEANCE CREEK BASIN, COLORADO}

\section{A.2.1 DeBeque Formation ( = Wasatch Formation) (Cont.)}

Stidham, T. A., 2000, Morphometrics and the paleobiology of Presbyornithidae (Neornithes, Anseriformes): Geological Society of America, 2000 annual meeting, Reno, NV, United States, Nov. 9-18, 2000, 32(7):15.

Stokes, W. L., 1986, Geology of Utah: Utah Museum of Natural History, University of Utah and Utah Geological and Mineral Survey, Department of Natural Resources.

Stucky, R. K., 1984, The Wasatchian-Bridgerian land mammal age boundary (Early to Middle Eocene) in western North America: Annals of the Carnegie Museum of Natural History, 53:347-382.

Townsend, K. and C. Harrisville-Wolff, 1993, A new species of Hyopsodus from the upper Graybull Beds of the Wasatchian from the Washakie Basin, Wyoming: Abstracts, Fifty-third annual meeting, Society of Vertebrate Paleontology, Albuquerque, NM, United States, Oct. 13-16, 1993, 13(3, Suppl):60.

Veatch, A. C., 1907, Geography and geology of a portion of southwestern Wyoming: U.S. Geological Survey Professional Paper 56:163 pp.

West, R. M., 1973, Geology and mammalian paleontology of the New Fork-Big Sandy area, Sublette County, Wyoming: Fieldiana: Geology (New Series), 29:193.

West, R. M. and M. R. Dawson, 1973, Fossil mammals from the upper part of the Cathedral Bluffs Tongue of the Wasatch Formation (early Bridgerian), northern Green River basin, Wyoming: Contributions to Geology, 12(1):33-41.

Wideman, N. K. and P. A. Holroyd, 1998, Coryphodon in the greater Green River basin, SW Wyoming; possible climatic \& taphonomic factors influencing distribution: Abstracts, Fifty-eighth annual meeting, Society of Vertebrate Paleontology, Snowbird, UT, United States, Sept. 30-Oct. 3, 1998, 18(3, Suppl):86.

Williams, B. A. and H. H. Covert, 1994, New Early Eocene anaptomorphine primate (Omomyidae) from the Washakie Basin, Wyoming, with comments on the phylogeny and paleobiology of anaptomorphines: American Journal of Physical Anthropology, 93:323-340.

Williamson, C., S. Strait, P. Holroyd, S. Ting, P. Gingerich, P. Higgins, B. Small and M. Fox, 2004, Rodents from a catastrophic assemblage in the early Eocene main body of the Wasatch Formation, Washakie Basin, Wyoming: Abstracts, Sixty-fourth annual meeting, Society of Vertebrate Paleontology, Denver, CO, United States, Nov. 3-6, 2004, 24(3, Suppl):129. 


\section{A.2 PICEANCE CREEK BASIN, COLORADO}

\section{A.2.1 DeBeque Formation ( = Wasatch Formation) (Cont.)}

Williamson, T. E., 1998, Meniscotherium mass-death assemblages; Abstracts of papers: Abstracts, Fifty-eighth annual meeting, Society of Vertebrate Paleontology, Snowbird, UT, United States, Sept. 30-Oct. 3, 1998, 18(3, Suppl):86.

Williamson, T. E., 2001, Meniscotherium mass-death assemblages; Eocene biodiversity; unusual occurrences and rarely sampled habitats: Topics in Geobiology, 18:335-360.

Winterfeld, G. F., 1982, Mammalian paleontology of the Fort Union Formation (Paleocene), eastern Rock Springs Uplift, Sweetwater County, Wyoming: Contributions to Geology, 21(1):73-111.

Wood, H. E., R. W. Chaney, J. Clark, E. H. Colbert, G. L. Jepsen, J. J. B. Reeside and C. Stock, 1941, Nomenclature and correlation of the North American continental Tertiary: Bulletin of the Geological Society of America, 52:1-48.

Woodburne, M. O. and C. C. I. Swisher, 1995, Land mammal high-resolution geochronology, intercontinental overland dispersals, sea level, climate, and vicariance, In: Geochronology, Time Scales, and Global Stratigraphic Correlations: Unified Temporal Framework for an Historical Geology (W. A. Berggren, D. V. Kent, M. P. Aubry and J. Hardenbol, eds.), SEPM Special Publication no. 54. 337-364.

Zack, S. P., 2004, An early Eocene arctostylopid (Mammalia, Arctostylopida) from the Green River basin, Wyoming: Journal of Vertebrate Paleontology, 24(2):498-501.

Zonneveld, J.-P. and G. F. Gunnell, 2003, A new species of cf. Dilophodon (Mammalia, Perissodactyla) from the early Bridgerian of southwestern Wyoming: Journal of Vertebrate Paleontology, 23(3):652-658.

Zonneveld, J.-P., G. F. Gunnell and W. S. Bartels, 2000, Early Eocene fossil vertebrates from the southwestern Green River basin, Lincoln and Uinta counties, Wyoming: Journal of Vertebrate Paleontology, 20(2):369-386.

Zonneveld, J. P., W. S. Bartels, S. D. Wolfe, G. F. Gunnell and J. I. Bloch, 2001, The occurrence of fossil vertebrates along strandlines of Paleolake Gosiute, Wasatch Formation, South Pass, Wyoming: Abstracts, Sixty-first annual meeting, Society of Vertebrate Paleontology, Bozeman, MT, United States, Oct. 3-6, 2001, 21(3, Suppl):117.

Zonneveld, J. P., J. M. Lavigne and W. S. Bartels, 2000, Ichnology of an early Eocene meandering fluvial system, Wasatch Formation, Fossil Butte National Monument, Wyoming: Geologic Society of America Abstracts with Programs, 32(7):309. 


\section{A.2 PICEANCE CREEK BASIN, COLORADO}

\section{A.2.2 Green River Formation}

Allmon, W. D., 2005, Paleontology of "turritella agate", a pleurocerid gastropod-dominated assemblage from the Eocene Green River Formation of Wyoming: Geological Society of America, Northeastern Section, 40th annual meeting, Saratoga Springs, NY, United States, March 14-16, 2005, 37(1):19.

Amato, T. J., H. P. Buchheim, R. A. Cushman and R. E. Biaggi, 2002, Climate change, salinity gradient or marginal freshwater lagoon? The story behind a unique fossiliferous unit of the Green River Formation in Fossil Basin, Wyoming: Geological Society of America, 2002 annual meeting, Denver, CO, United States, Oct. 27-30, 2002, 34(6):555.

Armstrong, H., 1991, Class I paleontological data inventory along a proposed highway route with alternates from Ouray to Cisco, Uintah and Grand Counties, Utah: Unpublished BLM Report. 1-211.

Armstrong, H. J. and D. G. Wolny, 1989, Paleontological resources of Northwest Colorado: A regional analysis: Museum of Western Colorado, Grand Junction.

Barclay, R. S., W. D. Bateman, K. R. Johnson, S. B. Wagner and M. L. Graham, 2003, The Parachute Creek Atlas Project; deciphering the floral diversity of the Green River Formation of Colorado and Utah: Geological Society of America, 2003 annual meeting, Seattle, WA, United States, Nov. 2-5, 2003, 35(6):588.

Bartels, W. S., 1993, Niche separation of fluvial and lacustrine reptiles from the Eocene Green River and Bridger formations of Wyoming: Abstracts, Fifty-third annual meeting, Society of Vertebrate Paleontology, Albuquerque, NM, United States, Oct. 13-16, 1993, 13(3, Suppl):25.

Benton, R., 1993, Fossil Butte National Monument, Kemmerer, Wyoming: Rocks and Minerals, 68(3):180-182.

Biaggi, R. E., H. P. Buchheim and R. A. Cushman, Jr., 2000, Deposition of a laminated, fossil rich facies in a nearshore oxic paleoenvironment, Eocene Lake Gosiute, Wyoming: Geological Society of America, 2000 annual meeting, Reno, NV, United States, Nov. 9-18, 2000, 32(7):415.

Biaggi, R. E., V. L. Leggitt and H. P. Buchheim, 1999, Caddisfly (Insecta; Trichoptera) larvae mounds from the Eocene Tipton Member, Green River Formation, Wyoming: Geological Society of America, 1999 annual meeting, Denver, CO, United States, Oct. 25-28, 1999, 31(7):242.

Bilbey, S. A., 2001, Final Paleontologic Report for the American Soda LLP Yankee Gulch Sodium Minerals Project, Parachute to Piceance Creek, Pipeline, Well Sites, Processing Plant, Garfield and Rio Blanco Counties, Colorado:81 pp. 


\section{A.2 PICEANCE CREEK BASIN, COLORADO}

\section{A.2.2 Green River Formation (Cont.)}

Black, C. C. and M. R. Dawson, 1966, A review of late Eocene mammalian faunas from North America: American Journal of Science, 264:321-349.

Black, C. C. and J. F. Sutton, 1984, Paleocene and Eocene rodents of North America; Papers in vertebrate paleontology honoring Robert Warren Wilson: Special Publication of Carnegie Museum of Natural History, 9:67-84.

Bradley, W. H., 1924, Fossil caddice fly cases from the Green River Formation of Wyoming: American Journal of Science, 7:310-312.

Bradley, W. H., 1926a, Fossil rhizopods of the Green River oil shale: Geological Society of America Bulletin, 37(1):160.

Bradley, W. H., 1926b, Shore fazes of the Green River Formation in northern Sweetwater County, Wyoming: U.S. Geological Survey Professional Paper 140-D:121-131.

Bradley, W.H., 1929, The varves and climate of the Green River epoch: U.S. Geological Survey Professional Paper 158-E, pp. 87-110.

Bradley, W. H., 1931, Origin and microfossils of the Green River Formation of Colorado and Utah: U.S. Geological Survey Professional Paper 168:58.

Bradley, W. H., 1959, Revision of stratigraphic nomenclature of Green River Formation of Wyoming: American Association of Petroleum Geologists Bulletin, 43(5):1072-1075.

Bradley, W. H., 1962, Chloroplast in Spirogyra from the Green River Formation of Wyoming: American Journal of Science, 260(6):455-459.

Bradley, W. H., 1964a, Geology of Green River Formation and associated Eocene rocks in southwestern Wyoming and adjacent parts of Colorado and Utah: U.S. Geological Survey Professional Paper 496-A:1-86.

Bradley, W. H., 1964b, Aquatic fungi from the Green River Formation of Wyoming: American Journal of Science, 262(3):413-416.

Bradley, W. H., 1967, Two aquatic fungi (Chytridiales) of Eocene age from the Green River Formation of Wyoming: American Journal of Botany, 54(5, Part 1):577-582.

Bradley, W. H., 1969, Geochemistry and paleolimnology of the trona deposits and associated authigenic minerals of the Green River Formation of Wyoming: U.S. Geological Survey Professional Paper 496-B:71 pp. 


\section{A.2 PICEANCE CREEK BASIN, COLORADO}

\section{A.2.2 Green River Formation (Cont.)}

Bradley, W. H., 1974, Oocardium tufa from the Eocene Green River Formation of Wyoming: Journal of Paleontology, 48(6):1289-1290.

Breithaupt, B. H., 1990, Early Tertiary fossils and environments of Wyoming; Jackson to Fossil Butte National Monument; Geologic field tours of western Wyoming and parts of adjacent Idaho, Montana, and Utah: Public Information Circular - Geological Survey of Wyoming, 29:57-72.

Brodkorb, P., 1965, New taxa of fossil birds: Florida Scientist, 28(2):197-198.

Brodkorb, P., 1970, An Eocene puffbird from Wyoming: Contributions to Geology, 9(1):13-15.

Bruner, J. C., 1991, Comments on the genus Amyzon (family Catostomidae): Journal of Paleontology, 65(4):678-686.

Bryant, B., C. W. Naeser, R. F. Marvin and H. H. Mehnert, 1989, Upper Cretaceous and Paleogene sedimentary rocks and isotopic ages of Paleogene tuffs, Uinta Basin, Utah: U.S. Geological Survey Bulletin, 1787-J:22 pp.

Buchheim, H. P., 1986, Paleoenvironments and sediment-fossil fish relationships; a case study from the Eocene Green River Formation, Wyoming; Fourth North American paleontological convention: Fourth North American paleontological convention, Boulder, CO, United States, Aug. 12-15, 1986, 4:A7.

Buchheim, H. P., 1994, Paleoenvironments, lithofacies, and varves of the Fossil Butte Member of the Eocene Green River Formation, Southwestern Wyoming: Contributions to Geology, University of Wyoming, 30(1):3-14.

Buchheim, H. P. and R. C. Surdam (1977). Paleoenvironments and fossil fishes of the Laney Member, Green River Formation, Wyoming; Communities of the past: Second North American paleontology convention, Lawrence, KS, United States (USA), Hutchinson Ross Publ. Co., Stroudsburg, PA, United States (USA).

Buchheim, H. P. and R. C. Surdam, 1981, Paleoenvironments and fossil fishes of the Laney Member, Green River Formation, Wyoming, In: Communities of the Past (J. Gray, ed.), Hutchinson and Ross Publishing Company, Pennsylvania. 415-452.

Buchheim, H. P. and R. C. Surdam, 1984, Fossil catfish in the Green River Formation, Wyoming; new discoveries and implications to depositional models; On research and exploration projects supported by the National Geographic Society for which an initial grant or continuing support was provided in the year 1976: Research Reports - National Geographic Society, $17: 245-255$. 


\section{A.2 PICEANCE CREEK BASIN, COLORADO}

\section{A.2.2 Green River Formation (Cont.)}

Carpenter, F. M., 1928, A scorpion-fly from the Green River Eocene: Annals of Carnegie Museum, 18, Part 1(1):241-248.

Carvalho, M., L. Grande, J. Maisey, J. Anderson, H.-D. Sues, M. Fox, J. A. Case, J. Eberle, M. Goodwin and S. Carlson, 2003, The evolution of stingrays (Chondrichthyes, Myliobatiformes), with special reference to the freshwater stingrays of the Green River Formation of Wyoming (early Eocene): Abstracts, Sixty-third annual meeting, Society of Vertebrate Paleontology, Science Museum of Minnesota, Saint Paul, MN, United States, Oct. 15-18, 2003, 23(3, Suppl):39.

Cashion, W. B., 1967, Geology and fuel resources of the Green River Formation, southeastern Uinta Basin Utah and Colorado: U.S. Geological Survey Professional Paper 548:48.

Cashion, W. B. and J. R. Donnell, 1974, Revision of nomenclature of the upper part of the Green River Formation, Piceance Creek Basin, Colorado, and eastern Uinta Basin, Utah: U.S. Geological Survey Bulletin 1394-G:G1-G9.

Chadey, H. F., 1973, Historical Aspects of the Green River Basin, Wyoming: Wyoming Geological Association, 25th Field Conference on the geology and mineral resources of the greater Green River Basin, Wyoming:27-33.

Cockerell, T. D. A., 1922, An ancient wasp [Hoplisus archorytes, Bear Gulch, Green River Formation, Colorado]: Nature (London), 110:313.

Cockerell, T. D. A., 1925, Plant and insect fossils from the Green River Eocene of Colorado: Proceedings of the United States National Museum, 66(19):13.

Cockerell, T. D. A., 1926, Plant and Insect Fossils from the Green River Eocene of Colorado: Proceedings of the United States National Museum, 66:1-13.

Cockerell, T. D. A., 1936, Tertiary floras: Science, 83(2154):350-351.

Codington, L. A., 1992a, Fossil spider web from the Eocene of western Colorado: 124th annual meeting of the Kansas Academy of Science, Hutchinson, KS, United States, March 26-27, 1992, 11:6.

Codington, L. A., 1992b, Fossil spider web from the Eocene of western Colorado: Geological Society of America, 1992 annual meeting, Cincinnati, OH, United States, Oct. 26-29, 1992, 24(7):344. 


\section{A.2 PICEANCE CREEK BASIN, COLORADO}

\section{A.2.2 Green River Formation (Cont.)}

Codington, L. A., 1993, Climatic implications of terrestrial arthropods from the Parachute Creek Member (middle Eocene), Green River Formation, Garfield County, Colorado: Fort Hays State University, Hays, KS, United States (USA) Master's.

Codington, L. A., 1993, New locality for fossil insects in the Green River Formation, western Colorado: The Compass, 70(3):90-91.

Cole, R. D. and M. D. Picard, 1978, Comparative mineralogy of nearshore and offshore lacustrine lithofacies, Parachute Creek Member of the Green River Formation, Piceance Creek Basin, Colorado, and eastern Uinta Basin, Utah: Geological Society of America Bulletin, 89:1441-1454.

Conrad, J. L., 2002, First fossil relative of Shinisaurus (Anguimorpha, Squamata) and the phylogenetic importance of Shinisauridae: Abstracts, Sixty-second annual meeting, Society of Vertebrate Paleontology, Norman, OK, United States, Oct. 9-12, 2002, 22(3, Suppl):46A.

Cope, E. D., 1884, Vertebrata of the Tertiary Formations of the West: Report of the U.S. Geological Survey of the Territories, vol. 3.

Crepet, W. L., D. L. Dilcher and W. L. Crepet, 1984, Advanced (constant) insect pollination mechanisms; pattern of evolution and implications vis-a-vis angiosperm diversity; Historical perspectives of angiosperm evolution: Thirtieth annual symposium, St. Louis, MO, United States, 1984, 71(2):607-630.

Dane, C. H., 1954, Stratigraphic and facies relationships of upper part of Green River Formation and lower part of Uinta Formation in Duchesne, Uintah, Wasatch Counties, Utah: American Association of Petroleum Geologists Bulletin, 38:405-425.

Davis, P. G. and D. E. G. Briggs, 1998, The impact of decay and disarticulation on the preservation of fossil birds: Palaios, 13(1):3-13.

Dawson, M. R., 1968, Middle Eocene rodents (Mammalia) from northeastern Utah: Annals of Carnegie Museum, 39:327-370.

Dayvault, R. and A. Gorski, 1989, Fossils from the Green River Formation, Douglas Pass area, Colorado: Rocks and Minerals, 64(2):134-139.

Dayvault, R. D., 1992, The Green River Formation fossil quarries of Wyoming: Rocks and Minerals, 67(4):256-261. 


\section{A.2 PICEANCE CREEK BASIN, COLORADO}

\section{A.2.2 Green River Formation (Cont.)}

de Carvalho, M. R., J. G. Maisey and L. Grande, 2004, Freshwater stingrays of the Green River Formation of Wyoming (early Eocene), with the description of a new genus and species and an analysis of its phylogenetic relationships (Chondrichthyes, Myliobatiformes): Bulletin of the American Museum of Natural History, 284:136.

Dlussky, G. M. and K. S. Perfilieva, 2003, Paleogene ants of the genus Archimyrmex Cockerell, 1923 (Hymenoptera, Formicidae, Myrmeciinae): Paleontological Journal, 37(1):39-47.

Doi, K., 1990, Geology, and paleontology of two primate families of the Raven Ridge, northwestern Colorado and northeastern Utah: University of Colorado, Boulder, CO, United States (USA) Master's.

Donnell, J. R., 1961, Tertiary geology and oil-shale resources of the Piceance Creek Basin between the Colorado and White Rivers, northwest Colorado: U.S. Geological Survey Bulletin, 1082-L:835-891.

Dorr, J. A., Jr. and P. D. Gingerich, 1980, Early Cenozoic mammalian paleontology, geologic structure, and tectonic history in the overthrust belt near LaBarge, western Wyoming Contributions to Geology, University of Wyoming, 18(2):101-115.

Duncan, D. C., W. J. Hail, Jr., R. B. O’Sullivan and G. N. Pipiringos, 1974, Four newly named tongues of the Eocene Green River Formation, northern Piceance Creek Basin, Colorado: U.S. Geological Survey Bulletin 1394-F:F1-F13.

Durden, C. J. and H. Rose, 1978, Butterflies from the middle Eocene; the earliest occurrence of fossil Papilionoidea (Lepidoptera): The Pearce-Sellards Series,(29):25-25.

Eastman, J. T., 1980, The caudal skeletons of catostomid fishes: American Midland Naturalist, 103(1):133-148.

Edwards, P., 1976, Fish coprolites from Fossil Butte, Wyoming: Contributions to Geology, $14(2): 115-117$.

Edwards, P. D., 1975, Preliminary notes on fish coprolites from the Green River Formation (Eocene) of Wyoming: Proceedings of the Nebraska Academy of Sciences and Affiliated Societies, 85:40.

Erickson, B. R., 1967, Fossil bird tracks from Utah: Museum Observer, 5(1):6-12.

Feduccia, A., 1973, A new Eocene Zygodactyl bird: Journal of Paleontology, 47(3):501-503. 


\section{A.2 PICEANCE CREEK BASIN, COLORADO}

\section{A.2.2 Green River Formation (Cont.)}

Feduccia, A., 1976, Neanis schucherti restudied; another Eocene piciform bird: Smithsonian Contributions to Paleobiology, no.27, Coll. pap. avian paleontol. honoring 90th birthday A.Wetmore:95-99.

Feduccia, A., 1978, Presbyornis and the evolution of ducks and flamingos: American Scientist, 66(3):298-304.

Feduccia, A. and L. D. Martin, 1976, The Eocene zygodactyl birds of North America (Aves; Piciformes): Smithsonian Contributions to Paleobiology, no.27, Coll. pap. avian paleontol. honoring 90th birthday A. Wetmore:101-110.

Feduccia, A. and P. O. McGrew, 1984, The rediscovery of the avian fossil Presbyornis from the Eocene of Wyoming; On research and exploration projects supported by the National Geographic Society, for which an initial grant or continuing support was provided in the year 1975: Research Reports - National Geographic Society, 16:481-485.

Feldmann, R. M., L. Grande, C. P. Birkhimer, J. T. Hannibal and D. L. McCoy, 1981, Decapod fauna of the Green River Formation (Eocene) of Wyoming: Journal of Paleontology, 55(4):788-799.

Ferber, C. T., 1987, Environmental interpretation of fish deposits in the Eocene Green River Formation of Utah and Wyoming: Kent State University, Kent, Kent, OH, United States (USA) Master's.

Ferber, C. T. and N. A. Wells, 1986, Fish taphonomy and environmental interpretation of parts of the Eocene Green River Formation, Utah; SEPM, annual midyear meeting; abstracts: SEPM annual midyear meeting, Raleigh, NC, United States, Sept. 26-28, 1986, 1986, Vol. 3:35-36.

Ferber, C. T. and N. A. Wells, 1995, Paleolimnology and taphonomy of some fish deposits in "Fossil" and "Uinta" Lakes of the Eocene Green River Formation, Utah and Wyoming: Palaeogeography, Palaeoclimatology, Palaeoecology, 117(3-4):185-210.

Fisher, E. J., C. E. Erdman and J. B. Reeside, Jr. , 1960, Cretaceous and Tertiary Formations of the Book Cliffs: Carbon, Emery, and Grand counties, Utah, and Garfield and Mesa counties, Colorado: U.S. Geological Survey Professional Paper, 332:80 pp.

Fouch, T. D., J. H. Hanley, R. M. Forester, C. W. Keighin, J. K. Pitman and D. J. Nichols, 1987, Chart showing lithology, mineralogy, and paleontology of the nonmarine North Horn Formation and Flagstaff Member of the Green River Formation, Price Canyon, central Utah; a principal reference section: U.S. Geological Survey, Miscellaneous Investigations Series, Map I-1797-A, 1 sheet. 


\section{A.2 PICEANCE CREEK BASIN, COLORADO}

\section{A.2.2 Green River Formation (Cont.)}

Franczyk, K. J., J. K. Pitman, and D. J. Nichols, 1990, Sedimentology, mineralogy, and depositional history of some Uppermost Cretaceous Lowermost Tertiary rocks along the Utah Book and Roan Cliffs east of the Green River: U.S. Geological Survey Bulletin 1787:27 pp.

Fremont, J. C., 1845, Report of the exploring expedition through the Rocky Mountains in the year 1842 and to Oregon and California in the years 1843-1844: Senate Document No. 174 and House Document No. 166, 28th Congress, 2nd session.

Froehlich, D. J. and B. H. Breithaupt, 1998, Mammals from the Eocene epoch Fossil Butte Member of the Green River Formation, Fossil Basin, Wyoming: Abstracts, Fifty-eighth annual meeting, Society of Vertebrate Paleontology, Snowbird, UT, United States, Sept. 30-Oct. 3, 1998, 18(3, Suppl):43-44.

Froehlich, D. J. and B. H. Breithaupt, 2002, Biostratigraphic and paleoenvironmental utility of Lambdotherium; tying down the Lagerstatten of the Green River Formation: Geological Society of America, 2002 annual meeting, Denver, CO, United States, Oct. 27-30, 2002, 34(6):556-557.

Froehlich, D. J., B. H. Breithaupt, J. Bolt and L. Grande, 1997, A Lambdotherium specimen from the Fossil Butte Member of the Green River Formation, with comments on its biostratigraphic and paleoenvironmental importance and the phylogenetic significance of its postcrania: Abstracts, Fifty-seventh annual meeting, Society of Vertebrate Paleontology, Chicago, IL, United States, Oct. 8-11, 1997, 17(3, Suppl):47.

Froehlich, J. W. and D. J. Froehlich, 2002, Using mammal fossils to locate the edge of the Green River lake in the Piceance Creek basin during the late-early Eocene: Geological Society of America, 2002 annual meeting, Denver, CO, United States, Oct. 27-30, 2002, 34(6):480-481.

Gardner, J. D., 1999, Comments on amphibians from the Green River Formation, with a description of a fossil tadpole; Vertebrate paleontology in Utah: Miscellaneous Publication Utah Geological Survey, 99-1:455-461.

Gauthier, J. A., 1982, Fossil xenosaurid and anguid lizards from the early Eocene Wasatch Formation, southeast Wyoming, and a revision of the Anguioidea: Contributions to Geology, 21:7-54.

Geo/Resource, 1984, Green River Basin geologic resources inventory: Unpublished Technical Report prepared for the Wyoming BLM.

Gnidovec, D. M., 1978, Taphonomy of the Powder Wash vertebrate quarry, Green River Formation; Eocene, Uintah County, Utah: Fort Hays State University, Hays, KS, United States (USA) Master's. 


\section{A.2 PICEANCE CREEK BASIN, COLORADO}

\section{A.2.2 Green River Formation (Cont.)}

Grande, L., 1979, Eohiodon falcatus, a new species of hiodontid (Pisces) from the late early Eocene Green River Formation of Wyoming: Journal of Paleontology, 53(1):103-111.

Grande, L., 1980a, Paleontology of the Green River Formation, with a review of the fish fauna: Bulletin - Geological Survey of Wyoming, 63:333.

Grande, L., 1982, A revision of the fossil genus Knightia, with a description of a new genus from the Green River Formation (Teleostei, Clupeidae): American Museum Novitates, 2731:22.

Grande, L., 1984, Paleontology of the Green River Formation, with a review of the fish fauna; second edition: Bulletin - Geological Survey of Wyoming, 63:333.

Grande, L., 1985, Fish fossils in the Eocene Green River Formation of southwestern Wyoming; On research and exploration projects supported by the National Geographic Society, for which an initial grant or continuing support was provided in the years 1980-1983: Research Reports National Geographic Society, 21:201-207.

Grande, L., 1987, Redescription of Hypsidoris farsonensis (Teleostei: Siluriformes), with a reassessment of its phylogenetic relationships: Journal of Vertebrate Paleontology, 7(1):24-54.

Grande, L., 1989, Fossil fauna of the Green River Formation; Conservation and the future of humanity: 82nd annual meeting of the Illinois State Academy of Science, Chicago, IL, United States, Oct. 20-21, 1989, 82, Suppl:66.

Grande, L., 1991, Transferred type specimens of well-preserved Eocene fishes from the Green River Formation: Journal of Paleontology, 65(5):889-890.

Grande, L., 1998, The first pickerel (Teleostei, Esocidae) from the Green River Formation, and a review of the world's most productive freshwater Lagerstatten; Abstracts of papers; fifty-eighth annual meeting; Society of Vertebrate Paleontology: Society of Vertebrate Paleontology fifty-eighth annual meeting, Snowbird, UT, United States, Sept. 30-Oct. 3, 1998, 18(3, Suppl):47.

Grande, L., 1999, The first Esox (Esocidae, Teleostei) from the Eocene Green River Formation, and a brief review of esocid fishes: Journal of Vertebrate Paleontology, 19(2):271-292.

Grande, L., 2001, An updated review of the fish faunas from the Green River Formation, the world's most productive freshwater Lagerstaetten; Eocene biodiversity; unusual occurrences and rarely sampled habitats: Topics in Geobiology, 18:1-38.

Grande, L. and W. E. Bemis, 1991, Osteology and phylogenetic relationships of fossil and Recent paddlefishes (Polyodontidae) with comments on the interrelationships of Acipenseriformes: Journal of Vertebrate Paleontology, 11(1, Supplement):121. 


\section{A.2 PICEANCE CREEK BASIN, COLORADO}

\section{A.2.2 Green River Formation (Cont.)}

Grande, L. and H. P. Buchheim, 1994, Paleontological and sedimentological variation in early Eocene Fossil Lake: Contributions to Geology, University of Wyoming, 30(1):33-56.

Grande, L., J. T. Eastman and T. M. Cavender, 1982, Amyzon gosiutensis, a new catostomid fish from the Green River Formation: Copeia, 1982(3):523-532.

Grande, L., M. C. McKenna, D. J. Chure, G. F. Englemann, L. Grande, R. K. Stucky, L. Krishtalka, M. R. Dawson, P. D. Gingerich, W. A. Clemens, J. K. Rigby, Jr., J. J. Flynn and P. M. Hanshaw, 1989, The Eocene Green River lake system, Fossil Lake, and the history of the North American fish fauna, In: Mesozoic/Cenozoic vertebrate paleontology; classic localities, contemporary approaches (Anonymous, eds.), United States (USA), Am. Geophys. Union, Washington, DC, United States (USA).

Grande, R. L., 1980b, Paleontology of the Green River Formation, with a review of the fish fauna: University of Minnesota, Minneapolis, Minneapolis, MN, United States (USA) Master's.

Gulas-Wroblewski, B., J. Anderson, H.-D. Sues, M. Fox, J. A. Case, J. Eberle, M. Goodwin and S. Carlson, 2003, Limnofregata; not a frigatebird any more: Abstracts, Sixty-third annual meeting, Society of Vertebrate Paleontology, Science Museum of Minnesota, Saint Paul, MN, United States, Oct. 15-18, 2003, 23(3, Suppl):58.

Gulas-Wroblewski, B. E., 2003, New evidence for pelecaniform (Aves, Pelecaniformes) diversity during the Eocene of Wyoming: Geological Society of America, Rocky Mountain Section, 55th annual meeting, Durango, CO, United States, May 7-9, 2003, 35(5):16.

Gulas-Wroblewski, B. E. and S. Uibreaslain, 2002, A new pelecaniform bird from the Green River Formation (Eocene) of Wyoming: Geological Society of America, 2002 annual meeting, Denver, CO, United States, Oct. 27-30, 2002, 34(6):425.

Gunnell, G., J. Anderson, H.-D. Sues, M. Fox, J. A. Case, J. Eberle, M. Goodwin and S. Carlson, 2003, New primitive microbat (Chiroptera) from the Green River Formation (upper lower Eocene), Fossil Basin, southwestern Wyoming: Abstracts, Sixty-third annual meeting, Society of Vertebrate Paleontology, Science Museum of Minnesota, Saint Paul, MN, United States, Oct. 15-18, 2003, 23(3, Suppl):58.

Gunnell, G. and W. S. Bartels, 1999, Middle Eocene vertebrates from the Uinta Basin, Utah, and their relationship with faunas from the southern Green River Basin, Wyoming: Utah Geological Survey Misc. Publications, 99-1:429-442.

Gunnell, G. F. and W. S. Bartels, 1994, Early Bridgerian (middle Eocene) vertebrate paleontology and paleoecology of the southern Green River Basin Wyoming: Contributions to Geology, University of Wyoming, 30(1):57-70. 


\section{A.2 PICEANCE CREEK BASIN, COLORADO}

\section{A.2.2 Green River Formation (Cont.)}

Gunnell, G. F. and W. S. Bartels, 2001, Basin margins, biodiversity, evolutionary innovation, and the origin of new taxa: Eocene biodiversity; unusual occurrences and rarely sampled habitats: Topics in Geobiology, 18:403-432.

Gunnell, G. F., W. S. Bartels and J.-P. Zonneveld, 2004, A late Wasatchian (late early Eocene) vertebrate assemblage preserved in meandering stream channel deposits, northern Red Desert, Wyoming: Geological Society of America, 2004 annual meeting, Denver, CO, United States, Nov. 7-10, 2004, 36(5):92.

Gunnell, G. F., W. S. Bartels and J. P. Zonneveld, 2002, Stratigraphy, vertebrate paleontology, and paleoecology of the Wasatch Formation, Fossil Butte National Monument, Wyoming: Geological Society of America, 2002 annual meeting, Denver, CO, United States, Oct. 27-30, 2002, 34(6):557.

Hail, W. J., Jr., 1990, Geology of the Lower Yellow Creek area, northwestern Colorado: U.S. Geological Survey Bulletin 1787-O:45 pp.

Haist, B., V. Santucci and A. Aase, 2002, The history of vertebrate paleontological fieldwork in Fossil Basin, Wyoming: Abstracts, Sixty-second annual meeting, Society of Vertebrate Paleontology, Norman, OK, United States, Oct. 9-12, 2002, 22(3, Suppl):62A.

Hanley, J. H., 1974, Systematics, paleoecology, and biostratigraphy of nonmarine Mollusca from the Green River and Wasatch formations (Eocene), southwestern Wyoming and northwestern Colorado: University of Wyoming, Laramie, WY, United States (USA) Doctoral.

Hanley, J. H., 1979, Reproduction of glochidium larva in an Eocene nonmarine bivalve: U.S. Geological Survey Professional Paper P-1150.

Hanley, J. H., R. W. Scott and R. R. West, 1976, Paleosynecology of nonmarine Mollusca from the Green River and Wasatch formations (Eocene), southwestern Wyoming and northwestern Colorado, In: Structure and classification of paleocommunities (Anonymous, eds.), United States (USA), Dowden, Hutchinson \& Ross, Inc., Stroudsburg, Pa., United States (USA).

Hartman, J. H., 2004, The collections of J. C. Fremont and the type locality and record of Viviparus paludinaeformis (Hall) (Gastropoda) from the Eocene of Wyoming; Fanfare for an uncommon paleontologist; papers in honor of Malcolm C. McKenna: Bulletin of Carnegie Museum of Natural History, 36:31-42.

Hayden, F. V., 1869, Preliminary field report (3rd ann.) of the U.S. Geological Survey of Colorado and New Mexico: U.S. Government, Washington. 155 pp. 


\section{A.2 PICEANCE CREEK BASIN, COLORADO}

\section{A.2.2 Green River Formation (Cont.)}

Hayden, F. V., 1871, Preliminary report of the United States Geological Survey of Wyoming and portions of contiguous territories (2nd Annual Report): U.S. Government Printing Office, Department of the Interior. $155 \mathrm{pp}$.

Hayden, F. V., 1873, First, Second, and Third Annual Reports Report of the U.S. Geological and Geographic Survey of the Territories, for the years 1867, 1868, and 1869: U.S. Government Printing Office, Washington. 261 pp.

Hayden, F. V., 1877, Notes on some artesian borings along the line of the Union Pacific Railroad in Wyoming Territory: U.S. Geological and Geographical Survey of the Territories, 3(1):181-185.

Henderson, J., 1909, Field Notes, University of Colorado Museum, transcribed by Professor Peter Robinson.

Henderson, J., 1924, The origin of the Green River Formation: Bulletin of the American Association of Petroleum Geologists, 8(5):662-668.

Hesse, A., 1992, A new species of Messelornis (Aves; Gruiformes; Messelornithidae) from the middle Eocene Green River Formation; Papers in avian paleontology; honoring Pierce Brodkorb: II International symposium of the Society of Avian Paleontology and Evolution, Los Angeles, CA, United States, Sept. 28-30, 1988, 36:171-178.

Hilton, E. J. and L. Grande, 2001, Osteology of Eohiodon (Teleostei, Hiodontiformes), based on new acid-prepared specimens from the Green River Formation (Eocene), Wyoming: Abstract, Sixty-first annual meeting, Society of Vertebrate Paleontology, Bozeman, MT, United States, Oct. 3-6, 2001, 21(3, Suppl):61-62.

Hodgkins, J. M. and D. M. Smith, 2002, A record of evolutionary change in an Eocene plantherbivore assemblage: Geological Society of America Abstracts with Programs. 34:4.

Holroyd, P. A., 2001, Contrasting early Eocene mammalian diversity and turnover in two contemporaneous Wyoming basins: Abstracts, Sixty-first annual meeting, Society of Vertebrate Paleontology, Bozeman, MT, United States, Oct. 3-6, 2001, 21(3, Suppl):62.

Holroyd, P. A., D. M. Erwin and J. H. Hutchison, 1997, Non-mammalian paleontology of the Wasatch Formation in the northern Green River basin, Wyoming: Geological Society of America, 1997 annual meeting, Salt Lake City, UT, United States, Oct. 20-23, 1997, 29(6):104-105. 


\section{A.2 PICEANCE CREEK BASIN, COLORADO}

\section{A.2.2 Green River Formation (Cont.)}

Holroyd, P. A. and K. T. Smith, 2000, Preliminary biostratigraphic evidence for age of the Wasatch and Green River formations, Washakie Basin, southwestern Wyoming: Geological Society of America, 2000 annual meeting, Reno, NV, United States, Nov. 9-18, 2000, 32(7):498.

Honey, J. G., 1990, New Washakiin Primates (Omomyidae) from the Eocene of Wyoming and Colorado, and comments on the evolution of the Washakiini: Journal of Vertebrate Paleontology, 10(2):206-221.

Houde, P. and S. L. Olson, 1981, Paleognathous carinate birds from the early Tertiary of North America: Science, 214(4526):1236-1237.

Hutchinson, J. H., 1984, Determinate growth in the Baenidae (Testudines); taxonomic, ecologic and stratigraphic significance: Journal of Vertebrate Paleontology, 3:148-151.

Ingalls, B. and L. E. Park, 2005, Paleoecology and taphonomy of an ostracode fauna from the Laney Member, Green River Formation, Wyoming: Geological Society of America, 2005 annual meeting, Salt Lake City, UT, United States, Oct. 16-19, 2005, 37(7):64.

Jennings, D. S., V. L. Santucci, H. P. Buchheim and S. T. Hasiotis, 2002, A preliminary inventory and assessment of ichnofossils from the Green River Formation: Geological Society of America, 2002 annual meeting, Denver, CO, United States, Oct. 27-30, 2002, 34(6):556.

Jepsen, G. L., 1966, Early Eocene bat from Wyoming: Science, 154(3754):1333-1339.

Johnson, K. R., W. Bateman, M. Graham, S. R. Manchester and B. Handley, 2002, The Parachute Creek atlas project; an overview of the megaflora of the Green River Formation from Colorado and Utah: Geological Society of America, 2002 annual meeting, Denver, CO, United States, Oct. 27-30, 2002, 34(6):480.

Johnson, K. R. and C. Plumb, 1995, Common plant fossils from the Green River Formation at Douglas Pass, Colorado and Bonanza, Utah, In: The Green River Formation in Piceance Creek and eastern Uinta basins, Grand Junction Geol. Society Guidebook. 121-130.

Johnson, R. C., 1981, Stratigraphic evidence for a deep Eocene Lake Uinta, Piceance Creek Basin, Colorado: Geology, v. 9, no. 5, pp. 55-62.

Johnson, R. C., 1984, New names for units in the lower part of the Green River Formation, Piceance Creek Basin, Colorado: U.S. Geological Survey Bulletin, B 1529-I. 


\section{A.2 PICEANCE CREEK BASIN, COLORADO}

\section{A.2.2 Green River Formation (Cont.)}

Johnson, R. C., 1985, Early Cenozoic history of the Uinta and Piceance Creek basins, Utah and Colorado, with special reference to the development of Eocene Lake Uinta, In: Cenozoic Paleogeography of West-Central United States (R. M. Flores and S. S. Kaplan, eds.), Society for Sedimentary Geology. 247-276.

Johnson, R. C., 1989, Geologic history and hydrocarbon potential of late Cretaceous-age, lowpermeability reservoirs, Piceance Basin, western Colorado: U.S. Geological Survey Bulletin, B 1787-E, $51 \mathrm{pp}$.

Kester, P. R. and A. K. Aase, 2002, Stratigraphic correlation of the early Cenozoic intermontane lacustrine deposits of Wyoming, Colorado, and Utah: Geological Society of America, 2002 annual meeting, Denver, CO, United States, Oct. 27-30, 2002, 34(6):558.

Kihm, A. J., 1984, Early Eocene mammalian faunas of the Piceance Creek basin, northwestern Colorado: University of Colorado, Boulder, CO, United States (USA) Doctoral.

King, C., 1877, Descriptive geology: U.S. Geological Exploration of the 40th Parallel, 2:202-277.

Krishtalka, L., 1976, Early Tertiary Adapisoricidae and Erinaceidae (Mammalia, Insectivora) of North America: Bulletin of Carnegie Museum of Natural History,(1):40-40.

Krishtalka, L., 1976, North American Nyctitheriidae; Mammalia, Insectivora: Annals of Carnegie Museum, 46(Article 2):7-28.

Krishtalka, L. and R. K. Stucky, 1984, Middle Eocene marsupials (Mammalia) from northeastern Utah and the mammalian fauna from Powder Wash: Annals of Carnegie Museum, 53(2):31-45.

Kuchta, M. A., 2000, Paleoenvironmental significance of nonmarine Mollusca in the Luman Tongue of the Green River Formation, Wyoming: Master's Thesis, University of Wisconsin, $63 \mathrm{pp}$.

Langston, W., Jr. and H. Rose, 1978, A yearling crocodilian from the middle Eocene Green River Formation of Colorado: Journal of Paleontology, 52(1):122-125.

Leggitt, V. L., R. Biaggi, H. P. Buchheim, S. Ting, P. Gingerich, P. Higgins, B. Small and M. Fox, 2004, Avian eggshell fragments confirm lake margin fluctuation; Tipton Shale Member, Eocene Lake Gosiute: Abstracts, Sixty-fourth annual meeting, Society of Vertebrate Paleontology, Denver, CO, United States, Nov. 3-6, 2004, 24(3, Suppl):82. 


\section{A.2 PICEANCE CREEK BASIN, COLORADO}

\section{A.2.2 Green River Formation (Cont.)}

Leggitt, V. L. and H. P. Buchheim, 1993, Radiograph aided taphonomic analysis of an avian fossil quarry; insights into the paleohabitat of the Tertiary bird, Presbyornis: Geological Society of America, 1993 annual meeting, Boston, MA, United States, Oct. 25-28, 1993, 25(6):58.

Leggitt, V. L. and H. P. Buchheim, 1996, An avian botulism epizootic affecting a nesting site population of Presbyornis on a carbonate mudflat shoreline of Eocene Fossil Lake: Sixth North American paleontological convention, Washington, DC, United States, June 9-12, 1996, $8: 234$.

Leggitt, V. L. and H. P. Buchheim, 1998a, Avian eggshell identified from a Presbyornis (Aves; Anseriformes) rookery; Eocene Lake Gosiute, Sweetwater County, Wyoming: Geological Society of America, 1998 annual meeting, Toronto, ON, Canada, Oct. 26-29, 1998, 30(7):32.

Leggitt, V. L. and H. P. Buchheim, 1998b, A new Presbyornis (Aves, Anseriformes) nesting site with abundant eggshell; Eocene Fossil Lake, Lincoln County, Wyoming: Abstracts, Fifty-eighth annual meeting, Society of Vertebrate Paleontology, Snowbird, UT, United States, Sept 30-Oct. 3, 1998, 18(3, Suppl):58.

Leggitt, V. L., H. P. Buchheim and R. E. Biaggi, 2001, Avian eggshell from caddisfly (Insecta, Trichoptera) mounds; Tipton Shale Member, Eocene Green River Formation: Abstracts, Sixty-first annual meeting, Society of Vertebrate Paleontology, Bozeman, MT, United States, Oct. 3-6, 2001, 21(3, Suppl):72.

Leggitt, V. L., H. P. Buchheim, J. Bolt and L. Grande, 1997, Presbyornis (Aves, Anseriformes) eggshell from three avian mass mortality sites; Eocene Fossil Lake, Lincoln County, Wyoming: Abstracts, Fifty-seventh annual meeting, Society of Vertebrate Paleontology, Chicago, IL, United States, Oct. 8-11, 1997, 17(3, Suppl):60.

Leggitt, V. L. and R. A. Cushman, 2001, Complex caddisfly-dominated bioherms from the Eocene Green River Formation: Sedimentary Geology, 145:377-396.

Leopold, E. B. and H. D. MacGinitie, 1972, Development and affinities of Tertiary floras in the Rocky Mountains, In: Floristics and Paleofloristics of Asia and Eastern North America, Elsevier, Amsterdam. pp. 147-200.

Li, G.-Q., L. Grande and M. V. H. Wilson, 1997, The species of Phareodus (Teleostei, Osteoglossidae) from the Eocene of North America and their phylogenetic relationships: Journal of Vertebrate Paleontology, 17(3):487-505. 


\section{A.2 Piceance Creek Basin, Colorado}

\section{A.2.2 Green River Formation (Cont.)}

Loewen, M. A. and H. P. Buchheim, 1998, Paleocommunities and trophic relationships during the latter stages of Eocene Fossil Lake, SW Wyoming: Abstracts, Fifty-eighth annual meeting, Society of Vertebrate Paleontology, Snowbird, UT, United States, Sept. 30-Oct. 3, 1998, 18(3, Suppl):59.

Loewen, M. A. and J. M. Gibert, 1999, The first occurrence of Cenozoic fish trails (Undichna) from Eocene Fossil Lake, Wyoming: Abstracts, Fifty-ninth annual meeting, Society of Vertebrate Paleontology, Denver, CO, United States, Oct. 20-23, 1999, 19(3, Suppl):59.

Loewen, M. A., V. L. Leggitt, R. E. Biaggi, H. P. Buchheim and R. A. Cushman, Jr., 1999, Morphologic variation in caddisfly (Trichoptera) larval case architecture from the Eocene Green River and Wasatch formations of Wyoming: Geological Society of America, 1999 annual meeting, Denver, CO, United States, Oct. 25-28, 1999, 31(7):470.

Lundberg, J. G. and G. R. Case, 1970, A new catfish from the Eocene Green River Formation, Wyoming: Journal of Paleontology, 44(3):451-457.

MacGinitie, H. D., 1969, The Eocene Green River flora of northwestern Colorado and northeastern Utah: University of California Publications in Geological Sciences, 83:202.

Martin, L. D. and A. Feduccia, 2002, Avifauna of the Green River deposits and the early radiation of modern birds: Geological Society of America, 2002 annual meeting, Denver, CO, United States, Oct. 27-30, 2002, 34(6):480.

Mauger, R. L., 1977, K-Ar ages of biotites from tuffs in Eocene rocks of the Green River Formation, Piceance Creek Basin, Colorado: Geology, 3:493-497.

Mayr, G. and M. Daniels, 2001, A new short-legged landbird from the early Eocene of Wyoming and contemporaneous European sites: Acta Palaeontologica Polonica, 46(3):393-402.

McGrew, P. O., 1971, Early and middle Eocene faunas of the Green River basin; Trona issue: Contributions to Geology, 10(1):65-68.

McGrew, P. O., 1975, Taphonomy of Eocene fish from Fossil Basin, Wyoming: Fieldiana: Geology 33(14):257-270.

McGrew, P. O., 1980, An Eocene flamingo nesting area, Sweetwater County, Wyoming: Research Reports - National Geographic Society, 12:473-478.

McGrew, P. O. and T. M. Bown, 1976, Fossil vertebrate faunas: Green Mountain, Ferris-Seven Lakes, and Sandy EIS areas, and Sweetwater County, Wyoming: Unpublished technical report prepared for the Wyoming BLM. $422 \mathrm{pp}$. 


\section{A.2 PICEANCE CREEK BASIN, COLORADO}

\section{A.2.2 Green River Formation (Cont.)}

McGrew, P. O. and T. M. Bown, 1977, Fossil vertebrate faunas: Carbon, Lincoln, and Uinta Counties, Wyoming: Unpublished technical report prepared for the Wyoming BLM. $251 \mathrm{pp}$.

McGrew, P. O. and M. Casilliano, 1975, The geological history of Fossil Butte National Monument and Fossil Basin: National Park Service Occasional Paper,(3):37-37.

Metz, R., 1987, Sinusoidal trail formed by a Recent biting midge (family Ceratopogonidae); trace fossil implications: Journal of Paleontology, 61(2):312-314.

Moncure, G. and R. C. Surdam, 1980, Depositional environment of the Green River Formation in the vicinity of the Douglas Creek Arch, Colorado and Utah: Contributions to Geology, University of Wyoming, 19(1):9-24.

Mook, C. C., 1959, A new species of fossil crocodile of the genus Leidyosuchus from the Green River beds [Wyoming]: American Museum Novitates, 1933:6.

Moussa, M. T., 1968, Fossil tracks from the Green River Formation (Eocene) near Soldier Summit, Utah: Journal of Paleontology, 42(6):1433-1438.

Moussa, M. T., 1970, Nematode fossil trails from the Green River Formation (Eocene) in the Uinta Basin, Utah: Journal of Paleontology, 44(2):304-307.

Nelson, M. E., J. H. Madsen, Jr. and W. L. Stokes, 1980, A titanothere from the Green River Formation, central Utah; Teleodus uintensis (Perissodactyla; Brontotheriidae): Contributions to Geology, 18(2):127-134.

Nichols, D. J., 1987, Palynology of the Vermillion Creek coal bed and associated strata: U.S. Geological Survey Professional Paper 1314-D:47-73.

Olson, S. L., 1977, A lower Eocene frigatebird from the Green River Formation of Wyoming (Pelecaniformes; Fregatidae): Smithsonian Contributions to Paleobiology,(35):33-33.

Olson, S. L., 1987, An early Eocene oilbird from the Green River Formation of Wyoming (Caprimulgiformes; Steatornithidae): The evolution of birds based on fossil evidence: Documents des Laboratoires de Geologie, Lyon, 99:57-69.

Olson, S. L., 1992, A new family of primitive landbirds from the lower Eocene Green River Formation of Wyoming; Papers in avian paleontology; honoring Pierce Brodkorb: II International symposium of the Society of Avian Paleontology and Evolution, Los Angeles, CA, United States, Sept. 28-30, 1988, 36:127-136. 


\section{A.2 PICEANCE CREEK BASIN, COLORADO}

\section{A.2.2 Green River Formation (Cont.)}

Oriel, S. F. and J. I. Tracey 1970, Uppermost Cretaceous and Tertiary stratigraphy of Fossil Basin, southwest Wyoming: U.S. Geological Survey Professional Paper 635:53 pp.

Parker, L. R., 1970, A titanothere from the Eocene Green River Formation of Utah: Abstracts with Programs - Geological Society of America, 2(6):400.

Peale, A. C., 1879, Report on the geology of the Green River district: 11th Annual Report, U.S. Geological Survey of the Territories Report on the geology of the Green River district.

Perry, M. L., 2003, Preliminary description of a new fossil scorpion from the middle Eocene, Green River Formation, Rio Blanco, Colorado: Abstracts, 74th annual meeting of the ColoradoWyoming Academy of Science, Greeley, CO, United States, April 26, 2003, 35(1):22.

Picard, M. D., 1963, Duration of Eocene Lake Uinta, Uinta Basin, Utah: Geological Society of America Bulletin, 74:89-90.

Prothero, D. R. and C. C. Swisher, III, 1992, Magnetostratigraphy and geochronology of the terrestrial Eocene-Oligocene transition in North America, In: Eocene-Oligocene Climatic and Biotic Evolution (D. R. Prothero and W. A. Berggren,eds.), Princeton University Press, Princeton, New Jersey. 46-73.

Rieppel, O. and L. Grande, 1998, A well-preserved fossil amphiumid (Lissamphibia; Caudata) from the Eocene Green River Formation of Wyoming: Journal of Vertebrate Paleontology, 18(4):700-708.

Robinson, P., 1978, Paleontological resources inventory and evaluation, Bureau of Mines Experimental Oil Shale Mine, Rio Blanco County, Colorado: Prepared for VTN Colorado, Inc. 2600 S. Parker Rd., Aurora, Colorado. 22 pp.

Robinson, P., D. J. Daitch and J. E. Haessig, 2000, Fossil vertebrate localities of southwestern Wyoming: a literature search, locality record, and formation evaluation: Unpublished technical report prepared for the Wyoming BLM.

Robinson, P., G. F. Gunnell, S. L. Walsh, W. C. Clyde, J. E. Storer, R. K. Stucky, D. J. Froehlich, I. F. Villafranca and M. C. McKenna, 2004, Wasatchian though Duschesnean biochronology, In: Late Cretaceous and Cenozoic Mammals of North America (M. O. Woodburne, ed.), Columbia University Press. 106-155.

Roehler, H. W., 1973, Stratigraphy of the Washakie Formation in the Washakie Basin, Wyoming: U.S. Geological Survey Bulletin, Report: B 1369:40. 


\section{A.2 PICEANCE CREEK BASIN, COLORADO}

\section{A.2.2 Green River Formation (Cont.)}

Roehler, H. W., 1992a, Geology of the Eocene Wasatch, Green River, and Bridger (Washakie) Formations, Greater Green River Basin, Wyoming, Utah and Colorado: Introduction to Greater Green River Basin Geology, Physiography, and History of Investigations: U.S. Geological Survey Professional Paper 1506-A:14.

Roehler, H. W., 1992b, Geology of the Eocene Wasatch, Green River, and Bridger (Washakie) Formations, Greater Green River Basin, Wyoming, Utah and Colorado: Description and Correlation of Eocene Rocks in Stratigraphic Reference Sections for the Green River and Washakie Basin, Southwest Wyoming: U.S. Geological Survey Professional Paper 1506-D:83 pp.

Roehler, H. W., 1992c, Geology of the Eocene Wasatch, Green River, and Bridger (Washakie) Formations, Greater Green River Basin, Wyoming, Utah and Colorado: Correlation, Composition, Areal Distribution, and Thickness of Eocene Stratigraphic Units, Greater Green River Basin, Wyoming, Utah, and Colorado: U.S. Geological Survey Professional Paper 1506-E:49 pp.

Roehler, H. W., 1993, Geology of the Eocene Wasatch, Green River, and Bridger (Washakie) Formations, Greater Green River Basin, Wyoming, Utah and Colorado: Eocene Climates, Depositional Environments, and Geography, Greater Green River Basin, Wyoming, Utah and Colorado: U.S. Geological Survey Professional Paper 1506-F:74 pp.

Savage, D. E. and D. E. Russell, 1983, Mammalian Paleofauna of the World: Addison-Wesley Publ. Co. 432 pp.

Savage, D. E., B. T. Waters and J. H. Hutchison, 1972, Early Eocene fossiliferous strata, northwest Washakie Basin, Sweetwater County, Wyoming: Abstracts, Thirty-second annual meeting, Society of Vertebrate Paleontology, pp. 7-8.

Schultz, A. R., 1914, Geology and geography of a portion of Lincoln County, Wyoming: U.S. Geological Survey Bulletin 543:1-141.

Scudder, S. H., 1868, The insects of the ancient American Tertiary beds of Green River: The American Naturalist, 1:625-634.

Scudder, S. H., 1890, The Tertiary Insects of North America: U.S. Geological Survey Report 13:734 pp.

Smith, M. E., 2001, Precise 40Ar/39Ar laser fusion geochronology of the Green River Formation, Wyoming: Geological Society of America Abstracts with Programs, annual meeting issue. 


\section{A.2 PICEANCE CREEK BASIN, COLORADO}

\section{A.2.2 Green River Formation (Cont.)}

Smith, M. E., B. Singer and A. R. Carroll, 2003, 40Ar/39Ar geochronology of the Eocene Green River Formation, Wyoming: Geological Society of America Bulletin, 115(5):545-565.

Spangler, C. L., J. D. Miller and R. J. Cuffey, 2005, Fishes from the Eocene Green River Formation around Fossil Butte, Wyoming; effect of small versus large sample size on species recovered and proportions observed: Geological Society of America, North-Central Section, 39th annual meeting, Minneapolis, MN, United States, May 19-20, 2005, 37(5):80-81.

Stidham, T. A., 1998, Phylogenetic and ecological diversification of waterfowl (Anseriformes) in the Late Cretaceous and Paleogene: Abstract, Fifty-eighth annual meeting, Society of Vertebrate Paleontology, Snowbird, UT, United States, Sept. 30-Oct. 3, 1998, 18(3, Suppl):80.

Stidham, T. A., 2000, Morphometrics and the paleobiology of Presbyornithidae (Neornithes, Anseriformes): Geological Society of America, 2000 annual meeting, Reno, NV, United States, Nov. 9-18, 2000, 32(7):15.

Stokes, W. L., 1978, Impressions of lizard scales from the Green River Formation (Eocene), Uinta Basin, Utah: Journal of Paleontology, 52(2):407-410.

Stokes, W. L., 1986, Geology of Utah: Utah Museum of Natural History, University of Utah and Utah Geological and Mineral Survey, Department of Natural Resources.

Surdam, R.C., and Stanley, K.O., 1979, Lacustrine sedimentation during the culminating phase of Eocene Lake Gosiute Wyoming (Green River Formation): Geological Society of America Bulletin, part 1, v. 90, no. 1, pp. 93-110.

Surdam, R. C. and K. O. Stanley, 1980a, Effects on changes in drainage basin boundaries on sedimentation in Eocene Lakes Gosiute and Uinta of Wyoming, Utah, and Colorado: Geology, 8:135-139.

Surdam, R. C. and K. O. Stanley, 1980b, The stratigraphic and sedimentologic framework of the Green River Formation, Wyoming: Wyoming Geological Association, 31st Field Conference Guidebook:205-221.

Swain, F. M., 1964, Early Tertiary freshwater Ostracoda from Colorado, Nevada and Utah and their stratigraphic distribution: Journal of Paleontology, 38(2):256-280.

Taylor, R. S., 1972, Paleoecology of ostracodes from the Luman Tongue and Tipton Member (early Eocene) of the Green River Formation, Wyoming: University of Kansas, Lawrence, KS, United States (USA) Doctoral. 


\section{A.2 PICEANCE CREEK BASIN, COLORADO}

\section{A.2.2 Green River Formation (Cont.)}

Tevesz, M. J. S., P. L. McCall, P. L. McCall, M. J. S. Tevesz and F. G. Stehli, 1982, Geological significance of aquatic nonmarine trace fossils, In: Animal-sediment relations; the biogenic alteration of sediments (Anonymous, eds.), United States (USA), Plenum Press, New York, NY, United States (USA).

Tuttle, M. L., 1991, Introduction, In: Geochemical, Biogeochemical, and Sedimentological Studies of the Green River Formation, Wyoming, Utah, and Colorado (M. L. Tuttle, ed.), U.S. Geological Survey Bulletin 1973-A-G. A1-A6.

Veatch, A. C., 1907, Geography and geology of a portion of southwestern Wyoming: U.S. Geological Survey Professional Paper 56:163 pp.

von Koenigswald, W., K. Rose, L. Grande, R. Martin, S. Ting, P. Gingerich, P. Higgins, B. Small and M. Fox, 2004, Apatemyid and pantolestid skeletons from the Eocene Fossil Butte Member (Wyoming) compared to those from Messel (Germany): Abstracts, Sixty-fourth annual meeting, Vertebrate Paleontology, Denver, CO, United States, Nov. 3-6, 2004, 24(3, Suppl):125.

Waterhouse, D., G. Dyke, J. Anderson, H.-D. Sues, M. Fox, J. Case, J. Eberle, M. Goodwin and S. Carlson, 2003, A new fossil charadriiform bird from the lower Eocene Green River Formation of Wyoming: Abstracts, Sixty-third annual meeting, Society of Vertebrate Paleontology, Science Museum of Minnesota, Saint Paul, MN, United States, Oct. 15-18, 2003, 23(3, Suppl):108.

Wehr, W. C. and L. L. Barksdale, 1995, Implications of middle Eocene feathers and crayfish from Republic, Washington: Washington Geology, 23(4):6-10.

West, R. M., 1973, Geology and mammalian paleontology of the New Fork-Big Sandy area, Sublette County, Wyoming: Fieldiana: Geology, 29:193.

West, R. M., 1990, Vertebrate paleontology of the Green River Basin, Wyoming, 1840-1910: Earth Sciences History, 9(1):45-56.

West, R. M. and M. R. Dawson, 1975, Eocene fossil Mammalia from the Sand Wash Basin, northwestern Moffat County, Colorado: Annals of Carnegie Museum, 45(Article 11):231-253.

Whitmore, J. H., L. R. Brand and H. P. Buchheim, 2002, Implications of modern fish taphonomy for the preservation states and depositional environments of fossil fish, Fossil Butte Member, Green River Formation, southwestern Wyoming: Geological Society of America, 2002 annual meeting, Denver, CO, United States, Oct. 27-30, 2002, 34(6):556.

Wood, H. E., R. W. Chaney, J. Clark, E. H. Colbert, G. L. Jepsen, J. J. B. Reeside and C. Stock, 1941, Nomenclature and correlation of the North American continental Tertiary: Bulletin of the Geological Society of America, 52:1-48. 


\section{A.2 PICEANCE CREEK BASIN, COLORADO}

\section{A.2.2 Green River Formation (Cont.)}

Woodburne, M. O. and C. C. I. Swisher, 1995, Land mammal high-resolution geochronology, intercontinental overland dispersals, sea level, climate, and vicariance, In: Geochronology, Time Scales, and Global Stratigraphic Correlations: Unified Temporal Framework for an Historical Geology (W. A. Berggren, D. V. Kent, M. P. Aubry and J. Hardenbol, eds.), SEPM Special Publication no. 54. 337-364.

Yang, S.-Y., M. G. Lockley, R. Greben, B. R. Erickson and S.-K. Lim, 1995, Flamingo and duck-like bird tracks from the Late Cretaceous and early Tertiary; evidence and implications: Ichnos, 4(1):21-34.

Zonneveld, J.-P., G. F. Gunnell and W. S. Bartels, 2000a, Early Eocene fossil vertebrates from the southwestern Green River Basin, Lincoln and Uinta counties, Wyoming: Journal of Vertebrate Paleontology, 20(2):369-386.

Zonneveld, J.-P., J. M. Lavigne and W. S. Bartels, 2000b, Ichnology of an early Eocene meandering fluvial system, Wasatch Formation, Fossil Butte National Monument, Wyoming: Geological Society of America Abstracts, 32(7):309. 


\section{A.2 PICEANCE CREEK BASIN, COLORADO}

\section{A.2.3 Uinta Formation}

Bilbey, S. A., E. Hall and D. A. Hall, 2002, Old and new vertebrate fossil sites in the Uinta Basin, Utah; Abstracts of papers: Sixty-second annual meeting, Norman, OK, United States, Oct. 9-12, 2002, 22(3, Suppl):36A.

Black, C. C., 1968, The Uintan rodent Mytonomys: Journal of Paleontology, 42(3):853-856.

Bryant, B., C. W. Naeser, R. F. Marvin and H. H. Mehnert, 1989, Upper Cretaceous and Paleogene sedimentary rocks and isotopic ages of Paleogene tuffs, Uinta Basin, Utah: U.S. Geological Survey Bulletin, 1787-J:22 pp.

Cashion, W. B. and J. R. Donnell, 1974, Revision of nomenclature of the upper part of the Green River Formation, Piceance Creek basin, Colorado, and eastern Uinta Basin, Utah: U.S. Geological Survey Bulletin B 1394-G, pp. G1-G9.

Cope, E. D., 1884, Vertebrata of the Tertiary Formations of the West: Report of the U.S. Geological Survey of the Territories, vol. 3.

Crawford, T., D. T. Rasmussen and G. Conroy, 2002, Forelimb morphology and limb proportions of middle Eocene Oxyaenodon (Mammalia, Creodonta): Abstracts, Sixty-second annual meeting, Society of Vertebrate Paleontology, Norman, OK, United States, Oct. 9-12, 2002, 22(3, Suppl):46A.

Dawson, M. R., 1966, Additional late Eocene rodents (Mammalia) from the Uinta Basin, Utah: Annals of Carnegie Museum, 38:97-114.

Dawson, M. R., 1968, Middle Eocene rodents (Mammalia) from northeastern Utah: Annals of Carnegie Museum, 39:327-370.

Doi, K., 1990, Geology, and paleontology of two primate families of the Raven Ridge, northwestern Colorado and northeastern Utah: University of Colorado, Boulder, CO, United States (USA) Master's.

Donnell, J. R., 1978, Intertonguing of the Green River and Uinta Formations in Rio Blanco County, Colorado: U.S. Geological Survey Professional Paper P 1100, pp. 25-26.

Dorr, J. A., Jr. and P. D. Gingerich, 1980, Early Cenozoic mammalian paleontology, geologic structure, and tectonic history in the overthrust belt near LaBarge, western Wyoming Contributions to Geology, University of Wyoming, 18(2):101-115.

Douglass, E., 1914, Geology of the Uinta Formation: Geological Society of America Bulletin:417-420. 


\section{A.2 PICEANCE CREEK BASIN, COLORADO}

\section{A.2.3 Uinta Formation (Cont.)}

Friscia, A. F., 1996, Middle Eocene Carnivora and Creodonta of the Uinta Formation, Uinta Basin, Utah: Abstracts, Fifty-sixth annual meeting, Society of Vertebrate Paleontology, New York, NY, United States, Oct. 16-19, 1996, 16(3, Suppl):35.

Geo/Resource, 1984, Green River Basin geologic resources inventory: Unpublished Technical Report prepared for the Wyoming BLM.

Gilmore, C. W., 1916, The fossil turtles of the Uinta Formation: Memoirs of the Carnegie Museum:101-161.

Gregson, J. D. and D. J. Chure, 2000, Geology and Paleontology of Dinosaur National Monument, Utah-Colorado, In: Geology of Utah's Parks and Monuments (D. A. Sprinkel, T. C. Chidsey Jr., and P. B. Anderson, eds.), Utah Geological Association Publication. 155-188.

Gunnell, G. F. and W. S. Bartels, 1999, Middle Eocene vertebrates from the Uinta Basin, Utah, and their relationship with faunas from the southern Green River basin, Wyoming: In: Vertebrate paleontology in Utah: Miscellaneous Publication - Utah Geological Survey, 99-1:429-442.

Hail, W. J., 1978, Contact between the Parachute Creek Member of the Green River Formation and the Uinta Formation of south-central Piceance Creek Basin in Colorado: U.S. Geological Survey Professional Paper P 1100, 26 pp.

Hail, W. J., Jr., 1990, Geology of the Lower Yellow Creek area, northwestern Colorado: U.S. Geological Survey Bulletin 1787-O:45 pp.

Hamblin, A. H., 1987, Paleogeography and paleoecology of the Myton Pocket, Uinta Basin, Utah (Uinta Formation-Upper Eocene): Brigham Young University Studies, 34:33-60.

Hamblin, A. H., W. A. S. Sarjeant and D. A. E. Spalding, 1998, A remarkable mammal trackway in the Uinta Formation (late Eocene) of Utah: Geology Studies, 43:9-18.

Hamblin, A. H., W. A. S. Sarjeant and D. A. E. Spalding, 1999, Vertebrate footprints in the Duchesne River and Uinta formations (middle to late Eocene), Uinta Basin, Utah; Vertebrate paleontology in Utah: Miscellaneous Publication - Utah Geological Survey, 99-1:443-454.

Henderson, J., 1909, Field Notes, University of Colorado Museum, transcribed by Professor Peter Robinson.

Holbrook, L. T. and S. G. Lucas, 1997, A new genus of rhinocerotoid from the Eocene of Utah and the status of North American "Forstercooperia": Journal of Vertebrate Paleontology, 17(2):384-396. 


\section{A.2 PICEANCE CREEK BASIN, COLORADO}

\section{A.2.3 Uinta Formation (Cont.)}

Kihm, A. J., 1984, Early Eocene mammalian faunas of the Piceance Creek basin, northwestern Colorado: University of Colorado, Boulder, CO, United States (USA) Doctoral.

Krishtalka, L., 1976, Early Tertiary Adapisoricidae and Erinaceidae (Mammalia, Insectivora) of North America: Bulletin of Carnegie Museum of Natural History,(1):40-40.

Mader, B. J., 2000, Pseudodiplacodon, a new generic name for Diplacodon progressum Peterson (Mammalia, Perissodactyla, Brontotheriidae): Journal of Vertebrate Paleontology, 20(1):164-166.

McGrew, P. O. and T. M. Bown, 1976, Fossil vertebrate faunas: Green Mountain, Ferris-Seven Lakes, and Sandy EIS areas, and Sweetwater County, Wyoming: Unpublished technical report prepared for the Wyoming BLM. $422 \mathrm{pp}$.

McGrew, P. O. and T. M. Bown, 1977, Fossil vertebrate faunas: Carbon, Lincoln, and Uinta Counties, Wyoming: Unpublished technical report prepared for the Wyoming BLM. 251 pp.

Peterson, O. A. and J. L. Kay, 1931, The upper Uinta Formation of northeastern Utah: Annals of Carnegie Museum, 20(3-4):293-306.

Picard, M. D., 1963, Duration of Eocene Lake Uinta, Uinta Basin, Utah: Geological Society of America Bulletin, 74:89-90.

Prothero, D. R., 1990, Magnetostratigraphy of the middle Eocene Uinta Formation, Uinta Basin, Utah: Abstracts, Fiftieth annual meeting, Society of Vertebrate Paleontology, Lawrence, KS, United States, Oct. 11-13, 1990, 10(3, Suppl):38A.

Prothero, D. R., D. R. Prothero and R. J. Emry, 1996, Magnetic stratigraphy and biostratigraphy of the middle Eocene Uinta Formation, Uinta Basin, Utah, In: The terrestrial Eocene-Oligocene transition in North America (Anonymous, eds.), United States (USA), Cambridge University Press, United States (USA).

Prothero, D. R. and C. C. Swisher, III, 1992, Magnetostratigraphy and geochronology of the terrestrial Eocene-Oligocene transition in North America, In: Eocene-Oligocene Climatic and Biotic Evolution (D. R. Prothero and W. A. Berggren,eds.), Princeton University Press, Princeton, New Jersey. 46-73.

Rasmussen, D. T., G. C. Conroy, A. R. Friscia, K. E. Townsend and M. D. Kinkel, 1999, Mammals of the middle Eocene Uinta Formation; Vertebrate paleontology in Utah: Miscellaneous Publication - Utah Geological Survey, 99-1:401-420. 


\section{A.2 PICEANCE CREEK BASIN, COLORADO}

\section{A.2.3 Uinta Formation (Cont.)}

Rasmussen, D. T. and K. E. Townsend, 1995, New small-bodied mammals from the Uinta Formation, Uintah Basin, Utah, contrast with the coeval small mammals of California: Abstracts, Fifty-fifth annual meeting, Society of Vertebrate Paleontology, Pittsburgh, PA, United States, Nov. 1-4, 1995, 15(3, Suppl):49.

Riggs, E. S. (1912) New or Little Known Titanotheres from the Lower Uintah Formations. Field Museum of Natural History Geological Series, 159:17-41 pp.

Roberts, D. C., 1962, A study of Echmatemys callopyge from the Uinta Eocene of Utah, and its redefinition as a subspecies of E. septaria: Harvard Coll. Mus. Comp. Zoology Bull., illus., tables, 127, no.6.

Robinson, P., D. J. Daitch and J. E. Haessig, 2000, Fossil vertebrate localities of southwestern Wyoming: a literature search, locality record, and formation evaluation: Unpublished technical report prepared for the Wyoming BLM.

Robinson, P., G. F. Gunnell, S. L. Walsh, W. C. Clyde, J. E. Storer, R. K. Stucky, D. J. Froehlich, I. -Villafranca, M. C. McKenna and M. O. Woodburne, 2004, Wasatchian through Duchesnean biochronology, In: Late Cretaceous and Cenozoic mammals of North America; biostratigraphy and geochronology (M. O. Woodburne, ed.), Columbia University Press, New York, NY, United States (USA) 107-155.

Scott, W. B., 1898, Preliminary note on the selenodont artiodactyls of the Uinta Formation: Proceedings of the American Philosophical Society:73-81.

Scott, W. B., 1937, Paradoxical fossil mammal from the Uinta Formation of northeastern Utah: Proceedings of the Geological Society of America: Abstract, p. 376.

Scott, W. B., 1945, Mammalia of the Duchesne River Oligocene: Transactions of the American Philosophical Society, 34:209-253.

Scott, W. B. and H. F. Osborn, 1888, Preliminary report on the vertebrate fossils of the Uinta Formation, collected by the Princeton expedition of 1886: Proceedings of the American Philosophical Society:255-264.

Scott, W. B. and H. F. Osborn, 1890, The Mammalia of the Uinta Formation: Transactions of the American Philosophical Society:461-572.

Stokes, W. L., 1986, Geology of Utah: Utah Museum of Natural History, University of Utah and Utah Geological and Mineral Survey, Department of Natural Resources. 


\section{A.2 PICEANCE CREEK BASIN, COLORADO}

\section{A.2.3 Uinta Formation (Cont.)}

Thornton, M. L. and D. T. Rasmussen, 2001, Taphonomic interpretation of Gnat-Out-of-Hell, an early Uintan small mammal locality in the Uinta Formation, Utah; Eocene biodiversity; unusual occurrences and rarely sampled habitats: Topics in Geobiology, 18:299-316.

Townsend, K. E., 2004, Stratigraphy, paleoecology, and habitat change in the middle Eocene of North America: Washington University, Saint Louis, MO, United States (USA) Doctoral.

Townsend, K. E., A. R. Friscia and D. Rasmussen, 2000, Local biostratigraphy of Uinta B and Uinta C rocks in the Uinta Formation, Utah: Abstracts, Sixtieth annual meeting, Society of Vertebrate Paleontology, Mexico City, Mexico, Oct. 25-28, 2000, 20(3, Suppl):74.

Townsend, K. E., A. R. Friscia and D. T. Rasmussen, 2002, Stratigraphic distribution of middle Eocene (Uintan land mammal age) fossil vertebrate localities in the eastern Uinta Basin, Uintah County, Utah, and its implications for Uintan biostratigraphy: Geological Society of America, 2002 annual meeting, Denver, CO, United States, Oct. 27-30, 2002, 34(6):430.

Townsend, K.E., Fricia, A.R., and Rasmussen, D.T., 2006, Stratigraphic distribution of upper middle Eocene fossil vertebrate localities in the eastern Uinta Basin, Utah, with comments on Uintan biostratigraphy: The Mountain Geologist, 45(2):115-134.

Townsend, K. E. and D. T. Rasmussen, 1995, Skeletal material of the small artiodactyl, Mesomeryx grangeri, from the Uinta Formation, Uintah Basin, Utah: Abstracts, Fifty-fifth annual meeting, Society of Vertebrate Paleontology, Pittsburgh, PA, United States, Nov. 1-4, 1995, 15(3, Suppl):57.

West, R. M., 1971, Late Eocene apatemyid insectivores; Utah and California: Abstracts with Programs - Geological Society of America, 3(2):215.

Wheeler, W. H., 1961, Revision of the Uintatheres: Bulletin - Peabody Museum of Natural History:93-93.

Wing, S. L., 1998, Tertiary vegetation of North America as a context for mammalian evolution, In: Evolution of Tertiary Mammals of North America (C. M. Janis, K. M. Scott and L. L. Jacobs, eds.), Cambridge University Press.

Wood, H. E., R. W. Chaney, J. Clark, E. H. Colbert, G. L. Jepsen, J. J. B. Reeside and C. Stock, 1941, Nomenclature and correlation of the North American continental Tertiary: Bulletin of the Geological Society of America, 52:1-48. 


\section{A.2 PICEANCE CREEK BASIN, COLORADO}

\section{A.2.3 Uinta Formation (Cont.)}

Woodburne, M. O. and C. C. I. Swisher, 1995, Land mammal high-resolution geochronology, intercontinental overland dispersals, sea level, climate, and vicariance, In: Geochronology, Time Scales, and Global Stratigraphic Correlations: Unified Temporal Framework for an Historical Geology (W. A. Berggren, D. V. Kent, M. P. Aubry and J. Hardenbol, eds.), SEPM Special Publication no. 54. 337-364. 


\section{A.2 PICEANCE CREEK BASIN, COLORADO}

\section{A.2.4 Quaternary Units}

Cook, H. J., 1930, Occurrence of mammoth and giant bison in Glacial moraines in the high mountains of Colorado: Science, 72, no. 1885:68.

Cook, H. J., 1931, More evidence of mammoths in the high mountains of Colorado: Science, 73, no. 1889:283-284.

Emslie, S. D., 1986, Late Pleistocene vertebrates from Gunnison County, Colorado: Journal of Paleontology, 60:170-176.

Geo/Resource, 1984, Green River Basin geologic resources inventory: Unpublished Technical Report prepared for the Wyoming BLM.

Gillette, D. D., C. J. Bell and M. C. Hayden, 1999b, Preliminary report of the Little Dell Dam fauna, Salt Lake County, Utah (Middle Pleistocene, Irvingtonian Land mammal Age):

In: Vertebrate paleontology in Utah: Miscellaneous Publication - Utah Geological Survey, 99-1:495-500.

Gillette, D. D., H. G. McDonald and M. C. Hayden, 1999a, The first record of Jefferson's Ground Sloth, Megalonyx Jeffersonii, in Utah (Pleistocene, Rancholabrean Land Mammal Age): In: Vertebrate paleontology in Utah Miscellaneous Publication - Utah Geological Survey, 99-1:509-522.

Gillette, D. D. and W. E. Miller, 1999, Catalogue of new Pleistocene mammalian sites and recovered fossils from Utah $\underline{\mathrm{In}}$ : Vertebrate paleontology in Utah: Miscellaneous Publication Utah Geological Survey, 99-1:523-530.

Heaton, T. H., 1999, Late Quaternary vertebrate history of the Great Basin: In: Vertebrate paleontology in Utah: Miscellaneous Publication - Utah Geological Survey, 99-1:501-508.

Hunt, C. B., 1954, Pleistocene and Recent deposits in the Denver area, Colorado: U.S. Geological Survey Bulletin 996-C: 91-140.

Larson, P. R., 1999, The Columbian mammoth (Mammuthus columbi) from Escalante Valley, Iron County, Utah--discovery and implications: In: Vertebrate paleontology in Utah: Miscellaneous Publication - Utah Geological Survey, 99-1:531-537.

Lewis, G. E., 1970, New discoveries of Pleistocene bison and peccaries in Colorado: U.S. Geological Survey Professional Paper 700-B:B137-B140.

McGrew, P. O. and T. M. Bown, 1976, Fossil vertebrate faunas: Green Mountain, Ferris-Seven Lakes, and Sandy EIS areas, and Sweetwater County, Wyoming: Unpublished technical report prepared for the Wyoming BLM. $422 \mathrm{pp}$. 


\section{A.2 PICEANCE CREEK BASIN, COLORADO}

\section{A.2.4 Quaternary Units (Cont.)}

McGrew, P. O. and T. M. Bown, 1977, Fossil vertebrate faunas: Carbon, Lincoln, and Uinta Counties, Wyoming: Unpublished technical report prepared for the Wyoming BLM. $251 \mathrm{pp}$.

Robinson, P., D. J. Daitch and J. E. Haessig, 2000, Fossil vertebrate localities of southwestern Wyoming: a literature search, locality record, and formation evaluation: Unpublished technical report prepared for the Wyoming BLM.

Scott, G. R., 1963, Quaternary geology and geomorphic history of the Kassler Quadrangle, Colorado: U.S. Geological Survey Professional Paper 421-A:70 pp.

Smith, K. S., R. L. Cifelli and N. J. Czaplewski, 1999, An early Holocene, high-altitude

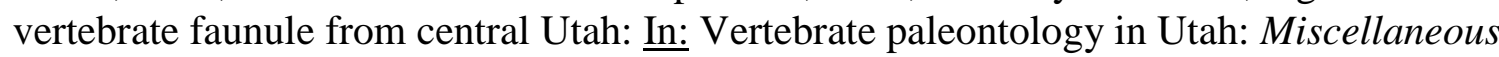
Publication - Utah Geological Survey, 99-1:537-543. 


\section{A.3 UINTA BASIN, UTAH}

\section{A.3.1 Mesaverde Group}

Archibald, J. D., 1987, Late Cretaceous (Judithian and Edmontonian) vertebrates and geology of the Williams Fork Formation, NW Colorado: Occasional Paper of the Tyrrell Museum of Palaeontology, 3:7-11.

Armstrong, H. J. and S. G. Baker, 1985, A monitor and mitigation report for paleontological resources at the Chandler Locality (5 RB 2695), Rio Blanco County, Colorado: Unpublished Technical Report Prepared for the Colorado BLM.

Armstrong, H. J. and D. G. Wolny, 1989, Paleontological resources of northwest Colorado: a regional analysis (Vols. 1-5): Unpublished Technical Report Prepared for the Colorado BLM. 221 pp. plus Appendices.

BLM, 1984, Utah combined hydrocarbon leasing EIS: Bureau of Land Management, Salt Lake City, UT.

Carpenter, K., 1992, Behavior of hadrosaurs as interpreted from footprints in the "Mesaverde" Group (Campanian) of Colorado, Utah, and Wyoming: Contributions to Geology, 29(2):81-96.

Case, G. R., 1987, A new selachian fauna from the late Campanian of Wyoming (Teapot Sandstone Member, Mesaverde Formation, Big Horn Basin): Palaeontographica Abteilung A: Palaeozoologie-Stratigraphie, 197(1-3):1-37.

DeCourten, F. L., 1990, The Long Walk Quarry and tracksite; a new chapter in the story of Colorado Plateau dinosaurs: AAPG Rocky Mountain Section meeting, Denver, CO, United States, Sept. 16-19, 1990, 74(8):1321.

Delevoryas, T., 1959, Investigations of North American cycadeoids; Monanthesia [New Mexico]: American Journal of Botany, 46(9):657-666.

Demar, D., Jr., B. Breithaupt, B. MacFadden, M. Terry, J. Scotchmoor, M. C. Mihlbachler, F. Rivals, G. Semprebon, N. Solounias, P. Reser, G. McCullough, X. Yu, J. Maisey, P. M. Barrett and T. Fedak, 2005, Faunal analysis and paleoecology of the lower vertebrate microfossil assemblages of the Mesaverde Formation (Upper Cretaceous, Campanian) of the Wind River and Bighorn Basins, Wyoming: Abstract, Sixty-fifth annual meeting, Society of Vertebrate Paleontology, Mesa, AZ, United States, Oct. 19-22, 2005, 25(3, Suppl):50-51.

Eaton, J. G., J. I. Kirkland and K. Doi, 1989, Evidence of reworked Cretaceous fossils and their bearing on the existence of Tertiary dinosaurs: Palaios, 4(3):281-286.

Estes, R., 1961, Change of name for a Cretaceous chimaeroid slightly revised: Journal of Paleontology, 35(5):1087. 


\section{A.3 UINTA BASIN, UTAH}

\section{A.3.1 Mesaverde Group (Cont.)}

Farke, A. A., 2004, Ceratopsid dinosaurs from the Upper Cretaceous Almond Formation of southwestern Wyoming: Rocky Mountain Geology, 39(1):1-5.

Fouch, T. D., T. F. Lawton, D. J. Nichols, W. B. Cashion and W. A. Cobban, 1983, Patterns and timing of synorogenic sedimentation in Upper Cretaceous rocks of central and northeast Utah, In: Mesozoic Paleogeography of the west-central United States (M. W. Reynolds and E. D. Dolly, eds.), Society of Economic Paleontologists and Mineralogists, Rocky Mountain Paleogeography Symposium, 2nd, Denver, Colorado. 305-336.

Henderson, J., 1910, Fossil invertebrates from northwestern Colorado: University of Colorado Studies, General Series A, 7:146-149.

Jenkins, J. T., Jr. and J. L. Jenkins, 1993, Colorado's dinosaurs: Special Publication - Colorado Geological Survey 35. 74 pp.

Johnson, R. C., 1989, Geologic history and hydrocarbon potential of late Cretaceous age, low permeability reservoirs, Piceance Basin, Western Colorado: U.S. Geological Survey Bulletin, 1787-E:51 pp.

Lillegraven, J. A., 1987, Stratigraphic and evolutionary implications of a new species of Meniscoessus (Multituberculata, Mammalia) from the Upper Cretaceous Williams Fork Formation, Moffat County, Colorado; Papers in vertebrate paleontology in honor of Morton Green: Dakoterra, 3:46-56.

Lillegraven, J. A. and M. C. McKenna, 1986, Fossil mammals from the "Mesaverde" Formation (Late Cretaceous, Judithian) of the Bighorn and Wind River basins, Wyoming, with definitions of Late Cretaceous North American land-mammal "ages": American Museum Novitates, 2840:68.

Lockley, M. G., B. H. Young and K. Carpenter, 1983, Hadrosaur locomotion and herding behavior; evidence from footprints in the Mesaverde Formation, Grand Mesa coal field, Colorado: The Mountain Geologist, 20(1):5-13.

Lucas, S. G. and A. J. Kihm, 1982, Paleontological resource study and inventory of part of the White River Resource Area and vicinity, Piceance Creek Basin, Colorado: Unpublished Technical Report Prepared for the Colorado BLM. 435 pp.

Morris, R. W., 1969, Microfaunal analysis of the upper part of the Mancos Formation, Mesaverde group (upper Cretaceous), and basal Lewis Formation (upper Cretaceous), in northwestern Colorado: Columbia University, Palisades, NY, United States (USA) Doctoral. 


\section{A.3 UINTA BASIN, UTAH}

\section{A.3.1 Mesaverde Group (Cont.)}

Morris, R. W., 1972, Upper Cretaceous foraminifera from the upper Mancos Formation, the Mesaverde Group, and the basal Lewis Formation, northwestern Colorado: Micropaleontology, 17(3):257-296.

Robison, S. F., 1991, Bird and frog tracks from the Late Cretaceous Blackhawk Formation in east-central Utah; Geology of east-central Utah: Utah Geological Association 1991 field symposium ; Geology of east-central Utah, USA, 1991, 19:325-334.

Sabins, F. F., Jr. and L. C. Bonham, 1960, New fossil occurrence in Mesaverde group, San Juan Basin, New Mexico: Bulletin of the American Association of Petroleum Geologists, 44(12):1936-1937.

Siverson, M., 1995, Revision of Cretorectolobus (Neoselachii) and description of Cederstroemia n. gen., a Cretaceous carpet shark (Orectolobiformes) with a cutting dentition: Journal of Paleontology, 69(5):974-979.

Toots, H. and J. F. Cutler, 1962, Gulf and Atlantic Coast mollusks in the Late Cretaceous Mesaverde Formation of Wyoming: Contributions to Geology, 1(1):7-12.

Wahl, W., J. Hogbin, J. Anderson, H.-D. Sues, M. Fox, J. Case, J. Eberle, M. Goodwin and S. Carlson, 2003, Deinosuchus material from the Mesaverde Formation of Wyoming; filling in a gap: Abstracts, Sixty-third annual meeting, Society of Vertebrate Paleontology, Science Museum of Minnesota, Saint Paul, MN, United States, Oct. 15-18, 2003, 23(3, Suppl):107.

Weil, A. I., 1999, Multituberculate phylogeny and mammalian biogeography in the Late Cretaceous and earliest Paleocene Western Interior of North America: University of California, Berkeley, Berkeley, CA, United States (USA) Doctoral.

Young, R. G. and W. R. Averett, 1987, Remains of ancient life in Cretaceous rocks of the Dinosaur Triangle, In: Paleontology and geology of the Dinosaur Triangle (Anonymous, eds.), United States (USA), Mus. West. Colo., Grand Junction, CO, United States (USA).

Young, R. G., H. R. Bollan and W. R. Averett, 1991, Centrosaurus remains from the Barnard Quarry near Rangely, Colorado, In: Guidebook for dinosaur quarries and tracksite tour, western Colorado and eastern Utah (W. R. Averett, ed.), United States (USA), Grand Junction Geol. Soc., Grand Junction, CO, United States (USA). 


\section{A.3 UINTA BASIN, UTAH}

\section{A.3.2 Wasatch Formation}

Ambrose, P., W. S. Bartels, G. F. Gunnell, E. M. Williams, J. Bolt and L. Grande, 1997, Stratigraphy and vertebrate paleontology of the Wasatch Formation, Fossil Butte National Monument, Wyoming: Abstract, Fifty-seventh annual meeting, Society of Vertebrate Paleontology, Chicago, IL, United States, Oct. 8-11, 1997, 17(3, Suppl):29.

Anemone, R. L., D. Bowen, L.-J. Davignon, D. Koepfer and D. J. Over, 1998, The Red Desert Basin Project; vertebrate paleontology and geology of an intermontane basin in southwestern Wyoming: Twenty-first annual fall scientific paper session, Rochester, NY, United States, Nov. 5 , 1994, 18(3):71.

Beasley, B. A., 1991, A late Pleistocene avifauna from the Blonquist Rockshelter, Summit County, Utah: 123rd annual meeting, Kansas Academy of Science, Lindsborg, KS, United States, Apr. 11-12, 1991, 123:3.

Beasley, B. A., M. E. Nelson, G. A. Liggett, J. C. Pugh and S. R. Ash, 1992, Paleontological investigation at the Blonquist rockshelter, Summit County, Utah: Geological Society of America, Rocky Mountain Section and associated societies, 45th annual meeting, Ogden, UT, United States, May 13-15, 1992, 24(6):2.

Black, C. C. and M. R. Dawson, 1966, A review of late Eocene mammalian fauna from North America: American Journal of Science, 264:321-349.

Breithaupt, B. H., 1990, Early Tertiary fossils and environments of Wyoming; Jackson to Fossil Butte National Monument; Geologic field tours of western Wyoming and parts of adjacent Idaho, Montana, and Utah: Public Information Circular - Geological Survey of Wyoming, 29:57-72.

Bryant, B., C. W. Naeser, R. F. Marvin and H. H. Mehnert, 1989, Upper Cretaceous and Paleogene sedimentary rocks and isotopic ages of Paleogene tuffs, Uinta Basin, Utah: U.S. Geological Survey Bulletin, 1787-J:22 pp.

Cope, E. D., 1884, Vertebrata of the Tertiary Formations of the West: Report of the U.S. Geological Survey of the Territories, vol. 3.

Dawson, M. R., 1968, Middle Eocene rodents (Mammalia) from northeastern Utah: Annals of Carnegie Museum, 39:327-370.

Doi, K., 1990, Geology, and paleontology of two primate families of the Raven Ridge, northwestern Colorado and northeastern Utah: University of Colorado, Boulder, CO, United States (USA) Master's. 


\section{A.3 UINTA BASIN, UTAH}

\section{A.3.2 Wasatch Formation (Cont.)}

Dorr, J. A., Jr., 1978, Revised and amended fossil vertebrate faunal lists, early Tertiary, Hoback Basin, Wyoming: Contributions to Geology, 16(2):79-84.

Dorr, J. A., Jr. and P. D. Gingerich, 1980, Early Cenozoic mammalian paleontology, geologic structure, and tectonic history in the overthrust belt near LaBarge, western Wyoming: Contributions to Geology, University of Wyoming, 18(2):101-115.

Eaton, J. G., J. I. Kirkland and K. Doi, 1989, Evidence of reworked Cretaceous fossils and their bearing on the existence of Tertiary dinosaurs: Palaios, 4(3):281-286.

Fisher, E. J., C. E. Erdman and J. B. Reeside, Jr. , 1960, Cretaceous and Tertiary Formations of the Book Cliffs: Carbon, Emery, and Grand counties, Utah, and Garfield and Mesa counties, Colorado: U.S. Geological Survey Professional Paper, 332:80 pp.

Foster, J. R., 2000, Amphibian tracks (Ambystomichnus?) from the Cathedral Bluffs Tongue of the Wasatch Formation (Eocene), southwestern Wyoming: Geological Society of America, Rocky Mountain Section, 52nd annual meeting, Missoula, MT, United States, April 17-18, 2000, 32(5):8-9.

Foster, J. R., 2001, Salamander tracks (Ambystomichnus?) from the Cathedral Bluffs Tongue of the Wasatch Formation (Eocene), northeastern Green River basin, Wyoming: Journal of Paleontology, 75(4):901-904.

Gauthier, J. A., 1982, Fossil xenosaurid and anguid lizards from the early Eocene Wasatch Formation, Southeast Wyoming, and a revision of the Anguioidea: Contributions to Geology, 21(1):7-54.

Geo/Resource, 1984, Green River Basin geologic resources inventory: Unpublished Technical Report prepared for the Wyoming BLM.

Gingerich, P. D. and J. A. Dorr, Jr., 1979, Mandible of Chiromyoides minor (Mammalia, Primates) from the upper Paleocene Chappo Member of the Wasatch Formation, Wyoming: Journal of Paleontology, 53(3):550-552.

Granger, W. and G. G. Simpson, 1928, Multituberculates in the Wasatch Formation: American Museum Novitates, 312:4.

Gregson, J. D. and D. J. Chure, 2000, Geology and Paleontology of Dinosaur National Monument, Utah-Colorado, In: Geology of Utah's Parks and Monuments (D. A. Sprinkel, T. C. Chidsey Jr., and P. B. Anderson, eds.), Utah Geological Association Publication. 155-188. 


\section{A.3 UINTA BASIN, UTAH}

\section{A.3.2 Wasatch Formation (Cont.)}

Gunnell, G. F., 1994, Paleocene mammals and faunal analysis of the Chappo type locality (Tiffanian), Green River Basin, Wyoming: Journal of Vertebrate Paleontology, 14(1):81-104.

Gunnell, G. F., W. S. Bartels, J. Bolt and L. Grande, 1997, Basin-margin mammalian assemblages from the Wasatch Formation (Bridgerian) of the northeastern Green River Basin, Wyoming; anachronistic taxa and the origin of new genera: Abstracts, Fifty-seventh annual meeting, Society of Vertebrate Paleontology, Chicago, IL, United States, Oct. 8-11, 1997, 17(3, Suppl):51.

Gunnell, G. F., W. S. Bartels and J.-P. Zonneveld, 2004, A late Wasatchian (late early Eocene) vertebrate assemblage preserved in meandering stream channel deposits, northern Red Desert, Wyoming: Geological Society of America, 2004 annual meeting, Denver, CO, United States, Nov. 7-10, 2004, 36(5):92.

Gunnell, G. F., W. S. Bartels and J. P. Zonneveld, 2002, Stratigraphy, vertebrate paleontology, and paleoecology of the Wasatch Formation, Fossil Butte National Monument, Wyoming: Geological Society of America, 2002 annual meeting, Denver, CO, United States, Oct. 27-30, 2002, 34(6):557.

Gunnell, G. F. and V. L. Yarborough, 2000, Brontotheriidae (Perissodactyla) from the late early and middle Eocene (Bridgerian), Wasatch and Bridger formations, southern Green River basin, southwestern Wyoming: Journal of Vertebrate Paleontology, 20(2):349-368.

Gunnell, G. F., J. P. Zonneveld and W. S. Bartels, In Press, Stratigraphy, vertebrate paleontology, and paleoecology of the Wasatch Formation, Fossil Butte National Monument, Wyoming Part 2: mammalian paleontology and age correlation: Wyoming State Geological Survey.

Hail, W. J., Jr., 1990, Geology of the Lower Yellow Creek area, northwestern Colorado: U.S. Geological Survey Bulletin 1787-O:45 pp.

Haist, B., V. Santucci and A. Aase, 2002, The history of vertebrate paleontological fieldwork in Fossil Basin, Wyoming: Abstracts, Sixty-second annual meeting, Society of Vertebrate Paleontology, Norman, OK, United States, Oct. 9-12, 2002, 22(3, Suppl):62A.

Hamrick, M. W. and H. H. Covert, 1991, A late Wasatchian mammalian fauna from the Washakie Basin, Wyoming: Abstracts, Fifty-first annual meeting, Society of Vertebrate Paleontology, San Diego, CA, United States, Oct. 24-26, 1991, 11(3, Suppl):33.

Hanley, J. H., 1974, Systematics, paleoecology, and biostratigraphy of nonmarine Mollusca from the Green River and Wasatch formations (Eocene), southwestern Wyoming and northwestern Colorado: University of Wyoming, Laramie, WY, United States (USA) Doctoral. 


\section{A.3 UINTA BASIN, UTAH}

\section{A.3.2 Wasatch Formation (Cont.)}

Hanley, J. H., R. W. Scott and R. R. West, 1976, Paleosynecology of nonmarine Mollusca from the Green River and Wasatch formations (Eocene), southwestern Wyoming and northwestern Colorado, In: Structure and classification of paleocommunities (Anonymous, eds.), Dowden, Hutchinson \& Ross, Inc., Stroudsburg, Pa., United States (USA).

Hartman, J. H., 1993, The Paleocene-Eocene nonmarine molluscan transition in the United States: Abstracts, Fifty-third annual meeting, Society of Vertebrate Paleontology, Albuquerque, NM, United States, Oct. 13-16, 1993, 13(3, Suppl):41.

Hayden, F. V., 1873, First, Second, and Third Annual Reports Report of the U.S. Geological and Geographic Survey of the Territories, for the years 1867, 1868, and 1869: U.S. Government Printing Office, Washington. 261 pp.

Holbrook, L., S. Lucas, S. Ting, P. Gingerich, P. Higgins, B. Small and M. Fox, 2004, The skull of Lambdotherium (Mammalia, Perissodactyla) and its phylogenetic implications: Abstracts, Sixty-fourth annual meeting, Society of Vertebrate Paleontology, Denver, CO, United States, Nov. 3-6, 2004, 24(3, Suppl):71.

Holroyd, P. A., 2001, Contrasting early Eocene mammalian diversity and turnover in two contemporaneous Wyoming basins: Abstracts, Sixty-first annual meeting, Society of Vertebrate Paleontology, Bozeman, MT, United States, Oct. 3-6, 2001, 21(3, Suppl):62.

Holroyd, P. A., D. M. Erwin and J. H. Hutchison, 1997, Non-mammalian paleontology of the Wasatch Formation in the northern Green River basin, Wyoming: Geological Society of America, 1997 annual meeting, Salt Lake City, UT, United States, Oct. 20-23, 1997, 29(6):104-105.

Holroyd, P. A. and K. T. Smith, 2000, Preliminary biostratigraphic evidence for age of the Wasatch and Green River formations, Washakie Basin, southwestern Wyoming: Geological Society of America, 2000 annual meeting, Reno, NV, United States, Nov. 9-18, 2000, 32(7):498.

Honey, J. G., H. W. Roehler, J. H. Hanley and J. G. Honey, 1988, A mammalian fauna from the base of the Eocene Cathedral Bluffs Tongue of the Wasatch Formation, Cottonwood Creek area, Southeast Washakie Basin, Wyoming, In: Geology and paleoecology of the Cottonwood Creek delta in the Eocene Tipton Tongue of the Green River Formation and a mammalian fauna from the Eocene Cathedral Bluffs Tongue of the Wasatch Formation, Southeast Washakie Basin, Wyoming: U.S. Geological Survey Bulletin B 1669 A-C, p. C1-C14.

Kay, J. L., 1934, The Tertiary formations of the Uinta Basin, Utah: Annals of the Carnegie Museum, 23:357-371. 


\section{A.3 UINTA BASIN, UTAH}

\section{A.3.2 Wasatch Formation (Cont.)}

Kester, P. R. and A. K. Aase, 2002, Stratigraphic correlation of the early Cenozoic intermontane lacustrine deposits of Wyoming, Colorado, and Utah: Geological Society of America, 2002 annual meeting, Denver, CO, United States, Oct. 27-30, 2002, 34(6):558.

Kihm, A. J., 1984, Early Eocene mammalian faunas of the Piceance Creek basin, northwestern Colorado: University of Colorado, Boulder, CO, United States (USA) Doctoral.

Krishtalka, L., 1976, Early Tertiary Adapisoricidae and Erinaceidae (Mammalia, Insectivora) of North America: Bulletin of Carnegie Museum of Natural History,(1):40-40.

Leggitt, V. L., H. Buchheim and M. A. Loewen, 1999, First report of a fully articulated Presbyornis (Aves; Anseriformes) wing from a Colorado Presbyornis nesting site: Abstracts, Fifty-ninth annual meeting of the Society of Vertebrate Paleontology, Denver, CO, United States, Oct. 20-23, 1999, 19(3, Suppl):59.

Leggitt, V. L., R. Cushman, J. Anderson, H.-D. Sues, M. Fox, J. A. Case, J. Eberle, M. Goodwin and S. Carlson, 2003, Flamingo nest mounds from a crocodilian nesting site in the Eocene Wasatch Formation; Lincoln County, Wyoming: Abstracts, Sixty-third annual meeting, Society of Vertebrate Paleontology, Science Museum of Minnesota, Saint Paul, MN, United States, Oct. 15-18, 2003, 23(3, Suppl):71.

Loewen, M. A., V. L. Leggitt, R. E. Biaggi, H. P. Buchheim and R. A. Cushman, Jr., 1999, Morphologic variation in caddisfly (Trichoptera) larval case architecture from the Eocene Green River and Wasatch formations of Wyoming: Geological Society of America, 1999 annual meeting, Denver, CO, United States, Oct. 25-28, 1999, 31(7):470.

Lucas, S. G. and L. T. Holbrook, 2004, The skull of the Eocene perissodactyl Lambdotherium and its phylogenetic significance; Paleogene mammals: Bulletin - New Mexico Museum of Natural History and Science, 26:81-87.

Lucas, S. G. and R. M. Schoch, 1990, Ontogenetic studies of early Cenozoic Coryphodon (Mammalia, Pantodonta): Journal of Paleontology, 64(5):831-841.

Matthew, W. D. and W. Granger, 1918, Fossil mammals of the Tiffany beds: Geological Society of America Bulletin, 29:152.

McGee, E., 2001, A mass death accumulation of Coryphodon anthracoideus (Mammalia, Pantodonta) at Roehler's Coryphodon Catastrophe Quarry (lower Eocene, Wasatch Formation), Washakie Basin, Wyoming; Eocene biodiversity; unusual occurrences and rarely sampled habitats: Topics in Geobiology, 18:317-333. 


\section{A.3 UINTA BASIN, UTAH}

\section{A.3.2 Wasatch Formation (Cont.)}

McGee, E. M., 1993, The taphonomy of Roehler's Coryphodon Catastrophe Quarry (lower Eocene, Wasatch Formation, Washakie Basin, Wyoming): Abstracts, Fifty-third annual meeting, Society of Vertebrate Paleontology, Albuquerque, NM, United States, Oct. 13-16, 1993, 13(3, Suppl):49.

McGee, E. M., 2002, Intraspecific dental variability in cf. Coryphodon anthracoideus (Mammalia, Pantodonta) from Roehler's Coryphodon Catastrophe Quarry, Washakie Basin, Wyoming: Rocky Mountain Geology, 37(1):61-73.

McGrew, P. O. and T. M. Bown, 1976, Fossil vertebrate faunas: Green Mountain, Ferris-Seven Lakes, and Sandy EIS areas, and Sweetwater County, Wyoming: Unpublished technical report prepared for the Wyoming BLM. $422 \mathrm{pp}$.

McGrew, P. O. and T. M. Bown, 1977, Fossil vertebrate faunas: Carbon, Lincoln, and Uinta Counties, Wyoming: Unpublished technical report prepared for the Wyoming BLM. 251 pp.

McKenna, M. C., 1955, Age of the Four Mile Local Fauna, northeast Sand Wash Basin, Colorado: Wyoming Geological Association Guidebook:105-107.

McKenna, M. C., 1958, Fossil Mammalia from the early Wasatchian Four Mile fauna, Eocene of Northwest Colorado: University of California, Berkeley, Berkeley, CA, United States (USA) Doctoral.

McKenna, M. C., 1960, Fossil Mammalia from the early Wasatchian Four Mile fauna, Eocene of northwest Colorado: University of California Publications in Geological Sciences, 37(1):1-130.

Mellett, J. S., 1982, Paleontologic resource inventory, Bookcliffs and Grand Hoback areas, western Colorado, Vols. 1 and 2: Unpublished BLM Report.

Nachman, B. A., 1998, Geology and vertebrate paleontology of the Great Divide Basin, SW Wyoming; Twenty-third annual fall scientific paper session [modified]: Twenty-third annual fall scientific paper session, Brockport, NY, United States, Nov. 23, 1996, 18(3):101.

Novacek, M., 1977, A review of Paleocene and Eocene Leptictidae (Eutheria; Mammalia) from North America: PaleoBios,(24):42-42.

Oriel, S. F. and J. I. Tracey 1970, Uppermost Cretaceous and Tertiary stratigraphy of Fossil Basin, southwest Wyoming: U.S. Geological Survey Professional Paper 635:53 pp.

Osborn, H. F. and J. L. Wortman, 1892, Fossil mammals of the Wasatch and Wind River beds: Bulletin of the American Museum of Natural History, 4:81-147. 


\section{A.3 UINTA BASIN, UTAH}

\section{A.3.2 Wasatch Formation (Cont.)}

Picard, M. D., 1963, Duration of Eocene Lake Uinta, Uinta Basin, Utah: Geological Society of America Bulletin, 74:89-90.

Podorsky, R. A., 1981, The stratigraphy and mammalian paleontology of the Wasatch Formation (Eocene), Fossil Butte National Monument, Lincoln County, Wyoming: Fort Hays State University, Hays, KS, United States (USA) Master's.

Rich, F. J., D. M. Johnson and T. V. Durkin, 2001, Occurrence and paleoecology of Marsilea from the Eocene Wasatch: Palaios, 16:608-613.

Robinson, P., 1978, Paleontological resources inventory and evaluation, Bureau of Mines Experimental Oil Shale Mine, Rio Blanco County, Colorado: Prepared for VTN Colorado, Inc. 2600 S. Parker Rd., Aurora, Colorado. 22 pp.

Robinson, P., D. J. Daitch and J. E. Haessig, 2000, Fossil vertebrate localities of southwestern Wyoming: a literature search, locality record, and formation evaluation: Unpublished technical report prepared for the Wyoming BLM.

Robinson, P., G. F. Gunnell, S. L. Walsh, W. C. Clyde, J. E. Storer, R. K. Stucky, D. J. Froehlich, I. F. Villafranca and M. C. McKenna, 2004, Wasatchian though Duschesnean biochronology, In: Late Cretaceous and Cenozoic Mammals of North America (M. O. Woodburne, ed.), Columbia University Press. 106-155.

Roehler, H. W., 1992a, Geology of the Eocene Wasatch, Green River, and Bridger (Washakie) Formations, Greater Green River Basin, Wyoming, Utah and Colorado: Introduction to Greater Green River Basin Geology, Physiography, and History of Investigations: U.S. Geological Survey Professional Paper 1506-A:14.

Roehler, H. W., 1992b, Geology of the Eocene Wasatch, Green River, and Bridger (Washakie) Formations, Greater Green River Basin, Wyoming, Utah and Colorado: Description and Correlation of Eocene Rocks in Stratigraphic Reference Sections for the Green River and Washakie Basin, Southwest Wyoming: U.S. Geological Survey Professional Paper 1506-D:83 pp.

Roehler, H. W., 1992c, Geology of the Eocene Wasatch, Green River, and Bridger (Washakie) Formations, Greater Green River Basin, Wyoming, Utah and Colorado: Correlation, Composition, Areal Distribution, and Thickness of Eocene Stratigraphic Units, Greater Green River Basin, Wyoming, Utah, and Colorado: U.S. Geological Survey Professional Paper 1506-E:49 pp. 


\section{A.3 UINTA BASIN, UTAH}

\section{A.3.2 Wasatch Formation (Cont.)}

Roehler, H. W., 1993, Geology of the Eocene Wasatch, Green River, and Bridger (Washakie) Formations, Greater Green River Basin, Wyoming, Utah and Colorado: Eocene Climates, Depositional Environments, and Geography, Greater Green River Basin, Wyoming, Utah and Colorado: U.S. Geological Survey Professional Paper 1506-F:74 pp.

Rose, K. D., 1977, Evolution of carpolestid primates and chronology of the North American middle and late Paleocene: Journal of Paleontology, 51(3):536-542.

Rose, K. D., T. M. Bown and E. L. Simons, 1977, An unusual new mammal from the early Eocene of Wyoming: Postilla,(172):10-10.

Savage, D. E. and D. E. Russell, 1983, Mammalian Paleofauna of the World: Addison-Wesley Publ. Co. 432 pp.

Savage, D. E. and B. T. Waters, 1978, A new omomyid primate from the Wasatch Formation of southern Wyoming: Folia Primatologica, 30(1):1-29.

Simnacher, F., 1970, Stratigraphy, depositional environments and paleontology of the Cathedral Bluffs tongue of the Wasatch Formation (Eocene), Parnell Creek area, Sweetwater County, Wyoming: University of Wyoming, Laramie, WY, United States (USA) Master's.

Simpson, G. G., 1935, The Tiffany fauna, upper Paleocene; 2, Structure and relationships of Plesiadapis: American Museum Novitates, 816:30.

Stidham, T. A., 1998, Phylogenetic and ecological diversification of waterfowl (Anseriformes) in the Late Cretaceous and Paleogene: Abstracts, Fifty-eighth annual meeting, Society of Vertebrate Paleontology, Snowbird, UT, United States, Sept. 30-Oct. 3, 1998, 18(3, Suppl):80.

Stidham, T. A., 2000, Morphometrics and the paleobiology of Presbyornithidae (Neornithes, Anseriformes): Geological Society of America, 2000 annual meeting, Reno, NV, United States, Nov. 9-18, 2000, 32(7):15.

Stokes, W. L., 1986, Geology of Utah: Utah Museum of Natural History, University of Utah and Utah Geological and Mineral Survey, Department of Natural Resources.

Stucky, R. K., 1984, The Wasatchian-Bridgerian land mammal age boundary (Early to Middle Eocene) in western North America: Annals of the Carnegie Museum of Natural History, 53:347-382. 


\section{A.3 UINTA BASIN, UTAH}

\section{A.3.2 Wasatch Formation (Cont.)}

Townsend, K. and C. Harrisville-Wolff, 1993, A new species of Hyopsodus from the upper Graybull Beds of the Wasatchian from the Washakie Basin, Wyoming: Abstracts, Fifty-third annual meeting, Society of Vertebrate Paleontology, Albuquerque, NM, United States, Oct. 13-16, 1993, 13(3, Suppl):60.

Veatch, A. C., 1907, Geography and geology of a portion of southwestern Wyoming: U.S. Geological Survey Professional Paper 56:163 pp.

Wanty, R. B., J. K. Pitman and T. D. Fouch, 1991,, Ground-water chemistry and diagenetic reactions in Tertiary sandstones of the Green River and Wasatch formations, Uinta Basin, Utah: U.S. Geological Survey Bulletin, 1787-X:21 pp.

West, R. M., 1973, Geology and mammalian paleontology of the New Fork-Big Sandy area, Sublette County, Wyoming: Fieldiana: Geology (New Series), 29:193.

West, R. M. and M. R. Dawson, 1973, Fossil mammals from the upper part of the Cathedral Bluffs Tongue of the Wasatch Formation (early Bridgerian), northern Green River basin, Wyoming: Contributions to Geology, 12(1):33-41.

Wideman, N. K. and P. A. Holroyd, 1998, Coryphodon in the greater Green River basin, SW Wyoming; possible climatic \& taphonomic factors influencing distribution: Abstracts, Fifty-eighth annual meeting, Society of Vertebrate Paleontology, Snowbird, UT, United States, Sept. 30-Oct. 3, 1998, 18(3, Suppl):86.

Williams, B. A. and H. H. Covert, 1994, New Early Eocene anaptomorphine primate (Omomyidae) from the Washakie Basin, Wyoming, with comments on the phylogeny and paleobiology of anaptomorphines: American Journal of Physical Anthropology, 93:323-340.

Williamson, C., S. Strait, P. Holroyd, S. Ting, P. Gingerich, P. Higgins, B. Small and M. Fox, 2004, Rodents from a catastrophic assemblage in the early Eocene main body of the Wasatch Formation, Washakie Basin, Wyoming: Abstracts, Sixty-fourth annual meeting, Society of Vertebrate Paleontology, Denver, CO, United States, Nov. 3-6, 2004, 24(3, Suppl):129.

Williamson, T. E., 1998, Meniscotherium mass-death assemblages; Abstracts of papers: Abstracts, Fifty-eighth annual meeting, Society of Vertebrate Paleontology, Snowbird, UT, United States, Sept. 30-Oct. 3, 1998, 18(3, Suppl):86.

Williamson, T. E., 2001, Meniscotherium mass-death assemblages; Eocene biodiversity; unusual occurrences and rarely sampled habitats: Topics in Geobiology, 18:335-360. 


\section{A.3 UINTA BASIN, UTAH}

\section{A.3.2 Wasatch Formation (Cont.)}

Winterfeld, G. F., 1982, Mammalian paleontology of the Fort Union Formation (Paleocene), eastern Rock Springs Uplift, Sweetwater County, Wyoming: Contributions to Geology, 21(1):73-111.

Wood, H. E., R. W. Chaney, J. Clark, E. H. Colbert, G. L. Jepsen, J. J. B. Reeside and C. Stock, 1941, Nomenclature and correlation of the North American continental Tertiary: Bulletin of the Geological Society of America, 52:1-48.

Woodburne, M. O. and C. C. I. Swisher, 1995, Land mammal high-resolution geochronology, intercontinental overland dispersals, sea level, climate, and vicariance, In: Geochronology, Time Scales, and Global Stratigraphic Correlations: Unified Temporal Framework for an Historical Geology (W. A. Berggren, D. V. Kent, M. P. Aubry and J. Hardenbol, eds.), SEPM Special Publication no. 54. 337-364.

Zack, S. P., 2004, An early Eocene arctostylopid (Mammalia, Arctostylopida) from the Green River basin, Wyoming: Journal of Vertebrate Paleontology, 24(2):498-501.

Zonneveld, J.-P. and G. F. Gunnell, 2003, A new species of cf. Dilophodon (Mammalia, Perissodactyla) from the early Bridgerian of southwestern Wyoming: Journal of Vertebrate Paleontology, 23(3):652-658.

Zonneveld, J.-P., G. F. Gunnell and W. S. Bartels, 2000, Early Eocene fossil vertebrates from the southwestern Green River basin, Lincoln and Uinta counties, Wyoming: Journal of Vertebrate Paleontology, 20(2):369-386.

Zonneveld, J. P., W. S. Bartels, S. D. Wolfe, G. F. Gunnell and J. I. Bloch, 2001, The occurrence of fossil vertebrates along strandlines of Paleolake Gosiute, Wasatch Formation, South Pass, Wyoming: Abstracts, Sixty-first annual meeting, Society of Vertebrate Paleontology, Bozeman, MT, United States, Oct. 3-6, 2001, 21(3, Suppl):117.

Zonneveld, J. P., J. M. Lavigne and W. S. Bartels, 2000, Ichnology of an early Eocene meandering fluvial system, Wasatch Formation, Fossil Butte National Monument, Wyoming: Geologic Society of America Abstracts with Programs, 32(7):309. 


\section{A.3 UINTA BASIN, UTAH}

\section{A.3.3 Colton Formation}

Hardy, J. W., 1959, A previously undescribed recurvirostrid from the Eocene of Utah: The Auk, 76(1):106-108.

Hughes, J. C., J. M. Zawiskie and R. A. Heimlich, 1986, Sedimentology and trace fossils of an Eocene intermontane suspended-load fluvial system; Colton Formation, central Utah: The Geological Society of America, North-Central Section, 20th annual meeting, Kent, OH, United States, April 24-25, 1986, 18(4):310.

Kay, J. L., 1934, The Tertiary formations of the Uinta Basin, Utah: Annals of the Carnegie Museum, 23:357-371.

Mercantel, E. L. and M. P. Weiss, 1968, Colton Formation (Eocene: fluviatile) and associated lacustrine beds, Gunnison Plateau, central Utah: The Ohio Journal of Science, 68(1):40-49.

Morris, T. H., D. R. Richmond and J. E. Marino, 1991, The Paleocene/Eocene Colton Formation; a fluvial-dominated lacustrine deltaic system, Roan Cliffs, Utah; Geology of east-central Utah: Utah Geological Association 1991 field symposium ; Geology of east-central Utah, USA, 1991, 19:129-139.

Picard, M. D., 1963, Duration of Eocene Lake Uinta, Uinta Basin, Utah: Geological Society of America Bulletin, 74:89-90.

Smith, J. D., 1986, Depositional environments of the Tertiary Colton and basal Green River formations in Emma Park, Utah: Geology Studies, 33(1):135-174.

Wood, H. E., R. W. Chaney, J. Clark, E. H. Colbert, G. L. Jepsen, J. J. B. Reeside and C. Stock, 1941, Nomenclature and correlation of the North American continental Tertiary: Bulletin of the Geological Society of America, 52:1-48.

Woodburne, M. O. and C. C. I. Swisher, 1995, Land mammal high-resolution geochronology, intercontinental overland dispersals, sea level, climate, and vicariance, In: Geochronology, Time Scales, and Global Stratigraphic Correlations: Unified Temporal Framework for an Historical Geology (W. A. Berggren, D. V. Kent, M. P. Aubry and J. Hardenbol, eds.), SEPM Special Publication no. 54. 337-364.

Zawiskie, J. M., P. Ericson and S. L. Olson, 1991, Stratigraphic setting of ?late Paleocene to mid-Eocene Presbyornis localities; Wasatch and Gunnison plateaus, central Utah: Geological Society of America, North-central Section; 25th annual meeting, Toledo, OH, United States, Apr. 18-19, 1991, 23(3):67. 


\section{A.3 UINTA BASIN, UTAH}

\section{A.3.4 Green River Formation}

Allmon, W. D., 2005, Paleontology of "turritella agate", a pleurocerid gastropod-dominated assemblage from the Eocene Green River Formation of Wyoming: Geological Society of America, Northeastern Section, 40th annual meeting, Saratoga Springs, NY, United States, March 14-16, 2005, 37(1):19.

Amato, T. J., H. P. Buchheim, R. A. Cushman and R. E. Biaggi, 2002, Climate change, salinity gradient or marginal freshwater lagoon? The story behind a unique fossiliferous unit of the Green River Formation in Fossil Basin, Wyoming: Geological Society of America, 2002 annual meeting, Denver, CO, United States, Oct. 27-30, 2002, 34(6):555.

Armstrong, H., 1991, Class I paleontological data inventory along a proposed highway route with alternates from Ouray to Cisco, Uintah and Grand Counties, Utah: Unpublished BLM Report. 1-211.

Armstrong, H. J. and D. G. Wolny, 1989, Paleontological resources of Northwest Colorado: A regional analysis: Museum of Western Colorado, Grand Junction.

Barclay, R. S., W. D. Bateman, K. R. Johnson, S. B. Wagner and M. L. Graham, 2003, The Parachute Creek Atlas Project; deciphering the floral diversity of the Green River Formation of Colorado and Utah: Geological Society of America, 2003 annual meeting, Seattle, WA, United States, Nov. 2-5, 2003, 35(6):588.

Bartels, W. S., 1993, Niche separation of fluvial and lacustrine reptiles from the Eocene Green River and Bridger formations of Wyoming: Abstracts, Fifty-third annual meeting, Society of Vertebrate Paleontology, Albuquerque, NM, United States, Oct. 13-16, 1993, 13(3, Suppl):25.

Benton, R., 1993, Fossil Butte National Monument, Kemmerer, Wyoming: Rocks and Minerals, 68(3):180-182.

Benton, R. C., 1999, Comparative taphonomy of Holocene microvertebrate faunas preserved in fissure fill versus shelter cave deposits: University of Iowa, Iowa City, IA, United States (USA) Doctoral.

Biaggi, R. E., H. P. Buchheim and R. A. Cushman, Jr., 2000, Deposition of a laminated, fossil rich facies in a nearshore oxic paleoenvironment, Eocene Lake Gosiute, Wyoming: Geological Society of America, 2000 annual meeting, Reno, NV, United States, Nov. 9-18, 2000, 32(7):415.

Biaggi, R. E., V. L. Leggitt and H. P. Buchheim, 1999, Caddisfly (Insecta; Trichoptera) larvae mounds from the Eocene Tipton Member, Green River Formation, Wyoming: Geological Society of America, 1999 annual meeting, Denver, CO, United States, Oct. 25-28, 1999, 31(7):242. 


\section{A.3 UINTA BASIN, UTAH}

\section{A.3.4 Green River Formation (Cont.)}

Bilbey, S. A., 2001, Final Paleontologic Report for the American Soda LLP Yankee Gulch Sodium Minerals Project, Parachute to Piceance Creek, Pipeline, Well Sites, Processing Plant, Garfield and Rio Blanco Counties, Colorado:81 pp.

Black, C. C. and M. R. Dawson, 1966, A review of late Eocene mammalian fauna from North America: American Journal of Science, 264:321-349.

Black, C. C. and J. F. Sutton, 1984, Paleocene and Eocene rodents of North America; Papers in vertebrate paleontology honoring Robert Warren Wilson: Special Publication of Carnegie Museum of Natural History, 9:67-84.

Bradley, W. H., 1924, Fossil caddice fly cases from the Green River Formation of Wyoming: American Journal of Science, 7:310-312.

Bradley, W. H., 1926a, Fossil rhizopods of the Green River oil shale: Geological Society of America Bulletin, 37(1):160.

Bradley, W. H., 1926b, Shore fazes of the Green River Formation in northern Sweetwater County, Wyoming: U.S. Geological Survey Professional Paper 140-D:121-131.

Bradley, W.H., 1929, The varves and climate of the Green River epoch: U.S. Geological Survey Professional Paper 158-E, p. 87-110.

Bradley, W. H., 1931, Origin and microfossils of the Green River Formation of Colorado and Utah: U.S. Geological Survey Professional Paper 168:58.

Bradley, W. H., 1959, Revision of stratigraphic nomenclature of Green River Formation of Wyoming: American Association of Petroleum Geologists Bulletin, 43(5):1072-1075.

Bradley, W. H., 1962, Chloroplast in Spirogyra from the Green River Formation of Wyoming: American Journal of Science, 260(6):455-459.

Bradley, W. H., 1964a, Geology of Green River Formation and associated Eocene rocks in southwestern Wyoming and adjacent parts of Colorado and Utah: U.S. Geological Survey Professional Paper 496-A:1-86.

Bradley, W. H., 1964b, Aquatic fungi from the Green River Formation of Wyoming: American Journal of Science, 262(3):413-416.

Bradley, W. H., 1967, Two aquatic fungi (Chytridiales) of Eocene age from the Green River Formation of Wyoming: American Journal of Botany, 54(5, Part 1):577-582. 


\section{A.3 UINTA BASIN, UTAH}

\section{A.3.4 Green River Formation (Cont.)}

Bradley, W. H., 1969, Geochemistry and paleolimnology of the trona deposits and associated authigenic minerals of the Green River Formation of Wyoming: U.S. Geological Survey Professional Paper 496-B:71 pp.

Bradley, W. H., 1974, Oocardium tufa from the Eocene Green River Formation of Wyoming: Journal of Paleontology, 48(6):1289-1290.

Breithaupt, B. H., 1990, Early Tertiary fossils and environments of Wyoming; Jackson to Fossil Butte National Monument; Geologic field tours of western Wyoming and parts of adjacent Idaho, Montana, and Utah: Public Information Circular - Geological Survey of Wyoming, 29:57-72.

Brodkorb, P., 1965, New taxa of fossil birds: Florida Scientist, 28(2):197-198.

Brodkorb, P., 1970, An Eocene puffbird from Wyoming: Contributions to Geology, 9(1):13-15.

Bruner, J. C., 1991, Comments on the genus Amyzon (family Catostomidae): Journal of Paleontology, 65(4):678-686.

Bryant, B., C. W. Naeser, R. F. Marvin and H. H. Mehnert, 1989, Upper Cretaceous and Paleogene sedimentary rocks and isotopic ages of Paleogene tuffs, Uinta Basin, Utah: U.S. Geological Survey Bulletin, 1787-J:22 pp.

Buchheim, H. P., 1986, Paleoenvironments and sediment-fossil fish relationships; a case study from the Eocene Green River Formation, Wyoming; Fourth North American paleontological convention: Fourth North American paleontological convention, Boulder, CO, United States, Aug. 12-15, 1986, 4:A7.

Buchheim, H. P., 1994, Paleoenvironments, lithofacies, and varves of the Fossil Butte Member of the Eocene Green River Formation, Southwestern Wyoming: Contributions to Geology, University of Wyoming, 30(1):3-14.

Buchheim, H. P. and R. C. Surdam (1977). Paleoenvironments and fossil fishes of the Laney Member, Green River Formation, Wyoming; Communities of the past: Second North American paleontology convention, Lawrence, KS, United States (USA), Hutchinson Ross Publ. Co., Stroudsburg, PA, United States (USA).

Buchheim, H. P. and R. C. Surdam, 1981, Paleoenvironments and fossil fishes of the Laney Member, Green River Formation, Wyoming, In: Communities of the Past (J. Gray, ed.), Hutchinson and Ross Publishing Company, Pennsylvania. 415-452. 


\section{A.3 UINTA BASIN, UTAH}

\section{A.3.4 Green River Formation (Cont.)}

Buchheim, H. P. and R. C. Surdam, 1984, Fossil catfish in the Green River Formation, Wyoming; new discoveries and implications to depositional models; On research and exploration projects supported by the National Geographic Society for which an initial grant or continuing support was provided in the year 1976: Research Reports - National Geographic Society, $17: 245-255$.

Carpenter, F. M., 1928, A scorpion-fly from the Green River Eocene: Annals of Carnegie Museum, 18, Part 1(1):241-248.

Carvalho, M., L. Grande, J. Maisey, J. Anderson, H.-D. Sues, M. Fox, J. A. Case, J. Eberle, M. Goodwin and S. Carlson, 2003, The evolution of stingrays (Chondrichthyes, Myliobatiformes), with special reference to the freshwater stingrays of the Green River Formation of Wyoming (early Eocene): Abstracts, Sixty-third annual meeting, Society of Vertebrate Paleontology, Science Museum of Minnesota, Saint Paul, MN, United States, Oct. 15-18, 2003, 23(3, Suppl):39.

Cashion, W. B., 1967, Geology and fuel resources of the Green River Formation, southeastern Uinta Basin Utah and Colorado: U.S. Geological Survey Professional Paper 548:48.

Cashion, W. B. and J. R. Donnell, 1974, Revision of nomenclature of the upper part of the Green River Formation, Piceance Creek Basin, Colorado, and eastern Uinta Basin, Utah: U.S. Geological Survey Bulletin 1394-G:G1-G9.

Chadey, H. F., 1973, Historical Aspects of the Green River Basin, Wyoming: Wyoming Geological Association, 25th Field Conference on the geology and mineral resources of the greater Green River Basin, Wyoming:27-33.

Cockerell, T. D. A., 1922, An ancient wasp [Hoplisus archorytes, Bear Gulch, Green River Formation, Colorado]: Nature (London), 110:313.

Cockerell, T. D. A., 1925, Plant and insect fossils from the Green River Eocene of Colorado: Proceedings of the United States National Museum, 66(19):13.

Cockerell, T. D. A., 1926, Plant and Insect Fossils from the Green River Eocene of Colorado: Proceedings of the United States National Museum, 66:1-13.

Cockerell, T. D. A., 1936, Tertiary floras: Science, 83(2154):350-351.

Codington, L. A., 1992a, Fossil spider web from the Eocene of western Colorado: 124th annual meeting of the Kansas Academy of Science, Hutchinson, KS, United States, March 26-27, 1992, 11:6. 


\section{A.3 UINTA BASIN, UTAH}

\section{A.3.4 Green River Formation (Cont.)}

Codington, L. A., 1992b, Fossil spider web from the Eocene of western Colorado: Geological Society of America, 1992 annual meeting, Cincinnati, OH, United States, Oct. 26-29, 1992, 24(7):344.

Codington, L. A., 1993, Climatic implications of terrestrial arthropods from the Parachute Creek Member (middle Eocene), Green River Formation, Garfield County, Colorado: Fort Hays State University, Hays, KS, United States (USA) Master's.

Codington, L. A., 1993, New locality for fossil insects in the Green River Formation, western Colorado: The Compass, 70(3):90-91.

Cole, R. D. and M. D. Picard, 1978, Comparative mineralogy of nearshore and offshore lacustrine lithofacies, Parachute Creek Member of the Green River Formation, Piceance Creek Basin, Colorado, and eastern Uinta Basin, Utah: Geological Society of America Bulletin, 89:1441-1454.

Conrad, J. L., 2002, First fossil relative of Shinisaurus (Anguimorpha, Squamata) and the phylogenetic importance of Shinisauridae: Abstracts, Sixty-second annual meeting, Society of Vertebrate Paleontology, Norman, OK, United States, Oct. 9-12, 2002, 22(3, Suppl):46A.

Cope, E. D., 1884, Vertebrata of the Tertiary Formations of the West: Report of the U.S. Geological Survey of the Territories, vol. 3.

Crepet, W. L., D. L. Dilcher and W. L. Crepet, 1984, Advanced (constant) insect pollination mechanisms; pattern of evolution and implications vis-a-vis angiosperm diversity; Historical perspectives of angiosperm evolution: Thirtieth annual symposium, St. Louis, MO, United States, 1984, 71(2):607-630.

Dane, C. H., 1954, Stratigraphic and facies relationships of upper part of Green River Formation and lower part of Uinta Formation in Duchesne, Uintah, Wasatch Counties, Utah: American Association of Petroleum Geologists Bulletin, 38:405-425.

Davis, P. G. and D. E. G. Briggs, 1998, The impact of decay and disarticulation on the preservation of fossil birds: Palaios, 13(1):3-13.

Dawson, M. R., 1968, Middle Eocene rodents (Mammalia) from northeastern Utah: Annals of Carnegie Museum, 39:327-370.

Dayvault, R. and A. Gorski, 1989, Fossils from the Green River Formation, Douglas Pass area, Colorado: Rocks and Minerals, 64(2):134-139. 


\section{A.3 UINTA BASIN, UTAH}

\section{A.3.4 Green River Formation (Cont.)}

Dayvault, R. D., 1992, The Green River Formation fossil quarries of Wyoming: Rocks and Minerals, 67(4):256-261.

de Carvalho, M. R., J. G. Maisey and L. Grande, 2004, Freshwater stingrays of the Green River Formation of Wyoming (early Eocene), with the description of a new genus and species and an analysis of its phylogenetic relationships (Chondrichthyes, Myliobatiformes): Bulletin of the American Museum of Natural History, 284:136.

Dlussky, G. M. and K. S. Perfilieva, 2003, Paleogene ants of the genus Archimyrmex Cockerell, 1923 (Hymenoptera, Formicidae, Myrmeciinae): Paleontological Journal, 37(1):39-47.

Doi, K., 1990, Geology, and paleontology of two primate families of the Raven Ridge, northwestern Colorado and northeastern Utah: University of Colorado, Boulder, CO, United States (USA) Master's.

Donnell, J. R., 1961, Tertiary geology and oil-shale resources of the Piceance Creek Basin between the Colorado and White Rivers, northwest Colorado: U.S. Geological Survey Bulletin, 1082-L:835-891.

Dorr, J. A., Jr. and P. D. Gingerich, 1980, Early Cenozoic mammalian paleontology, geologic structure, and tectonic history in the overthrust belt near LaBarge, western Wyoming Contributions to Geology, University of Wyoming, 18(2):101-115.

Duncan, D. C., W. J. Hail, Jr., R. B. O’Sullivan and G. N. Pipiringos, 1974, Four newly named tongues of the Eocene Green River Formation, northern Piceance Creek Basin, Colorado: U.S. Geological Survey Bulletin 1394-F:F1-F13.

Durden, C. J. and H. Rose, 1978, Butterflies from the middle Eocene; the earliest occurrence of fossil Papilionoidea (Lepidoptera): The Pearce-Sellards Series,(29):25-25.

Eastman, J. T., 1980, The caudal skeletons of catostomid fishes: American Midland Naturalist, 103(1):133-148.

Edwards, P., 1976, Fish coprolites from Fossil Butte, Wyoming: Contributions to Geology, 14(2):115-117.

Edwards, P. D., 1975, Preliminary notes on fish coprolites from the Green River Formation (Eocene) of Wyoming: Proceedings of the Nebraska Academy of Sciences and Affiliated Societies, 85:40.

Erickson, B. R., 1967, Fossil bird tracks from Utah: Museum Observer, 5(1):6-12. 


\section{A.3 UINTA BASIN, UTAH}

\section{A.3.4 Green River Formation (Cont.)}

Feduccia, A., 1973, A new Eocene Zygodactyl bird: Journal of Paleontology, 47(3):501-503.

Feduccia, A., 1976, Neanis schucherti restudied; another Eocene piciform bird: Smithsonian Contributions to Paleobiology, no.27, Coll. pap. avian paleontol. honoring 90th birthday A.Wetmore:95-99.

Feduccia, A., 1978, Presbyornis and the evolution of ducks and flamingos: American Scientist, 66(3):298-304.

Feduccia, A. and L. D. Martin, 1976, The Eocene zygodactyl birds of North America (Aves; Piciformes): Smithsonian Contributions to Paleobiology, no.27, Coll. pap. avian paleontol. honoring 90th birthday A. Wetmore:101-110.

Feduccia, A. and P. O. McGrew, 1984, The rediscovery of the avian fossil Presbyornis from the Eocene of Wyoming; On research and exploration projects supported by the National Geographic Society, for which an initial grant or continuing support was provided in the year 1975: Research Reports - National Geographic Society, 16:481-485.

Feldmann, R. M., L. Grande, C. P. Birkhimer, J. T. Hannibal and D. L. McCoy, 1981, Decapod fauna of the Green River Formation (Eocene) of Wyoming: Journal of Paleontology, 55(4):788-799.

Ferber, C. T., 1987, Environmental interpretation of fish deposits in the Eocene Green River Formation of Utah and Wyoming: Kent State University, Kent, Kent, OH, United States (USA) Master's.

Ferber, C. T. and N. A. Wells, 1986, Fish taphonomy and environmental interpretation of parts of the Eocene Green River Formation, Utah; SEPM, annual midyear meeting; abstracts: SEPM annual midyear meeting, Raleigh, NC, United States, Sept. 26-28, 1986, 1986, Vol. 3:35-36.

Ferber, C. T. and N. A. Wells, 1995, Paleolimnology and taphonomy of some fish deposits in "Fossil" and "Uinta" Lakes of the Eocene Green River Formation, Utah and Wyoming: Palaeogeography, Palaeoclimatology, Palaeoecology, 117(3-4):185-210.

Fisher, E. J., C. E. Erdman and J. B. Reeside, Jr. , 1960, Cretaceous and Tertiary Formations of the Book Cliffs: Carbon, Emery, and Grand counties, Utah, and Garfield and Mesa counties, Colorado: U.S. Geological Survey Professional Paper, 332:80 pp. 


\section{A.3 UINTA BASIN, UTAH}

\section{A.3.4 Green River Formation (Cont.)}

Fouch, T. D., J. H. Hanley, R. M. Forester, C. W. Keighin, J. K. Pitman and D. J. Nichols, 1987, Chart showing lithology, mineralogy, and paleontology of the nonmarine North Horn Formation and Flagstaff Member of the Green River Formation, Price Canyon, central Utah; a principal reference section: U.S. Geological Survey, Miscellaneous Investigations Series, Map I-1797-A, 1 sheet.

Franczyk, K. J., J. K. Pitman, and D. J. Nichols, 1990, Sedimentology, mineralogy, and depositional history of some Uppermost Cretaceous Lowermost Tertiary rocks along the Utah Book and Roan Cliffs east of the Green River: U.S. Geological Survey Bulletin 1787:27 pp.

Freemont, J. C., 1845, Report of the exploring expedition through the Rocky Mountains in the year 1842 and to Oregon and California in the years 1843-1844: Senate Document No. 174 and House Document No. 166, 28th Congress, 2nd session.

Froehlich, D. J. and B. H. Breithaupt, 1998, Mammals from the Eocene epoch Fossil Butte Member of the Green River Formation, Fossil Basin, Wyoming: Abstracts, Fifty-eighth annual meeting, Society of Vertebrate Paleontology, Snowbird, UT, United States, Sept. 30-Oct. 3, 1998, 18(3, Suppl):43-44.

Froehlich, D. J. and B. H. Breithaupt, 2002, Biostratigraphic and paleoenvironmental utility of Lambdotherium; tying down the Lagerstatten of the Green River Formation: Geological Society of America, 2002 annual meeting, Denver, CO, United States, Oct. 27-30, 2002, 34(6):556-557.

Froehlich, D. J., B. H. Breithaupt, J. Bolt and L. Grande, 1997, A Lambdotherium specimen from the Fossil Butte Member of the Green River Formation, with comments on its biostratigraphic and paleoenvironmental importance and the phylogenetic significance of its postcrania: Abstracts, Fifty-seventh annual meeting, Society of Vertebrate Paleontology, Chicago, IL, United States, Oct. 8-11, 1997, 17(3, Suppl):47.

Froehlich, J. W. and D. J. Froehlich, 2002, Using mammal fossils to locate the edge of the Green River lake in the Piceance Creek basin during the late-early Eocene: Geological Society of America, 2002 annual meeting, Denver, CO, United States, Oct. 27-30, 2002, 34(6):480-481.

Gardner, J. D., 1999, Comments on amphibians from the Green River Formation, with a description of a fossil tadpole; Vertebrate paleontology in Utah: Miscellaneous Publication Utah Geological Survey, 99-1:455-461.

Gauthier, J. A., 1982, Fossil xenosaurid and anguid lizards from the early Eocene Wasatch Formation, southeast Wyoming, and a revision of the Anguioidea: Contributions to Geology, 21:7-54. 


\section{A.3 UINTA BASIN, UTAH}

\section{A.3.4 Green River Formation (Cont.)}

Geo/Resource, 1984, Green River Basin geologic resources inventory: Unpublished Technical Report prepared for the Wyoming BLM.

Gnidovec, D. M., 1978, Taphonomy of the Powder Wash vertebrate quarry, Green River Formation; Eocene, Uintah County, Utah: Fort Hays State University, Hays, KS, United States (USA) Master's.

Grande, L., 1979, Eohiodon falcatus, a new species of hiodontid (Pisces) from the late early Eocene Green River Formation of Wyoming: Journal of Paleontology, 53(1):103-111.

Grande, L., 1980a, Paleontology of the Green River Formation, with a review of the fish fauna: Bulletin - Geological Survey of Wyoming, 63:333.

Grande, L., 1982, A revision of the fossil genus Knightia, with a description of a new genus from the Green River Formation (Teleostei, Clupeidae): American Museum Novitates, 2731:22.

Grande, L., 1984, Paleontology of the Green River Formation, with a review of the fish fauna; second edition: Bulletin - Geological Survey of Wyoming, 63:333.

Grande, L., 1985, Fish fossils in the Eocene Green River Formation of southwestern Wyoming; On research and exploration projects supported by the National Geographic Society, for which an initial grant or continuing support was provided in the years 1980-1983: Research Reports National Geographic Society, 21:201-207.

Grande, L., 1987, Redescription of Hypsidoris farsonensis (Teleostei: Siluriformes), with a reassessment of its phylogenetic relationships: Journal of Vertebrate Paleontology, 7(1):24-54.

Grande, L., 1989, Fossil fauna of the Green River Formation; Conservation and the future of humanity: 82nd annual meeting of the Illinois State Academy of Science, Chicago, IL, United States, Oct. 20-21, 1989, 82, Suppl:66.

Grande, L., 1991, Transferred type specimens of well-preserved Eocene fishes from the Green River Formation: Journal of Paleontology, 65(5):889-890.

Grande, L., 1998, The first pickerel (Teleostei, Esocidae) from the Green River Formation, and a review of the world's most productive freshwater Lagerstatten; Abstracts of papers; fifty-eighth annual meeting; Society of Vertebrate Paleontology: Society of Vertebrate Paleontology fifty-eighth annual meeting, Snowbird, UT, United States, Sept. 30-Oct. 3, 1998, 18(3, Suppl):47.

Grande, L., 1999, The first Esox (Esocidae, Teleostei) from the Eocene Green River Formation, and a brief review of esocid fishes: Journal of Vertebrate Paleontology, 19(2):271-292. 


\section{A.3 UINTA BASIN, UTAH}

\section{A.3.4 Green River Formation (Cont.)}

Grande, L., 2001, An updated review of the fish faunas from the Green River Formation, the world's most productive freshwater Lagerstaetten; Eocene biodiversity; unusual occurrences and rarely sampled habitats: Topics in Geobiology, 18:1-38.

Grande, L. and W. E. Bemis, 1991, Osteology and phylogenetic relationships of fossil and Recent paddlefishes (Polyodontidae) with comments on the interrelationships of Acipenseriformes: Journal of Vertebrate Paleontology, 11(1, Supplement):121.

Grande, L. and H. P. Buchheim, 1994, Paleontological and sedimentological variation in early Eocene Fossil Lake: Contributions to Geology, University of Wyoming, 30(1):33-56.

Grande, L., J. T. Eastman and T. M. Cavender, 1982, Amyzon gosiutensis, a new catostomid fish from the Green River Formation: Copeia, 1982(3):523-532.

Grande, L., M. C. McKenna, D. J. Chure, G. F. Englemann, L. Grande, R. K. Stucky, L. Krishtalka, M. R. Dawson, P. D. Gingerich, W. A. Clemens, J. K. Rigby, Jr., J. J. Flynn and P. M. Hanshaw, 1989, The Eocene Green River lake system, Fossil Lake, and the history of the North American fish fauna, In: Mesozoic/Cenozoic vertebrate paleontology; classic localities, contemporary approaches (Anonymous, eds.), United States (USA), Am. Geophys. Union, Washington, DC, United States (USA).

Grande, R. L., 1980, Paleontology of the Green River Formation, with a review of the fish fauna: University of Minnesota, Minneapolis, Minneapolis, MN, United States (USA) Master's.

Gregson, J. D. and D. J. Chure, 2000, Geology and Paleontology of Dinosaur National Monument, Utah-Colorado, In: Geology of Utah's Parks and Monuments (D. A. Sprinkel, T. C. Chidsey Jr., and P. B. Anderson, eds.), Utah Geological Association Publication. 155-188.

Gulas-Wroblewski, B., J. Anderson, H.-D. Sues, M. Fox, J. A. Case, J. Eberle, M. Goodwin and S. Carlson, 2003, Limnofregata; not a frigatebird any more: Abstracts, Sixty-third annual meeting, Society of Vertebrate Paleontology, Science Museum of Minnesota, Saint Paul, MN, United States, Oct. 15-18, 2003, 23(3, Suppl):58.

Gulas-Wroblewski, B. E., 2003, New evidence for pelecaniform (Aves, Pelecaniformes) diversity during the Eocene of Wyoming: Geological Society of America, Rocky Mountain Section, 55th annual meeting, Durango, CO, United States, May 7-9, 2003, 35(5):16.

Gulas-Wroblewski, B. E. and S. Uibreaslain, 2002, A new pelecaniform bird from the Green River Formation (Eocene) of Wyoming: Geological Society of America, 2002 annual meeting, Denver, CO, United States, Oct. 27-30, 2002, 34(6):425. 


\section{A.3 UINTA BASIN, UTAH}

\section{A.3.4 Green River Formation (Cont.)}

Gunnell, G., J. Anderson, H.-D. Sues, M. Fox, J. A. Case, J. Eberle, M. Goodwin and S. Carlson, 2003, New primitive microbat (Chiroptera) from the Green River Formation (upper lower Eocene), Fossil Basin, southwestern Wyoming: Abstracts, Sixty-third annual meeting, Society of Vertebrate Paleontology, Science Museum of Minnesota, Saint Paul, MN, United States, Oct. 15-18, 2003, 23(3, Suppl):58.

Gunnell, G. and W. S. Bartels, 1999, Middle Eocene vertebrates from the Uinta Basin, Utah, and their relationship with faunas from the southern Green River Basin, Wyoming: Utah Geological Survey Misc. Publications, 99-1:429-442.

Gunnell, G. F. and W. S. Bartels, 1994, Early Bridgerian (middle Eocene) vertebrate paleontology and paleoecology of the southern Green River Basin Wyoming: Contributions to Geology, University of Wyoming, 30(1):57-70.

Gunnell, G. F. and W. S. Bartels, 2001, Basin margins, biodiversity, evolutionary innovation, and the origin of new taxa; Eocene biodiversity; unusual occurrences and rarely sampled habitats: Topics in Geobiology, 18:403-432.

Gunnell, G. F., W. S. Bartels and J.-P. Zonneveld, 2004, A late Wasatchian (late early Eocene) vertebrate assemblage preserved in meandering stream channel deposits, northern Red Desert, Wyoming: Geological Society of America, 2004 annual meeting, Denver, CO, United States, Nov. 7-10, 2004, 36(5):92.

Gunnell, G. F., W. S. Bartels and J. P. Zonneveld, 2002, Stratigraphy, vertebrate paleontology, and paleoecology of the Wasatch Formation, Fossil Butte National Monument, Wyoming: Geological Society of America, 2002 annual meeting, Denver, CO, United States, Oct. 27-30, 2002, 34(6):557.

Hail, W. J., Jr., 1992, Geology of the Lower Yellow Creek area, northwestern Colorado: U.S. Geological Survey Bulletin 1787-O:45 pp.

Haist, B., V. Santucci and A. Aase, 2002, The history of vertebrate paleontological fieldwork in Fossil Basin, Wyoming: Abstracts, Sixty-second annual meeting, Society of Vertebrate Paleontology, Norman, OK, United States, Oct. 9-12, 2002, 22(3, Suppl):62A.

Hanley, J. H., 1974, Systematics, paleoecology, and biostratigraphy of nonmarine Mollusca from the Green River and Wasatch formations (Eocene), southwestern Wyoming and northwestern Colorado: University of Wyoming, Laramie, WY, United States (USA) Doctoral.

Hanley, J. H., 1979, Reproduction of glochidium larva in an Eocene nonmarine bivalve: U.S. Geological Survey Professional Paper P-1150. 


\section{A.3 UINTA BASIN, UTAH}

\section{A.3.4 Green River Formation (Cont.)}

Hanley, J. H., R. W. Scott and R. R. West, 1976, Paleosynecology of nonmarine Mollusca from the Green River and Wasatch formations (Eocene), southwestern Wyoming and northwestern Colorado, In: Structure and classification of paleocommunities (Anonymous, eds.), United States (USA), Dowden, Hutchinson \& Ross, Inc., Stroudsburg, Pa., United States (USA).

Hartman, J. H., 2004, The collections of J. C. Fremont and the type locality and record of Viviparus paludinaeformis (Hall) (Gastropoda) from the Eocene of Wyoming; Fanfare for an uncommon paleontologist; papers in honor of Malcolm C. McKenna: Bulletin of Carnegie Museum of Natural History, 36:31-42.

Hayden, F. V., 1869, Preliminary field report (3rd ann.) of the U.S. Geological Survey of Colorado and New Mexico: U.S. Government, Washington. $155 \mathrm{pp}$.

Hayden, F. V., 1871, Preliminary report of the United States Geological Survey of Wyoming and portions of contiguous territories (2nd Annual Report): U.S. Government Printing Office, Department of the Interior. $155 \mathrm{pp}$.

Hayden, F. V., 1873, First, Second, and Third Annual Reports Report of the U.S. Geological and Geographic Survey of the Territories, for the years 1867, 1868, and 1869: U.S. Government Printing Office, Washington. 261 pp.

Hayden, F. V., 1877, Notes on some artesian borings along the line of the Union Pacific Railroad in Wyoming Territory: U.S. Geological and Geographical Survey of the Territories, 3(1):181-185.

Henderson, J., 1924, The origin of the Green River Formation: Bulletin of the American Association of Petroleum Geologists, 8(5):662-668.

Hesse, A., 1992, A new species of Messelornis (Aves; Gruiformes; Messelornithidae) from the middle Eocene Green River Formation; Papers in avian paleontology; honoring Pierce Brodkorb: II International symposium of the Society of Avian Paleontology and Evolution, Los Angeles, CA, United States, Sept. 28-30, 1988, 36:171-178.

Hilton, E. J. and L. Grande, 2001, Osteology of Eohiodon (Teleostei, Hiodontiformes), based on new acid-prepared specimens from the Green River Formation (Eocene), Wyoming: Abstract, Sixty-first annual meeting, Society of Vertebrate Paleontology, Bozeman, MT, United States, Oct. 3-6, 2001, 21(3, Suppl):61-62.

Hodgkins, J. M. and D. M. Smith, 2002, A record of evolutionary change in an Eocene plantherbivore assemblage: Geological Society of America Abstracts with Programs, 34:4. 


\section{A.3 UINTA BASIN, UTAH}

\section{A.3.4 Green River Formation (Cont.)}

Holroyd, P. A., 2001, Contrasting early Eocene mammalian diversity and turnover in two contemporaneous Wyoming basins: Abstracts, Sixty-first annual meeting, Society of Vertebrate Paleontology, Bozeman, MT, United States, Oct. 3-6, 2001, 21(3, Suppl):62.

Holroyd, P. A., D. M. Erwin and J. H. Hutchison, 1997, Non-mammalian paleontology of the Wasatch Formation in the northern Green River basin, Wyoming: Geological Society of America, 1997 annual meeting, Salt Lake City, UT, United States, Oct. 20-23, 1997, 29(6):104-105.

Holroyd, P. A. and K. T. Smith, 2000, Preliminary biostratigraphic evidence for age of the Wasatch and Green River formations, Washakie Basin, southwestern Wyoming: Geological Society of America, 2000 annual meeting, Reno, NV, United States, Nov. 9-18, 2000, 32(7):498.

Honey, J. G., 1990, New Washakiin Primates (Omomyidae) from the Eocene of Wyoming and Colorado, and comments on the evolution of the Washakiini: Journal of Vertebrate Paleontology, 10(2):206-221.

Houde, P. and S. L. Olson, 1981, Paleognathous carinate birds from the early Tertiary of North America: Science, 214(4526):1236-1237.

Hutchinson, J. H., 1984, Determinate growth in the Baenidae (Testudines); taxonomic, ecologic and stratigraphic significance: Journal of Vertebrate Paleontology, 3:148-151.

Ingalls, B. and L. E. Park, 2005, Paleoecology and taphonomy of an ostracode fauna from the Laney Member, Green River Formation, Wyoming: Geological Society of America, 2005 annual meeting, Salt Lake City, UT, United States, Oct. 16-19, 2005, 37(7):64.

Jennings, D. S., V. L. Santucci, H. P. Buchheim and S. T. Hasiotis, 2002, A preliminary inventory and assessment of ichnofossils from the Green River Formation: Geological Society of America, 2002 annual meeting, Denver, CO, United States, Oct. 27-30, 2002, 34(6):556.

Jepsen, G. L., 1966, Early Eocene bat from Wyoming: Science, 154(3754):1333-1339.

Johnson, K. R., W. Bateman, M. Graham, S. R. Manchester and B. Handley, 2002, The Parachute Creek atlas project; an overview of the megaflora of the Green River Formation from Colorado and Utah: Geological Society of America, 2002 annual meeting, Denver, CO, United States, Oct. 27-30, 2002, 34(6):480.

Johnson, K. R. and C. Plumb, 1995, Common plant fossils from the Green River Formation at Douglas Pass, Colorado and Bonanza, Utah, In: The Green River Formation in Piceance Creek and eastern Uinta basins, Grand Junction Geol. Society Guidebook. 121-130. 


\section{A.3 UINTA BASIN, UTAH}

\section{A.3.4 Green River Formation (Cont.)}

Johnson, R.C., 1981, Stratigraphic evidence for a deep Eocene Lake Uinta, Piceance Creek Basin, Colorado: Geology, v. 9, no. 5, pp. 55-62.

Johnson, R. C., 1984, New names for units in the lower part of the Green River Formation, Piceance Creek Basin, Colorado: U.S. Geological Survey Bulletin, B 1529-I.

Johnson, R. C., 1985, Early Cenozoic history of the Uinta and Piceance Creek basins, Utah and Colorado, with special reference to the development of Eocene Lake Uinta, In: Cenozoic Paleogeography of West-Central United States (R. M. Flores and S. S. Kaplan, eds.), Society for Sedimentary Geology. 247-276

Johnson, R. C., 1989, Geologic history and hydrocarbon potential of late Cretaceous-age, lowpermeability reservoirs, Piceance Basin, western Colorado: U.S. Geological Survey Bulletin, B 1787-E, 51 pp.

Kay, J. L., 1934, The Tertiary formations of the Uinta Basin, Utah: Annals of the Carnegie Museum, 23:357-371.

Kester, P. R. and A. K. Aase, 2002, Stratigraphic correlation of the early Cenozoic intermontane lacustrine deposits of Wyoming, Colorado, and Utah: Geological Society of America, 2002 annual meeting, Denver, CO, United States, Oct. 27-30, 2002, 34(6):558.

Kihm, A. J., 1984, Early Eocene mammalian faunas of the Piceance Creek basin, northwestern Colorado: University of Colorado, Boulder, CO, United States (USA) Doctoral.

King, C., 1877, Descriptive geology: U.S. Geological Exploration of the 40th Parallel, $2: 202-277$.

Krishtalka, L., 1976, Early Tertiary Adapisoricidae and Erinaceidae (Mammalia, Insectivora) of North America: Bulletin of Carnegie Museum of Natural History,(1):40-40.

Krishtalka, L., 1976, North American Nyctitheriidae; Mammalia, Insectivora: Annals of Carnegie Museum, 46(Article 2):7-28.

Krishtalka, L. and R. K. Stucky, 1984, Middle Eocene marsupials (Mammalia) from northeastern Utah and the mammalian fauna from Powder Wash: Annals of Carnegie Museum, 53(2):31-45.

Kuchta, M. A., 2000, Paleoenvironmental significance of nonmarine Mollusca in the Luman Tongue of the Green River Formation, Wyoming: Master's Thesis, University of Wisconsin, $63 \mathrm{pp}$. 


\section{A.3 UINTA BASIN, UTAH}

\section{A.3.4 Green River Formation (Cont.)}

Langston, W., Jr. and H. Rose, 1978, A yearling crocodilian from the middle Eocene Green River Formation of Colorado: Journal of Paleontology, 52(1):122-125.

Leggitt, V. L., R. Biaggi, H. P. Buchheim, S. Ting, P. Gingerich, P. Higgins, B. Small and M. Fox, 2004, Avian eggshell fragments confirm lake margin fluctuation; Tipton Shale Member, Eocene Lake Gosiute: Abstracts, Sixty-fourth annual meeting, Society of Vertebrate Paleontology, Denver, CO, United States, Nov. 3-6, 2004, 24(3, Suppl):82.

Leggitt, V. L. and H. P. Buchheim, 1993, Radiograph aided taphonomic analysis of an avian fossil quarry; insights into the paleohabitat of the Tertiary bird, Presbyornis: Geological Society of America, 1993 annual meeting, Boston, MA, United States, Oct. 25-28, 1993, 25(6):58.

Leggitt, V. L. and H. P. Buchheim, 1996, An avian botulism epizootic affecting a nesting site population of Presbyornis on a carbonate mudflat shoreline of Eocene Fossil Lake: Sixth North American paleontological convention, Washington, DC, United States, June 9-12, 1996, $8: 234$.

Leggitt, V. L. and H. P. Buchheim, 1998a, Avian eggshell identified from a Presbyornis (Aves; Anseriformes) rookery; Eocene Lake Gosiute, Sweetwater County, Wyoming: Geological Society of America, 1998 annual meeting, Toronto, ON, Canada, Oct. 26-29, 1998, 30(7):32.

Leggitt, V. L. and H. P. Buchheim, 1998b, A new Presbyornis (Aves, Anseriformes) nesting site with abundant eggshell; Eocene Fossil Lake, Lincoln County, Wyoming: Abstracts, Fifty-eighth annual meeting, Society of Vertebrate Paleontology, Snowbird, UT, United States, Sept. 30-Oct. 3, 1998, 18(3, Suppl):58.

Leggitt, V. L., H. P. Buchheim and R. E. Biaggi, 2001, Avian eggshell from caddisfly (Insecta, Trichoptera) mounds; Tipton Shale Member, Eocene Green River Formation: Abstracts, Sixty-first annual meeting, Society of Vertebrate Paleontology, Bozeman, MT, United States, Oct. 3-6, 2001, 21(3, Suppl):72.

Leggitt, V. L., H. P. Buchheim, J. Bolt and L. Grande, 1997, Presbyornis (Aves, Anseriformes) eggshell from three avian mass mortality sites; Eocene Fossil Lake, Lincoln County, Wyoming: Abstracts, Fifty-seventh annual meeting, Society of Vertebrate Paleontology, Chicago, IL, United States, Oct. 8-11, 1997, 17(3, Suppl):60.

Leggitt, V. L. and R. A. Cushman, 2001, Complex caddisfly-dominated bioherms from the Eocene Green River Formation: Sedimentary Geology, 145:377-396.

Leopold, E. B. and H. D. MacGinitie, 1972, Development and affinities of Tertiary floras in the Rocky Mountains, In: Floristics and Paleofloristics of Asia and Eastern North America, Elsevier, Amsterdam. pp. 147-200. 


\section{A.3 UINTA BASIN, UTAH}

\section{A.3.4 Green River Formation (Cont.)}

Li, G.-Q., L. Grande and M. V. H. Wilson, 1997, The species of Phareodus (Teleostei, Osteoglossidae) from the Eocene of North America and their phylogenetic relationships: Journal of Vertebrate Paleontology, 17(3):487-505.

Loewen, M. A. and H. P. Buchheim, 1998, Paleocommunities and trophic relationships during the latter stages of Eocene Fossil Lake, SW Wyoming: Abstracts, Fifty-eighth annual meeting, Society of Vertebrate Paleontology, Snowbird, UT, United States, Sept. 30-Oct. 3, 1998, 18(3, Suppl):59.

Loewen, M. A. and J. M. Gibert, 1999, The first occurrence of Cenozoic fish trails (Undichna) from Eocene Fossil Lake, Wyoming: Abstracts, Fifty-ninth annual meeting, Society of Vertebrate Paleontology, Denver, CO, United States, Oct. 20-23, 1999, 19(3, Suppl):59.

Loewen, M. A., V. L. Leggitt, R. E. Biaggi, H. P. Buchheim and R. A. Cushman, Jr., 1999, Morphologic variation in caddisfly (Trichoptera) larval case architecture from the Eocene Green River and Wasatch formations of Wyoming: Geological Society of America, 1999 annual meeting, Denver, CO, United States, Oct. 25-28, 1999, 31(7):470.

Lundberg, J. G. and G. R. Case, 1970, A new catfish from the Eocene Green River Formation, Wyoming: Journal of Paleontology, 44(3):451-457.

MacGinitie, H. D., 1969, The Eocene Green River flora of northwestern Colorado and northeastern Utah: University of California Publications in Geological Sciences, 83:202.

Martin, L. D. and A. Feduccia, 2002, Avifauna of the Green River deposits and the early radiation of modern birds: Geological Society of America, 2002 annual meeting, Denver, CO, United States, Oct. 27-30, 2002, 34(6):480.

Mauger, R. L., 1977, K-Ar ages of biotites from tuffs in Eocene rocks of the Green River Formation, Piceance Creek Basin, Colorado: Geology, 3:493-497.

Mayr, G. and M. Daniels, 2001, A new short-legged landbird from the early Eocene of Wyoming and contemporaneous European sites: Acta Palaeontologica Polonica, 46(3):393-402.

McGrew, P. O., 1971, Early and middle Eocene faunas of the Green River basin; Trona issue: Contributions to Geology, 10(1):65-68.

McGrew, P. O., 1975, Taphonomy of Eocene fish from Fossil Basin, Wyoming: Fieldiana: Geology 33(14):257-270.

McGrew, P. O., 1980, An Eocene flamingo nesting area, Sweetwater County, Wyoming: Research Reports - National Geographic Society, 12:473-478. 


\section{A.3 UINTA BASIN, UTAH}

\section{A.3.4 Green River Formation (Cont.)}

McGrew, P. O. and T. M. Bown, 1976, Fossil vertebrate faunas: Green Mountain, Ferris-Seven Lakes, and Sandy EIS areas, and Sweetwater County, Wyoming: Unpublished technical report prepared for the Wyoming BLM. $422 \mathrm{pp}$.

McGrew, P. O. and T. M. Bown, 1977, Fossil vertebrate faunas: Carbon, Lincoln, and Uinta Counties, Wyoming: Unpublished technical report prepared for the Wyoming BLM. $251 \mathrm{pp}$.

McGrew, P. O. and M. Casilliano, 1975, The geological history of Fossil Butte National Monument and Fossil Basin: National Park Service Occasional Paper,(3):37-37.

Metz, R., 1987, Sinusoidal trail formed by a Recent biting midge (family Ceratopogonidae); trace fossil implications: Journal of Paleontology, 61(2):312-314.

Moncure, G. and R. C. Surdam, 1980, Depositional environment of the Green River Formation in the vicinity of the Douglas Creek Arch, Colorado and Utah: Contributions to Geology, University of Wyoming, 19(1):9-24.

Mook, C. C., 1959, A new species of fossil crocodile of the genus Leidyosuchus from the Green River beds [Wyoming]: American Museum Novitates, 1933:6.

Moussa, M. T., 1968, Fossil tracks from the Green River Formation (Eocene) near Soldier Summit, Utah: Journal of Paleontology, 42(6):1433-1438.

Moussa, M. T., 1970, Nematode fossil trails from the Green River Formation (Eocene) in the Uinta Basin, Utah: Journal of Paleontology, 44(2):304-307.

Nelson, M. E., J. H. Madsen, Jr. and W. L. Stokes, 1980, A titanothere from the Green River Formation, central Utah; Teleodus uintensis (Perissodactyla; Brontotheriidae): Contributions to Geology, 18(2):127-134.

Nichols, D. J., 1987, Palynology of the Vermillion Creek coal bed and associated strata: U.S. Geological Survey Professional Paper 1314-D:47-73.

Olson, S. L., 1977, A lower Eocene frigatebird from the Green River Formation of Wyoming (Pelecaniformes; Fregatidae): Smithsonian Contributions to Paleobiology,(35):33-33.

Olson, S. L., 1987, An early Eocene oilbird from the Green River Formation of Wyoming (Caprimulgiformes; Steatornithidae): The evolution of birds based on fossil evidence: Documents des Laboratoires de Geologie, Lyon, 99:57-69. 


\section{A.3 UINTA BASIN, UTAH}

\section{A.3.4 Green River Formation (Cont.)}

Olson, S. L., 1992, A new family of primitive landbirds from the lower Eocene Green River Formation of Wyoming; Papers in avian paleontology; honoring Pierce Brodkorb: II International symposium of the Society of Avian Paleontology and Evolution, Los Angeles, CA, United States, Sept. 28-30, 1988, 36:127-136.

Oriel, S. F. and J. I. Tracey 1970, Uppermost Cretaceous and Tertiary stratigraphy of Fossil Basin, southwest Wyoming: U.S. Geological Survey Professional Paper 635:53 pp.

Parker, L. R., 1970, A titanothere from the Eocene Green River Formation of Utah: Abstracts with Programs - Geological Society of America, 2(6):400.

Peale, A. C., 1879, Report on the geology of the Green River district: 11th Annual Report, U.S. Geological Survey of the Territories Report on the geology of the Green River district.

Perry, M. L., 2003, Preliminary description of a new fossil scorpion from the middle Eocene, Green River Formation, Rio Blanco, Colorado: Abstracts, 74th annual meeting of the ColoradoWyoming Academy of Science, Greeley, CO, United States, April 26, 2003, 35(1):22.

Picard, M. D., 1963, Duration of Eocene Lake Uinta, Uinta Basin, Utah: Geological Society of America Bulletin, 74:89-90.

Prothero, D. R. and C. C. Swisher, III, 1992, Magnetostratigraphy and geochronology of the terrestrial Eocene-Oligocene transition in North America, In: Eocene-Oligocene Climatic and Biotic Evolution (D. R. Prothero and W. A. Berggren,eds.), Princeton University Press, Princeton, New Jersey. 46-73.

Rieppel, O. and L. Grande, 1998, A well-preserved fossil amphiumid (Lissamphibia; Caudata) from the Eocene Green River Formation of Wyoming: Journal of Vertebrate Paleontology, 18(4):700-708.

Robinson, P., 1978, Paleontological resources inventory and evaluation, Bureau of Mines Experimental Oil Shale Mine, Rio Blanco County, Colorado: Prepared for VTN Colorado, Inc. 2600 S. Parker Rd., Aurora, Colorado. 22 pp.

Robinson, P., D. J. Daitch and J. E. Haessig, 2000, Fossil vertebrate localities of southwestern Wyoming: a literature search, locality record, and formation evaluation: Unpublished technical report prepared for the Wyoming BLM.

Robinson, P., G. F. Gunnell, S. L. Walsh, W. C. Clyde, J. E. Storer, R. K. Stucky, D. J. Froehlich, I. F. Villafranca and M. C. McKenna, 2004, Wasatchian though Duschesnean biochronology, In: Late Cretaceous and Cenozoic Mammals of North America (M. O. Woodburne, eds.), Columbia University Press. 106-155. 


\section{A.3 UINTA BASIN, UTAH}

\section{A.3.4 Green River Formation (Cont.)}

Roehler, H. W., 1973, Stratigraphy of the Washakie Formation in the Washakie Basin, Wyoming: U.S. Geological Survey Bulletin, Report: B 1369:40.

Roehler, H. W., 1992a, Geology of the Eocene Wasatch, Green River, and Bridger (Washakie) Formations, Greater Green River Basin, Wyoming, Utah and Colorado: Introduction to Greater Green River Basin Geology, Physiography, and History of Investigations: U.S. Geological Survey Professional Paper 1506-A:14.

Roehler, H. W., 1992b, Geology of the Eocene Wasatch, Green River, and Bridger (Washakie) Formations, Greater Green River Basin, Wyoming, Utah and Colorado: Description and Correlation of Eocene Rocks in Stratigraphic Reference Sections for the Green River and Washakie Basin, Southwest Wyoming: U.S. Geological Survey Professional Paper 1506-D:83 pp.

Roehler, H. W., 1992c, Geology of the Eocene Wasatch, Green River, and Bridger (Washakie) Formations, Greater Green River Basin, Wyoming, Utah and Colorado: Correlation, Composition, Areal Distribution, and Thickness of Eocene Stratigraphic Units, Greater Green River Basin, Wyoming, Utah, and Colorado: U.S. Geological Survey Professional Paper 1506-E:49 pp.

Roehler, H. W., 1993, Geology of the Eocene Wasatch, Green River, and Bridger (Washakie) Formations, Greater Green River Basin, Wyoming, Utah and Colorado: Eocene Climates, Depositional Environments, and Geography, Greater Green River Basin, Wyoming, Utah and Colorado: U.S. Geological Survey Professional Paper 1506-F:74 pp.

Savage, D. E. and D. E. Russell, 1983, Mammalian Paleofauna of the World: Addison-Wesley Publ. Co. 432 pp.

Savage, D. E., B. T. Waters and J. H. Hutchison, 1972, Early Eocene fossiliferous strata, northwest Washakie Basin, Sweetwater County, Wyoming: Abstracts, Thirty-second annual meeting, Society of Vertebrate Paleontology, pp. 7-8.

Schultz, A. R., 1914, Geology and geography of a portion of Lincoln County, Wyoming: U.S. Geological Survey Bulletin 543:1-141.

Scudder, S. H., 1868, The insects of the ancient American Tertiary beds of Green River: The American Naturalist, 1:625-634.

Scudder, S. H., 1890, The Tertiary Insects of North America: U.S. Geological Survey Report 13:734 pp. 


\section{A.3 UINTA BASIN, UTAH}

\section{A.3.4 Green River Formation (Cont.)}

Smith, M. E., 2001, Precise 40Ar/39Ar laser fusion geochronology of the Green River Formation, Wyoming: Geological Society of America Abstracts with Programs, annual meeting issue.

Smith, M. E., B. Singer and A. R. Carroll, 2003, 40Ar/39Ar geochronology of the Eocene Green River Formation, Wyoming: Geological Society of America Bulletin, 115(5):545-565.

Spangler, C. L., J. D. Miller and R. J. Cuffey, 2005, Fishes from the Eocene Green River Formation around Fossil Butte, Wyoming; effect of small versus large sample size on species recovered and proportions observed: Geological Society of America, North-Central Section, 39th annual meeting, Minneapolis, MN, United States, May 19-20, 2005, 37(5):80-81.

Stidham, T. A., 1998, Phylogenetic and ecological diversification of waterfowl (Anseriformes) in the Late Cretaceous and Paleogene: Abstract, Fifty-eighth annual meeting, Society of Vertebrate Paleontology, Snowbird, UT, United States, Sept. 30-Oct. 3, 1998, 18(3, Suppl):80.

Stidham, T. A., 2000, Morphometrics and the paleobiology of Presbyornithidae (Neornithes, Anseriformes): Geological Society of America, 2000 annual meeting, Reno, NV, United States, Nov. 9-18, 2000, 32(7):15.

Stokes, W. L., 1978, Impressions of lizard scales from the Green River Formation (Eocene), Uinta Basin, Utah: Journal of Paleontology, 52(2):407-410.

Stokes, W. L., 1986, Geology of Utah: Utah Museum of Natural History, University of Utah and Utah Geological and Mineral Survey, Department of Natural Resources.

Surdam, R.C., and Stanley, K.O., 1979, Lacustrine sedimentation during the culminating phase of Eocene Lake Gosiute Wyoming (Green River Formation): Geological Society of America Bulletin, part 1, v. 90, no. 1, pp. 93-110.

Surdam, R. C. and K. O. Stanley, 1980a, Effects on changes in drainage basin boundaries on sedimentation in Eocene Lakes Gosiute and Uinta of Wyoming, Utah, and Colorado: Geology, $8: 135-139$.

Surdam, R. C. and K. O. Stanley, 1980b, The stratigraphic and sedimentologic framework of the Green River Formation, Wyoming: Wyoming Geological Association, 31 st Field Conference Guidebook:205-221.

Swain, F. M., 1964, Early Tertiary freshwater Ostracoda from Colorado, Nevada and Utah and their stratigraphic distribution: Journal of Paleontology, 38(2):256-280. 


\section{A.3 UINTA BASIN, UTAH}

\section{A.3.4 Green River Formation (Cont.)}

Taylor, R. S., 1972, Paleoecology of ostracodes from the Luman Tongue and Tipton Member (early Eocene) of the Green River Formation, Wyoming: University of Kansas, Lawrence, KS, United States (USA) Doctoral.

Tevesz, M. J. S., P. L. McCall, P. L. McCall, M. J. S. Tevesz and F. G. Stehli, 1982, Geological significance of aquatic nonmarine trace fossils, In: Animal-sediment relations; the biogenic alteration of sediments (Anonymous, eds.), United States (USA), Plenum Press, New York, NY, United States (USA).

Tuttle, M. L., 1991, Introduction, In: Geochemical, Biogeochemical, and Sedimentological Studies of the Green River Formation, Wyoming, Utah, and Colorado (M. L. Tuttle, ed.), U.S. Geological Survey Bulletin 1973-A-G. A1-A6.

Veatch, A. C., 1907, Geography and geology of a portion of southwestern Wyoming: U.S. Geological Survey Professional Paper 56:163 pp.

von Koenigswald, W., K. Rose, L. Grande, R. Martin, S. Ting, P. Gingerich, P. Higgins, B. Small and M. Fox, 2004, Apatemyid and pantolestid skeletons from the Eocene Fossil Butte Member (Wyoming) compared to those from Messel (Germany): Abstracts, Sixty-fourth annual meeting, Vertebrate Paleontology, Denver, CO, United States, Nov. 3-6, 2004, 24(3, Suppl):125.

Wanty, R. B., J. K. Pitman and T. D. Fouch, 1991,, Ground-water chemistry and diagenetic reactions in Tertiary sandstones of the Green River and Wasatch formations, Uinta Basin, Utah: U.S. Geological Survey Bulletin, 1787-X:21 pp.

Waterhouse, D., G. Dyke, J. Anderson, H.-D. Sues, M. Fox, J. Case, J. Eberle, M. Goodwin and S. Carlson, 2003, A new fossil charadriiform bird from the lower Eocene Green River Formation of Wyoming: Abstracts, Sixty-third annual meeting, Society of Vertebrate Paleontology, Science Museum of Minnesota, Saint Paul, MN, United States, Oct. 15-18, 2003, 23(3, Suppl):108.

Wehr, W. C. and L. L. Barksdale, 1995, Implications of middle Eocene feathers and crayfish from Republic, Washington: Washington Geology, 23(4):6-10.

West, R. M., 1973, Geology and mammalian paleontology of the New Fork-Big Sandy area, Sublette County, Wyoming: Fieldiana: Geology, 29:193.

West, R. M., 1990, Vertebrate paleontology of the Green River Basin, Wyoming, 1840-1910: Earth Sciences History, 9(1):45-56.

West, R. M. and M. R. Dawson, 1975, Eocene fossil Mammalia from the Sand Wash Basin, northwestern Moffat County, Colorado: Annals of Carnegie Museum, 45(Article 11):231-253. 


\section{A.3 UINTA BASIN, UTAH}

\section{A.3.4 Green River Formation (Cont.)}

Whitmore, J. H., L. R. Brand and H. P. Buchheim, 2002, Implications of modern fish taphonomy for the preservation states and depositional environments of fossil fish, Fossil Butte Member, Green River Formation, southwestern Wyoming: Geological Society of America, 2002 annual meeting, Denver, CO, United States, Oct. 27-30, 2002, 34(6):556.

Wood, H. E., R. W. Chaney, J. Clark, E. H. Colbert, G. L. Jepsen, J. J. B. Reeside and C. Stock, 1941, Nomenclature and correlation of the North American continental Tertiary: Bulletin of the Geological Society of America, 52:1-48.

Woodburne, M. O. and C. C. I. Swisher, 1995, Land mammal high-resolution geochronology, intercontinental overland dispersals, sea level, climate, and vicariance, In: Geochronology, Time Scales, and Global Stratigraphic Correlations: Unified Temporal Framework for an Historical Geology (W. A. Berggren, D. V. Kent, M. P. Aubry and J. Hardenbol, eds.), SEPM Special Publication no. 54. 337-364.

Yang, S.-Y., M. G. Lockley, R. Greben, B. R. Erickson and S.-K. Lim, 1995, Flamingo and duck-like bird tracks from the Late Cretaceous and early Tertiary; evidence and implications: Ichnos, 4(1):21-34.

Zonneveld, J.-P., G. F. Gunnell and W. S. Bartels, 2000a, Early Eocene fossil vertebrates from the southwestern Green River Basin, Lincoln and Uinta counties, Wyoming: Journal of Vertebrate Paleontology, 20(2):369-386.

Zonneveld, J.-P., J. M. Lavigne and W. S. Bartels, 2000b, Ichnology of an early Eocene meandering fluvial system, Wasatch Formation, Fossil Butte National Monument, Wyoming: Geological Society of America Abstracts, 32(7):309. 


\section{A.3 UINTA BASIN, UTAH}

\section{A.3.5 Uinta Formation}

Bilbey, S. A., E. Hall and D. A. Hall, 2002, Old and new vertebrate fossil sites in the Uinta Basin, Utah; Abstracts of papers: Sixty-second annual meeting, Norman, OK, United States, Oct. 9-12, 2002, 22(3, Suppl):36A.

Black, C. C., 1968, The Uintan rodent Mytonomys: Journal of Paleontology, 42(3):853-856.

Black, C. C. and M. R. Dawson, 1966, A review of late Eocene mammalian faunas from North America: American Journal of Science, 264:321-349.

Bryant, B., C. W. Naeser, R. F. Marvin and H. H. Mehnert, 1989, Upper Cretaceous and Paleogene sedimentary rocks and isotopic ages of Paleogene tuffs, Uinta Basin, Utah: U.S. Geological Survey Bulletin, 1787-J:22 pp.

Cashion, W. B. and J. R. Donnell, 1974, Revision of nomenclature of the upper part of the Green River Formation, Piceance Creek basin, Colorado, and eastern Uinta Basin, Utah: U.S. Geological Survey Bulletin B 1394-G, p. G1-G9.

Cope, E. D., 1884, Vertebrata of the Tertiary Formations of the West: Report of the U.S. Geological Survey of the Territories, vol. 3.

Crawford, T., D. T. Rasmussen and G. Conroy, 2002, Forelimb morphology and limb proportions of middle Eocene Oxyaenodon (Mammalia, Creodonta): Abstracts, Sixty-second annual meeting, Society of Vertebrate Paleontology, Norman, OK, United States, Oct. 9-12, 2002, 22(3, Suppl):46A.

Dawson, M. R., 1966, Additional late Eocene rodents (Mammalia) from the Uinta Basin, Utah: Annals of Carnegie Museum, 38:97-114.

Dawson, M. R., 1968, Middle Eocene rodents (Mammalia) from northeastern Utah: Annals of Carnegie Museum, 39:327-370.

Doi, K., 1990, Geology, and paleontology of two primate families of the Raven Ridge, northwestern Colorado and northeastern Utah: University of Colorado, Boulder, CO, United States (USA) Master's.

Donnell, J. R., 1978, Intertonguing of the Green River and Uinta Formations in Rio Blanco County, Colorado: U.S. Geological Survey Professional Paper P 1100, p. 25-26.

Dorr, J. A., Jr. and P. D. Gingerich, 1980, Early Cenozoic mammalian paleontology, geologic structure, and tectonic history in the overthrust belt near LaBarge, western Wyoming Contributions to Geology, University of Wyoming, 18(2):101-115. 


\section{A.3 UINTA BASIN, UTAH}

\section{A.3.5 Uinta Formation (Cont.)}

Douglass, E., 1914, Geology of the Uinta Formation: Geological Society of America Bulletin:417-420.

Friscia, A. F., 1996, Middle Eocene Carnivora and Creodonta of the Uinta Formation, Uinta Basin, Utah: Abstracts, Fifty-sixth annual meeting, Society of Vertebrate Paleontology, New York, NY, United States, Oct. 16-19, 1996, 16(3, Suppl):35.

Geo/Resource, 1984, Green River Basin geologic resources inventory: Unpublished Technical Report prepared for the Wyoming BLM.

Gilmore, C. W., 1916, The fossil turtles of the Uinta Formation: Memoirs of the Carnegie Museum:101-161.

Gregson, J. D. and D. J. Chure, 2000, Geology and Paleontology of Dinosaur National Monument, Utah-Colorado, In: Geology of Utah's Parks and Monuments (D. A. Sprinkel, T. C. Chidsey Jr., and P. B. Anderson, eds.), Utah Geological Association Publication. 155-188.

Gunnell, G. F. and W. S. Bartels, 1999, Middle Eocene vertebrates from the Uinta Basin, Utah, and their relationship with faunas from the southern Green River basin, Wyoming: In: Vertebrate paleontology in Utah: Miscellaneous Publication - Utah Geological Survey, 99-1:429-442.

Hail, W. J., 1978, Contact between the Parachute Creek Member of the Green River Formation and the Uinta Formation of south-central Piceance Creek Basin in Colorado: U.S. Geological Survey Professional Paper P 1100, 26 pp.

Hail, W. J., Jr., 1990, Geology of the Lower Yellow Creek area, northwestern Colorado: U.S. Geological Survey Bulletin 1787-O:45 pp.

Hamblin, A. H., 1987, Paleogeography and paleoecology of the Myton Pocket, Uinta Basin, Utah (Uinta Formation-Upper Eocene): Brigham Young University Studies, 34:33-60.

Hamblin, A. H., W. A. S. Sarjeant and D. A. E. Spalding, 1998, A remarkable mammal trackway in the Uinta Formation (late Eocene) of Utah: Geology Studies, 43:9-18.

Hamblin, A. H., W. A. S. Sarjeant and D. A. E. Spalding, 1999, Vertebrate footprints in the Duchesne River and Uinta formations (middle to late Eocene), Uinta Basin, Utah; Vertebrate paleontology in Utah: Miscellaneous Publication - Utah Geological Survey, 99-1:443-454.

Holbrook, L. T. and S. G. Lucas, 1997, A new genus of rhinocerotoid from the Eocene of Utah and the status of North American "Forstercooperia": Journal of Vertebrate Paleontology, 17(2):384-396. 


\section{A.3 UINTA BASIN, UTAH}

\section{A.3.5 Uinta Formation (Cont.)}

Kay, J. L., 1934, The Tertiary formations of the Uinta Basin, Utah: Annals of the Carnegie Museum, 23:357-371.

Kihm, A. J., 1984, Early Eocene mammalian faunas of the Piceance Creek basin, northwestern Colorado: University of Colorado, Boulder, CO, United States (USA) Doctoral.

Krishtalka, L., 1976, Early Tertiary Adapisoricidae and Erinaceidae (Mammalia, Insectivora) of North America: Bulletin of Carnegie Museum of Natural History,(1):40-40.

Mader, B. J., 2000, Pseudodiplacodon, a new generic name for Diplacodon progressum Peterson (Mammalia, Perissodactyla, Brontotheriidae): Journal of Vertebrate Paleontology, 20(1):164-166.

McGrew, P. O. and T. M. Bown, 1976, Fossil vertebrate faunas: Green Mountain, Ferris-Seven Lakes, and Sandy EIS areas, and Sweetwater County, Wyoming: Unpublished technical report prepared for the Wyoming BLM. $422 \mathrm{pp}$.

McGrew, P. O. and T. M. Bown, 1977, Fossil vertebrate faunas: Carbon, Lincoln, and Uinta Counties, Wyoming: Unpublished technical report prepared for the Wyoming BLM. $251 \mathrm{pp}$.

Peterson, O. A. and J. L. Kay, 1931, The upper Uinta Formation of northeastern Utah: Annals of Carnegie Museum, 20(3-4):293-306.

Picard, M. D., 1963, Duration of Eocene Lake Uinta, Uinta Basin, Utah: Geological Society of America Bulletin, 74:89-90.

Prothero, D. R., 1990, Magnetostratigraphy of the middle Eocene Uinta Formation, Uinta Basin, Utah: Abstracts, Fiftieth annual meeting, Society of Vertebrate Paleontology, Lawrence, KS, United States, Oct. 11-13, 1990, 10(3, Suppl):38A.

Prothero, D. R., D. R. Prothero and R. J. Emry, 1996, Magnetic stratigraphy and biostratigraphy of the middle Eocene Uinta Formation, Uinta Basin, Utah, In: The terrestrial Eocene-Oligocene transition in North America (Anonymous, eds.), United States (USA), Cambridge University Press, United States (USA).

Prothero, D. R. and C. C. Swisher, III, 1992, Magnetostratigraphy and geochronology of the terrestrial Eocene-Oligocene transition in North America, In: Eocene-Oligocene Climatic and Biotic Evolution (D. R. Prothero and W. A. Berggren,eds.), Princeton University Press, Princeton, New Jersey. 46-73. 


\section{A.3 UINTA BASIN, UTAH}

\section{A.3.5 Uinta Formation (Cont.)}

Rasmussen, D. T., G. C. Conroy, A. R. Friscia, K. E. Townsend and M. D. Kinkel, 1999, Mammals of the middle Eocene Uinta Formation; Vertebrate paleontology in Utah: Miscellaneous Publication - Utah Geological Survey, 99-1:401-420.

Rasmussen, D. T. and K. E. Townsend, 1995, New small-bodied mammals from the Uinta Formation, Uintah Basin, Utah, contrast with the coeval small mammals of California: Abstracts, Fifty-fifth annual meeting, Society of Vertebrate Paleontology, Pittsburgh, PA, United States, Nov. 1-4, 1995, 15(3, Suppl):49.

Riggs, E. S., 1912, New or little known titanotheres from the lower Uinta formations, with notes on the stratigraphy and distribution of fossils.

Roberts, D. C., 1962, A study of Echmatemys callopyge from the Uinta Eocene of Utah, and its redefinition as a subspecies of E. septaria: Harvard Coll. Mus. Comp. Zoology Bull., illus., tables, 127 , no. 6 .

Robinson, P., D. J. Daitch and J. E. Haessig, 2000, Fossil vertebrate localities of southwestern Wyoming: a literature search, locality record, and formation evaluation: Unpublished technical report prepared for the Wyoming BLM.

Robinson, P., G. F. Gunnell, S. L. Walsh, W. C. Clyde, J. E. Storer, R. K. Stucky, D. J. Froehlich, I. Ferrusquia-Villafranca, M. C. McKenna and M. O. Woodburne, 2004, Wasatchian through Duchesnean biochronology, In: Late Cretaceous and Cenozoic mammals of North America; biostratigraphy and geochronology (Anonymous, eds.), United States (USA), Columbia University Press, New York, NY, United States (USA).

Robinson, P., G. F. Gunnell, S. L. Walsh, W. C. Clyde, J. E. Storer, R. K. Stucky, D. J. Froehlich, I. F. Villafranca and M. C. McKenna, 2004, Wasatchian though Duschesnean biochronology, In: Late Cretaceous and Cenozoic Mammals of North America (M. O. Woodburne, eds.), Columbia University Press. 106-155.

Scott, W. B., 1898, Preliminary note on the selenodont artiodactyls of the Uinta Formation: Proceedings of the American Philosophical Society:73-81.

Scott, W. B., 1937, Paradoxical fossil mammal from the Uinta Formation of northeastern Utah: Proceedings of the Geological Society of America: Abstract, p. 376.

Scott, W. B., 1945, Mammalia of the Duchesne River Oligocene: Transactions of the American Philosophical Society, 34:209-253. 


\section{A.3 UINTA BASIN, UTAH}

\section{A.3.5 Uinta Formation (Cont.)}

Scott, W. B. and H. F. Osborn, 1888, Preliminary report on the vertebrate fossils of the Uinta Formation, collected by the Princeton expedition of 1886: Proceedings of the American Philosophical Society:255-264.

Scott, W. B. and H. F. Osborn, 1890, The Mammalia of the Uinta Formation: Transactions of the American Philosophical Society:461-572.

Stokes, W. L., 1986, Geology of Utah: Utah Museum of Natural History, University of Utah and Utah Geological and Mineral Survey, Department of Natural Resources.

Thornton, M. L. and D. T. Rasmussen, 2001, Taphonomic interpretation of Gnat-Out-of-Hell, an early Uintan small mammal locality in the Uinta Formation, Utah; Eocene biodiversity; unusual occurrences and rarely sampled habitats: Topics in Geobiology, 18:299-316.

Townsend, K. E., 2004, Stratigraphy, paleoecology, and habitat change in the middle Eocene of North America: Washington University, Saint Louis, MO, United States (USA) Doctoral.

Townsend, K. E., A. R. Friscia and D. Rasmussen, 2000, Local biostratigraphy of Uinta B and Uinta $\mathrm{C}$ rocks in the Uinta Formation, Utah: Abstracts, Sixtieth annual meeting, Society of Vertebrate Paleontology, Mexico City, Mexico, Oct. 25-28, 2000, 20(3, Suppl):74.

Townsend, K. E., A. R. Friscia and D. T. Rasmussen, 2002, Stratigraphic distribution of middle Eocene (Uintan land mammal age) fossil vertebrate localities in the eastern Uinta Basin, Uintah County, Utah, and its implications for Uintan biostratigraphy: Geological Society of America, 2002 annual meeting, Denver, CO, United States, Oct. 27-30, 2002, 34(6):430.

Townsend, K. E. and D. T. Rasmussen, 1995, Skeletal material of the small artiodactyl, Mesomeryx grangeri, from the Uinta Formation, Uintah Basin, Utah: Abstracts, Fifty-fifth annual meeting, Society of Vertebrate Paleontology, Pittsburgh, PA, United States, Nov. 1-4, 1995, 15(3, Suppl):57.

West, R. M., 1971, Late Eocene apatemyid insectivores; Utah and California: Abstracts with Programs - Geological Society of America, 3(2):215.

Wheeler, W. H., 1961, Revision of the Uintatheres: Bulletin - Peabody Museum of Natural History:93-93.

Wing, S. L., 1998, Tertiary vegetation of North America as a context for mammalian evolution, In: Evolution of Tertiary Mammals of North America (C. M. Janis, K. M. Scott and L. L. Jacobs, eds.), Cambridge University Press. 


\section{A.3 UINTA BASIN, UTAH}

\section{A.3.5 Uinta Formation (Cont.)}

Wood, H. E., R. W. Chaney, J. Clark, E. H. Colbert, G. L. Jepsen, J. J. B. Reeside and C. Stock, 1941, Nomenclature and correlation of the North American continental Tertiary: Bulletin of the Geological Society of America, 52:1-48.

Woodburne, M. O. and C. C. I. Swisher, 1995, Land mammal high-resolution geochronology, intercontinental overland dispersals, sea level, climate, and vicariance, In: Geochronology, Time Scales, and Global Stratigraphic Correlations: Unified Temporal Framework for an Historical Geology (W. A. Berggren, D. V. Kent, M. P. Aubry and J. Hardenbol, eds.), SEPM Special Publication no. 54. 337-364. 


\section{A.3 UINTA BASIN, UTAH}

\section{A.3.6 Duchesne River Formation}

Anderson, D. W. and M. D. Picard, 1972, Stratigraphy of the Duchesne River Formation (Eocene-Oligocene), northern Uinta Basin, Northwestern Utah.: Bulletin of the Utah Geological Mineralogical Survey, 97:1-29.

Bilbey, S. A., E. Hall and D. A. Hall, 2002, Old and new vertebrate fossil sites in the Uinta Basin, Utah: Abstracts, Sixty-second annual meeting, Society of Vertebrate Paleontology, Norman, OK, United States, Oct. 9-12, 2002, 22(3, Suppl):36A.

Bishop, C. E. and B. T. Tripp, 1993, An overview of the tar sand resources of Utah: AAPG Rocky Mountain Section meeting, Salt Lake City, UT, United States, Sept. 12-15, 1993, 77(8):1443.

Black, C. C., 1970, A new Pareumys (Rodentia: Cylindrodontidae) from the Duchesne River Formation, Utah: Fieldiana: Geology (New Series), 16(17):453-459.

Black, C. C. and M. R. Dawson, 1966, A review of late Eocene mammalian faunas from North America: American Journal of Science, 264:321-349.

Burke, J. J., 1933, New Duchesne River rodents and a preliminary survey of the Adjidaumidae: Annals of the Carnegie Museum, 23(391-398).

Clark, J., 1932, New turtle from the Duchesne Oligocene of the Uinta Basin, northeastern Utah: University of Pittsburgh, Pittsburgh, PA, United States (USA) Master's.

D’Alessandro, A., A. A. Ekdale and M. D. Picard, 1987, Trace fossils in fluvial deposits of the Duchesne River Formation (Eocene), Uinta Basin, Utah: Palaeogeography, Palaeoclimatology, Palaeoecology, 61(3-4):285-301.

Dawson, M. R., 1966, Additional late Eocene rodents (Mammalia) from the Uinta Basin, Utah: Annals of Carnegie Museum, 38:97-114.

Emry, R. J., 1981, Additions to the mammalian fauna of the type Duchesnean, with comments on the status of the Duchesnean "age": Journal of Paleontology, 55(3):563-570.

Gazin, C. L., 1955 A review of the Upper Eocene Artiodactyla of North America: Smithsonian Miscellaneous Collections, 281(8):96 pp.

Hamblin, A. H., W. A. S. Sarjeant and D. A. E. Spalding, 1999, Vertebrate footprints in the Duchesne River and Uinta formations (middle to late Eocene), Uinta Basin, Utah; Vertebrate paleontology in Utah: Miscellaneous Publication - Utah Geological Survey, 99-1:443-454. 


\section{A.3 UINTA BASIN, UTAH}

\section{A.3.6 Duchesne River Formation (Cont.)}

Kay, J. L., 1934, The Tertiary formations of the Uinta Basin, Utah: Annals of the Carnegie Museum, 23:357-371.

Lander, E. B., 1980, Recorrelation and recalibration of the Duchesnean and Arikareean North American land-mammal ages with the European time scale: The Geological Society of America, 93rd annual meeting, Atlanta, GA, United States, Nov. 17-20, 1980, 12(7):468.

Lucas, S. G., 1992, Redefinition of the Duchesnean Land Mammal "Age," late Eocene of western North America, In: Eocene-Oligocene Climatic and Biotic Evolution (D. R. Prothero and W. A. Berggren,eds.), Princeton University Press, Princeton, New Jersey. 46-73.

Lucas, S. G. and R. M. Schoch, 1989, Taxonomy of Duchesneodus (Brontotheriidae) from the late Eocene of North America, In: The evolution of perissodactyls: Fourth International Theriological Congress; Workshop on the evolution of perissodactyls, Edmonton, AB, Canada, August 16, 1985, 15:490-503.

Picard, M. D., 1963, Duration of Eocene Lake Uinta, Uinta Basin, Utah: Geological Society of America Bulletin, 74:89-90.

Prothero, D. R. and C. C. Swisher, III, 1992, Magnetostratigraphy and geochronology of the terrestrial Eocene-Oligocene transition in North America, In: Eocene-Oligocene Climatic and Biotic Evolution (D. R. Prothero and W. A. Berggren,eds.), Princeton University Press, Princeton, New Jersey. 46-73.

Rasmussen, D. T., A. H. Hamblin and A. R. Tabrum, 1999, The mammals of the Eocene Duchesne River Formation; Vertebrate paleontology in Utah: Miscellaneous Publication - Utah Geological Survey, 99-1:421-427.

Robinson, P., G. F. Gunnell, S. L. Walsh, W. C. Clyde, J. E. Storer, R. K. Stucky, D. J. Froehlich, I. Ferrusquia-Villafranca, M. C. McKenna and M. O. Woodburne, 2004, Wasatchian through Duchesnean biochronology, In: Late Cretaceous and Cenozoic mammals of North America; biostratigraphy and geochronology (Anonymous, eds.), United States (USA), Columbia University Press, New York, NY, United States (USA).

Scott, W. B., 1945, The Mammalia of the Duchesne River Oligocene: Transactions of the American Philosophical Society, 34:209-253.

Simpson, G. G., 1946, The Duchesnean fauna and the Eocene-Oligocene boundary: American Journal of Science, 244:52-57.

Storer, J. E., 1990, Primates of the Lac Pelletier Lower Fauna (Eocene: Duchesnean), Saskatchewan: Canadian Journal of Earth Sciences, 27:520-524. 


\section{A.3 UINTA BASIN, UTAH}

\section{A.3.6 Duchesne River Formation (Cont.)}

Townsend, K. E., A. R. Friscia and D. Rasmussen, 2000, Local biostratigraphy of Uinta B and Uinta $\mathrm{C}$ rocks in the Uinta Formation, Utah: Abstracts, Sixtieth annual meeting, Society of Vertebrate Paleontology, Mexico City, Mexico, Oct. 25-28, 2000, 20(3, Suppl):74.

Wood, H. E., R. W. Chaney, J. Clark, E. H. Colbert, G. L. Jepsen, J. J. B. Reeside and C. Stock, 1941, Nomenclature and correlation of the North American continental Tertiary: Bulletin of the Geological Society of America, 52:1-48.

Woodburne, M. O. and C. C. I. Swisher, 1995, Land mammal high-resolution geochronology, intercontinental overland dispersals, sea level, climate, and vicariance, In: Geochronology, Time Scales, and Global Stratigraphic Correlations: Unified Temporal Framework for an Historical Geology (W. A. Berggren, D. V. Kent, M. P. Aubry and J. Hardenbol, eds.), SEPM Special Publication no. 54. 337-364. 


\section{A.3 UINTA BASIN, UTAH}

\section{A.3.7 Quaternary Units}

Cook, H. J., 1930, Occurrence of mammoth and giant bison in Glacial moraines in the high mountains of Colorado: Science, 72, no. 1885:68.

Cook, H. J., 1931, More evidence of mammoths in the high mountains of Colorado: Science, 73, no. 1889:283-284.

Emslie, S. D., 1986, Late Pleistocene vertebrates from Gunnison County, Colorado: Journal of Paleontology, 60:170-176.

Geo/Resource, 1984, Green River Basin geologic resources inventory: Unpublished Technical Report prepared for the Wyoming BLM.

Gillette, D. D., C. J. Bell and M. C. Hayden, 1999b, Preliminary report of the Little Dell Dam fauna, Salt Lake County, Utah (Middle Pleistocene, Irvingtonian Land mammal Age):

In: Vertebrate paleontology in Utah: Miscellaneous Publication - Utah Geological Survey, 99-1:495-500.

Gillette, D. D., H. G. McDonald and M. C. Hayden, 1999a, The first record of Jefferson's Ground Sloth, Megalonyx Jeffersonii, in Utah (Pleistocene, Rancholabrean Land Mammal Age): In: Vertebrate paleontology in Utah Miscellaneous Publication - Utah Geological Survey, 99-1:509-522.

Gillette, D. D. and W. E. Miller, 1999, Catalogue of new Pleistocene mammalian sites and

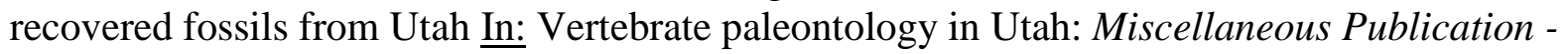
Utah Geological Survey, 99-1:523-530.

Heaton, T. H., 1999, Late Quaternary vertebrate history of the Great Basin: In: Vertebrate paleontology in Utah: Miscellaneous Publication - Utah Geological Survey, 99-1:501-508.

Hunt, C. B., 1954, Pleistocene and Recent deposits in the Denver area, Colorado: U.S. Geological Survey Bulletin 996-C: 91-140.

Larson, P. R., 1999, The Columbian mammoth (Mammuthus columbi) from Escalante Valley, Iron County, Utah--discovery and implications: In: Vertebrate paleontology in Utah: Miscellaneous Publication - Utah Geological Survey, 99-1:531-537.

Lewis, G. E., 1970, New discoveries of Pleistocene bison and peccaries in Colorado: U.S. Geological Survey Professional Paper 700-B:B137-B140.

McGrew, P. O. and T. M. Bown, 1976, Fossil vertebrate faunas: Green Mountain, Ferris-Seven Lakes, and Sandy EIS areas, and Sweetwater County, Wyoming: Unpublished technical report prepared for the Wyoming BLM. 422 pp. 


\section{A.3 UINTA BASIN, UTAH}

\section{A.3.7 Quaternary Units (Cont.)}

McGrew, P. O. and T. M. Bown, 1977, Fossil vertebrate faunas: Carbon, Lincoln, and Uinta Counties, Wyoming: Unpublished technical report prepared for the Wyoming BLM. $251 \mathrm{pp}$.

Robinson, P., D. J. Daitch and J. E. Haessig, 2000, Fossil vertebrate localities of southwestern Wyoming: a literature search, locality record, and formation evaluation: Unpublished technical report prepared for the Wyoming BLM.

Scott, G. R., 1963, Quaternary geology and geomorphic history of the Kassler Quadrangle, Colorado: U.S. Geological Survey Professional Paper 421-A:70 pp.

Smith, K. S., R. L. Cifelli and N. J. Czaplewski, 1999, An early Holocene, high-altitude vertebrate faunule from central Utah: In: Vertebrate paleontology in Utah: Miscellaneous Publication - Utah Geological Survey, 99-1:537-543. 


\section{A.4 EAST-CENTRAL AND SOUTHEAST UTAH SPECIAL TAR SAND AREAS}

\section{A.4.1 Cutler Formation}

Baars, D.L., 1962, Permian system of the Colorado Plateau: American Association of Petroleum Geologists Bulletin, v. 46, no. 2, p. 149-218.

Baird, D., 1965, Footprints from the Cutler Formation; Early Permian vertebrates from the Cutler Formation of the Placerville area, Colorado: U.S. Geological Survey Professional Paper P 0503-C, p. C47-C50.

Baker, A.A., and Reeside, J.B., 1929, Correlation of the Permian of southern Utah, northern Arizona, and northwestern New Mexico, and southwestern Colorado: American Association of Petroleum Geologists Bulletin, v. 13, p. 1413-1448.

Berman, D. S. and R. R. Reisz, 1986, Captorhinid reptiles from the Early Permian of New Mexico, with description of a new genus and species: Annals of Carnegie Museum, 55(1):1-8.

Berman, D. S., R. R. Reisz and D. A. Eberth, 1985, Ecolsonia cutlerensis, an Early Permian dissorophid amphibian from the Cutler Formation of north-central New Mexico: Circular New Mexico Bureau of Mines and Mineral Resources, 191:31.

Berman, D. S., R. R. Reisz and D. A. Eberth, 1987, A new genus and species of trematopid amphibian from the Late Pennsylvanian of north-central New Mexico: Journal of Vertebrate Paleontology, 7(3):252-269.

Berman, D. S., R. R. Reisz and D. A. Eberth, 1987, Seymouria sanjuanensis (Amphibia, Batrachosauria) from the Lower Permian Cutler Formation of north-central New Mexico and the occurrence of sexual dimorphism in that genus questioned: Canadian Journal of Earth Sciences, 24(9):1769-1784.

Bilbey, S. A. and E. Hall, 2002, Final paleontological report for the Rocky Mountain Expansion Loop Pipeline, Utah, Colorado and New Mexico: Unpublished technical report submitted to Williams Energy Co. and the Bureau of Land Management, Utah, Colorado and New Mexico:126.

Brinkman, D. B., D. S. Berman and D. A. Eberth, 1984, A new araeoscelid reptile, Zarcasaurus tanyderus, from the Cutler Formation (Lower Permian) of north-central New Mexico: New Mexico Geology, 6(2):34-39.

Cross, W. and E. Howe, 1905, Description of the Silverton Quadrangle, Colorado: U.S. Geological Survey Geology Atlas, Folio 120.

Eberth, D. A. and D. S. Berman, 1983, Sedimentology and paleontology of Lower Permian fluvial redbeds of north-central New Mexico; preliminary report: New Mexico Geology, 5(2):21-25. 


\section{A.4 EAST-CENTRAL AND SOUTHEAST UTAH SPECIAL TAR SAND AREAS}

\section{A.4.1 Cutler Formation (Cont.)}

Eberth, D. A. and D. S. Berman, 1993, Stratigraphy, sedimentology and vertebrate paleoecology of the Cutler Formation redbeds (Pennsylvanian-Permian) of north-central New Mexico, In: Vertebrate paleontology in New Mexico: 53rd annual meeting of the Society of Vertebrate Paleontology, Albuquerque, NM, United States, Oct. 13-16, 1993, 2:33-48.

Eberth, D. A. and A. D. Miall, 1991, Stratigraphy, sedimentology and evolution of a vertebratebearing, braided to anastomosed fluvial system, Cutler Formation (Permian-Pennsylvanian), north-central New Mexico: Sedimentary Geology, 72(3-4):225-252.

Fracasso, M. A., 1980, Age of the Permo-Carboniferous Cutler Formation vertebrate fauna from El Cobre Canyon, New Mexico: Journal of Paleontology, 54(6):1237-1244.

Frede, S. E., S. S. Sumida and D. S. Berman, 1993, New information on Early Permian vertebrates from the Halgaito Tongue of the Cutler Formation of southeastern Utah: Abstracts, Fifty-third annual meeting, Society of Vertebrate Paleontology, Albuquerque, NM, United States, Oct. 13-16, 1993, 13(3, Suppl):36.

Gregory, H. E., 1916, The Navajo country, a geographic and hydrographic reconnaissance of parts of Arizona, New Mexico, and Utah: U.S. Geological Survey Water Supply Paper 380:219 pp.

Gregory, H. E., 1917, Geology of the Navajo Country: U.S. Geological Survey Professional Paper, 93:161 pp.

Hannibal, J. T., S. G. Lucas, A. J. Lerner and D. S. Chaney, 2005, An eurypterid (Adelophthalmus sp.) from plant-rich lacustrine facies of Upper Pennsylvanian strata in El Cobre

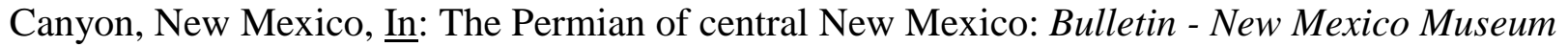
of Natural History and Science, 31:34-38.

Harris, S., S. Lucas, D. Berman, A. Henrici, S. Ting, P. Gingerich, P. Higgins, B. Small and M. Fox, 2004, Bolosauridae from the Pennsylvanian-Permian of New Mexico: Abstracts, sixty-fourth annual meeting, Society of Vertebrate Paleontology, Denver, CO, United States, Nov. 3-6, 2004, 24(3, Suppl):68.

Harris, S. K., S. G. Lucas and L. F. Rinehart, 2001, Diadectid skull from the Lower Permian (lower Wolfcampian) Red Tanks Formation of the Madera Group, central New Mexico: Geological Society of America, Rocky Mountain Section, 53rd annual meeting, Albuquerque, NM, United States, April 30-May 2, 2001, 33(5):55.

Hayden, F. V., 1875, Report on the San Juan district, Colorado: U.S. Geological Survey Annual Report, 9:245-248. 


\section{A.4 EAST-CENTRAL AND SOUTHEAST UTAH SPECIAL TAR SAND AREAS}

\section{A.4.1 Cutler Formation (Cont.)}

Hintze, L. F., 1973, Lower and Middle Ordovician stratigraphic sections in the Ibex area, Millard County, Utah: Brigham Young University Geology Studies, 20:3-36.

Hunt, A. P., S. G. Lucas and J. A. Spielmann, 2005, Early Permian vertebrate coprolites from north-central New Mexico with description of a new ichnogenus; The Permian of central New Mexico: Bulletin - New Mexico Museum of Natural History and Science, 31:39-42.

Irwin, C. D., 1976, Permian and Lower Triassic reservoir rocks of central Utah, In: Symposium on Geology of the Cordilleran Hingeline (J. G. Hill, eds.), Rocky Mountain Associate of Geologists Field Conference. 193-202.

Kamola, D. L., and Chan, M.A., 1988, Coastal dune facies, Permian Cutler Formation (White Rim Sandstone), Capitol Reef National Park area, southern Utah, In: Late Paleozoic and Mesozoic Eolian Deposits of the Western interior of the United States (G. Kocurek, ed.), Sedimentary Geology, 56. 341-356.

Kirkland, P. L., 1963, Permian stratigraphy and stratigraphic paleontology of a part of the Colorado Plateau; Shelf carbonates of the Paradox basin, a symposium--Four Corners Geol. Soc., 4th Field Conf., 1963.

Langston, W., Jr., 1966, Limnosceloides brachycoles (Reptilia: Captorhinomorpha), a new species from the lower Permian of New Mexico: Journal of Paleontology, 40(3):690-695.

Laurin, M., 1994, Re-evaluation of Cutleria wilmarthi, an Early Permian synapsid from Colorado: Journal of Vertebrate Paleontology, 14(1):134-138.

Lewis, G. E. and P. P. Vaughn, 1965, Early Permian vertebrates from the Cutler Formation of the Placerville area, Colorado: U.S. Geological Survey Professional Paper P 0503-C, p. C1-C50.

Loope, D. B., G. A. Sanderson and G. J. Verville, 1990, Abandonment of the name Elephant Canyon Formation in southeastern Utah: physical and temporal implications: Mountain Geologist, 27(4):119-130.

Lucas, S. G., 2004, Late Paleozoic tetrapod biochronology in the Western United States: Geological Society of America, Rocky Mountain Section, 56th annual meeting; Geological Society of America, Cordilleran Section, 100th annual meeting, Boise, ID, United States, May 3-5, 2004, 36(4):18.

Lucas, S. G., D. S. Berman, A. C. Henrici and A. P. Hunt, 2005a, Bolosaurus from the Lower Permian at Arroyo del Agua, New Mexico and its biostratigraphic significance, In: The Permian of central New Mexico: Bulletin - New Mexico Museum of Natural History and Science, 31:125-127. 


\section{A.4 EAST-CENTRAL AND SOUTHEAST UTAH SPECIAL TAR SAND AREAS}

\section{A.4.1 Cutler Formation (Cont.)}

Lucas, S. G., S. K. Harris, J. A. Spielmann, D. S. Berman and A. C. Henrici, 2005b, Vertebrate biostratigraphy and biochronology of the Pennsylvanian-Permian Cutler Group, El Cobre Canyon, northern New Mexico, In: The Permian of central New Mexico: Bulletin - New Mexico Museum of Natural History and Science, 31:128-139.

Lucas, S. G., L. F. Rinehart and A. P. Hunt, 2005c, Eryops (Amphibia, Temnospondyli) from the Upper Pennsylvanian of El Cobre Canyon, New Mexico, In: The Permian of central New Mexico: Bulletin - New Mexico Museum of Natural History and Science, 31:118-120.

Mamay, S. H. and W. J. Breed, 1970, Early Permian plants from the Cutler Formation in Monument Valley, Utah: U.S. Geological Survey Professional Paper P 0700-B, p. B109-B117.

Rinehart, L. F., S. G. Lucas, A. B. Heckert, K. E. Zeigler, D. S. Berman and A. C. Henrici, 2003, Nonmarine bivalves (Unionoida, Anthracosiidae) from the Lower Permian Cutler Formation of north-central New Mexico: New Mexico Geological Society spring meeting, Socorro, NM, United States, April 11, 2003, 25(2):52.

Schultz, A. W., 1984, Subaerial debris-flow deposition in the upper Paleozoic Cutler Formation, western Colorado: Journal of Sedimentary Petrology, 54(3):759-772.

Scott, K. M. and S. S. Sumida, 2004, Permo-Carboniferous vertebrate fossils from the Halgaito Shale, Cutler Group, southeastern Utah: Geological Society of America, 2004 annual meeting, Denver, CO, United States, Nov. 7-10, 2004, 36(5):230.

Steele, B. A., 1987, Depositional environments of the White Rim Sandstone Member of the Permian Cutler Formation, Canyonlands National Park, Utah: U.S. Geological Survey Bulletin, 1592.

Stewart, J. H., G. A. Williams, H. F. Albee and O. B. Raup, 1959, Stratigraphy of Triassic and associated formations in part of the Colorado Plateau Region: U.S. Geological Survey Bulletin, 1046-Q:576 pp.

Sumida, S.S., Walliser, J.B., Lombard, R.E., 1999a, Late Paleozoic Amphibian-Grade tetrapods of Utah: In: (D. Gillette, ed.) Vertebrate Paleontology in Utah, Utah Geological Survey Miscellaneous Publication 99-1, p. 21-30.

Sumida, S.S., Lombard, R.E., Berman, D.S., and Henrici, A.C., 1999b, Late Paleozoic amniotes and their near relatives from Utah and northeastern Arizona, with comments on the PermianPennsylvanian boundary in Utah and northern Arizona: In: (D. Gillette, ed.) Vertebrate Paleontology in Utah, Utah Geological Survey Miscellaneous Publication 99-1, p. 31-43. 


\section{A.4 EAST-CENTRAL AND SOUTHEAST UTAH SPECIAL TAR SAND AREAS}

\section{A.4.1 Cutler Formation (Cont.)}

Vaughn, P. P., 1962, Vertebrates from the Halgaito tongue of the Cutler Formation, Permian of San Juan County, Utah: Journal of Paleontology, 36(3):529-539.

Vaughn, P. P., 1973, Vertebrates from the Cutler group of Monument Valley and vicinity; Guidebook of Monument Valley and Vicinity, Arizona and Utah (edited by James, H. L.): Guidebook - New Mexico Geological Society, 24:99-105.

Zeigler, K. E., S. G. Lucas, A. B. Heckert, A. C. Henrici and D. S. Berman, 2003, Taphonomy of the early Permian Cardillo Quarry, a tetrapod bonebed in the Chama Basin, north-central New Mexico: Geological Society of America, Rocky Mountain Section, 55th annual meeting, Durango, CO, United States, May 7-9, 2003, 35(5):10. 


\section{A.4 EAST-CENTRAL AND SOUTHEAST UTAH SPECIAL TAR SAND AREAS}

\section{A.4.2 Kaibab Formation}

Ash, S. R., 1969, Ferns from the Chinle Formation (Upper Triassic) in the Fort Wingate area, New Mexico: U.S. Geological Survey Professional Paper P 0613-D, pp. D1-D51.

Bissell, H. J., 1962, Permian rocks of parts of Nevada, Utah, and Idaho: Geological Society of America Bulletin, 73(9):1083-1110.

Boyd, D. W. and N. D. Newell, 1978, Unusual pelecypods from the Permian of Arizona and New Mexico: The Geological Society of America, Cordilleran Section, 74th annual meeting, Tempe, Ariz., United States, March 29-31, 1978, 10(3):97.

Brady, L. F., 1955, Possible nautiloid mandibles from the Permian of Arizona: Journal of Paleontology, 29(1):102-104.

Cisne, J. L., 1971, Paleoecology of trilobites of the Kaibab limestone (Permian) in Arizona, Utah, and Nevada: Journal of Paleontology, 45(3):525-533.

Condon, S. M., 1997, Geology of the Pennsylvanian and Permian Cutler Group and Permian Kaibab Limestone in the Paradox Basin, southeastern Utah and southwestern Colorado: U.S. Geological Survey Bulletin B 2000-P, pp. P1-P46.

Darton, N. H., 1910, A reconnaissance of parts of northwestern New Mexico and northern Arizona: U.S. Geological Survey Bulletin, 435:88.

DeCourten, F. L., 1978, Scolecocoprus cameronensis Brady (1947) from the Kaibab Limestone of northern Arizona; a re-interpretation: Journal of Paleontology, 52(2):491-493.

DeMar, D. G. and B. H. Breithaupt, 2006, The nonmammalian vertebrate microfossil assemblages of the Mesaverde Formation (Upper Cretaceous, Campanian) of the Wind River and Bighorn Basins, Wyoming, In: Late Cretaceous Vertebrates from the Western Interior (S. G. Lucas and R. M. Sullivan, eds.), New Mexico Museum of Natural History and Science Bulletin 35:33-54.

Erwin, D. H., 1988, The genus Glyptospira (Gastropoda; Trochacea) from the Permian of the Southwestern United States: Journal of Paleontology, 62(6):868-879.

Gillette, D. D. and M. C. Hayden, 1997, A preliminary inventory of paleontological resources within the Grand Staircase-Escalante National Monument, Utah: Circular - Utah Geological Survey, 96:34 pp.

Gregory, H. E., 1950, Geology and geography of the Zion [National] Park region, Utah and Arizona: U.S. Geological Survey Professional Paper P 0220, 200 pp. 


\section{A.4 EAST-CENTRAL AND SOUTHEAST UTAH SPECIAL TAR SAND AREAS}

\section{A.4.2 Kaibab Formation (Cont.)}

Griffin, L. R., 1967, Actinocoelia maeandrina Finks, from the Kaibab Limestone of northern Arizona: Brigham Young University Research Studies, Geology Series, 13:105-108.

Hallgarth, W. E., 1962, Upper Paleozoic rocks exposed in Straight Wash Canyon, San Rafael Swell, Utah: Bulletin of the American Association of Petroleum Geologists, 46(8):1494-1501.

Hayden, F. V., 1875, Report on the San Juan district, Colorado: U.S. Geological Survey Annual Report, 9:245-248.

Hose, R. K. and C. A. Repenning, 1959, Stratigraphy of Pennsylvanian, Permian, and Lower Triassic rocks of Confusion Range, west-central Utah: Bulletin of the American Association of Petroleum Geologists, 43(9):2167-2196.

Hunt, A. P., S. G. Lucas, V. L. Santucci and D. K. Elliott, 2005, Permian vertebrates of Arizona; Vertebrate paleontology in Arizona: Bulletin - New Mexico Museum of Natural History and Science, 29:10-15.

Huntoon, J. E., P. L. Hansley and N. D. Naeser, 1999, The search for a source rock for the giant Tar Sand Triangle accumulation, southeastern Utah: AAPG Bulletin, 83(3):467-495.

Irwin, C. D., 1976, Permian and Lower Triassic reservoir rocks of central Utah, In: Symposium on Geology of the Cordilleran Hingeline (J. G. Hill, ed.), Rocky Mountain Associate of Geologists Field Conference. 193-202.

Kirkland, P. L., 1963, Permian stratigraphy and stratigraphic paleontology of a part of the Colorado Plateau; Shelf carbonates of the Paradox basin, a symposium--Four Corners Geol. Soc., 4th Field Conf., 1963.

Lupe, R. D., 1982, Depositional cycles in the Chinle Formation; Geological Survey research 1982: U.S. Geological Survey Professional Paper P 1375, 39 pp.

McKee, E. D., 1938, The environment and history of the Toroweap and Kaibab formations of northern Arizona and southern Utah: Carnegie Institution of Washington Publication:268-268.

Miller, A. K. and W. M. Furnish, Jr., 1957, A second Permian specimen of the nautiloid Aulametacoceras [Arizona]: Journal of Paleontology, 31(4):713-714.

Noble, L. F., 1928, A section of the Kaibab Limestone in Kaibab Gulch, Utah: U.S. Geological Survey Professional Paper P 0150-C, p. 41-60. 


\section{A.4 EAST-CENTRAL AND SOUTHEAST UTAH SPECIAL TAR SAND AREAS}

\section{A.4.2 Kaibab Formation (Cont.)}

O'Sullivan, R. B., 1970, The upper part of the Upper Triassic Chinle Formation and related rocks, southeastern Utah and adjacent areas: U.S. Geological Survey Professional Paper P 0644-E, p. E1-E22.

Repenning, C. A., M. E. Cooley and J. P. Akers, 1969, Stratigraphy of the Chinle and Moenkopi formations, Navajo and Hopi Indian reservations; Arizona, New Mexico, and Utah: U.S. Geological Survey Professional Paper P 521-B, p. B1-B34.

Stewart, J. H., F. G. Poole and R. F. Wilson, 1972, Stratigraphy and origin of the Chinle Formation and related Upper Triassic strata in the Colorado Plateau region: U.S. Geological Survey Professional Paper P 0690, 336 pp.

Stewart, J. H., G. A. Williams, H. F. Albee and O. B. Raup, 1959, Stratigraphy of Triassic and associated formations in part of the Colorado Plateau region: U.S. Geological Survey Bulletin B 1046-Q, p. 487-576.

Wagner, O. E., 1932, The paleontology and stratigraphy of the Kaibab Limestone: University of Illinois, Chicago, Chicago, IL, United States (USA) Doctoral.

Wilson, E. C. and R. L. Langenheim, Jr., 1962, Rugose and tabulate corals from Permian rocks in the Ely Quadrangle, White Pine County, Nevada: Journal of Paleontology, 36(3):495-520. 


\section{A.4 EAST-CENTRAL AND SOUTHEAST UTAH SPECIAL TAR SAND AREAS}

\section{A.4.3 Moenkopi Formation}

Batten, R. L. and W. L. Stokes, 1986, Early Triassic gastropods from the Sinbad Member of the Moenkopi Formation, San Rafael Swell, Utah: American Museum Novitates, 2864:33.

Blakey, R.C., 1973, Stratigraphy, depositional environments, and economic geology of the Moenkopi Formation, southeastern Utah: Unpublished Ph.D. dissertation, University of Iowa, Iowa City, 269 pp.

Blakey, R. C., 1974, Stratigraphic depositional analysis of the Moenkopi Formation, southeastern Utah: Utah Geological and Mineralogical Survey, Bulletin, 104:1-81.

Boy, J. A., R. R. Schoch and S. G. Lucas, 2001, The Moenkopi Formation in east central New Mexico; stratigraphy and vertebrate fauna; Geology of the Llano Estacado: New Mexico Geological Society, Fifty-second annual field conference, USA, Sept. 26-29, 2001, 52:103-110.

Dean, J. S., 1981, Carbonate petrology and depositional environment of the Sinbad Limestone Member of the Moenkopi Formation in the Teasdale Dome area, Wayne and Garfield Counties, Utah: Brigham Young University, Geological Series, 28:19-51.

Fraiser, M. L. and D. J. Bottjer, 2004, The non-actualistic Early Triassic gastropod fauna; a case study of the Lower Triassic Sinbad Limestone Member: Palaios, 19(3):259-275.

Gillette, D. D. and M. C. Hayden, 1997, A preliminary inventory of paleontological resources within the Grand Staircase-Escalante National Monument, Utah: Circular - Utah Geological Survey 96, 34 pp.

Gregory, H. E., 1950, Geology and geography of the Zion [National] Park region, Utah and Arizona: U.S. Geological Survey Professional Paper P 0220, 200 pp.

Hamblin, A. H., 1998, Mesozoic vertebrate footprints in the Grand Staircase-Escalante National Monument, Utah: Society of Vertebrate Paleontology fifty-eighth annual meeting, Snowbird, UT, United States, Sept. 30-Oct. 3, 1998, 18(3, Suppl):48.

Hamblin, H. A. and J. R. Foster, 2000, Ancient animal footprints and traces in the Grand Staircase-Escalante National Monument, south-central Utah; Geology of Utah's parks and monuments: Utah Geological Association Publication, 28:557-568.

Hautmann, M. and A. Nuetzel, 2005, First record of a heterodont bivalve (Mollusca) from the Early Triassic; palaeoecological significance and implications for the "Lazarus problem": Palaeontology, 48, Part 6:1131-1138.

Hayden, F. V., 1875, Report on the San Juan district, Colorado: U.S. Geological Survey Annual Report, 9:245-248. 


\section{A.4 EAST-CENTRAL AND SOUTHEAST UTAH SPECIAL TAR SAND AREAS}

\section{A.4.3 Moenkopi Formation (Cont.)}

Heckert, A. B., S. G. Lucas and J. W. Estep, 1998, Additions of the vertebrate fossil record of the Moenkopi Formation (Middle Triassic, Anisian), northern New Mexico: New Mexico Geological Society annual spring meeting, Socorro, NM, United States, April 9, 1998, 20(2):57.

Heckert, A. B., S. G. Lucas and J. W. Estep, 2002, Lower Chinle Group (Upper Triassic, upper Carnian) tetrapods from the vicinity of Cameron, Arizona; Upper Triassic stratigraphy and paleontology: Bulletin - New Mexico Museum of Natural History and Science, 21:73-76.

Heckert, A. B., S. G. Lucas and A. P. Hunt, 2005, Triassic vertebrate fossils in Arizona; Vertebrate paleontology in Arizona: Bulletin - New Mexico Museum of Natural History and Science, 29:16-44.

Hunt, A. P. and S. G. Lucas, 1993, Tetrapod footprints from the Middle Triassic Moenkopi Formation, west-central New Mexico; The nonmarine Triassic: International symposium and field trip on The nonmarine Triassic, Albuquerque, NM, United States, Oct. 17-24, 1993, 3:G20-G23.

Hunt, A. P. and S. G. Lucas, 1993, Triassic vertebrate paleontology and biochronology of New Mexico, In: Vertebrate paleontology in New Mexico: 53rd annual meeting of the Society of Vertebrate Paleontology, Albuquerque, NM, United States, Oct. 13-16, 1993, 2:49-60.

Hunt, A. P., S. G. Lucas, K. Martini and T. Martini, 1989, Triassic stratigraphy and paleontology, Mesa del Oro, Valencia County, New Mexico; Southeastern Colorado Plateau: New Mexico Geological Society 40th annual field conference, on southeastern Colorado Plateau, Albuquerque, NM, United States, Sept. 28 - Oct. 1, 40:8-91.

Hunt, A. P., V. L. Santucci, M. G. Lockley and T. J. Olson, 1993, Dicynodont trackways from the Holbrook Member of the Moenkopi Formation (Middle Triassic; Anisian), Arizona, USA, In: The nonmarine Triassic: International symposium and field trip on The nonmarine Triassic, Albuquerque, NM, United States, Oct. 17-24, 1993, 3:213-218.

Irwin, C. D., 1976, Permian and Lower Triassic reservoir rocks of central Utah, In: Symposium on Geology of the Cordilleran Hingeline (J. G. Hill, ed.), Rocky Mountain Associate of Geologists Field Conference. 193-202.

Kaplan, P., 2001, Description of earliest encrusting organisms(?) from the Mesozoic of North America: Geological Society of America, North-Central Section, 35th annual meeting, Bloomington-Normal, IL, United States, April 23-24, 2001, 33(4):23. 


\section{A.4 EAST-CENTRAL AND SOUTHEAST UTAH SPECIAL TAR SAND AREAS}

\section{A.4.3 Moenkopi Formation (Cont.)}

Kietzke, K. K., 1989, Calcareous microfossils from the Moenkopi Formation (Triassic, Scythian or Anisian) of central New Mexico; Southeastern Colorado Plateau: New Mexico Geological Society 40th annual field conference, on southeastern Colorado Plateau, Albuquerque, NM, United States, Sept. 28 - Oct. 1, 40:181-190.

Kirby, J. and J. McAllister, 1998, A description of subaqueous traceways of the Moenkopi Formation (Triassic), Capitol Reef National Park, south central Utah, USA: 74th annual meeting of the Pennsylvania Academy of Science, Monroeville, PA, United States, April 3-5, 1998, 71(Suppl. \& Index):181.

Lammers, G. E., 1964, Reptile tracks and the paleoenvironment of the Triassic Moenkopi of Capitol Reef National Monument, Utah; Contributions to the geology of northern Arizona-Major Brady Memorial: Museum of Northern Arizona Bulletin:49-55.

Larson, A. R., 1966, Stratigraphy and paleontology of Moenkopi Formation in southern Nevada: University of California, Los Angeles, Los Angeles, CA, United States (USA) Doctoral.

Lockley, M., 1986, A guide to dinosaur tracksites of the Colorado Plateau and American Southwest: Geology Department Magazine: Special Issue, 1:56.

Lockley, M. G., A. P. Hunt, C. Meyer, E. C. Rainforth and R. J. Schultz, 1998, A survey of fossil footprint sites at Glen Canyon National Recreation Area (Western USA); a case study in documentation of trace fossil resources at a national preserve: Ichnos, 5(3):177-211.

Lockley, M. G., C. Jennings and W. R. Averett, 1987, Dinosaur tracksites of western Colorado and eastern Utah, In: Paleontology and geology of the Dinosaur Triangle (Anonymous, eds.), United States (USA), Mus. West. Colo., Grand Junction, CO, United States (USA).

Lockley, M. G., R. J. Schultz and A. P. Hunt, 1994, Mesozoic amphibian and turtle traces; paleoecological implications of "swim tracks": Geological Society of America, Rocky Mountain Section, 46th annual meeting, Durango, CO, United States, May 4-6, 1994, 26(6):26.

Lucas, S. G., J. W. Estep and A. P. Hunt, 1998, Giant erythrosuchid archosaur from the Middle Triassic Moenkopi Formation, east-central New Mexico: Geological Society of America, Rocky Mountain Section, 50th annual meeting, Flagstaff, AZ, United States, May 25-26, 1998, 30(6):13-14.

Lucas, S. G. and S. N. Hayden, 1989, Triassic stratigraphy of west-central New Mexico; Southeastern Colorado Plateau: New Mexico Geological Society 40th annual field conference, on southeastern Colorado Plateau, Albuquerque, NM, United States, Sept. 28 - Oct. 1, 40:191-211. 


\section{A.4 EAST-CENTRAL AND SOUTHEAST UTAH SPECIAL TAR SAND AREAS}

\section{A.4.3 Moenkopi Formation (Cont.)}

Lucas, S. G. and R. R. Schoch, 2002, Triassic temnospondyl biostratigraphy, biochronology and correlation of the German Buntsandstein and North American Moenkopi Formation: Lethaia, 35(2):97-106.

McKee, E. D., 1954, Relationship between fauna and lithology in the Moenkopi Formation [Arizona-Utah]: Journal of Sedimentary Petrology, 24(2):136.

McKee, E. D., 1954, Stratigraphy and history of the Moenkopi Formation of Triassic age: Memoir - Geological Society of America:133-133.

Mickelson, D. L., 2002, The diversity and stratigraphic distribution of pre-dinosaurian communities from the Triassic Moenkopi Formation, Utah: Abstracts, Sixty-second annual meeting, Society of Vertebrate Paleontology, Norman, OK, United States, Oct. 9-12, 2002, 22(3, Suppl):88.

Mickelson, D. L., 2003, The diversity and stratigraphic distribution of vertebrate track horizons, from the Triassic Moenkopi Formation, Utah, USA: Geological Society of America, Rocky Mountain Section, 55th annual meeting, Durango, CO, United States, May 7-9, 2003, 35(5):10.

Mickelson, D. L., E. P. Kvale, D. Worthington, V. L. Santucci and N. R. Henderson, 2001, Triassic pre-dinosaurian communities national park's land, Utah; the oldest megatracksite in North America; 2001, a fossil odyssey; partners for a new millennium: The sixth conference on fossil resources, Grand Junction, CO, United States, Sept. 10-14, 2001, 6, unpaginated.

Morales, M., 1983, A preliminary report on the terrestrial paleoecology of the Triassic Moenkopi Formation: Geological Society of America; Rocky Mountain Section 36th annual meeting; Cordilleran Section 79th annual meeting, Salt Lake City, UT, United States, May 2-4, 1983, 15(5):284.

Morales, M., 1987, Terrestrial fauna and flora from the Triassic Moenkopi Formation of the southwestern United States: Journal of the Arizona-Nevada Academy of Science, 22(1):1-19.

Morales, M., 1993, Tetrapod biostratigraphy of the Lower-Middle Triassic Moenkopi Formation; The nonmarine Triassic: International symposium and field trip on The nonmarine Triassic, Albuquerque, NM, United States, Oct. 17-24, 1993, 3:355-356.

Nesbitt, S., 2002, The first discovery of a rhynchosaur from the upper Moenkopi Formation (Middle Triassic) of northern Arizona: Abstracts, Sixty-second annual meeting, Society of Vertebrate Paleontology, Norman, OK, United States, Oct. 9-12, 2002, 22(3, Suppl):92. 


\section{A.4 EAST-CENTRAL AND SOUTHEAST UTAH SPECIAL TAR SAND AREAS}

\section{A.4.3 Moenkopi Formation (Cont.)}

Nesbitt, S., J. Anderson, H.-D. Sues, M. Fox, J. A. Case, J. Eberle, M. Goodwin and S. Carlson, 2003, A new specimen of Arizonasaurus from the Moenkopi Formation (lower Middle Triassic) and its importance to pseudosuchian divergence: Abstracts, Sixty-third annual meeting, Society of Vertebrate Paleontology, Science Museum of Minnesota, Saint Paul, MN, United States, Oct. 15-18, 2003, 23(3, Suppl):82.

Nesbitt, S., K. Thiessen, S. Ting, P. Gingerich, P. Higgins, B. Small and M. Fox, 2004, A bizarre new, basal diapsid reptile from the lower Moenkopi Formation (Lower Triassic) of northern Arizona: Abstracts, Sixty-fourth annual meeting, Society of Vertebrate Paleontology, Denver, CO, United States, Nov. 3-6, 2004, 24(3, Suppl):97-98.

Nesbitt, S. J., 2001, New fossil vertebrate material from the Holbrook Member, Moenkopi Formation (Middle Triassic) from northern Arizona: Abstracts, Sixty-first annual meeting, Society of Vertebrate Paleontology, Bozeman, MT, United States, Oct. 3-6, 2001, 21(3, Suppl):83.

Nesbitt, S. J. and K. D. Angielczyk, 2002, New evidence of large dicynodonts in the upper Moenkopi Formation (Middle Triassic) of northern Arizona: PaleoBios, 22(2):10-17.

Nesbitt, S. J. and R. L. Whatley, 2004, The first discovery of a rhynchosaur from the upper Moenkopi Formation (Middle Triassic) of northern Arizona: PaleoBios, 24(3):1-10.

Parrish, J. M. and M. G. Lockley, 1984, Dinosaur trackways from the Triassic of western Colorado: The Geological Society of America, Rocky Mountain Section, 37th annual meeting, Durango, CO, United States, May 11-12, 1984, 16(4):250.

Peabody, F. E., 1948, Reptile and amphibian trackways from the Lower Triassic Moenkopi Formation of Arizona and Utah: University of California Publications in Geological Sciences, 27(57):295-467.

Peabody, F. E., 1956, Ichnites from the Triassic Moenkopi Formation of Arizona and Utah: Journal of Paleontology, 30(3):731-740.

Repenning, C. A., M. E. Cooley and J. P. Akers, 1969, Stratigraphy of the Chinle and Moenkopi formations, Navajo and Hopi Indian reservations; Arizona, New Mexico, and Utah: U.S. Geological Survey Professional Paper P 521-B, p. B1-B34.

Schaeffer, B. and J. T. Gregory, 1961, Coelacanth fishes from the continental Triassic of the western United States: American Museum Novitates, 2036:1-18. 


\section{A.4 EAST-CENTRAL AND SOUTHEAST UTAH SPECIAL TAR SAND AREAS}

\section{A.4.3 Moenkopi Formation (Cont.)}

Schoch, R. R., 2000, The status and osteology of two new cyclotosaurid amphibians from the upper Moenkopi Formation of Arizona (Amphibia, Temnospondyli, Middle Triassic): Neues Jahrbuch fuer Geologie und Palaeontologie Abhandlungen, 216(3):387-411.

Stewart, J. H., F. G. Poole, R. F. Wilson and R. A. Cadigan, 1972, Stratigraphy and origin of the Triassic Moenkopi Formation and related strata in the Colorado Plateau region: U.S. Geological Survey Professional Paper P 0691, 195 pp.

Stewart, J. H., G. A. Williams, H. F. Albee and O. B. Raup, 1959, Stratigraphy of Triassic and associated formations in part of the Colorado Plateau region: U.S. Geological Survey Bulletin B 1046-Q, p. 487-576.

Sumida, S.S., Lombard, R.E., Berman, D.S., and Henrici, A.C., 1999, Late Paleozoic amniotes and their near relatives from Utah and northeastern Arizona, with comments on the PermianPennsylvanian boundary in Utah and northern Arizona: In: (D. Gillette, ed.) Vertebrate Paleontology in Utah, Utah Geological Survey Miscellaneous Publication 99-1, p. 31-43.

Thiessen, K. R., 1990, A new reptile from the Triassic Moenkopi Formation of Arizona: Northern Arizona University, Flagstaff, AZ, United States (USA) Master's.

Twitchett, R. J., J. M. Feinberg, D. D. O’Connor, W. Alvarez and L. B. McCollum, 2005, Early Triassic ophiuroids; their paleoecology, taphonomy, and distribution: Palaios, 20(3):213-223.

Welles, S. P., 1993, A review of the lonchorhynchine trematosaurs (Labyrinthodontia), and a description of a new genus and species from the lower Moenkopi Formation of Arizona: PaleoBios, 14(3):24.

Welles, S. P. and J. Cosgriff, 1965, A revision of the labyrinthodont family Capitosauridae; and a description of Parotosaurus peabodyi, n. sp. from the Wupatki member of the Moenkopi Formation of northern Arizona: University of California Publications in Geological Sciences, $54: 148$.

Welles, S. P. and R. Estes, 1969, Hadrokkosaurus bradyi from the upper Moenkopi Formation of Arizona, with a review of the brachyopid labyrinthodonts: University of California Publications in Geological Sciences, 84:56.

Zeilstra, M. D. and C. F. Lohrengel, II, 2001, Reptile tracks in the Timpoweap Member, Moenkopi Formation (Triassic), Washington County, Utah: Geological Society of America, Rocky Mountain Section, 53rd annual meeting; Geological Society of America, South-Central Section, 35th annual meeting, Albuquerque, NM, United States, April 30-May 2, 2001, 33(5):55. 


\section{A.4 EAST-CENTRAL AND SOUTHEAST UTAH SPECIAL TAR SAND AREAS}

\section{A.4.4 Chinle Formation}

Ash, S. R., 1967, The Chinle (Upper Triassic) megaflora of the Zuni Mountains, New Mexico; Guidebook of Defiance-Zuni-Mt. Taylor region, Arizona and New Mexico--New Mexico Geol. Soc., 18th Field Conf. 1967.

Ash, S. R., 1968, A new species of Williamsonia from the upper Triassic Chinle Formation of New Mexico: Journal of the Linnaean Society of London, Botany, 61(384):113-120.

Ash, S. R., 1969, Ferns from the Chinle Formation (upper Triassic) in the Fort Wingate area, New Mexico: U.S. Geological Survey Professional Paper 613-D:52 pp.

Ash, S. R., 1970, Pagiophyllum simpsonii, a new conifer from the Chinle Formation (upper Triassic) of Arizona: Journal of Paleontology, 44(5):945-952.

Ash, S. R., 1972, Plant megafossil of the Chinle Formation. Museum of Northern Arizona Bulletin, 47:23-43.

Ash, S. R., 1978a, Geology, paleontology, and paleoecology of a Late Triassic lake, western New Mexico: Brigham Young University Research Studies, Geology Series, 25, Part 2:100.

Ash, S. R., 1978b, Summary of the fossils in the Ciniza Lake Beds; Geology, paleontology, and paleoecology of a Late Triassic lake, western New Mexico: Brigham Young University Research Studies, Geology Series, 25, Part 2:21-22.

Ash, S. R., 1978c, Plant megafossils; Geology, paleontology, and paleoecology of a Late Triassic lake, western New Mexico: Brigham Young University Research Studies, Geology Series, 25, Part 2:23-43.

Ash, S. R., 1978d, Coprolites; Geology, paleontology, and paleoecology of a Late Triassic lake, western New Mexico: Brigham Young University Research Studies, Geology Series, 25, Part 2:69-73.

Ash, S. R., 1978e, Fish scales; Geology, paleontology, and paleoecology of a Late Triassic lake, western New Mexico: Brigham Young University Research Studies, Geology Series, 25, Part 2:67-68.

Ash, S. R., 1982, Occurrence of the controversial plant fossil Sanmiguelia cf. S. lewisi Brown in the Upper Triassic of Utah: Journal of Paleontology, 56(3):751-754.

Ash, S. R., 2001, New cycadophytes from the Upper Triassic Chinle Formation of the Southwestern United States: PaleoBios, 21(1):15-28. 


\section{A.4 EAST-CENTRAL AND SOUTHEAST UTAH SPECIAL TAR SAND AREAS}

\section{A.4.4 Chinle Formation (Cont.)}

Ash, S. R., 2005, A new Upper Triassic flora and associated invertebrate fossils from the basal beds of the Chinle Formation, near Cameron, Arizona: PaleoBios, 25(1):17-34.

Berman, D. S. and R. R. Reisz, 1992, Dolabrosaurus aquatilis, a small lepidosauromorph reptile from the Upper Triassic Chinle Formation of north-central New Mexico: Journal of Paleontology, 66(6):1001-1009.

Breed, W. J., 1968, The age of dinosaurs in northern Arizona: Mus. North. Arizona.

Breed, W. J., 1972, Invertebrates of the Chinle Formation; Investigations in the Triassic Chinle Formation: Museum of Northern Arizona Bulletin, 47:19-22.

Brown, C. M., 2002, Paleontology of the Chinle Formation in the Wolverine Petrified Wood area; an overview: Geological Society of America, Rocky Mountain Section, 54th annual meeting, Cedar City, UT, United States, May 7-9, 2002, 34(4):13.

Camp, C. L., 1930, A study of the phytosaurs with description of new material from western North America: California University Memoir, 10:174.

Camp, C. L. and S. P. Welles, 1956, The North American genus Placerias [Arizona], Part 1 of Triassic dicynodont reptiles: Calif. Univ. Mem, 13(4):255-304.

Clark, J. M., H.-D. Sues and D. S. Berman, 2001, A new specimen of Hesperosuchus agilis from the Upper Triassic of New Mexico and the interrelationships of basal crocodylomorph archosaurs: Journal of Vertebrate Paleontology, 20(4):683-704.

Colbert, E. H., 1952, A pseudosuchian reptile from Arizona: Bulletin of the American Museum of Natural History, 99:561-592.

Colbert, E. H., 1972, Vertebrates from the Chinle Formation; Investigations in the Triassic Chinle Formation: Museum of Northern Arizona Bulletin, 47:1-11.

Colbert, E. H., 1985, The Petrified Forest and its vertebrate fauna in Triassic Pangaea: The Petrified Forest through the ages, 75th anniversary symposium, Nov. 6-7, 1981, 54:33-43.

Daugherty, L. H., 1960, Itopsidema, a new genus of the Osmundaceae from the Triassic of Arizona: American Journal of Botany, 47(9):771-777. 


\section{A.4 EAST-CENTRAL AND SOUTHEAST UTAH SPECIAL TAR SAND AREAS}

\section{A.4.4 Chinle Formation (Cont.)}

Deblieux, D. D., J. A. Smith, J. L. McGuire, V. L. Santucci, J. L. Kirkland, M. Butler, 2003, A paleontological inventory of Zion National Park, Utah, and the use of GIS technology to create paleontological sensitivity maps for use in resource management: Abstracts, Sixty-third annual meeting, Society of Vertebrate Paleontology, Science Museum of Minnesota, Saint Paul, MN, United States, Oct. 15-18, 2003, 23(3, Suppl):45.

Dubiel, R. F., 1987, Sedimentology of the Upper Triassic Chinle Formation, southeastern Utah; paleoclimatic implications: Journal of the Arizona-Nevada Academy of Science, 22(1):35-45.

Dubiel, R. F., S. C. Good and J. M. Parrish, 1989, Sedimentology and paleontology of the Upper Triassic Chinle Formation, Bedrock, Colorado: The Mountain Geologist, 26(4):113-126.

Dubiel, R. F., S. G. Lucas and A. P. Hunt, 1989, Depositional and climatic setting of the Upper Triassic Chinle Formation, Colorado Plateau, In: Dawn of the age of dinosaurs in the American Southwest (Anonymous, eds.), United States (USA), New Mexico Museum of Natural History, Albuquerque, NM, United States (USA).

Dubiel, R. F., A. D. Miall and N. Tyler, 1991, Architectural-facies analysis of nonmarine depositional systems in the Upper Triassic Chinle Formation, southeastern Utah; The threedimensional facies architecture of terrigenous clastic sediments and its implications for hydrocarbon discovery and recovery: Concepts in Sedimentology and Paleontology, 3:103-110.

Eastman, C. R., 1917, Fossil fishes in the collection of the United States National Museum. Proceedings of the United States National Museum, p. 235-304.

Elliott, D. K., 1987, A new specimen of Chinlea sorenseni from the Chinle Formation, Dolores River, Colorado: Journal of the Arizona-Nevada Academy of Science, 22(1):47-52.

Evensen, C. G., 1958, The Shinarump Member of the Chinle Formation. New Mexico Geological Society Guidebook, 9th Field Conference:95-97.

Fastovsky, D. E., K. Padian and D. J. Chure, 1989, Dinosaurs in space and time; the geological setting; The age of dinosaurs: Short Courses in Paleontology, 2:22-33.

Foster, J. R., 2002, Vertebrate track sites in the Chinle Formation (Late Triassic) of the Circle Cliffs area, southern Utah: Geological Society of America, Rocky Mountain Section, 54th annual meeting, Cedar City, UT, United States, May 7-9, 2002, 34(4):6.

Foster, J., A. L. Titus, G. F. Winterfeld, M. C. Hayden and A. H. Hamblin, 2001, Paleontological survey of the Grand Staircase-Escalante National Monument, Garfield and Kane Counties, Utah: Utah Geological Survey Special Study, 99:98 pp. 


\section{A.4 EAST-CENTRAL AND SOUTHEAST UTAH SPECIAL TAR SAND AREAS}

\section{A.4.4 Chinle Formation (Cont.)}

Fraser, N. C., R. B. Irmis, D. K. Elliott, C. Badgley, L. J. Flynn, L. L. Jacobs and L. H. Taylor, 2005, A procolophonid (Parareptilia) from the Owl Rock Member, Chinle Formation of Utah, USA; Paleontology in honor of William R. Downs III (1950-2002): Palaeontologia Electronica, $8(1): 7$.

Gillette, D. D., 1986, The age of transition; Coelophysis and the Late Triassic Chinle fauna, In: Dinosaurs Past and Present, (Vol. I) (S. J. Czerkas and E. C. Olson, eds.), Los Angeles, CA.

Good, S. C., 2000, Taphonomic analysis of crevasse splay bivalve death assemblages, Upper Triassic Chinle Formation, Petrified Forest National Park, Arizona: Geological Society of America, Northeastern Section, 35th annual meeting, New Brunswick, NJ, United States, March 13-15, 2000, 32(1):21.

Good, S. C., P. A. Johnston and J. W. Haggart, 1998, Freshwater bivalve fauna of the Late Triassic (Carnian-Norian) Chinle, Dockum, and Dolores formations of the Southwest United States, In: Bivalves; an eon of evolution; paleobiological studies honoring Norman D. Newell (Anonymous, eds.), Canada (CAN), University of Calgary Press, Calgary, AB, Canada $(C A N)$.

Good, S. C., J. M. Parrish and R. F. Dubiel, 1987, Paleoenvironmental implications of sedimentology and paleontology of the Upper Triassic Chinle Formation, southeastern Utah; Geology of Cataract Canyon and vicinity 1987; field symposium: Tenth field conference ; Geology of Cataract Canyon and vicinity 1987, Durango, CO, United States, May 14-17, 1987, 10:117-119.

Gottesfeld, A. S., 1972, Paleoecology of the Lower Part of the Chinle Formation; Investigations in the Triassic Chinle Formation: Museum of Northern Arizona Bulletin, 47:59-73.

Gregory, H. E., 1950, Geology and geography of the Zion [National] Park region, Utah and Arizona: U.S. Geological Survey Professional Paper P 0220, 200 pp.

Hamblin, A. H., 1998, Mesozoic vertebrate footprints in the Grand Staircase-Escalante National Monument, Utah: Abstracts, Fifty-eighth annual meeting, Society of Vertebrate Paleontology, Snowbird, UT, United States, Sept. 30-Oct. 3, 1998, 18(3, Suppl):48.

Harris, J. D. and A. Downs, 2002, A drepanosaurid pectoral girdle from the Ghost Ranch (Whitaker) Coelophysis quarry (Chinle Group, Rock Point Formation, Rhaetian), New Mexico: Journal of Vertebrate Paleontology, 22(1):70-75. 


\section{A.4 EAST-CENTRAL AND SOUTHEAST UTAH SPECIAL TAR SAND AREAS}

\section{A.4.4 Chinle Formation (Cont.)}

Harris, J. D., S. G. Lucas and A. B. Heckert, 1999, Preliminary analysis of sphenodontian (Lepidosauria) diversity in the Upper Triassic Chinle Group, southwestern USA: Abstracts, Fifty-ninth annual meeting, Society of Vertebrate Paleontology, Denver, CO, United States, Oct. 20-23, 1999, 19(3, Suppl):49.

Harris, S. K., A. B. Heckert, S. G. Lucas and A. P. Hunt, 2002, The oldest North American prosauropod, from the Upper Triassic Tecovas Formation of the Chinle Group (Adamanian, latest Carnian), West Texas; Upper Triassic stratigraphy and paleontology: Bulletin New Mexico Museum of Natural History and Science, 21:249-252.

Hasiotis, S. T., 1991, Paleontology, ichnology, and paleoecology of the Upper Triassic Chinle Formation of the Canyonlands, southeastern Utah: SUNY at Buffalo, Buffalo, NY, United States (USA) Master's.

Hasiotis, S. T. and R. F. Dubiel, 1995, Termite (Insecta; Isoptera) nest ichnofossils from the Upper Triassic Chinle Formation, Petrified Forest National Park, Arizona: Ichnos, 4(2):119-130.

Hasiotis, S. T. and R. E. Hannigan, 1991, Use of periodic acid schiff (PAS) in the identification of possible lungfish burrows in the Upper Triassic Chinle Formation of southeastern Utah and western Colorado: Geological Society of America, Northeastern Section, 26th annual meeting and Southeastern Section 40th annual meeting, Baltimore, MD, United States, Mar. 14-16, 1991, 23(1):42.

Hasiotis, S. T., C. E. Mitchell, R. F. Dubiel, R. H. Blodgett and T. M. Bown, 1989, Lungfish burrows in the Upper Triassic Chinle and Dolores formations, Colorado Plateau; new evidence suggests origin by a burrowing decapod crustacean; discussion and reply: Journal of Sedimentary Petrology, 59(5):871-880.

Hayden, F. V., 1875, Report on the San Juan district, Colorado: U.S. Geological Survey Annual Report, 9:245-248.

Heckert, A. B., 2001, The microvertebrate record of the Upper Triassic lower Chinle Group (Carnian), Southwestern U.S.A. and the early evolution of dinosaurs: University of New Mexico, Albuquerque, NM, United States (USA) Doctoral.

Heckert, A. B., 2002, A revision of the Upper Triassic ornithischian dinosaur Revueltosaurus, with a description of a new species; Upper Triassic stratigraphy and paleontology: Bulletin New Mexico Museum of Natural History and Science, 21:253-268. 


\section{A.4 EAST-CENTRAL AND SOUTHEAST UTAH SPECIAL TAR SAND AREAS}

\section{A.4.4 Chinle Formation (Cont.)}

Heckert, A. B., 2002, The rise of the ruling reptiles was no accident; the microvertebrate record of the Upper Triassic Chinle Group, Southwestern U.S.A: Abstracts, Sixty-second annual meeting, Society of Vertebrate Paleontology, Norman, OK, United States, Oct. 9-12, 2002, 22(3, Suppl):63A.

Heckert, A. B., 2004, Late Triassic microvertebrates from the lower Chinle Group (OtischalkianAdamanian, Carnian), Southwestern U.S.A: Bulletin - New Mexico Museum of Natural History and Science, 27:170.

Heckert, A. B. and K. E. Zeigler, 2003, The Late Triassic Snyder Quarry; a brief history of discovery and excavation; Paleontology and geology of the Upper Triassic (Revueltian) Snyder Quarry, New Mexico: Bulletin - New Mexico Museum of Natural History and Science, 24:5-13.

Heckert, A. B., K. E. Zeigler and S. G. Lucas, 2003, Aetosaurs (Archosauria, Stagonolepididae) from the Upper Triassic (Revueltian) Snyder Quarry, New Mexico; Paleontology and geology of the Upper Triassic (Revueltian) Snyder Quarry, New Mexico: Bulletin - New Mexico Museum of Natural History and Science, 24:115-126.

Heckert, A. B., K. E. Zeigler, S. G. Lucas and L. F. Rinehart, 2003, Coelophysids (Dinosauria, Theropoda) from the Upper Triassic (Revueltian) Snyder Quarry, In: Paleontology and geology of the Upper Triassic (Revueltian) Snyder Quarry, New Mexico: Bulletin - New Mexico Museum of Natural History and Science, 24:127-132.

Heckert, A. B., K. E. Zeigler, S. G. Lucas, L. F. Rinehart and J. D. Harris, 2000, Preliminary description of coelophysoids (Dinosauria, Theropoda) from the Upper Triassic (Revueltian,

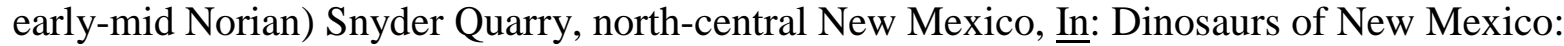
Bulletin - New Mexico Museum of Natural History and Science, 17:27-32.

Hesse, C. J., 1935, Semionotus cf. gigas, from the Triassic of Zion Park, Utah.: American Journal of Science, 29:526-531.

Hunt, A., S. G. Lucas and M. G. Lockley, 2001, Vertebrate ichnofauna of the Upper Triassic Redonda Formation (Chinle Group), east-central New Mexico: Geological Society of America, Rocky Mountain Section, 53rd annual meeting; South-Central Section, 35th annual meeting, Albuquerque, NM, United States, April 30-May 2, 2001, 33(5):56.

Hunt, A. P., 1997, A new coelacanth (Osteichthyes, Actinistia) from the continental Upper Triassic of New Mexico; New Mexico's fossil record 1: Bulletin of the New Mexico Museum of Natural History and Science, 11:25-27. 


\section{A.4 EAST-CENTRAL AND SOUTHEAST UTAH SPECIAL TAR SAND AREAS}

\section{A.4.4 Chinle Formation (Cont.)}

Hunt, A. P. and A. Downs, 2002, Taphonomy of the Late Triassic Canjilon Quarry (Petrified Forest Formation, Chinle Group), north-central New Mexico; data from new excavations, In: Upper Triassic stratigraphy and paleontology: Bulletin - New Mexico Museum of Natural History and Science, 21:291-296.

Hunt, A. P., A. B. Heckert, S. G. Lucas and A. Downs, 2002, The distribution of the enigmatic reptile Vancleavea in the Upper Triassic Chinle Group of the western United States, In: Upper Triassic stratigraphy and paleontology: Bulletin - New Mexico Museum of Natural History and Science, 21:269-273.

Hunt, A. P. and S. G. Lucas, 1992, The first occurrence of the aetosaur Paratypothorax andressi (Reptilia, Aetosauria) in the western United States and its biochronological significance: Palaeontologische Zeitschrift, 66(1-2):147-157.

Hunt, A. P. and S. G. Lucas, 1993, Stratigraphy and vertebrate paleontology of the Chinle Group (Upper Triassic), Chama Basin, north-central New Mexico; Vertebrate paleontology in New Mexico: 53rd annual meeting of the Society of Vertebrate Paleontology, Albuquerque, NM, United States, Oct. 13-16, 1993, 2:61-69.

Hunt, A. P. and S. G. Lucas, 1993, Triassic vertebrate paleontology and biochronology of New Mexico; Vertebrate paleontology in New Mexico: 53rd annual meeting of the Society of Vertebrate Paleontology, Albuquerque, NM, United States, Oct. 13-16, 1993, 2:49-60.

Hunt, A. P., S. G. Lucas and A. B. Heckert, 2002, A Revueltian (Norian) phytosaur from the Sonsela Member of the Petrified Forest Formation (Chinle Group, Upper Triassic), Petrified Forest National Park, Arizona; Upper Triassic stratigraphy and paleontology: Bulletin New Mexico Museum of Natural History and Science, 21:165-169.

Hunt, A. P., S. G. Lucas, A. B. Heckert, R. M. Sullivan and M. G. Lockley, 1998, Late Triassic dinosaurs from the Western United States: Geobios, 31(4):511-531.

Hunt, A. P., S. G. Lucas and M. G. Lockley, 1993, Fossil limuloid trackways from Petrified Forest National Park, Arizona, USA; The nonmarine Triassic: International symposium and field trip on The nonmarine Triassic, Albuquerque, NM, United States, Oct. 17-24, 1993, 3:205-207.

Hunt, A. P., S. G. Lucas and M. G. Lockley, 1998, Taxonomy and stratigraphic and facies significance of vertebrate coprolites of the Upper Triassic Chinle Group, Western United States: Ichnos (Chur, Switzerland), 5(3):225-234. 


\section{A.4 EAST-CENTRAL AND SOUTHEAST UTAH SPECIAL TAR SAND AREAS}

\section{A.4.4 Chinle Formation (Cont.)}

Hunt, A. P., S. G. Lucas and J. A. Spielmann, 2005a, The holotype specimen of Vancleavea campi from Petrified Forest National Park, Arizona, with notes on the taxonomy and distribution of the taxon, In: Vertebrate paleontology in Arizona: Bulletin - New Mexico Museum of Natural History and Science, 29:59-66.

Hunt, A. P., S. G. Lucas and J. A. Spielmann, 2005b, The postcranial skeleton of Revueltosaurus callenderi (Archosauria, Crurotarsi) from the Upper Triassic of Arizona and New Mexico, USA, In: Vertebrate paleontology in Arizona: Bulletin - New Mexico Museum of Natural History and Science, 29:67-76.

Irmis, R. B., 2005, The vertebrate fauna of the Upper Triassic Chinle Formation in northern Arizona, In: Guidebook to the Triassic Formation of the Colorado Plateau in Northern Arizona: Geology, Paleontology, and History (S. J. Nesbitt, W. G. Parker, and R. B. Irmis eds.), Mesa Southwest Museum Bulletin, 9:26 pp.

Irmis, R. B. and W. G. Parker, 2005, Unusual tetrapod teeth from the Upper Triassic Chinle Formation, Arizona, USA: Canadian Journal of Earth Sciences, 42(7):1339-1345.

Jacobs, L. L., 1985, Small vertebrate fossils from the Chinle Formation (Triassic) near St. Johns, Arizona; On research and exploration projects supported by the National Geographic Society, for which an initial grant or continuing support was provided in the year 1979: Research Reports National Geographic Society, 20:417-419.

Jacobs, L. L., P. A. Murry and L. L. Jacobs, 1980, The vertebrate community of the Triassic Chinle Formation near St. Johns, Arizona, In: Aspects of vertebrate history; essays in honor of Edwin Harris Colbert (Anonymous, eds.), United States (USA), Mus. North. Ariz. Press, Flagstaff, AZ, United States (USA).

Litwin, R. J. and A. Traverse, 1984, Palynostratigraphic significance of palynoflora and sporebearing organs of Triassic ferns of the Chinle Formation of Arizona and New Mexico: The Geological Society of America, Northeastern Section, 19th annual meeting, Providence, RI, United States, Mar. 15-17, 1984, 16(1):47.

Lockley, M., K. Conrad and M. Paquette, 1992, New discoveries of fossil footprints at Dinosaur National Monument: Park Science, 12(3):4-5.

Lockley, M., A. Hunt, K. Conrad and J. Robinson, 1992, Tracking dinosaurs and other extinct animals at Lake Powell: Park Science, 12(3):16-17.

Lockley, M. G., A. P. Hunt, C. Meyer, E. C. Rainforth and R. J. Schultz, 1998, A survey of fossil footprint sites at Glen Canyon National Recreation Area (Western USA); a case study in documentation of trace fossil resources at a national preserve: Ichnos, 5(3):177-211. 


\section{A.4 EAST-CENTRAL AND SOUTHEAST UTAH SPECIAL TAR SAND AREAS}

\section{A.4.4 Chinle Formation (Cont.)}

Lockley, M. G., C. Jennings and W. R. Averett, 1987, Dinosaur tracksites of western Colorado and eastern Utah, In: Paleontology and geology of the Dinosaur Triangle, United States (USA), Mus. West. Colo., Grand Junction, CO, United States (USA).

Lockley, M. G., S. G. Lucas and A. P. Hunt, 2000, Dinosaur tracksites in New Mexico; a review; Dinosaurs of New Mexico: Bulletin - New Mexico Museum of Natural History and Science, 17:9-16.

Lockley, M. G., R. Prunty, K. Cart and J. Foster, 2005, The Gateway localities of Mesa County, Colorado and the continuing early Mesozoic fossil footprint bonanza: Geological Society of America, Rocky Mountain Section, 57th annual meeting, Grand Junction, CO, United States, May 23-25, 2005, 37(6):37.

Long, R. A. and K. Padian, 1986, Vertebrate biostratigraphy of the Late Triassic Chinle Formation, Petrified Forest National Park, Arizona: preliminary results, In: The Beginning of the Age of Dinosaurs (K. Padian, ed.), London, Cambridge University Press. 161-169.

Lucas, S. G. and K. K. Kietzke, 1984, Distribution of Triassic vertebrates, Upper Shale Member of the Chinle Formation, Bull Canyon, east-central New Mexico: New Mexico Academy of Science, general meeting, Clovis, NM, United States, Sept. 28-29, 1984, 24(2):23-24.

Lucas, S. G. and W. Oakes, 1988, A Late Triassic cynodont from the American South-West: Palaeontology, 31, Part 2:445-449.

Lucas, S. G., 1992, A nonmarine standard for part of Late Triassic time: Park Science, 12(3):18-19.

Lucas, S. G., 1993, The Chinle Group: revised stratigraphy and chronology of Upper Triassic non-marine strata in the western United States: Museum of Northern Arizona Bulletin, 59:27-50.

Lucas, S. G., and A. P. Hunt, 1993a, Tetrapod biochronology of the Chinle Group (Upper Triassic), western United States: New Mexico Museum of Natural History \& Science Bulletin, 3:327-329.

Lucas, S. G., and A. P. Hunt, 1993b, A dicynodont from the Upper Triassic of New Mexico and its biochronological significance: New Mexico Museum of Natural History \& Science Bulletin, 3:321-325.

Lucas, S. G., F. L. Decourten and A. P. Hunt, 1993, Phytosaur from the Upper Triassic Chinle Group in the San Rafael Swell, east-central Utah, In: The nonmarine Triassic: International symposium and field trip on The nonmarine Triassic, Albuquerque, NM, United States, Oct. 17-24, 1993, 3:307-309. 


\section{A.4 EAST-CENTRAL AND SOUTHEAST UTAH SPECIAL TAR SAND AREAS}

\section{A.4.4 Chinle Formation (Cont.)}

Lucas, S. G. and A. P. Hunt, 1993, Tetrapod biochronology of the Chinle Group (Upper Triassic), Western United States, In: The nonmarine Triassic: International symposium and field trip on The nonmarine Triassic, Albuquerque, NM, United States, Oct. 17-24, 1993, 3:327-329.

Lucas, S. G. and P. Huber, 1996, Vertebrate biostratigraphy and biochronology of the nonmarine Late Triassic; The great rift valleys of Pangaea in eastern North America; Volume 2, Sedimentology, stratigraphy, and paleontology: Aspects of Triassic-Jurassic rift basin geoscience, Rock Hill, CT, United States (USA), Columbia University Press, New York, NY, United States (USA).

Lucas, S. G., A. B. Heckert and O. J. Anderson, 1997, Triassic stratigraphy and paleontology on the Fort Wingate Quadrangle, west-central New Mexico: New Mexico Geology, 19(2):33-42.

Lucas, S. G., A. B. Heckert, J. W. Estep and O. J. Anderson, 1997, Stratigraphy, biostratigraphy, and sequence stratigraphy of the Upper Triassic Chinle Group, Four Corners region; Mesozoic geology and paleontology of the Four Corners region: New Mexico Geological Society, 48th annual field conference, Cortez, NM, United States, Oct. 1-4, 1997, 48:81-107.

Lucas, S. G., A. B. Heckert, and A. P. Hunt, 1997, Stratigraphy and biochronological significance of the Late Triassic Placerias Quarry, eastern Arizona (U.S.A.): Neues Jahrbuch für Geologie und Paläontologie, Abhandlungen, 203:23-46.

Lucas, S. G., 1998, Global Triassic tetrapod biostratigraphy and biochronology: Palaeogeography, Palaeoclimatology, Palaeoecology, 143:347-384.

Lucas, S. G. and A. B. Heckert, 2002, Skull of the dicynodont Placerias from the Upper Triassic of Arizona; Upper Triassic stratigraphy and paleontology: Bulletin - New Mexico Museum of Natural History and Science, 21:127-130.

Lucas, S. G., and A.B. Heckert, 2002, Skull of the dicynodont Placerias from the Upper Triassic of Arizona: New Mexico Museum of Natural History \& Science Bulletin, 21:127-130.

Lucas, S. G., A. B. Heckert, and A. P. Hunt, 2002, A new species of the aetosaur Typothorax (Archosauria: Stagonolepididae) from the Upper Triassic of east-central New Mexico: New Mexico Museum of Natural History \& Science Bulletin, 21:221-233.

Lucas, S. G., A. B. Heckert, K. E. Zeigler, and A. P. Hunt, 2002, The type locality of Belodon buceros Cope, 1881, a phytosaur (Archosauria: Parasuchidae) from the Upper Triassic of northcentral New Mexico: New Mexico Museum of Natural History \& Science Bulletin, 21:189-192. 


\section{A.4 EAST-CENTRAL AND SOUTHEAST UTAH SPECIAL TAR SAND AREAS}

\section{A.4.4 Chinle Formation (Cont.)}

Lucas, S. G. and A. B. Heckert, 2002, Upper Triassic dinosaur track from Fort Wingate, New Mexico; Upper Triassic stratigraphy and paleontology: Bulletin - New Mexico Museum of Natural History and Science, 21:245-247.

Lucas, S. G., A. B. Heckert and K. E. Zeigler, 2002, Provenance of the holotype of Belodon buceros Cope, 1881, a phytosaur from the Upper Triassic of north-central New Mexico: New Mexico Geological Society spring meeting, Socorro, NM, United States, April 5, 2002, 24(2):66.

Triassic Snyder Quarry, Chinle Group, Chama Basin, New Mexico; Paleontology and geology of the Upper Triassic (Revueltian) Snyder Quarry, New Mexico: Bulletin - New Mexico Museum of Natural History and Science, 24:63-66.

Lucas, S. G., K. E. Zeigler, A. B. Heckert and A. P. Hunt, 2003, Upper Triassic stratigraphy and biostratigraphy, Chama Basin, north-central New Mexico; Paleontology and geology of the Upper Triassic (Revueltian) Snyder Quarry, New Mexico: Bulletin - New Mexico Museum of Natural History and Science, 24:15-39.

Lucas, S. G., L. H. Tanner and A. B. Heckert, 2005, Tetrapod biostratigraphy and biochronology across the Triassic-Jurassic boundary in northeastern Arizona; Vertebrate paleontology in Arizona: Bulletin - New Mexico Museum of Natural History and Science, 29:84-94.

Lucas, S. G., K. E. Zeigler and A. B. Heckert, 2003, Invertebrate paleontology of the Upper Lupe, R. D., 1982, Depositional cycles in the Chinle Formation; Geological Survey research 1982: U.S. Geological Survey Professional Paper P 1375, 39 pp.

Martz, J. W., 2002, A new map for the Late Triassic Canjillon Quarry (Petrified Forest Member, Chinle Formation), and the ontogeny of Typothorax coccinarum (Archosauria, Stagonolepididae): Sixty-second annual meeting, Norman, OK, United States, Oct. 9-12, 2002, 22(3, Suppl):84.

Miller, G. L. and S. R. Ash, 1988, The oldest freshwater decapod crustacean, from the Triassic of Arizona: Palaeontology, 31, Part 2:273-279.

Morales, M., 1993, A small metoposaurid partial skull from the Chinle Formation near St. Johns, Arizona; The nonmarine Triassic: International symposium and field trip on The nonmarine Triassic, Albuquerque, NM, United States, Oct. 17-24, 1993, 3:353.

Murry, P. A., 1987, New reptiles from the Upper Triassic Chinle Formation of Arizona: Journal of Paleontology, 61(4):773-786. 


\section{A.4 EAST-CENTRAL AND SOUTHEAST UTAH SPECIAL TAR SAND AREAS}

\section{A.4.4 Chinle Formation (Cont.)}

Murry, P. A. and R. E. Kirby, 2002, A new hybodont shark from the Chinle and Bull Canyon formations, Arizona, Utah and New Mexico; Upper Triassic stratigraphy and paleontology: Bulletin - New Mexico Museum of Natural History and Science, 21:87-106.

Murry, P. A., R. A. Long, S. G. Lucas and A. P. Hunt, 1989, Geology and paleontology of the Chinle Formation, Petrified Forest National Park and vicinity, Arizona and a discussion of vertebrate fossils of the southwestern Upper Triassic, In: Dawn of the age of dinosaurs in the American Southwest (Anonymous, eds.), United States (USA), New Mexico Museum of Natural History, Albuquerque, NM, United States (USA).

Murry, P. A., S. G. Lucas and A. P. Hunt, 1989, Paleoecology and vertebrate faunal relationships of the Upper Triassic Dockum and Chinle formations, Southwestern United States, In: Dawn of the age of dinosaurs in the American Southwest (Anonymous, eds.), United States (USA), New Mexico Museum of Natural History, Albuquerque, NM, United States (USA).

Novak, S. E., J. Anderson, H.-D. Sues, M. Fox, J. A. Case, J. Eberle, M. Goodwin and S. Carlson, 2003, The postcranial skeleton of the Ghost Ranch Postosuchus with special consideration of the manus: Abstracts, Sixty-third annual meeting, Society of Vertebrate Paleontology, Science Museum of Minnesota, Saint Paul, MN, United States, Oct. 15-18, 2003, 23(3, Suppl):83.

O'Sullivan, R. B., 1970, The upper part of the Upper Triassic Chinle Formation and related rocks, southeastern Utah and adjacent areas: U.S. Geological Survey Professional Paper $P$ 0644-E, p. E1-E22.

Padian, K., 1990, The ornithischian form genus Revueltosaurus from the Petrified Forest of Arizona (Late Triassic: Norian; Chinle Formation): Journal of Vertebrate Paleontology, 10(2):268-269.

Parker, W. G., 1999, A new specimen of the aetosaur Desmatosuchus sp. (Archosauromorpha) from the Upper Triassic Chinle Formation of northern Arizona: Abstracts, Fifty-ninth annual meeting, Society of Vertebrate Paleontology, Denver, CO, United States, Oct. 20-23, 1999, 19(3, Suppl):68.

Parker, W. G., 2001, A new specimen of the aetosaur Desmatosuchus haplocerus (Archosauromorpha) from the Upper Triassic Chinle Formation of northern Arizona: Abstracts, Sixty-first annual meeting, Society of Vertebrate Paleontology, Bozeman, MT, United States, Oct. 3-6, 2001, 21(3, Suppl):87.

Parker, W. G., 2002, Correlation of locality numbers for vertebrate fossil sites in Petrified Forest National Park, Arizona; Upper Triassic stratigraphy and paleontology: Bulletin - New Mexico Museum of Natural History and Science, 21:37-42. 


\section{A.4 EAST-CENTRAL AND SOUTHEAST UTAH SPECIAL TAR SAND AREAS}

\section{A.4.4 Chinle Formation (Cont.)}

Parker, W. G., 2005, Faunal review of the Upper Triassic Chinle Formation of Arizona, In: Vertebrate Paleontology of Arizona, Mesa Southwest Museum Bulletin 11 (R. D. McCord, ed.), $21 \mathrm{pp}$.

Parker, W. G. and R. B. Irmis, 2005, Advanced in Late Triassic vertebrate paleontology based on new material from Petrified Forest National Park, Arizona; Vertebrate paleontology in Arizona: Bulletin - New Mexico Museum of Natural History and Science, 29:45-58.

Parrish, J. M., 1989, Vertebrate paleoecology of the Chinle Formation (Late Triassic) of the Southwestern United States: Palaeogeography, Palaeoclimatology, Palaeoecology, 72(3-4):227-247.

Parrish, J. M., 1991, A new specimen of an early crocodylomorph (cf. Sphenosuchus sp.) from the Upper Triassic Chinle Formation of Petrified Forest National Park, Arizona: Journal of Vertebrate Paleontology, 11(2):198-212.

Parrish, J. M., 1999, Small fossil vertebrates from the Chinle Formation (Upper Triassic) of southern Utah; Vertebrate paleontology in Utah: Miscellaneous Publication - Utah Geological Survey, 99-1:45-50.

Polcyn, M. J., D. A. Winkler, L. L. Jacobs and K. Newman, 2002, Fossil occurrences and structural disturbance in the Triassic Chinle Formation at North Stinking Springs Mountain near St. Johns, Arizona; Upper Triassic stratigraphy and paleontology: Bulletin - New Mexico Museum of Natural History and Science, 21:43-49.

Raines, T., 1987, A Triassic freshwater coelacanth from Colorado: Fossils Quarterly, 6(3-4):33-42.

Repenning, C. A., M. E. Cooley and J. P. Akers, 1969, Stratigraphy of the Chinle and Moenkopi formations, Navajo and Hopi Indian reservations; Arizona, New Mexico, and Utah:

U.S. Geological Survey Professional Paper P 521-B, B1-B34, 34 pp.

Rinehart, L. F., A. B. Heckert and S. G. Lucas, 1999, A probable decapod crustacean from the Upper Triassic Petrified Forest Formation of the Chinle Group, north-central New Mexico: New Mexico Geological Society annual spring meeting, Socorro, NM, United States, April 9, 1999, 21(2):43.

Rinehart, L. F., A. B. Heckert and S. G. Lucas, 1999, An Upper Triassic decapod crustacean from the Chinle Group, north-central New Mexico: Geological Society of America, 1999 annual meeting, Denver, CO, United States, Oct. 25-28, 1999, 31(7):464. 


\section{A.4 EAST-CENTRAL AND SOUTHEAST UTAH SPECIAL TAR SAND AREAS}

\section{A.4.4 Chinle Formation (Cont.)}

Rinehart, L. F., S. G. Lucas and A. B. Heckert, 2003, An early eubrachyuran (Malacostraca, Decapoda) from the Upper Triassic Snyder Quarry, Petrified Forest Formation, north-central New Mexico, In: Paleontology and geology of the Upper Triassic (Revueltian) Snyder Quarry, New Mexico: Bulletin - New Mexico Museum of Natural History and Science, 24:67-70.

Rinehart, L. F., S. G. Lucas, A. B. Heckert and A. P. Hunt, 2004, Ostracodes and conchostracans from the Upper Triassic Whitaker Quarry, Rock Point Formation, Chinle Group, north-central New Mexico: Geological Society of America, Rocky Mountain Section, 56th annual meeting; Geological Society of America, Cordilleran Section, 100th annual meeting, Boise, ID, United States, May 3-5, 2004, 36(4):6.

Rowe, T., 1979, Placerias; an unusual reptile from the Chinle Formation: Plateau, 51(4):30-32.

Schaeffer, B. and D. H. Dunkle, 1950, A semionotid fish from the Chinle Formation [Utah], with consideration of its relationships: American Museum Novitates, 1457:29.

Schaeffer, B. and N. G. McDonald, 1978, Redfieldiid fishes from the Triassic-Liassic Newark Supergroup of eastern North America: Bulletin of the American Museum of Natural History, 159, no.4, p. 129-174.

Schwartz, H. L. and D. D. Gillette, 1994, Geology and taphonomy of the Coelophysis quarry, Upper Triassic Chinle Formation, Ghost Ranch, New Mexico: Journal of Paleontology, 68(5):1118-1130.

Scott, R. A., 1960, Pollen of Ephedra from the Chinle Formation (Upper Triassic) [Arizona] and the genus Equisetosporites: Micropaleontology, 6(3):271-276.

Small, B. J., 1998, The occurrence of Aetosaurus in the Chinle Formation (Late Triassic, USA) and its biostratigraphic significance: Neues Jahrbuch fuer Geologie und Palaeontologie Monatshefte, 1998(5):285-296.

Small, B. J., 2001, Geology and paleontology of the Main Elk Creek locality (Late Triassic, Norian), Colorado: Abstracts, Sixty-first annual meeting, Society of Vertebrate Paleontology, Bozeman, MT, United States, Oct. 3-6, 2001, 21(3, Suppl):102.

Spielmann, J. A., A. B. Heckert, S. G. Lucas, L. F. Rinehart and A. P. Hunt, 2004, The Late Triassic archosauromorph Trilophosaurus as an arboreal climber: Geological Society of America, 2004 annual meeting, Denver, CO, United States, Nov. 7-10, 2004, 36(5):61.

Stewart, J. H., F. G. Poole and R. F. Wilson, 1972, Stratigraphy and origin of the Chinle Formation and related Upper Triassic strata in the Colorado Plateau region: U.S. Geological Survey Professional Paper P 0690, 336 pp. 


\section{A.4 EAST-CENTRAL AND SOUTHEAST UTAH SPECIAL TAR SAND AREAS}

\section{A.4.4 Chinle Formation (Cont.)}

Stewart, J. H., G. A. Williams, H. F. Albee and O. B. Raup, 1959, Stratigraphy of Triassic and associated formations in part of the Colorado Plateau Region: U.S. Geological Survey Bulletin, 1046-Q:576 pp.

Stocker, M., W. Parker, R. Irmis, J. Shuman, S. Ting, P. Gingerich, P. Higgins, B. Small and M. Fox, 2004, New discoveries from the Upper Triassic Chinle Formation as the result of the ongoing paleontological inventory of Petrified Forest National Park, Arizona: Abstracts, Sixty-fourth annual meeting, Society of Vertebrate Paleontology, Denver, CO, United States, Nov. 3-6, 2004, 24(3, Suppl):118.

Stone, J. F., 1978, Pollen and spores; Geology, paleontology, and paleoecology of a Late Triassic lake, western New Mexico: Brigham Young University Research Studies, Geology Series, 25, Part 2:45-59.

Sues, H.-D., 1996, A reptilian tooth with apparent venom canals from the Chinle Group (Upper Triassic) of Arizona: Journal of Vertebrate Paleontology, 16(3):571-572.

Tanner, L. H., M. G. Chapman and K. E. Zeigler, 2003, Facies analysis and sedimentologic model for deposition of bone-bearing strata in the Upper Triassic Petrified Forest Formation at the Snyder Quarry, north-central New Mexico, In: Paleontology and geology of the Upper Triassic (Revueltian) Snyder Quarry, New Mexico: Bulletin - New Mexico Museum of Natural History and Science, 24:41-48.

Tasch, P., 1978, Clam shrimps; Geology, paleontology, and paleoecology of a Late Triassic lake, western New Mexico: Brigham Young University Research Studies, Geology Series, 25, Part 2:61-65.

Welles, S. P., 1972, Fossil-Hunting for Tetrapods in the Chinle Formation; A Brief Pictorial History; Investigations in the Triassic Chinle Formation: Museum of Northern Arizona Bulletin, 47:13-18.

Willis, G. C., J. I. Kirkland, D. D. De Blieux, R. F. Biek and M. Butler, 2004, Geologic maps form the foundation for paleontological resource evaluations in Utah's national parks:

Geological Society of America, 2004 annual meeting, Denver, CO, United States, Nov. 7-10, 2004, 36(5):231.

Woody, D., W. Parker, J. Anderson, H.-D. Sues, M. Fox, J. Case, J. Eberle, M. Goodwin and S. Carlson, 2003, A new skeleton of the aetosaur Stagonolepis wellesi (Archosauria, Crurotarsi) from Petrified Forest National Park and preliminary results from a significant new bonebed from the lower Chinle Formation (Late Triassic) of Arizona: Sixty-third annual meeting, Society of Vertebrate Paleontology, Science Museum of Minnesota, Saint Paul, MN, United States, Oct. 15-18, 2003, 23(3, Suppl):112. 


\section{A.4 EAST-CENTRAL AND SOUTHEAST UTAH SPECIAL TAR SAND AREAS}

\section{A.4.4 Chinle Formation (Cont.)}

Woody, D., W. G. Parker, S. Ting, P. Gingerich, P. Higgins, B. Small and M. Fox, 2004, Evidence for a transitional fauna within the Sonsela Member of the Chinle Formation, Petrified Forest National Park, Arizona: Abstracts, Sixty-fourth annual meeting, Society of Vertebrate Paleontology, Denver, CO, United States, Nov. 3-6, 2004, 24(3, Suppl):132.

Zeigler, K., A. B. Heckert and S. G. Lucas, 2002, A taphonomic analysis of a fire-related Late Triassic vertebrate fossil assemblage: Abstracts, Sixty-second annual meeting; Society of Vertebrate Paleontology, Norman, OK, United States, Oct. 9-12, 2002, 22(3, Suppl):121-122.

Zeigler, K. E., 2003, Taphonomic analysis of the Snyder Quarry; a fire-related Upper Triassic vertebrate fossil assemblage from north-central New Mexico; Paleontology and geology of the Upper Triassic (Revueltian) Snyder Quarry, New Mexico: Bulletin - New Mexico Museum of Natural History and Science, 24:49-62.

Zeigler, K. E., A. B. Heckert and S. G. Lucas, 2001, A taphonomic comparison of two Late Triassic (Chinle Group) fossil localities from New Mexico: New Mexico Geological Society spring meeting, Socorro, NM, United States, March 23, 2001, 23(2):56.

Zeigler, K. E., A. B. Heckert and S. G. Lucas, 2002a, A new species of Desmatosuchus (Archosauria, Aetosauria) from the Upper Triassic of the Chama Basin, north-central New Mexico, In: Upper Triassic stratigraphy and paleontology: Bulletin - New Mexico Museum of Natural History and Science, 21:215-219.

Zeigler, K. E., A. B. Heckert and S. G. Lucas, 2002b, A tale of two sites; a taphonomic comparison of two Late Triassic (Chinle Group) vertebrate fossil localities from New Mexico, In: Upper Triassic stratigraphy and paleontology: Bulletin - New Mexico Museum of Natural History and Science, 21:285-290.

Zeigler, K. E., A. B. Heckert and S. G. Lucas, 2003b, An illustrated atlas of the phytosaur (Archosauria, Parasuchidae) postcrania from the Upper Triassic Snyder Quarry (Petrified Forest Formation, Chinle Group), In: Paleontology and geology of the Upper Triassic (Revueltian) Snyder Quarry, New Mexico: Bulletin - New Mexico Museum of Natural History and Science, 24:89-103.

Zeigler, K. E., A. B. Heckert and S. G. Lucas, 2003c, Phytosaur (Archosauria, Parasuchidae) cranial and mandibular material from the Upper Triassic Snyder Quarry (Petrified Forest Formation, Chinle Group), In: Paleontology and geology of the Upper Triassic (Revueltian) Snyder Quarry, New Mexico: Bulletin - New Mexico Museum of Natural History and Science, 24:81-88. 


\section{A.4 EAST-CENTRAL AND SOUTHEAST UTAH SPECIAL TAR SAND AREAS}

\section{A.4.4 Chinle Formation (Cont.)}

Zeigler, K. E., A. B. Heckert and S. G. Lucas, 2003d, The vertebrate fauna of the Upper Triassic (Revueltian) Snyder Quarry, In: Paleontology and geology of the Upper Triassic (Revueltian) Snyder Quarry, New Mexico: Bulletin - New Mexico Museum of Natural History and Science, 24:71-79.

Zeigler, K. E., A. B. Heckert, S. G. Lucas and A. P. Hunt, 2003a, A taphonomic survey of the bonebeds of the Upper Triassic Chinle Group, Southwestern United States; Geological Society of America, Rocky Mountain Section, 55th annual meeting: Geological Society of America, Rocky Mountain Section, 55th annual meeting, Durango, CO, United States, May 7-9, 2003, 35(5):35.

Zeigler, K. E., S. G. Lucas and A. B. Heckert, 2002c, A phytosaur skull from the Upper Triassic Snyder Quarry (Petrified Forest Formation, Chinle Group) of north-central New Mexico, In: Upper Triassic stratigraphy and paleontology: Bulletin - New Mexico Museum of Natural History and Science, 21:171-177.

Zeigler, K. E., V. L. Morgan and S. G. Lucas, 2004, The Late Triassic vertebrate fauna of the Mesa Montosa Member (Petrified Forest Formation, Chinle Group) in Coyote Amphitheater, north-central New Mexico: Geological Society of America, Rocky Mountain Section, 56th annual meeting; Geological Society of America, Cordilleran Section, 100th annual meeting, Boise, ID, United States, May 3-5, 2004, 36(4):6.

Ziegler, K. E. and S. G. Lucas, 2002d, Taphonomy of the Late Triassic Lamy Amphibian Quarry (Garita Creek Formation, Chinle Group), central New Mexico: New Mexico Geological Society spring meeting, Socorro, NM, United States, April 5, 2002, 24(2):61. 


\section{A.4 EAST-CENTRAL AND SOUTHEAST UTAH SPECIAL TAR SAND AREAS}

\section{A.4.5 Quaternary Units}

Cook, H. J., 1930, Occurrence of mammoth and giant bison in Glacial moraines in the high mountains of Colorado: Science, 72, no. 1885:68.

Cook, H. J., 1931, More evidence of mammoths in the high mountains of Colorado: Science, 73, no. 1889:283-284.

Emslie, S. D., 1986, Late Pleistocene vertebrates from Gunnison County, Colorado: Journal of Paleontology, 60:170-176.

Geo/Resource, 1984, Green River Basin geologic resources inventory: Unpublished Technical Report prepared for the Wyoming BLM.

Gillette, D. D., C. J. Bell and M. C. Hayden, 1999b, Preliminary report of the Little Dell Dam fauna, Salt Lake County, Utah (Middle Pleistocene, Irvingtonian Land mammal Age):

In: Vertebrate paleontology in Utah: Miscellaneous Publication - Utah Geological Survey, 99-1:495-500.

Gillette, D. D., H. G. McDonald and M. C. Hayden, 1999a, The first record of Jefferson's Ground Sloth, Megalonyx Jeffersonii, in Utah (Pleistocene, Rancholabrean Land Mammal Age): In: Vertebrate paleontology in Utah Miscellaneous Publication - Utah Geological Survey, 99-1:509-522.

Gillette, D. D. and W. E. Miller, 1999, Catalogue of new Pleistocene mammalian sites and

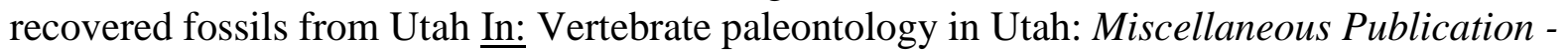
Utah Geological Survey, 99-1:523-530.

Heaton, T. H., 1999, Late Quaternary vertebrate history of the Great Basin: In: Vertebrate paleontology in Utah: Miscellaneous Publication - Utah Geological Survey, 99-1:501-508.

Hunt, C. B., 1954, Pleistocene and Recent deposits in the Denver area, Colorado: U.S. Geological Survey Bulletin 996-C: 91-140.

Larson, P. R., 1999, The Columbian mammoth (Mammuthus columbi) from Escalante Valley, Iron County, Utah--discovery and implications: In: Vertebrate paleontology in Utah: Miscellaneous Publication - Utah Geological Survey, 99-1:531-537.

Lewis, G. E., 1970, New discoveries of Pleistocene bison and peccaries in Colorado: U.S. Geological Survey Professional Paper 700-B:B137-B140.

McGrew, P. O. and T. M. Bown, 1976, Fossil vertebrate faunas: Green Mountain, Ferris-Seven Lakes, and Sandy EIS areas, and Sweetwater County, Wyoming: Unpublished technical report prepared for the Wyoming BLM. 422 pp. 


\section{A.4 EAST-CENTRAL AND SOUTHEAST UTAH SPECIAL TAR SAND AREAS}

\section{A.4.5 Quaternary Units (Cont.)}

McGrew, P. O. and T. M. Bown, 1977, Fossil vertebrate faunas: Carbon, Lincoln, and Uinta Counties, Wyoming: Unpublished technical report prepared for the Wyoming BLM. $251 \mathrm{pp}$.

Robinson, P., D. J. Daitch and J. E. Haessig, 2000, Fossil vertebrate localities of southwestern Wyoming: a literature search, locality record, and formation evaluation: Unpublished technical report prepared for the Wyoming BLM.

Scott, G. R., 1963, Quaternary geology and geomorphic history of the Kassler Quadrangle, Colorado: U.S. Geological Survey Professional Paper 421-A:70 pp.

Smith, K. S., R. L. Cifelli and N. J. Czaplewski, 1999, An early Holocene, high-altitude

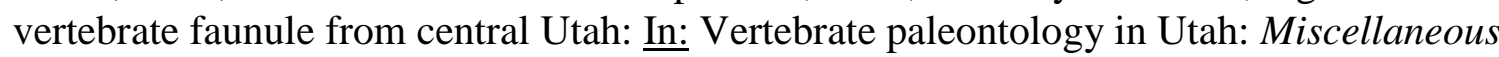
Publication - Utah Geological Survey, 99-1:537-543. 


\section{A.4 EAST-CENTRAL AND SOUTHEAST UTAH SPECIAL TAR SAND AREAS}

\section{A.4.6 Miscellaneous References}

Cope, E. D., 1877, On a Dinosaurian from the Trias of Utah: Proceedings of the American Philosophical Society, 16:579-587.

Foos, A.F., 1999, Geology of the Colorado Plateau, internet publication copyrighted by author, 6 pp: www2.nature.nps.gov/geology/education/foos/plateau.pdf.

Holmes, W. H., 1877, Report of William H. Holmes, Geologist of the San Juan Division: U.S. Geological and Geographical Survey of the Territories (Hayden), 9th Annual Report:237-276.

Holmes, W. H., 1878 Report of the geology of the Sierra Abajo and west San Miguel Mountains: U.S. Geological and Geographical Survey of the Territories (Hayden), 10th Annual Report:187-195.

Lanham, U., 1973, The Bone Hunters: The Historic Age of Paleontology in the American West: Dover Publications, New York. 285 pp.

Macomb, J. N., 1876, Report of the exploring expedition from Santa Fe, New Mexico, to the junction of the Grand and Green Rivers of the Great Colorado of the West: Engineering Department, U.S. Army, Government Printing Office, Washington:152 pp.

Marcou, J., 1856, Resume of a geological reconnaissance extending from Napolean at the junction of the Arkansas with the Mississippi to the Pueblo de Los Angeles in California, In: Report of Explorations for a Railway Route Near the Thirty-Fifth Parallel of Latitude from the Mississippi River to the Pacific Ocean (A. D. Whipple, ed.), U.S. Pacific R.R. Explor. (U.S. 33rd Congress, 2nd Session, S. Ex. Doc. 78 and H. Ex. Doc. 91), v. 3, pt. 4:165-171.

Marcou, J., 1858, Geology of North America, with two reports on the prairies of Arkansas and Texas, and the Sierra Nevada of California: Zurich, 144 pp. (Reviewed by J.D. Dana, Am Jour. Sci. 2nd ser., v. 26, p. 323-333).

Miller, W. E. and D. A. Hall, 1990, Earliest history of vertebrate paleontology in Utah: Last half of the 19th Century: Earth Sciences History, 9(1):28-33.

Powell, J. W., 1876, Report on the geology of the eastern portion of the Uinta Mountains and a region of country adjacent thereto: U.S. Geological and Geographical Survey of the Territories (Powell):218 pp.

Rigby, J. K., 1977, Southern Colorado Plateau: K/H Geology Field Guide Series: Kendall Hunt Publishing Co., Dubuque, IA. 148 pp. 


\section{A.4 EAST-CENTRAL AND SOUTHEAST UTAH SPECIAL TAR SAND AREAS}

\section{A.4.6 Miscellaneous References (Cont.)}

USGS (U.S. Geological Survey), 1980a, Argyle Canyon-Willow Creek, Utah tar sand leasing minutes no. 9: Minutes of the Mineral Land Evaluation Committee, 7 pp.

USGS, 1980b, Asphalt Ridge-Whiterocks and Vicinity, Utah tar sand leasing minutes no. 3: Minutes of the Mineral Land Evaluation Committee, 28 pp.

USGS, 1980c, Circle Cliffs East and West Flanks, Utah tar sand leasing minutes no. 5: Minutes of the Mineral Land Evaluation Committee, 15 pp.

USGS, 1980d, Hill Creek, Utah tar sand leasing minutes no. 5: Minutes of the Mineral Land Evaluation Committee, $12 \mathrm{pp}$.

USGS, 1980e, Pariette, Utah tar sand leasing minutes: Minutes of the Mineral Land Evaluation Committee, 8 pp.

USGS, 1980f, P.R. Spring, Utah tar sand leasing minutes: Minutes of the Mineral Land Evaluation Committee, 17 pp.

USGS, 1980g, Raven Ridge-Rim Rock and Vicinity, Utah tar sand leasing minutes no. 8: Minutes of the Mineral Land Evaluation Committee, 12 pp.

USGS, 1980h, San Rafael Swell, Utah tar sand leasing minutes no. 7: Minutes of the Mineral Land Evaluation Committee, 27 pp.

USGS, 1980i, Sunnyside and Vicinity, Utah tar sand leasing minutes no. 4: Minutes of the Mineral Land Evaluation Committee, 16 pp.

USGS, 1980j, Tar Sand Triangle, Utah tar sand leasing minutes no. 2: Minutes of the Mineral Land Evaluation Committee, 14 pp.

USGS, 1980k, White Canyon, Utah tar sand leasing minutes no. 11: Minutes of the Mineral Land Evaluation Committee, $11 \mathrm{pp}$.

Woodruff, E. G., 1912, Geology of the San Juan oil field, Utah: U.S. Geological Survey Bulletin 471-A:76-104. 


\section{APPENDIX B:}

BIBLIOGRAPHY OF GEOLOGIC MAPS COVERING THE OIL SHALE AND TAR SANDS PEIS STUDY AREA 


\section{APPENDIX B:}

\section{BIBLIOGRAPHY OF GEOLOGIC MAPS COVERING THE OIL SHALE AND TAR SANDS PEIS STUDY AREA}

Barnum, B. E. and W. J. Hail, Jr., 1996, Geologic map of the Gillam Draw Quadrangle, Rio Blanco County, Colorado: U.S. Geological Survey Miscellaneous Field Studies Map MF-2314, 1 Sheet (Scale 1:24,000).

Bradley, W. H., 1945, Geology of the Washakie Basin, Sweetwater and Carbon counties, Wyoming, and Moffat County, Colorado: U.S. Geological Survey Oil and Gas Investigations Map OM-0032, 1 Sheet.

Bradley, W. H., 1961, Geologic map of a part of Southwestern Wyoming and adjacent states: U.S. Geological Survey Miscellaneous Investigations Series, 1 Sheet (Scale 1:250,000).

Brand, L., P. C. Murphey, J. E. Haessig, and A. A. Smith, 2007a, Bedrock Geologic Map of the Linwood Canyon 7.5' Quadrangle, Sweetwater County, Wyoming: Wyoming State Geological Survey Open File Map, 1 Sheet (Scale 1:24,000).

Brand, L., P. C. Murphey, J. E. Haessig, and A. A. Smith, 2007b, Bedrock Geologic Map of the Antelope Wash 7.5' Quadrangle, Sweetwater County, Wyoming: Wyoming State Geological Survey Open File Map, 1 Sheet (Scale 1:24,000).

Bryant, B. H., 1992, Geologic and structure maps of the Salt Lake City 1 degree X 2 degrees Quadrangle, Utah and Wyoming: U.S. Geological Survey Miscellaneous Investigations Series I-1997, 3 Sheets (Scale 1:125,000).

Cashion, W. B., 1969, Geologic map of the Black Cabin Gulch Quadrangle, Rio Blanco County, Colorado: U.S. Geological Survey Geologic Quadrangle Map GQ-0812, 1 Sheet (Scale 1:24,000).

Cashion, W. B., 1973, Geologic and structure map of the Grand Junction Quadrangle, Colorado and Utah: U.S. Geological Survey Miscellaneous Investigations Series I- 0736, 1 Sheet (Scale 1:250,000).

Cashion, W. B., 1974, Geologic map of the Southam Canyon Quadrangle, Uintah County, Utah: U.S. Geological Survey Miscellaneous Field Studies Map MF-0579, 1 Sheet (Scale 1:24,000).

Cashion, W. B., 1977, Geologic map of the Weaver Ridge Quadrangle, Uintah County, Utah, and Rio Blanco County, Colorado: U.S. Geological Survey Miscellaneous Field Studies Map MF-0824, 1 Sheet (Scale 1:24,000). 
Cashion, W.B., 1986, Geologic map of the Bonanza Quadrangle, Uintah County, Utah: U.S. Geological Survey Miscellaneous Field Studies Map MF-1865 (Scale 1:24,000).

Courtright, T. R. and W. A. Braddock, 1989, Geologic map of the Table Mountain Quadrangle and adjacent parts of the Round Butte and Buckeye quadrangles, Larimer County, Colorado, and Laramie County, Wyoming: U.S. Geological Survey Miscellaneous Investigations Series I-1805, 1 Sheet (Scale 1:24,000).

Cullins, H. L., 1968, Geologic map of the Banty Point Quadrangle, Rio Blanco County, Colorado: U.S. Geological Survey Geologic Quadrangle Map GQ-0703, 1 Sheet (Scale 1:24,000).

Cullins, H. L., 1969, Geologic map of the Mellen Hill Quadrangle, Rio Blanco and Moffat counties, Colorado: U.S. Geological Survey Geologic Quadrangle Map GQ-0835, 1 Sheet (Scale 1:24,000).

Doelling, H. H., 2002, Geologic map of the Moab and Eastern Part of San Rafael Desert 30’ X 60' Quadrangle, Grand and Emery counties, Utah, and Mesa County, Colorado: Utah Geological Survey Map 180, 3 Sheets (Scale 1:100,000).

Doelling, H. H., 2004, Geologic map of the La Sal 30’ X 60’ Quadrangle, San Juan, Wayne and Garfield counties, Utah, and Montrose and San Miguel counties, Colorado: Utah Geological Survey Map 205, 2 Sheets (Scale 1:100,000).

Donnell, J. R., 1982, Preliminary geologic map of the Sagebrush Hill Quadrangle, Rio Blanco County, Colorado: U.S. Geological Survey Miscellaneous Field Studies Map MF-1398, 1 Sheet (Scale 1:24,000).

Donnell, J. R., L. J. Schmitt, and M. C. Smith, 1992, Geologic map of the Red Pinnacle Quadrangle, Garfield County, Colorado: U.S. Geological Survey Miscellaneous Field Studies Map MF-2202, 1 Sheet (Scale 1:24,000).

Donnell, J. R., W. E. Yeend, L. J. Schmitt, and M. C. Smith, 1992, Geologic map of the DeBeque Quadrangle, Garfield and Mesa counties, Colorado: U.S. Geological Survey Miscellaneous Field Studies Map MF-2201, 1 Sheet (Scale 1:24,000).

Donnell, J. R., W. E. Yeend, and M. C. Smith, 1985a, Preliminary geologic map of the Collbran Quadrangle, Mesa County, Colorado: U.S. Geological Survey Miscellaneous Field Studies Map MF-1825, 1 Sheet (Scale 1:24,000).

Donnell, J. R., W. E. Yeend, and M. C. Smith, 1985b, Preliminary geologic map of the Molina Quadrangle, Mesa County, Colorado: U.S. Geological Survey Miscellaneous Field Studies Map MF-1784, 1 Sheet (Scale 1:24,000). 
Donnell, J. R., W. E. Yeend, and M. C. Smith, 1990, Geologic map of the South Mamm Peak Quadrangle, Garfield and Mesa counties, Colorado: U.S. Geological Survey Miscellaneous Field Studies Map MF-2113, 1 Sheet (Scale 1:24,000).

Dover, J. H. and J. W. McGonigle, 1993, Geologic map of the Evanston 30' X 60' Quadrangle, Uinta and Sweetwater counties, Wyoming: U.S. Geological Survey Miscellaneous Investigations Series I-2168, 1 Sheet (Scale 1:100,000).

Duncan, D. C., 1976, Preliminary geologic map of Jessup Gulch Quadrangle, Rio Blanco County, Colorado: U.S. Geological Survey Miscellaneous Field Studies Map MF-756, 1 Sheet (Scale 1:24,000).

Duncan, D. C., 1976, Preliminary geologic map of Square S Ranch Quadrangle, Rio Blanco County, Colorado: U.S. Geological Survey Miscellaneous Field Studies Map MF-754, 1 Sheet (Scale 1:24,000).

Duncan, D. C., 1976, Preliminary geologic map of Yankee Gulch Quadrangle, Rio Blanco County, Colorado: U.S. Geological Survey Miscellaneous Field Studies Map MF-758, 1 Sheet (Scale 1:24,000).

Ellis, M. S. and V. L. Freeman, 1984, Geologic map and cross sections of the Carbondale 30' by 60' Quadrangle, west-central Colorado: U.S. Geological Survey Coal Investigations Map C-0097-A, 1 Sheet (Scale 1:100,000).

Ellis, M. S. and V. Gabaldo, 1989, Geologic map and cross sections of parts of the Grand Junction and Delta 30' X 60' quadrangles, west-central Colorado: U.S. Geological Survey Coal Investigations Map C-0124, 1 Sheet (Scale 1:100,000).

Evanoff, E., P. C. Murphey, J. E. Haessig, A. A. Smith, and N. Matthews, 2007, Bedrock geologic map of the Reed Reservoir 7.5' Quadrangle, Sweetwater County, Wyoming: Wyoming State Geological Survey Open File Map. 1 Sheet (Scale 1:24,000).

Gualtieri, J. L., 1988, Geologic map of the Westwater 30' by 60' Quadrangle, Grand and Uintah counties, Utah and Garfield and Mesa counties, Colorado: U.S. Geological Survey Miscellaneous Investigations Series I-1765, 1 Sheet (Scale 1:100,000).

Hackman, R. J. and D. G. Wyant, 1973, Geology, structure, and uranium deposits of the Escalante Quadrangle, Utah and Arizona: U.S. Geological Survey Miscellaneous Investigations Series I-744, 1 Sheet (Scale 1:250,000).

Hail, W. J., Jr., 1978, Preliminary geologic map of the Mount Blaine Quadrangle, Garfield County, Colorado: U.S. Geological Survey Miscellaneous Field Studies Map MF-984, 1 Sheet (Scale 1:24,000). 
Hail, W. J., Jr., 1982, Preliminary geologic map of the Circle Dot Gulch Quadrangle, Garfield County, Colorado: U.S. Geological Survey Miscellaneous Field Studies Map MF-1293, 1 Sheet (Scale 1:24,000).

Hail, W. J., Jr., 1984, Geologic map of the Barcus Creek Quadrangle, Rio Blanco County, Colorado: U.S. Geological Survey Geologic Quadrangle Map GQ-1578, 1 Sheet (Scale 1:24,000).

Hail, W. J., Jr., 1988, Geologic map of the Barcus Creek SE Quadrangle, Rio Blanco County, Colorado: U.S. Geological Survey Geologic Quadrangle Map GQ-1613, 1 Sheet (Scale 1:24,000).

Hansen, W. R., P. D. Rowley, and P. E. Carrara, 1983, Geologic map of Dinosaur National Monument and vicinity, Utah and Colorado: U.S. Geological Survey Miscellaneous Investigations Series I-1407, 1 Sheet (Scale 1:50,000).

Haynes, D. D., J. D. Vogel, and D.G. Wyant, 1972, Geology, structure and uranium deposits of the Cortez Quadrangle, Colorado and Utah: U.S. Geological Survey Miscellaneous Investigations Map I-629, 2 Sheets (Scale 1:250,000).

Hintze, L.F., 2000, Digital Geologic Map of Utah: U.S. Geological Survey Map (Scale 1:500,000).

Johnson, R. C., 1977, Preliminary geologic map of the Figure Four Spring Quadrangle, Rio Blanco and Garfield counties, Colorado: U.S. Geological Survey Miscellaneous Field Studies Map MF-912, 1 Sheet (Scale 1:24,000).

Johnson, R. C., 1980, Preliminary geologic map of the Middle Dry Fork Quadrangle, Garfield County, Colorado: U.S. Geological Survey Miscellaneous Field Studies Map MF-1215, 1 Sheet (Scale 1:24,000).

Johnson, R. C., 1981, Preliminary geologic map of the Desert Gulch Quadrangle, Garfield County, Colorado: U.S. Geological Survey Miscellaneous Field Studies Map MF-1328, 1 Sheet (Scale 1:24,000).

Johnson, R. C. and M. C. Smith, 1993, Geologic map of the Philadelphia Creek Quadrangle, Rio Blanco County, Colorado: U.S. Geological Survey Miscellaneous Field Studies Map MF-2216, 1 Sheet (Scale 1:24,000).

Keighin, C. W., 1977a, Preliminary geologic map of the Burnt Timber Canyon Quadrangle, Uintah County, Utah: U.S. Geological Survey Miscellaneous Field Studies Map MF-0875, 1 Sheet (Scale 1:24,000). 
Keighin, C. W., 1977b, Preliminary geologic map of the Cooper Canyon Quadrangle, Uintah County, Utah: U.S. Geological Survey Miscellaneous Field Studies Map MF-0874, 1 Sheet (Scale 1:24,000).

Love, J.D., and Christiansen, A.C., 1985, Geologic Map of Wyoming: U.S. Geological Survey Map, 3 Sheets (Scale 1:500,000).

M'Gonigle, J. W. and J. H. Dover, 1992, Geologic map of the Kemmerer 30' X 60' Quadrangle, Lincoln, Uinta, and Sweetwater counties, Wyoming: U.S. Geological Survey Miscellaneous Investigations Series I-2079, 1 Sheet (Scale 1:100,000).

McKay, E. J., 1974, Geologic map of the Lone Mountain Quadrangle, Moffat County, Colorado: U.S. Geological Survey Geologic Quadrangle Map GQ-1144, 1 Sheet (Scale 1:62,500).

McKay, E. J. and M. J. Bergin, 1974, Geologic map of the Maybell Quadrangle, Moffat County, Colorado: U.S. Geological Survey Geologic Quadrangle Map GQ-1145, 1 Sheet (Scale 1:62,500).

Murphey, P. C., J. E. Haessig, L. Brand, and N. Matthews, 2007a, Bedrock geologic map of the Soap Holes Reservoir 7.5' Quadrangle, Sweetwater County, Wyoming: Wyoming State Geological Survey Open File Map, 1 Sheet (Scale 1:24,000).

Murphey, P. C., J. E. Haessig, L. Brand, and N. Matthews, 2007b, Bedrock geologic map of the McKinnon 7.5' Quadrangle, Sweetwater County, Wyoming: Wyoming State Geological Survey Open File Map, 1 Sheet (Scale 1:24,000).

Murphey, P. C., J. E. Haessig, and L. Brand, 2007c, Bedrock geologic map of the Horse Ranch 7.5' Quadrangle, Sweetwater County Wyoming: Wyoming State Geological Survey Open File Map,1 Sheet (Scale 1:24,000).

Murphey, P. C., E. Evanoff, J. E. Haessig, and N. Matthews, 2007d, Bedrock geologic map of the Lonetree 7.5' Quadrangle, Sweetwater County, Wyoming: Wyoming State Geological Survey Open File Map, 1 Sheet (Scale 1:24,000).

Murphey, P. C., E. Evanoff, J. E. Haessig, and N. Matthews, 2007e, Bedrock geologic map of the Burntfork 7.5' Quadrangle, Sweetwater County, Wyoming: Wyoming State Geological Survey Open File Map, 1 Sheet (Scale 1:24,000).

Murphey, P. C., L. Brand, J. E. Haessig, and A. A. Smith, 2007f, Bedrock geologic map of the Devils Playground 7.5' Quadrangle, Sweetwater County, Wyoming: Wyoming State Geological Survey Open File Map, 1 Sheet (Scale 1:24,000).

Murphey, P. C., L. Brand, and J. E. Haessig, 2007g, Bedrock geologic map of the Black Spring Reservoir 7.5' Quadrangle, Sweetwater County, Wyoming: Wyoming State Geological Survey Open File Map, 1 Sheet (Scale 1:24,000). 
Nichols, D. J. and B. Bryant, 1990, Geologic map of the Salt Lake City 30' X 60' Quadrangle, north-central Utah, and Uinta County, Wyoming: U.S. Geological Survey Miscellaneous Investigations Series I-1944, 2 Sheet (Scale 1:100,000).

O’Sullivan, R. B., 1974, Preliminary geologic map of the Segar Mountain Quadrangle, Rio Blanco County, Colorado: U.S. Geological Survey Miscellaneous Field Studies Map MF-0570, 1 Sheet (Scale 1:24,000).

O’Sullivan, R. B., 1986, Preliminary geologic map of the Anvil Points Quadrangle, Garfield County, Colorado: U.S. Geological Survey Miscellaneous Field Studies Map MF-1882, 1 Sheet (Scale 1:24,000).

O’Sullivan, R. B., 1987, Preliminary geologic map of the No-Name Ridge Quadrangle, Rio Blanco County, Colorado: U.S. Geological Survey Miscellaneous Field Studies Map MF-1989, 1 Sheet (Scale 1:24,000).

O’Sullivan, R. B. and W. J. Hail, Jr., 1987, Preliminary geologic map of the Forked Gulch Quadrangle, Garfield County, Colorado: U.S. Geological Survey Miscellaneous Field Studies Map MF-1953, 1 Sheet (Scale 1:24,000).

O’Sullivan, R. B. and M. C. Smith, 1985, Preliminary geologic map of the west half of the Thirteenmile Creek Quadrangle, Rio Blanco and Garfield counties, Colorado: U.S. Geological Survey Miscellaneous Field Studies Map MF-1789, 1 Sheet (Scale 1:24,000).

Oriel, S. S. and L. B. Platt, 1980, Geologic map of the Preston 1 degree by 2 degrees quadrangle, southeastern Idaho and western Wyoming: U.S. Geological Survey Miscellaneous Investigations Series I-1127, 1 Sheet (Scale 1:250,000).

Pantea, M. P., 1987, Preliminary geologic map of the Davis Canyon Quadrangle, Uintah County, Utah and Garfield and Rio Blanco counties, Colorado: U.S. Geological Survey Miscellaneous Field Studies Map MF-1933, 1 Sheet (Scale 1:24,000).

Pantea, M. P., 1993, Preliminary geologic map of the East Evacuation Creek Quadrangle, Garfield and Rio Blanco Counties, Colorado: U.S. Geological Survey Miscellaneous Investigations Series, 1 Sheet (Scale 1:24,000).

Pantea, M. P. and L. J. Schmitt, 1996, Geologic map of the Banta Ridge Quadrangle, Rio Blanco County, Colorado: U.S. Geological Survey Miscellaneous Field Studies Map MF-2308, 1 Sheet (Scale 1:24,000).

Pipiringos, G. N. and R. C. Johnson, 1976, Preliminary geologic map and correlation diagram of the White River City Quadrangle, Rio Blanco County, Colorado: U.S. Geological Survey Miscellaneous Field Studies Map MF-736, 1 Sheet (Scale 1:24,000). 
Pipiringos, G. N. and G. C. Rosenlund, 1977, Preliminary geologic map of the Indian Valley Quadrangle, Rio Blanco and Moffat counties, Colorado: U.S. Geological Survey Miscellaneous Field Studies Map MF-836, 1 Sheet (Scale 1:24,000).

Pipiringos, G. N. and G. C. Rosenlund, 1977, Preliminary geologic map of the White Rock Quadrangle, Rio Blanco and Moffat counties, Colorado: U.S. Geological Survey Miscellaneous Field Studies Map MF-837, 1 Sheet (Scale 1:24,000).

Privrasky, N. C., 1963, Geology of the Big Piney area, Sublette County, Wyoming: U.S. Geological Survey Oil and Gas Investigations Map OM-0205, 2 Sheets (Scale 1:31,680).

Roehler, H. W., 1972a, Geologic map of the Red Creek Ranch Quadrangle, Wyoming, Utah, and Colorado: U.S. Geological Survey Geologic Quadrangle Map GQ-1001, 1 Sheet (Scale 1:24,000).

Roehler, H. W., 1972b, Geologic map of the Four J Rim Quadrangle, Sweetwater County, Wyoming, and Moffat County, Colorado: U.S. Geological Survey Geologic Quadrangle Map GQ-1002, 1 Sheet (Scale 1:24,000).

Roehler, H. W., 1972c, Geologic map of the Razorback Ridge Quadrangle, Rio Blanco and Garfield counties, Colorado: U.S. Geological Survey Geologic Quadrangle Map GQ-1019, 1 Sheet (Scale 1:24,000).

Roehler, H. W., 1973a, Geologic map of the Chicken Creek East Quadrangle, Sweetwater County, Wyoming: U.S. Geological Survey Geologic Quadrangle Map GQ-1128, 1 Sheet (Scale 1:24,000).

Roehler, H. W., 1973b, Geologic map of the Henderson Ridge Quadrangle, Garfield County, Colorado: U.S. Geological Survey Geologic Quadrangle Map GQ-1113, 1 Sheet (Scale 1:24,000).

Roehler, H. W., 1973c, Geologic map of the Potter Mountain Quadrangle, Sweetwater County, Wyoming: U.S. Geological Survey Geologic Quadrangle Map GQ-1082, 1 Sheet (Scale 1:24,000).

Roehler, H. W., 1973d, Geologic map of the Titsworth Gap Quadrangle, Sweetwater County, Wyoming: U.S. Geological Survey Geologic Quadrangle Map GQ-1083, 1 Sheet (Scale 1:24,000).

Roehler, H. W., 1973e, Geologic map of the Calf Canyon Quadrangle, Garfield County, Colorado: U.S. Geological Survey Geologic Quadrangle Map GQ-1086, 1 Sheet (Scale 1:24,000).

Roehler, H. W., 1974a, Geologic map of the Chicken Creek West Quadrangle, Sweetwater County, Wyoming: U.S. Geological Survey Geologic Quadrangle Map GQ-1139, 1 Sheet (Scale 1:24,000). 
Roehler, H. W., 1974b, Geologic map of the Scrivner Butte Quadrangle, Sweetwater County, Wyoming, and Moffat County, Colorado: U.S. Geological Survey Geologic Quadrangle Map GQ-1166, 1 Sheet (Scale 1:24,000).

Roehler, H. W., 1974c, Geologic map of the Pine Butte Quadrangle, Sweetwater County, Wyoming: U.S. Geological Survey Geologic Quadrangle Map, 1 Sheet (Scale 1:24,000).

Roehler, H. W., 1975, Geologic map of the Sand Butte Rim SE Quadrangle, Sweetwater County, Wyoming: U.S. Geological Survey Geologic Quadrangle Map GQ-1231, 1 Sheet (Scale 1:24,000).

Roehler, H. W., 1977, Geologic map of the Sand Butte Rim NW Quadrangle, Sweetwater County, Wyoming: U.S. Geological Survey Geologic Quadrangle Map GQ- 1372, 1 Sheet (Scale 1:24,000).

Roehler, H. W., 1978a, Geologic map of the Chicken Creek SE quadrangle, Sweetwater County, Wyoming: U.S. Geological Survey Geologic Quadrangle Map GQ-1454, 1 Sheet (Scale 1:24,000).

Roehler, H. W., 1978b, Geologic map of the Chicken Creek SW quadrangle, Sweetwater County, Wyoming, and Moffat County, Colorado: U.S. Geological Survey Geologic Quadrangle Map GQ-1443, 1 Sheet (Scale 1:24,000).

Roehler, H. W., 1985, Geologic map of the Kinney Rim 30 by 60 minute Quadrangle, Wyoming and Colorado: U.S. Geological Survey Miscellaneous Investigations Series I-1615, 1 Sheet (Scale 1:100,000).

Roehler, H. W. and J. Valcarce, 1978, Geologic map of the Antelope Flats Quadrangle, Sweetwater County, Wyoming: U.S. Geological Survey Geologic Quadrangle Map GQ-1437, 1 Sheet (Scale 1:24,000).

Rowley, P. D. and W. R. Hansen, 1979, Geologic map of the Plug Hat Rock Quadrangle, Moffat County, Colorado: U.S. Geological Survey Geologic Quadrangle Map GQ-1514, 1 Sheet (Scale 1:24,000).

Rowley, P. D., W. R. Hansen, O. Tweto, and P. E. Carrara, 1985, Geologic map of the Vernal 1 degree by 2 degrees Quadrangle, Colorado, Utah, and Wyoming: U.S. Geological Survey Miscellaneous Investigations Series I-1526, 1 Sheet (Scale 1:250,000).

Rubey, W. W., 1968a, Preliminary geologic map of the Kemmerer quadrangle, Lincoln County, Wyoming: U.S. Geological Survey Open File Map.

Rubey, W. W., 1968b, Preliminary map of the Sage quadrangle, Lincoln County, Wyoming: U.S. Geological Survey Open File Map. 
Rubey, W. W., 1973, Geologic map of the Afton Quadrangle and part of the Big Piney Quadrangle, Lincoln and Sublette counties, Wyoming: U.S. Geological Survey Miscellaneous Investigations Series I-0686, 2 Sheets (Scale 1:62,500).

Scott, R. B., P. E. Carrara, W. C. Hood, and K. E. Murray, 2002, Geologic map of the Grand Junction Quadrangle, Mesa County, Colorado: U.S. Geological Survey Miscellaneous Field Studies Map MF-2363, 1 Sheet (Scale 1:24,000).

Scott, R. W., Jr. and M. P. Pantea, 1990, Geologic map of the Texas Creek Quadrangle, Rio Blanco County, Colorado: U.S. Geological Survey Miscellaneous Field Studies Map MF-2134, 1 Sheet (Scale 1:24,000).

Snyder, G. L., 1992, Geologic map of the La Bonte Gabbro area, Albany and Converse counties, Wyoming: U.S. Geological Survey Miscellaneous Investigations Series I-2231, 1 Sheet (Scale 1:24,000).

Tweto, O., 1979, Geologic Map of Colorado: U.S. Geological Survey Map, 3 Sheets (Scale 1:500,000).

Tweto, O., R. H. Moench and J. C. Reed, Jr., 1978, Geologic map of the Leadville 1 degree by 2 degrees quadrangle, northeastern Colorado: U.S. Geological Survey Miscellaneous Investigations Series I-999, 1 Sheet (Scale 1:250,000).

Weiss, M. P., I. J. Witkind and W. B. Cashion, 1990, Geologic map of the Price 30' X 60' Quadrangle, Carbon, Duchesne, Uintah, Utah, and Wasatch counties, Utah: U.S. Geological Survey Miscellaneous Investigations Series I-1981, 1 Sheet (Scale 1:100,000).

Whitney, J. W., 1981, Surficial geologic map of the Grand Junction 1 degree by 2 degrees quadrangle, Colorado and Utah: U.S. Geological Survey Miscellaneous Investigations Series I-1289, 1 Sheet (Scale 1:00,000).

Williams, P.L., 1964, Geology, structure and uranium deposits of the Moab Quadrangle, Colorado and Utah: U.S. Geological Survey Miscellaneous Investigations Map I-360, 2 Sheets (Scale 1:250,000).

Williams, P. L., 1972, Map showing types of bedrock and surficial deposits, Salina Quadrangle, Utah: U.S. Geological Survey Miscellaneous Investigations Series I-0591-H, 1 Sheet (Scale 1:250,000).

Williams, P.L., and Hackman, R.J., 1971, Geology of the Salina Quadrangle, Utah: U.S. Geological Survey Miscellaneous Investigations Map I-591-A, 1 Sheet (Scale 1:250,000).

Witkind, I. J., 1988, Geologic map of the Huntington 30' by 60' Quadrangle, Carbon, Emery, Grand, and Uintah counties, Utah: U.S. Geological Survey Miscellaneous Investigations Series I-1764, 1 Sheet (Scale 1:100,000). 
Witkind, I. J., 1995, Geologic map of the Price 1 degree $\times 2$ degrees Quadrangle, Utah: U.S. Geological Survey Miscellaneous Investigations Series I-2462, 1 Sheet (Scale 1:250,000).

Witkind, I.J., 2004, Geologic map of the Huntington 30' and 60' Quadrangle, Carbon, Emery, Grand, and Uintah counties, Utah: Utah Geological Survey Open File Report 440DM, 5 Sheets (Scale 1:100,000).

Witkind, I. J. and M. P. Weiss, 1991, Geologic map of the Nephi 30' × 60' Quadrangle, Carbon, Emery, Juab, Sanpete, Utah, and Wasatch counties, Utah: U.S. Geological Survey Miscellaneous Investigations Series I-1937, 1 Sheet plus Pamphlet (Scale 1:100,000).

Worl, R. G., M. E. Koesterer, and T. P. Hulsebosch, 1986, Geologic map of the Bridger Wilderness and the Green-Sweetwater Roadless Area, Sublette and Fremont counties, Wyoming: U.S. Geological Survey Miscellaneous Field Studies Map MF-1636-B, 1 Sheet (Scale 1:250,000).

Yeend, W.E., Donnell, J.R., and Smith, M.C., 1988, Geologic map of the Rulison Quadrangle, Garfield County, Colorado: U.S. Geological Survey Miscellaneous Field Studies Map MF-2060, 1 Sheet (Scale 1:24,000).

Zeller, H. D. and E. V. Stephens, 1964a, Geologic map of the Continental Peak Quadrangle, Fremont and Sweetwater counties, Wyoming: U.S. Geological Survey Miscellaneous Field Studies Map MF-0292, 1 Sheet (Scale 1:24,000).

Zeller, H. D. and E. V. Stephens, 1964b, Geology of the NE 1/4 of the Essex Mountain Quadrangle, Sweetwater County, Wyoming: U.S. Geological Survey Miscellaneous Field Studies Map MF-0285, 1 Sheet (Scale 1:24,000).

Zeller, H. D. and E. V. Stephens, 1964c, Geology of the NE 1/4 of Freighter Gap Quadrangle, Sweetwater County, Wyoming: U.S. Geological Survey Miscellaneous Field Studies Map MF-0288, 1 Sheet (Scale 1:24,000).

Zeller, H. D. and E. V. Stephens, 1964d, Geology of the NW 1/4 of Freighter Gap Quadrangle, Sweetwater County, Wyoming: U.S. Geological Survey Miscellaneous Field Studies Map MF-0289, 1 Sheet (Scale 1:24,000).

Zeller, H. D. and E. V. Stephens, 1964e, Geologic map of the Pacific Springs Quadrangle, Fremont and Sweetwater counties, Wyoming: U.S. Geological Survey Miscellaneous Field Studies Map MF-0294, 1 Sheet (Scale 1:24,000).

Zeller, H. D. and E. V. Stephens, 1964f, Geologic map of the Tule Butte Quadrangle, Sweetwater County, Wyoming: U.S. Geological Survey Miscellaneous Field Studies Map MF-0297, 1 Sheet (Scale 1:24,000). 


\section{APPENDIX C:}

TAXONOMIC LISTS OF FOSSILS FROM POTENTIALLY AFFECTED GEOLOGIC UNITS WITHIN THE OIL SHALE AND TAR SANDS PEIS STUDY AREA 


\title{
APPENDIX C:
}

\section{TAXONOMIC LISTS OF FOSSILS FROM POTENTIALLY AFFECTED GEOLOGIC UNITS WITHIN THE OIL SHALE AND TAR SANDS PEIS STUDY AREA}

\author{
Geologic units are listed from approximately oldest to youngest.
}

\section{C.1 Cutler Group}

Faunal list compiled from Lewis and Vaughn (1965), Vaughn (1962), Fracasso (1980), Sumida et al. (1999a,b), and Mamay and Breed (1970). Common names are provided when possible. Taxa are mostly ordered as listed in the source publication. Partial vertebrate higher taxonomy is provided, and is taken from Carroll (1988).

Plantae (Plants)

Protoblechnum

Supaia

Taeniopteris

Brongniart

Subphylum Vertebrata

Class Chondrichthyes (sharks and rays)

Order Xenacanthida

Family Xenacanthidae

Orthacanthus spp.

Xenacanthus sp.

Class Osteichthyes (bony fishes)

Subclass Actinopterygii

Order Palaeonisciformes

Suborder Palaeoniscoidea indet. 


\section{C.1 Cutler Group (Cont.)}

Subclass Sarcopterygii

Order Crossopterygii

Family Osteolepidae

Ectosteorhachis sp.

Lohsania sp.

Order Dipnoi (lungfishes)

Family Sagenodontidae

Sagenodus sp.

Family Lepidosirenidae

Gnathorhiza sp.

Class Amphibia (modern forms include frogs, salamanders, and caecilians)

Subclass Labyrinthodontia

Order Temnospondyli

Family Eryopidae

Eryops sp.

Family Dissorophidae

Platyhystrix sp.

Aspidosaurus sp.

Family Cochleosauridae

Chenoprosopus sp.

Order Anthracosauria

Family Archeriidae

Archeria sp. 


\section{C.1 Cutler Group (Cont.)}

Family Limnoscelidae

Limnoscelis sp.

Limnoscelidae indet.

Family Seymouridae indet.

Subclass Lepospondyli

Order Nectridea

Family Keraterpetontidae

Diplocaulus sp.

Nectridea indet.

Order Aistopoda

Family Phlegethontiidae

Phlegethontia sp.

Class Incertae Sedis

Order Incertae Sedis

Family Diadectidae

Desmatodon sp.

Diadectes sp.

Class Reptilia (modern forms include lizards, snakes, crocodiles, and turtles)

Subclass Anapsida

Order Captorhinida

Family Captorhinidae

Captorhinidae indet.

Subclass Synapsida (ancestral mammal-like reptiles) 


\section{C.1 Cutler Group (Cont.)}

Order Pelycosauria

Family Ophiacodontidae

Ophiacodon sp.

Baldwinonus sp.

Family Varanopseidae

Mycterosaurus sp.

Aerosaurus sp.

Family Sphenacodontidae

Dimetrodon sp.

Sphenacodon sp.

Sphenacodontidae indet.

Family Edaphosauridae

\section{Edaphosaurus sp.}

Ichnofossils (trace fossils)

Limnopus cutlerensis (amphibian tracks)

cf. Brachydactylopus sp. (amphibian tracks)

Ophiomorpha sp. (shrimp burrows) 


\section{C.2 Kaibab Limestone}

This faunal list was compiled using Gillette and Hayden (1997), Gregory (1950), and Wagner (1932). Common names are provided when possible. Taxa are mostly ordered as listed in the source publication. Identifications are to lowest possible taxonomic level.

\section{Cnidaria (corals)}

Campophyllum sp.

Chonetes spp.

Favosites sp.

Lithostrotion sp.

Lophophyllum sp.

Bryozoa (colonial coral-like animals commonly referred to as "moss-animals")

Batostomella spp.

Fenestella sp.

Hemitrypa sp.

Lioclema sp.

Phyllopora sp.

Polypora sp.

Rhombopora sp.

Septopora sp.

Tabulipora sp.

Brachiopoda (primitive double-valved animals like clams and oysters, but not related)

Lingula sp.

Terabratula spp. 


\section{C.2 Kaibab Limestone (Cont.)}

Productus spp.

Echinauris sp.

Koslowskia sp.

Cliothyridina sp.

Composita spp.

Derbya spp.

Dielasma sp.

Marginifera spp.

Orthotetes sp.

Pugnax sp.

Pustula spp.

Schizophoria sp.

Spiriferina sp.

Spirorbis sp.

Bivalvia (clams, oysters, mussels, etc.)

Acanthopecten spp.

Astartella sp.

Aviculopecten spp.

Deltopecten spp.

Edmondia sp.

Leda sp.

Lima sp.

Myalina spp. 


\section{C.2 Kaibab Limestone (Cont.)}

Myoconcha sp.

Nucula sp.

Parallelodon spp.

Pernipecten sp.

Pleurophorus spp.

Pleurophorella sp.

Pseudomonotis sp.

Pteria spp.

Schizodus spp.

Solenomya sp.

Squamularia spp.

Scaphopoda (tusk shells)

Plagioglypta sp.

Gastropoda (snails)

Aclisina

Bellerophon

Girtyella

Goniospira

Bucanopsis

Euomphalus

Euphemus

Naticopsis

Platyceras 


\section{C.2 Kaibab Limestone (Cont.)}

Pleurotomaria

Cephalopoda: Ammonoids and Nautiloids (extinct shelled tentacled animals like the modern chambered nautilus)

Matacoceras sp.

Nautilus sp.

Orthoceras sp.

Meekoceras sp.

Trilobita (trilobites)

Delaria sp.

Griffithides sp.

Anisopyge sp.

Vidria sp.

Conodonta (no modern analogy, thought to be skeletal parts of a primitive chordate)

Anchignathodus sp.

Ellisonia sp.

Neogondolella sp.

Neostreptognathodus sp.

Xariognathus sp.

Vertebrata

Indet. fish teeth and scales

\section{Alphabetical taxonomic list from Gregory (1950) and Wagner (1932).}

Allerisma sp.

Anisopyge sp. 


\section{C.2 Kaibab Limestone (Cont.)}

Amphissites sp.

Archaeocidaris spp.

Aviculipinna sp.

Bairdia sp.

Cytherella sp.

Echinocrinus sp.

Euchondria sp.

Euphemites sp.

Fistulipora sp.

Glyptopleura sp.

Hollina sp.

Hustedia sp.

Manzanella sp.

Meekella sp.

Meekopora sp.

Murchisonia sp.

Orbiculoidea sp.

Orthonema spp.

Patellostium sp.

Phyloporella sp.

Pugnoides sp.

Rhipidomella sp.

Serpulopsis sp. 


\section{C.2 Kaibab Limestone (Cont.)}

Stenopora sp.

Waagenoconcha sp.

Worthenia sp.

Zygopleura sp. 


\section{C.3 Moenkopi Formation}

Faunal list compiled from Batten and Stokes (1986), Gregory (1950), Morales (1987), Nesbitt and Whately (2004), Nesbitt and Angielczyk (2002), and Stewart et al. (1972). Common names are provided when possible. Taxa are mostly ordered as listed in the source publication. Partial vertebrate higher taxonomy is provided and was taken from Carroll (1988).

Plantae (Plants)

Sphenophyta

Neocalamites sp. (giant horsetail)

Filicophyta (ferns)

Fern indet.

Coniferophyta (conifers)

Araucarioxylon sp.

incertae sedis (petrified wood)

Invertebrata

Arthropoda

Crustacea (shrimp-like animals)

Halicyne sp.

Ostracoda indet.

Brachiopoda (primitive double-valved animals like clams and oysters, but not related)

\section{Lingula $\mathrm{sp}$.}

Mollusca

Bivalvia (oysters, clams, etc.)

Aviculopecten spp. 


\section{C.3 Moenkopi Formation (Cont.)}

Myalina spp.

Pseudomonotis spp.

Monotis sp.

Bakewellia spp.

Pleurophorus sp.

Myophoria spp.

Sinbadiella sp.

Bivalvia indet.

Gastropoda (snails)

Worthenia spp.

Boutillieria sp.

Natiria spp.

Chartronella sp.

Naticopsis spp.

Neritaria spp.

Vernelia sp.

Zygopleura spp.

Kittliconcha sp.

Anoptychia sp.

Coelostylina spp.

Omphaloptychia spp.

Promathilda sp.

Strobeus sp. 


\title{
C.3 Moenkopi Formation (Cont.)
}

\author{
Cylindrobullina sp.
}

Scaphopoda (tusk shells)

Laevidentalium sp.

Plagioglypta sp.

Subphylum Vertebrata

Class Chondrichthyes (sharks and rays)

Order Ctenacanthiformes

Family Ctenacanthidae

Hybodus sp.

Class Osteichthyes (bony fishes)

Subclass Actinopterygii

Order Palaeonisciformes

Palaeonisciformes indet.

Family Acrolepidae

\section{Boreosomus sp.}

Subclass Sarcopterygii

Order Crossopterygii

Family Coelacanthidae

Moenkopia sp. (coelacanth)

Order Dipnoi (lungfishes)

Dipnoi indet.

Class Amphibia (modern forms include frogs, salamanders, and caecilians)

Subclass Labyrinthodontia 


\section{C.3 Moenkopi Formation (Cont.)}

Order Temnospondyli

Family Capitosauridae

Parotosuchus spp.

Eocyclotosaurus sp.

Family Brachyopidae

Hadrokkosaurus sp.

Family incertae sedis spp.

Class Reptilia (modern forms include lizards, snakes, crocodiles, and turtles)

Subclass Anapsida indet.

Subclass Procolophonia indet. (possibly related to ancestral turtles)

Subclass Diapsida

Infraclass Archosauromorpha

Order Trilophosauria

Family Trilophosauridae

Anisodontosaurus sp.

Order Thecodontia

Family Erythrosuchidae

\section{Arizonasaurus sp.}

Order Rhynchosauria

Family Rhynchosauridae indet.

Family Rauisuchidae and/or Poposauridae indet.

Unidentified small aquatic(?) reptile

Ichnofossils (trace fossils) 


\section{C.3 Moenkopi Formation (Cont.)}

Annelida (worm borings and trails)

Merostomata (horseshoe crab-like tracks)

Scorpionida (scorpion-like tracks)

Crustacea incertae sedis (Isopodichnus-like tracks)

Capitosauroides sp.

Rhyncosauroides spp.

Chirotherium spp.

Isochirotherium spp.

Synaptichnium spp.

Rotodactylus spp.

Dicynodontia (present in Holbrook Member only)

Therapsipus

\section{Alphabetical list of invertebrate fossils compiled from Gregory (1950).}

Bulimorpha sp.

Discina sp.

Entolium sp.

Inoceramus? sp.

Isocrinus $\mathrm{sp}$.

Leda? sp.

Macrocheilina sp.

Meekoceras spp.

Natica spp.

Pinna? sp. 


\section{C.3 Moenkopi Formation (Cont.)}

Pseudomelania spp.

Pugnax sp.

Pugnoides sp

Spirorbis sp.

Terebratula spp.

Trigonodus spp.

Turritella sp.

Wasatchites sp. 


\section{C.4 Chinle Formation}

Faunal list compiled from Ash (1972, 1978 a-e, 2001, 2005), Colbert (1972), Eastman (1917), Foster et al. (2001), Hesse (1935), Hunt et al. (2005a,b), Irmis (2005), Long and Padian (1986), Parker (2005), Parrish (1999), and Schaeffer and Dunkle (1950). Common names are provided when possible. Taxa are mostly ordered as listed in the source publication. Partial vertebrate higher taxonomy is provided and was taken from Carroll (1988).

Plantae (Plants)

Thallophyta

Polyporales

Polyporites sp.

Sphenophyta

Equisetales (horsetails)

Neocalamites sp.

Equisetites spp.

Pterophyta

Isoetales

Isoetites (present in SE Utah)

Lycopodeiales

Chinlea spp.

Lycopodites sp.

Lycostrobus sp.

Itopsidema $\mathrm{sp}$.

Pteridophyta

Filicales (ferns) 


\section{C.4 Chinle Formation (Cont.)}

Cameronopteris sp.

Reticulatisporites sp.

Verrucosisporites spp.

Dictyophyllidites sp.

Todites sp.

Cynepteris sp.

Wingatea $\mathrm{sp}$.

Phlebopteris spp.

Clathropteris sp.

Apachea sp.

Cladophlebis spp.

Pteridospermophyta (seed ferns)

Pteridospermales

Vitreisporites sp.

Alisporites spp.

Coniferophyta

Cordaitales

Dadoxylon sp.

Pelourdea sp.

Samaropis sp.

Coniferales

Patinasporites sp.

Pityosporites sp. 


\section{C.4 Chinle Formation (Cont.)}

Platysaccus sp.

Araucarioxylon sp.

Araucariorhiza sp.

Woodworthia sp.

Pagiophyllum spp.

Minutosaccus sp.

Klausipollenites sp.

Granosaccus sp.

Equisetosporites sp.

Brachyphyllum sp.

Gymnospermophyta

Ginkgoales

Baiera sp.

Cycadales

Lyssoxylon

Nilssonia sp.

Bennettitales

Otozamites spp. (present in SE Utah)

Nilssoniopteris $\mathrm{sp}$.

Williamsonia sp.

Pterophyllum (present in SE Utah)

Zamites spp.

Gnetales 


\section{C.4 Chinle Formation (Cont.)}

Schilderia sp.

Cycadophyta

Cycadopites spp.

Granomonocolpites sp.

Incertae Sedis

Carpolithus sp.

Ctenis sp.

Spenopteris sp.

Dinophyton sp.

Enzonalasporites sp.

Brodispora sp.

Pollen

Enzonalasporites sp.

Brodiospora sp.

Dictyophyllidites sp.

Verrucosisporites sp.

Reticulatisporites sp.

Vitreisporites sp.

Allisporites sp.

Cycadopites sp.

Granamonocolpites sp.

Platysaccus sp.

Patinasporites sp. 


\section{C.4 Chinle Formation (Cont.)}

Pityosporites sp.

Minutosaccus sp.

Klausipollenites sp.

Granosaccus sp.

Equisetosporites sp.

Invertebrata

Brachiopoda (primitive double-valved animals like clams and oysters, but not related)

$$
\text { Cyzicus sp. (Lioestheria) }
$$

Bivalvia (clams, mussels, and oysters)

Unio sp.

Invertebrate Ichnofossils (trace fossils)

Indet. trails

Subphylum Vertebrata

Class Chondrichthyes (cartilagenous fishes: sharks and rays)

Order Xenacanthida

Family Xenacanthidae

Xenacanthus sp.

Order Ctenacathiformes

Family Hybodontidae

Lonchidion sp.

Acrodus sp.

Family Phoebodontidae 


\section{C.4 Chinle Formation (Cont.)}

Phoebodus sp.

Class Osteichthyes (bony fishes)

Subclass Actinopterygii

Infraclass Chondrostei

Order Saurichthyiformes

Family not assigned

Tanaocrossus sp.

Order Redfieldiiformes

Family Redfieldiidae

Redfieldiidae indet.

Cionichthys sp.

Lasalichthys sp.

Synorichthys sp.

Order Palaeonisciformes

Family Palaeoniscidae

Palaeoniscidae indet.

Turseodus sp.

Order Pholidopleuriformes

Family Pholidopleuridae

cf. Australosomus sp.

Infraclass Neopterygii

Order Semionotiformes

Family Semionotidae 


\section{C.4 Chinle Formation (Cont.)}

Semionotidae indet.

Semionotus spp.

Lepidotes sp.

Hemicalypterus sp.

Sublass Sarcopterygii

Order Crossopterygii

Family Coelacanthidae indet. (coelacanths)

Coelacanthidae indet.

Chinlea sp.

Order Dipnoi (lungfishes)

Family Ceratodontidae

Ceratodus sp.

Arganodus sp.

Fish Trace Fossils

Lungfish burrows

Class Amphibia (modern forms include frogs, salamanders, and caecilians)

Order Temnospondyli

Family Metoposauridae

Metoposaurus sp.

Apachesaurus sp.

Buettneria sp.

Amphibia indet.

Class Reptilia (modern forms include lizards, snakes, crocodiles, and turtles) 


\section{C.4 Chinle Formation (Cont.)}

Subclass Anapsida

Order Captorhinida

Family Procolophonidae

Procolophonidae indet. (possible turtle ancestor)

Subclass Diapsida

Superorder Lepidosauria

Order Sphenodontida

Family Sphenodontidae

Sphenodontidae indet. (primitive lizard)

Infraclass Archosauromorpha (ancestral forms of crocodiles and dinosaurs)

Archosauromorpha incertae sedis

Vancleavea sp.

Revueltosaurus sp.

Order Trilophosauria

Family Trilophosauridae

Trilophosaurus sp.

Order Thecodontia

Family Phytosauridae

Phytosaurus sp.

Leptosuchus sp.

Rutiodon sp.

Smilosuchus sp.

Family Stagonolepididae 


\section{C.4 Chinle Formation (Cont.)}

Desmatosuchus sp.

Typothorax sp.

Calyptosuchus sp.

Paratypothorax sp.

Order Crocodylia

Family Sphenosuchidae

Hesperosuchus sp.

Order Saurischia

Family Podokesauridae

Coelophysis sp.

Indet. Archosaurs from Southern Utah

Subclass Synapsida (mammal-like reptiles)

Order Therapsida

Suborder Dicynodontia

Family Kannemeyeriidae

Placerias sp.

Suborder Cynodontia

Cynodontia indet.

Herpetological ichnofossils (trace fossils)

Pseudotetrasauropus sp.

Rhynchosauroides sp.

?Gwyneddichnium sp.

Large reptile tracks 


\section{C.4 Chinle Formation (Cont.)}

Tridactyl dinosauroid tracks

Quadrupedal trackways 


\section{C.5 Mesaverde Group}

Faunal and flora list compiled from Archibald (1987) and unpublished University of Colorado Museum fossil collections data (compiled in 2000). Common names are provided when possible. Taxa are mostly ordered as listed in the source publication. Partial vertebrate higher taxonomy is provided and was taken from Carroll (1988) and McKenna and Bell (1997).

Plantae (Plants)

Bryophyta (liverworts

Lycopsida (clubmoss-like plants)

Filicopsida (ferns)

Cyathea sp.

Onoclea sp.

Osmunda sp.

Cycadopsida (cycad-like plants)

Nageiopsis sp.

Podozamites sp.

Coniferopsida (coniferous plants)

Araucaria sp.

Sequoia sp.

Protophyllocladus sp.

Brachyphyllum sp.

Moriconia sp.

Androvettia sp.

Metasequoia sp.

Widdringtonites $\mathrm{sp}$. 


\section{C.5 Mesaverde Group (Cont.)}

Conites sp.

Indet. conifer

Invertebrata

Mollusca

Misc. Bivalvia (clams and oysters)

Misc. Gastropoda (snails)

Misc. Cephalopoda (ammonites and nautiloids)

Subphylum Vertebrata

Class Chondrichthyes

5-6 species of sharks and skates

Class Osteichthyes (bony fishes)

Order Acipenseriformes (?)

1 species

Order Amiiformes

Family Amiidae

Amia sp.

Class Amphibia (modern forms include frogs and salamanders)

Anura indet.

Order Urodela

Family Scapherpetontidae

Melvius sp.

Urodela indet. 


\section{C.5 Mesaverde Group (Cont.)}

Class Reptilia (modern forms include lizards, snakes, crocodiles, and turtles)

Subclass Anapsida

Order Chelonia (turtles)

Family Neurankylidae

Neurankylus sp.

Boremys sp.

Thescelus sp.

Compsemys (?)

Family Trionychidae

Trionyx sp.

Family Dermatemydidae

Adocous sp.

Subclass Diapsida

Order Choristodera

Family Champsosauridae

Champsosauridae indet.

Order Squamata (lizards and snakes)

2-3 species of lizards

Order Crocodylia (crocodiles and alligators)

Family Crocodylidae

Leidyosuchus sp.

Family Alligatoridae

Brachychampsa sp. 


\section{C.5 Mesaverde Group (Cont.)}

Order Saurischia

4-5 species of saurischian dinosaurs

Order Ornithischia

3 species of ornithischican dinosaurs

Class Mammalia

Subclass Theriiformes

Order Multituberculata (primitive mammals)

Family Cimolodontidae

Mesodma sp.

Cimolodon sp.

Family Taeniolabididae

Meniscoessus sp.

Family Cimolomyidae

aff. Cimolomys sp.

Family indet.

?Paracimexomys sp.

1 ? new gen. et. sp.

Cohort Marsupialia (metatherian mamals: modern forms include opossums, kangaroos, and koalas).

Order Didelphimorphia

Family Didelphidae

Alphadon aff.

Alphadon sp. nov? 


\section{C.5 Mesaverde Group (Cont.)}

Family Pediomyidae

Pediomys spp.

Cohort Placentalia

indet. Proteutherian 


\section{C.6 DeBeque Formation (= Wasatch Formation in Piceance Creek Basin, northwestern Colorado)}

Faunal list compiled from Kihm (1984) and unpublished University of Colorado Museum records (compiled in 2001). Common names are provided when possible. Taxa are mostly ordered as listed in the source publication. Partial vertebrate higher taxonomy is provided and was taken from Carroll (1988) and McKenna and Bell (1997).

Subphylum Vertebrata

Class Osteichthyes (bony fishes)

Order Semionotiformes

Family Semionotidae indet.

Order Lepiosteiformes

Family Lepisosteidae

Lepisosteus sp.

Class Amphibia (modern forms include frogs, salamanders, and caecilians)

Order Anura

Class Reptilia

Order Chelonia (turtles)

Family indet.

Order Crocodylia (crocodiles and alligators)

Family indet.

Family Alligatoridae

Allognathosuchus sp.

Ceratosuchus spp.

Family Crocodylidae 


\section{C.6 DeBeque Formation (= Wasatch Formation in Piceance Creek Basin, northwestern Colorado) (Cont.)}

gen. and sp. indet.

Crocodylus sp.

Family Gavialidae

gen. and sp. indet.

Order Squamata (lizards and snakes)

Suborder Lacertilia

Family indet.

Family Anguidae

gen. and sp. indet.

Glyptosaurus sp.

Family Varanidae

Saniwa sp.

Suborder Serpentes

gen. and sp. indet.

Class Aves (birds)

Order indet.

Class Mammalia

Subclass Theriiformes

Order Multituberculata

Family indet.

Family Eucosmodontidae

Neoliotomus sp.

Family Ptilodontidae 


\section{C.6 DeBeque Formation (= Wasatch Formation in Piceance Creek Basin, northwestern Colorado) (Cont.)}

\section{Ptilodus sp.}

Cohort Marsupialia (metatherian mammals: modern forms include opossums, kangaroos, and koalas)

Order Didelphimorphia

Family Didelphidae

Mimoperadectes sp.

Cohort Placentalia

Order Artiodactyla (even-toed ungulates: modern forms include deer, sheep, antelope, bison, camel, giraffe, moose, and others)

Dichobunidae

gen. indet.

Bunophorus sp.

Diacodexis sp.

Order Carnivora (modern forms include dogs, bears, cats, weasels, and others)

Family indet.

Family Viverravidae

gen. indet

Didymictis sp.

Protictis sp.

Viverravus sp.

Family Miacidae

Miacis sp.

Uintacyon sp.

Vulpavus spp. 


\section{C.6 DeBeque Formation (= Wasatch Formation in Piceance Creek Basin, northwestern Colorado) (Cont.)}

Order Condylarthra (group that was in part ancestral to ungulates)

Family Hyopsodontidae

Hyopsodus spp.

Haplomylus spp.

Apheliscus sp.

Aletodon sp.

Phenacodaptes sp.

Order Procreodi

Family Oxyclaenidae

Chriacus sp.

Thryptacodon spp.

Family Arctocyonidae

Lambertocyon spp.

gen. indet.

Family Phenacodontidae

Meniscotherium sp.

gen. indet.

Ectocion sp.

Phenacodus spp.

Order Cimolesta

Family Cimolestidae

Didelphodus sp.

Family Apatemyidae 


\section{C.6 DeBeque Formation (= Wasatch Formation in Piceance Creek Basin, northwestern Colorado) (Cont.)}

Apatemys sp.

Order Creodonta (carnivore-like mammals)

Family Hyaenodontidae

gen. indet.

Arfia spp.

Prolimnocyon sp.

Sinopa sp.

Tritemnodon $\mathrm{sp}$.

Family Oxyaenidae

gen. indet.

Oxyaena spp.

Order Primates (modern forms include apes, monkeys, and prosimians)

Family Microsyopidae

Microsyops sp.

Niptomomys sp.

gen. indet.

Family Picrodontidae

Zanycteris sp.

Family Plesiadapidae

Nannodectes spp.

Plesiadapis spp.

Chiromyoides spp.

gen. indet. 


\section{C.6 DeBeque Formation (= Wasatch Formation in Piceance Creek Basin, northwestern} Colorado) (Cont.)

Suborder Dermoptera (flying lemurs)

Family Paromomyidae

Ingacius sp.

Phenacolemur sp.

Simpsonlemur sp.

Suborder Euprimates

Family Adapidae

gen. indet.

Cantius sp.

Copelemur sp.

Pelycodus spp.

Family Omomyidae

Absarokius sp.

Teilhardina sp.

Tetonius sp.

Washakius spp.

Order Cete (whales and terrestrial relatives)

Mesonychidae

Dissacus sp.

Pachyaena sp.

Order Cimolesta

Family Metacheiromyidae

Palaeanodon sp. 


\section{C.6 DeBeque Formation (= Wasatch Formation in Piceance Creek Basin, northwestern Colorado) (Cont.)}

Family Coryphodontidae

Coryphodon sp.

Family Barylambdidae

Barylambda sp.

Family Pantolestidae

Palaeosinopa sp.

Family Stylinodontidae

gen. indet.

Ectoganus sp.

Family Tillotheriidae

Esthonyx sp.

Order Perissodactyla (modern forms include horses, tapirs, and rhinos)

Family indet.

Family Brontotheriidae

gen. indet.

Lambdotherium spp.

Xenicohippus spp.

Family Equidae

Hyracotherium sp.

Family Helatidae

Heptodon sp.

Family Isectolophidae

gen. indet. 


\section{C.6 DeBeque Formation (= Wasatch Formation in Piceance Creek Basin, northwestern Colorado) (Cont.)}

Homogalax spp.

Family Palaeotheriidae

Superorder Leptictida (extinct shrew-like mammal)

Family Leptictidae

gen indet.

Prodiacodon sp.

Palaeictops spp.

Order Rodentia (mice, squirrels, and beavers)

Family Ischyromyidae

gen. indet.

Leptotomus sp.

Lophioparamys spp.

Paramys spp.

Pseudotomus spp.

Thisbemys spp.

Family Reithroparamyidae

Reithroparamys spp.

Family Sciuravidae

gen. indet.

Knightomys sp.

Sciuravus sp.

Grandorder Lipotyphla (modern forms include shrews and moles)

Family indet. 
C.6 DeBeque Formation (= Wasatch Formation in Piceance Creek Basin, northwestern Colorado) (Cont.)

Order Erinaceomorpha

Family Amphilemuridae

Macrocranion spp.

Family Sespedectidae

gen. indet.

Scenopagus sp. 


\section{C.7 Wasatch Formation}

Faunal list compiled from Carroll (1988), Dorr (1978), Gunnell (1994), McKenna (1955, 1958), Stucky (1984,) and West and Dawson (1973). Common names are provided when possible. Taxa are mostly ordered as listed in the source publication. Partial vertebrate higher taxonomy is provided and was taken from Carroll (1988) and McKenna and Bell (1997).

\section{Cathedral Bluffs Tongue (Northern Green River Basin) (from West and Dawson 1973).}

Class Mammalia

Subclass Theriiformes

Cohort Marsupialia (metatherian mammals: modern forms include opossums, kangaroos, and koalas)

Order Didelphimorphia

Family Didelphidae

Peratherium sp.

Peradectes sp.

Cohort Placentalia

Order Primates (modern forms include apes, monkeys, and prosimians)

Family Microsyopidae

Microsyops sp.

Niptomomys sp.

Suborder Dermoptera (flying lemurs)

Family Paromomyidae

Phenacolemur sp.

Suborder Euprimates

Family Omomyidae 


\section{C.7 Wasatch Formation (Cont.)}

\section{Omomys sp}

Anaptomorphus sp.

Order Carnivora (modern forms include dogs, bears, cats, weasels, etc.)

Suborder Caniformia

Miacidae indet.

Order Condylarthra (group that was in part ancestral to ungulates)

Family Hyopsodontidae

Hyopsodus spp.

Order Perissodactyla (modern forms include horses, tapirs, and rhinos)

Family Hyracodontidae

Hyrachyus sp.

Family Helaletidae

Helaletes sp.

Family Equidae

Orohippus sp.

Order Artiodactyla (modern forms include deer, sheep, antelopes, cows, and camels)

Family Dichobunidae

Antiacodon sp.

Order Rodentia (mice, squirrels, and beavers)

Family Ischyromyidae

cf. Pseudotomus

Paramys spp.

Microparamys spp. 


\section{C.7 Wasatch Formation (Cont.)}

Family Reithroparamyidae

Reithroparamys spp.

Family Sciuravidae

Knightomys sp.

Sciuravus spp.

Pauromys sp.

Tillomys spp.

Family Cylindrodontidae

Mysops sp.

Order Cimolesta

Family Apatemyidae

Apatemys sp.

Grandorder Lipotyphla (modern forms include shrews and moles)

Family indet.

Order Soricomorpha

Family Nyctitheriidae

Nyctitherium sp.

Order Erinaceomorpha

Family Sespedectidae

gen. indet.

Scenopagus sp.

Four Mile Fauna (Hiawatha Member) Northwestern Colorado (from McKenna 1955, 1958). 


\section{C.7 Wasatch Formation (Cont.)}

Class Chondrichthyes (sharks and rays)

Chondrichthyes indet.

Class Osteichthyes (bony fishes)

Order Amiiformes

Family Amiidae

cf. Amia sp.

Order Lepisosteiformes

Family Lepisosteidae

Lepisosteus sp.

Class Amphibia (modern forms include frogs, salamanders, and caecilians)

Amphibia indet.

Class Reptilia

Subclass Anapsida

Order Chelonia

Family Dermatemyidae indet.

Family Trionychidae indet.

Subclass Diapsida

Order Crocodylia (crocodiles and alligators)

Family Crocodylidae

Crocodylidae indet.

Family Alligatoridae

cf. Allognathosuchus sp.

Order Squamata (lizards and snakes) 


\section{C.7 Wasatch Formation (Cont.)}

Suborder Lacertilia

Family Varanidae (monitor lizards)

Saniwa sp.

Family Necrosauridae

Parasaniwa sp.

Family Anguidae

Glyptosaurus spp.

Gerrhonotus sp.

Family Teiidae indet.

Teiidae indet.

Family Amphisbaenidae

Amphisbaenidae ident.

Family Rhineuridae

Lestophis sp.

Family incertae sedis

Suborder Serpentes

Family Boidae

Boidae indet.

Class Mammalia

Subclass Theriiformes

Order Multituberculata

Family Ptilodontidae

Ectypodus spp. 


\section{C.7 Wasatch Formation (Cont.)}

Family Eucosmodontidae

Neoliotomus sp.

Cohort Marsupialia (metatherian mammals: modern forms include opossums, kangaroos, and koalas)

Order Didelphimorphia

Family Didelphidae

Peradectes sp.

Cohort Placentalia

Order Cimolesta

Family Pantolestidae

Palaeosinopa sp.

Family Apatemyidae

Apatemys spp.

Superorder Leptictida

Family Leptictidae

Leptictidae indet.

Order Primates (modern forms include apes, monkeys, and prosimians)

Family Microsyopidae

Microsyops sp.

Niptomomys sp.

Suborder Dermoptera (flying lemurs)

Family Paromomyidae

Phenacolemur sp.

Suborder Euprimates 


\section{C.7 Wasatch Formation (Cont.)}

Family Omomyidae

Anaptomorphus sp.

Trogolemur sp.

Tetonius sp.

Family Adapidae

Pelycodus sp.

Order Rodentia (mice, squirrels, and beavers)

Family Ischyromyidae

Paramys spp.

Order Cimolesta

Family Tillotheriidae

Esthonyx sp.

Family Coryphodontidae

Coryphodon sp.

Family Cimolestidae

Didelphodus spp.

Order Cete (whales and terrestrial relatives)

Family Mesonychidae

Pachyaena sp.

Order Creodonta (carnivore-like mammals)

Family Hyaenodontidae

Sinopa sp.

Prototomus sp. 


\section{C.7 Wasatch Formation (Cont.)}

Family Oxyaenidae

Oxyaena sp.

Order Carnivora (modern forms include dogs, bears, cats, weasels, etc.)

Suborder Caniformia

Family Miacidae

Miacis sp.

Suborder Feliformia

Family Viverravidae

Didymictis sp.

Viverravus sp.

Order Condylarthra (group that was in part ancestral to ungulates)

Family Hyopsodontidae

Hyopsodus spp.

Haplomylus spp.

Apheliscus sp.

Order Procreodi

Family Arctocyonidae

Family Oxyclaenidae

Chriacus sp.

Thryptacodon sp.

Family Phenacodontidae

Phenacodus spp.

Ectocion sp. 


\section{C.7 Wasatch Formation (Cont.)}

Order Perissodactyla (modern forms include horses, tapirs, and rhinos)

Family Equidae

Hyracotherium sp.

Family Isectolophidae

$$
\text { cf. Homogalax sp. }
$$

Order Artiodactyla (modern forms include deer, sheep, antelopes, cows, and camels)

Family Dichobunidae

Bunophorus sp.

Diacodexis sp.

Grandorder Lipotyphla (modern forms include shrews and moles)

Order Soricomorpha

Family Geolabididae

Centetodon sp.

Family Nyctitheriidae

Nyctitherium sp.

Order Erinaceomorpha

Family Amphilemuridae.

Amphilemuridae indet.

Chappo Member, including Chappo type locality (Green River Basin, Wyoming). From Gunnell (1994) and Dorr (1978).

Class Osteichthyes (bony fishes)

Order Lepisosteiformes

Family Lepidostidae 


\section{C.7 Wasatch Formation (Cont.)}

\section{Lepisosteus sp.}

Class Reptilia

Subclass Anapsida

Order Chelonia (turtles)

Chelonia indet.

Subclass Diapsida

Order Crocodylia

Crocodylia indet. (crocodile)

Class Mammalia

Subclass Theriiformes

Order Multituberculata

Family Ptilodontidae

Ptilodus sp.

Neoplagiaulax sp.

Ectypodus sp.

Mesodma sp.

Cohort Marsupialia (metatherian mammals: modern forms include opossums, kangaroos, and koalas)

Order Didelphimorpha

Family Didelphidae

Peradectes sp.

Cohort Placentalia

Order Leptictida 


\section{C.7 Wasatch Formation (Cont.)}

Family Leptictidae

Prodiacodon spp.

Order Cimolesta

Family Palaeoryctidae

Palaeoryctes spp.

Family Coryphodontidae

Coryphodon spp.

Family Pantolestidae

Pantolestes sp.

Propalaeosinopa sp.

Palaeosinopa sp.

Family Apatemyidae

Unuchinia sp.

Apatemys sp.

Family Stylinodontidae

Stylinodontidae indet.

Family Tillotheriidae

Esthonyx sp.

Order Primates (modern forms include apes, monkeys, and prosimians)

Family Plesiadapidae

Chiromyoides sp.

Plesiadapis sp.

Family Picrodontidae 


\section{C.7 Wasatch Formation (Cont.)}

Picrodus sp.

Suborder Dermoptera (flying lemurs)

Family Paromomyidae

Ignacius $\mathrm{sp}$.

Suborder Euprimates

Family Carpolestidae

Carpodaptes sp.

Order Condylarthra (group that was in part ancestral to ungulates)

Family Hyopsodontidae

Haplomylus sp.

Aletodon sp.

Hyopsodus sp.

Dorraletes sp.

Order Procreodi

Family Oxyclaenidae

Chriacus sp.

Thryptacodon sp.

Family Arctocyonidae

Lambertocyon sp.

Claenodon spp.

Family Phenacodontidae

Phenacodus sp.

Ectocion sp. 


\section{C.7 Wasatch Formation (Cont.)}

Order Cete (whales and terrestrial relatives)

Family Mesonychidae

Dissacus sp.

Order Carnivora (modern forms include dogs, bears, cats, weasels, and others)

Suborder Feliformia

Family Viverravidae

Protictis spp.

Raphictis sp.

Order Creodonta (carnivore-like mammals)

Family Oxyaenidae

Tythaena sp.

Order Dinocerata

Family Uintatheriidae

Prodinoceras sp.

Order Perissodactyla (modern forms include horses, tapirs, and rhinos)

Family Equidae

Hyracotherium sp.

Order Artiodactyla (modern forms include deer, sheep, antelopes, cows, and camels)

Family Dichobunidae

Diacodexis sp.

Grandorder Lipotyphla (modern forms include shrews and moles)

Order Soricomorpha

Family Nyctitheriidae 


\section{C.7 Wasatch Formation (Cont.)}

\section{Leptacodon $\mathrm{sp}$.}

Family incertae sedis

Order Erinaceomorpha

Family indet.

\section{Adunator sp.}

Litocherus sp.

Family Erinaceidae

Cedrocherus sp.

\section{Dad Local mammalian fauna (Wyoming) (from Stucky 1984).}

Class Mammalia

Subclass Theriiformes

Cohort Placentalia

Order Primates (modern forms include apeas, monkeys, and prosimians)

Suborder Euprimates

Family Omomyidae

Chlororhysis sp.

Family Adapidae

Cantius sp.

Notharctus sp.

Order Cimolesta

Family Tillotheriidae

Esthonyx sp.

Family Coryphodontidae 


\section{C.7 Wasatch Formation (Cont.)}

\section{Coryphodon sp.}

Order Creodonta (carnivore-like mammals)

Family Oxyaenidae

Oxyaena sp.

Patriofelis sp.

Ambloctonus sp.

Order Carnivora (modern forms include dogs, bears, cats, weasels, etc.)

Suborder Feliformia

Family Viverravidae

Didymictis sp

Viverravus sp.

Suborder Caniformia

Family Miacidae

Vulpavus sp.

Order Condylarthra (group that was in part ancestral to ungulates)

Family Hyopsodontidae

Hyopsodus sp.

Order Perissodactyla (modern forms include horses, tapirs, and rhinos)

Family Brontotheriidae

Lambdotherium sp.

Family Isectolophidae

cf. Homogalax sp.

Family Helaletidae 


\section{C.7 Wasatch Formation (Cont.)}

\section{Heptodon sp.}

Order Artiodactyla (modern forms include deer, sheep, antelopes, cows, and camels)

Family Dichobunidae

Diacodexis sp.

Bunophorus sp.

Hexacodus sp.

Order Rodentia (mice, squirrels, beavers, and others)

Family Ischyromyidae

Paramys sp.

\section{LaBarge Local mammalian fauna (Wyoming) (from Stucky 1984).}

Class Mammalia

Subclass Theriiformes

Cohort Marsupialia (pouched, opossum-like mammals)

Order Didelphimorphia

Family Didelphidae

Peratherium sp.

Peradectes sp.

Cohort Placentalia

Superorder Leptictida

Family Leptictidae

Palaeictops sp.

Order Cimolesta 


\section{C.7 Wasatch Formation (Cont.)}

Family Apatemyidae

Apatemys sp.

Family Stylinodontidae

Ectoganus sp.

Stylinodon sp.

Family Tillotheriidae

Esthonyx sp.

Family Coryphodontidae

Coryphodon sp.

Order Primates (modern forms include apes, monkeys, and prosimians)

Family Microsyopidae

Microsyops sp.

Suborder Euprimates

Family Omomyidae

Loveina sp.

Tetonius sp.

Absarokius sp.

Chlororhysis sp.

Family Adapidae

Cantius sp.

Notharctus sp.

Order Creodonta (carnivore-like mammals)

Family Oxyaenidae 


\section{C.7 Wasatch Formation (Cont.)}

Oxyaena sp.

Patriofelis sp.

Ambloctonus sp.

Family Hyaenodontidae

Prolimnocyon sp.

Prototomus sp.

Tritemnodon sp.

Order Carnivora (modern forms include dogs, bears, cats, weasels, and others)

Suborder Feliformia

Family Viverravidae

Didymictis sp.

Viverravus sp.

Suborder Caniformia

Family Miacidae

Vulpavus sp.

Miacis sp.

Uintacyon sp.

Order Condylarthra (group that was in part ancestral to ungulates)

Family Hyopsodontidae

Hyopsodus sp.

Family Phenacodontidae

Meniscotherium sp.

Order Procreodi 


\section{C.7 Wasatch Formation (Cont.)}

Family Oxyclaenidae

Thryptacodon sp.

Order Perissodactyla (modern forms include horses, tapirs, and rhinos)

Family Equidae

Hyracotherium sp.

Family Brontotheriidae

Lambdotherium sp.

Family Helaletidae

Heptodon sp.

Order Artiodactyla (modern forms include deer, sheep, antelopes, cows, and camels)

Family Dichobunidae

Diacodexis sp.

Bunophorus sp.

Hexacodus sp.

Order Rodentia (mice, squirrels, beavers, and others)

Family Ischyromyidae

Paramys sp.

Family Sciuravidae

Knightomys sp.

Family Cylindrodontidae

Dawsonomys sp.

New Fork Tongue mammalian fauna (Wyoming) (from Stucky 1984).

Class Mammalia 


\section{C.7 Wasatch Formation (Cont.)}

Subclass Theriiformes

Cohort Placentalia

Superorder Leptictida

Family Leptictidae

Palaeictops sp.

Order Cimolesta

Family Pantolestidae

Palaeosinopa sp.

Family Stylinodontidae

Ectoganus sp.

Stylinodon sp.

Family Tillotheriidae

Esthonyx sp.

Family Coryphodontidae

Coryphodon sp.

Family Epoicotheriidae

Pentapassalus sp.

Order Primates (modern forms include apes, monkeys, and prosimians)

Family Microsyopidae

Microsyops sp.

Suborder Euprimates

Family Omomyidae

Loveina sp. 


\section{C.7 Wasatch Formation (Cont.)}

Shoshonius sp.

Family Adapidae

Cantius sp.

Notharctus sp.

Order Creodonta (carnivore-like mammals)

Family Oxyaenidae

Oxyaena sp.

Patriofelis sp.

Family Hyaenodontidae

Prolimnocyon sp.

Prototomus sp.

Tritemnodon sp.

Order Carnivora (modern forms include dogs, bears, cats, weasels, and others)

Suborder Feliformia

Family Viverravidae

Didymictis sp.

Viverravus sp.

Suborder Caniformia

Family Miacidae

Vulpavus sp.

Uintacyon sp.

Miacis sp.

Order Condylarthra (group that was in part ancestral to ungulates) 


\section{C.7 Wasatch Formation (Cont.)}

Family Hyopsodontidae

Hyopsodus sp.

Family Phenacodontidae

Meniscotherium sp.

Order Cete (whales and terrestrial relatives)

Family Mesonychidae

Pachyaena sp.

Mesonyx sp.

Order Perissodactyla (modern forms include horses, tapirs, and rhinos)

Family Equidae

Hyracotherium sp.

Family Brontotheriidae

Lambdotherium sp.

Palaeosyops sp.

Family Helaletidae

Heptodon sp.

Family Hyracodontidae

Hyrachyus sp.

Order Artiodactyla (modern forms include deer, sheep, antelopes, cows, and camels)

Family Dichobunidae

Diacodexis sp.

Bunophorus sp. 


\section{C.7 Wasatch Formation (Cont.)}

\section{Hexacodus sp.}

Order Rodentia (mice, squirrels, and beavers)

Family Ischyromyidae

Paramys sp.

Family Sciuravidae

Sciuravus sp. 


\section{C.8 Green River Formation}

Faunal list compiled from Armstrong (1991), Gardner (1999), Grande (1980, 1987, 1998, 1999), Grande et al. (1982), Hilton and Grande (2001), Jepsen (1966), Loewen et al. (1999), McGrew and Casilliano (1975), Moussa (1970), Olson (1977), Parker (1970), Perry (2003), Rieppel and Grande (1998), Waterhouse et al. (2003), Yang et al. (1995), Zonneveld et al. (2000), and unpublished University of Colorado Museum fossil collection data (compiled 2002). Taxa are mostly ordered as listed in the source publication. Partial vertebrate higher taxonomy is provided and was taken from Carroll (1988) and McKenna and Bell (1997).

Plantae (Plants)

Quercus sp.

Araliophyllum sp.

Leguminosites sp.

Legume sp.

Lygodium sp.

Acrostichum sp.

Eugenia sp.

Populus sp.

Rebinia sp.

Invertebrata

Arthropoda indet.

Chelicerata

Uintascorpio sp.

Ostracoda (Pseudocypus sp. most common)

Insecta (insects)

Dicranomyia sp. 


\section{C.8 Green River Formation (Cont.)}

Diptera

Cylindrotoma sp.

Cyttaromyia sp.

Tipula sp.

Bibionidae indet.

Diptera indet.

Orthoptera indet.

Hemiptera indet.

Hymenoptera

Eoformica sp.

Chalcididae Indet.

Ichneumonidae indet

Mollusca

Gastropoda (snails)

Land snails: Grangerella, Discus, Oreoconus spp.

Pond snails: Goniobasis, Physa, Planorbis, Elimia, Biomphalaria, Omalodiscus spp.

Bivalvia (oysters and clams)

Unio, Plesielliptio, Pisidium, Sphaerium spp.

Subphylum Vertebrata

Class Chondrichthyes (sharks and rays)

Order Batoidea

Dasyatidae 


\section{C.8 Green River Formation (Cont.)}

Dasyatis sp. (freshwater stingray)

Class Osteichthyes (bony fishes)

Subclass Actinopterygii

Order Acipenseriformes

Family Polyodontidae (paddlefish)

Crossopholis sp.

Order Lepisosteiformes

Family Lepisosteidae (gar pike)

Lepisosteus spp.

Order Amiiformes

Family Amiidae (bowfin)

Amia spp.

Order Osteoglossiformes

Family Hiodontidae (mooneye)

Eohiodon sp.

Family Osteoglossidae (arawana)

Phareodus sp.

Order Clupeiformes

Family Clupeidae (herring)

Knightia spp.

Order Ellimmichthyiformes

Family Ellimmichthyidae

Diplomystus spp. 


\section{C.8 Green River Formation (Cont.)}

Order Gonorhynciformes

Family Gonorhynchidae (sand fish)

Notogoneus sp.

Order Cypriniformes

Family Catostomidae indet. (suckers)

Amyzon sp.

Order Siluriformes (catfish)

Family Ictaluridae

Astephus sp.

Order Percopsiformes

Family Aphredoderidae (trout perch)

Amphiplaga sp.

Erismatopterus sp.

Asineops sp.

Order Salmoniformes

Family Esodidae indet.

Esox sp.

Order Perciformes

Family Percidae (perch)

Mioplosus spp.

Family Pomacentridae

Priscacara spp.

Class Amphibia (frogs and salamanders) 


\section{C.8 Green River Formation (Cont.)}

Order Anura

Family Pelobatidae

cf. Eopelobates sp.

Anura indet.

Order Urodela

Family Amphiumidae

Paleoamphiuma sp.

Amphiumidae indet.

Amphibia indet.

Class Reptilia

Subclass Anapsida

Order Chelonia (turtles)

Family Trionychidae

Family Emydidae

\section{Echmatemys sp.}

Subclass Diapsida

Order Crocodylia (crocodiles and alligators)

Family Crocodylidae

Leidyosuchus sp.

Crocodylus sp.

Family Alligatoridae

Allognathosuchus sp.

Order Squamata (snakes and lizards) 


\section{C.8 Green River Formation (Cont.)}

Suborder Lacertilia

Family Agamidae

Tinosaurus sp.

Family Varanidae

Saniwa sp.

Suborder Serpentes

Family Boidae

Boavus sp.

Class Aves (birds)

Order Gruiformes

Family Messelornithidae

Messelornis sp.

Order Charadriiformes

Chardriiformes indet.

Order Pelicaniformes

Family Fregatidae

Limnofregata sp.

Order Galliformes

Family Cracidae

Gallinuloides sp.

Order Anseriformes

Family Presbyornithidae

Presbyornis sp. 


\section{C.8 Green River Formation (Cont.)}

Order Coraciiformes

Family Primobucconidae

Primobucca spp.

Neanis spp.

ClassMammalia

Subclass Theriiformes

Cohort Marsupialia (metatherian mammals: modern forms include opossums, kangaroos, and koalas)

Order Didelphimorphia

Family Didelphidae

Peratherium spp.

Cohort Placentalia

Order Primates (modern forms include apes, monkeys, and prosimians)

Family Microsyopidae

Microsyops sp.

Uintasorex sp.

Suborder Euprimates

Family Adapidae

Notharctus spp.

Family Omomyidae

Omomys sp.

Tetonius sp.

Washakius sp.

Order Cimolesta 


\section{C.8 Green River Formation (Cont.)}

Family Tillotheriidae

Tillotheriidae indet.

Order Chiroptera (bats)

Family Icaronycteridae

Icaronycteris sp.

Order Rodentia (mice, squirrels, and beavers)

Family Ischyromyidae

Thisbemys spp.

Paramys sp.

Family Sciuravidae

Sciuravus sp.

Order Creodonta (carnivore-like mammals)

Family Hyaenodontidae

Sinopa spp.

Order Carnivora (modern forms include dogs, bears, cats, weasels, and others)

Suborder Feliformia

Family Viverravidae

Viverravus spp.

Suborder Caniformia

Family Miacidae

Vulpavus spp.

Order Condylarthra (group that was in part ancestral to ungulates)

Family Hyopsodontidae 


\section{C.8 Green River Formation (Cont.)}

Hyopsodus spp.

Order Perissodactyla (modern forms include horses, tapirs, and rhinos)

Family Brontotheriidae

Mesatirhinus sp.

Order Artiodactyla (modern forms include deer, sheep, antelopes, cows, and camels)

Family Dichobunidae

Antiacodon sp.

Diacodexis sp.

Microsus sp.

Grandorder Lypotyphla (modern forms include shrews and moles)

Order Soricomorpha

Family Nyctitheriidae

Nyctitherium spp.

Order Erinaceomorpha

Family incertae sedis

Talpavus sp.

Ichnofossils (trace fossils)

Caddisfly larval cases

Indet. burrows

Arenicolites sp.

Skolithos sp.

Scoyenia sp. 


\section{C.8 Green River Formation (Cont.)}

Rusophycus sp.

Taenidium sp.

Planolites sp.

Palaeophycus sp.

Crayfish(?)

Camborygma sp.

cf. Ophiomorpha sp.

Spongeliomorpha sp.

Thalassinoides sp.

Tracks

Flamingo-like

Duck-like

Trails

Nematode 


\section{C.9 Bridger Formation}

Faunal list compiled from Gazin (1976), Gulas-Wroblewski and Uibreaslain (2002), Gunnell and Bartels (1999), Mook (1962), Murphey et al. (2001), and unpublished University of Colorado Museum paleontological data (compiled 2001). Common names are provided when possible. Taxa are mostly ordered as listed in the source publication. Partial vertebrate higher taxonomy is provided and was taken from Carroll (1988) and McKenna and Bell (1997).

Plantae (Plants)

Tracheophyta

Angiospermopsida

\section{Stipidium sp.}

Angiospermopsida indet.

Magnoliophyta indet.

Chlorophyta indet.

Charophytes sp.

Invertebrata

Mollusca

Gastropoda (snails)

Goniobasis sp.

Discus sp.

Biomphalaria sp.

Omalodiscus sp.

Viviparus sp.

Gyraulus sp.

Oreoconus sp. 


\title{
C.9 Bridger Formation (Cont.)
}

\author{
Holospira sp. \\ Pupillidae \\ Lymnaeidae \\ Physidae \\ Bivalvia (clams, oysters) \\ Pleisielliptio sp.
}

Arthropoda

Arachnida indet.

Insecta indet.

Subphylum Vertebrata

Class Osteichthyes (bony fishes)

Subclass Actinopteryigii

Infraclass Neopterygii

Order Lepisosteiformes

Family Lepisosteidae

Lepisosteus $\mathrm{sp}$.

Order Amiiformes

Family Amiidae

Amia sp.

Order Siluriformes

Class Reptilia

Subclass Anapsida

Order Chelonia (turtles) 


\section{C.9 Bridger Formation (Cont.)}

Family Trionychidae

Family Baenidae

Family Testudinidae

Hadrianus sp.

Family Dermatemyididae

Baptemys sp.

Family Emydidae

Echmatemys sp.

Subclass Diapsida

Order Crocodylia (crocodiles and alligators)

Family Crocodylidae

Brachyuranochampsa sp.

Crocodylus sp.

Leidyosuchus sp.

Family Alligatoridae

Allognathosuchus sp.

Order Squamata (lizards and snakes)

Suborder Lacertilia

Family Anguidae

Glyptosaurus sp.

Melanosaurus sp.

Family Agamidae

Tinosaurus sp. 


\section{C.9 Bridger Formation (Cont.)}

Family Varanidae

\section{Saniwa sp.}

Class Aves (birds)

Order Galliformes indet.

Order Ciconiiformes

Family indet.

Juncitarsus gracillimus

Falconiformes

Family Accipitridae

Accipitridae, 2 species

Order Charadriiformes

Family Burhinidae

Burhinidae indet.

Order Gruiformes

Family Rallidae

Rallidae indet.

Family Geranoididae

Geranoididae indet.

ClassMammalia

Subclass Theriiformes

Cohort Marsupialia (metatherian mammals: modern forms include opossums, kangaroos, and koalas)

Order Didelphimorphia 


\section{C.9 Bridger Formation (Cont.)}

Family Didelphidae

Peratherium spp.

Peradectes sp.

cf. Armintodelphys sp.

Cohort Placentalia

Order Leptictida

Family Leptictidae

Palaeictops sp.

Order Cimolesta

Family Palaeoryctidae

Didelphodus sp.

Family Pantolestidae

Pantolestes spp.

Family Apatemyidae

Apatemys spp.

Family Tillotheriidae

Trogosus spp.

Tillodon sp.

Family Stylinodontidae

Stylinodon spp.

Family Metacheiromyidae

Metacheiromys spp.

Brachianodon sp. 


\section{C.9 Bridger Formation (Cont.)}

Family Epoicotheriidae

Tetrapassalus sp.

Order Primates (modern forms include apes, monkeys, and prosimians)

Family Microsyopidae

Microsyops sp.

Arctodontomys sp.

Uintasorex sp.

Suborder Euprimates

Family Adapidae

Notharctus spp.

Smilodectes sp.

Copelemur sp.

Family Omomyidae

Ageitodendron sp.

Absarokius sp.

Anaptomorphus sp.

Trogolemur spp.

Uintanius spp.

Washakius sp.

Omomys sp.

Wyomomys sp.

Hemiacodon sp.

Sphacorhysis sp. 


\section{C.9 Bridger Formation (Cont.)}

Order Rodentia (mice, squirrels, and beavers)

Family Ischyromyidae

Paramys spp.

Reithroparamys sp.

Pseudotomus sp.

Leptotomus spp.

Thisbemys spp.

Ischyrotomus spp.

Microparamys spp.

Family Eomyidae

Namatomys sp.

Family Sciuravidae

Sciuravus sp.

Pauromys sp.

Tillomys sp.

Taxymys sp.

Family Cylindrodontidae

Mysops spp.

Order Creodonta (carnivore-like mammals)

Family Oxyaenidae

Patriofelis sp.

Family Hyaenodontidae

Sinopa spp. 


\section{C.9 Bridger Formation (Cont.)}

Thinocyon spp.

Tritemnodon sp.

Machaeroides sp.

Limnocyon sp.

Order Carnivora (modern forms include dogs, bears, cats, weasels, and others)

Suborder Feliformia

Family Viverravidae

Viverravus spp.

Suborder Caniformia

Family Miacidae

Miacis spp.

Uintacyon spp.

Palaearctonyx sp.

Oödectes sp.

Vulpavus spp.

Order Condylarthra (group that was in part ancestral to ungulates)

Family Hyopsodontidae

Hyopsodus spp.

Order Procreodi

Family Phenacodontidae

Ectocion sp.

Tetraclaenodon sp.

Order Dinocerata 


\section{C.9 Bridger Formation (Cont.)}

Family Uintatheriidae

Uintatherium sp.

Bathyopsis sp.

Order Perissodactyla (modern forms include horses, tapirs, and rhinos)

Family Equidae

Orohippus spp.

Family Brontotheriidae

Palaeosyops sp

Limnohyops sp.

Telmatherium spp.

Mesatirhinus sp.

Family Isectolophidae

Isectolophus sp.

Family Helaletidae

Helaletes sp.

Family Hyracodontidae

Dilophodon sp.

Hyrachyus spp.

Order Artiodactyla (modern forms include deer, sheep, antelopes, cows, and camels)

Family Dichobunidae

Homacodon sp.

Diacodexis sp.

Antiacodon sp. 


\section{C.9 Bridger Formation (Cont.)}

Microsus sp.

Family Helohyidae

Helohyus spp.

Order Cete (whales and terrestrial relatives)

Family Mesonychidae

Mesonyx sp.

Harpagolestes sp.

Order Chiroptera (bats)

Chiroptera indet.

Grandorder Lypotyphla (modern forms include shrews and moles)

Order Soricomorpha

Family Geolabididae

Centetodon spp.

Family Nyctitheriidae

Nyctitherium spp.

Pontifactor sp.

Order Erinaceomorpha

Family incertae sedis

Entomolestes sp.

Talpavus sp.

Family Sespedectidae

Scenopagus spp. 


\section{C.9 Bridger Formation (Cont.)}

Ichnofossils (trace fossils)

Caddisfly larval cases

Vertebrate coprolites

Earthworm pellets

Solitary bee cases 


\section{C.10 Washakie Formation}

Faunal list compiled from Carroll (1998) and Stucky et al. (1996). Common names are provided when possible. Taxa are mostly ordered as listed in the source publication. Partial vertebrate higher taxonomy is provided and was taken from Carroll (1988) and McKenna and Bell (1997).

Subphylum Vertebrata

Class Osteichthyes (bony fishes)

Subclass Actinoptetygii

Order Lepisosteiformes

Family Lepisostidae

Lepisosteus sp.

Order Amiiformes

Famly Amiidae

Amia sp.

Order Cypriniformes

Family Catostomidae

Catostomidae indet.

Order Siluriformes

Family Arriidae

Rhineastes sp.

Class Reptilia

Subclass Anapsida

Order Chelonia (turtles) 


\section{C.10 Washakie Formation (Cont.)}

Family Baenidae

Baena sp.

Family Dermatemyidae

Baptemys sp.

Family Testudinindae

Echmatemys spp.

Subclass Diapsida

Order Crocodylia (crocodiles and alligators)

Family Crocodylidae

Crocodylus sp.

Pristichampsus sp.

Family Alligatoridae

Allognathosuchus sp.

Order Squamata (lizards and snakes)

Suborder Lacertilia

Family Anguidae indet.

Anguidae indet.

Family Varanidae (monitor lizards)

Saniwa sp.

Suborder Serpentes.

Serpentes indet.

Class Mammalia

Subclass Theriiformes 


\section{C.10 Washakie Formation (Cont.)}

Cohort Marsupialia (metatherian mammals, modern forms include opossums, kangaroos, and koalas)

Order Didelphimorphia

Family Didelphidae

Peratherium spp.

Cohort Placentalia

Order Leptictida

Family Leptictidae

Leptictidae indet.

Order Cimolesta

Family Pantolestidae

Pantolestes sp.

Order Dinocerata

Family Uintatheriidae

Uintatherium sp.

Eobasileus sp.

Order Primates (modern forms include apes, monkeys, and prosimians)

Family Microsyopidae

Microsyops spp.

Suborder Euprimates

Family Adapidae

Notharctus sp.

Family Omomyidae

Hemiacodon sp. 


\section{C.10 Washakie Formation (Cont.)}

Omomyidae indet.

Order Carnivora (modern forms include dogs, bears, cats, weasels, and others)

Suborder Feliformia

Family Viverravidae

Viverravus spp.

Suborder Caniformia

Family Miacidae

Uintacyon sp.

Order Rodentia (mice, squirrels, and beavers)

Family Ischyromyidae

Leptotomus spp.

Thisbemys sp.

Ischyromyidae indet.

Family Sciuravidae

Sciuravus sp.

Tillomys sp.

Family Eomyidae

Namatomys sp.

Order Condylarthra (group that was in part ancestral to ungulates)

Family Hyopsodontidae

Hyopsodus spp.

Order Artiodactyla (modern forms include deer, sheep, antelopes, cows, and camels) 


\section{C.10 Washakie Formation (Cont.)}

Family Dichobunidae

Hylomeryx sp.

Family Helyohyidae

Helohyidae indet.

Family Agriochoeridae

Protoreodon sp.

Family Oromerycidae

Oromeryx sp.

Order Cete (whales and terrestrial relatives)

Family Mesonychidae

Mesonyx sp.

Order Perissodactyla (modern forms include horses, tapirs, and rhinos)

Family Equidae

Epihippus sp.

Orohippus sp.

Family Brontotheriidae

Metarhinus sp.

Sphenocoelus spp.

Telmatherium sp.

Family Isectlophidae

Isectolophus sp.

Family Hyracodontidae

Dilophodon sp. 


\section{C.10 Washakie Formation (Cont.)}

Hyrachyus sp.

Forstercooperia sp.

Triplopus sp.

Grandorder Lypotyphla (modern forms include shrews and moles)

Order Soricomorpha

Family Geolabididae

Centetodon spp.

Family Apternodontidae

Apternodontidae indet. 


\section{C.11 Uinta Formation}

Faunal list compiled from Armstrong (1991) and Gunnell and Bartels (1999). Common names are provided when possible. Taxa are mostly ordered as listed in the source publication. Partial vertebrate higher taxonomy is provided and was taken from Carroll (1988) and McKenna and Bell (1997).

Subphylum Vertebrata

Class Osteichthyes (bony fishes)

Family Amiidae

Pappichthys sp.

Class Reptilia

Subclass Anapsida

Order Chelonia (turtles)

Family Testudinidae

Testudinidae indet.

Family Baenidae

Baena spp.

Family Emydidae

Echmatemys spp.

Family Trionychidae

Trionychidae indet.

Subclass Diapsida

Order Crocodylia (crocodiles and alligators)

Crocodylus sp.

Order Squamata (lizards and snakes) 


\section{C.11 Uinta Formation (Cont.)}

Family Anguidae

Glyptosaurus sp.

Family Varanidae

Saniwa sp.

Squamata indet.

Class Aves (birds)

Aves indet.

\section{Uinta A-C (Gunnell and Bartels 1999).}

Class Mammalia

Subclass Theriiformes

Cohort Placentalia

Order Lagomorpha (rabbits and pikas)

Family Leporidae

Mytonolagus sp.

Order Cimolesta

Family Apatemyidae

Apatemys sp.

Family Stylinodontidae

Stylinodon sp.

Order Creodonta (carnivore-like mammals)

Family Hyaenodontidae

Limnocyon spp.

Oxyaenodon sp. 


\section{C.11 Uinta Formation (Cont.)}

Apataelurus sp.

Order Carnivora (modern forms include dogs, bears, cats, weasels, and others)

Suborder indet.

Eosictis sp.

Suborder Caniformia

Suborder Feliformia

Family Viverravidae

Tapocyon sp.

Family Miacidae

Miacis spp.

Prodaphaenus sp.

Family Canidae

Procynodictis sp.

Order Primates (modern forms include apes, monkeys, and prosimians)

Suborder Euprimates

Family Omomyidae

Ourayia spp.

Trogolemur sp.

Chipetaia sp.

Order Dinocerata

Family Uintatheriidae

Uintatherium sp.

Eobasileus sp. 


\section{C.11 Uinta Formation (Cont.)}

Order Cete (whales and terrestrial relatives)

Family Mesonychidae

Mesonyx sp.

Harpagolestes sp.

Order Condylarthra (group that was in part ancestral to ungulates)

Family Hyopsodontidae

Hyopsodus spp.

Order Perissodactyla (modern forms include horses, tapirs, and rhinos)

Family Equidae

Epihippus spp.

Family Brontotheriidae

Metarhinus sp.

Sphenocoelus sp.

Sthenodectes spp.

Telmatherium sp.

Protitanotherium sp.

Diplacodon spp.

Eotitanotheriun

Family Isectolophidae

Isectolophus spp.

Family Hyracodontidae

Dilophodon sp.

Triplopus spp. 


\section{C.11 Uinta Formation (Cont.)}

Forstercooperia sp.

Epitriplopus sp.

Family Rhinocerotidae

Amynodon sp.

Family Eomoropidae

Eomoropus sp.

Order Artiodactyla (modern forms include deer, sheep, antelopes, cows, and camels)

Family Dichobunidae

Pentacemylus spp.

Mytonomeryx sp.

Hylomeryx spp.

Bunomeryx spp.

Mesomeryx sp.

Family Helohyidae

Achaenodon spp.

Family Agriochoeridae

Protoreodon spp.

Diplobunops spp.

Family Protoceratidae

Leptotragulus spp.

Leptoreodon sp.

Family Oromerycidae

Oromeryx sp. 


\section{C.11 Uinta Formation (Cont.)}

Protylopus spp.

Family Camelidae

Poëbrodon sp.

Order Rodentia (mice, squirrels, and beavers)

Family Ischyromyidae

Ischyrotomus spp.

Leptotomus spp.

Microparamys sp.

Thisbemys spp.

Mytonomys sp.

Family Reithroparamyidae

Reithroparamys sp.

Family Eutypomyidae

Janimus sp.

Family Sciuravidae

Sciuravus spp.

Family Cylindrodontidae

Pareumys spp.

Family Protoptychidae

Protoptychus sp. 


\section{C.12 Duchesne River Formation}

Faunal list compiled from Rasmussen (1999) and Clark (1932). Common names are provided when possible. Taxa are ordered as listed in the source publication. Partial vertebrate higher taxonomy is provided and was taken from Carroll (1988) and McKenna and Bell (1997).

Subphylum Vertebrata

Class Reptilia

Subclass Anapsida

Order Chelonia (turtles)

Chelonia indet

Lapoint Member (from Rasmussen 1999)

Class Mammalia

Subclass Theriiformes

Order Rodentia (rodents)

Family Cylindrodontidae

Pareumys sp.

Family Eomyidae

Protadjidaumo sp.

Order Cete (whales and terrestrial relatives)

Family Mesonychidae

Hessolestes sp.

Order Creodonta (carnivore-like mammals)

Family Hyaenodontidae

Hyaenodon sp. 


\section{C.12 Duchesne River Formation (Cont.)}

Order Carnivora (modern forms include dogs, bears, cats, weasels, and others) Family indet.

Order Perissodactyla (modern forms include horses, tapirs, and rhinos)

Family Equidae

Duchesnehippus spp.

Family Helaletidae

\section{Colodon sp.}

Family Hyracodontidae

Hyracodon sp.

Family Rhinocerotidae

Rhinocerotidae indet.

Order Artiodactyla (modern forms include deer, sheep, antelopes, cows, and camels)

Family Entelodontidae

Brachyhyops sp.

Dyscritochoerus sp.

Family Agriochoeridae

Protoreodon spp.

Agriochoerus sp.

Family Hypertragulidae

Simimeryx sp.

Grandorder Lypotyphla (modern forms include shrews and moles)

Order Soricomorpha

Family Geolabididae

Centetodon spp. 


\section{C.12 Duchesne River Formation (Cont.)}

Brennan Basin Member (Roughly equal to the Randlett horizon [lower 2/3] and Halfway horizon [upper 1/3] of Anderson and Picard [1972]). Faunal list from Rasmussen (1999).

Class Mammalia

Order Cimolesta

Family indet.

\section{Simidectes sp.}

Order Rodentia (mice, squirrels, and beavers)

Family Cylindrodontidae

Pareumys spp.

Family Ischyromyidae

Mytonomys sp.

Order Lagomorpha (rabbits and pikas)

Mytonolagus sp.

Order Perissodactyla (modern forms include horses, tapirs, and rhinos)

Family Hyracodontidae

Dilophodon sp.

Epitriplopus sp.

Family Rhinocerotidae

Megalamynodon sp.

Family Brontotheriidae

Duchesneodus sp.

brontotheriidae indet.

Order Artiodactyla (modern forms include deer, sheep, antelopes, cows, and camels) 


\section{C.12 Duchesne River Formation (Cont.)}

Artiodactyla indet. 


\section{C.13 Browns Park Formation}

Faunal list compiled from Honey and Izett (1988) and McGrew (1951). Common names are provided when possible. Taxa are ordered as listed in the source publication. Partial vertebrate higher taxonomy is provided and was taken from Carroll (1988) and McKenna and Bell (1997).

Class Mammalia

Subclass Theriiformes

Cohort Placentalia

Order Carnivora (modern forms include dogs, bears, cats, weasels, and others)

Suborder Caniformia

Family Canidae (dogs, wolves, foxes, and coyotes)

Tomarctus sp.

Bassariscops sp.

Family Mustelidae (badgers, weasels, skunks, and ferrets)

genus nov.

Order Perissodactyla

Family Equidae (horses)

Megahippus sp.

Parahippus sp.

Family Rhinocerotidae (rhinos)

Aphelops sp.

Family Chalicotheriidae

Moropus sp.

Order Artiodactyla (modern forms include deer, sheep, antelopes, cows, and camels) 


\section{C.13 Browns Park Formation (Cont.)}

Family Merycoidodontidae

Merycoidodontidae indet.

Family Antilocapridae (pronghorn antelope)

Merycodus spp.

Family Camelidae (camels)

Procamelus sp.

Blickomylus sp.

Protolabis sp.

Michenia sp.

Aepycamelus sp.

Gentilocamelus sp.

Order Probiscidea (modern forms include elephants and hyraxes)

Family Gomphotheriidae

Gomphotherium sp. 


\section{C.14 Quaternary (Pleistocene) Units}

Faunal list compiled from Carroll (1988), Gillette and Miller (1999),

Gillette et al. (1999a, 1999b), Heaton (1999), Larson (1999), and Smith et al. (1999). Common names are provided when possible. Taxa are mostly ordered as listed in the source publication. Partial vertebrate higher taxonomy is provided and was taken from Carroll (1988) and McKenna and Bell (1997).

Class Mammalia

Subclass Theriiformes

Cohort Placentalia

Order Perissodactyla (horses, rhinos, and tapirs)

Family Equidae (horses)

Equus sp.

Order Proboscidea (elephants, mammoths, and mastodonts)

Family Mammutidae

Mammut sp.

Family Elephantidae

Mammuthus spp.

Order Rodentia (mice, squirrels, beavers, etc.)

Family Sciuridae (squirrels)

Spermophilus spp.

Marmota sp.

Tamias spp.

Family Cricetidae (pack rats, lemmings, voles, etc.)

Mimomys sp.

Phenacomys sp. 


\section{C.14 Quaternary (Pleistocene) Units (Cont.)}

Lemmiscus sp.

Mictomys sp.

Microtus sp.

Family Muridae (mice)

Neotoma sp.

Peromyscus sp.

Family Geomyidae (pocket gophers)

Thomomys sp.

Family Heteromyidae

Perognathus sp.

Family Zapodidae

Zapus sp.

Order Pilosa (sloths and armadillos)

Family Megalonychidae

Megalonyx sp.

Family Megatheriidae

Nothrotheriops sp.

Family Mylodontidae

Glossotherium sp.

Order Carnivora (modern forms include dogs, bears, cats, weasels, and others)

Suborder Feliformia

Family Felidae (cats)

Smilodon sp. 


\section{C.14 Quaternary (Pleistocene) Units (Cont.)}

Panthera sp.

Acinonyx sp.

Suborder Caniformia

Family Canidae (wolves, dogs, foxes, and coyotes)

Canis sp.

Vulpes sp.

Family Mustelidae (weasels and badgers)

Brachyprotoma sp.

Martes sp.

Mustella sp.

Gulo sp.

Family Ursidae (bears)

Arctodus sp.

Order Lagomorpha (rabbits and pikas)

Family Ochotonidae

Ochotona sp.

Family Leporidae

Sylvilagus sp.

Lepus sp.

Order Artiodactyla (deer, sheep, antelopes, cows, camels, and others)

Family Suidae (pigs)

Platygonus sp.

Family Camelidae (camels) 


\section{C.14 Quaternary (Pleistocene) Units (Cont.)}

Camelops sp.

Hemiauchenia sp.

Family Antilocapridae (pronghorn)

Tetrameryx sp.

Capromeryx sp.

Family Bovidae (cows, buffalo, sheep, etc.)

Oreamnos sp.

Euceratherium sp.

Bootherium spp.

Bison sp.

Ovis sp.

Family Cervidae (deer)

Odocoileus sp.

Grandorder Lypotyphla (shrews, moles, and others)

Order Soricomorpha

Family Soricidae

Sorex sp. 


\section{APPENDIX C REFERENCES}

Anderson, D.W. and M.D. Picard, 1972, Stratigraphy of the Duchesne River Formation (EoceneOligocene), northern Uinta Basin, Northwestern Utah: Bulletin of the Utah Geological Mineralogical Survey, 97:1-29.

Archibald, J.D., 1987, Late Cretaceous (Judithian and Edmontonian) vertebrates and geology of the Williams Fork Formation, NW Colorado: Occasional Paper of the Tyrrell Museum of Palaeontology, 3:7-11.

Armstrong, H., 1991, Class I paleontological data inventory along a proposed highway route with alternates from Ouray to Cisco, Uintah and Grand Counties, Utah: Unpublished BLM Report. 1-211.

Ash, S.R., 1972, Plant megafossil of the Chinle Formation. Museum of Northern Arizona Bulletin, 47:23-43.

Ash, S.R., 1978a, Geology, paleontology, and paleoecology of a Late Triassic lake, western New Mexico: Brigham Young University Research Studies, Geology Series, 25, Part 2:100 pp.

Ash, S.R., 1978b, Summary of the fossils in the Ciniza Lake Beds; Geology, paleontology, and paleoecology of a Late Triassic lake, western New Mexico: Brigham Young University Research Studies, Geology Series, 25, Part 2:21-22.

Ash, S.R., 1978c, Plant megafossils; Geology, paleontology, and paleoecology of a Late Triassic lake, western New Mexico: Brigham Young University Research Studies, Geology Series, 25, Part 2:23-43.

Ash, S.R., 1978d, Coprolites; Geology, paleontology, and paleoecology of a Late Triassic lake, western New Mexico: Brigham Young University Research Studies, Geology Series, 25, Part 2:69-73.

Ash, S.R., 1978e, Fish scales; Geology, paleontology, and paleoecology of a Late Triassic lake, western New Mexico: Brigham Young University Research Studies, Geology Series, 25, Part 2:67-68.

Ash, S.R., 2001, New cycadophytes from the Upper Triassic Chinle Formation of the Southwestern United States: PaleoBios, 21(1):15-28.

Ash, S.R., 2005, A new Upper Triassic flora and associated invertebrate fossils from the basal beds of the Chinle Formation, near Cameron, Arizona: PaleoBios, 25(1):17-34.

Batten, R.L. and W.L. Stokes, 1986, Early Triassic gastropods from the Sinbad Member of the Moenkopi Formation, San Rafael Swell, Utah: American Museum Novitates, 2864:33 pp. 
Carroll, R.L., 1988, Vertebrate Paleontology and Evolution: W.H. Freeman and Company, $698 \mathrm{pp}$.

Clark, J., 1932, New turtle from the Duchesne Oligocene of the Uinta Basin, northeastern Utah: University of Pittsburgh, Pittsburgh, PA, United States (USA) Master's Thesis.

Colbert, E.H., 1972, Vertebrates from the Chinle Formation; Investigations in the Triassic Chinle Formation: Museum of Northern Arizona Bulletin, 47:1-11.

Dorr, J.A., Jr., 1978, Revised and amended fossil vertebrate faunal lists, early Tertiary, Hoback Basin, Wyoming: Contributions to Geology, 16(2):79-84.

Eastman, C. R., 1917, Fossil fishes in the collection of the United States National Museum. Proceedings of the United States National Museum, pp. 235-304.

Foster, J., A.L. Titus, G.F. Winterfeld, M.C. Hayden, and A.H. Hamblin, 2001, Paleontological survey of the Grand Staircase-Escalante National Monument, Garfield and Kane counties, Utah: Utah Geological Survey Special Study 99:98 pp.

Fracasso, M.A., 1980, Age of the Permo-Carboniferous Cutler Formation vertebrate fauna from El Cobre Canyon, New Mexico: Journal of Paleontology, 54(6):1237-1244.

Gardner, J.D., 1999, Comments on amphibians from the Green River Formation, with a description of a fossil tadpole; Vertebrate paleontology in Utah: Miscellaneous PublicationUtah Geological Survey, 99-1:455-461.

Gazin, C.L., 1976, Mammalian faunal zones of the Bridger middle Eocene: Smithsonian Contributions to Paleobiology,(26):25-25.

Gillette, D.D. and M.C. Hayden, 1997, A preliminary inventory of paleontological resources within the Grand Staircase-Escalante National Monument, Utah: Circular-Utah Geological Survey, 96:34 pp.

Gillette, D.D. and W.E. Miller, 1999, Catalogue of new Pleistocene mammalian sites and recovered fossils from Utah In: Vertebrate paleontology in Utah: Miscellaneous Publication-Utah Geological Survey, 99-1:523-530.

Gillette, D.D., H.G. McDonald, and M.C. Hayden, 1999a, The first record of Jefferson's Ground Sloth, Megalonyx Jeffersonii, in Utah (Pleistocene, Rancholabrean Land Mammal Age): In: Vertebrate paleontology in Utah: Miscellaneous Publication-Utah Geological Survey, 99-1:509-522.

Gillette, D.D., C.J. Bell, and M.C. Hayden, 1999b, Preliminary report of the Little Dell Dam fauna, Salt Lake County, Utah (Middle Pleistocene, Irvingtonian Land mammal Age): In: Vertebrate paleontology in Utah: Miscellaneous Publication-Utah Geological Survey, 99-1:495-500. 
Grande, L., 1980, Paleontology of the Green River Formation, with a review of the fish fauna: Bulletin-Geological Survey of Wyoming, 63:333 pp.

Grande, L., 1987, Redescription of Hypsidoris farsonensis (Teleostei: Siluriformes), with a reassessment of its phylogenetic relationships: Journal of Vertebrate Paleontology, 7(1):24-54.

Grande, L., 1998, The first pickerel (Teleostei, Esocidae) from the Green River Formation, and a review of the world's most productive freshwater Lagerstatten; Abstracts of papers; Society of Vertebrate Paleontology Fifty-Eighth Annual Meeting, Snowbird, UT, United States, Sept. 30-Oct. 3, 1998, 18(3, Suppl):47 pp.

Grande, L., 1999, The first Esox (Esocidae, Teleostei) from the Eocene Green River Formation, and a brief review of esocid fishes: Journal of Vertebrate Paleontology, 19(2):271-292.

Grande, L., J.T. Eastman, and T.M. Cavender, 1982, Amyzon gosiutensis, a new catostomid fish from the Green River Formation: Copeia, 1982(3):523-532.

Gregory, H.E., 1950, Geology and geography of the Zion [National] Park region, Utah and Arizona: U.S. Geological Survey Professional Paper P 0220:200 pp.

Gulas-Wroblewski, B.E. and S. Uibreaslain, 2002, A new pelecaniform bird from the Green River Formation (Eocene) of Wyoming: Geological Society of America, 2002 annual meeting, Denver, CO, United States, Oct. 27-30, 2002, 34(6):425.

Gunnell, G.F., 1994, Paleocene mammals and faunal analysis of the Chappo type locality (Tiffanian), Green River Basin, Wyoming: Journal of Vertebrate Paleontology, 14(1):81-104.

Gunnell, G. and W.S. Bartels, 1999, Middle Eocene vertebrates from the Uinta Basin, Utah, and their relationship with faunas from the southern Green River Basin, Wyoming: Utah Geological Survey Misc. Publications, 99-1:429-442.

Heaton, T.H., 1999, Late Quaternary vertebrate history of the Great Basin: In: Vertebrate paleontology in Utah: Miscellaneous Publication-Utah Geological Survey, 99-1:501-508.

Hesse, C. J., 1935, Semionotus cf. gigas, from the Triassic of Zion Park, Utah.: American Journal of Science, 29:526-531.

Hilton, E. J. and L. Grande, 2001, Osteology of Eohiodon (Teleostei, Hiodontiformes), based on new acid-prepared specimens from the Green River Formation (Eocene), Wyoming: Abstract, Sixty-first annual meeting, Society of Vertebrate Paleontology, Bozeman, MT, United States, Oct. 3-6, 2001, 21(3, Suppl):61-62.

Honey, J.G. and G.A. Izett, 1988, Paleontology, taphonomy, and stratigraphy of the Browns Park Formation (Oligocene and Miocene) near Maybell, Moffat County, Colorado: U.S. Geological Survey Professional Paper 1358:52 pp. 
Hunt, A.P., S.G. Lucas, and J.A. Spielmann, 2005a, The holotype specimen of Vancleavea campi from Petrified Forest National Park, Arizona, with notes on the taxonomy and distribution of the taxon, In: Vertebrate paleontology in Arizona: Bulletin-New Mexico Museum of Natural History and Science, 29:59-66.

Hunt, A.P., S.G. Lucas, and J.A. Spielmann, 2005b, The postcranial skeleton of Revueltosaurus callenderi (Archosauria, Crurotarsi) from the Upper Triassic of Arizona and New Mexico, USA,

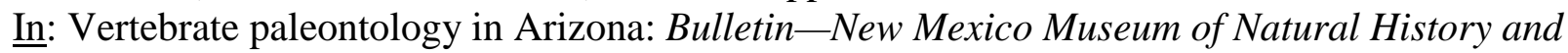
Science, 29:67-76.

Irmis, R.B., 2005, The vertebrate fauna of the Upper Triassic Chinle Formation in northern

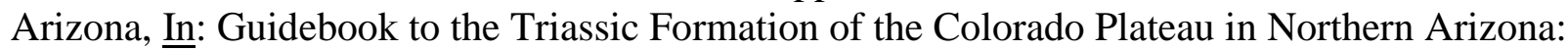
Geology, Paleontology, and History (S.J. Nesbitt, W.G. Parker, and R.B. Irmis, eds.), Mesa Southwest Museum Bulletin, 9:26 pp.

Jepsen, G.L., 1966, Early Eocene bat from Wyoming: Science, 154(3754):1333-1339.

Kihm, A.J., 1984, Early Eocene mammalian faunas of the Piceance Creek basin, northwestern Colorado: University of Colorado, Boulder, CO, United States (USA) Doctoral Dissertation.

Larson, P.R., 1999, The Columbian mammoth (Mammuthus columbi) from Escalante Valley, Iron County, Utah-discovery and implications: In: Vertebrate paleontology in Utah: Miscellaneous Publication-Utah Geological Survey, 99-1:531-537.

Lewis, G.E. and P.P. Vaughn, 1965, Early Permian vertebrates from the Cutler Formation of the Placerville area, Colorado: U.S. Geological Survey Professional Paper P 0503-C: pp. C1-C50.

Loewen, M.A., V.L. Leggitt, R.E. Biaggi, H.P. Buchheim, and R.A. Cushman, Jr., 1999, Morphologic variation in caddisfly (Trichoptera) larval case architecture from the Eocene Green River and Wasatch formations of Wyoming: Geological Society of America, 1999 annual meeting, Denver, CO, United States, Oct. 25-28, 1999, 31(7):470.

Long, R.A. and K. Padian, 1986, Vertebrate biostratigraphy of the Late Triassic Chinle Formation, Petrified Forest National Park, Arizona: preliminary results, In: The Beginning of the Age of Dinosaurs (K. Padian, ed.), London, Cambridge University Press, pp. 161-169.

Mamay, S.H. and W.J. Breed, 1970, Early Permian plants from the Cutler Formation in Monument Valley, Utah: U.S. Geological Survey Professional Paper P 0700-B:B109-B117.

McGrew, E.J., 1951, Tertiary stratigraphy and paleontology of south-central Wyoming: Wyoming Geological Association Guidebook, Sixth Annual Field Conference, South-central Wyoming, pp. 54-57.

McGrew, P.O. and M. Casilliano, 1975, The geological history of Fossil Butte National Monument and Fossil Basin: National Park Service Occasional Paper, (3):37 pp. 
McKenna, M.C., 1955, Age of the Four Mile Local Fauna, northeast Sand Wash Basin, Colorado: Wyoming Geological Association Guidebook, pp. 105-107.

McKenna, M.C., 1958, Fossil Mammalia from the early Wasatchian Four Mile fauna, Eocene of Northwest Colorado: University of California, Berkeley, Berkeley, CA, United States (USA) Doctoral Dissertation.

McKenna, M.C. and S.K. Bell, 1997, Classification of Mammals above the Species Level: Columbia University Press, 631 pp.

Mook, C.C., 1962, A new species of Brachyuranochampsa (Crocodilia) from the Bridger Beds of Wyoming: American Museum Novitates, 2079:6.

Morales, M., 1987, Terrestrial fauna and flora from the Triassic Moenkopi Formation of the southwestern United States: Journal of the Arizona-Nevada Academy of Science, 22(1):1-19.

Moussa, M.T., 1970, Nematode fossil trails from the Green River Formation (Eocene) in the Uinta Basin, Utah: Journal of Paleontology, 44(2):304-307.

Murphey, P.C., L.L. Torick, E.S. Bray, R. Chandler, and E. Evanoff, 2001, Taphonomy, fauna, and depositional environment of the Omomys Quarry, an unusual accumulation from the Bridger Formation (middle Eocene) of southwestern Wyoming (USA); Eocene biodiversity; unusual occurrences and rarely sampled habitats: Topics in Geobiology, 18:361-402.

Nesbitt, S.J. and K.D. Angielczyk, 2002, New evidence of large dicynodonts in the upper Moenkopi Formation (Middle Triassic) of northern Arizona: PaleoBios, 22(2):10-17.

Nesbitt, S.J. and R.L. Whatley, 2004, The first discovery of a rhynchosaur from the upper Moenkopi Formation (Middle Triassic) of northern Arizona: PaleoBios, 24(3):1-10.

Olson, S.L., 1977, A lower Eocene frigatebird from the Green River Formation of Wyoming (Pelecaniformes; Fregatidae): Smithsonian Contributions to Paleobiology,(35):33-33.

Parker, L.R., 1970, A titanothere from the Eocene Green River Formation of Utah: Abstracts with Programs-Geological Society of America, 2(6):400.

Parker, W.G., 2005, Faunal review of the Upper Triassic Chinle Formation of Arizona, In: Vertebrate Paleontology of Arizona, Mesa Southwest Museum Bulletin 11 (R.D. McCord, ed.), $21 \mathrm{pp}$.

Parrish, J.M., 1999, Small fossil vertebrates from the Chinle Formation (Upper Triassic) of southern Utah; Vertebrate paleontology in Utah: Miscellaneous Publication - Utah Geological Survey, 99-1:45-50. 
Perry, M.L., 2003, Preliminary description of a new fossil scorpion from the middle Eocene, Green River Formation, Rio Blanco, Colorado: Abstracts, 74th annual meeting of the ColoradoWyoming Academy of Science, Greeley, CO, United States, April 26, 2003, 35(1):22.

Rasmussen, D.T., G.C. Conroy, A.R. Friscia, K.E. Townsend, and M.D. Kinkel, 1999, Mammals of the middle Eocene Uinta Formation; Vertebrate paleontology in Utah: Miscellaneous Publication - Utah Geological Survey, 99-1:401-420.

Rieppel, O. and L. Grande, 1998, A well-preserved fossil amphiumid (Lissamphibia; Caudata) from the Eocene Green River Formation of Wyoming: Journal of Vertebrate Paleontology, 18(4):700-708.

Schaeffer, B. and D.H. Dunkle, 1950, A semionotid fish from the Chinle Formation [Utah], with consideration of its relationships: American Museum Novitates, 1457:29 pp.

Smith, K.S., R.L. Cifelli, and N.J. Czaplewski, 1999, An early Holocene, high-altitude vertebrate faunule from central Utah: In: Vertebrate paleontology in Utah: Miscellaneous PublicationUtah Geological Survey, 99-1:537-543.

Stucky, R.K., 1984, The Wasatchian-Bridgerian land mammal age boundary (Early to Middle Eocene) in western North America: Annals of the Carnegie Museum of Natural History, $53: 347-382$.

Stucky, R.K., D.R. Prothero, W.G. Lohr, and J.R. Snyder, 1996, Magnetic stratigraphy, sedimentology, and mammalian faunas of the early Uintan Washakie Formation, Sand Wash Basin, Colorado, In: The Terrestrial Eocene-Oligocene Transition in North America (D.R. Prothero and R.J. Emry, eds.), Cambridge University Press, pp. 40-51.

Sumida, S.S., J.B. Walliser, and R.E. Lombard, 1999a, Late Paleozoic Amphibian-Grade tetrapods of Utah: In: Vertebrate Paleontology in Utah (D. Gillette, ed.)-Miscellaneous Publication, Utah Geological Survey, 99-1:21-30.

Sumida, S.S., R.E. Lombard, D.S. Berman, and A.C. Henrici, 1999b, Late Paleozoic amniotes and their near relatives from Utah and northeastern Arizona, with comments on the PermianPennsylvanian boundary in Utah and northern Arizona: In: Vertebrate Paleontology in Utah (D. Gillette, ed.)—Miscellaneous Publication, Utah Geological Survey, 99-1:31-43.

Vaughn, P.P., 1962, Vertebrates from the Halgaito tongue of the Cutler Formation, Permian of San Juan County, Utah: Journal of Paleontology, 36(3):529-539.

Wagner, O.E., 1932, The paleontology and stratigraphy of the Kaibab Limestone: University of Illinois, Chicago, Chicago, IL, United States (USA) Doctoral Dissertation. 
Waterhouse, D., G. Dyke, J. Anderson, H.-D. Sues, M. Fox, J. Case, J. Eberle, M. Goodwin, and S. Carlson, 2003, A new fossil charadriiform bird from the lower Eocene Green River Formation of Wyoming: Abstracts, Sixty-third annual meeting, Society of Vertebrate Paleontology, Science Museum of Minnesota, Saint Paul, MN, United States, Oct. 15-18, 2003, 23(3, Suppl):108.

West, R.M. and M.R. Dawson, 1973, Fossil mammals from the upper part of the Cathedral Bluffs Tongue of the Wasatch Formation (early Bridgerian), northern Green River basin, Wyoming: Contributions to Geology, 12(1):33-41.

Yang, S.-Y., M.G. Lockley, R. Greben, B.R. Erickson, and S.-K. Lim, 1995, Flamingo and ducklike bird tracks from the Late Cretaceous and early Tertiary; evidence and implications: Ichnos, $4(1): 21-34$.

Zonneveld, J.-P., G.F. Gunnell, and W.S. Bartels, 2000, Early Eocene fossil vertebrates from the southwestern Green River basin, Lincoln and Uinta counties, Wyoming: Journal of Vertebrate Paleontology, 20(2):369-386. 


\section{APPENDIX D:}

BLM SENSITIVITY MAPS OF PALEONTOLOGICAL FORMATIONS WITHIN THE OIL SHALE AND TAR SANDS PEIS STUDY AREA 


\section{APPENDIX D:}

\section{BLM SENSITIVITY MAPS OF PALEONTOLOGICAL FORMATIONS WITHIN THE OIL SHALE AND TAR SANDS PEIS STUDY AREA}

This appendix consists of a series of paleontological sensitivity maps of the study area (Figures D-1 through D-6). The maps are provided as foldout plates in the back pockets of this report.

Six separate paleontological sensitivity maps have been prepared at a scale of 1:500,000 using digital maps published by Green (1992), Green and Drouillard (1994), and Hintze et al. (2000). These maps show the distribution of geologic units that could potentially be impacted by oil shale and tar sands development. Because this report employed two classification systems, the Bureau of Land Management (BLM) classification system (Conditions 1-3) (BLM 1998) and the U.S. Forest Service (USFS) Potential Fossil Yield Classification (PFYC) system (Classes 1-5) (USFS 1996), two sets of maps for each affected state, one for each classification system, are provided. Figures D-1 and D-2 are the maps for Colorado; Figures D-3 and D-4 are the maps for Utah; and Figures D-5 and D-6 are the maps for Wyoming.

A scale of 1:500,000 was chosen because smaller-scale geologic mapping was not available for parts of the study area. The sensitivity designations shown on these maps under both classification systems were assigned by BLM regional paleontologists and do not correlate completely with the designations presented in the body of this report. These designations are color coded according to BLM's scheme.

It is anticipated that smaller-scale maps, as available, will be employed for projectspecific analyses within the study area. It is important to note that at the 1:500,000 scale, the paleontological sensitivity maps do not reflect the level of geologic detail (of formations and members) presented in the body of this report. This lack of detail results from the combination of geologic units at the 1:500,000 scale, to which differing paleontological sensitivities are assigned in this report. Consequently, in constructing the paleontological sensitivity maps, the highest resource sensitivity designation was applied to each combined unit. For example, if members of the Green River Formation are not distinguished on the 1:500,000-scale geologic map, a PFYC Class 5 designation was applied to the entire Green River Formation because at least one of its members is designated as Class 5. Tables 3, 4, 5, and 6 of this report give a comprehensive list of potentially affected geologic units and their paleontological sensitivities.

The sensitivity designations under the PFYC and BLM Condition systems are models that attempt to predict locations where future land use projects are most likely to impact significant paleontological resources. The sensitivity designation assignments were made by BLM regional paleontologists who are knowledgeable about each state's paleontological resources. In coordination, BLM regional paleontologists continue to maintain the latest PFYC and BLM Condition assignments, which are subject to change as new data are collected. The 
latest PFYC or BLM Condition assignments for each state may be obtained by contacting BLM state offices.

In some areas, PFYC or BLM Condition assignments are inconsistent across state line boundaries. According to the BLM, there are two reasons for this inconsistency: (1) the geological formations are mapped, defined, or grouped differently on the baseline 1:500,000 scale geological maps, and (2) the abundance of fossil resources varies across these boundaries.

1. Each of the six paleontological sensitivity maps is based on the respective U.S. Geological Survey or state geological survey 1:500,000-scale geological map (Green 1992; Green and Drouillard 1994;

Hintze et al. 2000). Because of the large scale of these maps, the authors of each map found it necessary to group multiple formations together into single polygons. As stated above, the paleontological sensitivity of each polygon is based on the assignment of the formation (or formations) with the greatest potential to have significant paleontological resources. However, because it is necessary to group multiple formations into single polygons, and because the authors of each map have grouped these formations in different ways, in some locations, there is an apparent difference in paleontological sensitivity across state lines. This type of inconsistency can be addressed on a project-specific basis using smallerscale (e.g., 1:100,000-scale) geologic maps.

2. The potential for a geologic formation to produce significant fossil resources varies both geographically and stratigraphically. Therefore, in order to precisely capture the paleontological sensitivity of a formation, it may be necessary to apply different sensitivity designations to the same formation in different geographic areas. In practice, these different designations are often reflected across state, county, or field office boundaries. According to the BLM, all of the geologic units that are specific to the Oil Shale and Tar Sands Programmatic Environmental Impact Statement (Tables 3-6) received similar sensitivity designations across all three states (Colorado, Utah, and Wyoming). Inconsistencies, if present, can be addressed on a project-specific basis using smaller-scale (e.g., 1:100,000-scale) geologic maps.

\section{APPENDIX D REFERENCES}

BLM (U.S. Bureau of Land Management), 1998, Paleontology Resources Management Manual, 8270, $12 \mathrm{pp}$, and Handbook, H-8270-1, 38 pp.

Green, G.N., 1992, The Digital Geologic Map of Colorado in ARC/INFO Format, U.S. Geological Survey, Open-File Report 92-0507, scale 1:500,000. 
Green, G.N. and P.H. Drouillard, 1994, The Digital Geologic Map of Wyoming in ARC/INFO Format, U.S. Geological Survey, Open-File Report 94-0425, scale 1:500,000.

Hintze, L.F., G.C. Willis, D.Y.M. Laes, D.A. Sprinkel, and K.D. Brown, 2000, Digital Geologic Map of Utah, Utah Geological Survey, Map 179DM compact disc, scale 1:500,000.

USFS (U.S. Forest Service), 1996, Potential fossil yield classification (PFYC): Developed by the Paleontology Center of Excellence and the Region 2 (USFS) Paleo Initiative. 
Figure D-1 Paleontological Sensitivity of Formations That May Be Impacted by Oil Shale Development in Colorado Using the BLM Classification System (Conditions 1-3)

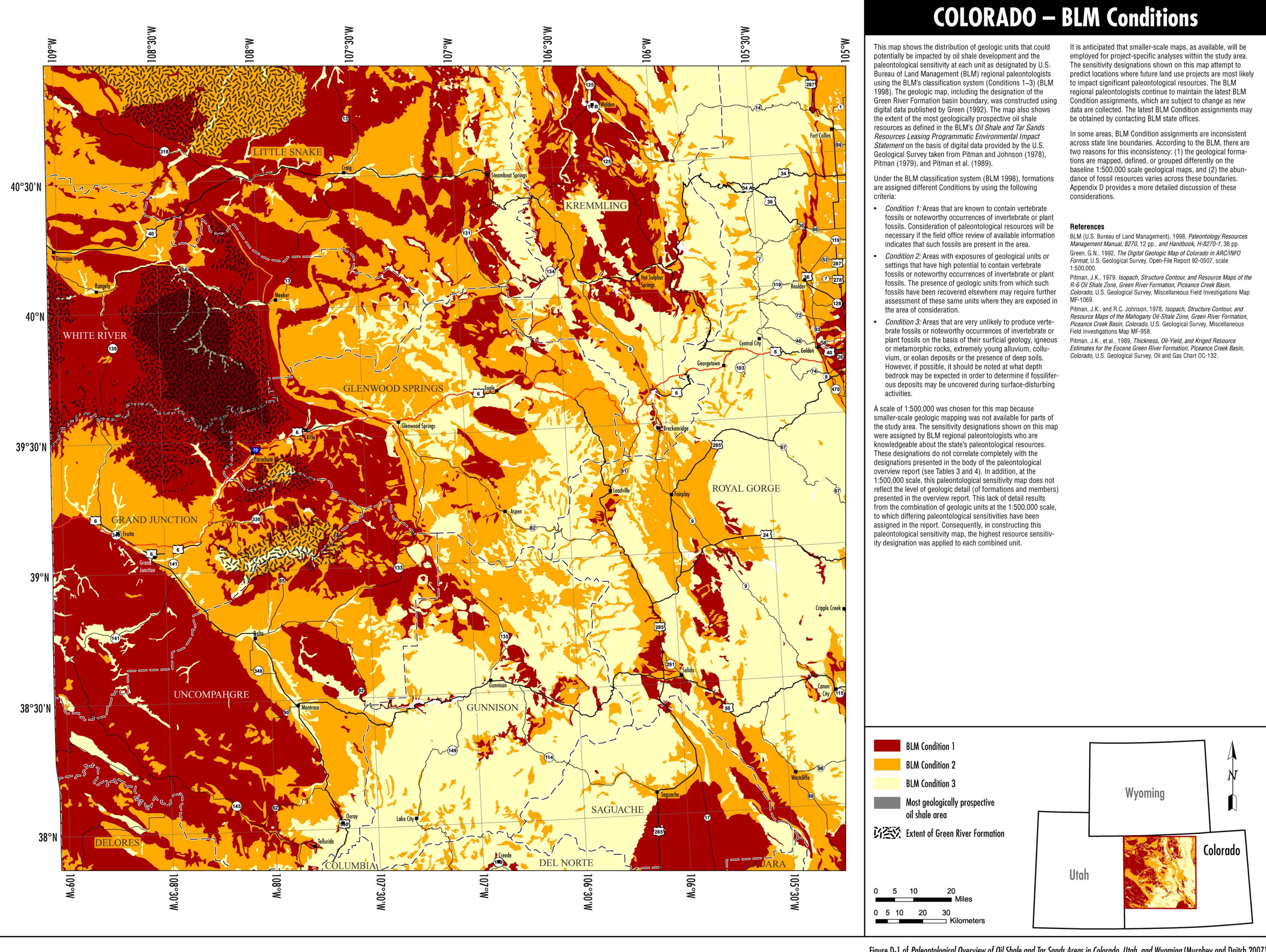


Figure D-2 Paleontological Sensitivity of Formations That May Be Impacted by Oil Shale Development in Colorado Using the USFS Potential Fossil Yield Classification System (PFYC Classes 1-5)

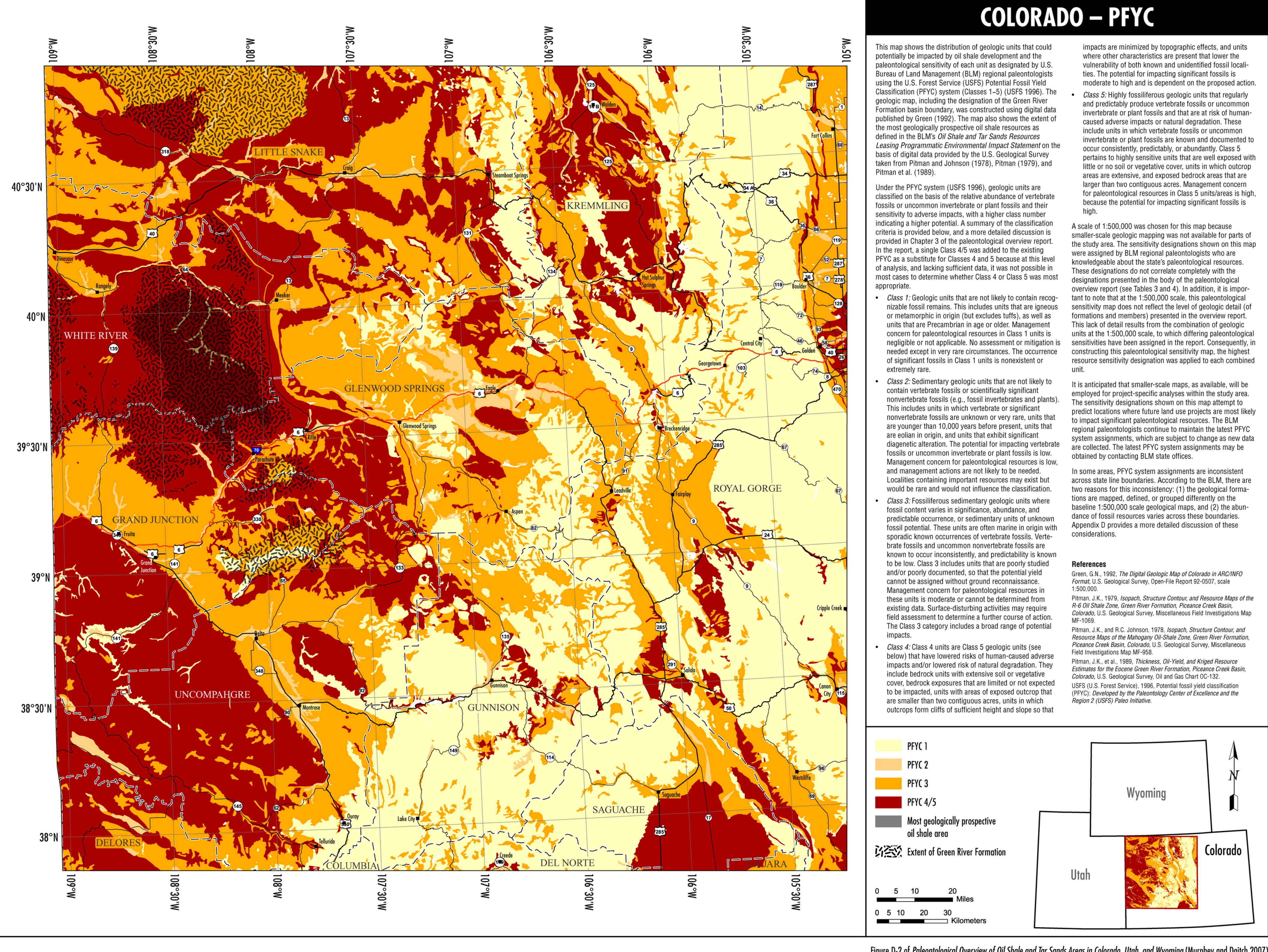


Figure D-3 Paleontological Sensitivity of Formations That May Be Impacted by Oil Shale or Tar Sands Development in Utah Using the BLM Classification System (Conditions 1-3)

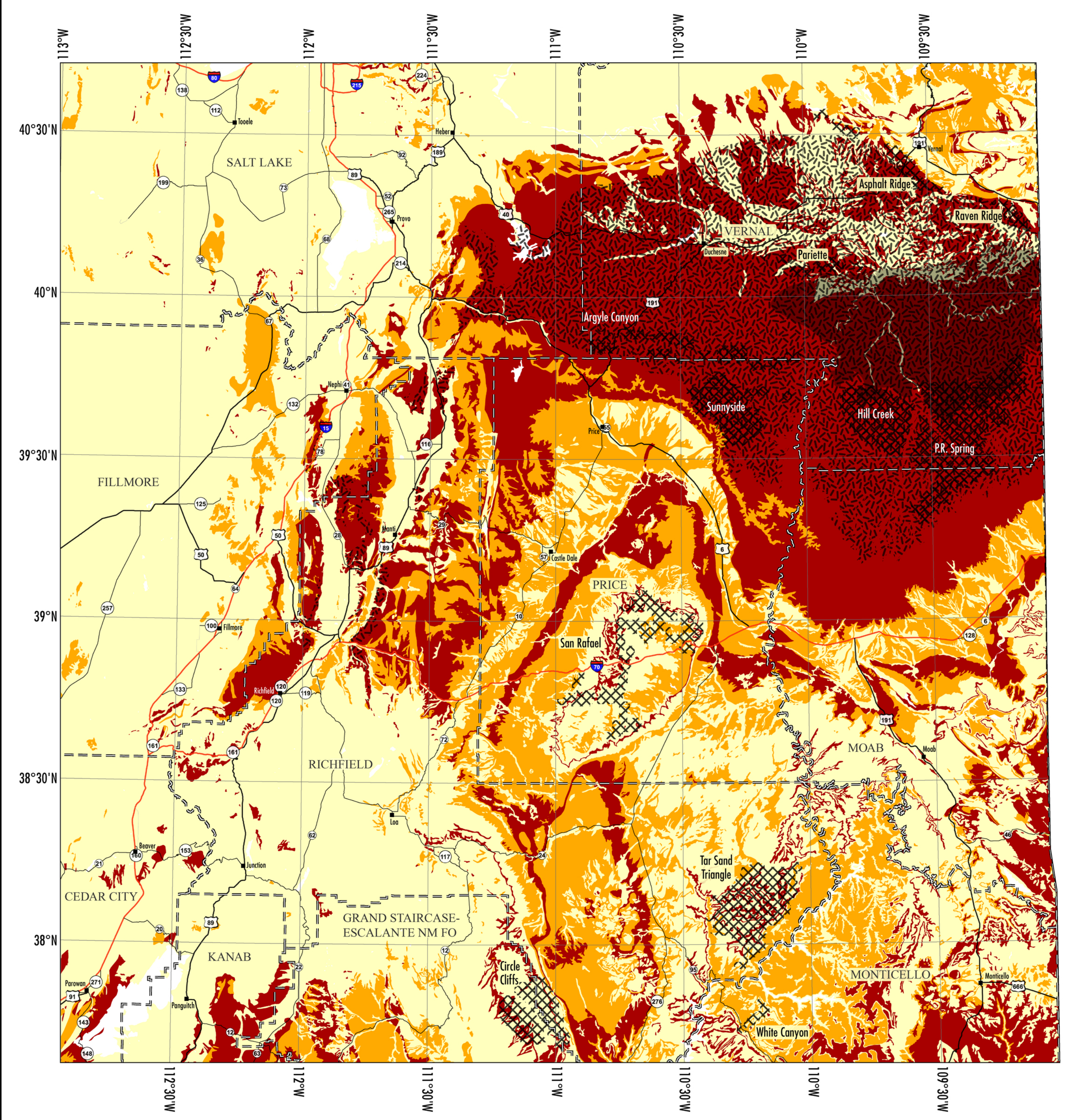

UTAH - BLM Conditions

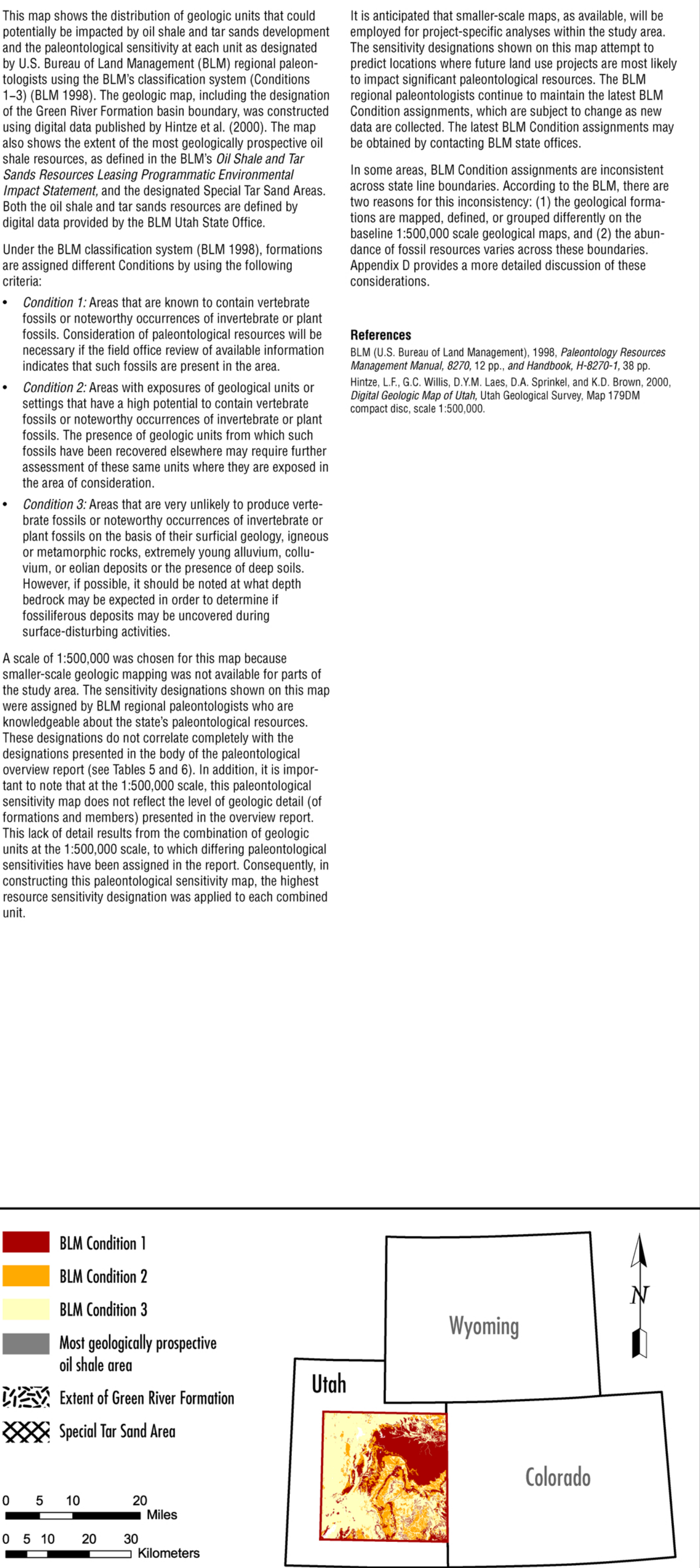

Figure D-3 of Paleontological Overview of Oil Shale and Tar Sands Areas in Colorado, Utah and Wyoming (Murphey and Daith 2007) 
Figure D-4 Paleontological Sensitivity of Formations That May Be Impacted by Oil Shale or Tar Sands Development in Utah Using the USFS Potential Fossil Yield Classification System (PFYC Classes 1-5)

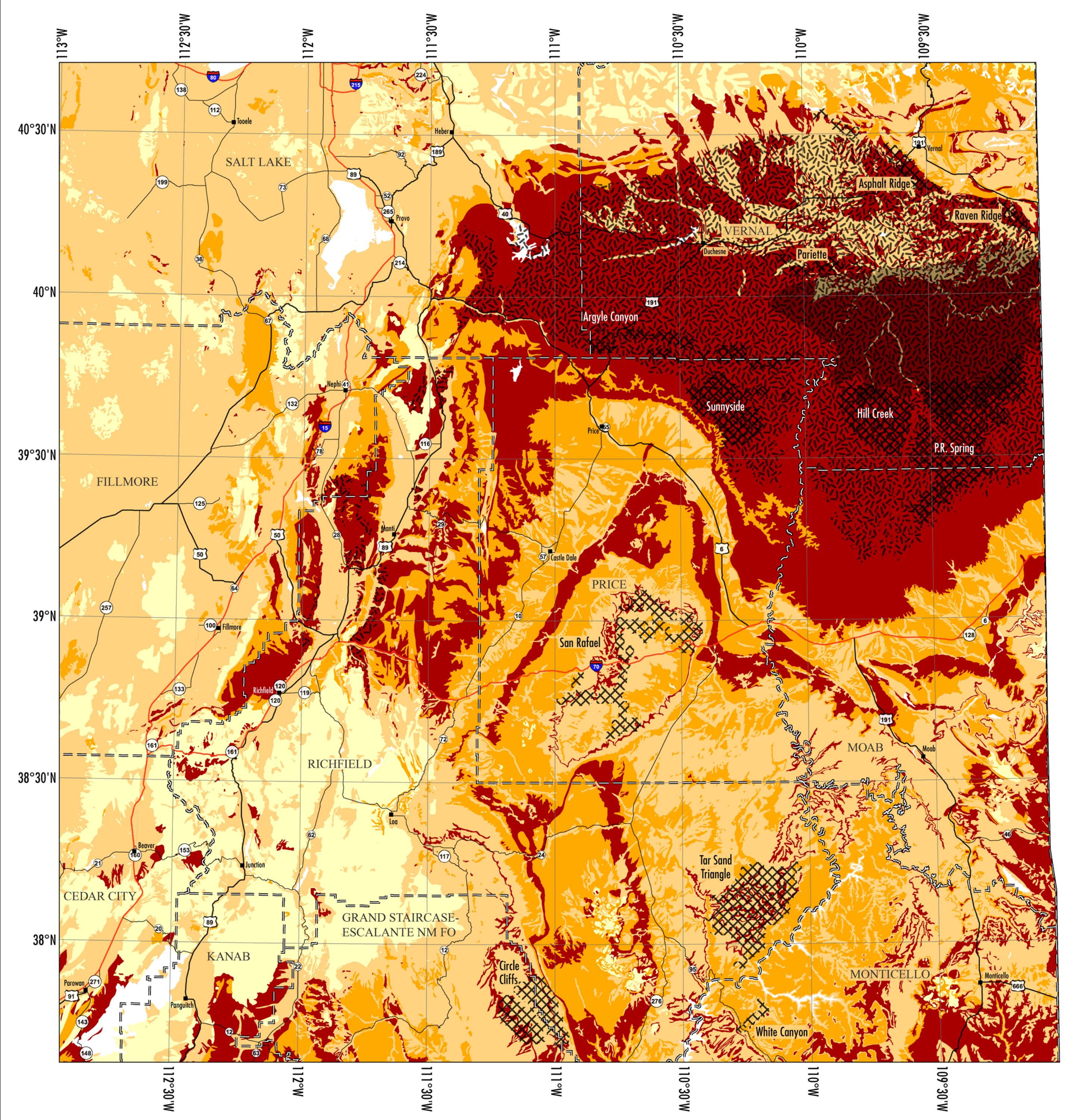

\section{UTAH - PFYC}

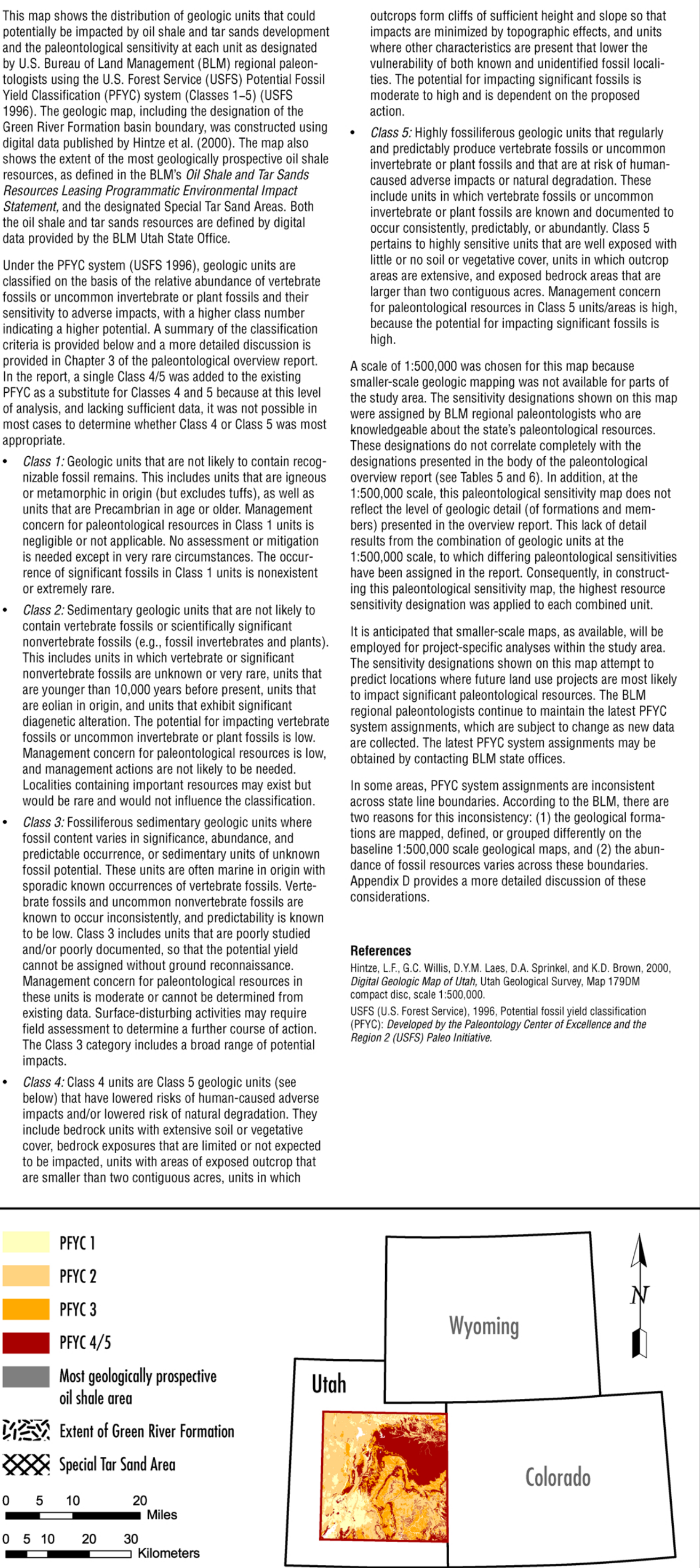

Figure D-4 of Paleontological Overview of oil Shale and Tar Sands Areas in Colorado, Utah, and Wyoming (Murphey and Daith 2007) 
Figure D-5 Paleontological Sensitivity of Formations That May Be Impacted by Oil Shale Development in Wyoming Using the BLM Classification System (Conditions 1-3)

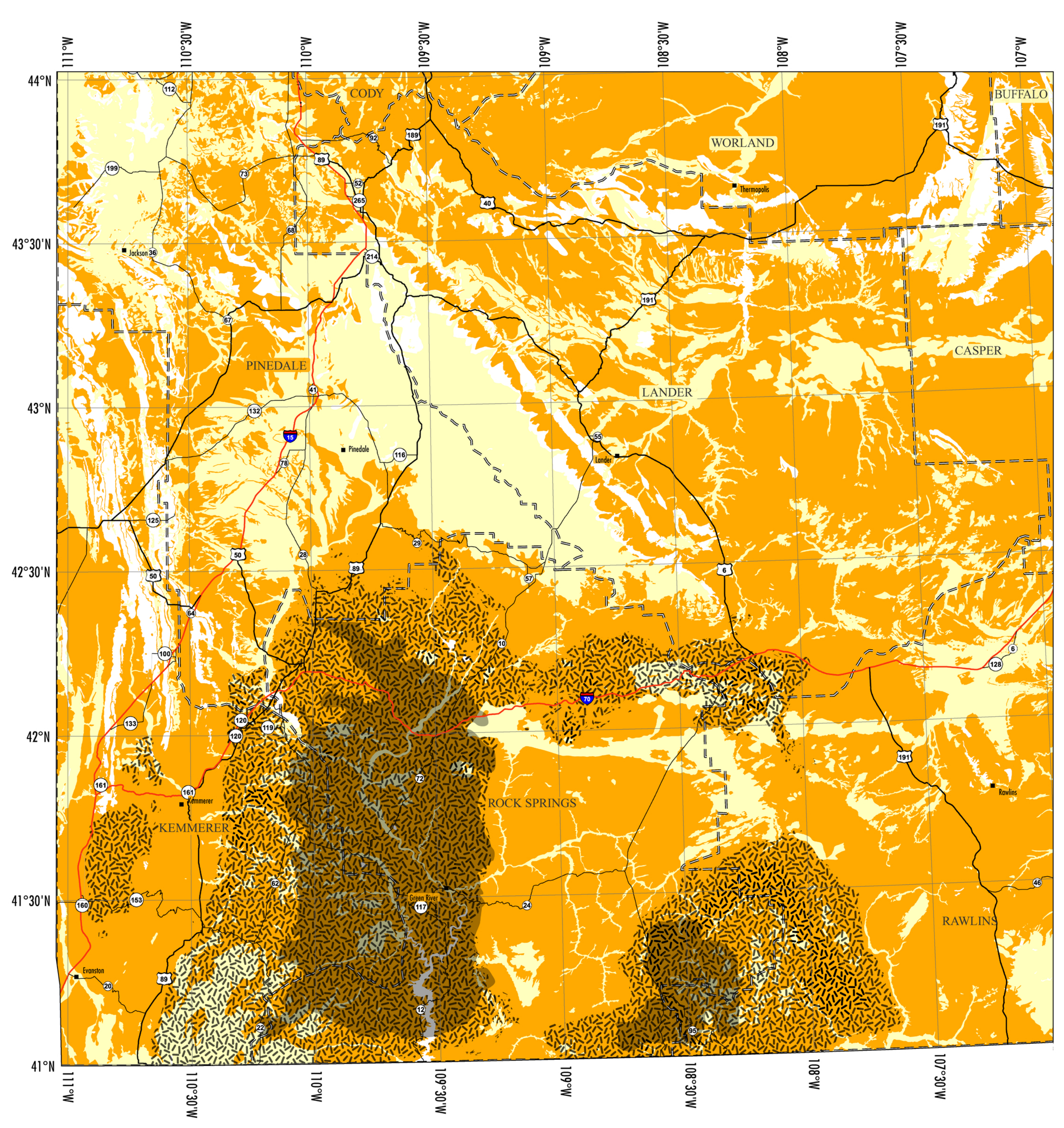

\section{WYOMING - BLM Conditions}

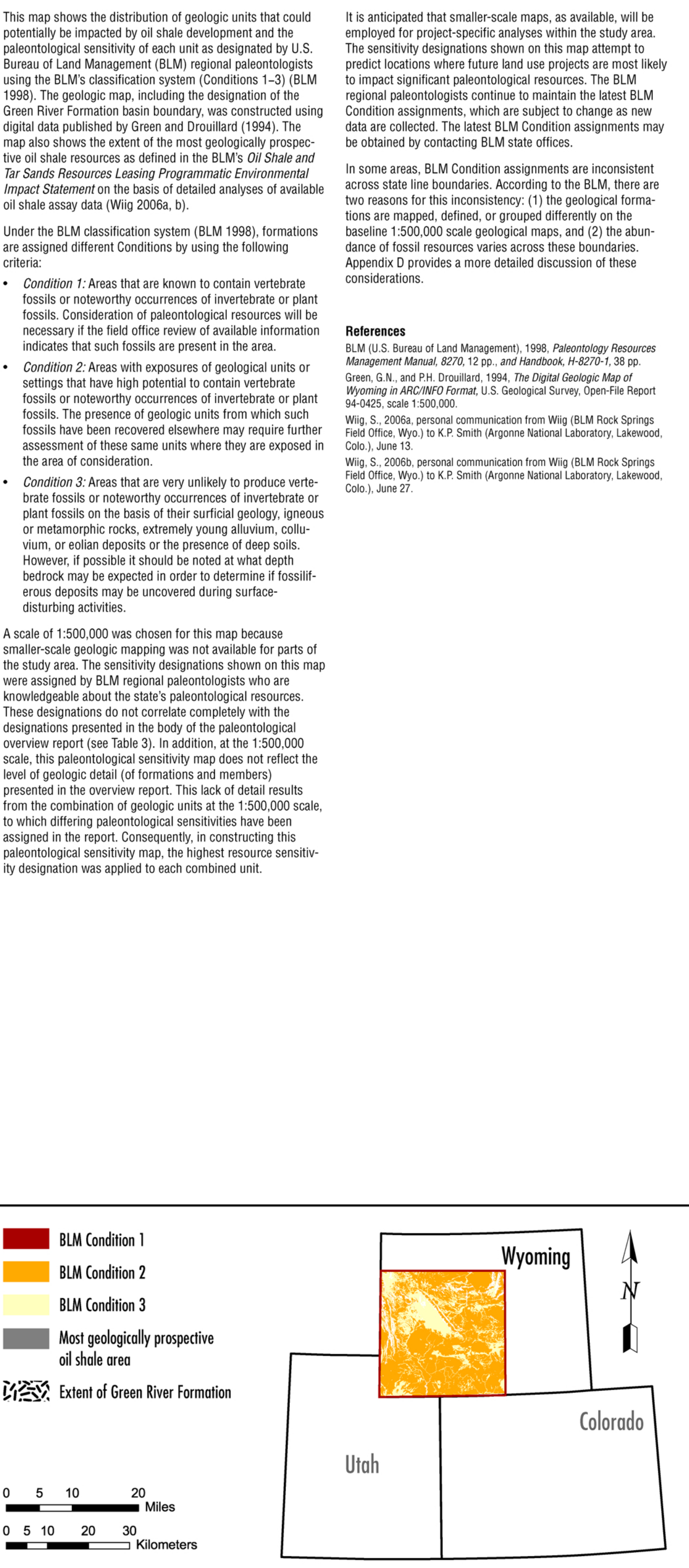

Figure D.5 of Paleontological Overview of Oil Shale and Tar Sands Areas in Colorade, Utah, and Wyoming (Murphey and Daitch 2007) 
Figure D-6 Paleontological Sensitivity of Formations That May Be Impacted by Oil Shale Development in Wyoming Using the USFS Potential Fossil Yield Classification System (PFYC Classes 1-5)

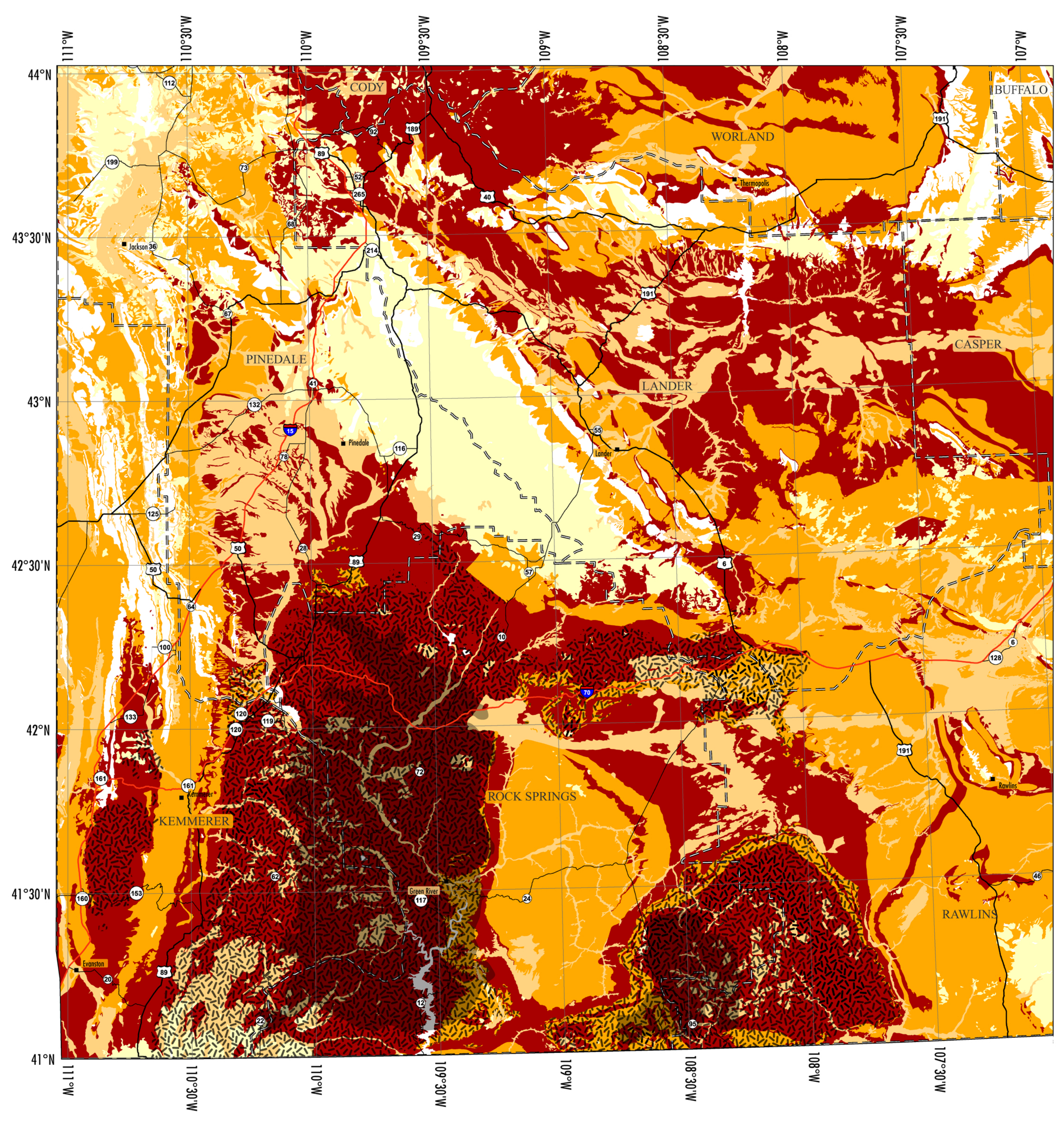

\section{WYOMING - PFYC}

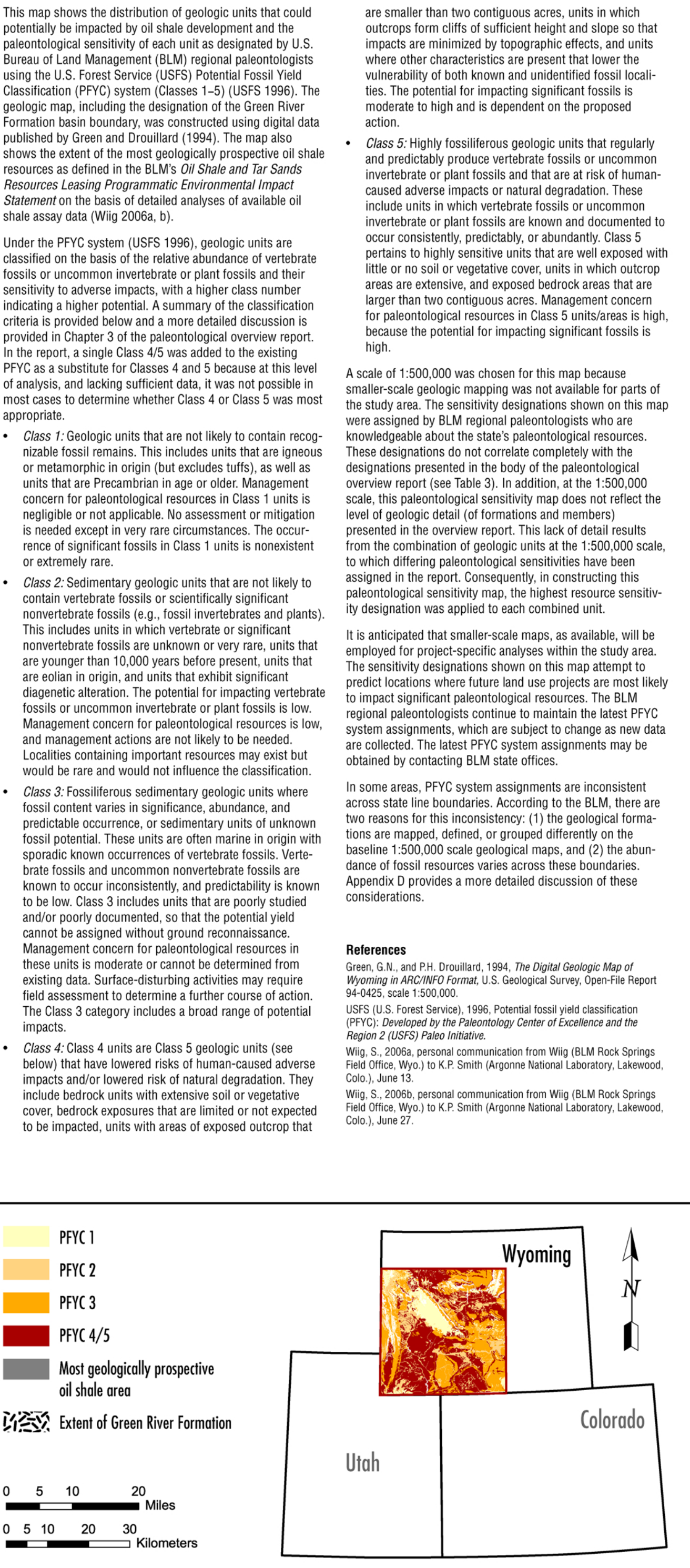

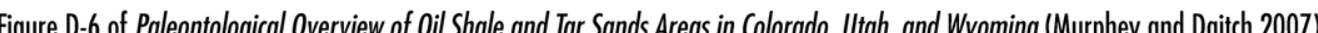

